\title{
10TH APPLIED ISOTOPE GEOCHEMISTRY CONFERENCE
}

\author{
22-27 SEPTEMBER 2013, BUDAPEST, HUNGARY
}

Hungarian Academy of Sciences

Széchenyi István tér 9, H-1051 Budapest, Hungary

\section{AIG10 10th Applied Isotope Geochemistry Conference}
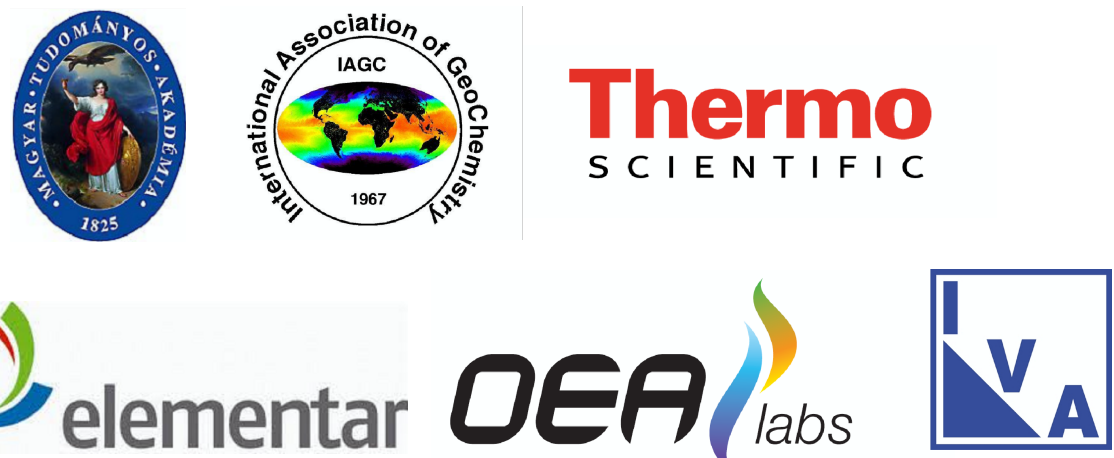


\title{
002 - DIRECT MEASUREMENT OF PORE WATER $\delta^{2} H$ AND $\delta^{18} O$ FROM DRILL CORE SAMPLES VIA $\mathrm{H}_{2} \mathrm{O}_{\text {(LIQUID) }}-\mathrm{H}_{2} \mathrm{O}_{\text {(VAPOUR) }}$ EQUILIBRIUM LASER SPECTROSCOPY
}

\author{
Richard Crane $^{1,2}-$ Adam Hartland $^{3}-$ Wendy Timms ${ }^{2,4}$ \\ ${ }^{1}$ School of Civil and Environmental Engineering, University of New South Wales, \\ Sydney, NSW, Australia; e-mail: R.Crane@wrl.unsw.edu.au \\ ${ }^{2}$ National Centre for Groundwater Research and Training \\ ${ }^{3}$ Chemistry Department and Environmental Research Institute, \\ University of Waikato, New Zealand \\ ${ }^{4}$ School of Mining Engineering, University of New South Wales, Sydney, NSW, \\ Australia and Australian Centre for Sustainable Mining Practices
}

In the current work a new method to extract and analyse pore water $\delta^{2} \mathrm{H}$ and $\mathrm{d}^{18} \mathrm{O}$ from drill core samples via $\mathrm{H}_{2} \mathrm{O}_{\text {(liquid) }}-\mathrm{H}_{2} \mathrm{O}_{\text {(vapour) }}$ equilibrium laser spectroscopy is presented. The method combines a $\mathrm{H}_{2} \mathrm{O}_{\text {(liquid) }}-\mathrm{H}_{2} \mathrm{O}_{\text {(vapour) }}$ equilibrium cell with a Los Gatos Research (LGR) cavity ring down mass spectrometer (CRDS) and follows and adaption of the original method presented by Wassenaar et al. (2008). Sediment and rock samples taken from a research site in New South Wales, Australia were first equilibrated in a fixed volume of dehumidified air and then directly sampled by the LGR mass spectrometer. Results provide clear evidence that the technique is repeatable and can be conducted on geologic media that contain volumetric water content as low as $5 \%$, with $\mathrm{H}_{2} \mathrm{O}_{\text {(liquid) }}-\mathrm{H}_{2} \mathrm{O}_{\text {(vapour) }}$ equilibrium occurring over time periods as short as 120 minutes. The faster sample analysis time and lower associated consumable and instrumentation costs of the method compared to conventional techniques for pore water extraction (centrifugation, squeezing, installation of monitoring bores, etc.) and analysis therefore presents great potential for field deployment, enabling hydrogeological profiling without the need to remove drill core samples from site.

\section{Reference}

Wassenaar, L.I., Hendry, M.J., Chostner, V.L. and Lis, G.P., High resolution pore water $\delta^{2} \mathrm{H}$ and $\delta^{18} \mathrm{O}$ measurements by $\mathrm{H}_{2} \mathrm{O}_{\text {(liquid) }}-\mathrm{H}_{2} \mathrm{O}_{\text {(vapour) }}$ equilibrium laser spectroscopy. Environ. Sci. Technol., 42, pp. 9262-9267, 2008. 


\title{
003 - ORIGIN OF NATURAL GAS-FED "ETERNAL FLAMES" IN THE NORTHERN APPALACHIAN BASIN, USA
}

\author{
Arndt Schimmelmann ${ }^{1}$ - Giuseppe Etiope $e^{2}$ - Agnieszka Drobniak ${ }^{3}$ \\ ${ }^{1}$ Department of Geological Sciences, Indiana University, Bloomington, Indiana, USA; \\ e-mail: aschimme@indiana.edu \\ ${ }^{2}$ Istituto Nazionale di Geofisica e Vulcanologia, Roma, Italy, and Faculty of Environmental \\ Science and Engineering, Babes-Bolyai University, Cluj-Napoca, Romania \\ ${ }^{3}$ Indiana Geological Survey, Indiana University, Bloomington, Indiana, USA
}

Natural hydrocarbon gas seeps are surface expressions of petroleum seepage systems, where gas ascends through faults and conduits from pressurized reservoirs that are typically associated with conventional reservoirs in sandstones or limestones. These rare natural gas seeps provide opportunities for direct sampling of gas from subsurface hydrocarbon accumulations without the need for drilling or other costly means of petroleum exploration.
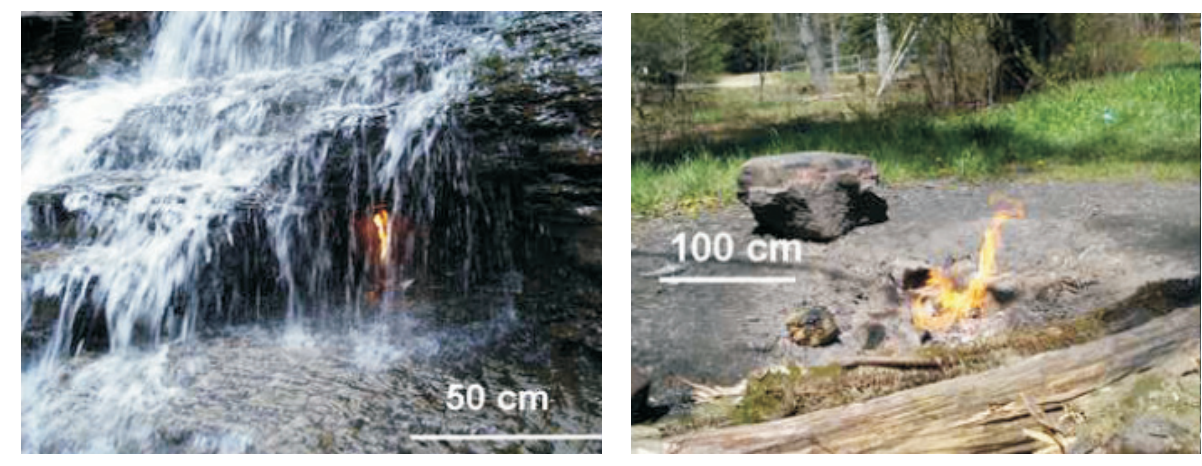

Figure 1. Eternal flames behind the veil of a waterfall in Chestnut Ridge County Park in New York State (left) and near Clarington in Pennsylvania (right)

We have documented a site in the northern Appalachian Basin, at Chestnut Ridge County Park, New York (Fig. 1, left), where gas seepage has supported a spectacular "eternal flame" throughout available recorded history, and which may have burnt naturally for many hundreds or even thousands of years. This remarkable flame marks a natural gas macroseep of dominantly thermogenic origin. Gas emanates directly from deep shale source rocks, probably the Rhinestreet Shale of the Upper Devonian West Falls Group, which makes this a rare case in contrast to most petroleum seepage systems where gas derives from conventional reservoirs.

The main flaming seep releases about $1 \mathrm{~kg}$ of methane per day and seems to feature the highest ethane and propane $\left(\mathrm{C}_{2}+\mathrm{C}_{3}\right)$ concentration ever reported for a natural gas seep ( $\sim 35$ vol. \%). The same gas is also released to the atmosphere from the ground through nearby invisible and diffuse seepages. The comparison of our chemical and 
stable isotope data with available gas-geochemical data of reservoir gases in the region and the stratigraphy of underlying shales suggests that the thermogenic gas originates from Upper Devonian shales without intermediation of a conventional reservoir (Fig. 2).

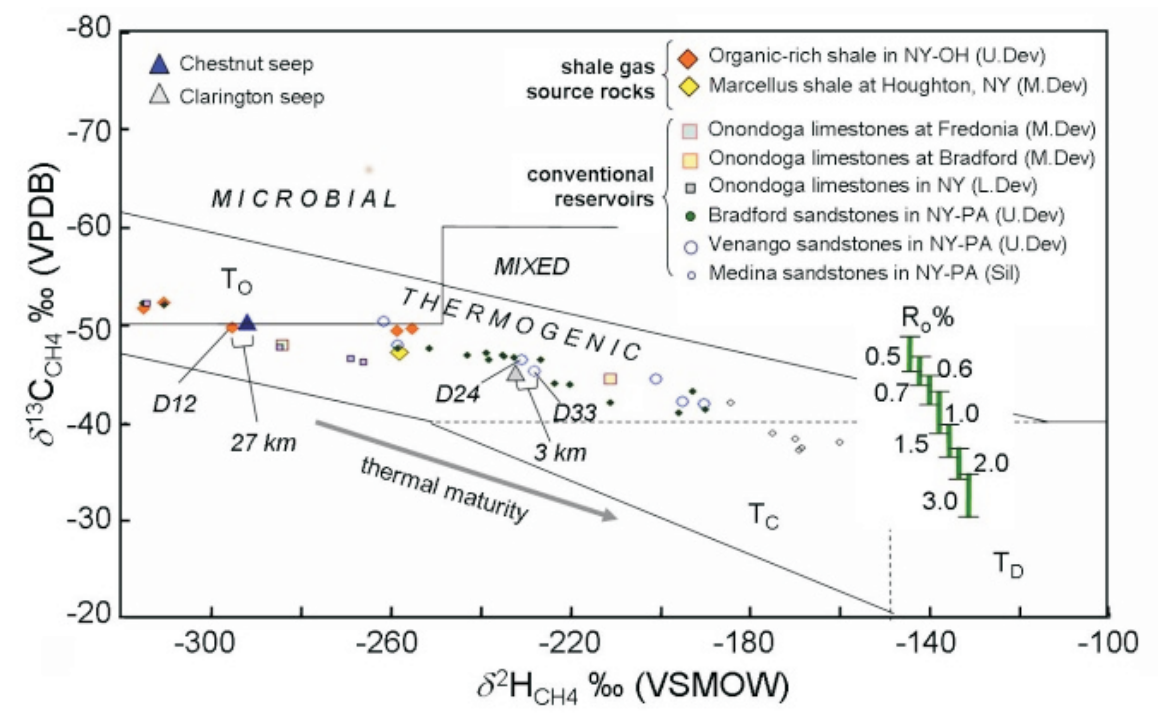

Figure 2. Isotopic composition of methane of seep gases from Chestnut Ridge County Park (New York State, $\boldsymbol{\Delta}$ ) and Clarington (Pennsylvania, $\triangle$ ) compared with published data on shale gases and conventional reservoir gases in the Northern Appalachian Basin. $\mathrm{T}_{\mathrm{O}}=$ thermogenic gas with oil; $T_{C}=$ thermogenic gas with condensate; $T_{D}=$ dry thermogenic gas; $R_{0}$ : vitrinite reflectance index; NY: New York; OH: Ohio; PA: Pennsylvania. Data sources cited in Etiope et al. (in press)

A burning seep near Clarington, Pennsylvania (Fig. 1, right), also releases thermogenic gas, but may not represent a natural seep. Instead, the gas likely derives from a conventional reservoir in Venango sandstone (Devonian) and is transmitted to the surface through an abandoned and improperly sealed gas or oil well.

\section{Reference}

1. Etiope, G., Drobniak, A. and Schimmelmann, A. (in press): Natural seepage of shale gas and the origin of "eternal flames" in the Northern Appalachian Basin, USA. Mar. Pet. Geol. http://dx.doi.org/10.1016/j.marpetgeo.2013.02.009. 


\title{
004 - APPORTIONING OF A THALLIUM CONTAMINATION TO THE EMITTER BY ITS STABLE ISOTOPE COMPOSITION
}

\author{
Michael Kersten ${ }^{1}$ - Katharina Kreissig ${ }^{2}$ - Mark Rehkämper ${ }^{2}$ \\ ${ }^{1}$ Geosciences Institute, Gutenberg-University, Mainz 55099, Germany; \\ e-mail: kersten@uni-mainz.de \\ ${ }^{2}$ Department of Earth Science and Engineering, Imperial College, London SW7 2AZ, UK
}

Thallium compounds are volatile at high temperature and not efficiently retained by emission control facilities of combustion sources. This study represents the first use of stable isotope ratios to apportion near-source $\mathrm{Tl}$ deposition to the emitter. In 1979, dust containing $\mathrm{Tl}$ was emitted by a cement plant near Lengerich, NW Germany. The emission event was caused by a ferric oxide additive used for the production of special cements, but which contained a Tl-bearing residue of pyrite roasting. Following the emission event, sheep died and rabbits and horses were reported to loose fur and hair in the vicinity of the cement plant [1]. Yet, the cement plant owners denied responsibility for the bulk of the emissions. We determined the $\mathrm{Tl}$ isotope composition $\left(\mathrm{e}^{205} \mathrm{Tl}\right)$ by a sophisticated methodology detailed elsewhere [2]. The $\mathrm{e}^{205} \mathrm{Tl}$ values of the cement dust (black symbol) and soil cores down to $100 \mathrm{~cm}$ depth (open symbols) are in accord with a two-source mixing line due to the high-T process emissions (Fig. 1). Our novel isotope analysis approach ultimately helped the plaintiffs to settle the case by showing the causation of the pollution event, even though the emissions happened more than 30 years ago.

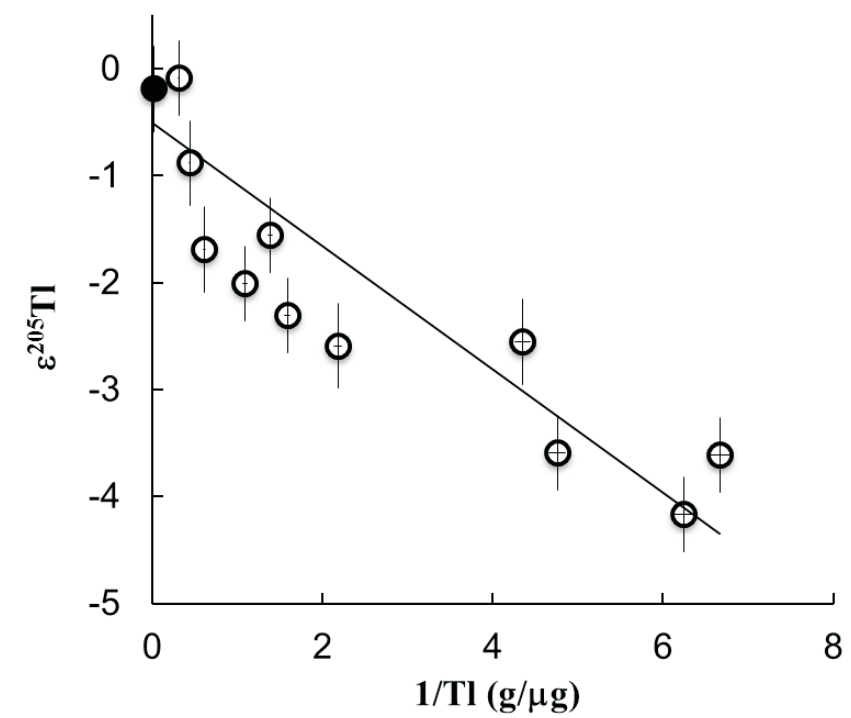

Figure 1. Tl stable isotope data vs. inverse concentrations for soil samples of increasing depth from left to right 


\title{
References
}

1. J. Schoer, Thallium. In: O. Hutzinger (ed.), Handbook of Environmental Chemistry, Vol. 3, Part C. Springer, New York, pp. 143-214, 1984.

2. M. Rehkämper and S.G. Nielsen, The mass balance of dissolved thallium in the oceans. Mar. Chem., 85, pp. 125-139, 2004.

\section{5 - SHRIMP FARM FEED: WHERE DOES THE CARBON GO?}

\author{
Leonel da Silveira Lobo Sternberg ${ }^{1}$ - Carlos Augusto Ramos e Silva ${ }^{2,3}$ \\ Pablo Bezerra Dávalos ${ }^{2}$ \\ ${ }^{1}$ Department of Biology, University of Miami, Coral Gables, Florida 33124, USA; \\ e-mail: leo@bio.miami.edu \\ ${ }^{2}$ Departamento de Oceanografia e Limnologia, Universidade Federal do Rio Grande do Norte, \\ Natal/RN, CEP 59075-970, Brazil; e-mails: caugusto@yahoo.com, pablobd@yahoo.com \\ ${ }^{3}$ Programa de Pós-Graduação em Dinâmica dos Oceanos e da Terra, Universidade Federal \\ Fluminense, Niterói/RJ, Caixa Postal: 106051, CEP: 24230-971, Brazil; \\ e-mail: caugusto_99@yahoo.com
}

Net profits from shrimp farming can run in billions of U.S. dollars with Thailand and China being the leading producers followed by other Asian and Latin American Countries. Feeding shrimp in intensive shrimp farms is one of the most expensive endeavours during the maintenance of the pond. Feed can vary in composition depending on the brand, some providing a mixture of ground fishmeal others providing terrestrial animal and plant proteins. In addition to causing a significant impact on wild fish stocks, use of feed promotes eutrophication and the ensuing anoxic conditions. The latter of which, makes it necessary to artificially aerate pond water by agitation with motor driven paddles. Further, the introduction of feed can promote viral, bacterial and fungal parasites in the shrimp population. We show here, with stable carbon isotope analysis, that adding organic feed to shrimp ponds, with its ensuing environmental problems, provides little if any carbon to shrimp biomass. Most of the carbon from the organic feed is deposited in the sediment and not available for consumption. Results of our findings suggest that intensive shrimp farmers should reconsider the use of organic feed and thereby mitigate some of the environmental problems associated with shrimp farming.

\section{References}

1. L.S.L. Sternberg and C.A. Ramos e Silva, Traçadores isotópicos. (In: Oceanografia Química. Interciência, Rio de Janeiro, Chapter 5, 2011, pp. 147-188.

2. C.A. Ramos e Silva, P.B. Dávalos, L.S.L. Sternberg, F.E.S. Souza, M.H.C. Spyrides and P.S. Lucio, The influence of shrimp farms organic waste management on chemical water quality. Estuarine, Coastal and Shelf Science, 90, pp. 55-60, 2010. 


\title{
006 - ANAEROBIC ACTIVITY OF NITRITE-OXIDIZING MICROORGANISMS AFFECTS THE $\delta^{18}$ O OF DISSOLVED NITRATE DURING MICROBIAL DENITRIFICATION
}

\author{
Anja Wunderlich ${ }^{1,2,3}$ - Rainer U. Meckenstock ${ }^{1}$ - Florian Einsiedl ${ }^{2}$ \\ ${ }^{1}$ Institute of Groundwater Ecology, Helmholtz Center Munich, Ingolstädter Landstraße 1, \\ Neuherberg, Germany \\ ${ }^{2}$ Technische Universität München, Chair of Hydrogeology, \\ Arcisstrasse 21, Munich, Germany \\ 3anja.wunderlich@tum.de
}

The stable isotopes of nitrate in water are frequently used to assess denitrification and determine the sources of nitrate in the environment. Nitrate reduction also is a process that eliminates organic contaminants from groundwater, so nitrate isotope analysis is also used to determine biodegradation [1]. It was originally assumed that a relative increase in $\delta^{18} \mathrm{O}$ of nitrate compared to its $\delta^{15} \mathrm{~N}\left(\Delta \delta^{18} \mathrm{O} / \Delta \delta^{15} \mathrm{~N}\right)$ of 0.5 is indicative of denitrification and thus also of biodegradation of contaminants with nitrate as $e^{-}$-acceptor. More recently this ratio was found to vary considerably while in incubations of pure cultures said ratio was consistently close to 1 (e.g. [2,3]). This potentially makes assessment of microbial nitrate reduction using this parameter unreliable.

To determine if an isotope exchange process could lead to these variations, we anaerobically incubated sediments with natural microbial populations from 3 different anoxic, denitrifying habitats in strongly ${ }^{18} \mathrm{O}$-labeled site-water with the addition of nitrate and adequate electron donors. In a second experiment we incubated a pure culture of the nitrite oxidizing bacterium Nitrobacter vulgaris under similar conditions. A significant influence of $\delta^{18} \mathrm{O}$ of water on the $\delta^{18} \mathrm{O}$ of nitrate was found in all experiments (Fig. 1). All incubations also clearly expressed microbial denitrification. Given oxic conditions, the microbial populations of all incubations were also able to oxidize nitrite.

As nitrite oxidizers catalyze the observed isotopic shift in the incubations of pure cultures, they are likely also the driving parameter of the observed shift in the environmental incubations. This shift fundamentally questions the stability of predicted $\Delta \delta^{18} \mathrm{O} / \Delta \delta^{15} \mathrm{~N}$ ratios in the environment during denitrification. Such a shift in $\delta^{18} \mathrm{O}$ of nitrate under anoxic conditions also questions the validity of nitrate source determination by $2 \mathrm{D}$ isotopic fingerprinting, specifically in respect to the $\delta^{18} \mathrm{O}$-axis.

Nitrite oxidizing microorganisms possess a nitrite oxidoreductase enzyme (NXR) which is able to oxidize nitrite as well as reduce nitrate, depending on the redox conditions [4]. Regular denitrifiers possess a nitrate reductase (Nar) which only reduces nitrate irreversibly $[3,5]$. We hypothesize that the nitrate reduction reaction at the NXR enzyme by nitrite oxidizing microorganisms is reversible even under anoxic conditions, allowing the incorporation of oxygen-atoms from water into nitrate. 


$$
\mathrm{NO}_{3}^{-}+2 \mathrm{H}^{+} \leftrightarrow \mathrm{NO}_{2}^{-}+\mathrm{H}_{2} \mathrm{O}
$$

It is likely that a variable activity of nitrite oxidizers in anoxic environments produces a variable shift of $\delta^{18} \mathrm{O}$ of nitrate and thus varied ratios of $\Delta \delta^{18} \mathrm{O} / \Delta \delta^{15} \mathrm{~N}$. We conclude that $\delta^{18} \mathrm{O}$ of nitrate is not a reliable parameter for the assessment of biodegradation processes, and a presence or absence of a fractionation in $\delta^{18} \mathrm{O}$ does not necessarily confirm or exclude denitrification and concurrent biodegradation of organic contaminants.
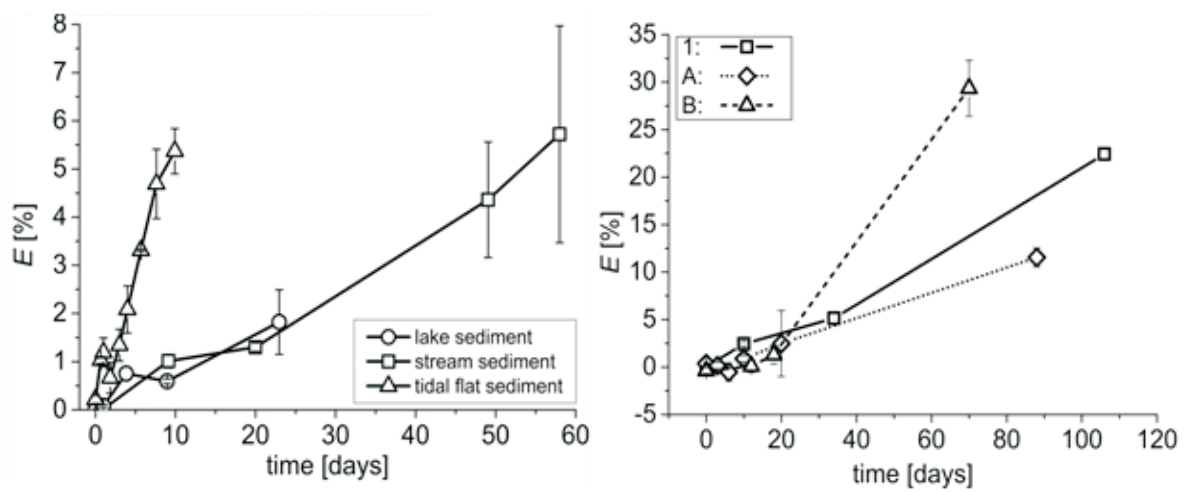

Figure 1. Calculated percentage of oxygen atoms from ambient water that was incorporated into dissolved nitrate under anoxic conditions. This process was concurrent with microbial denitrification. Data on the left is from sediment incubations of three different anoxic environments.

Data from the right is from three pure cultures of Nitrobacter vulgaris

\section{References}

1. P.B. Hatzinger, J.K. Böhlke, N.C. Sturchio, B. Gu, L.J. Heraty and R.C. Borden, Fractionation of stable isotopes in perchlorate and nitrate during in situ biodegradation in a sandy aquifer. Environ. Chem., 6(1), pp. 44-52, 2009.

2. J. Granger, D.M. Sigman, M.F. Lehmann and P.D. Tortell, Nitrogen and oxygen isotope fractionation during dissimilatory nitrate reduction by denitrifying bacteria. Limnol. Oceanogr., 53(6), pp. 2533-2545, 2008.

3. A. Wunderlich, R.U. Meckenstock and F. Einsiedl, Effect of different carbon substrates on nitrate stable isotope fractionation during microbial denitrification. Environ. Sci. Technol., 46(9), pp. 4861-4868, 2012.

4. S.H. Friedman, W. Massefski Jr, and T.C. Hollocher, Catalysis of intermolecular oxygen atom transfer by nitrite dehydrogenase of Nitrobacter agilis. J. Biol. Chem., 261(23), pp. 10538, 1986.

5. K. Knöller, C. Vogt, M. Haupt, S. Feisthauer and H.-H. Richnow, Experimental investigation of nitrogen and oxygen isotope fractionation in nitrate and nitrite during denitrification. Biogeochemistry, 103(1), pp. 371-384, 2011. 
AIG10 - 2013

\title{
007 - SULFUR ISOTOPE COMPOSITIONS FROM DIFFERENT TYPE OF DEPOSITS IN THE BUCHIM-DAMJAN-BOROV DOL ORE DISTRICT, EASTERN MACEDONIA
}

\author{
Todor Serafimovski - Goran Tasev \\ Department of Ore Deposits, Faculty of Natural and Technical Sciences, University \\ "GoceDelcev", Goce Delcev 89, 2000 Stip, R. Macedonia; \\ e-mail: todor.serafimovski@ugd.edu.mk
}

For, at least in part, determination of the origin of metals and sulfur in the ore district Buchim-Damjan-Borov Dol we made a series of complex research and analysis of the light isotope $\left({ }^{32} \mathrm{~S}\right)$, heavy isotope $\left({ }^{34} \mathrm{~S}\right)$, and their isotopic ratio $\left(\delta^{34} \mathrm{~S}\right)$. In three deposits of the Buchim-Damjan-Borov ore district were sampled mostly pyrites from the hydrothermal range $250-350^{\circ} \mathrm{C}$ (from each ore body mineral parageneses). For the porphyry copper ore deposits Buchim isotopic ratio values ranged from 0 to $+2.09 \%$ averaging $+0.982 \%$, while the Borov Dol values have shown wider range starting from -7.25 up to $+0.72 \%$ averaging $-2.238 \%$, due to enrichment with lighter sulfur isotope. Sulfur isotopic ratios for the Damjan Fe-skarn deposit have shown relative enrichment with heavy sulfur isotope resulting in value range of +1.75 up to $+8.68 \%$ o averaging $+5.248 \%$.

\section{Introduction}

The Buchim-Damjan-Borov Dol ore district has been situated $15 \mathrm{~km}$ north-western from the city of Radoviš, Eastern Macedonia. This ore district is one of the most important in the country in regards of copper and iron deposits. Production of iron from the Fe-skarn deposit Damjan lasted from 1962 until 1992, the production of copper from the Buchim copper porphyry deposit started in 1979 and continues today as well, while the copper Borov Dol is at the stage of preparations for start of production. Sulfur isotope composition of sulfide minerals from the deposits in the Buchim-DamjanBorov Dol ore district up to date have been studied by Serafimovski (1993), Serafimovski and Tasev (2005), etc. Analyses of sulfur isotope composition have been performed mainly on pyrite, rarely chalcopyrite and occasionally on galena (Borov Dol). This paper summarizes our latest findings concerning sulfur isotope composition of sulfide minerals from deposits in the aforementioned ore district.

\section{Geological setting}

The Buchim-Damjan-Borov Dol ore district has been defined as an individual metallogenic unit on the basis of the regional and local factors of metallogenetic control. Spatially, this ore district lies in two large geotectonic units (SMM and the Vardar zone), but metallogenetically it is part of the Lece-Chalkidiki metallogenetic zone (Serafimovski, 1993). The metallogeny of this ore district is directly related to the Tertiary intermediary calc-alkaline magmatism, which on today's erosion level has been 
represented by subvolcanic-volcanic facies of andesite, latite, quartz-latite, trachyte, trachy-rhyolite, etc. The endogene mineralization of $\mathrm{Fe}, \mathrm{Cu}, \mathrm{Au}, \mathrm{Pb}-\mathrm{Zn}$ is related to this volcanogeno intrusive formation, genetically and spatially controlled by fault structures with NW-SE, NNW-SSE, NE-SW striking and at the places of their junctions and intersections. The endogene mineralization cycle in this area is related to the young Alpine metallogenetic epoch. Spatially, the deposits belong to two geotectonic blocks (the Buchim block and Damjan block), whereas genetically and paragenetically are related to the disjunctive structures and the Tertiary magmatism. The volcanic activity started by the end of Oligocene, while the ore mineralization took place during Miocene. Significant skarn type iron deposits, porphyry copper-gold deposits accompanied, locally, by hydrothermal vein type $\mathrm{Pb}-\mathrm{Zn}$, Ba mineralization, are dominant in this ore district. Generally, the ore mineralization was concentrated in three ore deposits: Buchim, Borov Dol (Cu-porphyry deposits) and Damjan (Fe-skarn deposit) .

\section{Analytical methods}

Within this study were analyzed pyrite, chalcopyrite and galena samples from the Buchim, Borov Dol and pyrites from the Damjan deposit (34 samples in total). The analyses were performed at the analytical facilities of the Geology Department at the Royal Holloway, University of London. The Fisons Instruments "Isochrom-EA" system used here consists of an elemental analyzer (EA1500 series 2), on line to an Optima mass spectrometer operating in continuous flow mode (Grassineau et al., 2001). Measured sulfur contents are within $1-1.5 \%$ of expected values and the reproducibility of $\delta^{34} \mathrm{~S}$ values is $(0.1 \%$ o $(1 \sigma)$.

\section{Results and Discussion}

Three ore were subject for study of sulfur isotope ratios in major sulfide minerals within the Buchim-Damjan-Borov Dol ore district. Two of them are Cu-porphyry copper deposits (Buchim and Borov Dol) while the third one is Fe-skarn deposit (Damjan) that is localized on the central parts of the district. The results and discussion are shown separately for each deposit. The Figure 1 shows the variation diagram of the isotopic composition of sulfur $\left(\delta^{34} \mathrm{~S}\right)$ in individual deposits in the Republic of Macedonia and the southwestern parts of North America (Cooke, 1983; Anderson et al., 2001) and as can be seen, Buchim and Borov Dol porphyry Cu-deposits show quite compatible range with for example Mariquita deposit (Salas et al., 2013). Also, the Damjan Fe-skarn deposit sulfur isotope ratios does not differ much from similar deposits elsewhere, Nifty (Cooke, 1983). According to the histogram illustration and comparative graphic analysis shown at Figure 1 it can be concluded that all of the three deposits from the Buchim-Damjan-Borov Dol ore district show sulfur isotope ratio values within range $-7.58-+8.68 \%$, which confirms that sulfur in studied minerals is of endogene origin and does not exceeds limit values of $-10-+10 \%$ (Ohmoto and Rye, 1979; Shimazaki and Sakai, 1984). Data show that sulfur, and probably the ore metals 

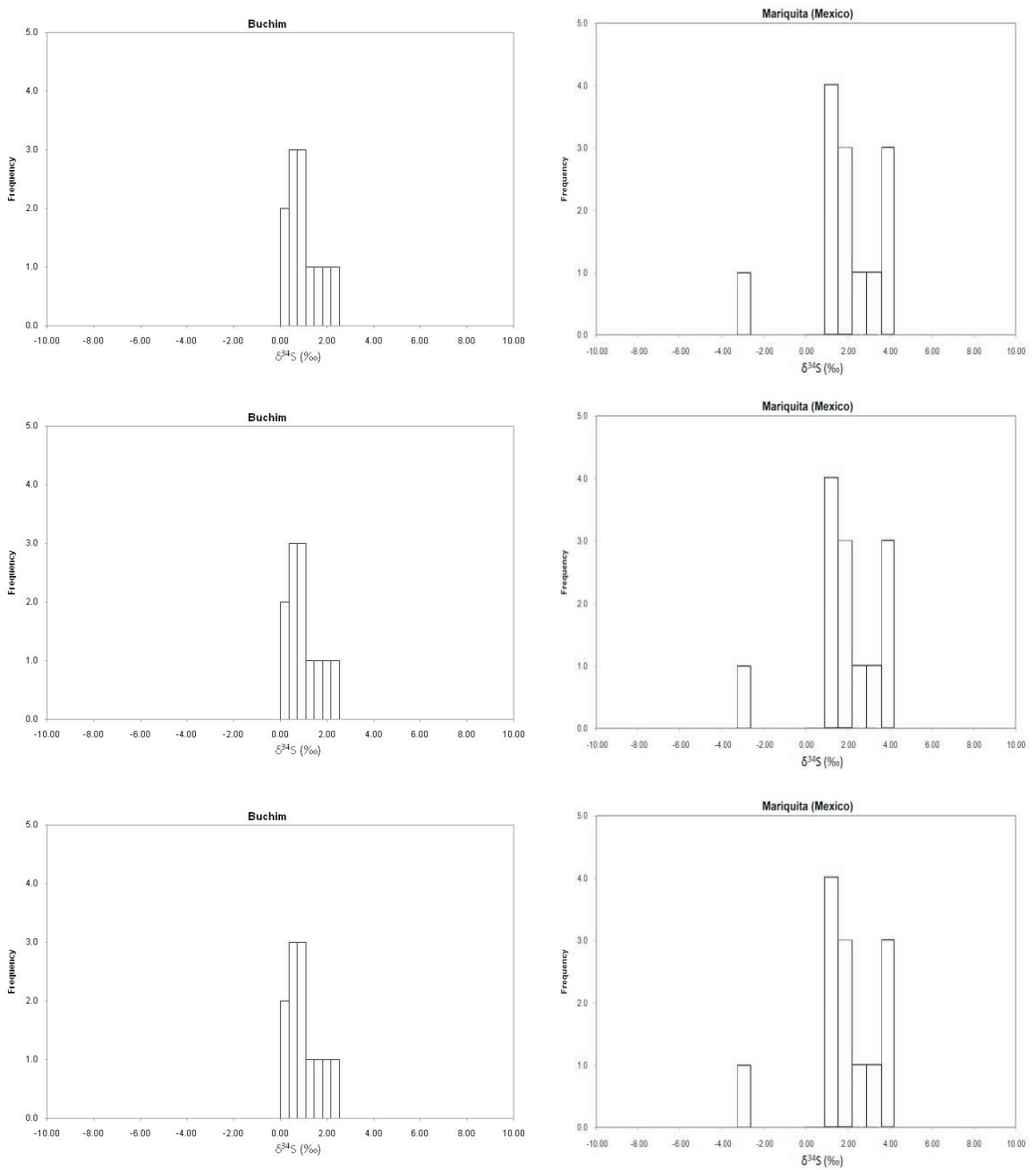

Figure 1. Histograms of distribution frequency for $\delta^{34} \mathrm{~S}$ in the studied and compared deposits a) Buchim porphyry copper deposit; b) Borov Dol porphyry copper deposit; c) Damjan Fe-skarn deposit; d) Mariquita porhyry copper deposit and e) Nifty Cu-skarn deposit

in the deposit as well, are of primary origin and sulfur sources are related to the deep parts of the Earth's crust or the bordering area between the continental crust and the upper mantle. The range of $\delta^{34} \mathrm{~S}$ values is close to values characteristic for magmatic sulfur, $0 \%{ }_{0} \pm 5 \%{ }_{0} \delta^{34} \mathrm{~S}$ (Field and Gustafson 1976; Ohmoto and Rye 1979; Shelton and Rye 1982; Weihed and Fallick 1994). However we do not want to overlook fact that magmatic fluids assimilated one small fraction of sulfur from adjacent rocks (Ohmoto and Goldhaber, 1997). Determined range of $\delta^{34} \mathrm{~S}$ values in sulfide minerals from the 
Buchim and Borov Dol deposits is representative for ore-bearing parts in granitic composition rocks, as it was mentioned elsewhere (Douglas et al., 2003) and porphyry $\mathrm{Cu}$ \pm Mo deposits.

Bearing in mind that the majority of sulfur isotope ratios for the Buchim and Borov Dol ranged -3.02 to $+2.53 \%$, indicates that the source of sulfur for both deposits is clearly magmatic (Salas et al., 2013). Sulfur deposited at high temperatures should show less fractionation between minerals than that deposited at low temperatures (Brownlow, 1996). However, it is possible that one small fraction, of slightly increased positive values of $\delta^{34} \mathrm{~S}$ in particular parts of the studied area are due to increased influence of sulfur from meteoritic waters (Bi et al., 2004; Ohmoto and Rye, 1979). This is especially accented in oxidation and secondary enrichment zones where due to direct connection of meteoritic waters with magmatic ones resulted in sulfur fractionation and occurred enrichment of heavy $\mathrm{S}$ isotope. However, narrow range of values and local presence of pyrrhotite suggests homogenous source and reduction ore-bearing fluid with sulfide domination that corresponds with claims of Ohmoto and Rye (1979).

The most consistent values of sulfur isotope ratios has been determined in studied minerals from the Buchim deposit $\left(+0.16-2.53 \% 0 \delta^{34} \mathrm{~S}\right)$, which beside other factors probably is due to movement of ore-bearing fluids through the homogeneous stratigraphic sequences of the Serbo-Macedonian mass' crystalline.

For the Borov Dol Cu-porphyry deposit has been evident existence of sulfur fractionation and enrichment with lighter sulfur isotope $\left(-7.52\right.$ to $\left.+0.72 \%{ }^{34} \mathrm{~S}\right)$, especially within galena that in the particular mineral assemblage came the latest at temperatures lower than $200^{\circ} \mathrm{C}$.

The Damjan Fe-skarn deposit has been characterized by relatively increased positive values of $\delta^{34} \mathrm{~S}(+1.75$ to +8.68 , Table 3, Fig. 2), which points out to sulfur fractionation and subsequent enrichment with heavier sulfur isotope. According to ours aforementioned explanation, beside that the ore-bearing solutions passed through the different lithological units (marls, limestone, clays, skarns etc.), here once again we would like to point out that sulfur isotope composition has been studied in pyrites from the latest stage of the ore-bearing process (Serafimovski, 1982). They are morphologically almost ideal (typical hexahedra), very large $(2-3 \mathrm{~cm})$ and exhibit zonal internal composition, which points out to the fact that they have crystallized from gel mixtures at far lower temperatures compared to the major iron ore minerals in the Damjan deposit, magnetite and hematite (Zarić, 1977).

\section{Conclusion}

The studies of sulfur isotope composition, in three copper and iron deposits of porphyry and skarn genetic type in the Republic of Macedonia, have shown that the narrowest range of sulfur stable isotope values were determined with study of ore samples from the Buchim $\mathrm{Cu}$-porphyry deposit $\left(+0.16-2.53 \% 0 \delta^{34} \mathrm{~S}\right)$, which coincides with 
values determined in similar deposits elsewhere in the World. Studies of sulfur stable isotope ratio ranging $-7.52-0.72 \% 0 \delta^{34} \mathrm{~S}$ in Borov Dol Cu-porphyry deposit have shown emphasized sulfur fractionation and change of its primary composition followed by enrichment with lighter sulfur, as a result of lithostratigraphic setting (ophiolite melange, Creataceous sediments, volcanic rocks) where have passed orebearing fluids. The sulfur isotope composition in the Damjan Fe-skarn deposit varies from +4.02 up to to $+8.68 \%$ and shows tendency of fractionation and enrichment with heavier sulfur, which is similar to data shown elsewhere (Shimazaki and Sakai, 1984). To the change of primary sulfur contributed ore deposition setting (carbonates, skarns, flysch sediments) as well as deposition of coarse grained pyrites during the later low-temperature mineralization stage.

\section{References}

1. Anderson, R.B., Gemmell, J.B. and Berry, F.R. 2001. The Geology of the Nifty Copper Deposit, Throssell Group, Western Australia: Implications for Ore Genesis. Economic Geology, 96, pp. $1535-1565$.

2. Bi, X., Hu, R. and Cornell, D.H. 2004. The alkaline porhyry associated Yao'an gold deposit, Yunnan, China: rare earth element and stable isotope evidence for magmatic-hydrothermal ore formation. Mineralium Deposita, 39, pp. 21-30.

3. Cooke, J.B. 1983. Geology, mineral equilibria, sulfur, rubidium-strontium and lead isotopes and intrusion chemistry of the McDame tungsten skarn prospect, North Central British Columbia. Master thesis, The Universityof British Columbia Dept. Geol. Sci., 63 pp.

4. Douglas, T.A., Chamberlain, C.P., Poage, M.A., Abruzzese, M., Shultz, S., Henneberry, J. and Layer, P. 2003. Fluid flow and the Heart Mountain fault: A stable isotopic, fluid inclusion, and geochronologic study. Geofluids 3(1), pp. 13-32.

5. Field, C.W. and Gustafson, L.B., 1976. Sulfur isotopes in the porphyry copper deposit at El Salvador, Chile. Econ. Geol. 71, pp. 1533-1548.

6. Grassineau, V.N., Mattey, P.D. and Lowry, D., 2001. Sulfur Isotope analysis of sulfide and sulfate minerals by continuous flow-isotope ratio mass spectrometry. Analytical Chemistry, 73(2), pp. 220-225.

7. Ohmoto, H. and Goldhaber, B.M. 1997. Sulfur and carbon isotopes. In: Geochemistry of hydrothermal ore deposits. Ed. Hubert Lloyd Barnes, 3rd edn. Wiley \& Sons, Inc., 972 pp.

8. Ohmoto, H. and Rye, R.O. 1979. Isotopes of sulfur and carbon. In: Geochemistry of hydrothermal ore deposits, Ed. H.L. Barnes, 2nd edn. Wiley \& Sons, Inc., pp. 509-567.

9. Salas, R.D.R, Ochoa-Landín, L., Ruiz, J., Eastoe, C., Meza-Figueroa, D., Zuñiga-Hernández, H., Mendívil-Quijada, H. and Quintanar-Ruiz, F. 2013. Geology, stable isotope, and U-Pb geochronology of the Mariquita porphyry copper and Lucy Cu-Mo deposits, Cananea District, Mexico: A contribution to regional exploration. Journal of Geochemical Exploration, 124, 2013, pp. $140-154$.

10. Serafimovski,T.1982: Metalogenetske karakteristike skarnovskog Fe-lezista Damjan. Magistarska teza, RGF-Beograd, Beograd.

11. Serafimovski, T.1993: Structural-metallogenetic Features of the Lece-Chakidiki Zone: Types of Mineral Deposits and Distribution. Faculty of Mining and Geology, Geological Department, Special Issue No. 2, p. 328, Stip.

12. Serafimovski, T. and Tasev, G. 2005: Sulfur isotope composition of some polymetalic deposits in the Republic of Macedonia. Geologica Macedonica, Stip, 19, pp. 1-11. 
13. Shelton, K.L. and Rye, D.M. 1982. Sulfur isotope compositions of ore from Mines Gaspe, Quebec: An example of sulfate-sulfide isotopic disequilibria in ore-forming fluids with applications to other porphyry-type deposits. Economic Geology, 77, pp. 1688-1709.

14. Shimazaki, H. and Sakai, H. 1984. Regional Variation of Sulfur Isotopic Composition of Skarn Deposits in the Westernmost Part ofthe Inner Zone of Southwest Japan. Mining Geology, 34(6), pp. 419-424.

15. Weihed, P. and Fallick, A.E. 1994. A stable isotope study of the Palaeoproterozoic Tallberg porphyry-type deposit, northern Sweden. Mineralium Deposita, 29(2), pp. 128-138.

16. Zarić, P. 1977. Typomorph metallogenetic features of magnetites in Yugoslavia. Doctoral thesis, Faculty of Mining and Geology, Belgrade, 287 pp. (in Serbian)

\title{
008 - LEAD ISOTOPES AS TRACER FOR LAND USE POLLUTION IN SOILS AND SEDIMENTS OF TWO DIFFERENT WATERSHEDS
}

\author{
Rawaa Ammar ${ }^{1,2}$ - Véronique Kazpard ${ }^{1}$ - Nabil Amacha ${ }^{3}$ - Bruno Lartiges $^{4}$ - \\ Zeinab Saad ${ }^{1}$ - Lei Chou ${ }^{2}$ \\ ${ }^{1}$ Research and analysis Platform for Environmental Science, Doctoral School of Science and \\ Technology, Faculty of Sciences, Lebanese University, P.O. Box 5, \\ Campus Rafic Hariri-Beirut-Lebanon; e-mail: Rawaa.ammar@ulb.ac.be \\ ${ }^{2}$ Service de Biogéochimie et Modélisation du Système Terre Département des Sciences de la \\ Terre et de 1'Environnement. Université Libre de Bruxelles, Campus de la Plaine, \\ CP 208 Boulevard du Triomphe, B-1050 Bruxelles-Belgium \\ ${ }^{3}$ Litani River Authority, Beirut, Lebanon \\ ${ }^{4}$ Laboratory of Géosciences Environnement, Université Paul Sabatier, Toulouse, France
}

Lebanon shows an important advancement in both agricultural and industrial sectors during the last 30 years. However, the untreated wastes from industrial and agricultural practices are rejected to the terrestrial and aquatic environment. The waste of the 288 local industries along the Litani basin and the fertilizer factory on the Levantine basin are enriched by $\mathrm{Pb}$, thus we chose stable $\mathrm{Pb}$ isotopes to originate pollution source and detect contamination level in this geochemical research due to its precision and specificity. Stable $\mathrm{Pb}$ isotopic ratios ${ }^{204} \mathrm{~Pb},{ }^{206} \mathrm{~Pb},{ }^{207} \mathrm{~Pb}$, and ${ }^{208} \mathrm{~Pb}$ in two different watersheds in Lebanon were analyzed for soil and sediments. Samples were collected from both costal industrial area and inland agricultural water catchments. In the industrial area, data show a clear mixing line between 2 sources: natural bed rock and contaminated fuel and aerosol, by which samples in the vicinity of the factory are more contaminated $[1,2]$. The high $\mathrm{Pb}^{206} / \mathrm{Pb}^{207}$ ratio (mean ratio of the costal marine sediment is 1.81) is due to the fact that $\mathrm{Pb}$ is a daughter element of decayed uranium [3], which is originated from apatite rocks used as row material in the manufacturing process. $\mathrm{Pb}$ Isotopic ratios in the agricultural area vary in the sediments collected from the reservoir spatially and seasonally, by which it divides the reservoir into 3 zones (river inlet, central and dam zone). We observe a clear mixing line between sediments in the reservoir by which river inlet brought more anthropogenic contaminated sediments and the first flush wash out the dissolved solids from the upper basin. Particulate $\mathrm{Ca}$ 
shows a positive correlation with $\mathrm{Pb}$ isotopes in the reservoir that indicates the dominance of natural weathering and rock cutting activities in the basin [4].The main pollutant source in the industrial area is the fertilizer factory implemented on the Mediterranean coast, while in the agricultural area it is a mixture of contaminants deriving from farming, urbanization (waste incineration) and industrial activities carried by the river to the dam lake.

\title{
References
}

1. C. Abi-Ghanem, J.F. Chiffoleau, A. Bermond, K. Nakhlé, G. Khalaf, D. Borschneck and D. Cossa. Lead and its isotopes in the sediment of three sites on the Lebanese coast: Identification of contamination sources and mobility, Applied Geochemistry, 24, pp. 1990-1999, 1999.

2. Y. Erel and J. Torrent. Contribution of Saharan dust to Mediterranean soils assessed by sequential extraction and $\mathrm{Pb}$ and $\mathrm{Sr}$ isotopes. Chemical Geology, 275, pp. 19-25, 2010.

3. W.C. Burnett, P. Chin, S. Deetae and P. Panik. Release of Radium and other decay-series isotopes from Florida Phosphate rock. Florida Institute of Phosphate Research, publication No. 05-016-059, 2009.

4. J.M. Luck and D.B. Othman. Geochemistry and water dynamics. II. Trace metals and $\mathrm{Pb}-\mathrm{Sr}$ isotopes as tracers of water movements and erosion processes. Chem. Geol., 150, pp. 263-282, 1998.

\section{9 - THE ISOTOPIC COMPOSITION OF THE ICE, WATER AND CONDENSATE SODA LAKE DORONINSKOE (EASTERN TRANSBAIKALIA, RUSSIA) DUE TO THE FORMARION OF SALT DEPOSITS ON THE SURFACE OF ITS ICE COVER}

\author{
Leonid V. Zamana
}

Institute of Natural Resources, Ecology and Cryology of Siberian Branch of RAS, 16 Nedorezova st., Chita, Russia; e-mail:1.v.zamana@mail.ru

On the ice surface Doroninskoe meromictic soda lake in Eastern Transbaikalia $\left(51^{\circ} 14^{\prime} 08^{\prime \prime} \mathrm{N}, 112^{\circ} 13^{\prime} 59^{\prime \prime} \mathrm{E}\right.$, Altitude $780 \mathrm{~m}$ asl) is often at the beginning of winter in the snow-free period is deposited salt, the formation of which researchers explain the evaporation of the ice. As observations on putting labels, the ice at this time does not evaporate (daytime temperature $-15-25^{\circ} \mathrm{C}$, the night before the $-30-35^{\circ} \mathrm{C}$ ), a slight evaporation it is only possible in the spring (March-April). To clarify the possible nature of the salt deposits we have studied the isotopic composition of lake water, ice, condensate (frost) and dropped out of the lake snow. The sampling carried out in February and April 2011. Condensate collected at a height of $15 \mathrm{~cm}$ above the surface of the ice in insulated from outside air traps from plastic film. Clouding of the film due condensation occurs immediately after installing traps. In trap for overriding ice film moisture not condensed.

The isotopes were measured at the Analitical Center, Far East Geological Institute, Far East Division of RAS on a Finnigan-MAT 252 mass spectrometer (Germany). An intralaboratory standard calibrated using the international standards 
Table. Isotopic composition of liquid and solid aquatic phases of lake Doroninskoe

\begin{tabular}{|c|c|c|c|c|c|c|}
\hline \multicolumn{2}{|c|}{$\begin{array}{l}\text { Date The type and location } \\
\text { sampling of sampling }\end{array}$} & \multirow{2}{*}{$\begin{array}{l}\mathrm{pH} \\
9.86\end{array}$} & \multirow{2}{*}{$\begin{array}{l}\text { TDS, } \\
\mathrm{mg} / 1\end{array}$} & \multirow{2}{*}{$\begin{array}{c}\delta^{18} \mathrm{O}_{\text {SMOW }}, \% 0 \\
-25.7\end{array}$} & \multirow{2}{*}{$\begin{array}{l}\delta \mathrm{D}_{\mathrm{SMOW}}, \% 0 \\
-205.8\end{array}$} & \multirow{2}{*}{$\frac{\mathrm{d}_{\mathrm{exc}} \% 0}{-0.2}$} \\
\hline 02.21 & Snow on ice surface & & & & & \\
\hline 02.03 & Condensate & 7.94 & 37.7 & $7 \quad-6.7$ & -62.5 & -8.9 \\
\hline 02.21 & - & - & - & -3.9 & -51.8 & -20.6 \\
\hline 02.21 & Ice, interval $0-10 \mathrm{~cm}$ & 10.02 & 3836 & -1.3 & -35.7 & -25.3 \\
\hline 02.21 & $30-40 \mathrm{~cm}$ & 10.09 & 6075 & -1.6 & -36.8 & -24.0 \\
\hline 02.21 & $60-70 \mathrm{~cm}$ & 10.08 & 6083 & -1.5 & -35.4 & -23.4 \\
\hline 02.21 & $90-100 \mathrm{~cm}$ & 10.11 & 5435 & -2.2 & -40.2 & -22.6 \\
\hline 02.21 & $110-120 \mathrm{~cm}$ & 10.08 & 3211 & -2.3 & -43.3 & -24.9 \\
\hline 02.21 & Water, deep $0.1 \mathrm{~m}$ (in hole) & 10.02 & 31966 & -5.9 & -57.4 & -10.2 \\
\hline 04.02 & Water, deep $0.1 \mathrm{~m}$ (in hole) & 9.81 & 34564 & -6.6 & -66.3 & -13.5 \\
\hline 02.21 & deep $2.0 \mathrm{~m}$ & 9.97 & 33492 & -6.6 & -58.3 & -5.5 \\
\hline 02.21 & deep $3.0 \mathrm{~m}$ & 9.97 & 33389 & -6.4 & -55.6 & -4.4 \\
\hline 04.02 & deep $3.0 \mathrm{~m}$ & 9.82 & 35422 & -6.0 & -64.6 & -16.6 \\
\hline 02.21 & deep $4.0 \mathrm{~m}$ & 9.99 & 33715 & -4.7 & -54.7 & -17.1 \\
\hline 02.21 & deep $5.0 \mathrm{~m}$ & 9.99 & 33926 & -6.1 & -53.4 & -4.6 \\
\hline 04.02 & deep $5.0 \mathrm{~m}$ & 9.82 & 35331 & -6.1 & -65.7 & -16.9 \\
\hline 02.21 & deep $5.2 \mathrm{~m}$ & - & - & -6.2 & -54.5 & -4.9 \\
\hline
\end{tabular}

VSMOW, SLAP, and GISP was used for analysis. The error was $\pm 0.15 \%$ and $1.2 \%$ for oxygen and hydrogen, respectively [1].

The lake is located in the semi-arid zone, drainless, its depth is up to $6.0 \mathrm{~m}$, the water area is nearly $5 \mathrm{~km}^{2}$. The average annual precipitation in region around $340 \mathrm{~mm}$, the evaporation from the water surface is estimated to be $450-500 \mathrm{~mm}$. Lake situated in the intermountain basins filled with terrigenous sediments of Mesozoic. Salinity by season and annual dynamics fluctuated in the last decade ranges $15.8-36.2 \mathrm{~g} / \mathrm{l}$ in the upper layer and 28.0-35.5 g/l - in the lower. She is due to evaporative concentration and composition of the water-mainly of sulfate reduction [2]. In winter the salinity of water column may become even because of ice demineralization, TDS that does not exceed $20 \%$ of the water salinity (table).

Factor of isotope fractionation between ice and water in deuterium is less than 1.0202, which is within the experimental values [3]. Oxygen-18 for the bottom layer of ice to the average values for the top layer of water it above these values, reaching 1.0041. Ratio between isotopes is characterized by high deuterium excess, which is determined by a more intense shift in oxygen with respect to the GMWL (Fig.) normal to the evaporation basins. The isotopic composition showed that the condensate corresponds more the under ice water than ice.

The received isotopic data is regarded as proof, firstly, through the possible migration of the under ice water due to lack of vapor saturation of air above the surface, and, secondly, salt deposits due to evaporation of this water. 


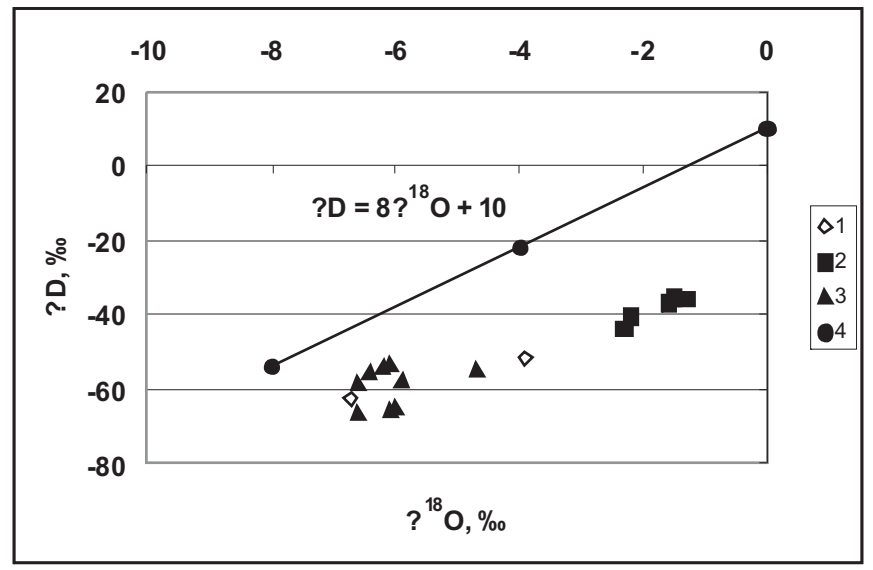

Figure. Legend: 1 - condensate; 2 - ice; 3 - water; 4 - GMWL (Global Meteoritic Water Line)

\title{
References
}

1. L.V. Zamana, Isotopes of Hydrogen and Oxygen in Nitrogen Hot Springs of Baikal Rift Zone in Terms of Interaction in the Water-Rock System. Dokl. Earth Sci., 442(1), pp. 81-85, 2012. DOI: $10.1134 /$ S1028334X12010114.

2. L.V. Zamana and S.V. Borzenko, Hydrogen Sulfide and Other Reduced Forms of Sulfur in Oxic Waters of Lake Doroninskoe, Eastern Transbaikalia. Dokl. Earth Sci. 417(8), pp. 1268-1271, 2007. DOI: 10.1134/S1028334X070803.

3. M. Lehmann, U. Siegenthaler, Equilibrium oxygen- and hydrogen-isotope fractionation between ice and water. J. Glaciol., 38(125), pp. 23-26, 1991.

\section{0 - HYDROCARBON GASES IN MARINE SEDIMENTS OF THE NEW JERSEY SHALLOW SHELF}

\author{
Susanne Stadler ${ }^{1}$ - Robert van Geldern ${ }^{2}$ - Stefan Schloemer ${ }^{1}$
}

${ }^{1}$ Federal Institute for Geosciences and Natural Resources, 30655 Hanover, Germany; e-mail: s.schloemer@bgr.de

${ }^{2}$ GeoZentrum Nordbayern, Schlossgarten 5, FAU Erlangen-Nuremberg, 91054 Erlangen, Germany

Three cores (M0027A, M0028A and M0029A) were recovered during IODP Expedition 313 that targeted Miocene sedimentary sequences up to $67 \mathrm{~km}$ off the coast of New Jersey, USA, to investigate the timing and magnitude of global sea-level change (Mountain et al., 2010). We analyzed $\delta^{13} \mathrm{C}$ of dissolved inorganic carbon, organic matter, methane $\left(C_{1}\right)$, ethane $\left(C_{2}\right)$, propane $\left(C_{3}\right)$ and butane $\left(n-C_{4}\right)$ to understand processes related to gas geochemistry in the investigated shallow shelf. Concentrations and stable carbon isotope compositions of $\mathrm{C}_{1}$ to $\mathrm{C}_{4}$ gases were analyzed by gas chromatography and continuous flow isotope ratio mass spectrometry (GC-IRMS). 
Methane starts to occur below $250 \mathrm{mbsf}$. It reaches concentrations of several thousand ppm (see van Geldern et al., 2013) and shows $\delta^{13} \mathrm{C}_{\mathrm{CH} 4}$ values between $-73 \%$ and $-87 \%$. Ethane, propane and butane are only present in the deeper core parts. Sedimentary organic matter revealed $\delta^{13} \mathrm{C}_{\text {org }}$ values between $-22 \%$ and $-28 \%$ at all three sites. These values may indicate a mixture of marine and terrestrial organic matter whereas the latter is characterized by lower isotope values in case it originates from $\mathrm{C}_{3}$-plant vegetation.

Methane appears to be of biogenic origin as indicated by the low $\delta^{13} \mathrm{C}_{\mathrm{CH} 4}$ values and corresponding gas concentrations ratios $C_{1} / C_{2+}$ (after Bernard et al., 1978). If methane is produced by a biogenic process this could be in principle also the case for $\mathrm{C}_{2+}$ gases (Hinrichs et al., 2006).

However, other studies attributed these gases to low temperature cracking of kerogen (cf. Rowe and Muehlenbachs, 1999). Relating the carbon isotope ratio of the individual gaseous molecules to the inverse carbon number following Chung et al. (1988) yields a straight correlation between isotopic value and carbon number. A closer examination of methane and co-existing carbon dioxide $\delta^{13} \mathrm{C}$ values suggests that the biogenic methane off New Jersey may mainly originate from the carbonate reduction pathway (Whiticar et al., 1986; Whiticar and Faber, 1986).

Carbon isotope composition of methane, ethane and propane can also be used to determine the source of the organic material (marine, terrestrial, sapropel) and the degree of thermal alteration. Different types of organic matter show different initial isotopic compositions and isotope fractionation factors for hydrocarbon formation. Based on experimental data clear relationships have been established between isotope composition of organic material and thermal alteration (Berner and Faber, 1996 and references therein). A comparison of the isotope data from the New Jersey shelf and the maturity lines methane/ethane and ethane/propane suggest that the origin of the gas might be a marine source rock in a very immature stage with almost no hydrocarbon generation. From our data we suppose, that the hydrocarbons in the upper sedimentary column are a mixture of biogenic methane and a thermally generated gas.

\section{References}

B. Bernard, J.M. Brooks and W.M. Sackett (1978). A geochemical model for characterization of hydrocarbon sources in marine sediments, Ninth Annual Offshore Technology, Conference Preprints 3, pp. 435-438.

C.M. Chung, J.R. Gormly and R.M. Squires (1988). Origin of gaseous hydrocarbons in subsurface environments: theoretical considerations of carbon isotope distributions. Chemical Geology 71, pp. 97-103.

K.U. Hinrichs, J.M. Hayes, W.Bach, A.J. Spivackl, L.R. Hmelo, N.G. Holm, N.G., S.G. Johnson and S.P. Sylva (2006). Biological formation of ethane and propane in the deep marine subsurface. Proceedings of the National Academy of Sciences of the United States of America, 103, pp. 14684-14689.

G. Mountain, J.-N. Proust, D. McInroy, C. Cotterill, and the Expedition 313 Scientists (2010). Proceedings of the Integrated Ocean Drilling Program, Volume 313: Tokyo (Integrated Ocean Drilling Program Management International, Inc.). 
D. Rowe and A. Muehlenbachs (1999). Low-temperature thermal generation of hydrocarbon gases in shallow shales. Nature (London), 398, pp. 61-63.

R. van Geldern, T. Hayashi, M.E. Böttcher, M.J. Mottl, J.A.C. Barth and S. Stadler (2013). Stable isotope geochemistry of pore waters and marine sediments from the New Jersey shelf: Methane formation and fluid origin. Geosphere 9(1), pp. 96-112 .

M.J. Whiticar, E. Faber and M. Schoell (1986). Biogenic methane formation in marine and freshwater environments: $\mathrm{CO} 2$ reduction versus acetate fermentation - isotope evidence. Geochimica et Cosmochimica Acta, 50, pp. 693-709.

M.J. Whiticar and E. Faber (1986). Methane oxidation in sediment and water coloumn environments isotope evidence. Organic Geochemistry, 10, pp. 759-768.

U. Berner and E. Faber (1996). Empirical carbon isotope/maturity relationships for gases from algal kerogens and terrigenous organic matter, based on dry-, open-system pyrolysis. Organic Geochemistry, 24(10-11), pp. 947-955.

\title{
011 - EDIACARAN CARBONATE SEDIMENTATION ON SIBERIAN PLATFORM AND AROUND IT: STRONTIUM AND CARBON ISOTOPIC DATA
}

\author{
Irina Vishnevskaya ${ }^{1}$ - Natalia Pisareva ${ }^{1}-$ Nadejda Kanygina ${ }^{2}$ \\ ${ }^{1}$ Sobolev Institute of Geology and Mineralogy SB RAS, 3 Koptyuga Ave., \\ Novosibirsk, Russia; e-mail: vishia@igm.nsc.ru \\ ${ }^{2}$ Novosibirsk State University, Novosibirsk, Russia
}

After the breakup of the Rodinia super continent the Siberia for a long time was a continent surrounded by the water (700 Ma; [1]). Thick carbonate deposits have been accumulated on its passive border and on the microcontinents surrounding in Ediacarian time. Long low dislocated sections situated nowadays on the territory of Siberia are of great importance for geologists. This is concerned first of all, with the presence of bauxite and phosphorite deposits in those sediments. However depositional ages for these rocks have not been clearly ascertained. The method of Sr isotopic chemostratigraphy is based on comparison of initial ${ }^{87} \mathrm{Sr} /{ }^{86} \mathrm{Sr}$ ratios in least-altered carbonates precipitated from seawater that capture the secular variations of ${ }^{87} \mathrm{Sr} /{ }^{86} \mathrm{Sr}$ in ancient oceans. Sr chemostratigraphy is most useful in studies of Precambrian sequences where biostratigraphy is limited. Changes in the Sr isotopic composition of seawater over time reflect the redistribution between two global Sr fluxes: non-radiogenic strontium derived from hydrothermal alteration of oceanic crust and radiogenic input from continental weathering. Variations in ${ }^{87} \mathrm{Sr} /{ }^{86} \mathrm{Sr}$ values recorded by marine carbonate sediments are a means of reconstructing short time spans of geological history because the $\mathrm{Sr}$ isotopic signatures of coeval carbonates are similar worldwide due to the homogeneity of oceans and marginal seas with respect to their ${ }^{87} \mathrm{Sr} /{ }^{86} \mathrm{Sr}$ composition. Thus, Sr chemostratigraphy can be used as a tool for indirect dating of otherwise undated Precambrian sedimentary successions via correlations with well-dated sections. 
We studied $\mathrm{Sr}$ and $\mathrm{C}$ isotope composition of Ediacaran and Cambrian carbonates in the in the south of Siberian Craton (Baikal Gr; No. 1 on Fig. 1) and north of one (Khorbusuonka Gr; No. 2 on Fig. 1), as well as Tuva-Mongolian (Boxon and Khubsugul groups and Muren Fm of eastern Sayan and northern Mongolia; Nos 3 and 4 on Fig. 1), Zavkhan (Tsagaan Olom and Bayan Gol formations of Western Mongolia; No. 5 on Fig. 1), Batenev (Yenisei Fm, Alatau Kuznetsk; No. 6 on Fig. 1) and North-Muya (Yangud Fm, nortn of Baikal ridge; No. 7 on Fig. 1) microcontinents.

Based on petrographic and geochemical analyses we identified the least altered rock samples; these samples are thought to have primary $\mathrm{Sr}$ and $\mathrm{C}$ isotope compositions reflecting these of the paleocean. We used samples with the lowest amount of terrigenous component and meeting the following criteria: $\mathrm{Mg} / \mathrm{Ca}<0.1, \mathrm{Fe} / \mathrm{Sr}<5.0$, $\mathrm{Mn} / \mathrm{Sr}<0.2$ for limestones and $\mathrm{Mg} / \mathrm{Ca}<0.6, \mathrm{Fe} / \mathrm{Sr}<3.0, \mathrm{Mn} / \mathrm{Sr}<1.2$ for dolomites with the lowest degree of postsedimentary alteration [2].

All Rb-Sr author's data was investigated by the method of selective dissolution with the preliminary removal of epigenetic carbonate phases. The isotope dilution method with mixed ${ }^{87} \mathrm{Rb}+{ }^{84} \mathrm{Sr}$ spike was used to determine $\mathrm{Rb}$ and $\mathrm{Sr}$ concentrations in both fractions on the MI $1201 \mathrm{~T}$ mass spectrometer. Rb and $\mathrm{Sr}$ were separated by the ion-exchange method with the Dowex AG50Wx8 (200-400 mesh) resin and with $2 \mathrm{~N}$ $\mathrm{HCl}$ as eluent. $\mathrm{Sr}$ isotope ratios were measured on the Finnigan MAT-262 (the Baikal Analytical Center for Collective Use, Irkutsk, Russia) and Triton TI (Institute of Precambrian Geology and Geochronology, RAS, St. Petersburg, Russia) in static acquisition mode. During the period of data acquisition, the average ${ }^{87} \mathrm{Sr}{ }^{86} \mathrm{Sr}$ ratios normalized to ${ }^{88} \mathrm{Sr} /{ }^{86} \mathrm{Sr}=8.3752$ were $0.70800 \pm 0.00002$ (2бaver, $\mathrm{n}=9$ ) and $0.71026 \pm$ 0.00002 (20aver, $\mathrm{n}=8$ ) for VNIIM and NIST SRM 987 standard samples, respectively. The C-O isotopic composition in carbon samples was measured on the complex equipment: sample preparing line Gas Bench II and Finnigan MAT-253 multi-collector mass spectrometer. During the period of the measuring the average $\delta^{13} \mathrm{C}$ value was $+1.9 \%$ and $\delta^{18} \mathrm{O}$ value was $+28.6 \%$ for NBS standard sample. All data are given in parts per million (\%), $\delta^{13} \mathrm{C}$ relative to the standard $\mathrm{PDB}, \delta^{18} \mathrm{O}$ relative to the standard SMOW

The Neoproterozoic sedimentary succession exposed along Lake Baikal in the southern margin of the Siberian Platform is rocks of Baikal Group (Fig. 1). The siliciclastic-carbonate succession unconformably lies on the metamorphosed rocks of the Archean-Paleoproterozoic basement and weathered granites of the Paleoproterozoic Primorsky Complex. The Group starts with conglomerates, sandstones and organic-rich siltstones with phosphate-siliceous layers. The middle part of this $\mathrm{Gr}$ includes dark-gray stromatolitic and oncolitic limestones, dolomitic layers and lightgray dolostones. The upper part is marked by rhythmical alternation of quartz-feldspars sandstones, siltstones and phyllites with thin lenses of calcareous shales. The $\delta^{13} \mathrm{C}$ values of carbonates vary from $+3 \%$ to $+6 \%$ in the Baikal $\mathrm{Gr}$ [3], this data are typical for a wide age interval. The ${ }^{87} \mathrm{Sr} /{ }^{86} \mathrm{Sr}$ ratios of the least altered samples of 


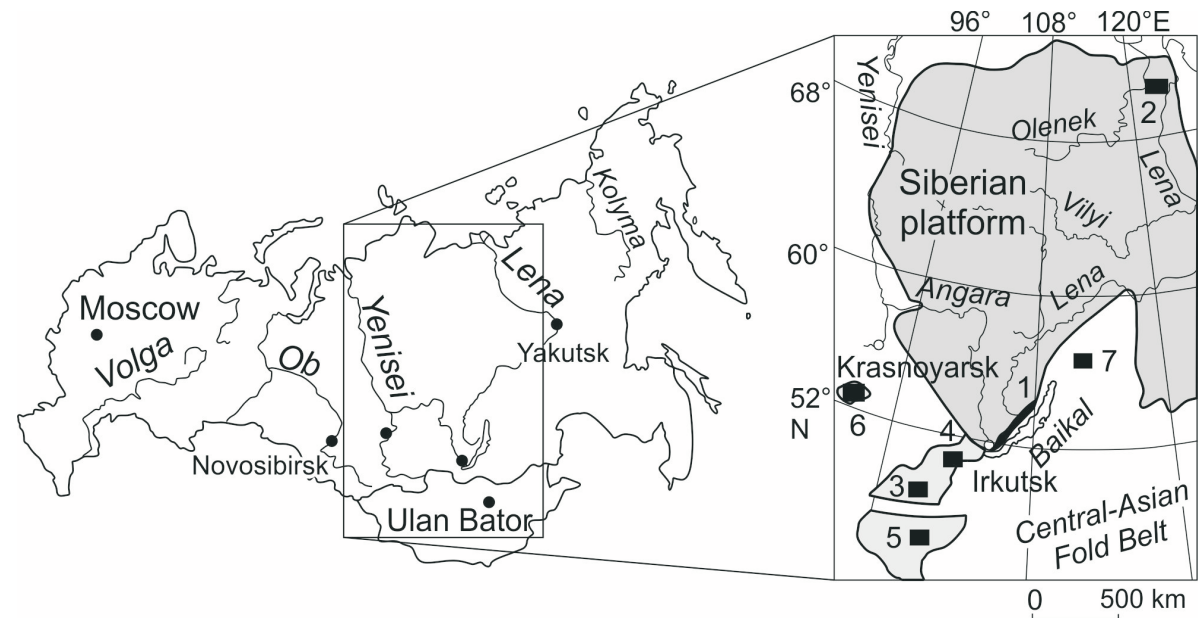

Figure 1. Objects of investigation. Sedimentary rocks of: 1 - Baikal Gr on the south of Siberian Platform; 2 - Khorbusuonka Gr on the north of one; 3, 4- Tuva-Mongolian microcontinent: 3 - Muren Fm, 4 - Boxon and Khubsugul groups; 5 - Tsagaan Olom and Bayan Gol formations of Zavkhan microcontinent; 6 - Yenisei Fm of Batenev microcontinent; 7 - Yangud Fm of North-Muya microcontinent

high-Sr limestones are considered to be the best proxy for the original carbonate sediments. The Sr isotope data varies in the range of 0.70842-0.70874 (Fig. 2). These values are consistent with depositional ages of 580-550 Ma. Also this data is confirmed by $\mathrm{Pb}-\mathrm{Pb}$ isochronal age of $560 \pm 30 \mathrm{Ma}$, which has been obtained for the least-altered high-Sr limestone using the stepwise dissolution method [4].

Sedimentary rocks on the North of Siberian Platform are presented by the Khorbusuonka Group, which divided on Maastakh, Khatyspyt, and Turkut formations (Figs 1,2). The carbonate rocks of the Maastakh and Turkut formations are represented by different varieties of dolomites. The Khatyspyt Formation is composed of bedded and detrital, frequently, bituminous, and, locally, clayey limestones. Finds of Late Ediacaran biota of the Ediacaran and Miaohen types and ichnofossils in the Khatyspyt Fm and also small shelled fossils characteristic of the uppermost Ediacaran (Nemakit-Daldynian Horizon) in the Turkut Formation provide very important paleontological data [5,6]. The oldest age of the overlying Kesyusya Group is estimated by the SHRIMP U-Pb method on zircons from tuff breccias of the uppermost Khorbusuonka Group to be $543 \pm 0.3 \mathrm{Ma}$ [7]. The Maastakh Formation are characterized by ${ }^{87} \mathrm{Sr} /{ }^{86} \mathrm{Sr}$ ratio about 0.70822 and the $\delta^{13} \mathrm{C}$ value is $+4.8 \ldots+6.0 \%$. The ${ }^{87} \mathrm{Sr} /{ }^{86} \mathrm{Sr}$ ratios in limestones of the Khatyspyt Formation, are uniform varying from 0.70783 to 0.70806 (Fig. 2). The carbon isotopic composition slowly decrease from bottom $(+3.7 \%)$ to top $(-0.2 \%)$ of section. The Sr isotopic composition (0.70854-0.70914) of the Turkut Formation is only isotope signatures for this stratigraphic unit, because it is recrystallize very much. Based on the on biostratigraphy data and $\mathrm{C}$ isotopic composi- 

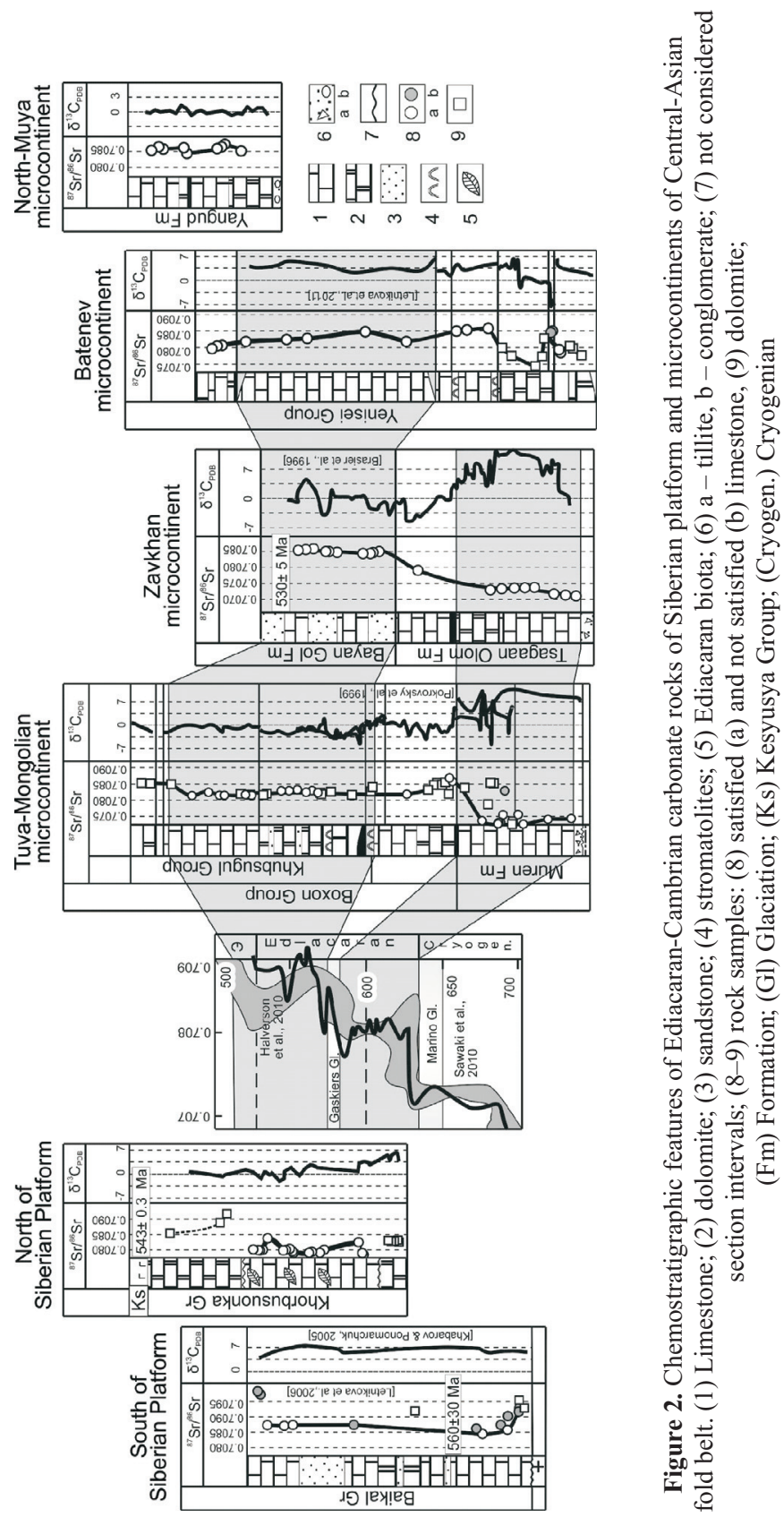

Central European Geology 56, 2013 
tion were made a conclusion that the obtained $\mathrm{Sr}$ isotopic characteristics of carbonate rocks from the Khatyspyt Formation indicate a $\mathrm{Sr}$ isotopic composition in seawater 560-550 Ma [8].

We have studied the sediments from Ediacaran-Cambrian covers of microcontinents (Tuva-Mongolian, Zavkhan, Batenev, North-Muya), situated in the framing of Siberian platform on the territory of pale Azian ocean. Terrains, composing this structure can be found nowadays in the range of Central-Asian fold belt (Nos 3-7 on Fig. 1).

The most investigated object is the Ediacaran-Cambrian cover of Tuva-Mongolian terrain. Huge phosphorite deposits (Bokson in Russia and Khubsugul in Mongolia) are here. The cover represented by Muren Formation, Boxon and Khubsugul groups. Muren Fm is represented generally by limestones with rare sandstone layers, mudstones and silica rocks. Boxon Gr is composed of dolomites, which change by limestones to the top of the section. Khubsugul Gr is represented by limestones with different habit. In the section of both groups we have explored the phosphorite layers and in it's upper parts - lower Cambrian archaeocyathas and trilobites. In the basement of Khubsugul and Boxon groups we can see the tillite. The least altered carbonates of the Tuva-Mongolia terrane have $\mathrm{Sr}$ isotope values of 0.7073-0.7086. The lowest ${ }^{87} \mathrm{Sr} /{ }^{86} \mathrm{Sr}$ ratios are obtained for carbonates of the lower formation of Boxon $\mathrm{Gr}$ and Muren Fm, which are also characterized by high (up to $+10.5 \%$ ) values of $\delta^{13} \mathrm{C}$ [9]. Estimated $\mathrm{Pb}-\mathrm{Pb}$ age of Zabit Fm phosphorite is $560-550 \mathrm{Ma}$ (Fig. 2). If we compare $\mathrm{Sr}$ and $\mathrm{C}$ isotopic composition variation curves for Tuva-Mongolian terrains and those received for geochronologically corresponded sections $[10,11]$ showed that rocks from the cover of Tuva-Mongolian microcontinent started to form 600-580 Ma, while the formation of Khubsugul Gr deposits started 580-560 Ma.

Shelf deposits of Zavkhan microcontinent (Zavkhan terrane) start with the sediments of Tsagaan Olom Formation, which is represented by limestone and dolomites with the sickness of 1500 meters. These sediments with angular unconformity lie on the sediments of volcanogenic - sedimentary Zavkhan Gr and are overlade by sediments of Bayan Gol Formation. Study of isotopic composition Sr and C (variations $\delta^{13} \mathrm{C}$ are received from [10]) in carbonate deposits of Zavkhan terrain showed that $\mathrm{Sr}$ isotopic composition of unaltered limestones from Tsagaan Olom Formation vary between 0.7072 and 0.7079 (Fig. 2), and the values of $\delta^{13} C_{\mathrm{PDB}}$ are positively high (from +3 to $+14 \%$ ).

This can be correlated both with the data received for Muren Formation of Tuva-Mongolian terrain, and with $\mathrm{Sr}$ and $\mathrm{C}$ variation curves for ancient ocean 590-560 Ma. For the Bayan Gol Fm, overlying these deposits ${ }^{87} \mathrm{Sr} /{ }^{86} \mathrm{Sr}$ rations of $0.7084-0.7086$ are typical and $\delta^{13} \mathrm{C}$ values alter from -1.7 to $+5.0 \%$, which indicates early Cambrian age [9]. It has been showed that tillite at the very bottom of carbonate covers in the range of Tuva-Mongolian and Zavkhan terrains are similar and correspond to Marino glaciation (Fig. 2). 
The cover of Batenev microcontinent is formed by the sediments of Yenisei Group. It is represented by alteration of gray dolomites and limestones with the thick barite-bearing member in it's upper part. The age of these deposits is determined by $\mathrm{Pb}-\mathrm{Pb}$ method as $523 \pm 5 \mathrm{Ma}$ [12]. Original ${ }^{87} \mathrm{Sr} /{ }^{86} \mathrm{Sr}$ ratio for limestones increases from 0.7075 in the lower part of the Gr (Bidjin Fm) to 0.7085 in the upper parts of the section (Sorna Fm). C isotopic composition grows from $-1.8 \%$ at the $\mathrm{Gr}$ bottom to $+6.1 \%$ in its middle parts. Second part of the section is characterised by lower values from -2.5 to $+3.7 \%$ (Fig. 2). Thus, the sediments of Yenisi Gr start to form in Ediacaran (580-550 Ma) and the sedimentation took place until the second half of early Cambrian (525-517 Ma) [13].

Cambrian carbonate deposits are studied in the range of the North-Muya terrain cover (Northern Baikal region) are represented by the sediments of Yangud Fm, composed generally of dolomites with thin layers of limestones. As the result of isotopic-geochemical researches it has been discovered that original ${ }^{87} \mathrm{Sr} /{ }^{86} \mathrm{Sr}$ ratio in the less altered dolomites from Yangud Fm vary in small range from 0.7084 to 0.7087 (Fig. 2). Comparison of received isotopic data for Yangud Fm with the Sr isotopic variation curve in the waters of Cambrian ocean [14] shows that Yangud Fm carbonates started to form in the thin time interval from Toyonian to Amgaian of early Cambrian (515-520 Ma). This indicates that the passive continental border environment took place from that time in the range of North-Muya terrain.

Listed results shows that the isotopic chemostratigraphy method has wide range of applying while comparison of close age deposits and tillite. This method can also be used for carbonate sedimentation time recognizing for paleontologically undefined layers. With the help of Khorbusonska Gr deposit containing remarkable complex of organic remains we have identified the $\mathrm{Sr}$ isotopic composition in the ocean 560-550 Ma. The following age constrains are established by methods of isotope chemostratigraphy. Maximum age of the Baikal Gr in the south of Siberian Craton is late Ediacaran (550-520 Ma). Carbonates of the Tsagaan Oloom Fm formed during the Ediacaran (590-560 Ma), and the Bayan Gol Fm, mostly in the early Cambrian (550-520 Ma). Carbonate sedimentation in various parts of the Tuva-Mongolian terrane was diachronous and started between 600-580 Ma and continued into middle Cambrian. The Yenisei Gr was deposited during Ediacaran and early Cambrian (580-517 Ma). The youngest object is sediments of Yangud Fm, formed 515-520 Ma. All in all, these deposits with close age have unified $\mathrm{Sr}$ isotopic composition no matter where they have been accumulated and this give us evidence about their origination in open sea basin.

Acknowledgements. The work was supported by the Russian Foundation of Basic Research (projects nos. 12-05-00569 \& 12-05-33076) and the Presidium of the Siberian Branch of Russian Academy of Sciences (project no. 53.68). 


\section{References}

1. Li, Z.X., Bogdanova, S.V., Collins, A.S., Davidson, A., De Waele, B., Ernst, R.E., Fitzsimons, I.C.W., Fuck, R.A., Gladkochub, D.P., Jacobs, J., Karlstrom, K.E., Lul, S., Natapovm, L.M., Pease, V., Pisarevsky, S.A., Thrane, K. and Vernikovsky, V., Assembly, configuration, and break-up history of Rodinia: A synthesis. Precam. Res,. 160, pp. 179-210, 2008.

2. Kuznetsov, A.B., Gorokhov, I.M., Mel'nikov, N.N., Konstantinova, G.V., Kutyavin, E.P. and Semikhatov, M.A., Sr isotope composition in carbonates of the Karatau Group, southern Urals, and standard curve of ${ }^{87} \mathrm{Sr} /{ }^{86} \mathrm{Sr}$ variations in the Late Riphean Ocean. Stratigraphy and Geol. Correl., 11(5), pp. 415-449, 2003.

3. Khabarov, E.M. and Ponomarchuk, V.A., Carbon isotopes in the Upper Riphean deposits of the Baikal Group in western Cisbaikalia: stratigraphic implications. Russian Geology and Geophysics, 46, pp. 1003-1023, 2005.

4. Kuznetsov, A.B., Ovchinnikova, G.V., Gorokhov, I.M., Letnikova, E.F., Kaurova, O.K. and Konstantinova, G.V., Age constraints on the Neoproterozoic Baikal Group from combined Sr isotopes and $\mathrm{Pb}-\mathrm{Pb}$ dating of carbonates from the Baikal type section, southeastern Siberia. Journal of Asian Earth Sciences, 62, pp. 51-66, 2013.

5. Grazhdankin, D.V., Nagovitsin, K.E., Kochnev, B.B. and Balthasar, U., Carbonate-hosted Avalon-type fossils in Arctic Siberia. Geology, 36(10), pp. 803-806, 2008.

6. Rogov, V., Marusin, V., Bykova, N., Goy, Y., Nagovitsin, K., Kochnev, B., Karlova, G. and Grazhdankin, D., The oldest evidence of bioturbation on Earth. Geology, 40(5), pp. 395-398, 2012.

7. Bowring, S.A. Grotzinger, J.P., Isachsen, C.E., Knoll, A.H., Pelechaty, S.M. and Kolosov, P., Calibrating rates of Early Cambrian evolution. Science, 261, pp. 1293-1298, 1993.

8. Vishnevskaya, I.A., Kochnev, B.B., Letnikova, E.F., Kiseleva, V.Yu. and Pisareva, N.I., Sr Isotope Signatures in the Vendian Khorbusuonka Group of the Olenek Uplift (Northeastern Siberian Platform). Doklady Earth Sciences, 449(1), pp. 298-302, 2013.

9. Vishnevskaya, I.A. and Letnikova, E.F., Chemostratigraphy of Vendian-Cambrian carbonate of Tuva-Mongolian microcontinent sedimentary shelf. Russian Geology and Geophysics, 2013 (in press)

10. Brasier, M.D., Dorjnamjaa, D. and Lindsay, J.F., The Neoproterozoic to early Cambrian in southwest Mongolia: an introduction. Geol. Mag,. 133(4), pp. 365-369, 1996.

11. Halverson, G.P., Wade, B.P., Hurtgen, M.T. and Barovich, K.M., Neoproterozoic chemostratigraphy. Precambrian Research 182, pp. 337-350, 2010.

12. Ovchinnikova, G.V. et al., U-Pb age and Sr-chemostratigraphy of limestone from the Soma Formation, Azyr-Tal Range, Kuznetsk Alatau. Doklady Earth Sciences, 437, pp. 331-334, 2011.

13. Letnikova, E.F., Kuznetsov, A.B., Vishnevskaya, I.A., Terleev, A.A. and Konstantinova, G.V., Geochemical and isotopic ( $\mathrm{Sr}, \mathrm{C}, \mathrm{O})$ characteristics of Vendian and Cambrian carbonates of the Azyrtal Ranges (Kuznetsk Alatau): chemostratigraphy and sedimentogenesis. Russian Geology and Geophysics, 52, pp. 1154-1170, 2011.

14. Mazumdara, A. and Strauss, H., Sulfur and strontium isotopic compositions of carbonate and evaporate rocks from the late Neoproterozoic-early Cambrian Bilara Group (Nagaur-Ganganagar Basin, India): Constraints on intrabasinal correlation and global sulfur cycle. Precambrian Research, 149, pp. 217-230, 2006.

15. Letnikova, E.F., Kuznetsov, A.B., Veshcheva, S.V. and Kovach, V.P., The Vendian passive continental margin of the southern Siberian Craton: Evidence from geochemical, Sm-Nd, and Sr isotope data. Doklady Earth Sciences, 409, pp. 818-823, 2006.

16. Sawaki, Y., Ohnoa, T., Tahata, M., Komiya, T., Hirata, T., Maruyama, S., Windley, B.F., Han, J., $\mathrm{Shu}, \mathrm{D}$. and Li, Y., The Ediacaran radiogenic Sr isotope excursion in the Doushantuo Formation in the Three Gorges area, South China. Precambrian Research, 5, 176, pp. 46-64, 2010. 
17. Pokrovsky, B.G., Letnikova, E.F. and Samugin, S.G., Isotopic stratigraphy of Boxon Group, Vendian-Cambrian of Eastern Sayan. Stratigraphy and Geol. Correl., 7(3), 23-41, 1999 [in Russian].

\title{
012 - ISOTOPIC SIGNALS OF CLIMATE CHANGES RELATED TO THE TOARCIAN OCEANIC ANOXIC EVENT. EXAMPLE OF THE BETIC CORDILLERA (SPAIN)
}

\author{
Luis M. Nieto-Matías Reolid \\ Department of Geology and Centre of Advances Research in Earth Sciences, \\ University of Jaén, E-23071 Jaén; e-mails: 1mnieto@ujaen.es; mreolid@ujaen.es
}

In the Pliensbachian, a main rifting stage of the Western Tethys happened. This event was related to the Central Atlantic opening, as consequence, Proto - Atlantic Ocean was developed. In the South Iberian Palaeomargin, this event involved the disintegration of the Hettangian to middle - upper Pliensbachian carbonate platform. Then, a pelagic basin was making up, with an irregular bottom morphology related to halfgraben structures, controlled by listric faults. These faults favored the block - rotation and the development of sub-basins with differential subsidence, even into a same block. In this pelagic environment were deposited a marls - marly limestone rhythmite, from the Latest Pliensbachian until Earliest Toarcian (Polymorphum Zone). Overlying the rhythmite, a thin - laminated black marlstone can be detected. These materials are characterized by the absence of ichnofossil and any evidence related to organic activity. Thin stratified limestones are getting over the thin - laminated black marlstones. Both kinds of rocks are dated as Serpentinum Zone by correlation with other sections.

In other regions, a sea-level fall has been detected in the Pliensbachian Toarcian boundary. This fact was consequence to a drastic cooling event occurred during the last Pliensbachian zone $[1,2]$. The Early Toarcian Oceanic Anoxic Event (T-OAE) is characterized by the record of organic-rich sediments associated with a negative excursion in $\delta^{13} \mathrm{C}[3]$, in a context of exceptionally warm conditions [4] and sea-level rise [5].

The isotopic data $\left(\delta^{13} \mathrm{C}\right.$ and $\left.\delta^{18} \mathrm{O}\right)$ together with other geochemical proxies such as $\mathrm{Mo} / \mathrm{Al}$, total organic carbon (TOC) and total content in sulphur (TS) were achieved from the Cueva del Agua section, located in the Subbetic Domain (Betic Cordillera, SE Spain). The special feature of this section is this palaeogeographic location, in the westernmost Tethys, in the passage to Proto - Atlantic Ocean. In this section, the $\delta^{13} \mathrm{C}$ values in the rhythmite (Polymorphum Zone) change between 0.96 to $0.63 \%$. However, in the thin - laminated black marlstones (lowest Serpentinum biozone), these values decreasing to -1.87 and $-1.70 \%$. On the other hand, the $\delta^{18} \mathrm{O}$ values show a clear negative excursion in the transition between Polymorphum and Serpentinum 
zones. In the Polymorphum Zone these data are nearly to $-3 \%$, showing an abrupt decrease to -5.36 and $-4.95 \%$ in the lowest Serpentinum Zone. Later to this negative excursion, an increase of the values of this isotopic ratio happen, but values equivalent to detected in the Polymorphum Zone have not showed until the thin - limestones, overlying the thin - laminated black marlstones. Simultaneously to the previous isotopic changes, a sharp increase in TOC, TS and Mo/Al ratio was detected.

According to several authors ([1] or [6], for example), the decreasing in the $\delta^{13} \mathrm{C}$ detected in the base of Serpentinum Zone could be related to the ${ }^{12} \mathrm{C}$ massif contribution to the ocean - atmosphere system as consequence to the volcanism in the Karoo - Ferrar large igneous province or to the methane big injection related to the rifting event. Moreover, in the South Iberian Palaeomargin, the beginning of the submarine volcanism added to this ${ }^{12} \mathrm{C}$ input. Hesselbo et al. [6], show that the increase of the ${ }^{12} \mathrm{C}$ in the atmosphere-ocean system could also be related to the sheet ice melt, and the contribution of this water to the ocean. This melt should be consequence to the temperature increase deduced from the negative excursion in the $\delta^{18} \mathrm{O}$ ratio shown in the Polymorphum-Serpentinum zones boundary. Different authors ([1], [6], among other) show temperature increase from $24^{\circ} \mathrm{C}$ in the Polymorphum Zone to $32^{\circ} \mathrm{C}$ in the Serpentinum Zone. This change could be related to global warming as consequence to rise in the sea level. A reduction in the oxygen water solubility occurred as result to water warming. These conditions also favored the water stratification and the reduction of the ocean water circulation. This context was favorable to organic matter preservation (increase in TOC and TS). Increase in values of $\mathrm{Mo} / \mathrm{Al}$ ratio indicate a decrease in the sea-bottom oxygenation as the same time that $\delta^{18} \mathrm{O}$ excursion, confirming the suboxic to anoxic conditions that explain the preservation of organic matter as well as the absence of ichnofossil and benthic organisms in the thin- laminated black marlstones.

\section{References}

1. G.D. Price, The evidence and implications of polar ice during the Mesozoic. Earth-Science Reviews, 48, pp. 183-210, 1999.

2. C. Korte and S.P. Hesselbo, Shallow marine carbon and oxygen isotope and elemental records indicate icehouse-greenhouse cycles during the Early Jurassic. Paleoceanography, 26, PA4219, 2011.

3. M. Hermoso, L. Le Callonnec, F. Minoletti, M. Renard and S.P. Hesselbo, Expression of the Early Toarcin negative carbon-isotope excursion in separated carbonate microfractions (Jurassic, Paris Basin). Earth and Planetary Science Letters, 277, pp. 194-203, 2009.

4. G. Suan, B.L. Nikitenko, M.A. Rogov, F. Baudin, J.E. Spangenberg, V.G. Knyazev, L.A. Glinskikh, A.A. Goryacheva, T. Adatte, J.B. Riding, K.B. Föllmi, B. Pittet, E. Mattioli and C. Lécuyer, Polar record of Early Jurassic massive carbon injection. Earth and Planetary Science Letters, 312, pp. 102-113, 2011.

5. A. Hallam, A review of the broad pattern of Jurassic sea-level changes and their possible causes in the light of current knowledge. Palaeogeography, Palaeoclimatology, Palaeoecology, 167, pp. 23-37, 2001 
6. S.P. Hesselbo, H.C. Jenkyns, L.V. Duarte and L.C.V. Oliveira, Carbon-isotope record of the Early Jurassic (Toarcian) Oceanic Anoxic Event from fossil wood and marine carbonate (Lusitanian Basin, Portugal). Earth and Planetary Science Letters, 253, pp. 455-470, 2007.

\title{
013 - AN ISOTOPIC REFERENCE DATABASE FOR WHITE CRYSTALLINE MARBLES USED IN ANTIQUITY
}

\author{
Fabrizio Antonelli - Lorenzo Lazzarini \\ Laboratorio di Analisi dei Materiali Antichi (LAMA), University Iuav of Venice, \\ San Polo 2468, 30125 Venezia, Italy; e-mails: fabrizio.antonelli@iuav.it; lorenzo@iuav.it
}

The identification of the quarry of provenance of ancient marble artefacts is, on one hand, of the utmost interest to archaeologists and art historians, on other hand, one of the most debated problem of petroarchaeometry. Scholars of different disciplines (mineralogists, petrographers, geochemists, physicists) have been trying for more than a century such an identification by means of a unique or multiple laboratory analysis without totally positive results. To-date the best probability of success are obtained by combining together at least two analytical methodologies and jointly processing all the data obtained. In particular, the detailed minero-petrographic examination of a thin section and the determination of the $\mathrm{C} \& \mathrm{O}$ stable isotopic ratios on the same sample is currently the most widely used combination. Such a combination takes advantage of the best existing databases for the main Mediterranean marbles very commonly used in Classical antiquity. On the basis of a detailed scrutiny of the recent literature data published from 2002 to 2012, we propose here an upgrade and a chronological reorganization on a geographic base of the isotopic databank based on hundreds of analyses relative to the marbles from the major and some minor quarries active in Greek and Roman times. These new data, never considered before all together, let us both to increase the statistical significance of the whole database and draw new global reference isotopic diagrams related to the maximum grain size (MGS) of the different lithotypes which are useful to better establish the provenance of a given archaeological objects.

Keywords: ancient marbles, petroarchaeometry, isotope composition, provenance

\section{4 - CHALLENGES IN ISOTOPIC ${ }^{13}$ C NMR SPECTROMETRY FOR MODELLING ISOTOPE EFFECTS IN SOIL CONTAMINATION}

\author{
Pierrick Nun ${ }^{1}$ - Maxime Julien ${ }^{1}$ - Julien Parinet ${ }^{2}$ - Patrick Höhener ${ }^{2}$ - \\ Richard J. Robins ${ }^{1}-$ Gérald S. Remaud ${ }^{1}$ \\ ${ }^{1}$ EBSI team, CEISAM UMR 6230, University of Nantes, 2 rue de la Houssinière BP 92208, \\ 44322 Nantes cedex 3, France; e-mail: pierrick.nun@univ-nantes.fr \\ ${ }^{2}$ Aix Marseille Université, CNRS FRE 3416, 3 place Victor Hugo - Case 29, \\ 13331 Marseille, France
}


In Europe, ethers such as methyl tert-butyl ether (MTBE), ethyl tert-butyl ether (ETBE) and tert-amyl methyl ether (TAME) are commonly added to gasoline as octane enhancers. These compounds are present in contaminated soil and groundwater and there is an urgent need to have accurate methods to check whether bioremediation works in situ, whether it leads to mineralization, whether clean-up standards have been achieved and to trace the origin of contamination.

Nowadays irm-MS is the most common analytical tool for measuring isotope ratios, but this instrument cannot resolve site-specific isotope abundances and assumes a random isotope distribution throughout the entire molecule. The novelty of our approach is to couple results obtained with irm-MS to determine global isotopic ratios with quantitative ${ }^{13} \mathrm{C}$ NMR (qNMR) to resolve site specific isotope abundances [1].

The requirement to analyse samples by isotopic ${ }^{13} \mathrm{C}$ NMR generates new challenges. With irm-MS, only a few mg of the target compound are necessary, and purity is not an issue when GC-irm-MS can be used. With NMR, hundreds of milligrams of pure product need to be obtained and isolated, with high yields and without any overlap of signals. Moreover, we need to ensure that no fractionation occurs during the extraction and purification process.

Our preliminary work focusses on the degradation of MTBE by several ways; oxidation, hydrolysis, biodegradation. The main product obtained in these cases is tert-butyl alcohol (TBA). To study the potential isotopic fractionation of these reactions, we need to separate both remaining MTBE and TBA from the reaction mixture and then to purify each compound for isotopic qNMR analyses. The reactions are carried out in aqueous media, so MTBE and TBA (b.p. $55^{\circ} \mathrm{C}$ and $82^{\circ} \mathrm{C}$, respectively) can be extracted from water by distillation. Nevertheless, as distillation is known to fractionate against ${ }^{13} \mathrm{C}[2]$, a very high recovery $(>95 \%)$ of each compound has to be achieved. Furthermore, MTBE and TBA cannot be efficiently separated by distillation, so flash column chromatography is necessary to separate them. Finally, distillation of the eluting solvent gives the compounds in a pure form for qNMR analysis. The validation of the separation protocol is presented in relation to the constraints of isotopic ${ }^{13} \mathrm{C}$ NMR.

\section{References}

1. E. Caytan, E.P. Botosoa, V. Silvestre, R.J. Robins, S. Akoka and G.S. Remaud, Accurate quantitative C-13 NMR spectroscopy: Repeatability over time of site-specific C-13 isotope ratio determination. Anal. Chem., 79, pp. 8266-8269, 2007.

2. E.P. Botosoa, E. Caytan, V. Silvestre, R.J. Robins, S. Akoka and G.S. Remaud, Unexpected fractionation in site-specific ${ }^{13} \mathrm{C}$ isotopic distribution detected by quantitative ${ }^{13} \mathrm{C}$ NMR at natural abundance. J. Am. Chem. Soc., 130, pp. 414-415, 2008. 


\title{
015 - INTRAMOLECULAR ${ }^{13}$ C COMPOSITION BY ISOTOPIC NMR SPECTROMETRY: NEW INSIGHTS ON ISOTOPE FRACTIONATION STUDIES
}

\author{
Gérald S. Remaud ${ }^{l}$ - Maxime Julien ${ }^{1}$ - Julien Parinet ${ }^{2}-$ Pierrick Nun $^{1}-$ \\ Patrick Höhener ${ }^{2}-$ Richard J. Robins ${ }^{1}$ \\ ${ }^{1}$ EBSI team, CEISAM UMR 6230, University of Nantes, 2 rue de la Houssinière, BP 92208 , \\ F-44322 Nantes Cedex 3, France; e-mail: gerald.remaud@univ-nantes.fr \\ ${ }^{2}$ Aix Marseille Université, CNRS FRE 3416, 3 place Victor Hugo - Case 29, \\ 13331 Marseille, France
}

Isotope ratio mass spectrometry (irm-MS) is commonly used to access the average isotope ratio for a given element in the target analyte. Nuclear Magnetic Resonance (NMR) spectrometry, however, offers a more refined approach because of its double intrinsic property: separation of the signal of each site of the molecule and quantification of the amount of resonating nuclei under the peak. To implement this approach for ${ }^{13} \mathrm{C}$, some problems fundamental to ${ }^{13} \mathrm{C}$ NMR have to be solved in order to attain a target precision of $1 \%$, satisfactory for most applications to the transformation of natural products [1]. The recent development of the reliable determination by NMR of ${ }^{13} \mathrm{C}$ intramolecular distributions at natural abundance has opened the door to the analysis of a wide range of products and to the determination of isotopes effects.

A major highlight of what can be learned from these investigations is illustrated by the very new information obtained on ${ }^{13} \mathrm{C}$ fractionation, unrevealed by irm-MS. Only knowing the average $\delta^{13} \mathrm{C}$ value can be misleading when interpreting isotope effects occurring during the transformation (physical, chemical or biological) of a substrate (starting material) into a product (final material) based solely on the $\Delta \delta^{13} \mathrm{C}$ shift. If this is equal to 0 , does it mean that there is no fractionation or, rather, that there is a counteractive contribution of normal and inverse isotope effects from different carbon sites? The site-specific isotope ratios obtained by isotopic qNMR allow a refinement of the data and emphasize that isotope effects may be manifest in different ways at different carbon positions.

Thus, unexpected fractionations have been shown by isotopic ${ }^{13} \mathrm{C}$ NMR. This presentation will cover some of them:

(i) Differences in intramolecular ${ }^{13} \mathrm{C}$ composition in sugars from $\mathrm{C}_{3}, \mathrm{C}_{4}$ and $\mathrm{CAM}$ plants. [2, 3];

(ii) Normal and inverse ${ }^{13} \mathrm{C}$ non-covalent isotope effects (NCIE), within a molecule, during sorption/desorption experiments [4];

(iii) Distillation, volatilization, evaporation: all are liquid/vapour equilibria but leading to different intramolecular ${ }^{13} \mathrm{C}$ patterns, either for the remaining liquid (substrate) or on the condensed vapour (product).

It will be clearly shown that isotopic ${ }^{13} \mathrm{C}$ NMR is a very good complement to irm-MS, especially as a valuable tool for modelling in environmental studies. 


\title{
References
}

1. E. Caytan, E.P. Botosoa, V. Silvestre, R.J. Robins, S. Akoka and G.S. Remaud, Accurate quantitative C-13 NMR spectroscopy: Repeatability over time of site-specific C-13 isotope ratio determination. Anal. Chem., 79, pp. 8266-8269, 2007.

2. F. Thomas, C. Randet, A. Gilbert, V. Silvestre, E. Jamin, S. Akoka, G. Remaud, N. Segebarth and C. Guillou, Improved Characterization of the Botanical Origin of Sugar by Carbon-13 SNIF-NMR Applied to Ethanol. J. Agric. Food Chem., 58, pp. 11580-11585, 2010.

3. A. Gilbert, R.J. Robins, G.S. Remaud and G. Tcherkez, Intramolecular ${ }^{13} \mathrm{C}$-pattern in hexoses from autotrophic and heterotrophic C3 plant tissues. Proc. Natl. Acad. Sci. USA, 109, pp. 18204-18209, 2012.

4. P. Höhener, V. Silvestre, A. Lefrançois, D. Loquet, E.P. Botosoa, R.J. Robins and G.S. Remaud, Analytical model for site-specific isotope fractionation in ${ }^{13} \mathrm{C}$ during sorption: Determination by isotopic ${ }^{13} \mathrm{C}$ NMR spectrometry with vanillin as model compound. Chemosphere, 87, pp. 445-452, 2012.

\section{6 - INTRA-MOLECULAR ${ }^{13}$ C FRACTIONATION PATTERNS DURING LIQUID/VAPOUR TRANSFORMATIONS}

\author{
Maxime Julien ${ }^{1}$ - Julien Parinet ${ }^{2}$ - Pierrick Nun ${ }^{1}$ - Patrick Höhener ${ }^{2}$ - \\ Richard J. Robins ${ }^{1}-$ Gérald S. Remaud ${ }^{1}$
}

${ }^{1}$ EBSI team, CEISAM UMR 6230, University of Nantes, 2 rue de la Houssinière BP 92208 , F-44322 Nantes cedex 3, France; e-mail: maxime.julien@univ-nantes.fr

${ }^{2}$ Aix Marseille Université, CNRS FRE 3416, 3 place Victor Hugo - Case 29, 13331 Marseille, France

Contamination of soils and aquifers is a problem that needs to be better understood. There are different natural ways for the elimination of pollutants, principally bioremediation, oxidation or volatilization. All these processes have already been studied using measurements of ${ }^{13} \mathrm{C}$ isotopic fractionation [1]. In most cases, ${ }^{13} \mathrm{C}$ analyses have been carried out with irm-MS, but the disadvantage of this method is that it only gives a global $\delta^{13} \mathrm{C}$ value.

Isotopic ${ }^{13} \mathrm{C}$ NMR spectrometry (qNMR) is a technique that allows observation of site-specific isotopic fractionation [2]. The information obtained gives more details about the studied phenomenon and shows the influence of the different chemical functions present in the target contaminants. qNMR has previously proved to be an efficient method to study non-covalent isotope effects (NCIE) [3] as well as distillation processes [4].

Evaporation is one of the pathways of elimination of a pollutant from a contaminated soil or surface water. Several approaches have been proposed to simulate the liquid to vapour change. All of these aim at giving better understanding of isotope fractionation during these processes. Using irm-MS, small isotope effects were observed, which were either normal or inverse. It is therefore difficult to assess the contribution of evaporation during the whole remediation (biotic and abiotic) on the isotope signature of the remaining contaminant. 
In the present work, different molecules containing various chemical functions (ether, alcohol, carboxylic acid) and miscellaneous carbon skeleton structures (different chain length, aromatic nucleus) have been studied by isotopic qNMR and irm-MS to compare these processes in order to understand how evaporation depends on chemical structure. As a result the question "What is the best model to describe the evaporation of the pollutant in the field?" can be tackled. This fundamental study should provide data that can be used to predict volatilization processes in natural polluted soil or water.

\title{
References
}

1. M. Elsner, Stable isotope fractionation to investigate natural transformation mechanisms of organic contaminants: principles, prospects and limitations. J. Environ. Monit., 12, pp. 2005-2031, 2010.

2. E. Caytan, E.P. Botosoa, V. Silvestre, R.J. Robins, S. Akoka and G.S. Remaud, Accurate quantitative C-13 NMR spectroscopy: Repeatability over time of site-specific C-13 isotope ratio determination. Anal. Chem., 79, pp. 8266-8269, 2007.

3. E.P. Botosoa, V. Silvestre, R.J. Robins, J.M. Moreno Rojas, C. Guillou and G.S. Remaud, Evidence of long-range ${ }^{13} \mathrm{C}$ non-covalent isotope effects obtained by quantitative ${ }^{13} \mathrm{C}$ nuclear magnetic spectroscopy at natural abundance during normal phase liquid chromatography. $\mathrm{J}$. Chromatogr. A, 1216, pp. 7043-7048, 2009.

4. E.P. Botosoa, E. Caytan, V. Silvestre, R.J. Robins, S. Akoka and G.S. Remaud, Unexpected fractionation in site-specific ${ }^{13} \mathrm{C}$ isotopic distribution detected by quantitative ${ }^{13} \mathrm{C}$ NMR at natural abundance. J. Am. Chem. Soc., 130, pp. 414-415, 2008.

\section{7 - SITE-SPECIFIC ${ }^{13}$ C FRACTIONATION DUE TO DISTILLATION: INFLUENCE OF MOLECULAR STRUCTURE OF ALCOHOLS}

\author{
Maxime Julien $^{1}$ - Julien Parinet ${ }^{2}$ - Pierrick Nun ${ }^{1}$ - Patrick Höhener ${ }^{2}$ - \\ Richard J. Robins ${ }^{l}$ - Gérald S. Remaud
}

${ }^{1}$ EBSI team, CEISAM UMR 6230, University of Nantes, 2 rue de la Houssinière BP 92208 , F-44322 Nantes cedex 3, France; e-mail: maxime.julien@univ-nantes.fr

${ }^{2}$ Aix Marseille Université, CNRS FRE 3416, 3 place Victor Hugo - Case 29, 13331 Marseille, France

Isotopic analysis has proved to be an excellent method to understand enzymatic activity, chemical reactions and many other phenomena. In this study, isotopic measurement wasused to understandhow molecules which have an alcohol function $(-\mathrm{OH})$ behavein distillation depending on their carbon chain length (from methanol to pentanol) and their molecular organization (ex: comparison of propanol and isopropanol).

Currently, the most commonly used technique to measure isotope ratios is irm-MS. But, this method only gives a global $\delta^{13} \mathrm{C}$ value. To analyse the ${ }^{13} \mathrm{C}$ distribution at different positions of a molecule by irm-MS requires a difficult sample preparation to fragment the molecule and separate the products. This is limited to small molecules $\left(\mathrm{C}_{1}-\mathrm{C}_{3}\right)$ [1]. Isotopic ${ }^{13} \mathrm{C}$ NMR spectrometry (qNMR) is a technique that allows 
measurement of the intramolecular ${ }^{13} \mathrm{C}$ isotope composition at natural abundance [2]. This method gives more information about isotopic fractionation and can be used to confirm or invalidate previous observations obtained with global ${ }^{13} \mathrm{C}$ measurements [3]. It also gives access to more complex molecules that are not amenable to degradation and analysis by irm-MS.

Distillation experiments were carried out using a spinning band distillation column. This particular distillation system gives a better separation of products, creating a high number of theoretical plates. A previous work indicated that ${ }^{13} \mathrm{C}$ intramolecular composition in ethanol is modified upon distillation [4]. In the present investigation we extended this study to other alcohols. The first $3 \%$ of the distilled product was isolated at equilibrium and analysed to compare it with the starting material. The ${ }^{13} \mathrm{C}$ EA-irm-MS analysis showed a global isotopic enrichment in the distilled products in comparison with the starting materials. The site-by-site analysis made with ${ }^{13} \mathrm{C}$ qNMR added detail to this observation. It is shown that (a) the ${ }^{13} \mathrm{C}$ isotopic enrichment is mainly located on the carbon bearing the alcohol function $\left(\Delta \delta^{13} \mathrm{C}=+4 \%\right.$ in most cases), and (b) that the magnitude of the isotopic fractionation diminishes as the carbon becomes more and more distal to the alcohol function.

\title{
References
}

1. A. Gilbert, R. Hattori, V. Silvestre, N. Wasano, S. Akoka, S. Hirano, K. Yamada, N. Yoshida and G.S. Remaud, Comparison of IRMS and NMR spectrometry for the determination of intramolecular ${ }^{13} \mathrm{C}$ isotope composition: application to ethanol. Talanta 99, pp. 1035-1039, 2012.

2. E. Caytan, E.P. Botosoa, V. Silvestre, R.J. Robins, S. Akoka and G.S. Remaud, Accurate quantitative C-13 NMR spectroscopy: Repeatability over time of site-specific C-13 isotope ratio determination. Anal. Chem., 79, pp. 8266-8269, 2007.

3. P. Höhener, V. Silvestre, A. Lefrançois, D. Loquet, E.P. Botosoa, R.J. Robins and G.S. Remaud, Analytical model for site-specific isotope fractionation in ${ }^{13} \mathrm{C}$ during sorption: determination by isotopic ${ }^{13} \mathrm{C}$ NMR spectrometry with vanillin as model compound. Chemosphere, 87, pp. 445-452, 2012

4. E.P. Botosoa, E. Caytan, V. Silvestre, R.J. Robins, S. Akoka and G.S. Remaud, Unexpected fractionation in site-specific ${ }^{13} \mathrm{C}$ isotopic distribution detected by quantitative ${ }^{13} \mathrm{C}$ NMR at natural abundance. J. Am. Chem. Soc., 130, pp. 414-415, 2008.

\section{8 - SCLEROCHRONOLOGIC ISOTOPE PATTERNS IN SHELLS OF THE AQUATIC GASTROPOD RADIX: A HYDROLOGIC AND CLIMATIC ARCHIVE FOR THE TIBETAN PLATEAU IN SUB-SEASONAL RESOLUTION}

\author{
Linda Taft ${ }^{1}$ - Steffen Mischke ${ }^{1,2}$ - Uwe Wiechert ${ }^{1}$ - Hucai Zhang ${ }^{3}$
}

${ }^{1}$ Department of Geological Sciences, Free University Berlin, Malteserstr. 74-100, 12249 Berlin, Germany, e-mail: linda.taft@fu-berlin.de (*corresponding author)

${ }^{2}$ Institute of Earth and Environmental Science, University of Potsdam, Karl-Liebknecht-Str. 24-25, 14476 Potsdam-Golm

${ }^{3}$ Key Laboratory of Plateau Lake Ecology and Global Change, College of Tourism and Geography, Yunnan Normal University, Kunming 650092, China 
It has been established that the Tibetan Plateau is one of the driving factors which fuels the atmospheric circulation on a regional and global scale. Particularly it influences the Asian monsoon system on which a billion people depend. The Tibetan Plateau hosts more than 1,000 lakes [1] and the headwaters of major southeast Asian rivers. It is therefore essential to understand the dynamics and processes of moisture transport and variability of modern and past conditions to implicate this knowledge to future scenarios. This is especially important concerning global change studies. However, archives from which palaeo-moisture signals can be inferred in a high resolution are scarce in this region.

Taft et al. [2, 3] have shown that the shells of the aquatic gastropod Radix represent such an archive. Sclerochronological $\delta^{18} \mathrm{O}$ and $\delta^{13} \mathrm{C}$ patterns provide useful information characterizing lake systems, climate and environmental conditions. Currently, Radix is widely distributed on the Tibetan Plateau and the fossil record reaches back to the Miocene. Aragonite shells of Radix have been analyzed by up to 30 sub-samples along the growth lines in order to obtain isotope signals from a complete annual hydrological cycle.

Our results show that $\delta^{18} \mathrm{O}$ signals in modern shells mirror single events and site characteristics (e.g. precipitation, meltwater inflow, ice cover period, evaporation) as well as general climate conditions and regional settings (e.g. monsoon/westerly influence). The $\delta^{13} \mathrm{C}$ compositions are primarily dependent on different carbon sources and biological activity in the lake.

In order to test the ability of fossils, 21 Radix shells from a sediment core taken in Lake Karakul, Tajikistan, have been studied. Generally high $\delta^{18} \mathrm{O}$ values indicate high evaporation and arid conditions. Negative shifts in the $\delta^{18} \mathrm{O}$ sclerochronological patterns mirror periods with freshwater input from melting glaciers in the catchment.

It has been reported that the Indian monsoon reached the most western part of the Tibetan Plateau during the early-mid Holocene [4]. In the near future, we will apply our approach to fossil shells from this region to examine whether this hypothesis is supported by the isotope shell patterns.

\section{References}

1. J. Hou, W.J. D'Andrea, Z. Liu, The influence of ${ }^{14} \mathrm{C}$ reservoir age on interpretation of paleolimnological records from the Tibetan Plateau. Quat. Sci. Rev., 48, pp. 67-79, 2012.

2. L. Taft, U. Wiechert, F. Riedel, M. Weynell, H.C. Zhang, Sub-seasonal oxygen and carbon isotope variations in shells of modern Radix sp. (Gastropoda) from the Tibetan Plateau: Potential of a new archive for palaeoclimatic studies. Quat. Sci. Rev., 34, pp. 44-56, 2012.

3. L. Taft, U. Wiechert, H.C. Zhang, G.L. Lei, S. Mischke, B. Plessen, M. Weynell, A. Winkler, F. Riedel, Oxygen and carbon isotope patterns archived in shells of the aquatic gastropod Radix: Hydrologic and climatic signals across the Tibetan Plateau in sub-monthly resolution. Quat. Int., 290-291, pp. 282-298, 2013.

4. E. Van Campo and F. Gasse, Pollen- and diatom-inferred climatic and hydrological changes in Sumxi Co Basin (Western Tibet) since 13,000 yr BP. Quat. Res., 39, pp. 300-313, 1993. 


\title{
019 - IS THERE ANY OBJECTIVE REASON TO OUTDATE THE K-AR METHOD APPLIED TO FINE-GRAINED MINERALS?
}

\author{
Norbert Clauer \\ Laboratoire d'Hydrologie et Géochimie de Strasbourg (CNRS/UdS), Strasbourg, France; \\ e-mail: nclauer@unistra.fr
}

A common claim these days is that he $\mathrm{K}-\mathrm{Ar}$ method is outdated and best replaced by the alternative ${ }^{40} \mathrm{Ar}{ }^{39} \mathrm{Ar}$ method. Made by non-specialists, including isotope geochemists, this claim is far from being straightforward, as it ignores the drawbacks of the alternative ${ }^{40} \mathrm{Ar} /{ }^{39} \mathrm{Ar}$ method. Beyond the reproducibility of the K-Ar method known to be less than that of the ${ }^{40} \mathrm{Ar} /{ }^{39} \mathrm{Ar}$ method, the accuracy can be at the same level depending on the investigators.

If the strengths and weaknesses of the two methods are only evaluated in strictly comparing coeval results obtained on the same mineral separates, and not on personal believes, the two methods are of equivalent potential when applied to finegrained clay-type materials. Prerequisites are the same for both, including well-controlled mineral preparation, particle size fractionation and mineral characterization, making failures resulting from inadequate steps of the analytical procedure and not from the used method.

Based on such strict comparisons, the major weaknesses of the K-Ar method are in the uncertainty of the $\mathrm{K}_{2} \mathrm{O}$ determinations, and in its pioneering status that incline some to consider it as no longer accurate, despite high quality equipments. Alternatively, the weaknesses of the ${ }^{40} \mathrm{Ar} /{ }^{39} \mathrm{Ar}$ method are clearly in the ${ }^{39} \mathrm{Ar}$ recoil, which becomes larger than the size of the crystals in studies of nanometric sized crystals, the necessary encapsulation procedure, the reintegration of the recoiled ${ }^{39} \mathrm{Ar}$ into the step-heating patterns, and even the meaning of the step-heating patterns.

In summary, the two methods are more complementary than outdating each other. More comparative studies on the same mineral powders need to be pursued for sound and realistic claims. At this point, such comparisons show that if the K-Ar method remains the preferred method for dating diagenetic clay processes such as glauconitization, nucleation and growth of nanometric illite crystals, or low-temperature hydrothermal activities, while the ${ }^{40} \mathrm{Ar}{ }^{39} \mathrm{Ar}$ method has probably more potential in dating clay gouges of tectono-thermal features and in decrypting pluri-generation low-grade metamorphic illite mixtures.

\section{0 - K-AR ISOTOPIC GEOCHEMISTRY OF MANTLE PHLOGOPITES: EXAMPLE OF UDACHNAYA-EAST KIMBERLITE}

\author{
D.S. Yudin - A.A. Tomilenko-A.V. Travin - T.A. Alifirova-D.V. Alekseev \\ Sobolev Institute of Geology and Mineralogy SB RAS, Novosibirsk, Russia; \\ e-mail: dsyudin@gmail.com
}


The technique of ${ }^{40} \mathrm{Ar} /{ }^{39} \mathrm{Ar}$ age determination of kimberlite entrainment on the example of different types of phlogopites from Udachnaya-East kimberlite pipe was suggested. Phlogopite (with grain size less than $50 \mu \mathrm{m}$ ) forming kelyphitic rims around garnets (KR-phlogopite) was of special interest. The genesis of these phlogopites from kelyphitic rims still remains debatable.

${ }^{40} \mathrm{Ar} /{ }^{39} \mathrm{Ar}$ step-heating procedure was conducted using technique described by Travin et al., 2009 [1]. The isotopic composition of argon was measured using a multi-collector mass spectrometer Argus (GV-Instruments, England). The errors quoted below correspond to $\pm 1 \sigma$.

${ }^{40} \mathrm{Ar} /{ }^{39} \mathrm{Ar}$ dating results of KR-phlogopites from mantle xenoliths of Udachnaya-East kimberlite pipe have shown ages varying from 600 to $333 \mathrm{Myr}$. Complex ${ }^{40} \mathrm{Ar}{ }^{39} \mathrm{Ar}$ age spectra were obtained for most of the samples (Fig. 1).

Among the analyzed samples only the KR-phlogopite of garnet selected directly from kimberlite matrix has age spectrum corresponding (within error) to the time of kimberlite entrainment [2] (Fig. 2).

Previously reported that ${ }^{40} \mathrm{Ar} /{ }^{39} \mathrm{Ar}$ ages of of phlogopites from xenoliths significantly exceed the intrusion age of host kimberlite [3]. Problem of argon preservation in phlogopite under deep conditions at temperatures significantly above the ${ }^{40} \mathrm{Ar} /{ }^{39} \mathrm{Ar}$ isotopic system closing temperature $[4,5]$ is well described in [6]. It is known that Ar in mica has solubility higher than that of other mantle minerals $[6,7,8]$. Thus, with no other "drains" presenting, Ar is more likely to be redistributed into phlogopite than into olivine, garnet, and pyroxenes having denser crystal lattices.

Based on ${ }^{40} \mathrm{Ar} /{ }^{39} \mathrm{Ar}$ geochronological data, the following suggestions can be done: 1) kelyphitic rims were formed before the entrainment of kimberlitic melt, 2) the effect of temperature of kimberlite melt on phlogopite resulted to rejuvenation of its $\mathrm{K} / \mathrm{Ar}$ isotopic system.

The situation may be considered through the Baxter model [9]. Mobility of argon within grain is described by bulk diffusion law. Radiogenic argon exchange between phlogopite and its environment takes place in the intergranular space characterizing by relatively high mobility of argon and limited capacity. The migration of argon goes directly to the proximate potential "traps". Given the above, only the grains of phlogopite can play role of these "traps" under mantle conditions. In this conjunction, an effective accumulation of radiogenic argon occurs in phlogopite grains, that allows one to date mantle events using ${ }^{40} \mathrm{Ar} /{ }^{39} \mathrm{Ar}$ method. Capturing of mantle xenoliths by melt leads to the migration of argon through the intergranular space out from the xenolith. Since the rate of this migration is high, it is similar to zero conditions at the grain boundary of phlogopite, what is confirmed by ${ }^{40} \mathrm{Ar} /{ }^{39} \mathrm{Ar}$ studies.

The results of numerical modeling for the presence of phlogopite in kimberlite melt (with zero conditions at a grain boundary) had shown an essential effect of the grain size on the stability of phlogopite isotopic system [10]. Given that the temperature of kimberlite melt is about $1100-1200^{\circ} \mathrm{C}$ and the duration of phlogopite presence 


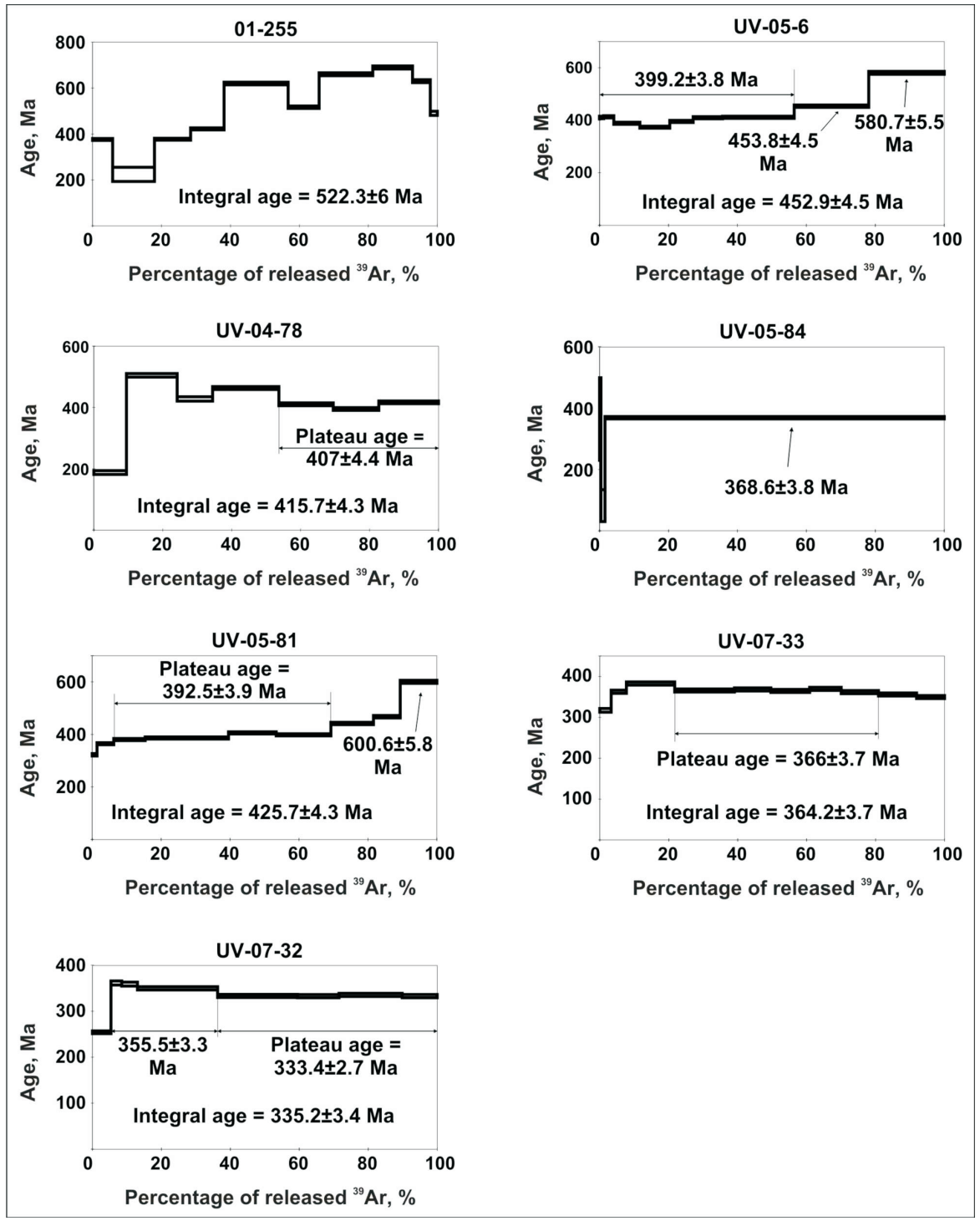

Figure 1. ${ }^{40} \mathrm{Ar} /{ }^{39} \mathrm{Ar}$ age spectra of KR-phlogopites from mantle xenoliths (Udachnaya-East kimberlite)

in kimberlite melt (from the capture of xenolith to the moment of displacement to the surface with further cooling) is about 40-60 minutes based on published data and our estimates of duration $[2,11]$. The $\mathrm{K} / \mathrm{Ar}$ isotope system of phlogopite (with grain size less than $0.05 \mathrm{~mm}$ ) will be completely reset to zero and will show an age of kimberlite entrainment. Grains of $0.05 \mathrm{~mm}$ size or more will give the age of phlogopite formation, 


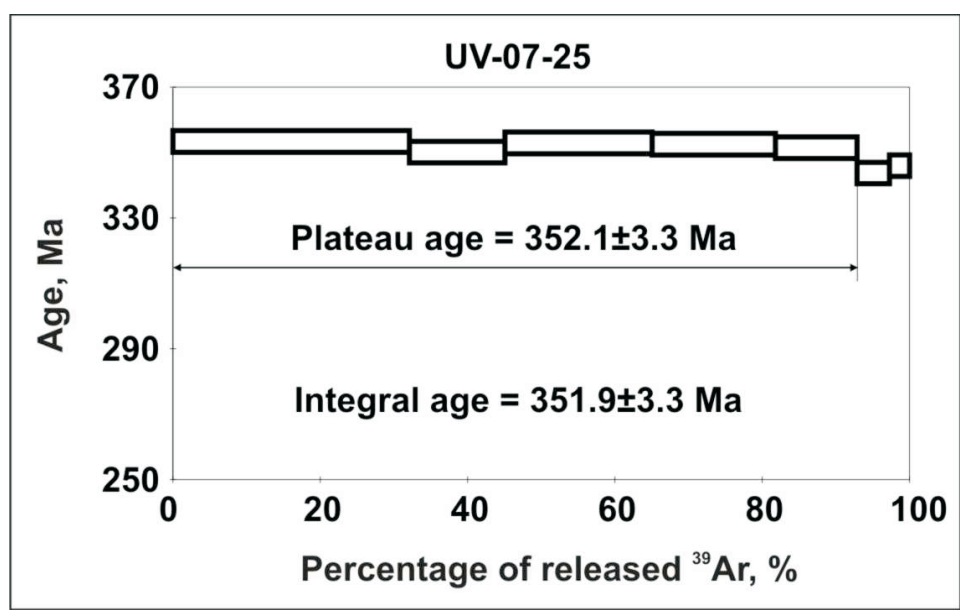

Figure 2. ${ }^{40} \mathrm{Ar} /{ }^{39} \mathrm{Ar}$ age spectrum of KR-phlogopite (case of contacting rim with kimberlite matrix)

or the value of age intermediate between the formation of phlogopite and the age of kimberlite intrusion. Figure 3 demonstrates the results of numerical modeling of ${ }^{40} \mathrm{Ar}$ loss as a function of phlogopite grain size. These results are in agreement with our ${ }^{40} \mathrm{Ar} /{ }^{39} \mathrm{Ar}$ data and observations of natural samples from Udachnaya-East kimberlite [this study; 3].

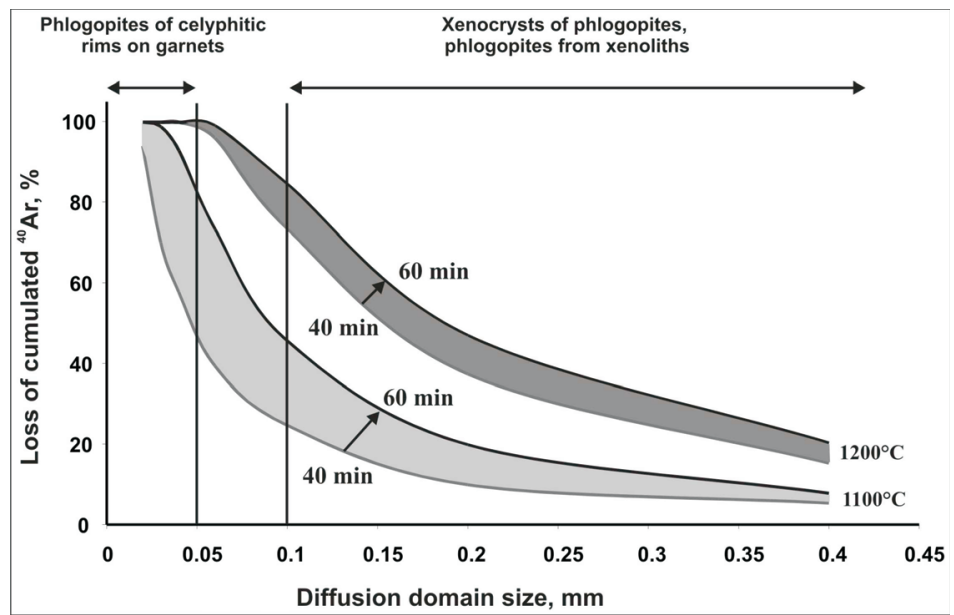

Figure 3. Dependence between losses of cumulated radiogenic ${ }^{40} \mathrm{Ar}$ and size of phlogopite grains is shown 
Summarizing the facts, it can be concluded that:

1) phlogopites from kelyphitic rims around garnets had been formed before the capturing of xenoliths by kimberlitic melt;

2) temperature effect of kimberlitic melt on the phlogopite had resulted to the rejuvenation of $\mathrm{K} / \mathrm{Ar}$ isotopic system of phlogopite.

According to numerical modeling results, fundamental criteria for the selection of phlogopite to age determining of kimberlite melt entrainment could be suggested: a) a grain size of phlogopite should not exceed $50 \mu \mathrm{m}, \mathrm{b}$ ) phlogopite should not be conserved inside other minerals (i.e. intergranular space should present, allowing argon freely migrate out from grain).

Acknowledgements: The work was supported by RFBR (grants Nor. 11-05-00144 and 11-05-00758), IP-22, and the grant of the President of Russia MK-3495.2012.5.

\section{References}

1. Travin, A.V., Yudin, D.S., Vladimirov, A.G., Khromykh, S.V., Volkova, N.I., Mekhonoshin, A.S. and Kolotilina, T.B., Thermochronology of the Chernorud Granulite Zone, Ol'khon Region, Western Baikal Area. Geochemistry International, 47(11), pp. 1107-1124, 2009.

2. Yudin, D.S., Pokhilenko, L.N., Tomilenko, A.A., Alifirova, T.A., Travin, A.V. and Alekseev, D.V., The estimation of the rate of kimberlite melt lifting. Large Igneous Provinces of Asia: Mantle Plumes and Metallogeny (Abstract volume). Irkutsk, Russia. August 20-23, pp. 305-307, 2011.

3. Pokhilenko, L.N., Alifirova, T.A. and Yudin, D.S. ${ }^{40} \mathrm{Ar} /{ }^{39} \mathrm{Ar}$-dating of phlogopite from the mantle xenoliths: evidence for deep ancient metasomatism of the Siberian craton lithosphere. Doklady Earth Sciences, 449(Part 1), pp. 309-312, 2013.

4. Dodson, M.H., Closure temperature in cooling geochronological and petrological systems. Contribs. Mineral. and Petrol., 40, pp. 259-274, 1973.

5. Giletti, B., Studies in diffusion. 1: Ar in phlogopite mica. In: Geochemical Transport and Kinetics. Hofmann, A., Gilleti, B.J., Yoder, H.S. Jr., Yund, R.A. (eds), Carnegie Institute of Washington Publ. 1974, pp.. 107-115.

6. Foland, K.A., Limited mobility of argon in a metamorphic terrain. Geochimica et Cosmochimica Acta, 43, pp. 793-801, 1979.

7. Roddick, J.C. Cliff, R.A. and Rex, D.C., The evolution of excess argon in Alpine biotites. A ${ }^{40} \mathrm{Ar} /{ }^{39} \mathrm{Ar}$ analysis. Earth Planet. Sci. Lett., 48, pp. 185-208, 1980.

8. Dahl, P.S., The crystal-chemical basis for Ar retention in micas: Inferences from interlayer partitioning and implications for geochronology. Contrib. Mineral Petrol., 123, pp. 22-39, 1996.

9. Baxter, E.F., Quantification of the factors controlling the presence of excess ${ }^{40} \mathrm{Ar}$ or $4 \mathrm{He}$. Earth Planet. Sci. Lett., 216, pp. 619-634, 2003.

10. Wheeler, J., Diffarg: a program for simulating argon diffusion profiles in minerals. Computers \& Geosciences, 22(8), pp. 919-929, 1996.

11. Wartho, J-A. and Kelley, S.P. ${ }^{40} \mathrm{Ar} /{ }^{39} \mathrm{Ar}$ ages in mantle xenolith phlogopites: Determining the ages of multiple lithospheric mantle events and diatreme ascent rates in southern Africa and Malaita,Solomon Islands. In: Vance, D., Müller, W. and Villa, I.M. (eds.), Geochronology: Linking the Isotopic Record with Petrology and Textures, Geological Journal, London, Special Publications, 220, pp. 231-248, 2003. 


\title{
021 - ON THE NATURE OF MINERALIZING FLUIDS OF THE BUGDAYA LARGE GOLD-BEARING Mo-W-PORPHYRY DEPOSIT (ESTERN TRANSBAIKALIA, RUSSIA): THE O-S-Sr ISOTOPIC CONSTRAINTS
}

\author{
Vladimir Kovalenker - Anna Avdeenko - Andrei Chugaev - \\ Galina Kiseleva Tan'ana Krylova \\ Institute of Geology of Ore deposits, Petrography, Mineralogy and Geochemistry RAS, \\ Moscow, Russia; e-mail: kva@igem.ru
}

\section{Introduction}

The large (third in the world for Mo resources) Bugdaya gold-bearing W-Mo-porphyry deposit (Eastern Transbaikalia, Russia), is located in the central part of volcanic dome within the Variscan Undinsk granitic pluton. This is a Climax-type deposit that differs by Au-enrichment. We have previously shown [1] that: (1) ores of the deposit were formed during Pre-ore (the $1^{\text {st }}$ ), Quartz-molybdenite (the $2^{\text {nd }}$ ) and Gold-base metal (the $3^{\text {rd }}$ ) stages of hydrothermal process; (2) gold enrichment of deposit was the result of overprinting of sub-epithermal Au-base-metal vein mineralization upon the earlier Mo-W-porphyry ores.

\section{Mineralizing fluids}

Temperatures of mineralizing fluids of the $1^{\text {st }}$ and the $2^{\text {nd }}$ stages that had $\mathrm{Na}-\left(\mathrm{Mg}\right.$ ?Ca?)-chloride composition varied from 560 to $350^{\circ} \mathrm{C}$. At the same time the temperature of fluids of the $3^{\text {rd }}$ stage that had $\mathrm{Na}-(\mathrm{Mg}$ ? Ca?)-chloride-bicarbonate (sulphate?) composition, were below $360^{\circ} \mathrm{C}$. Salinity of fluids of early $\left(1^{\text {st }}\right.$ and $\left.2^{\text {nd }}\right)$ stages reached $73 \mathrm{wt} . \% \mathrm{NaCl}$-equiv. and in the fluids of the $3^{\text {rd }}$ stage ranged from 0.5 to 23 wt.\% NaCl-equiv. The very strong variations in the concentrations of major components of the fluid have been found $\left(\mathrm{g} / \mathrm{kg} \mathrm{H}_{2} \mathrm{O}\right)$ : $\mathrm{CO}_{2}(145.3-3.9), \mathrm{CH}_{4}(0.8-0.05)$, Cl(129.8-5.0), SO4 (2 -) (28.0-2.7), $\mathrm{HCO}_{3}(-)$ (1378.2-17.3), Na (64.3-2.3), Ca (256.1-0.8), $\mathrm{K}(133.4-9.5)$ and $\mathrm{Mg}$ (85.3-1.3), with maximum values of many of these components in fluids of early associations of the $1^{\text {st }}$ and $2^{\text {nd }}$ stages. The $\mathrm{K} / \mathrm{Rb}$ ratio varies from 90 to 173 , which corresponds to at least for the early associations, to a range of magmatic fluid related to granitoids [2], and indicates a mixed double-source origin of fluid for later assemblages

\section{Isotopic studies}

To clarify the nature of fluids and estimate the contribution of various sources of the mineralizing solutions of the Bugdaya deposits, we studied the isotopic composition of oxygen, sulfur and strontium. Oxygen isotope composition of quartz belonging to different mineral assemblages of the $1^{\text {st }}, 2^{\text {nd }}$ and $3^{\text {rd }}$ stages was studied to assess the variation of oxygen isotope composition of water fluids during the ore-formation. The obtained values of $\delta^{18} \mathrm{O}$ of quartz were converted to oxygen isotope composition of water 
equilibrated with the quartz. We used the well-known equation [3] for the temperature range $500-250^{\circ} \mathrm{C}$ and the formation temperatures of each mineral assemblage obtained from studies of fluid inclusions. The significant variations in the values of $\delta^{18} \mathrm{O}$ in $\mathrm{H}_{2} \mathrm{O}$ fluid were revealed which show that fluids of the $1^{\text {st }}$ and $2^{\text {nd }}$ stages had $\delta^{18} \mathrm{O}$ values typical of magmatic fluid. At the same time, the mineral-solution of the $3^{\text {rd }}$ stage was characterized by the values that indicate magmatic and meteoric waters mixing in different proportions. In this case, according to our data, the latest low-temperature portions of the solutions were completely represented by meteoric water. This means that in the course of mineralizing process the contribution of magmatic components in the fluid was gradually decreasing at the expense of meteoric water.

The primary magmatic origin of mineralizing fluids is also supported by our results of sulfur isotope composition analyses of principal sulfide minerals (23 samples) from the mineral assemblages of the $2^{\text {nd }}$ and $3^{\text {rd }}$ stages. The variations in $\delta^{34} \mathrm{~S}$ are within a narrow range $(\%)$ : from -1.72 to $+3.07(n=10$ samples; average +0.37$)$ in pyrite, from +0.78 to +0.98 in chalcopyrite $(n=2)$, from +0.78 to $+4.97(n=5 ;+3.21)$ in sphalerite, from 2.60 to $+3.15(\mathrm{n}=5 ;+1.22)$ in galena and 1.08 in molybdenite $(\mathrm{n}=1)$. Based on these data and using known equations [4], and accepted average temperatures of mineralizing fluid, the $\delta^{34} \mathrm{~S}_{2} \mathrm{Saq}$ value were estimated and found to vary from +0.1 to $+0.4 \%$ for the $2^{\text {nd }}$ stage $\left(400^{\circ} \mathrm{C}\right)$ and from -2.1 to $-3.1 \%$ for the $3^{\text {rd }}$ stage $\left(300^{\circ} \mathrm{C}\right)$. These values correspond to magmatic source of sulfur.

In order to clarify the nature of fluid sources that generated productive for $\mathrm{Au}$, $\mathrm{Pb}$ and $\mathrm{Zn}$ mineralization of the $3^{\text {rd }}$ stage, the $\mathrm{Sr}$ isotope composition in carbonate of filling veins has been analyzed. The measured values of ${ }^{87} \mathrm{Sr} /{ }^{86} \mathrm{Sr}$ isotopic ratio vary in a relatively narrow range from 0.7079 to 0.7082 . Based on these values, there is no doubt that the geochemical source type of $\mathrm{Sr}$ in the ore-forming solution was of a crustal nature. We suggest that the most likely source of Sr were the Upper Permian granites of Undinsk massif that hosts the stockwork and vein mineralization concentrated at the endocontact of rhyolite-porphyry stock intruding this granite massif. This assumption is based on the fact that the $\mathrm{Sr}$ isotope composition of granites, during the evolution of mineralizing process, ranged from 0.708 to 0.710 [5], i.e. was close to the isotope composition of $\mathrm{Sr}$ in carbonate of this deposit. This means that $\mathrm{Sr}$ was extracted from these granites by circulating hydrothermal fluids infiltration through them.

\section{Conclusion}

The results of isotope studies show that: (1) the primary source of the mineralizing water solutions were the fluids of magmatic origin, that were mixed with meteoric water in the final periods of mineralization; (2) the sulfur involved in the mineral formation, had a magmatic source; (3) the most likely source of $\mathrm{Sr}$ carbonates, that formed in the final stage of mineralization, were granites of Undinsk pluton from which $\mathrm{Sr}$ was extracted by circulating hydrothermal fluids. 
Acknowledgement: This work was supported by RFBR, projects of 13-05-12043-ofi-m and 13-05-00622a.

\title{
References
}

1. V. A. Kovalenker, G. D. Kiseleva, T. L. Krylova and O. V. Andreeva, Mineralogy and Ore Formation Conditions of the Bugdaya Au_Bearing W-Mo Porphyry Deposit, Eastern Transbaikal Region, Russia. Geology of Ore Deposits, 53, pp. 93-125, 2011.

2. W. Irber, The lantanide tetrad effect and its correlation with $\mathrm{K} / \mathrm{Rb}, \mathrm{Eu} / \mathrm{Eu}{ }^{*}, \mathrm{Sr} / \mathrm{Eu}, \mathrm{Y} / \mathrm{Ho}$, and $\mathrm{Zr} / \mathrm{Hf}$ of evolving peraluminous granite suites. Geochim. et Cosmochim. Acta, 63(3/4), pp. 489-508, 1999.

3. Y. Matsuhisa, J.R. Goldsmith and R.N. Clyton, Oxygen isotopic fractionation in the system quartz-albite-anorthite-water. Geochimica et Cosmochimica Acta, 43, pp. 1131-1140, 1979.

4. C.W. Field and R.H. Fifarek, Light stable isotope systematics in the epithermal environment. Rev. in Economic Geology, 2, pp. 99-128, 1985.

5. V.D. Kozlov, S.V. Efremov, S.I. Dril and G.P. Sandimirova, Geochemistry, isotope geochronology and genetic features of the Verhneundins granite batholith (Eastern Transbaikalia). Geochemistry International, 4, pp. 408-425, 2004.

\section{2 - ISOTOPIC PATTERN IN DECAYING WOOD INDICATE NITROGEN TRANSLOCATION AND USE OF EXTERNAL NITROGEN SOURCES DURING THE DECOMPOSITION OF NORWAY SPRUCE LOGS}

\author{
S.P. Sah-R. Mäkipää \\ Finnish Forest Research Institute (METLA), PL 18 (01370 Jokiniemenkuja 1), \\ 01301 VANTAA, Finland; e-mail: Shambhu.sah@metla.fi
}

Nitrogen $(\mathrm{N})$ content increases with advancing wood decay; however, the sources contributing to such increase have rarely been investigated. Similarly, C-sources (external to the decomposing wood) during wood decay remain unexplored. The overall aim was to investigate the nitrogen and carbon dynamics of decomposing wood in two boreal forest ecosystems. Two unmanaged semi-natural boreal Norway spruce (Picea abies (L.) Karst.) in Loppi and Lapinjärvi, southern Finland, were selected for the present study. For this purpose, we analysed stable isotopes of decaying wood. Our results indicated that both $\delta^{13} \mathrm{C}$ and $\delta^{15} \mathrm{~N}$ values varied significantly with mass loss of decomposing wood, showing the variations in the sources of C and N. In the both stands, the $\delta^{13} \mathrm{C}$ values of decaying wood showed the significant $(\mathrm{p} \leq 0.05)$ decreasing trend (Lapinjärvi site, $-24.2 \%$ to $-25.6 \%$ and Loppi site. $-25.4 \%$ to $-26.5 \%$ ) and ${ }^{15} \mathrm{~N}$ showed the significant ( $\mathrm{p} \leq 0.05$ ) increasing trend (Lapinjärvi site, $-4.5 \%$ o to $-3.8 \%$ o and Loppi site, $-4.1 \%$ to $-2.4 \%$ ) with the mass loss. The observed wood ${ }^{15} \mathrm{~N}$ enrichment across the mass loss is attributed to the fungal translocation of $\mathrm{N}$ (due to their broad range of ${ }^{15} \mathrm{~N}$ values from -6 to $+15 \%$ ) to the decaying wood, because other external factors (such as, atmospheric N2-fixation, atmospheric N-deposition, litter resi- 
dues on the decaying wood, and microbial biomass in-growth) are not able to explain this either due to its more depleted ${ }^{15} \mathrm{~N}$ values than the fresh decaying wood or due to its low amount availability. We hypothesize that forest soil, in general, seems to be a more dominant source for fungal $\mathrm{N}$ translocation during the advanced decay stages of $\log .{ }^{13} \mathrm{C}$ depletion in decaying wood is attributed to the accumulation of ${ }^{13} \mathrm{C}$-depleted lignin with decay and hence it seems that the decaying wood substrate remains major source of $\mathrm{C}$ to the decaying wood. Further researches on the natural abundance of ${ }^{13} \mathrm{C}$ and ${ }^{15} \mathrm{~N}$ isotopes in the different substrates, and in the sporocarps of the various functional groups of fungi occurring at the different phases of decay, are needed to explain in more detail the mechanisms of $\mathrm{C}$ and $\mathrm{N}$ dynamics underlying in decaying wood.

\section{3 - AN ISOTOPIC $\left(\delta^{18}\right.$ O) APPROACH IN THE ASSESSMENT OF SHALLOW/THERMOMINERAL WATER INTERACTIONS IN A KARST REGION (PORTUGAL)}

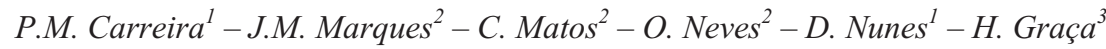

${ }^{1}$ Instituto Superior Técnico, Campus Tecnológico e Nuclear (IST/CTN), Technical University of Lisbon, Estrada Nacional no 10, 2686 - 953 Sacavém, Portugal; e-mail: carreira@ctn.ist.utl.pt

${ }^{2}$ Instituto Superior Técnico, Technical University of Lisbon, CEPGIST/CERENA, Lisboa, Portugal

${ }^{3}$ Centro Hospitalar das Caldas da Rainha, Caldas da Rainha, Portugal
}

The main objective of this study is to increase knowledge on the existence of possible mixing processes between Caldas da Rainha deep thermomineral waters $\left(\mathrm{T} \approx 32^{\circ} \mathrm{C}\right)$, used in local Spas, and local shallow cold groundwaters. For this purpose a structural geology, hydrogeomorphology, hydrogeochemistry and isotope hydrology (e.g. $\delta^{18} \mathrm{O}$, $\delta^{13} \mathrm{C},{ }^{3} \mathrm{H}$ and ${ }^{14} \mathrm{C}$ ) interdisciplinary geosciences survey was used.

Caldas da Rainha thermomineral waters (Fig. 1) discharge from springs and boreholes located close to a locally N-S oriented oblique fault $\left(60^{\circ} \mathrm{E}\right)$ that places loamy detritic Upper Jurassic rocks and Hetangian-Retian marls (and evaporitic deposits) in contact (Marques et al., 2007).

The $\mathrm{HCO}_{3}{ }^{-}, \mathrm{Ca}^{2+}$ and $\mathrm{Mg}^{2+}$ signatures are related to water/calcite-dolomite interaction, whereas $\mathrm{Na}^{+}, \mathrm{Cl}^{-}$and $\mathrm{SO}_{4}{ }^{2-}$ concentrations are mainly associated with halite and gypsum dissolution. Dry residuum values are around $3000 \mathrm{mg} / \mathrm{L}$.

The $\delta^{18} \mathrm{O}$ values indicate that the hydromineral aquifer system is depleted in heavy isotopes, indicating a main recharge area related to the Lower Jurassic carbonate formations of the Candeeiros Mountain (the main karstified region of the system, east of Caldas da Rainha).

The systematic tritium measurements carried out in the thermomineral borehole waters shows contents ranging from 1.1 to $2.8 \mathrm{TU}$. To a first approach, these ${ }^{3} \mathrm{H}$ concentrations could be interpreted as the result of mixing with shallow groundwaters 


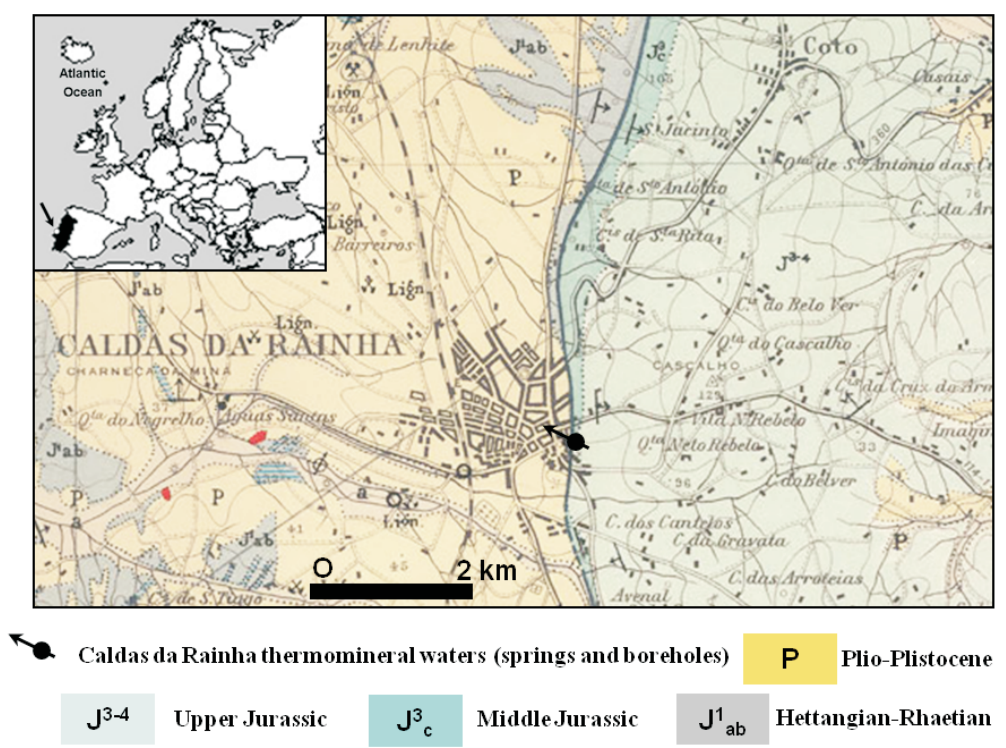

Figure 1. Geographic location of Caldas da Rainha thermomineral waters and simplified geology of the study region. Adapted from Zbyszewski and Moitinho de Almeida, 1960

systems. However, the presence of ${ }^{3} \mathrm{H}$ in the thermomineral borehole waters is not accompanied by an increase in $\mathrm{SO}_{4}{ }^{2-}$ and $\mathrm{NO}_{3}^{-}$which, in agricultural areas, are good indicators of anthropogenic contamination. The presence of ${ }^{3} \mathrm{H}$ in the thermomineral borehole waters seems to be related with shallow and shorter underground flowpaths. On the other hand, the possibility of mixing between these systems through leaking borehole casing (small amounts of water) should be unreliable considering the tritium content in the atmosphere around $4 \mathrm{TU}$ (Carreira et al., 2005) or even the peak of tritium during the thermonuclear tests performed during the 1960s.

The $\delta^{13} \mathrm{C}$ values are typical for carbonate dissolution enhanced by soil derived $\mathrm{H}_{2} \mathrm{CO}_{3}$ (Goldscheider and Drew, 2007). This hydrothermal aquifer system is dominated by deep karst/fissured-porous Lower Jurassic carbonate formations containing slow flowing groundwater. ${ }^{14} \mathrm{C}$ determinations indicate a mean apparent radiocarbon "age" of about 1600 years BP for the thermal waters (Marques et al., 2012).

A reservoir temperature between $100^{\circ} \mathrm{C}$ and $150^{\circ} \mathrm{C}$ was obtained by the $\mathrm{SO}_{4}{ }^{2-}-\mathrm{H}_{2} \mathrm{O}$ isotope geothermometer (Lloyd, 1968; Mizutani and Rafter, 1969). The lack of mixing trends between the thermal and the local shallow cold groundwaters indicates that both water sources are distinct, which is important for maintaining the quality of the thermal water resources of the study region.

This study shows the wide applicability of geochemical and environmental isotopic methods in thermal waters assessment in karst regions. 
AIG10 - 2013

Acknowledgement: This study was proposed and funded by the Ministry of Health / Centro Hospitalar das Caldas da Rainha / Portugal, under the Research Contract HIDROCALDAS No. 1577.

\title{
References
}

G. Zbyszewski and F. Moitinho de Almeida, Carta Geológica de Portugal, escala 1/50 000. Notícia Explicativa da Folha 26-D - Caldas da Rainha. Serviços Geológicos de Portugal, Lisbon, 1960.

J.M. Marques, H. Graça, H.G.M. Eggenkamp, P.M. Carreira, B. Mayer and D. Nunes, Contribuição de traçadores geoquímicos e isotópicos para a avaliação das águas termais das Caldas da Rainha. Comun. Geol., 99 (2), pp. 43-51, 2012.

J.M. Marques, H. Graça, P.M. Carreira, M.J. Matias, R.C. Graça and D. Nunes, Updating Caldas da Rainha thermomineral waters conceptual model (Central Portugal): a preliminary isotopic $\left({ }^{18} \mathrm{O}\right.$, ${ }^{2} \mathrm{H}$ and ${ }^{3} \mathrm{H}$ ) approach. Proceedings of the Symposium on Thermal and Mineral waters in Hard Rock Terrains (Marques, J.M., Chambel, A. \& Ribeiro, L. eds), pp. 131-144, 2007.

N. Goldscheider and D. Drew, Methods in karst Hydrogeology. Taylor and Francis Group, London, 2007.

P.M. Carreira, P. Valério, D. Nunes and M.F. Araújo, Temporal and seasonal variation of stable isotopes and tritium in precipitation over Portugal. Proceedings of the International Conference Isotopes in Environmental Studies. Aquatic Forum 2004. IAEA Conference Symposium Papers 26/P, Vienna, pp. 370-373, 2005.

R.M. Lloyd, Oxygen isotope behaviour in the sulphate-water system. J. Geophys. Res., 73, pp. 6099-6110, 1968.

Y. Mizutani, and T.A. Rafter, Oxygen isotopic composition of sulphates, Part 3: Oxygen isotopic fractionation in the bisulphate ion-water system. New Zeal. J. Sci., 12, pp. 54-59, 1969.

\section{4 - METHANE AND ETHANE IN HYPERALKALINE MINERAL WATERS IN THE ALTER-DO-CHÃO ULTRAMAFIC INTRUSIVE MASSIF (CABEÇO DE VIDE - PORTUGAL)}

\author{
José Marques $^{1}$ - Steve Vance $^{2}$ - Lance Christensen ${ }^{2}$ - Giuseppe Etiope ${ }^{3}$ - \\ Paula Carreira ${ }^{4}$ - Shino Suzuki ${ }^{5}$
}

${ }^{1}$ Instituto Superior Técnico, Technical University of Lisbon, CEPGIST / CERENA, Lisboa, Portugal; e-mail: jose.marques@ist.utl.pt

${ }^{2}$ NASA - Jet Propulsion Laboratory, California Institute of Technology, Pasadena, USA

${ }^{3}$ Istituto Nazionale di Geofisica e Vulcanologia, Sezione Roma 2, Roma, Italy and Faculty of Environmental Science and Engineering, Babes-Bolyai University Cluj-Napoca, Romania

${ }^{4}$ Campus Tecnológico e Nuclear IST/CTN, Instituto Superior Técnico, Technical University of Lisbon, Portugal

${ }^{5}$ John Craig Venter Institute, San Diego, California, USA

\section{Introduction}

To date, the surface outflow of dominantly abiotic hydrocarbons in low temperature $\left(<100-150^{\circ} \mathrm{C}\right)$ environments was identified in the Atlantic Lost City hydrothermal system (e.g., Proskurowski et al., 2008) and, documented with complete $\mathrm{C}$ and $\mathrm{H}$ isotopic composition of $\mathrm{CH}_{4}$, in the Philippines, Oman, New Zealand, Turkey, Italy, 
Greece and Japan. In these continental sites gas is issuing from seeps or water springs in ophiolitic rocks or igneous intrusions with evidence of present-day serpentinization (see review by Etiope and Sherwood Lollar, 2013). Ultramafic rocks (e.g., peridotites in ophiolites) are widespread all over the world and signs of active serpentinization on land (e.g., occurrence of $\mathrm{H}_{2}$, methane or hyperalkaline springs) are known in other regions (e.g., California; Morrill et al., 2013; Canada, Romania, Cyprus and Jordan; Etiope et al., 2013a).

The list is growing. Methane with ${ }^{13} \mathrm{C}$ enriched composition has more recently been discovered in hyperalkaline waters in Portugal, at Cabeço de Vide (Etiope et al., 2013b). Here we focus on this new gas-bearing serpentinization site, summarizing and integrating the main results reported by Marques et al. (2008) on the water chemistry and by Etiope et al. (2013b) on gas chemistry, in order to develop a general fluid circulation model applicable to other cases. Isotopic data for water and gas will be decisive in this task.

This study has implications in microbiology and origin of life on Earth and other planets (e.g., Schulte et al., 2006; Russell et al., 2010; Etiope et al., 2011). For life to have emerged from rocks and water on such environments, a continuous source of chemically transducible energy is essential (e.g., Russell et al., 2010). The serpentinization process is emerging as an increasingly likely source of that energy (e.g., Fritz et al., 1992; Etiope et al., 2011). Recent evidence indicates that liquid water was once abundant at surface of Mars, and also that serpentinization was and may continue to be an important process there (e.g., Michalski et al., 2013). Additional evidence points to the contemporary presence of liquid water in icy satellites, with Europa and Enceladus emerging as places that may host serpentinization-derived life to the present day (Vance et al., 2007). Assuming the possibility that the observed methane and ethane degassing from the Cabeço de Vide serpentinized ultramafic geological environment may also occur in the serpentinized rocks on Mars, we might speculate on the significance of Cabeço de Vide as a Mars analog site. Thus, understanding the nature of serpentinization at Cabeço de Vide could have far-reaching implications.

\section{Site description}

Cabeço de Vide spring and borehole mineral waters are located in the Alter-do-Chão pluton, a ring-like intrusion with NW-SE elongated shape, following the Variscan orientation. Mafic rocks (mainly gabbros) outcrop surrounding the ultramafic core comprising dunites, serpentinized dunites to serpentinites and peridotites (Fig. 1).

This pluton has been faced as a cumulate-type structure of Ordovician age (Ribeiro da Costa et al., 1993). The serpentinization is driven by meteoric water infiltration (present-day serpentinization), according to models described by Barnes et al. (1967; 1972), Bruni et al. (2002) and Marques et al. (2008).

Local $\mathrm{HCO}_{3}$-Mg-type waters constitute most of the surface (stream) and shallow groundwaters discharging from the serpentinites (Marques et al., 2008). Serpen- 


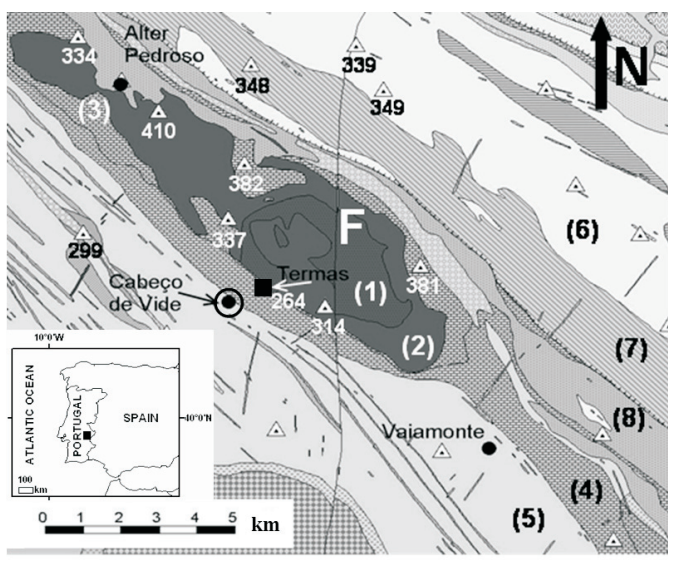

Figure 1. Location and geologic map of Cabeço de Vide area (1) serpentinized ultramafic rocks; (2) mafic and ultramafic rocks; (3) hornfels; (4) carbonate rocks, displaying contact metamorphism;

(5) Cambrian rocks: schists, quartzites and greywackes; (6) pre-Cambrian rocks: metamorphic schists and greywackes; (7) orthogneisses and (8) orthogneisses and hyperalkaline syenites.

"Termas" stands for Cabeço de Vide spa and boreholes. F stands for the main regional NNE-SSW trending fault. Altitude (m a.s.l.) is given through the geodetic marks $(\triangle)$.

Adapted from Marques et al. (2008) and J. Fernandes (pers. comm.)

tine dissolution might explain the high $\mathrm{Mg}^{2+}$ and $\mathrm{SiO}_{2}$ concentrations found in the local $\mathrm{Mg}^{-} \mathrm{HCO}_{3}$-type waters (e.g., Barnes et al., 1967).

The Cabeço de Vide mineral waters discharge with a temperature between 17 and $20^{\circ} \mathrm{C}$, very alkaline $\mathrm{pH}$ values $(10.5<\mathrm{pH}<11.5)$ and electrical conductivity values between 400 and $650 \mu \mathrm{S} / \mathrm{cm}$. Their main chemical characteristics are: i) $\mathrm{Na}-\mathrm{Cl} / \mathrm{Ca}-\mathrm{OH}$ facies; ii) rather low mineralization (dry residuum around $200 \mathrm{mg} / \mathrm{L}$ ); iii) $\mathrm{C}_{\text {total }}<3.0 \mathrm{mg} / \mathrm{L}$; and vi) extremely low $\mathrm{Mg}^{2+}$ and silica concentrations, below 0.3 and $6.5 \mathrm{mg} / \mathrm{L}$, respectively (Marques et al. 2008). Barnes et al. (1967) suggest that serpentinization of the ultramafic rocks might contribute to the development of such type of mineral waters.

\section{Water isotopic composition}

Isotopic $\left({ }^{18} \mathrm{O} /{ }^{16} \mathrm{O}\right.$ and $\left.{ }^{2} \mathrm{H} /{ }^{1} \mathrm{H}\right)$ ratios were used to estimate the relative importance of locally infiltrated meteoric waters to the recharge of the Cabeço de Vide mineral waters (Marques et al., 2008). For most of the samples, the relationship between the concentrations of the environmental stable isotopes $\left(\delta^{2} \mathrm{H}\right.$ and $\left.\delta^{18} \mathrm{O}\right)$ in Cabeço de Vide mineral waters (Fig. 2) is comparable to the relationship in the Global Meteoric Water Line (GMWL: $\delta^{2} \mathrm{H}=8 \delta^{18} \mathrm{O}+10$ ) defined by Craig (1961), indicating that i) they are meteoric waters, and ii) there is no evidence of water/rock interaction at high temperatures, consistent with the low issue temperature of the Cabeço de Vide mineral waters (Marques et al., 2008). 


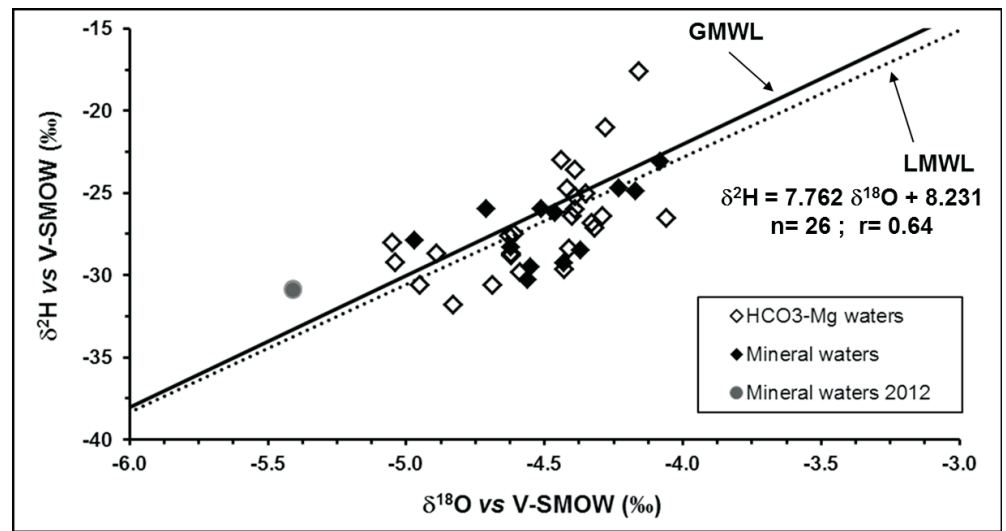

Figure 2. $\delta^{2} \mathrm{H}$ vs. $\delta^{18} \mathrm{O}$ relationship in water samples from the Cabeço de Vide region. Data from Marques et al. (2008) and from a recent (2012) field work campaign

The local shallow $\mathrm{HCO}_{3}-\mathrm{Mg}$ groundwaters, discharging from the serpentinized dunites, and the Cabeço de Vide mineral waters have similar $\delta^{2} \mathrm{H}$ and $\delta^{18} \mathrm{O}$ values (around $-27 \%$ and $-4.5 \%$, respectively), indicating that the mineral waters could have evolved ascribed to the deep infiltration of the shallow $\mathrm{HCO}_{3}-\mathrm{Mg}$ groundwaters (Marques et al., 2008). However, the recent isotopic data obtained from the 2012 fieldwork campaign in the same boreholes (AC3 and AC5) reveals isotopic depletion of about $1 \%$ in ${ }^{18} \mathrm{O}$ and of $4 \%$ in ${ }^{2} \mathrm{H}$. This discrepancy could be ascribed to the different analytical methods used: in the previous isotopic measurements (Marques et al., 2008) a SIRA 10 mass spectrometer from VG ISOGAS was used following the analytical methods proposed by Epstein and Mayeda (1953) for ${ }^{18} \mathrm{O}$ and Friedman (1953) for ${ }^{2} \mathrm{H}$, while in 2012 laser spectroscopic analysis was used LWIA-24d from LGR.

Cabeço de Vide mineral waters were collected for ${ }^{14} \mathrm{C}$-age determinations by AMS (Geochron Laboratories, USA). Based on a closed system model (Salem et al., 1980), an apparent groundwater age between $3.6 \pm 2.3 \mathrm{ka} \mathrm{BP}$ and $6.0 \pm 2.2 \mathrm{ka} \mathrm{BP}$, was obtained in boreholes AC5 and AC3, respectively.

\section{Gas chemistry and methane isotopic composition}

In 2012 gas has been detected in solution in the Cabeço de Vide mineral waters, from the $\mathrm{AC} 3$ and $\mathrm{AC} 5$ boreholes, through multiple analytical techniques including sensors adopted for gas exploration on Earth and Mars (Etiope et al. 2013b). On site measurements using Jet Propulsion Laboratory instrumentation, a tunable diode laser absorption spectrometer (TDLAS) adapted to be hand-carried (Christensen et al., 2010) provided immediate recognition of the presence of both methane and ethane. Successive laboratory analyses confirmed the presence of methane and ethane $(1.2$ and $0.03 \mathrm{mg} / \mathrm{L}$, respectively), the lack of $\mathrm{CO}_{2}$ and $\mathrm{H}_{2}$ and determined the isotopic composition of methane. While the absence of $\mathrm{CO}_{2}$ is the norm in hyperalkaline waters, the absence of 
$\mathrm{H}_{2}$ is apparently unusual, since $\mathrm{H}_{2}$ should be the primary gas produced by serpentinization. Similar observations however have been reported in ophiolitic hyperalkaline waters in Italy and Greece (Boschetti et al., 2013; Etiope et al., 2013a). The paucity of $\mathrm{H}_{2}$ could be due to its complete consumption by $\mathrm{CO}_{2}$ reduction in a limited or decreased $\mathrm{H}_{2}$ production system (Etiope et al., 2013b). Microbiological studies may verify, in the future, if $\mathrm{H}_{2}$ consumption is also due to microbial activity since the most dominant microbe in Cabeço de Vide mineral water from the AC3 is close to well-known hydrogen oxydizing bacterium (Tiago and Veríssimo, 2012; Willems et al. 1989).

The $\mathrm{CH}_{4}$ isotopic composition is substantially different from that of typical microbial or thermogenic gas, falling in the range of typical abiotic gas found in other serpentinizing sites (Fig. 3). The origin of ethane is unknown at this stage; isotopic analyses shall be performed in a next study.

Both on site and laboratory measurements showed a low $\mathrm{C}_{1} / \mathrm{C}_{2}$ ratio (40 and 35 in $\mathrm{AC} 3$ and $\mathrm{AC} 5$ boreholes, respectively) suggesting a predominantly non-microbial source; the existence of microbial $\mathrm{CH}_{4}$ is likely precluded by the lack of methanogenic archaea, as recently observed by Tiago and Veríssimo (2012).

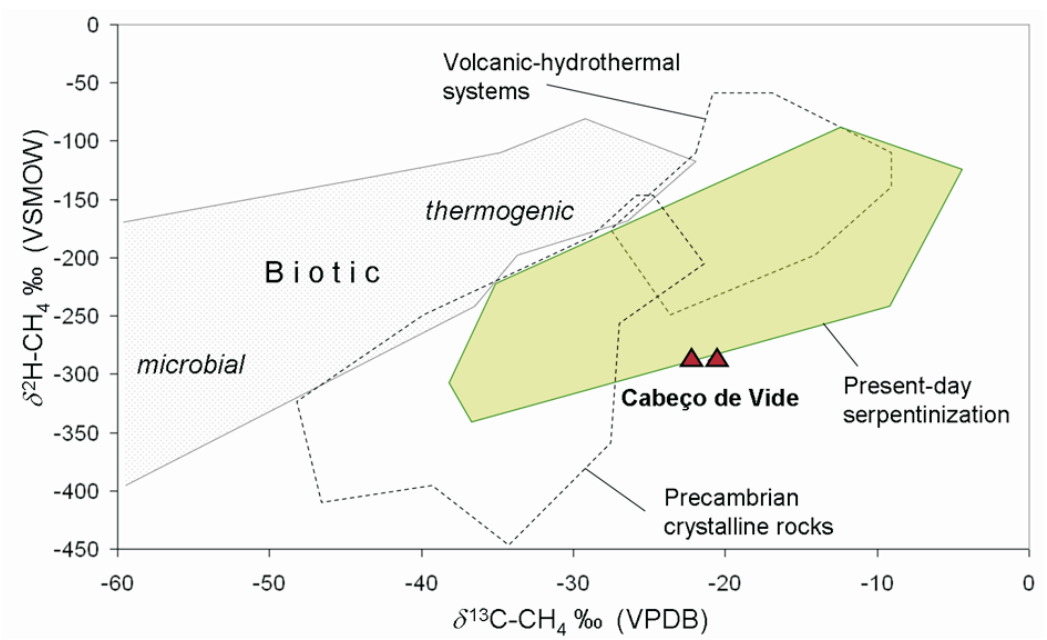

Figure 3. $\delta^{13} \mathrm{C}_{\mathrm{CH} 4}$ vs. $\delta^{2} \mathrm{H}_{\mathrm{CH} 4}$ diagram of Cabeço de Vide mineral waters compared with the fields of all biotic- vs. abiotic-driven gases so far documented (data from Etiope et al., 2013b, and references therein)

\section{Gas-water circulation model}

The existence of methane and other hydrocarbons in hyperalkaline waters is today a well known phenomenon. While present-day serpentinization produces two types of waters, $\mathrm{HCO}_{3}-\mathrm{Mg}$-type with moderate $\mathrm{pH}$ and $\mathrm{Ca}^{2+}-\mathrm{OH}^{-}$-type with $\mathrm{pH}>10$, it seems 
that the hydrocarbons occur only in the second type (Etiope et al., 2013a). The data of Cabeco-de-Vide confirm this hypothesis.

The $\mathrm{HCO}_{3}-\mathrm{Mg}$-rich waters result from a shallow and low residence circulation time, while the hyperalkaline waters represent a deeper circuit, where water interacted, with longer residence times (as suggested by isotopic data) with serpentinizing rocks. During this interaction the water becomes enriched in gases within the rocks, probably produced by $\mathrm{CO}_{2}$ hydrogenation (Etiope and Sherwood Lollar, 2013 and references therein).

Integrating the water and gas chemistry results described above, we propose a fluid circulation model, starting from the preliminary model suggested by Marques et al. (2008). The improved model can be summarized as follows:

(a) Local shallow waters are generated in a first step, under open $\mathrm{CO}_{2}$ conditions, due to meteoric water-serpentinite interactions; these are the $\mathrm{HCO}_{3}-\mathrm{Mg}$-rich waters;

(b) The mineral waters are produced in a later step, under closed $\mathrm{CO}_{2}$ conditions, due to water-dunite interaction at depth; increasing the $\mathrm{pH}$ values and favouring calcite precipitation (see Photo 1). The minero-petrographic studies performed on drill cores from Cabeço de Vide AC3 and AC5 boreholes corroborate this model, with most of the $\mathrm{Mg}$ and $\mathrm{SiO}_{2}$ retained in serpentines and vein brucite;

(c) Under these deep and closed conditions, $\mathrm{CO}_{2}$ exsolves from the water due to the high calcium levels and carbonate buffering is insignificant. In addition $\mathrm{CO}_{2}$ is likely consumed by hydrogenation to form $\mathrm{CH}_{4}$;

(d) Methane produced by $\mathrm{CO}_{2}$ hydrogenation in deep serpentinized rocks enters the waters and is transported to the surface. The exact location of gas production

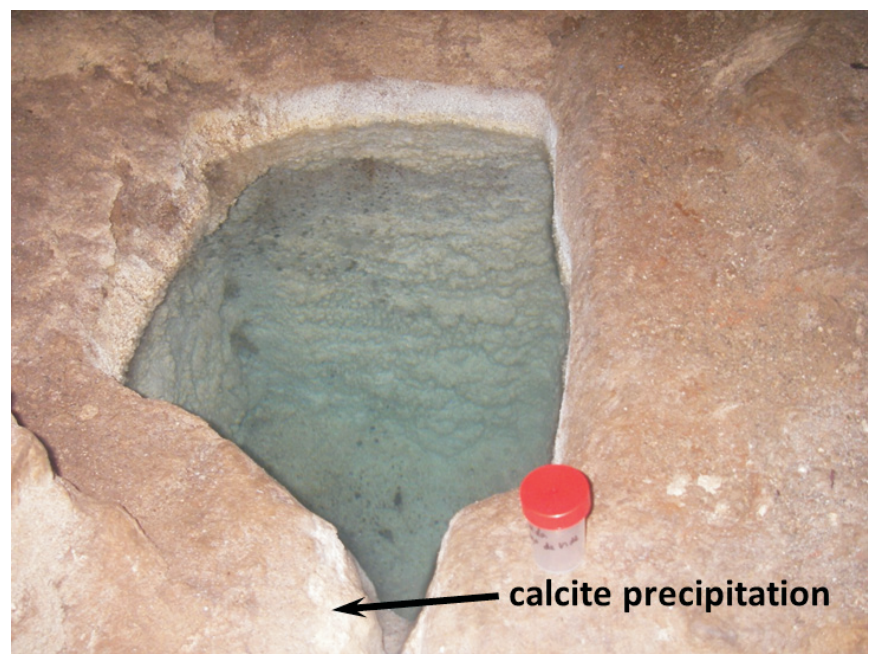

Photo 1. The spring Ermida at Cabeço de Vide (Portugal) discharging hyperalkaline mineral waters 
(the source rock) is unknown; it should however correspond to the rocks having favourable conditions for gas synthesis (presence of $\mathrm{CO}_{2}$ and $\mathrm{H}_{2}$ and suitable metal catalysts) and accumulation (secondary permeability, fractures). In this respect a specific study is going to be discussed elsewhere (Etiope, unpublished data).

In this framework microbial activity can operate on two levels: contribute to $\mathrm{CH}_{4}$ production and/or consumption, and contribute to $\mathrm{H}_{2}$ consumption, both in shallow or deep rocks, along the water circulation path.

\section{Concluding remarks and outlook}

In this case study, we have reported methane of apparent abiotic origin in continental serpentinized ultramafic rocks, degassing from hyperalkaline $(\mathrm{pH}>10) \mathrm{Ca}^{2+}-\mathrm{OH}^{-}$ mineral waters (of meteoric origin) in boreholes drilled in the Alter-do-Chão igneous intrusion, at Cabeço de Vide (mainland Portugal). ${ }^{13} \mathrm{C}$-enrichment in $\mathrm{CH}_{4}$ suggests a dominant abiotic source, although minor thermogenic contributions cannot be excluded. Also, low methane-to-ethane ratios suggest a mainly non-microbial source, consistent with former microbiological data showing the lack of methanogenic archaea in these waters. The use of isotopic tracers has proved to be highly effective in the improvement of the conceptual model of Cabeço de Vide mineral waters. We expect that future development of these studies significantly contribute to a greater understanding not only of extremophiles (the data may provide a milestone in terms of understanding a new type of alkaline microbial community), but to models of early Earthly life, and possibly of life in non-Earth (e.g., Mars) geochemically-driven systems.

Acknowledgements: Parts of these studies were supported by FCT/MEC (PIDDAC) funds under the scope of the Project PTDC/AAG-MAA/2891/2012. Laboratory molecular and isotopic analyses were performed by INGV project funds related to the institutional Specific Objective 4.5 - Natural degassing and petroleum gases. Work performed at the Jet Propulsion Laboratory, California Institute of Technology, was done under contract with NASA and funded by NASA ASTEP and Astrobiology Programs.

\section{References}

I. Barnes, V.C. LaMarche Jr., and G.R. Himmelberg, Geochemical evidence of present-day serpentinization. Science, 56, pp. 830-832, 1967.

I. Barnes, J.B. Rapp, J.R. O’Neil, R.A. Sheppard and A.J. Gude, Metamorphic assemblages and the direction of flow of metamorphic fluids in four instances of serpentinization. Contrib. Mineral. Petrol., 35, pp. 263-276, 1972.

T. Boschetti, G. Etiope and L. Toscani, Abiotic methane in the hyperalkaline springs of Genova, Italy. Proc. Earth Planet. Sci., http://dx.doi.org/10.1016/j.proeps.2013.02.004, 2013.

J. Bruni, M. Canepa, F. Cipolli, L. Marini, G. Ottonello and M. Vetuschi Zuccolini, Irreversible water-rock mass transfer accompanying the generation of the neutral, $\mathrm{Mg}-\mathrm{HCO}_{3}$ and high-pH, $\mathrm{Ca}-\mathrm{OH}$ spring waters of the Genova province, Italy. Appl. Geochem., 17, pp. 455-474, 2002.

L.E. Christensen, K. Mansour and R.Q. Yang, Thermoelectrically-cooled interband cascade laser for field measurements. Opt. Eng., 49, pp. 111-119, 2010. 
H. Craig, Isotopic variations in meteoric waters. Science, 133, pp. 1703-1704, 1961.

S. Epstein and T. Mayeda, Variation of ${ }^{18} \mathrm{O}$ content of waters from natural sources. Geochim. Cosmochim. Acta, 4, pp. 213-224, 1953.

G. Etiope, M. Schoell and H. Hosgormez, Abiotic methane flux from the Chimaera seep and Tekirova ophiolites (Turkey): understanding gas exhalation from low temperature serpentinization and implications for Mars. Earth Plan. Sci. Lett., 310, pp. 96-104, 2011.

G. Etiope and B. Sherwood Lollar, Abiotic methane on Earth. Rev. Geoph., doi: 10.1002/rog.20011, 2013.

G. Etiope, B. Tsikouras, S. Kordella, E. Ifandi, D. Christodoulou and G. Papatheodorou, Methane flux and origin in the Othrys ophiolite hyperalkaline springs, Greece. Chem. Geol., http://dx.doi.org/10.1016/j.chemgeo.2013.04.003, 2013a.

G. Etiope, S. Vance, L.E. Christensen, J.M. Marques and I. Ribeiro da Costa, Methane in serpentinized ultramafic rocks in mainland Portugal. Mar. Petrol. Geol., doi: 10.1016/j.marpetgeo.2013.04.009, 2013b.

I. Friedman, Deuterium content of natural waters and other substances. Geochim. Cosmochim. Acta, 4, pp. 89-103, 1953.

P. Fritz, I.D. Clark, J.-C. Fontes, M.J. Whiticar and E. Faber, Deuterium and ${ }^{13} \mathrm{C}$ evidence for low temperature production of hydrogen and methane in a highly alkaline groundwater environment in Oman. In: K. Maest (ed.), Water-rock Interaction, Rotterdam, 1992.

J.M. Marques, P.M. Carreira, M.R. Carvalho, M.J. Matias, F.E. Goff, M.J. Basto, R.C. Graça, L. Aires-Barros and L. Rocha, Origins of high $\mathrm{pH}$ mineral waters from ultramafic rocks, Central Portugal. Appl. Geochem., 23, pp. 3278-3289, 2008.

J.R. Michalski, J. Cuadros, B.N. Paul, J. Parnell, A. Deanne Rogers and P.W. Shawn, Groundwater activity on Mars and implications for a deep biosphere. Nature Geosci., 6(2), pp. 133-138, 2013.

P.L. Morrill, J.G. Kuenen, O.J. Johnson, S. Suzuki, A. Rietze, A.L. Sessions, M.L. Fogel and K.H, Nealson, Geochemistry and geobiology of a present-day serpentinization site in California: The Cedars, Geochim. Cosmochim. Acta, 109, pp. 222-240, 2013.

G. Proskurowski, M.D. Lilley, J.S. Seewald, G.L. Früh-Green, E.J. Olson, J.E. Lupton, S.P. Sylva and D.S. Kelley, Abiogenic hydrocarbon production at Lost City hydrothermal field. Science, 319, pp. 604-607, 2008.

I. Ribeiro da Costa, F.J.A.S. Barriga, J. Mata and Munhá, Rodingitization and serpentinization processes in the Alter do Chão Massif (NE Alentejo). Mem. Mus. Lab. Min. Geol. Fac. Ciênc. Univ. Porto, 3, pp. 27-31, 1993.

M.J. Russell, A.J. Hall and W. Martin, Serpentinization as a source of energy at the origin of life. Geobiol., 8, pp. 355-371, 2010.

O. Salem, J.M. Visser, M. Dray and R. Gonfiantini, Groundwater flow patterns in the western Libyan Arab Jamahiriya evaluated from isotopic data. In: I.A.E.A. (Ed.), Arid-Zone Hydrology: Investigation with Isotope Techniques, pp. 165-179, 1980.

M. Schulte, D. Blake, T. Hoehler and T. McCollom, Serpentinization and its implications for life on the early Earth and Mars. Astrobiol., 6, pp. 364-376, 2006.

I. Tiago, A. Veríssimo, Microbial and functional diversity of a subterrestrial high $\mathrm{pH}$ groundwater associated to serpentinization. Env. Microbiol., doi:10.1111/1462-2920.12034, 2012.

S. Vance, J. Harnmeijer, J. Kimura, H. Hussmann, B. de Martin and J.M. Brown, Hydrothermal systems in small ocean planets. Astrobiol., 7(6), pp. 987-1005, 2007.

A. Willems, J. Busse, M. Goor, B. Pot, E. False, E. Jantzen, B. Hoste., M. Gillis, K. Ketsters, G. Auling and J. De Ley, Hydrogenophaga, a new genus of hydrogen-oxidizing bacteria that includes Hydrogenophaga flava comb. nov. (formerly Pseudomonas flava), Hydrogenophaga palleronii comb. nov. (formerly Pseudomonas palleronii), Hydrogenophaga pseudoflava comb. nov. (formerly Pseudomonas pseudoflava and "Pseudomonas carboxydoflava"), and Hydrogenophaga taeniospiralis comb. nov. (formerly Pseudomonas taeniospiralis). Int. J. Syst. Bacteriol., 39, pp. 319-333, 1989. 


\title{
025 - ANCIENT COAL FIRES AS NEW CLIMATE TRACERS (EXAMPLE FROM THE KUZNETSK COAL BASIN, SW SIBERIA, RUSSIA)
}

\author{
Sophia Korzhova - Ella Sokol - Daniil Alekseev - Alexey Travin \\ Sobolev Institute of Geology and Mineralogy Siberian Branch of Russian Academy \\ of Sciences, 3 Koptyuga Ave., Novosibirsk 630090, Russia; e-mail: sa_novikova@inbox.ru
}

Motivation. Natural coal fires and related thermal alteration (combustion metamorphism) of sediments constitute a separate global-scale geological phenomenon. Numerous coal ignition events occurred in Pliocene-Holocene time (Sokol et al., 2005; Stracher et al., 2010). In situ coal seams cannot burn for the lack of oxygen but combustion becomes possible as coal-bearing sediments reach the surface aeration zone as a result of uplift and ensuing erosion. Once being exposed to aeration, coal absorbs oxygen and either inflames or rapidly looses the ignition ability by oxygen deactivation (Kukharenko, 1960; Stracher et al., 2010). Large coal fires are common to areas of warm climate (Pogrebnov, 1978; Heffern et al., 2007; Stracher et al., 2010). Therefore, large-scale combustion of coal may have been a prompt response to tectonic activity and erosion, mostly during Late Cenozoic warm cycles.

Development of isotope dating methods of combustion metamorphic (CM) rocks makes it possible to use natural coal fires as new climate tracers. This approach was first applied to CM complexes of the US Great Plains (Heffern et al., 2007), which were dated by the (U-Th)/He and fission-track methods on detrital zircons from clinker sintered during coal fires. With these ages, it became possible to reconstruct the history of the present river network and time the fires within Pleistocene interglacials. However, the approach has natural paleogeographic limitations from deposition environments of coal-bearing sediments, as zircons accumulate only in coastal facies. We have developed an alternative approach to such reconstructions while studying natural coal fires in the Kuznetsk Coal Basin. Having adapted the standard ${ }^{40} \mathrm{Ar} /{ }^{39} \mathrm{Ar}$ method to dating young $\mathrm{CM}$ rocks (paralavas and clinkers), we obtained reasonable time constraints on the coal fires in the area (Novikov et al., 2008).

Coal fires in the Kuznetsk Coal Basin. Combustion metamorphic complexes produced by ancient coal fires exist all over the Kuznetsk basin. We studied and compared such complexes in the periphery (in the west and southwest) and interior of the basin (Fig. 1), which differ in geological conditions. Thus we inferred different scenarios of natural coal fires.

The western periphery of the Kuznetsk basin (Salair zone) is its most strongly deformed part being subject to compression from the west. Multiple faults (up to 15) produce a rugged terrain, with three piedmont steps. The folds are mostly narrow, often recumbent, with high-angle $\left(40\right.$ to $\left.90^{\circ}\right)$ limbs.

Large natural combustion events occurred mostly in thick (3.5-24 m) steeply dipping seams of Lower Permian $\left(\mathrm{P}_{1} i s, \mathrm{P}_{1} \mathrm{~km}\right)$ crushed high-grade vitrain-clarain coal. 
CM rocks are commonly found in weakly deformed hinges or arches of anticlines or less often in their limbs. The coal seams rose to the surface as the respective fault blocks of coaliferous sediments were uplifted during Late Cenozoic rejuvenation of pre-Cenozoic faults (Novikov et al., 2008). The faulting accelerated erosion in basin flank along the boundary with the Salair ridge, and the coal seams became exposed to air.

Coal in the western basin part is resistant to oxidation and stable against self-heating even on mining at highest fire risks (Manukyan, 1947). Furthermore, unfired coal seams often found above the fired ones also evidence of low fire proneness of coal in the area. Therefore, the probability of natural spontaneous ignition is quite low, and the ancient fires must have had external triggers. Ignition from external sources is supported by the fire propagation pattern from top to bottom of coal seams (unlike self-ignition which always spreads upwards). Coal burning was most probably triggered by steppe fires frequent in areas of dry and warm climate (Heffern et al., 2007). The unusually large depth of the paleo-fires $(200 \mathrm{~m})$ is another convincing proof for a climate control. Inasmuch as fires never penetrate below aquifers, the combustion events in the western Kuznetsk basin obviously occurred during the warm and dry spells of Quaternary time when the groundwater table was much deeper (Yavorsky and Radugina, 1932; Usov, 1935). During glacials, the Kuznetsk depression most likely was within the reach of permafrost, and ignition was impossible because cracks in coalbeds were cemented with ice and impermeable for gas (Pogrebnov, 1978; Sidorchuk et al., 2008).

According to geological evidence and ${ }^{40} \mathrm{Ar} /{ }^{39} \mathrm{Ar}$ data, the oldest fires in the western Kuznetsk basin occurred $1.7 \pm 0.3 \mathrm{Ma}$ ago. The lower bound of this estimate $(2.0 \mathrm{Ma})$ is proximal to the onset of a warm and dry interglacial after a long cold cycle (Zykin et al., 2008). The area experienced the first wave of extensive coal fires between 1.3 and $0.9 \mathrm{Ma}$, in the Pleistocene. That was the time of the Quaternary warmest climate in southern West Siberia, with a dry steppe landscape in the Kuznetsk basin (Foronova, 2001). The reconstructed interval of later large-scale fires from 0.3 to $0.1 \mathrm{Ma}$ ago comprises three warm spells of Shirta, Koinikha, and Kazantsevo. The combustion events were the most probable in the warmest and driest second half of the Kazantsevo interglacial, about 0.1 Ma (Foronova, 2001; Zykin et al., 2008). Note that the spells when the coal fires were abundant (1.3-0.9 and 0.3-0.1 Ma) were also the time of rapid erosion (Figs 2, 3).

In the basin interior, coal-bearing sediments are faulted and folded only weakly (folds are low-angle, with their limbs dipping at 6-20 $0^{\circ}$. Paleo-fires arose in spontaneously igniting (Lindenau et al., 1982) folded low-angle 1.5-15 $\mathrm{m}$ thick seams of Late Permian $\left(\mathrm{P}_{2} l n, \mathrm{P}_{2} t l\right)$ medium-grade vitrain coal. The coal became exposed to aeration in erosion cutouts, judging by the locations of $\mathrm{CM}$ foci restricted to the valleys of the Tom River tributaries. The fires never propagated below the first (upper) terraces, which prompts that they arose during erosion of the recent drainage system. The latter 
initiated when the ice sheets of the Taz glaciation melted during the Kazantsevo warming at 0.13-0.10 Ma (Yavorsky, 1967). The sediments overlying the weakly eroded CM complexes of the area are $\sim 23 \mathrm{Ka}$ the oldest (Foronova, 2001) (Fig. 1). Therefore,
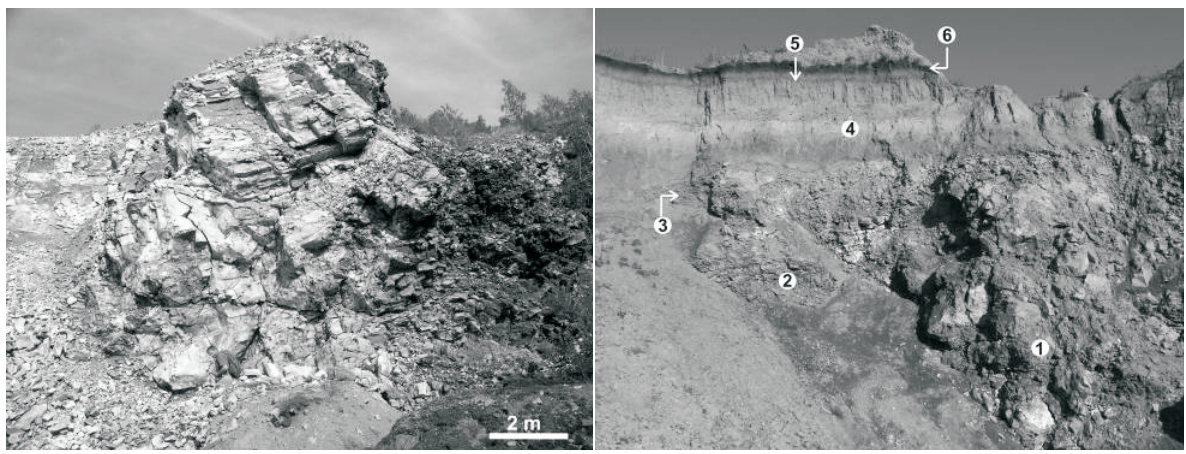

a

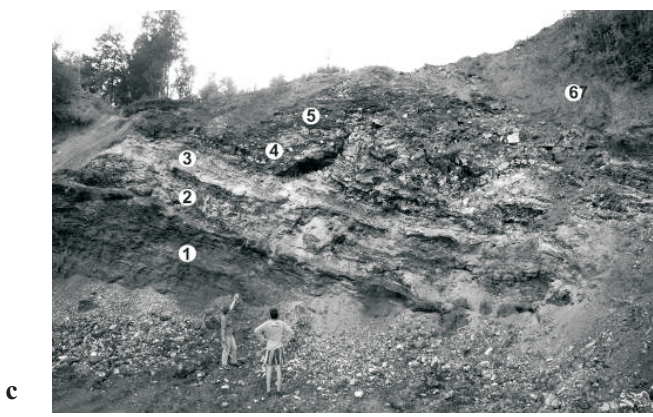

Figure 1. Combustion metamorphic (CM) complexes from Kuznetsk Coal Basin

a - The deeply eroded hills of CM rocks from western periphery of Kuznetsk basin. CM rocks are collapse breccias consisting of melted metasedimentary rocks: clasts of clinker (partially fused pelitic sediments) are baked into a monolith and cemented with paralavas (totally fused mixture of pelitic sediments and siderite/ankerite)

b - Combustion metamorphic complex "Sokolovo" from interior of the Kuznetsk basin (1). "Chimney structure" consisting of high-temperature CM breccia and abundant paralavas within weakly and moderate altered CM rocks (2). CM rocks are covered with weathering residue (3), brown loam and loess (4), paleosoil (5) and present-day soil (6)

$\mathrm{c}$ - Combustion metamorphic complex from Kondoma river valley side, southwestern periphery of Kuznetsk basin. (1) Unaltered sedimentary rocks; (2) smoldered bone-coal; (3) ash horizon;

(4) collapse breccia; (5) weakly and moderate altered CM rocks; (6) brown loam and loess

the fires in the central Kuznetsk basin were bracketed between 130 and $23 \mathrm{Ka} \mathrm{BP}$. The ${ }^{40} \mathrm{Ar} /{ }^{39} \mathrm{Ar}$ ages of CM rocks in the area $(0.1 \pm 0.1$ and $0.3 \pm 0.2 \mathrm{Ma})$ agree with these estimates, but their large uncertainty does not allow tighter constraints on the interval. Coal ignition in this basin part may have been either spontaneous or had external triggers. The latter left traces of fire propagation toward the seam bottom and apparently acted during the dry Kazantsevo interglacial (Figs 2, 3). 

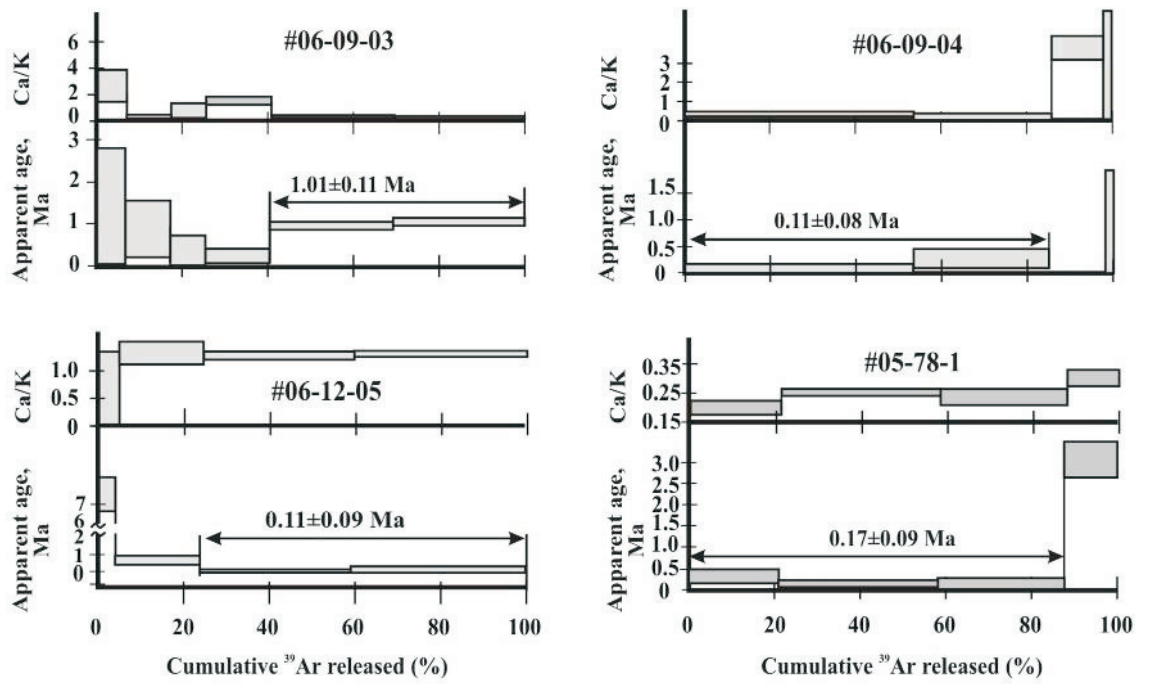

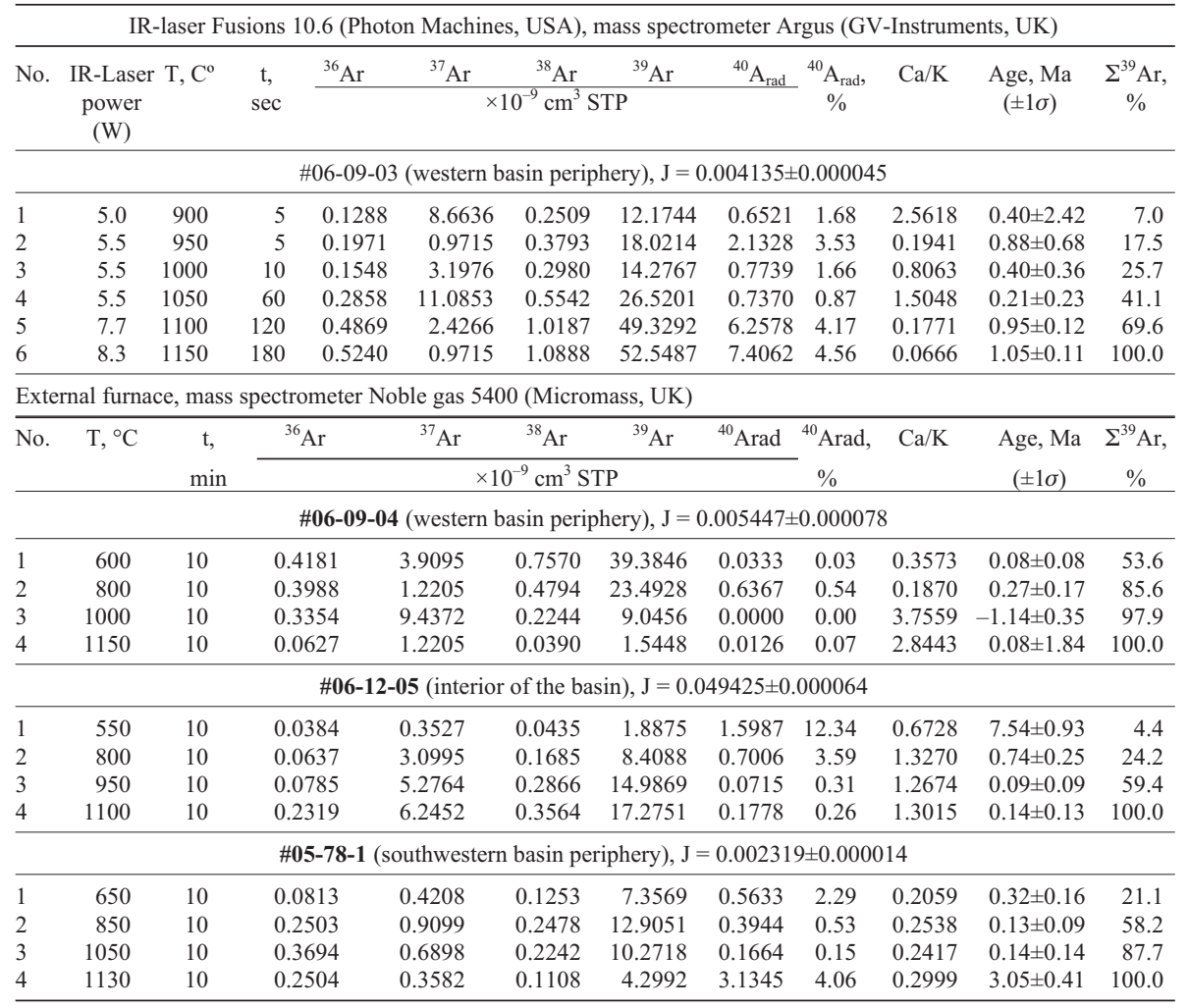

Figure 2. ${ }^{40} \mathrm{Ar}{ }^{39} \mathrm{Ar}$ age spectra for representative samples of clinker and paralava from Kuznetsk basin 
Coal-bearing sediments in the southwestern basin periphery are likewise weakly deformed, with few faults and low-angle $\left(<20^{\circ}\right)$ folds. Coal fires arose in gently dipping 5.5-8.3 m thick seams of Permian $\left(\mathrm{P}_{1} i s, \mathrm{P}_{1} \mathrm{~km}\right)$ high-grade coal. The section we studied is located within the first (upper) terrace above the Kondoma River floodplain (Fig. 1). The ancient fire was confined to this level and thus was apparently coeval with the Kondoma incision into the coaliferous sediments. Then, the age of the combustion event may be correlated with the onset of the Kazantsevo warming $130 \mathrm{Ka}$ ago and the origin of the present drainage pattern of the Kuznetsk basin (Yavorsky, 1967). This timing is in line with the ${ }^{40} \mathrm{Ar} /{ }^{39} \mathrm{Ar}$ age of CM rocks $(0.17 \pm 0.09 \mathrm{Ma})$. Thus, the ancient coal fires in the southwestern Kuznetsk basin occurred between 130 and 80 $\mathrm{Ka} \mathrm{BP}$, in the interval that encompassed the entire Kazantsevo interglacial (Figs 2, 3).

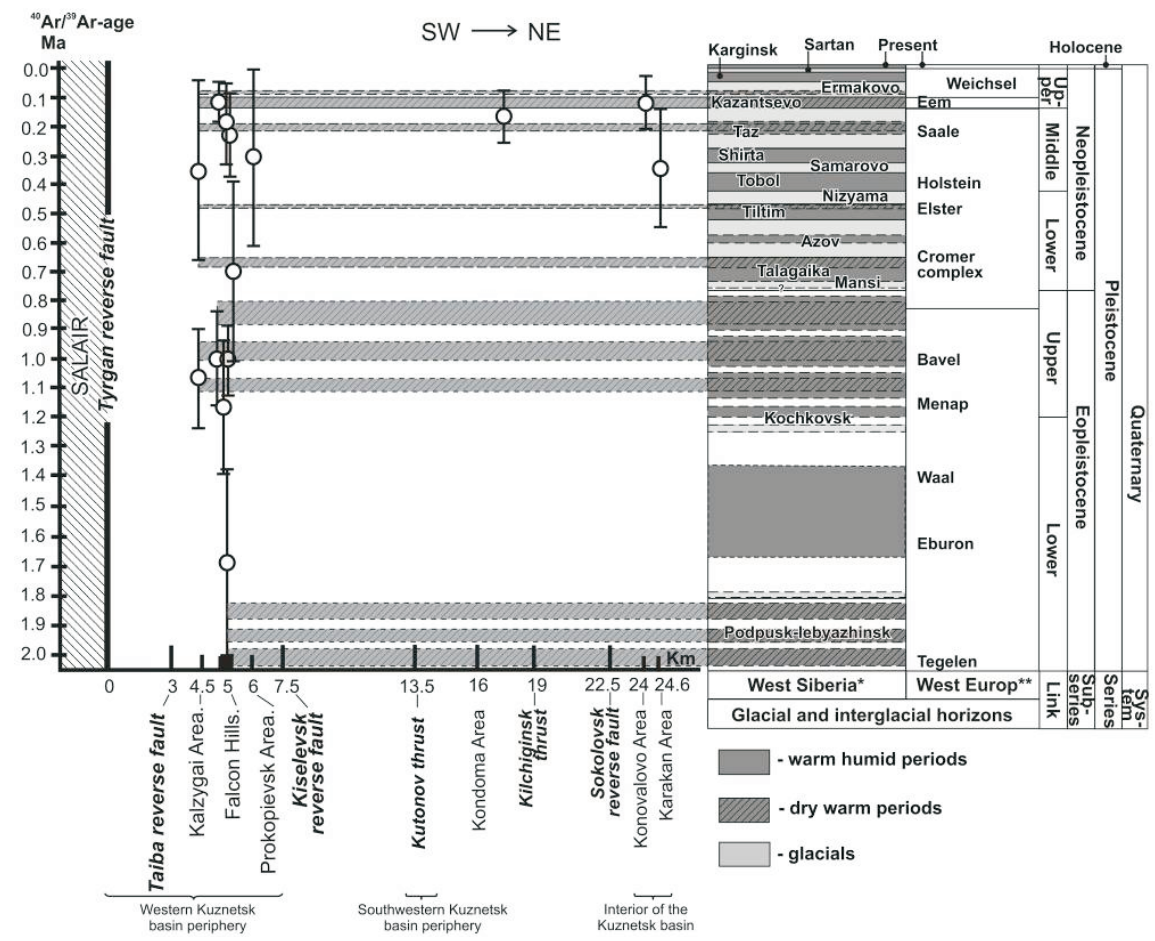

Figure 3. Correlation of kuznetsk coal fires ${ }^{40} \mathrm{Ar} /{ }^{39} \mathrm{Ar}$-ages with Pleistocene glacials and interglacials

* Regional stratigraphic scheme of Pleistocene deposits in West Siberia after (Foronova, 2001; Zykin et al., 2008; International..., 2012);

** Stratigraphic scheme of Pleistocene deposits in West Europe after (Velichko, Wright, 2005); Falcon Hills, Kalzygai, Prokopievsk, Kondoma, Konovalovo and Karakan Areas are the fields of studied CM rocks; on the $\mathrm{x}$-axis is distance from Tyrgan thrust dividing coal-bearing sediments of the Kuznetsk basin from Devonian coal-free rocks of the Salair 
Acknowledgements: The study was supported by grants 12-05-31037_mol_a and 12-05-33028_mol_a_ved from the Russian Foundation for Basic Research.

\section{References}

1. I.V. Foronova. Quaternary mammals of southern West Siberia. Kuznetsk depression (in Russian). SB RAS Publishing House, Novosibirsk, 2001.

2. E.L. Heffern, P.W. Reiners, C.W. Naeser, D.A. Coates, Geochronology of clinker and implications for evolution of the Powder River Basin landscape, Wyoming and Montana. Geological Society of America, Reviews in Engineering Geology, 2007, pp. 155-175.

3. International chronostratigraphic chart, International commission of stratigraphy, August 2012.

4. T.A. Kukharenko. Chemistry and Genesis of Coal Deposits (in Russian). Gosgortekhizdat, Moscow, 1960.

5. N.N. Lindenau, V.M. Maevskaya, E.S. Vakhrusheva. Catalog of coal prone to spontaneous ignition (in Russian). Publishing House Nedra, Moscow, 1982.

6. P.A. Manukyan. Underground fires in coal mines (in Russian). Ugletekhizdat, Moscow, 1947.

7. I.S. Novikov, E.V. Sokol, A.V. Travin, S.A. Novikova, Signature of Cenozoic orogenic movements in combustion metamorphic rocks: mineralogy and geochronology (example of the Salair-Kuznetsk basin transition). Russian Geol. Geophys., 49, pp. 378-396, 2008.

8. N.I. Pogrebnov (Ed.). Geology of coal and bituminous shale deposits in the USSR. Book XII (in Russian). Publishing House Nedra, Moscow, 1978.

9. G.B. Stracher, A. Prakash, E.V. Sokol (Eds). Coal and peat fires: A global perspective. Volume 1: Coal Geology and Combustion. Elsevier, Amsterdam, 2010.

10. A.Y. Sidorchuk, A.V. Panin, O.K. Borisova, Late Glacial Paleochannels of Rivers in Western Siberia (in Russian), Izv. Akad. Nauk, Ser. Geogr., No. 2, pp. 67-75, 2008.

11. E.V. Sokol, N.V. Maksimova, E.N. Nigmatulina, V.V. Sharygin, V.M Kalugin. Combustion metamorphism (in Russian). SB RAS Publishing House, Novosibirsk, 2005.

12. M.A. Usov, Underground fires in Prokopievsk mine as geological process (in Russian), Vestnik Zap.-Sib. Geologorazvedochnogo Tresta, Is. 4, pp. 34-39, 1933.

13. A.A. Velichko, H.E. Wright (eds), Cenozoic Climate And Environmental Changes In Russia. Geological Society of America, Boulder, CO, 2005.

14. V.I. Yavorsky, L.V. Radugina, Coal fires in the Kuznetsk coal basin and related phenomena (in Russian), Gornyi Zhurnal, No. 10, pp. 55-59, 1932.

15. V.I. Yavorsky (ed.). Geology of the USSR. Book XIV. West Siberia (Altai region, Kemerovo, Novosibirsk, Omsk, Tomsk regions). Part I. Geological Description (in Russian). Gos. Izd. Geol. Lit., Moscow-Leningrad, 1967.

16. V.S. Zykin, V.S. Zykina, L.A. Orlova, Late Cenozoic environmental and climate changes in West Siberia. Late Cenozioc global and regional environmental and climate changes in Siberia (in Russian). SB RAS Publishing House, Novosibirsk, pp. 175-245, 2008. 
AIG10 - 2013

\title{
026 - EVALUATION OF GROUNDWATER AGES AND ISOTOPIC COMPOSITION ALONG DEFINED FLOW PATH IN THE NORTHEASTERN SECTOR OF GUARANI AQUIFER SYSTEM (GAS) - BRAZIL
}

\author{
Didier Gastmans ${ }^{1}$ - Hung Kiang Chang ${ }^{2}$ - Pradeep Aggarwal ${ }^{3}$ - Luis Araguas ${ }^{3}$ - \\ Takuya Matsumoto ${ }^{3}$ - Neil Sturchio ${ }^{4}$ \\ ${ }^{1}$ Centre of Environmental Research - UNESP Rio Claro, Av. 24A, 1515, Bela Vista, \\ 13.506-900 Rio Claro (SP), Brazil; e-mail: gastmans@rc.unesp.br \\ ${ }^{2}$ Department of Applied Geology - UNESP Rio Claro, Av. 24A, 1515, Bela Vista, \\ 13.506-900 Rio Claro (SP), Brazil \\ ${ }^{3}$ Isotope Hydrology Section, International Atomic Energy Agency, Vienna, Austria \\ ${ }^{4}$ Earth and Environmental Science, University of Illinois at Chicago, Chicago, IL, USA
}

Guarani Aquifer System (GAS) represents one of the most important groundwater reservoirs in South America, constituting a typical example of transboundary aquifer, which extends for about 1,100,000 $\mathrm{km}^{2}$ over the territory of: Argentina $(228,255.26$ $\left.\mathrm{km}^{2}\right)$, Brazil $\left(735,917.75 \mathrm{~km}^{2}\right)$, Paraguay $\left(87,535.63 \mathrm{~km}^{2}\right)$ and Uruguay $(36,170.51$

$\mathrm{km}^{2}$ ). In this continental scale aquifer groundwaters aged over 30,000 years, based on ${ }^{14} \mathrm{C}$ determinations, were recognized in confined portion of the aquifer during isotopic studies carried out by several authors (Gallo and Sinelli, 1980; Silva, 1983; Kimmelman et al., 1989 and OAS, 2009). Due the uncertainties related to ${ }^{14} \mathrm{C}$ limit, these ages could not represent the correct ages for the older GAS groundwater. Estimations using $\mathrm{U}$-isotopes indicates a long groundwater residence time that can reach 640 $\mathrm{Ka}$, in dependence of the approach used to calculate this ages (Bonotto, 2005). When residence times exceed the range measurable by ${ }^{14} \mathrm{C}$, there are only a few isotopic tracers available which may constrain greater residence times, including cosmogenic radionuclides ${ }^{36} \mathrm{Cl}$, and ${ }^{81} \mathrm{Kr}$, and the stable nuclide ${ }^{4} \mathrm{He}$ produced by alpha decay of the U-Th series nuclides. Whereas ${ }^{36} \mathrm{Cl}$ has been applied in numerous groundwater studies since its measurement by accelerator mass spectrometry first became a routine practice in the $1980 \mathrm{~s},{ }^{81} \mathrm{Kr}$ measurements remain technically challenging, and only few measurements have been published for groundwater. In order to estimate the groundwater age, associated to the geochemical evolution and past climate recharge conditions in the northern portion of Guarani Aquifer System, five wells located along a selected groundwater flow path that runs from the outcrop area in the east to the deep confined zone in the west, where the aquifer is up to about $1000 \mathrm{~m}$ deep, were sampled to determine their abundance of ${ }^{81} \mathrm{Kr}$, stable isotope ratios, ${ }^{14} \mathrm{C}$ content and chemical composition. ${ }^{14} \mathrm{C}$ measurements were made with an AMS, ${ }^{81} \mathrm{Kr}$ by atom trap trace analysis (ATTA), stable isotopes ratios in water were analysed using mass spectrometry routine measurements and chemical composition determined by ion chromatography and ICP-AES. Along this flow path groundwater evolves from $\mathrm{Ca}-\mathrm{Mg}-\mathrm{HCO}_{3}$ type near the recharge areas to $\mathrm{Na}-\mathrm{HCO}_{3}$ waters and then to $\mathrm{Na}-\mathrm{HCO}_{3} / \mathrm{Na}-\mathrm{Cl}-\mathrm{SO}_{4}$ waters, indicating dissolution and exchange processes with the aquifer matrix, as proposed by Gastmans 
et al. (2010). More negative water stable isotope contents (up to 3 permil in O-18, compared to present-day recharge) are found in large portions of the study area, indicating distinct climate recharge conditions in the past. Present groundwater recharge occurs in the outcrop areas, as indicated by the presence of modern ${ }^{14} \mathrm{C}$ (more than $100 \mathrm{PCM}$ ). At relatively short distances (less than $30 \mathrm{Km}$ ) from the outcrop (recharge) zone, ${ }^{14} \mathrm{C}$ activities reach values near the detection limit, besides the abundance of ${ }^{81} \mathrm{Kr}$ (half-life $229 \mathrm{Ka}$ ), in samples free of $\mathrm{C}-14$, decreases from $0.81 \pm 0.11$ (expressed as $\left.\left({ }^{81} \mathrm{Kr} / \mathrm{Kr}\right)_{\text {sample }} /\left({ }^{81} \mathrm{Kr} / \mathrm{Kr}\right)_{\text {air }}\right)$ in the east to $0.18 \pm 0.03$ in the western-most sample, where the estimated age reach $566 \pm 60 \mathrm{ka}$.

\title{
References
}

1. Bonotto, D., Hydro(radio)chemical relationships in the giant Guarani Aquifer, Brazil. Journal of Hydrology 323, pp. 353-386, 2005.

2. Gallo, G. and Sinelli, O., Estudo Isotópico das Águas Subterrâneas na Região de Ribeirão Preto. Revista Brasileira de Geociências, São Paulo, v.10, pp. 130-139, 1980.

3. Gastmans, D., Chang, H.K. and Hutcheon, I., Groundwater geochemical evolution in the northern portion of Guarani Aquifer System (Brazil) and its relationship to diagenetic features. Applied Geochemistry, 25(1):15-36. doi:10.1016/j.apgeochem.2009.09.024, 2010.

4. Kimmelmann e Silva, A.A., Rebouças, A.C. and Santiago, M.M.F., ${ }^{14} \mathrm{C}$ Analyses of Groundwater from Botucatu Aquifer System in Brazil. Radiocarbon, v. 31(3), pp. 926-933, 1989.

5. Organization of American States. Strategic Action Program. 424 pp., 2009.

6. Silva, R.B.G., Estudo Hidroquímico e Isotópico do Aquífero Botucatu no Estado de São Paulo. Doctoral Thesis - Instituto de Geociências - Universidade de São Paulo, São Paulo, 133 pp., 1983.

\section{7 - STABLE ISOTOPIC AND GEOCHEMICAL CHARACTERISTICS OF GROUNDWATERS FROM SERRA GERAL AQUIFER IN SÃO PAULO STATE (BRAZIL)}

\author{
Didier Gastmans $^{1}$ - Júlia Cristina Bonani Faracini ${ }^{2}$ \\ ${ }^{1}$ Centre of Environmental Research - UNESP Rio Claro, Av. 24A, 1515, Bela Vista, \\ 13.506-900 Rio Claro (SP), Brazil; e-mail: gastmans@rc.unesp.br \\ ${ }^{2}$ Centre of Environmental Research - UNESP Rio Claro, Av. 24A, 1515, Bela Vista,
} 13.506-900 Rio Claro (SP), Brazil

Aquifers hosted in basaltic rocks represent an important source for groundwater supply in several parts of the world, mainly due the low salinity of their waters associated to the amount of water stored, function of the regional extension of the volcanic lava flows reach and their thickness. Groundwater flow in basaltic aquifers takes place mainly through open fractures and joints, as well as in zones between two lava flow events, where the basalt rock presents vesicular texture, and the groundwater flow is essentially horizontal. Due these discontinuities the existence of perched aquifers, which represents the local flow, and deeper aquifers, corresponding to the regional flow, can be recognized in these units using hydrochemical and isotopic signatures. In 
Brazilian territory one of the largest continental flood basalts of the world occurs, associated to the opening of the South Atlantic Ocean, and represented mainly by tholeitic basalts of the Serra Geral Formation, with maximum thickness reaching over $1700 \mathrm{~m}$ at the central axis of the Paraná Basin. In the western portion of São Paulo state, southeastern of Brazil, the basalts encompass the Serra Geral Aquifer (SGA), which constitute an important aquifer responsible by the water supply in several cities located over this unit. Groundwater samples were collected, between January 2013 to April 2013, over the extension of Serra Geral Aquifer in São Paulo state (Brazil), to study the hydrochemistry, stable isotopic composition and dating using C14 content of groundwater stored in this aquifer. The hydrochemical and isotopic data are important to identify flow paths through the basalts, and can help to set up a geochemical model for the chemical reactions which occur in the aquifer due the interaction water-rock, as well as evaluate the past recharge conditions by the isotopic content variations.

\title{
028 - STABLE CARBON ISOTOPE RATIOS OF DISSOLVED METHANE IN HYDROTHERMAL PLUMES IN THE CENTRAL INDIAN RIDGE
}

\author{
Moonkoo Kim ${ }^{1}$ - Ok-Rye You ${ }^{2}$ - Seung Kyu Son ${ }^{2}$ - Juwon Son ${ }^{2}$ - Mi Jin Kim ${ }^{2}-$ \\ Jai-Woon Moon ${ }^{2}$ \\ ${ }^{1}$ South Sea Environment Research Division, Korea Institute of Ocean Science and \\ Technology, Geoje 656-834, Republic of Korea; e-mail: mkim@kiost.ac \\ ${ }^{2}$ Deep-sea and Seabed Resources Research Division, Korea Institute of Ocean Science and \\ Technology, Ansan 425-600, Republic of Korea
}

Stable carbon isotopic composition $\left(\delta^{13} \mathrm{C}\right)$ of dissolved methane, along with its vertical distributions, were measured to trace the hydrothermal plume and identify the source and behavior of methane in the Central Indian Ridge $\left(11-13^{\circ} \mathrm{S}\right)$. Significant hydrothermal plumes were observed at depths of $2500-3500 \mathrm{~m}$. The concentration and $\delta^{13} \mathrm{C}$ of methane in the plumes (Sts. IR02 and IR03) ranged from 3.3 to $42.3 \mathrm{nmol} \mathrm{kg}^{-1}$ and -30.0 to $-15.4 \%$, respectively. The concentration and $\delta^{13} \mathrm{C}$ of methane in the background seawater (St. IR01) ranged from 0.52 to $1.15 \mathrm{nmol} \mathrm{kg}^{-1}$ and -35.1 to $-28.9 \%$, respectively. The $\delta^{13} \mathrm{C}$ of methane was highest in the center of the plumes at St. IR02 $(-15.4 \%)$ and St. IR03 $(-17.8 \%)$. The $\delta^{13} \mathrm{C}$ of methane in the source hydrothermal vents estimated using methane distribution and its stable isotopic composition was approximately $-22 \%$. The results indicated that the methane was most likely derived from magmatic outgassing or the chemical synthesis of inorganic matter. The behavior of the methane can be explained by the relationship between the $\delta^{13} \mathrm{C}$ of methane and $1 /[\mathrm{CH} 4]$. If the behavior of methane was controlled by simple mixing with ambient seawater, the measured stable carbon isotope ratios of methane would fall on the mixing line between vent and ambient methane. However, if the behavior of methane was 
influenced by microbial oxidation, the measured stable carbon isotope ratios would be higher than those estimated by simple mixing. During the microbial oxidation, the stable carbon isotope ratio of residual methane increases because methane-oxidizing bacteria preferentially consume the lighter carbon compound. The behavior of the methane at St. IR03 was mainly controlled by the physical mixing with ambient seawater. However, the stable carbon isotope ratio of methane at St. IR02 increased with decreasing methane concentrations at the bottom layers. This increase of $\delta^{13} \mathrm{C}$ with decreasing concentration seems to be related to the microbial oxidation of methane. The microbial activity at St. IR02 was also verified by the higher bacterial production rate than those generally reported for deep-sea environment. The differences in the methane behavior between the two areas (St. IR02 vs. IR03) might be derived from their topographical difference. St. IR03 was located on an open slope of a ridge, whereas St. IR02 was located in a lower small basin surrounded by wall structures enclosing the area. Because the methane at St. IR02 could not mix quickly with the ambient seawater, the hydrothermal plume may be relatively stagnant and old, which would lead to the methane being more exposed to microbial oxidation.

Acknowledgement: This research was a part of the project titled "Exploration of seafloor hydrothermal deposits and Fe-Mn crusts in the southwestern Pacific and Indian Oceans" funded by the Ministry of Oceans and Fisheries, Korea.

\title{
029 - INTEGRATED USE OF ISOTOPIC TRACERS AND NUMERICAL SIMULATION FOR ANALYZING WATER SOURCE SEPARATION BETWEEN COEXISTING PLANT SPECIES
}

\author{
Tsutomu Yamanaka \\ Faculty of Life and Environmental Sciences, University of Tsukuba, Tsukuba, Japan; \\ e-mail: yamanaka.tsutomu.fu@u.tsukuba.ac.jp
}

Competition for water among plant species coexisting within a community is an important phenomenon for properly understanding ecosystem dynamics under various environmental forcing. Isotopic approach has enabled the characterization of differential water uptake among different species, so there are now many reports on the water source separation from a wide range of ecosystems (Ehleringer and Dawson 1992; Dawson et al. 2002). However, validation of such an approach is not yet completed, and there still remain uncertainties on the mechanism of the water source separation phenomenon. Objectives of the present study are [1] to improve evaluation of root water uptake profile by integrated use of isotopic tracers and numerical simulation techniques, and [2] to address mechanism of water source separation in temperate forests in Japan. First, a numerical model describing canopy energy balance and root water uptake as well as isotope transport was constructed for simulation. In addition, an in- 
verse estimation technique for water uptake profile using isotopic tracers was developed. These two approaches were applied independently for a conifer forest without competition. Results from the two approaches were not in agreement, and thus model parameters (e.g., root permeability) in numerical simulation were modified so as to provide a better result. Secondly, the same approach was applied a conifer forest under competitive environments. A model calibrated with isotopic tracers successfully reproduced water source separation. If competition among plants were excluded, use of deep water source was not reproduced. Variable root permeability suggests that root function is changed by plants actively rather than passively. Thus, it can be concluded that water source separation is a strategy to avoid inter-specific competition for water and assure sustainable water use by an ecosystem composed of different plant species.

\title{
References
}

1. T.E. Dawson, S. Mambelli, A.H. Plamboeck, P.H. Templer and K.P. Tu, Stable isotopes in plant ecology. Ann. Rev. Ecol. Sys., 33, pp. 507-559, 2002.

2. J.R. Ehleringer and T.E. Dawson, Water uptake by plants: perspectives from stable isotope composition. Plant Cell Environ., 15, pp. 1073-1082, 1992.

\section{0 - MAGNESIUM ISOTOPE FRACTIONATION DURING BIOTITE DISSOLUTION AT $T=25^{\circ} \mathrm{C}$ : THE PH DEPENDENCE}

\author{
Jong-Sik Ryu ${ }^{1}-$ Sin-Woo Lee $e^{1}-$ Kwang-Sik Lee ${ }^{1,2}-$ Min-Seok Choi ${ }^{1}$ \\ ${ }^{1}$ Division of Earth and Environmental Sciences, Korea Basic Science Institute, \\ Chungbuk 363-883, South Korea; e-mail: jongsikryu@gmail.com \\ ${ }^{2}$ Graduate School of Analytical Science and Technology, Chungnam National University, \\ Daejeon 305-764, South Korea
}

Biotite is one of common Mg-bearing minerals at the surface of the continental crust, but its role in the behaviour of $\mathrm{Mg}$ isotopes during weathering processes is poorly constrained. Here, we conducted plug flow reactor experiments in dilute $\mathrm{HCl}(\mathrm{pH}=1$ and 5) at $T=25^{\circ} \mathrm{C}$ using the $63-245 \mu \mathrm{m}$ size fraction of crushed biotite. The purpose of the study is to constrain the influence of mineral weathering on the $\mathrm{Mg}$ isotope geochemistry of terrestrial waters.

When plotted versus time during biotite dissolutions at $\mathrm{pH}=1$, concentrations of $\mathrm{Al}, \mathrm{Fe}, \mathrm{Mg}$, and $\mathrm{Si}$ in the eluate display a rapid decrease followed by a rise and a steady-state, whereas concentrations of $\mathrm{Ca}$ and $\mathrm{Sr}$ display a rapid decrease followed by a decay to zero. In contrast, at $\mathrm{pH}=5$ concentrations of all elements, except of $\mathrm{Mg}$, display a rapid decrease followed by a decay to zero. All solutions are undersaturated with respect to secondary phases.

Biotite has a $\delta^{26} \mathrm{Mg}$ value of $-0.35 \%$. $\mathrm{Mg}$ in the exchangeable and carbonate fractions has $\delta^{26} \mathrm{Mg}$ values of $-0.77 \%$ and $-1.45 \%$, respectively, suggesting either that freshly cleaved surfaces created by the powdering process are enriched in light isotopes (Ziegler et al., 2005) or leached layers formed during dissolution preferen- 
tially release light isotopes (Brantley et al., 2004), resulting in lower $\delta^{26} \mathrm{Mg}$ values of labile $\mathrm{Mg}$. In contrast, $\mathrm{Mg}$ in the residual fraction has a $\delta^{26} \mathrm{Mg}$ value of $-0.39 \%$, accounting for a $\delta^{26} \mathrm{Mg}$ value of pure biotite.

During biotite dissolution, the output solutions are enriched in light $\mathrm{Mg}$ isotopes, varying from -1.29 to $-0.38 \%$ in $\delta^{26} \mathrm{Mg}$ at $\mathrm{pH}=1$, and from -1.50 to $-0.54 \%$ in $\delta^{26} \mathrm{Mg}$ at $\mathrm{pH}=5$, relative to pure biotite. Given that the labile $\mathrm{Mg}$ is already enriched in ${ }^{24} \mathrm{Mg}$, the observed trends during dissolution at $\mathrm{pH}=1$ and 5 could be attributed to the mixing between labile $\mathrm{Mg}$ (the exchangeable and carbonate fractions) and structural $\mathrm{Mg}$ (the residual fraction) rather than preferential release of light isotopes. It is expected that these findings will have several implications for understanding the observations made in natural settings with river waters draining silicate rocks nearly always enriched in the light isotope of $\mathrm{Mg}$ compared to the parent rock.

\title{
References
}

1. S.L. Brantley, L.J. Liermann, R.L. Guynn, A. Anbar, G.A. Icopini and J. Barling, Fe isotopic fractionation during mineral dissolution with and without bacteria. Geochim. Cosmochim. Acta, 68, pp. 3189-3204, 2004.

2. K. Ziegler, O. Chadwick, M. Brzezinski and E. Kelly, Natural variations of $\delta^{30}$ Si ratios during pregressive basalt weatherng, Hawaiian Islands. Geochim. Cosmochim. Acta, 69, pp. 4597-4610, 2005.

\section{1 - PALEOENVIRONMENTAL AND PALEOCLIMATOLOGY STUDY ON THE LATE QUATERNARY - HOLOCENE OLD SHORELINES (RAISED CORAL REEF TERRACES) BASED ON ISOTOPIC ANALYSIS AND AGE DATING, EASTERN RED SEA COASTAL PLAIN, SAUDI ARABIA}

\author{
A.M. Gheith ${ }^{1}$ - Hamad Al-Washmi ${ }^{2}$ \\ ${ }^{1}$ Geology Dept., Faulty of Science, Mansoura University, Mansoura, Egypt \\ ${ }^{2}$ Marine Geology Dept., Faculty of Marine Science, King Abdellaziz University, \\ Jeddah, Saudi Arabia
}

The shore zone of the eastern Red Sea coastal plain is characterised by Late Quaternary raised coral reef terraces outcrops as old shorelines with hight varies between 0.5 $\mathrm{m}$ and $3 \mathrm{~m}$ above sea level. These old shorelines represent the transgression of the sea during the last interglacial period and carry important informations about the paleoenvironmental and paleocimatology conditions prevailed during deposition. 20 samples have been collected all over the reef terraces exposed at three localities; Rabigh, Jeddah and Shuaiba and analyzed for isotopic composition $\left({ }^{13} \mathrm{C}\right.$ and $\left.{ }^{18} \mathrm{O}\right)$ for the raw carbonate materials, age dating $\left(\mathrm{C}^{14}\right)$ for the shell fragments, thin sections for identify biotic components, sediments and cements, provided a data base of informa- 
tion about the reef growth conditions and subsequent change. XRD analysis for bulk and clay mineral assemblages.

Values of isotopic composition determined for these old shorelines ranged between $\delta-1.36$ and $\delta 3.36$ for ${ }^{13} \mathrm{C}$, while ${ }^{18} \mathrm{O}$ values varies from $\delta-4.53$ to $\delta 0.17$. The youngest dated shells detected in the beachrock is 420 years while the oldest dated reef shells is 34450 years. The rate of uplift applied in this paper is the maximum possible at $11.5 \mathrm{~mm} /$ year.

\title{
032 - HYDROCHEMICAL AND ISOTOPE CHARACTERISTICS OF THE MAJOR AQUIFERS OF THE BENIN FORMATION, CALABAR, NIGERIA
}

\author{
Aniekan Ede ${ }^{l}-$ Richard Henry Worden ${ }^{2}$ \\ ${ }^{1}$ Department of Geology, University of Calabar, POB 3609 UPO, Calabar, Nigeria; \\ e-mail: aniekanedet@yahoo.com \\ ${ }^{2}$ Department of Earth and Ocean Sciences, University of Liverpool, 4 Brownlow Street, \\ Liverpool L69 3GP, UK
}

The groundwater characteristics of the Calabar area, Nigeria have been studied, with emphasis on the hydrochemical and isotopic characteristics. The area is underlain by Coastal Plain Sands with two aquifers, an upper gravelly and lower sandy aquifers. Four rainwater, 13 river water and 16 groundwater samples were surveyed. The study aimed primarily to determine the different water types and identify the possible sources of groundwater recharge using oxygen and hydrogen isotopes. The results indicate that the rainwater, river water and groundwater quality of the area are acidic, fresh and soft. The chemical compositions of these waters are within acceptable limits for drinking, domestic and agricultural uses. The different waters were characterized by $\mathrm{Na}-\mathrm{HCO}_{3}$ (upper-and lower aquifer), $\mathrm{Na}-\mathrm{Cl}$ (river water) and $\mathrm{Ca}-\mathrm{HCO}_{3}$ (rain water). The isotopic composition of rainwater from Calabar varied from -3.35 to $-8.35 \%$ and -19.9 to $-59.8 \%$ for $\delta^{18} \mathrm{O}$ and $\delta \mathrm{D}$ respectively. The isotopic values for the river water samples ranged from -3.10 to $-1.61 \%$ from -15.00 to $-5.60 \%$ respectively for $\delta^{18} \mathrm{O}$ and $\delta \mathrm{D}$, with averages $-2.47 \%$ and $-10.80 \%$. The isotope values for water from the upper aquifer ranged from -3.05 to $-2.04 \% 0\left(\delta^{18} \mathrm{O}\right)$ and from -17.60 to $-7.50 \%$ $(\delta \mathrm{D})$. For the lower sandy aquifer, the isotopic values ranged from -3.22 to $-2.74 \%$ o (mean, $-2.95 \%$ ) for $\delta^{18} \mathrm{O}$ and from -15.60 to $-11.50 \%$ (mean $-13.49 \%$ ) for $\delta \mathrm{D}$. The characteristics $\delta \mathrm{D}$ and $\delta^{18} \mathrm{O}$ in precipitation, was used to define the local meteoric water line, river water meteoric line and groundwater meteoric line. The $\delta^{18} \mathrm{O}$ and $\delta \mathrm{D}$ values of these groundwater samples were isotopically enriched compared to the precipitation, indicating precipitation as a source groundwater recharge. Also, the closeness of the isotopic values of groundwater to river water composition and similar d-excess indicated that the river was a contributor to the groundwater recharge in the area. 


\title{
033 - DETERMINING SOLUTE SOURCES AND WATER FLOWPATHS IN A FORESTED HEADWATER CATCHMENT: ADVANCES WITH THE CA-SR-BA MULTI-TRACER
}

\author{
Thomas Bullen $^{1}$ - Scott Bailey ${ }^{2}$ - Kevin McGuire ${ }^{3}$ - Donald Ross ${ }^{4}$ \\ ${ }^{1}$ U.S. Geological Survey, Menlo Park, CA 94025, USA; e-mail: tdbullen@usgs.gov \\ ${ }^{2}$ U.S. Forest Service, North Woodstock, NH USA \\ ${ }^{3}$ Virginia Tech, Blacksburg, VA USA \\ ${ }^{4}$ University of Vermont, Burlington, VT USA
}

Determining solute sources and water flowpaths in catchments is of critical importance to development of models that effectively describe catchment function. For solutes in soil water and stream water, simple mass balance models that compare precipitation input to catchment outlet compositions can predict average mineral weathering contributions for the catchment as a whole, but fail to provide information about either variability of contributions from different portions of the catchment and different soil depths or processes such as ion exchange and biological cycling. In order to better understand how forested headwater catchments function, we are interpreting concentration and isotope ratios of the alkaline earth elements $\mathrm{Ca}, \mathrm{Sr}$ and $\mathrm{Ba}(\mathrm{Sr} / \mathrm{Ba}, \mathrm{Ca} / \mathrm{Sr}$, ${ }^{87} \mathrm{Sr} /{ }^{86} \mathrm{Sr},{ }^{44} \mathrm{Ca} /{ }^{40} \mathrm{Ca},{ }^{88} \mathrm{Sr} /{ }^{86} \mathrm{Sr},{ }^{138} \mathrm{Ba} /{ }^{134} \mathrm{Ba}$ ) in stream water, groundwater, the soil ion exchange pool and plants in a hydropedologic context at the 41 hectare hydrologic reference catchment (Watershed 3) at the Hubbard Brook Experimental Forest, New Hampshire, USA. This forested headwater catchment consists of a beech-birch-maple-spruce forest growing on vertically- and laterally-developed Spodosols and Inceptisols formed on granitoid glacial till that mantles Paleozoic metamorphic bedrock.

Across the watershed ${ }^{87} \mathrm{Sr} /{ }^{86} \mathrm{Sr}$ of soil exchangeable Sr spans a broad range from 0.715 to 0.725 , with highest values occurring along the mid-to upper flanks of the catchment and lowest values in a broad zone along the central axis of the catchment associated with numerous groundwater seeps. Thus, variations of ${ }^{87} \mathrm{Sr} /{ }^{86} \mathrm{Sr}$ in streamwater provide evidence of the spatial distribution of water flowpaths feeding the streams. The exchangeable fraction of organic soils has high $\mathrm{Sr} / \mathrm{Ba}$ and $\mathrm{Ca} / \mathrm{Sr}$ ratios and the lightest $\mathrm{Ca}, \mathrm{Sr}$ and $\mathrm{Ba}$ stable isotope compositions of any soil pool, reflecting the strong influence of biologic element cycling through the forest plant ecosystem. In comparison, the exchangeable fraction of mineral soils has intermediate $\mathrm{Sr} / \mathrm{Ba}$ and low $\mathrm{Ca} / \mathrm{Sr}$ ratios and at intermediate depths the heaviest $\mathrm{Ca}$, $\mathrm{Sr}$ and $\mathrm{Ba}$ stable isotope compositions of any soil pool. The exchangeable fraction of relatively unweathered till in the $\mathrm{C}$ horizon has low $\mathrm{Sr} / \mathrm{Ba}$ and high $\mathrm{Ca} / \mathrm{Sr}$ ratios and intermediate $\mathrm{Ca}, \mathrm{Sr}$ and $\mathrm{Ba}$ stable isotope compositions. Waters moving through these various compartments obtain $\mathrm{Sr} / \mathrm{Ba}$ and $\mathrm{Ca} / \mathrm{Sr}$ ratios reflecting these characteristics, and thus we are evaluating the hypothesis that variations of $\mathrm{Sr} / \mathrm{Ba}$ and $\mathrm{Ca} / \mathrm{Sr}$ of stream water provide evidence of the depth of water flowpaths feeding the streams. In any given tributary, ${ }^{44} \mathrm{Ca} /{ }^{40} \mathrm{Ca}$, ${ }^{88} \mathrm{Sr} /{ }^{86} \mathrm{Sr}$ and ${ }^{138} \mathrm{Ba} /{ }^{134} \mathrm{Ba}$ ratios of stream water generally increase downstream, reflect- 
ing increasing depth of flowpaths contributing to stream water in the downstream direction. Finally, at one intensely sampled point on a tributary displaying broad spatial and temporal variability of $\mathrm{Sr} / \mathrm{Ba}$ and $\mathrm{Ca} / \mathrm{Sr}$ ratios of stream water, ${ }^{44} \mathrm{Ca} /{ }^{40} \mathrm{Ca},{ }^{88} \mathrm{Sr} /{ }^{86} \mathrm{Sr}$

and ${ }^{138} \mathrm{Ba} /{ }^{134} \mathrm{Ba}$ of stream water each display a unique pattern of seasonal variability indicating that these alkaline earth elements are not behaving in a geochemically coherent fashion. We hypothesize that differences in the behaviour of and signals provided by $\mathrm{Ca}, \mathrm{Sr}$ and $\mathrm{Ba}$ reflect the fact that biologically-cycled $\mathrm{Ca}$ is efficiently retained in the organic soil-plant system, while biologically-cycled $\mathrm{Sr}$ and especially $\mathrm{Ba}$ will be more easily leached by soil waters and delivered to the streams. Thus $\mathrm{Ca}, \mathrm{Sr}$ and $\mathrm{Ba}$ stable isotope ratios may provide an additional means to distinguish between shallow and deep water flowpaths in forested catchments.

\title{
034 - URANIUM ISOTOPIC SIGNATURES IN SEDIMENT AND LICHEN FROM THE VICINITY OF THE FERNALD FEED MATERIALS PRODUCTION CENTER, SOUTHWEST OHIO, USA
}

\author{
Elisabeth Widom $^{1}$ - Rebecca Tortorello ${ }^{1}$ - William Renwick ${ }^{2}$ \\ ${ }^{1}$ Department of Geology \& Environmental Earth Science, Miami University, \\ Oxford, OH, USA; e-mail: widome@MiamiOH.edu \\ ${ }^{2}$ Department of Geography, Miami University, Oxford, OH, USA
}

The Fernald Feed Materials Production Center (FFMPC) in SW Ohio operated from late 1951 to 1989 , during which time it produced and recycled more than 227 million $\mathrm{kg}$ of uranium metal for use in nuclear reactors, with estimated losses to the environment of $90,000-450,000 \mathrm{~kg}$ of uranium [1]. We have investigated $\mathrm{U}$ isotopic signatures and $\mathrm{U}$ and $\mathrm{Th}$ concentrations in a sediment core and lichens from the vicinity of the FFMPC in order to evaluate their utility as archives of the timing and spatial extent of anthropogenic environmental uranium contamination. An $80 \mathrm{~cm}$ long sediment core from an impoundment $\sim 7 \mathrm{~km}$ from the FFMPC was subdivided into $2 \mathrm{~cm}$ sections, and analysed for Th and $\mathrm{U}$ concentrations, ${ }^{137} \mathrm{Cs}$, and ${ }^{235} \mathrm{U} /{ }^{238} \mathrm{U}$ and ${ }^{236} \mathrm{U} /{ }^{238} \mathrm{U}$ ratios. The basal core sample lacks detectable ${ }^{137} \mathrm{Cs}$, which along with natural ${ }^{235} \mathrm{U} /{ }^{238} \mathrm{U}$ and no measureable ${ }^{236} \mathrm{U}$ indicates that the base of the sediment core pre-dates FFMPC activity and is free of anthropogenic U. However, 7 consecutive core samples immediately above the base have anomalously elevated $U$ relative to Th concentrations and exhibit non-natural ${ }^{235} \mathrm{U}^{238} \mathrm{U}$ and measureable ${ }^{236} \mathrm{U}$, demonstrating that they contain anthropogenic U from the nuclear industry. Both depleted (DU) and enriched (EU) ${ }^{235} \mathrm{U} /{ }^{238} \mathrm{U}$ signatures are observed, with the sediment core recording an early phase of DU contamination followed by a distinct phase of EU contamination. Constraints based on the ${ }^{137} \mathrm{Cs}$ activity data indicate that this sediment interval spans $\sim 1952$ to the mid-1960s, corresponding to the timing of the two largest known releases of $U$ dust from the FFMPC. The upper half of the sediment core exhibits natural ${ }^{235} \mathrm{U} /{ }^{238} \mathrm{U}$ ratios, 
but all of the samples contain measureable ${ }^{236} \mathrm{U}$, indicating that anthropogenic $\mathrm{U}$ contamination persists in the environment to the present day, and highlighting the sensitivity of the minor isotope ${ }^{236} \mathrm{U}$ as a contaminant tracer. Three lichens sampled within $4 \mathrm{~km}$ of the FFMPC all exhibit non-natural ${ }^{235} \mathrm{U} /{ }^{238} \mathrm{U}$ signatures (both DU and EU) and measureable ${ }^{236} \mathrm{U}$, suggesting that lichens are viable biomonitors of the time-integrated accumulation of uranium from airborne dust, and can serve as valuable archives for investigating the degree and aerial extent of environmental $U$ contamination.

\title{
References
}

1. A. Makhijani, Radioactivity in the Fernald Neighborhood. Institute for Energy and Environmental Research SDA, 5(3), 2000.

\section{5 - FACTORS CONTROLLING CONCENTRATIONS OF RADIUM ISOTOPES AND THEIR ACTIVITY RATIO IN GROUNDWATERS}

\author{
Nguyen Dinh Chau - Mariusz Kopeć \\ AGH University of Science and Technology. Al. Mickiewicza 30, 30-059 Krakow, Poland; \\ e-mail: Nguyen.Chau@fis.agh.edu.pl
}

Radium isotopes concentrations and their activity ratio in groundwaters are controlled not only by uranium and thorium concentrations in the host aquifer, but also by the recoil alpha effect, water desorption and adsorption factors.

For the theoretical analysis of the mentioned factors, a model of the processes leading to the change of radium isotopes content in groundwaters was proposed. Based on that model activity concentrations of radium isotopes and their activity ratio were estimated by Monte-Carlo (MC) method - the history of the every nucleus created by radioactive decay starting from uranium (U-238) or thorium (Th-232) nuclei to Ra-226 or Ra-224 nuclei, respectively, were registered. The data introduced into simulation were probabilities of the alternative processes - alpha recoil, desorption and adsorption. The results of the theoretical analysis and the MC simulation show that (i) if there are no desorption/adsorption processes, activity ratio of radium isotopes (Ra-226/Ra-228) is equal to 1.18; (ii) for groundwaters with moderate desorption and adsorption coefficients, activity of radium isotopes are at the mean level and the activity ratio (Ra-226/Ra-228) is similar to that of uranium and thorium (U-238/Th232) in the host rock aquifer; (iii) concentrations of radium isotopes and their activity ratio are the largest in waters with high desorption coefficient and the lowest in waters withf high adsorption coefficient.

To check the results obtained by MC simulation, several tens of mineral water samples collected from Polish Carpathian Mountains were analyzed. The Carpathian Mountains are localized in the South-East of Poland and consist principally of sandstone and conglomerate layers (flysch formations). The rocks are mixed with shale of 
different degrees. The concentrations of the uranium and thorium isotopes in water bearing formations vary from 1.04 to 1.98 and from 4.3 to $5.88 \mathrm{ppm}$, respectively. The ranges of uranium and thorium mass concentrations of are related to their activity ratio (U-238/Th-232) being within 0.88 to 1.2 values. From the hydrological point of view, most of the mineral waters occurring in the investigated region belong to the hydro-carbonated, chloride and sulfite types. For every water sample the mineralization, chemical ion composition and activity concentrations of Ra-226 and Ra-228 isotopes were determined. The results show that radium isotopes concentration in mineral waters generally increases with its mineralization. The concentrations of radium isotopes and their activity ratio (Ra-226/Ra-228) are the largest for chloride, medium for hydro-carbonated and the lowest for sulfate waters. The average activity ratios of radium isotopes (Ra-226/Ra-228) are equal to $2.05 \pm 0.48,0.67 \pm 0.08$ and $0.32 \pm 0.14$ for chloride, hydro-carbonated and sulfite waters, respectively. These results are in agreement with the data obtained by MC simulation and also confirm an influence of the desorption/adsorption coefficients - the desorption coefficients are the highest for $\mathrm{Cl}-\mathrm{Na}$, moderate for the $\mathrm{HCO}_{3}-\mathrm{Ca}$ and the lowest for sulfate waters (in contrast to the adsorption properties in these waters).

\title{
036 - EXTRACTING THE CLIMATE SIGNAL FROM STABLE ISOTOPIC SERIES AS THE FIRST METHODOLOGICAL STEP IN ASSESSING THE IMPACT OF POLLUTION ON ISOTOPIC DATA
}

\author{
Christian Bégin - Martine M. Savard - Joëlle Marion \\ Geological Survey of Canada - GSC-Q, 490 de la Couronne, \\ Québec (Qc), Canada, G1K 9A9; e-mail: cbegin@nrcan.gc.ca
}

Stable isotopes in tree-ring series are increasingly used to document present and historical effects of pollution on tree physiology and forest ecosystems. The approach was applied to various Canadian forested areas exposed to point sources of pollutants [1], diffuse pollution [2] and recently, to oil sands operations [3]. In all cases, changes in isotopic trends are inferred to result from pollution effect because they depart from natural values (mostly climatic) revealed by reference isotopic series (remote sites) or by statistical modeling. Therefore, when assessing the potential impact of anthropogenic activities on isotopic series in trees, the separation of the pollution signal from the natural one requires the fundamental methodological step of perfecting our knowledge of the influence of climatic factors on isotopic values. With the aim of understanding the relationship between isotopic values and climatic parameters for spruce trees, the species best suited for pollution studies, here we have analyzed stable isotope ratios $\left(\mathrm{d}^{13} \mathrm{C}\right.$ and $\left.\delta^{18} \mathrm{O}\right)$ in ring series from three spruce stands in the 'pristine' northeastern Canadian boreal region. We also wanted to determine how much of the signal is controlled by climatic conditions, and at which scale (local or regional) this control is operating.

Central European Geology 56, 2013 
All produced ring series cover the 1800-2004 period; bi-annual analyses were performed for the 1800-1940 part, whereas the 1941-2004 part was analyzed at an annual resolution so that the dendroisotopic results can be compared with measured climatic parameters. The $\delta^{18} \mathrm{O}$ results show a strong coherence between all sites indicating that oxygen isotopes express an important regional component. For the $\delta^{13} \mathrm{C}$ series, slight inter-tree and inter-site differences suggest the influence of local conditions; however, the good correspondence of the long-term trends indicates that regional conditions also play an important role. Statistical tests used to unravel the climatic control on mean isotopic ratios show that $\delta^{18} \mathrm{O}$ values mainly directly reflect summer temperatures $(r=0.65)$ but also correlate negatively with regional water inflow during the July-November period $(r=-0.64)$. On the other hand, $\mathrm{d}^{13} \mathrm{C}$ values correlate with the summer climatic index $(\mathrm{r}=-0.61)$ integrating temperature and precipitation effects. We also show that combining $\delta^{18} \mathrm{O}$ and $\delta^{13} \mathrm{C}$ values increases correlations with several climatic parameters.

Finally, isotopic data were modeled using response functions to test the reproducibility of isotopic series based on the isotope-climate relationship. As $\delta^{18} \mathrm{O}$ and $\delta^{13} \mathrm{C}$ values are sensitive to climatic variables that are linked and commonly associated in typical boreal climate ambiances (warm-dry, cold-wet), combining their response patterns shows a higher sensitivity to climatic parameters and helps better define the natural isotopic responses expected in trees growing under 'clean' (non-polluted) conditions from the ones possibly related to pollution effects.

\section{References}

1. M.M. Savard, C. Bégin, M. Parent, A. Smirnoff and J. Marion, Effects of Smelter Sulfur Dioxide Emissions: A Spatiotemporal Perspective Using Carbon Isotopes in Tree Rings. Journal of Environmental Quality, 33, pp. 13-26, 2004.

2. A. Doucet, M.M. Savard, C. Bégin, J. Marion, A. Smirnoff and T.B.M.J. Ouarda, Combining tree-ring metal concentrations and lead, carbon and oxygen isotopes to reconstruct peri-urban atmospheric pollution. Tellus B, 64, 19005, 2012, http://dx.doi.org/ 10.3402/tellusb.v64i0.19005.

3. M.M. Savard, C. Bégin and J. Marion, Modeling carbon isotopes in spruce trees reproduces air quality changes due to oil sands operations. Submitted.

\section{8 - GROUNDWATER TRACERS IN LJUBLJNA AQUIFER}

$$
\text { Janja Vrzel }{ }^{1,3}-\text { Samo Tamše }{ }^{2,3}-\text { Kip Solomon }^{4} \text { - Nives Ogrinc }{ }^{2,3}
$$

\footnotetext{
${ }^{1}$ Institute for Environmental Engineering, Ltd, Ljubljanska 9, SI-2000 Maribor, Slovenia; e-mail: janja.vrzel@iei.si

${ }^{2}$ Jožef Stefan Institute, Department of Environmental Sciences, Jamova 39, SI-1000 Ljubljana, Slovenia; email: nives.ogrinc@ijs.si

${ }^{3}$ International Postgraduate School Jožef Stefan, Jamova 39, SI-1000 Ljubljana, Slovenia

${ }^{4}$ University of Utah, Salt Lake City, UT, USA
} 
Radioactive and stable isotopes have been widely applied in groundwater studies for better understanding of groundwater formation, infiltration areas, groundwater dynamics, its age and vulnerability to contamination. Ljubljana field was taking as a study area. It is one of the biggest aquifer in Slovenia that provides drinking water for the inhabitants of the Slovenian capital and its surroundings.

Groundwater were taken monthly at 7 wells at 3 different locations NE of Ljubljana (Kleče, Hrastje and Jarški prod) through one hydrological cycle in 2010 and 2011. Monthly sampling also included precipitation and surface water from the River Sava. Physicochemical parameters (T, pH, conductivity) were measured on site. The groundwater was dated using ${ }^{3} \mathrm{H}$ and ${ }^{3} \mathrm{H} /{ }^{3} \mathrm{He}$ method. In water sample the isotopic composition of oxygen $\left(\delta^{18} \mathrm{O}\right)$ and hydrogen $\left(\delta^{2} \mathrm{H}\right)$ was measured, while in nitrate the determination of the isotopic composition of nitrogen and oxygen $\left(\delta^{15} \mathrm{~N}\right.$ and $\left.\delta^{18} \mathrm{O}\right)$ was performed. Concentrations of major cations and anions were also measured.

At Kleče high concentrations of terrigenic ${ }^{4} \mathrm{He}$ indicate that young water from Sava is mixed with very old water. The data helium data suggest that groundwater contains no more than $10 \%$ of old water. At Hrastje the groundwater is younger with not much older water. Differences in ages are probably due to different flow paths sampled by the wells. In some wells the transit time for Sava River water to reach the wells it 8 to 7 years. The $\delta^{18} \mathrm{O}$ and $\delta^{2} \mathrm{H}$ values at these two locations show that the main source of groundwater is precipitation mixed with a small amount of upstream river water. At Jarški prod the samples do not have the component of old water with ages that vary from 2 to 7 years. This is further supported by the $\delta^{18} \mathrm{O}$ measurements that show that the groundwater is composed of up to $70 \%$ of precipitation and $30 \%$ of river Sava. The $\delta^{15} \mathrm{~N}$ values of nitrate ranged between 1.4 and $9.7 \%$, while $\delta^{18} \mathrm{O}$ values in nitrate ranged from 6.3 to $34.6 \%$. Isotope mixing models indicated that Hrastje is the station that is most polluted with nitrates. Approximately $63 \%$ of nitrate comes from sewage/manure sources, $23 \%$ from mineral fertilizers and $13 \%$ from atmospheric deposition. At station Kleče around $50 \%$ of nitrate comes from pristine soil, $40 \%$ from agricultural land and $10 \%$ from atmospheric deposition. Jarški prod is the station that is most vulnerable to pollution due to its short retention time. This is further supported by the $\delta^{18} \mathrm{O}$ measurements that show that the groundwater is composed of up to $70 \%$ of precipitation and $30 \%$ of river Sava. The nitrate sources were $40 \%$ from atmospheric deposition, 30\% from agricultural land and 30\% from pristine soil. 


\title{
039 - DISCRIMINATION OF THE GEOGRAPHIC ORIGIN OF CABBAGES
}

\author{
Yeon-Sik Bong ${ }^{1}$ - Byeong-Yeol Song ${ }^{2}$ - Mukesh Kumar Gautam ${ }^{1}$ - Chang-Soon Jang ${ }^{3}-$ \\ Hyun Joo $A n^{2}-$ Kwang-Sik Lee $e^{1,2}$ \\ ${ }^{1}$ Division of Earth \& Environmental Sciences, Korea Basic Science Institute Chungbuk \\ 363-883, Republic of Korea; e-mail: bong_geo@kbsi.re.kr \\ ${ }^{2}$ Graduate School of Analytical Science and Technology, Chungnam National University, \\ Daejeon 305-764, Republic of Korea \\ ${ }^{3}$ Hankook Seed Co., Gyeonggi 459-703, Republic of Korea
}

Cabbage is widely produced and consumed in China, Japan, and especially Korea, where it is the main ingredient of kimchi. Recently, Korea has imported large quantities of cabbage produced in China. Given the huge difference in the prices of Chinese and Korean cabbages, Korean consumers have become increasingly interested in the geographic origin of this product. Geologic features of the production area, such as soil type, are assumed to be important factors affecting the determination of origin.

Combined chemical analysis of multiple elements and statistical analysis was performed to distinguish the geographic origin of 363 cabbage samples produced in Korea and China. Multielement analysis showed a significant difference in the contents of many elements of cabbages between Korea and China. The results of analysis revealed good distinction among individual geographic origins. The lithology of cabbage-producing areas was well reflected in the indicators of geographic origin. The present results demonstrate that the method of combining chemical and statistical analyses is very effective for determining the geographic origin of cabbages.

\section{0 - DISSOLVED NITRATE IN THE HAN RIVER BASIN, SOUTH KOREA: IDENTIFICATION OF THE SOURCES USING A DUAL ISOTOPE OF NITRATE}

\author{
Insu Kim ${ }^{1}-$ Jong-Sik Ryu ${ }^{1}-$ Kwang-Sik Lee $e^{1,2}$ \\ ${ }^{1}$ Division of Earth and Environmental Sciences, Korea Basic Science Institute, \\ Chungbuk 363-883, South Korea; e-mail: kis0823@kbsi.re.kr \\ ${ }^{2}$ Graduate School of Analytical Science and Technology, Chungnam National University, \\ Daejeon 305-764, South Korea
}

Dissolved nitrate $\left(\mathrm{NO}_{3}^{-}\right)$could cause negative effects on the ecosystem and human as surface and ground waters are affected by nitrate pollution. Hence, many previous studies have used various tracers to identify the sources of nitrate contamination, such as septic systems, animal waste, commercial fertilizer, and soil organic matter, of which a dual isotope of nitrate $\left(\delta^{15} \mathrm{~N}_{\mathrm{NO} 3}\right.$ and $\left.\delta^{18} \mathrm{O}_{\mathrm{NO} 3}\right)$ has been known as the most powerful tool. 
AIG10 - 2013

The Han River (HR) is the largest river in South Korea which runs through a metropolitan area, Seoul, supporting industrial and agricultural activities, and residential water. It consists of two major tributaries, the North Han River (NHR) and South Han River (SHR), of which lithologies are quite distinct, silicates and carbonates, respectively. Total 14 samples were collected along with each river, each six in the NHR and SHR, and two in the main channel of the HR, in order to investigate the level of nitrate and their sources in the Han River basin.

Average concentration of $\mathrm{NO}_{3}{ }^{-}$in both rivers was little different with $12 \mathrm{mg} / \mathrm{L}$, while a dual isotope was quite distinct. The $\delta^{15} \mathrm{~N}_{\mathrm{NO} 3}$ values of the NHR ranged from +2.9 to $+8.0 \%$, with an average of $+5.9 \%$ and those of the SHR ranged from +7.2 to $+10.8 \%$, with an average of $+8.4 \%$. Similarly, the $\delta^{18} \mathrm{O}_{\mathrm{NO} 3}$ values of the NHR varied from -0.8 to $+4.5 \%$, with an average of $+2.4 \%$ and those of the SHR varied from +2.6 to $+6.7 \%$, with an average of $+4.6 \%$. A plot of $\delta^{18} \mathrm{O}_{\mathrm{NO} 3}$ versus $\delta^{15} \mathrm{~N}_{\mathrm{NO} 3}$ indicates that nitrate in the NHR is mainly from soil organic matter, while septic waste and/or manure are the main sources in the SHR. Furthermore, as the HR flows through Seoul, it becomes affected by septic waste. This study suggests that better management of septic systems in the Han River basin is needed to prevent nitrate pollution and to protect residents.

\title{
041 - STABLE ISOTOPE RATIO ANALYSIS FOR VERIFYING THE AUTHENTICITY OF BALSAMIC WINE VINEGAR
}

\author{
Matteo Perini ${ }^{1}$ - Mauro Paolini ${ }^{1}$ - Marco Simoni ${ }^{1}$ - Massimo Sacco ${ }^{2}$ - Federica Camin ${ }^{1}$ \\ ${ }^{1}$ IASMA Edmund Mach Foundation, Via E. Mach 1, 38010 San Michele all'Adige (TN), \\ Italy; e-mail: matteo.perini@iasma.it \\ ${ }^{2}$ PONTI S.p.a. Via E. Ferrari 7, 28074 Ghemme (NO), Italy
}

Balsamic vinegar of Modena, which recently obtained PGI status (Protected Geographical Indication) with EC Regulations 583/2009, is a common salad dressing obtained by mixing wine vinegar, caramel and grape must. Wine vinegar is defined by EC Regulations 479/2008 (Annex IV, sections 1 and 17) and 123/2007 (Annex XI ter, sections 1 and 17) as a product obtained exclusively from the acetous fermentation of wine, which is in turn defined as a product exclusively obtained from the alcoholic fermentation of fresh grapes, whether crushed or not, or from grape must.

According to this definition, wine vinegar cannot contain acetic acids obtained from either petroleum derivatives or the pyrolysis of wood (synthetic acetic acid) or from the fermentation of sugar not coming from grapes (e.g. beet and cane sugar).

Since 2000 the Organisation Internationale de la Vigna et du Vin (OIV) and more recently the European Committee for Standardization (CEN) have established official isotopic analytical methods in order to detect the illegal addition of sugar to wine vinegar (OIV resolution 71/2000, EN 16466). 
Isotopic methods are based on determination of the $\mathrm{D} / \mathrm{H}$ ratio in the methylic site of acetic acid using SNIF-NMR (Site Specific Nuclear Isotope Fractionation- Nuclear Magnetic Resonance) and the ${ }^{13} \mathrm{C} /{ }^{12} \mathrm{C}$ ratio of acetic acid using IRMS (Isotope Ratio Mass Spectrometry). Acetic acid is extracted from the sample by liquid-liquid extraction and purified using a Cadiot column, obtaining a solution with an acetic acid content higher then $80 \%$.

In this study we investigated the variation in $\mathrm{D} / \mathrm{H}$ and ${ }^{13} \mathrm{C} /{ }^{12} \mathrm{C}$ values from wine ethanol to acetic acid in vinegar and balsamic vinegar, in order to determine whether the two CEN methods can also be applied to balsamic vinegar. The ${ }^{13} \mathrm{C} /{ }^{12} \mathrm{C}$ of the extracted acetic acid was measured both using an EA (Elemental analyser)-IRMS, which measures the bulk solution, and GC-C-IRMS (Gas chromatography - combustion), which can measure pure acetic acid.

Fifteen different production chains were considered, each made up of wine, wine vinegar, must, caramel and balsamic vinegar. Furthermore, two different experiments with adulterated samples (with the addition of beet and cane sugar) were carried out.

In none of the production chains was there any variation in the $\mathrm{D} / \mathrm{H}$ and ${ }^{13} \mathrm{C} /{ }^{12} \mathrm{C}$ values from wine ethanol to acetic acid extracted from both wine vinegar and balsamic vinegar. This means that CEN methods can also be used for analysis of balsamic vinegars. The ${ }^{13} \mathrm{C} /{ }^{12} \mathrm{C}$ of acetic acid can be indifferently measured using an EA-IRMS or GC-C system, obtaining the same results.

\section{References}

1. EC Regulations $583 / 2009$ of 3 July 2009 entering a name in the register of protected designations of origin and protected geographical indications [Aceto Balsamico di Modena (PGI)].

2. EC Regulations 479/2008 of 29 April 2008 on the common organisation of the market in wine.

3. Method OIV Resolution $71 / 2000$ Vinaigres de vin - Authentification par FINS-RMN ${ }^{\circledR}$ et d'autres methodes isotopiques.

4. Method CEN EN 16466 Vinegar - Isotopic analysis of acetic acid and water. 


\title{
042 - LATE HOLOCENE SEA-LEVEL RECORD IN MALLORCA INFERRRED FROM U-TH DATING OF OVERGROWTHS ON SPELEOTHEMS: IMPLICATIONS FOR GIA MODELS IN THE WESTERN MEDITERRANEAN
}

\author{
Paola Tuccimei ${ }^{1}$ - Michele Soligo ${ }^{1}$ - Joan Fornós ${ }^{2}$ - Angel Ginés ${ }^{2}$ - Joaquin Ginés ${ }^{2}$ \\ Giorgio Spada ${ }^{3}$-Igor M. Villa, ${ }^{4,5}-$ Bogdan P. Onac $^{6}$ \\ ${ }^{1}$ Dipartimento di Scienze, Università "Roma Tre. Largo San Leonardo Murialdo 1, \\ 00145 Roma, Italy; paola.tuccimei@uniroma3.it \\ ${ }^{2}$ Departament de Ciències de la Terra, Universitat de les Illes Balears, \\ Carretera Valldemossa km 7 .5, Palma de Mallorca, 07122, Spain \\ ${ }^{3}$ Dipartimento di Scienze di Base e Fondamenti, Università degli Studi Carlo Bo, \\ Via Santa Chiara 27, 61029 Urbino (PU), Italy \\ ${ }^{4}$ Institut für Geologie, Universität Bern, Bern, Switzerland, Baltzerstrasse 1+3, \\ CH-3012, Switzerland \\ ${ }^{5}$ Dipartimento di Scienze dell'Ambiente e del Territorio, Università di Milano - \\ Bicocca, P. della Scienza, 20126 MI, Italy \\ ${ }^{6}$ Department of Geology, University of South Florida, 4202 E. Fowler Ave, SCA 528, \\ Tampa, FL 33620 USA
}

Among the many impacts associated with impending climate change, those related to rapid sea-level rise are of immediate concern to society. Relative sea-level change at a given site reflects not only changes in global ice volume, but also the Earth's response to changes in surface loading in the form of surface deformation and geoid changes. This Earth response is referred to as "glacial isostatic adjustment" (GIA), and has both glacio- and hydro-components. Eustatic (ice equivalent) sea-level reconstructions require accurate models of GIA, which involve prescriptions of ice sheet history (including distribution, volume, and duration) and Earth's rheological properties (e.g., lithospheric and mantle heterogeneities, viscosity). Because uncertainties are inherent to all models, there is a continued need for additional, independent sources of sea-level data that might provide unique insight and cross-checks to the existing framework of past sea-level changes. The coastal caves of Mallorca with their phreatic encrustations on speleothems (POS) provide an additional, precise (independently-dated) and less ambiguous indicator of the timing and the absolute elevation of various sea-level stands in the western Mediterranean region.

The POS are carbonate encrustations deposited at the cave water table in peculiar coastal karst microenvironments, having morphologies that directly relate them to the sea level positions at their time of formation. The U-Th ages of calcite overgrowths associated with the present-day water table in Cova de sa Gleda, Cova des Rafal des Porcs and Cova de ses Tortugues, littoral caves of Mallorca, were determined using high-precision MC-ICPMS techniques. U-Th ages indicate that POS deposition occurred between ca 3,700 and 100 years BP and seem to be in agreement with an archeologically estimated age (3,700 to 3,000 years BP) of a drowned prehistoric construction, located $1 \mathrm{~m}$ below current sea level in Cova Genovesa, a cave in the sur- 
rounding area. These data confirm the results from previous studies on Late Holocene POS collected in two other caves of Mallorca (Cova de Cala Varques A and Cova des Pas de Vallgornera) showing that sea level stood at its present elevation since $\sim 2,800$ years BP.

Overall, the outcomes of this research suggest that Mallorca largely tracks the eustatic sea level curve and indicate that in the study region sea level reached the present level about 4,000 years ago. The outputs of some GIA models available from the literature are tested against this finding, and the implications for the global melting chronology of the major late-Holocene ice sheets are discussed.

\title{
043 - THE BURIALS OF THE SAN GIOVANNI DEI CAVALIERI CHURCH (THE LATE MIDDLE AGES, PRATA DI PORDENONE, ITALY). THE CASE OF THE MISSING FRIARS: A STABLE ISOTOPE CONTRIBUTION TO ARCHAEOLOGY
}

\author{
Elisa Galli ${ }^{l}$ - Paola Iacumin ${ }^{1}-$ Fabio Cavali ${ }^{2}$ \\ ${ }^{1}$ Department of Physics and Earth Sciences "Macedonio Melloni. Parma University, \\ Campus universitario - Viale delle Scienze 157/A, 43100 Parma, Italy; \\ e-mail: elisa.galli@studenti.unipr.it \\ ${ }^{2}$ Accademia di Studi medievali Jaufré Roudel, Sezione di Storia della Medicina e \\ Bioarcheologia, Museo Lapidario, Via Battisti, Gradisca d'Isonzo, Gorizia, Italy
}

We studied 39 buried individuals dating back to the XIII-XIV century, from a set of tombs belonging to the church of San Giovanni dei Cavalieri in Prata di Pordenone (Friuli-Venezia Giulia, Italy).

The burials are organized in two groups (burials inside and outside the church). The two groups are classically attributed to two branches of the same local noble family, the Counts of Prata [1]. Although the identities and relationships between individuals buried inside the church are well defined, individuals buried outside are basically unknown, and the current interpretation is that they are members of a cadet branch of the same family.

The $\mathrm{C}, \mathrm{N}$ and $\mathrm{O}$ stable isotope composition of skeletal carbonate and collagen have been measured to determine the human diet and to corroborate or not the possible relationship between the two groups.

The general profile of the diet of these individuals is characterized by the consumption of $\mathrm{C}_{3}$ plants, associated with a variable amount of $\mathrm{C}_{4}$ plants, terrestrial animals and freshwater fish.

The internal and external individuals differ in the calculated $\delta^{18} \mathrm{O}$ values of ingested water [2] (-6.7\% in the individuals buried within; $-8.5 \%$ in individuals buried outside). A possible explanation for this discrepancy may be related to a certain consumption of wine in the first group. The wine has higher $\delta^{18} \mathrm{O}$ values than the environ- 
mental water as a result of the process of evapotranspiration in the grape. Consequently, also the skeletal apatite $\delta^{18} \mathrm{O}$ values will be higher. The two groups also differ in $\delta^{15} \mathrm{~N}$ values: the external individuals are identified with more positive values, suggesting increased consumption of freshwater fish.

We therefore propose an alternative interpretation than the current one for the identity of the outside individuals: the external burials could not be associated to a different treatment within the same family (for which it is expected that the branch of the family enjoyed a similar degree of well-being), but to a group essentially unrelated. This group may be represented by the friar hospitaliers who ran the church, whose tombs have not yet been identified. The low or no consumption of wine and the high consumption of fish would then be attributable to the respect of the Rule of St. Benedict.

\title{
References
}

1. F. Cavalli, I cavalieri invisibili. La Chiesa di San Giovanni a Prata di Pordenone. Indagini archeologiche 2007, Tipografia Sartor, Pordenone, 2009.

2. A. Longinelli, Oxygen isotopes in mammal bone phosphate: A new tool for paleohydrological and paleoclimatological resarch? Geochimica et Cosmochimica Acta, 48, pp. 385-390, 1984.

\section{4 - SEDIMENTOLOGY AND ENVIRONMENTAL INTERPRETATION OF MICROBIALLY MEDIATED CARBONATE FORMATION IN EVAPORITES-BEARING MIOCENE SUCCESSION IN THE NORTHERN WESTERN DESERT, EGYPT}

\author{
Ahmed S. Mansour \\ Departmenr of Geology, Faculty of Science, Alexandria University, 21511, Moharam Beih, \\ Alexandria, Egypt; e-mail: ah_sadek@hotmail.com
}

After the end of the Middle Miocene, the Mediterranean area underwent well defined paleoenvironmental changes from normal marine to hypersaline conditions associated with the beginning of an evaporitic phase at the early of Messinian. An Upper Miocene evaporite sequence overlying normal marine (Middle Miocene?) carbonates is recorded in Al-Barqan area, northern Western Desert of Egypt. A thin fossiliferous and gypsiferous carbonate unit ( $2 \mathrm{~m}$ thick) located in the base of evaporite sequence represents a transitional stage of sedimentation between the normal marine carbonates and the evaporite deposits. The work aims to interpret the conditions of formation of these carbonates, whether they were formed in hypersaline settings or they represent normal salinity marine sediments formed before the main restriction and evaporite deposition, and provide evidences of the role of microbes in precipitation of these carbonates as they did in the precipitation of the overlying laminated gypsum. Polarizing microscope, SEM, XRD and oxygen and carbon stable isotopic data are used in this work. 
The basal part of the carbonate unit is represented by shallow marine calcareous facies (peloids-bioclasts grainstone). The variation of this facies to carbonate mudstone dominated by dolomite and gypsum at the top of the unit followed by the precipitation of gypsum deposits are indicative to marked changes in the chemical composition of the waters, climatic variation and progressive shallowing and restriction of the basin during the precipitation of these rocks.

The highly negative $\delta^{18} \mathrm{O}$ values (up to $-9.99 \%$ ), the low $\mathrm{Sr}$ content of the limestones and the presence of vugs created by dissolution of carbonate components and gypsum crystals reflect that the early formed marine calcareous sediments might be recrystallized by ${ }^{18} \mathrm{O}$-depleted freshwater. On the other hand, the very finely crystalline nature of the dolomite, its association with some gypsum, the relatively high $\mathrm{Na}$ content and the lack of petrographic evidence indicating replacement processes reflect that this dolomite is usually interpreted as a primary evaporative dolomite or is considered a very early diagenetic product. However, the stoichiometric composition of the dolomite, the oxygen isotope values $(-0.77$ to $-1.2 \%)$ and the low Sr content may reflect the freshwater-mediated recrystallization of early formed marine-evaporative dolomite.

Although the less negative $\delta^{13} \mathrm{C}$ values $(-0.17$ to $1.34 \%$ ) of the carbonates, which indicate that the major source of $\mathrm{CO}_{3}^{-2}$ was derived from inorganic $\mathrm{HCO}_{3}^{-}$, the presence of small filaments of bacteria and biofilms coated calcite and dolomite crystals and the spheroidal fabrics of some carbonate grains may point to the contribution of some organic carbon originated as a byproduct of bacterial sulfate reduction as a minor source of the carbonate carbon.

\section{References}

1. T.F. Anderson and M.A. Arthur, Stable isotopes of oxygen and carbon and their application to sedimentologic and paleoenvironmental problems. In: M.A. Arthur, T.F. Anderson, I.R. Kaplan and J. Veizer (eds), Stable isotopes in sedimentary geology, SEPM, short course, 10, pp. 1-151, 1983.

2. M.A. Aref, Lithofacies characteristics, depositional environment and karstification of the Late Miocene (Messinian) gypsum deposits in the Northern Western Desert, Egypt. Sediment. Egypt, 11, pp. 9-27, 2003.

3. C. Arenas and L. Pomar, Microbial deposits in upper Miocene carbonates, Mallorca, Spain. Palaeogeog, Palaeoclim, Palaeoecol., 297, pp. 465-485, 2010.

4. M.A. Bassettia, V. Manzib, S. Luglic, M. Roverib, A. Longinellib, F.R. Lucchid, M. Barbierie, Paleoenvironmental significance of Messinian post-evaporitic lacustrine carbonates in the northern Apennines, Italy Maria Angela. Sed Geol., 172, pp. 1-18, 2004.

5. T.R. Bontognali, C. Vasconcelos, R.J. Warthmann, S.N. Bernnasconi, C. Dupraz, C.J. Strohmenger and J.A. Mckenzie, Dolomite formation within microbial mats in the coastal sabkha of Abu Dhabi (United Arab Emirates). Sedimentology, 57, pp. 824-844, 2010.

6. C. Glunk, C. Dupraz, O. Braissant, K.L. Gallacher, E.P. Verrecchia and P.T. Visscher, Microbially mediated carbonate precipitation in a hypersaline lake, Big Pond (Eleuthera, Bahamas). Sedimentology, 58, pp. 720-738, 2011. 
7. M. Jasionowski and T.M. Peryt, Isotopic composition of dolomite associated with Middle Miocene Badenian anhydrites in the Carpathian Foredeep Basin of SE Poland. Geol. Quarterly, 54, pp. 533-548, 2010.

8. D.T. Wright and A. Oren, Nonphotosynthetic bacteria and the formation of carbonates and evaporites through time. Geomicrobiology J., 22, pp. 27-53, 2005.

\title{
045 - EVIDENCE FOR FLUID EVOLUTION IN BEDROCK FRACTURES FROM C AND O ISOTOPES AND FLUID INCLUSIONS IN CALCITE FILLINGS
}

\author{
Elina Sahlstedt ${ }^{1}$ - Juha A. Karhu ${ }^{1}-$ Petteri Pitkänen ${ }^{2}$ \\ ${ }^{1}$ Department of Geosciences and Geography, University of Helsinki, P.O.Box 64, \\ 00014 Helsinki, Finland; e-mail: elina.sahlstedt@helsinki.fi \\ ${ }^{2}$ Posiva Oy, Olkiluoto, Finland
}

Fracture mineral studies have been carried out at Olkiluoto, SW Finland in order to investigate paleofluid flow in the area. Calcite is in fractures present as different generations, which, however, show significant overlap in their $\delta^{13} \mathrm{C}$ and $\delta^{18} \mathrm{O}$ values [1]. In this study, our intention is to apply detailed $\mathrm{O}$ and $\mathrm{C}$ isotopic data from massive vein fillings, complemented by fluid inclusion data, to study the earliest hydrothermal fluid evolution at the site. Olkiluoto is planned to be the site to host the geological repository of spent nuclear fuel. Information on the past circulation of fluids in the bedrock provides important data for the planning of the repository site.

The earliest calcite fillings are thick veins, where calcite is associated with sulphides, clays (illite, kaolinite, smectite), quartz, feldspars and minor fluorite and zeolite [1-3]. Typically, calcite occurs as a vein closing mineral. Occasionally, the calcite veins contain vugs filled with euhedral crystals. The isotopic composition of the calcite is variable, the $\delta^{18} \mathrm{O}$ values range from -18.4 to $-8.4 \%$ and the $\delta^{13} \mathrm{C}$ values from -14.7 to $1.2 \%$ (VPDB). According to Blyth et al. [3], calcite with both low $\delta^{13} \mathrm{C}$ and $\delta^{18} \mathrm{O}$ values are associated with the earliest calcite fillings in closed veins at depths $>500 \mathrm{~m}$ (b.l.s.). New studies have found this calcite type to be present also closer to current ground surface $[1,2]$. Fluid inclusion data is available from limited amount of samples and indicate formation temperatures of $130-245^{\circ} \mathrm{C}$, from a low salinity, $\mathrm{NaCl}-\mathrm{H}_{2} \mathrm{O}$-type fluid ([1-3], new data). The $\delta^{18} \mathrm{O}$ values of the fluid precipitating calcite was -0.3 to $7.2 \%$ (VSMOW), calculated from the fluid inclusion homogenisation temperatures and isotopic composition of the calcite. The $\delta^{13} \mathrm{C}$ values from the same calcite fillings were -8 to $-21 \%$ (VPDB). Based on the isotopic data, the precipitating fluid was unlikely to be of (pure) magmatic origin. As suggested by Blyth et al. [3], the fluid may have been influenced by meteoric waters. Covariation of the $\delta^{13} \mathrm{C}$ and $\delta^{18} \mathrm{O}$ values in the earliest calcite fillings has been interpreted to represent calcite precipitation in a cooling fluid. Due to the association of these calcite fillings with strong alteration zones and the high formation temperatures of up to $245^{\circ} \mathrm{C}$, calcite is interpreted 
to have precipitated from hydrothermal fluids. It is speculated that the calcite fillings were formed as a result of hydrothermal circulation created by the emplacement of a large rapakivi granite intrusion. The Eurajoki rapakivi granite stock ( $1571 \pm 3$ to 1548 $\pm 3 \mathrm{Ma}$, refs. [4, 5]) outcropping is $\sim 4 \mathrm{~km}$ away from the study area. A seismic reflection survey suggests that the granite body may continue below the Olkiluoto island at a depth of 3-3.5 km [6]. It cannot be excluded that other episodes of high temperature hydrothermal alteration occurred later in association with the intrusion of diabase dykes at $1225 \mathrm{Ma}$.

\section{References}

1. E. Sahlstedt, J.A. Karhu, and P. Pitkänen, Indications for the past redox environments in deep groundwaters from the isotopic composition of carbon and oxygen in fracture calcite, Olkiluoto, SW Finland. Isotop. in Env. and Heath Stud., 46, pp. 370-391, 2010.

2. E. Sahlstedt, J.A. Karhu, P. Pitkänen and M. Whitehouse, Implications of sulfur isotope fractionation in fracture-filling sulfides in crystalline bedrock, Olkiluoto, Finland. Appl. Geochem., 32, pp. 52-69, 2013.

3. A. Blyth, S. Frape, R. Blomqvist and P. Nissinen, Assessing the past thermal and chemical history of fluids in crystalline rock by combining fluid inclusion and isotopic investigations of fracture calcite. Appl. Geochem., 15, pp. 1417-1437, 2000.

4. M. Vaasjoki, The Laitila rapakivi batholith revisited: new, more precise radiometric ages. In: I. Haapala, O.T. Rämö and P. Kosunen (eds), The Seventh International Symposium on Rapakivi Granites and Related Rocks, Wednesday 24 - Friday 26 July, 1996, University of Helsinki, Helsinki - Finland: abstract volume. Helsinki: University Press, p. 82, 1996.

5. I. Haapala, Petrography and geochemistry of the Eurajoki stock: A rapakivigranite complex with greisen-type mineralization in southwestern Finland. Geol. Soc. of Fin. Bull., 286, pp. 1-128, 1977.

6. I. Kukkonen, M. Paananen, S. Elo, S. Paulamäki, J. Laitinen, Hire Working Group of the Geological Survey of Finland, P. Heikkinen and S. Heinonen, HIRE Seismic Reflection Survey in the Olkiluoto Area. Posiva Working Report 2010-57, 62 pp., 2010.

7. I. Mänttäri, J. Mattila, H. Zwingmann and A.J. Todd, Illite K-Ar Dating of Fault Breccia Samples from ONKALO Underground Research Facility, Olkiluoto, Eurajoki, SW Finland. Posiva Working Report 2007-67, 40 pp., 2007.

\section{6 - IN-SITU U-Th DATING OF SPELEOTHEMS BY LA-MC-ICPMS - PRELIMINARY RESULTS}

Christophe Innocent ${ }^{1}$ - Michèle Robert ${ }^{2}$ - Sophie Verheyden ${ }^{3}-$ Emmanuelle Petelet-Giraud ${ }^{4}$

${ }^{1}$ BRGM, 3 avenue Claude Guillemin, BP 6009, 45060 Orléans cedex 2, France; e-mail: c.innocent@brgm.fr

${ }^{2}$ BRGM, 3 avenue Claude Guillemin, BP 6009, 45060 Orléans cedex 2, France; e-mail: m.robert@brgm.fr

${ }^{3}$ Geological Survey of Belgium, Royal Belgian Insitute of Natural Sciences, Jennerstreet 13, 1000 Brussels, Belgium; e-mail: sophie.verheyden@naturalsciences.be

${ }^{4}$ BRGM, 3 avenue Claude Guillemin, BP 6009, 45060 Orléans cedex 2, France; e-mail: e.petelet@brgm.fr 
The recent development of the measurement of ${ }^{230} \mathrm{Th}-{ }^{234} \mathrm{U}-{ }^{238} \mathrm{U}$ isotope ratios by laser ablation (LA) multi-collector (MC) ICPMS [1] allows the accurate in situ dating of quaternary material, thus overcoming sub-sampling problems and drastically reducing sample preparation processes. A number of different materials may be investigated [2], but so far most studies have focused on calcium carbonates [3-5].

In this study, we attempt to date recent (holocene) speleothems by this technique. The Neptune MC-ICPMS is coupled to a $213 \mathrm{~nm}$ Cetac LSX-213 laser. Two U-rich speleothems (stalagmites) from the Han s/Lesse cave (Belgium), Han-stm7422 and Han-stm-7423, have been analyzed. In addition to laser analyses, Han-stm-7422 has been sub-sampled for classical measurements using the dissolution method, in order to compare the results obtained by the two techniques.

Han-stm-7422 is approximately $15 \mathrm{~cm}$-long, made of calcite in its internal part, surrounded by an aragonitic rim, especially towards the apex (Fig. 1). Two points have been sampled in the calcitic part, near the base of the speleothem (P4) and just below the calcite-aragonite limit (P3). A third point has been sampled just above this limit (P2), in the aragonitic part. Laser ablation lines have been performed as close as possible to each of these 3 sampling points. Finally, an additional ablation line (P1) has been done half-way between P2 and the apex.

Uranium concentrations are more than one order of magnitude higher in the aragonite (68 ppm) than in the calcite (from 1 to $5 \mathrm{ppm}$ ). Isotopic ratios are higher than the secular equilibrium value in both mineralogical facies (Fig. 1). Ratios obtained by laser ablation are comparable within error to those derived from dissolution measurements. However, laser average values of the ${ }^{234} \mathrm{U} /{ }^{238} \mathrm{U}$ ratio are systematically lower than for dissolution analyses. Overall, the ${ }^{230} \mathrm{Th} /{ }^{234} \mathrm{U}$ ratios tell the same story (laser values are slightly lower for P2). Calculated simple ages are relatively concordant between dissolution and laser ablation analyses, and indicate an apparent $\sim 2 \mathrm{kyr}$ hiatus, either due to a growth interruption or to $\mathrm{U}$ migration from the calcitic to the aragonitic part.

Han-stm-7423 is completely made of aragonite, and has been only analyzed by laser ablation. Results obtained on 3 ablation lines display ${ }^{234} U /{ }^{238} U$ isotopic ratios that are very reproducible from a measurement to the other (with rather large analytical uncertainties), and largely higher than secular equilibrium (1.45 in activity ratio). ${ }^{230} \mathrm{Th} /{ }^{234} \mathrm{U}$ ratios are also very constant, around 0.02 , which leads to simple ages clustering between 2258 and 2536 years. Such values are in agreement with ages obtained previously by alpha spectrometry on a similar speleothem (from $4100 \pm 1700$ years to $1200 \pm 100$ years).

Additional dissolution and laser analyses are currently underway in order to better constrain the preliminary conclusions that can be drawn from these data. 

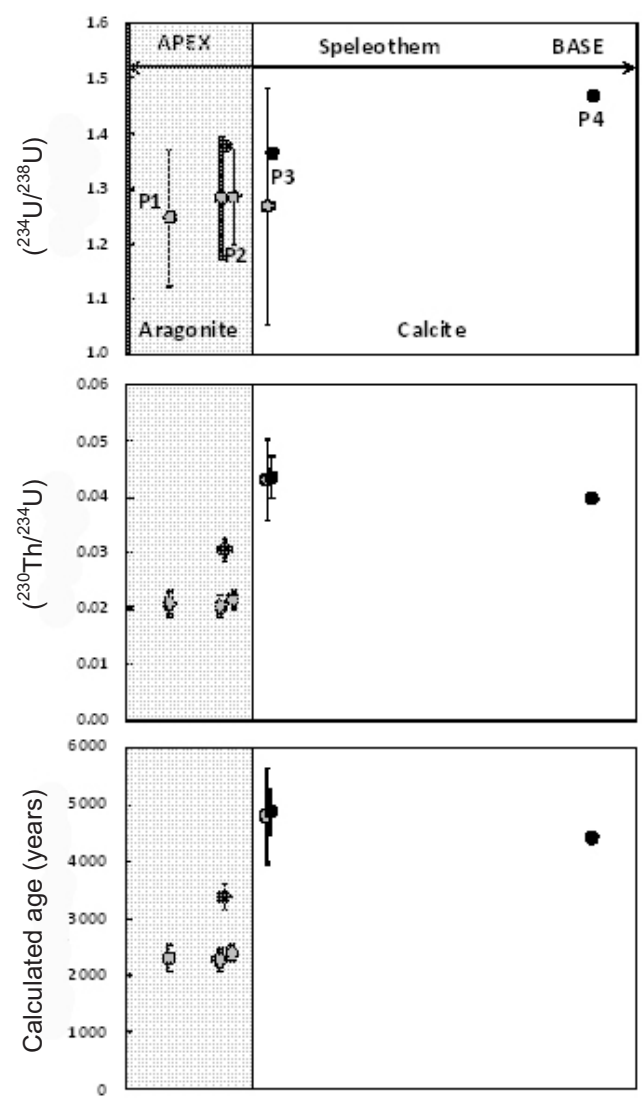

Figure 1. $\left({ }^{234} \mathrm{U} /{ }^{238} \mathrm{U}\right),\left({ }^{230} \mathrm{Th} /{ }^{234} \mathrm{U}\right)$ ratios and calculated ages as a function of the location of the datapoints within the speleothem Han-stm-7422. Black points: dissolution analyses; grey points: laser ablation analyses

\section{References}

1. C.H. Stirling, D.C. Lee, J.N. Christensen and A.N. Halliday, High-precision in situ ${ }^{238} \mathrm{U}^{234} \mathrm{U}{ }^{230} \mathrm{Th}$ isotopic analysis using laser ablation multiple-collector ICPMS. Geochim. Cosmochim. Acta, 64, pp. 3737-3750, 2000.

2. S.M. Eggins, R. Grün, M.T. McCulloch, A.W.G. Pike, J. Chappell, L. Kingsley, G. Mortimer, M. Shelley, C.V. Murray-Wallace, C. Spötl and L. Taylor, In situ U-series dating by laser-ablation multi-collector ICPMS: New prospects for Quaternary geochronology. Quarter. Sci. Rev., 24, pp. 2523-2538, 2005.

3. E.-K. Potter, C.H. Stirling, U.H. Wiechert, A.N. Halliday and C. Spötl, Uranium-series dating of corals in situ using laser-ablation MC-ICPMS. Int. J. Mass Spectrom., 240, pp. 27-35, 2005.

4. D.L. Hoffmann, C. Spötl and A. Mangini, Micromill and in situ laser ablation sampling techniques for high spatial resolution MC-ICPMS U-Th dating of carbonates. Chem. Geol., 259, pp. 253-261, 2009.

5. H.V. McGregor, J. Hellstrom, D. Fink, Q. Hua and C.D. Woodroffe, Rapid U-series dating of young fossil corals by laser ablation MC-ICPMS. Quarter. Geochronol., 6, pp. 195-206, 2011. 


\title{
047 - THE SOURCE AND MEAN RESIDENCE TIME OF RIVER WATER IN SMALL AND MEDIUM SIZED CATCHMENTS IN SOUTHERN FINLAND: A STABLE ISOTOPE APPROACH
}

\author{
Paula Niinikoski ${ }^{1}$ - Nina Hendriksson ${ }^{2}$ - Juha A. Karhu ${ }^{1}$ \\ ${ }^{1}$ Department of Geosciences and Geography, University of Helsinki, P.O. Box 64, \\ FI-00014 University of Helsinki, Finland; e-mail: paula.niinikoski@helsinki.fi \\ ${ }^{2}$ Geological Survey of Finland, GTK, Espoo, Finland
}

Seasonal fluctuations of the isotopic compositions of oxygen and hydrogen in rainfall are inherited by river water. However, the retention of water in surficial and groundwater reservoirs reduces the amplitude of the seasonal, sinusoidal isotope curve. Comparing the mean annual isotopic values of rain and river water assists in constraining the storage of water as groundwater or in surface reservoirs. The mean residence time of river water can be determined from the curve by two methods relying either on amplitude damping or phase shift [1].

In this study, two rivers were examined, the River Kokemäenjoki and the River Vantaanjoki, located in densely populated areas of southern and western Finland. In the case of the River Vantaanjoki some interaction with groundwater has been reported but the extent of groundwater discharge to the river remains open [2]. In the River Kokemäenjoki, the interaction between river water and groundwater is poorly constrained. The volume of discharge in these two rivers is very different, the mean discharge of the River Kokemäenjoki $\left(180 \mathrm{~m}^{3} / \mathrm{s}\right)$ being over 10 times that of the River Vantaanjoki $\left(16 \mathrm{~m}^{3} / \mathrm{s}\right)$. However, during the spring flood period, the increase in the mean discharge of the River Vantaanjoki is a 100-fold in comparison to the mean discharge, whereas the discharge of the River Kokemäenjoki is only doubled during the spring time. The flood period of the River Vantaanjoki is considerably shorter, with only approximately two weeks of high discharge (over $100 \mathrm{~m}^{3} / \mathrm{s}$ ), than that of the River Kokemäenjoki, in which there are two months of high discharge (over $300 \mathrm{~m}^{3} / \mathrm{s}$ ).

The aim of this study was to examine how these differences are reflected in the residence time of water and to determine the proportion of base flow for both rivers. The water sources were determined by analysing the stable isotope composition of oxygen, hydrogen and dissolved inorganic carbon in the river water. Residence times were estimated by comparing the seasonal variation in the isotopic composition of oxygen in rainfall with the seasonal trends in river water.

The mean annual $\delta^{18} \mathrm{O}_{\text {VSMOw }}$ value for rainfall in southern Finland was $-12 \ldots-11 \%$ during years $2010-2011$. In the River Vantaanjoki the annual mean was $-12 \%$ and in the River Kokemäenjoki it was $-9.5 \%$. This suggests that the water in the River Kokemäenjoki has been subjected to considerable evaporation, which is not the case for the River Vantaanjoki. The fluctuation of the isotopic composition of oxygen in the River Kokemäenjoki water follows a sinusoidal curve with a minimum value in the spring and a maximum in the autumn. The phase shift method gives an estimate for the mean residence time of 80 days. The seasonal isotope curve is more complicated 
for the River Vantaanjoki. The most dominant isotopic feature of the River Vantaanjoki is a distinct negative snow melt peak during a short time period of the spring flood, giving a similar mean residence time of 80 days for the River Vantaanjoki as well. Excepting the spring flood, the isotope curve for the River Vantaanjoki is almost flat, suggesting a large fraction of base flow (Fig. 1).

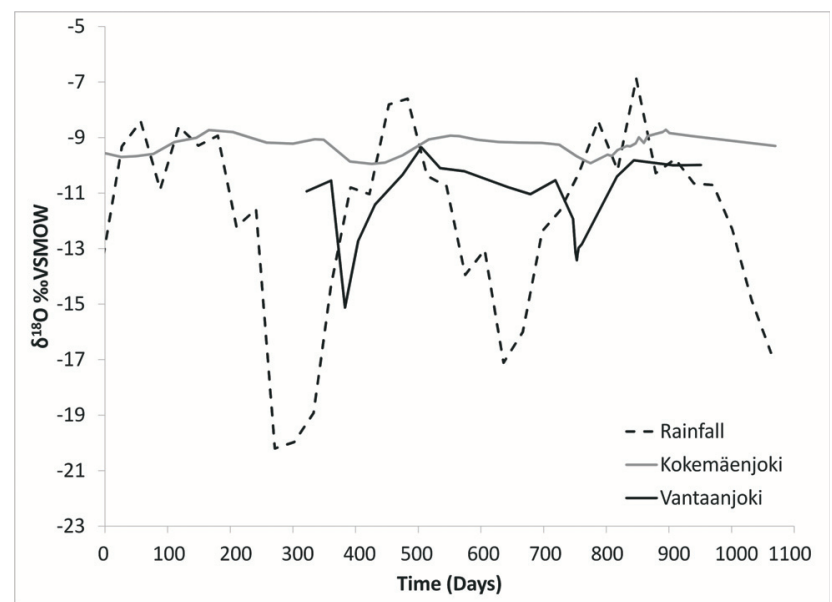

Figure 1. The $\delta^{18} \mathrm{O}$ values of rainfall and rivers Kokemäenjoki and Vantaanjoki 2009-2011

\title{
References
}

1. J.O. Burgman, B. Calles and F. Westman, Conclusions from a ten year study of oxygen-18 in precipitation and runoff in Sweden. Isotope Techniques in Water Resources Development. IAEA-SM-299/107, pp. 579-590, 1987.

2. K. Korkka-Niemi, A-L. Kivimäki, K. Lahti, M. Nygård, A.B.K. Rautio, V-P. Salonen and P. Pellikka, Observations on groundwater-surface water interactions at River Vantaa, Finland. Management of Environmental Quality, 2012(23), pp. 222-231, 2012.

\section{8 - STABLE CARBON, HYDROGEN AND NITROGEN ISOTOPE COMPOSITIONS AND ORIGIN OF NATURAL GASES ACCUMULATED IN THE ZECHSTEIN MAIN DOLOMITE RESERVOIR OF THE CENTRAL PART OF THE POLISH PERMIAN BASIN}

\author{
Elżbieta Bilkiewicz ${ }^{1}-$ Maciej J. Kotarba ${ }^{2}$ \\ ${ }^{1}$ AGH University of Science and Technology, Faculty of Geology, Geophysics and \\ Environmental Protection, Al. Mickiewicza 30, 30-059 Krakow, Poland; \\ e-mail: ebil@agh.edu.pl \\ ${ }^{2}$ AGH University of Science and Technology, Faculty of Geology, Geophysics and \\ Environmental Protection, Al. Mickiewicza 30, 30-059 Krakow, Poland; \\ e-mail: kotarba@agh.edu.pl
}




\section{Introduction}

The objective of this study is determining the origin of natural gases associated and non-associated with oil accumulated in the Zechstein Main Dolomite carbonates of the central part of the Polish Permian Basin were analysed for molecular and stable isotope compositions as follows: ${ }^{12,13} \mathrm{C}_{\text {in }} \mathrm{CH}_{4}, \mathrm{C}_{2} \mathrm{H}_{6}, \mathrm{C}_{3} \mathrm{H}_{8}, n \mathrm{C}_{4} \mathrm{H}_{10}, i \mathrm{C}_{4} \mathrm{H}_{10}, n \mathrm{C}_{5} \mathrm{H}_{12}$, $i \mathrm{C}_{5} \mathrm{H}_{12}$ and $\mathrm{CO}_{2},{ }^{1,2} \mathrm{H}$ in $\mathrm{CH}_{4}$, and ${ }^{14,15} \mathrm{~N}$ in $\mathrm{N}_{2}$.

Kotarba et al. [1] made a preliminary study of the origin of natural gases accumulated in the Zechstein Main Dolomite reservoir of the Polish part of the Permian Basin.

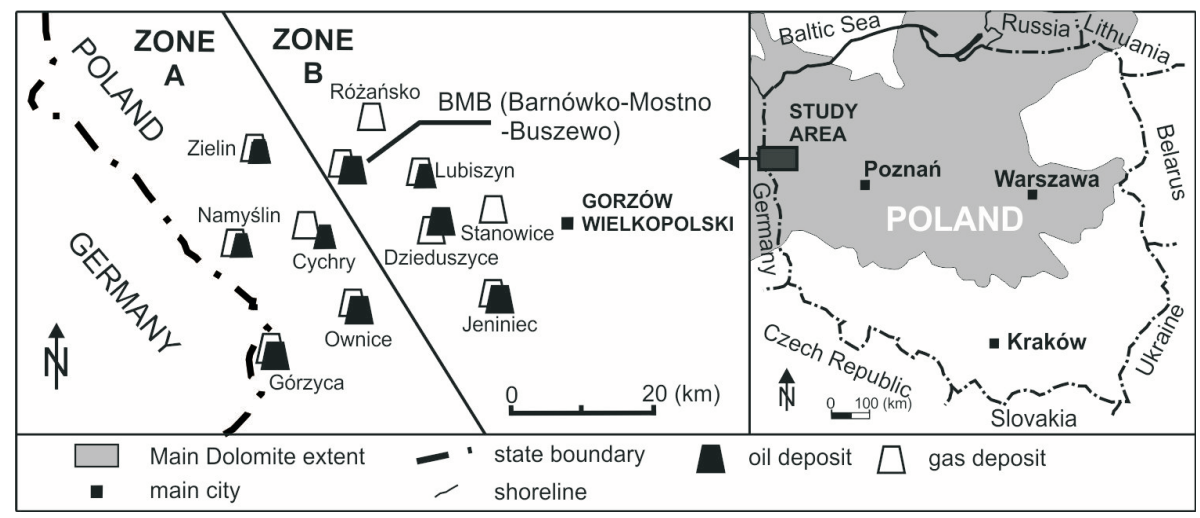

Figure 1. Location of the gas sampling fields

\section{Geological setting and petroleum occurrence}

The study area is located in western Poland and covers about $4962 \mathrm{~km}^{2}$. Tectonically it lies on the Gorzów block which is part of the Mid-Polish Swell. The discussed hydrocarbon accumulations occur in the Zechstein Main Dolomite carbonates of the Permian Basin of the Polish Lowlands. The Main Dolomite lithostratigraphic unit occurs at the base of the Zechstein PZ2 cyclothem called Stassfurt sequence. The Main Dolomite carbonates are both source and reservoir rocks for hydrocarbon deposits which makes them one of the main targets of petroleum exploration in the Polish Lowlands [2]. The closed hydrodynamic system is formed by carbonates of the Main Dolomite isolated by evaporates both on the top and on the bottom [2].

The hydrocarbon fields of the study area are located in: BMB (BarnówkoMostno-Buszewo) (oil-gas, 14 samples), Cychry (oil-gas, 2 samples), Dzieduszyce (oil-gas, 1 sample), Górzyca (oil-gas, 4 samples), Namyślin (oil, 1 sample), Jeniniec (oil-gas, 1 sample), Ownice (oil-gas, 1 sample), Lubiszyn (oil-gas, 2 samples), Różańsko (gas, 1 sample), Stanowice (gas, 1 sample), and Zielin (oil-gas, 2 samples). The study area was divided into two zones: (A) south-western zone including Cychry, Górzyca, Namyœlin, Ownice, and Zielin fields, and (B) north-eastern zone including 
BMB (Barnówko-Mostno-Buszewo), Dzieduszyce, Namyślin, Różańsko, and Stanowice fields. The locations of analysed oil and gas fields are shown in Fig. 1.

\section{Sampling procedure and analytical methods}

Free natural gas samples from producing wells were collected directly at the well head to a metal container $\left(\sim 1000 \mathrm{~cm}^{3}\right)$ and gases dissolved in oil and condensate from separators to a glass container $\left(\sim 500 \mathrm{~cm}^{3}\right)$. In general 30 gas samples were collected from the Main Dolomite reservoirs. The location of the sampling sites is shown in the Fig. 1.

Molecular composition of natural gases $\left(\mathrm{CH}_{4}, \mathrm{C}_{2} \mathrm{H}_{6}, \mathrm{C}_{3} \mathrm{H}_{8}, i \mathrm{C}_{4} \mathrm{H}_{10}, n \mathrm{C}_{4} \mathrm{H}_{10}\right.$, $i \mathrm{C}_{5} \mathrm{H}_{12}, n \mathrm{C}_{5} \mathrm{H}_{12}, \mathrm{C}_{6} \mathrm{H}_{14}, \mathrm{CO}_{2}, \mathrm{O}_{2}, \mathrm{H}_{2}, \mathrm{~N}_{2}, \mathrm{He}$, Ar) was analysed in a set of columns on Hewlett Packard 5890 Series II, Fisons Instruments 8000 and Carlo Erba 6000 gas chromatographs. Stable carbon, hydrogen, and nitrogen isotope analyses were performed using Finnigan Delta Plus and Micromass VG Optima mass spectrometers. The stable carbon and hydrogen isotope data are presented in the d-notation relative to the V-PDB and V-SMOW standards [3], respectively. Analytical precision is estimated to be $\pm 0.2 \%$ and $\pm 3 \%$, respectively. Methane, ethane, propane, $i$-butane, $n$-butane, $i$-propane, and $n$-propane were separated chromatographically for stable carbon isotope analyses. They were combusted over hot copper oxide $\left(850^{\circ} \mathrm{C}\right)$, produced by the on-line system and then transmitted to a mass spectrometer. Water resulting from the combustion of methane for stable hydrogen isotope analyses was reduced to gaseous hydrogen with zinc. The result of stable nitrogen isotope analysis is presented in the $\delta$-notation $\left(\delta^{15} \mathrm{~N}, \%\right)$ relative to air nitrogen standard. Analytical precision is estimated to be $\pm 0.4 \%$. Gaseous nitrogen was separated chromatographically for stable nitrogen isotope analysis and was transmitted to the mass spectrometer via the on-line system.

\section{Results and Discussion}

The analysed hydrocarbon gases accumulated in Zechstein Main Dolomite reservoirs of the central part of the Polish Permian Basin insignificantly vary both in their molecular and isotopic compositions. Molecular composition, gas indices and stable isotope ratios vary within the following ranges: $\mathrm{CH}_{4}$ from 5.3 to 72.6 vol\%, $\mathrm{C}_{2} \mathrm{H}_{6}$ from 1.4 to $30.7 \mathrm{vol} \%, \mathrm{C}_{3} \mathrm{H}_{8}$ from 0.89 to $12.5 \mathrm{vol} \%, n \mathrm{C}_{4} \mathrm{H}_{10}$ from 0.35 to $4.08 \mathrm{vol} \%, i \mathrm{C}_{4} \mathrm{H}_{10}$ from 0.13 to $2.15 \mathrm{vol} \%, n \mathrm{C}_{5} \mathrm{H}_{12}$ from 0.00 to $0.96 \mathrm{vol} \%, i \mathrm{C}_{5} \mathrm{H}_{12}$ from 0.10 to $1.13 \mathrm{vol} \%$, hy-

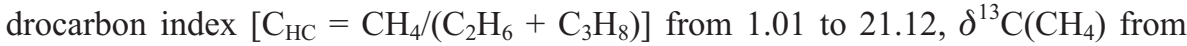
-56.8 to $-47.3 \%, \delta^{2} \mathrm{H}\left(\mathrm{CH}_{4}\right)$ from -292 to $-211 \%$, $\delta^{13} \mathrm{C}\left(\mathrm{C}_{2} \mathrm{H}_{6}\right)$ from -38.4 to $-31.2 \%$, $\delta^{13} \mathrm{C}\left(\mathrm{C}_{3} \mathrm{H}_{8}\right)$ from -29.7 to $-25 \%$, $\delta^{13} \mathrm{C}\left(\mathrm{C}_{4} \mathrm{H}_{10}\right)$ from -29.2 to $-28 \%$, $\delta^{13} \mathrm{C}\left(n \mathrm{C}_{4} \mathrm{H}_{10}\right)$

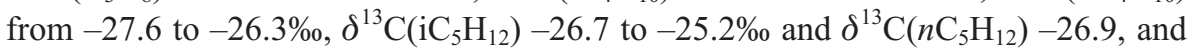
$-25.3 \%$. For identification of the origin of analysed hydrocarbon gases, the genetic diagrams (Figs 2 and 3) were applied after Schoell [4] and Whiticar [5]. An important implication for the interpretation are also correlations between $\left.\delta^{13} \mathrm{C}_{(} \mathrm{CH}_{4}\right)$ and $\delta^{13} \mathrm{C}\left(\mathrm{C}_{2} \mathrm{H}_{6}\right)$, and between $\delta^{13} \mathrm{C}\left(\mathrm{C}_{3} \mathrm{H}_{8}\right)$ and $\delta^{13} \mathrm{C}_{\left(\mathrm{C}_{2} \mathrm{H}_{6}\right)}$ [6] as well as a relationship of 


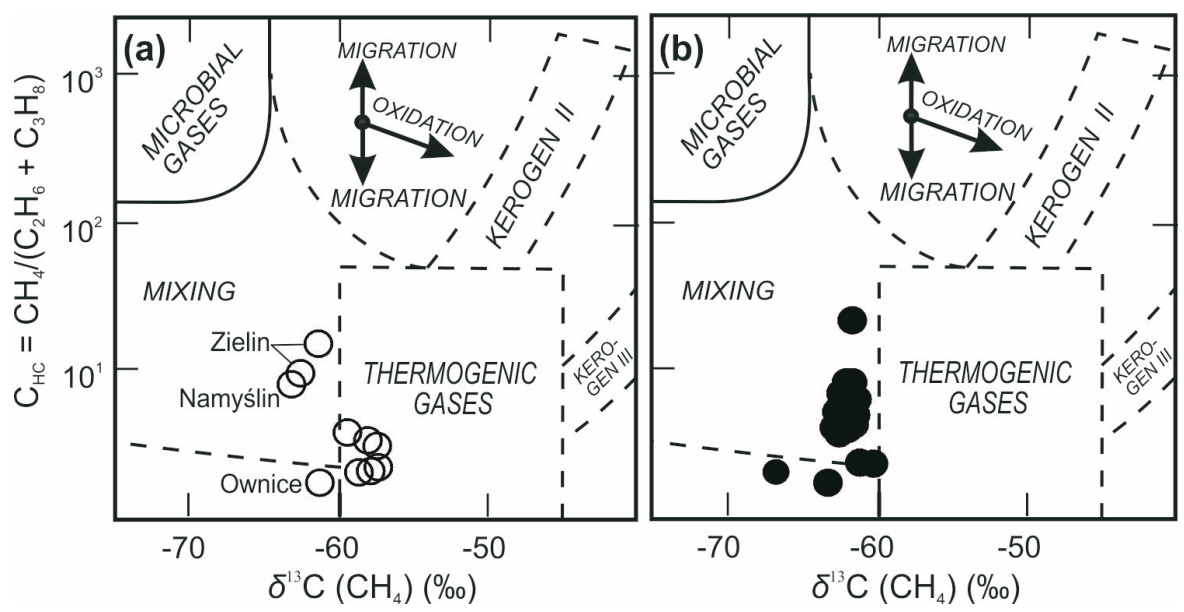

Figure 2. $\mathrm{C}_{\mathrm{HC}}$ gas hydrocarbon index versus $\delta^{13} \mathrm{C}$ of methane for gases from (a) zone $\mathrm{A}$ and (b) zone B of the Main Dolomite reservoir. Compositional fields are from [4]

stable carbon isotopes of methane, ethane, propane, butanes, and pentanes versus their reciprocal carbon number $[7,8,9]$. The results of stable carbon and hydrogen isotope compositions of methane from natural gas accumulated within the Zechstein Main Dolomite carbonates (Figs 2 and 3) indicate that this gas was generated during both the microbial and the thermogenic processes. In south-western zone A thermogenic gases dominate (Figs 2a and 3a). Microbial methane occurs only in Zielin, Ownice, and Namyœlin fields. In north-eastern zone B microbial methane dominates (Figs $2 \mathrm{~b}$ and $3 b)$.

The presence of methane generated during microbial process suggests that in these deposits the traps had already been formed and sealed during the migration of microbial methane. The traps have been successively supplied with thermogenic methane and higher hydrocarbons generated from type II kerogen at successively higher maturation stages.

Carbon dioxide concentrations in analysed natural gases vary from 0.03 to 6.1 vol $\%$ and $\delta^{13} \mathrm{C}$ values of the carbon dioxide from -12.8 to 3.2\%. Correlation between $\delta^{13} \mathrm{C}$ values of the carbon dioxide and $\delta^{13} \mathrm{C}$ values of the methane revealed that carbon dioxide in analysed natural gases was generated during thermogenic processes.

$\delta^{15} \mathrm{~N}$-values of nitrogen of natural gases change from 9.2 to $15.9 \%$ [10]. This isotopic fractionation results from primary genetic factors and secondary processes taking place during migration at the gas-rock and gas-reservoir fluids interface e.g. $[10,11]$. Nitrogen occurs in the analysed natural gases in concentrations from 3.3 to $91.1 \mathrm{~mol} \%$. The increasing trend of $\delta^{15} \mathrm{~N}\left(\mathrm{~N}_{2}\right)$ values with the growth of $\mathrm{N}_{2}$ concentration may suggest that nitrogen was generated during thermal transformation of organic matters of Zechstein Main Dolomite carbonates. 


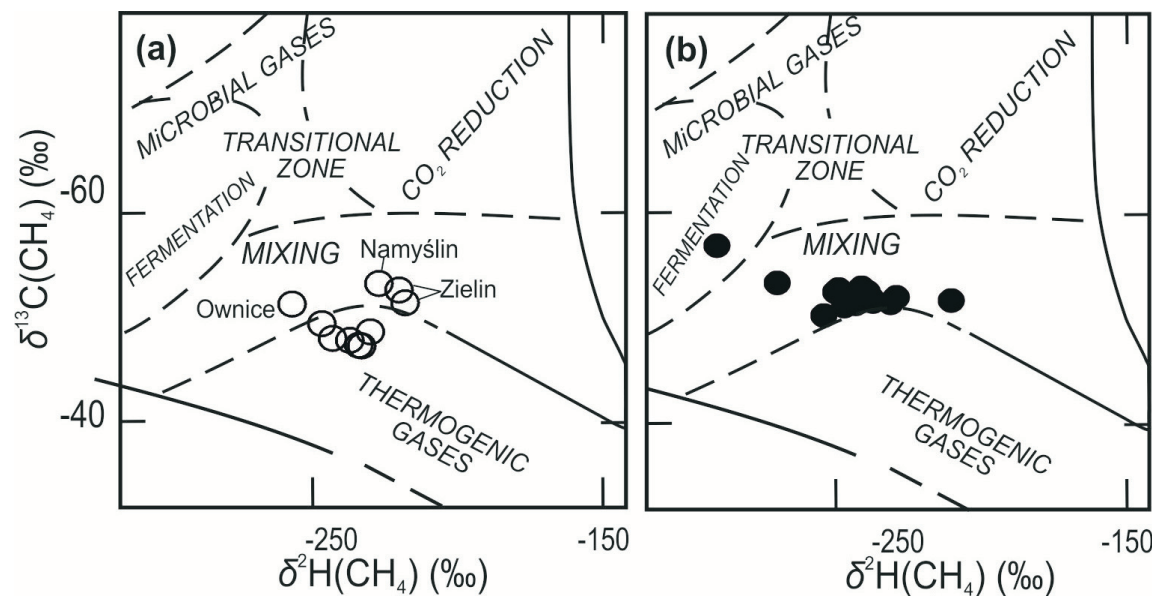

Figure 3. $\delta^{13} \mathrm{C}$ of methane versus $\delta^{2} \mathrm{H}$ of methane for gases from (a) zone $\mathrm{A}$ and (b) zone $\mathrm{B}$ of the Main Dolomite reservoir. Compositional fields are from [5]

Acknowledgements: The research has been financially supported by the National Science Centre (Ministry of Science and Higher Education) grant No. 744/N-IRAN/2010/0 (28.28.140.7017) (AGH University of Science and Technology). Analytical work by A. Kowalski and T. Kowalski is gratefully acknowledged.

\section{References}

1. M.J. Kotarba, W. Więcław and Z. Stecko, Composition, origin and habitat of natural gases within Zechstein Main Dolomite strata of the western part of the Fore-Sudetic area, SW Poland. Przegl. Geol., 48, pp. 429-435, 2000 [in Polish with Engl. abst.].

2. M.J. Kotarba and R. Wagner, Generation potential of the Zechstein Main Dolomite (Ca2) carbonates In the Gorzów Wielkopolski-Miȩdzychód-Lubiatów area: Geological and geochemical approach to microbial-algal source rock. Przegl. Geol., 55, pp. 1025-1035, 2007.

3. T.B. Coplen, Guidelines and recommended terms for expression of stable-isotope-ratio and gas-ratio measurement results. Rap. Comm. Mass Spectr., 25, pp. 2538-2560, 2011.

4. M. Schoell, Multiple origins of methane in the Earth. Chem. Geol., 71, pp. 1-10, 1988.

5. M.J. Whiticar, Correlation of natural gases with their sources. In: L.B. Magoon and W.G. Dow (eds), The petroleum system - from source to trap. AAPG Memoir 60, pp. 261-283, 1994.

6. U. Berner and E. Faber, Empirical carbon isotope/maturity relationships for gases from algal kerogens and terrigenous organic matter, based on dry, open-system pyrolysis. Org. Geochem., 24, pp. 947-955, 1996.

7. H.M. Chung, J.R. Gormly and R.M. Squires, Origin of gaseous hydrocarbons in subsurface environments: Theoretical considerations of carbon isotope distribution. Chem. Geol., 71, pp. 91-103, 1988.

8. Y.-R. Zou, Y. Cai, Ch. Zhang, X. Zhang and P. Peng, Variations of natural gas carbon isotope-type curves and their interpretation - A case study. Org. Geochem. ,38, pp. 1398-1415, 2007.

9. M.J. Kotarba and M.D. Lewan, Sources of natural gases in Middle Cambrian reservoirs in Polish and Lithuanian Baltic Basin as determined by stable isotopes and hydrous pyrolysis of Lower Palaeozoic source rocks. Chemical Geology, 345, pp. 62-76, 2013. 
10. P. Gerling, E. Idiz, G. Everlien and E. Sohns, New aspects on the origin of nitrogen in natural gas in Northern Germany. Geol. Jahrb. D103, pp. 65-84, 1997.

11. B.M. Krooss, L. Friberg, Y. Gensterblum, J. Hollenstein, D. Prinz and R. Littke, Investigation of the pyrolytic liberation of molecular nitrogen from Paleozoic sedimentary rocks. Inter. J. Earth Sciences, 94, pp. 1023-1038, 2005.

\title{
049 - ANALYSE OF A LARGE ISOTOPIC RAINFALL SERIES IN VARIOUS CLIMATIC CONTEXT IN ECUADOR: CLIMATE IMPLICATION
}

\author{
Jean Denis Taupin - Carla Manciati - Nicolas Patris \\ UMR Hydrosciences (IRD, CNRS, UM1, UM2), Maison des Sciences de l'eau, \\ 300 av. Jeanbrau, Montpellier, France
}

The isotopic (oxygen18, deuterium) composition of rainfall gives some information about circulation of air masses and is an indicator of climate variability. Since 2000, IRD in collaboration with local institutes has set up and has been managing various rainfall networks in South America (Ecuador, Peru and Bolivia - $[1,2])$ to monitor the isotopic composition of precipitation (deuterium and oxygen - 18) at different time-scales (daily to monthly). In Ecuador, a network of 15 stations was carried out. The stations are mainly located along two axis, the East-West direction represents the main trajectory of air mass circulation coming from the Atlantic ocean through the Amazonian basin, and the North-South direction along the coastal border represents the natural climate variability linked to the Humbold Current. This study presents some results from Ecuador's isotopic rainfall network in Amazonian, Andean and Costal (semi arid) part. Isotopic data at daily time scale have been analysed during 6 and 11 years at 5 stations (Puyo, Novo Rocafuerte, Quito, Izobamba, Porto Viejo). The seasonal bimodal signal observed at Andean and Amazonian station reflects the regional air mass circulation with two annual crossings of the ITCZ over Ecuador which give lower isotopic values completely synchronous between Amazonian and Andes part. In semi arid costal part, the effect of evaporation is predominant with a large dry season. Comparing isotopic rainfall with climatic data, the results show that the correlation with temperature and relative humidity is poor at all time scales. The amount effect at the monthly scale shows the best correlation but does not explain the total variability. Finally, a strong link exists between Amazonian and Andean rainfall isotopic variability and the convection variability over the north eastern part of Brazilian Amazon basin. This relationship is confirmed at the daily scale $\left(\mathrm{R}^{2}>0.4\right)$ over the total measurement period with a time-lag of 3-5 days, time period to transport air mass from north eastern Amazon basin to the stations. It seems than the zone of deep convection in Amazon basin is the biggest factor which impacts the isotopic variability of rainfall in the Andean and Amazonian Ecuador. 


\title{
References
}

1. M. Villacís, F. Vimeux and J.D. Taupin, Analysis of the climate controls on the isotopic composition of precipitation $\left(\delta^{18} \mathrm{O}\right)$ at Nuevo Rocafuerte, $74.5^{\circ} \mathrm{W}, 0.9^{\circ} \mathrm{S}, 250 \mathrm{~m}$, Ecuador. C.R. Géosciences, Paris, vol 340/1, pp. 1-9, 2008.

2. R. Gallaire, A. Taupin and A. Coudrain, Recent developments in the cryo-climatic parameters and isotopic content of precipitation in the Bolivian Andes: La Paz and the Zongo Glacier. Hydr. Sciences J., 55(4), pp. p467-483. 2010.

\section{0 - OPEN-SYSTEM CALCITE DISSOLUTION INFERRED FROM MULTIPLE ISOTOPE TRACERS: IMPLICATIONS FOR GROUNDWATER DATING}

\author{
Ian Cartwright ${ }^{1,2}$ \\ ${ }^{1}$ School of Geosciences, Monash University, Clayton, Vic. 3800, Australia; \\ e-mail ian.cartwright@monash.edu \\ ${ }^{2}$ National Centre for Groundwater Research and Training, GPO Box 2100, \\ Flinders University, Adelaide SA 5001, Australia
}

Determining groundwater residence times is critical to our understanding of hydrogeological systems and to the sustainable management of groundwater resources. Because of its capacity to date groundwater that is up to 30,000 years old, ${ }^{14} \mathrm{C}$ activities $\left(\mathrm{a}^{14} \mathrm{C}\right)$ of dissolved inorganic carbon (DIC) is the most widely used radiogenic dating technique in regional aquifers. Closed-system dissolution of matrix calcite, methanogenesis, or mantle $\mathrm{CO}_{2}$ input adds ${ }^{14} \mathrm{C}$-free carbon that lowers the $\mathrm{a}^{14} \mathrm{C}$ of DIC, potentially resulting in overestimation of groundwater ages. There are many studies that have used $\delta^{13} \mathrm{C}$ values, ${ }^{87} \mathrm{Sr} /{ }^{86} \mathrm{Sr}$ ratios, and/or major ion geochemistry to correct ${ }^{14} \mathrm{C}$ ages for these processes. Calcite dissolution, which is the most common of these processes, produces trends of increasing $\delta^{13} \mathrm{C}$ values and decreasing ${ }^{87} \mathrm{Sr} /{ }^{86} \mathrm{Sr}$ ratios as $\mathrm{a}^{14} \mathrm{C}$ decreases. However, open-system calcite dissolution during recharge is also potentially important. During open-system calcite dissolution in the unsaturated zone, DIC exchanges carbon with the relatively young reservoir of $\mathrm{CO}_{2}$ in the soil zone or regolith and hence maintains high $\mathrm{a}^{14} \mathrm{C} . \delta^{13} \mathrm{C}$ values of DIC increase because calcite dissolution raises $\mathrm{pH}$, which changes the ${ }^{13} \mathrm{C}$ fractionation between $\mathrm{CO}_{2}$ and DIC. Open-system calcite dissolution will also decrease ${ }^{87} \mathrm{Sr} /{ }^{86} \mathrm{Sr}$ ratios in a similar manner to closed-system dissolution. While open-system calcite dissolution is tacitly recognised in many studies, there is commonly little attempt to assess its importance. This is probably due to ${ }^{14} \mathrm{C}$ being commonly used to date deeper groundwater that is at some distance from its recharge area and hence removed from the site where open-system dissolution may have occurred. However, assigning all the changes in $\delta^{13} \mathrm{C}$ values and ${ }^{87} \mathrm{Sr} /{ }^{86} \mathrm{Sr}$ ratios to closed-system calcite dissolution will overcorrect ${ }^{14} \mathrm{C}$ ages.

This study uses ${ }^{3} \mathrm{H}$ concentrations, ${ }^{14} \mathrm{C},{ }^{87} \mathrm{Sr} /{ }^{86} \mathrm{Sr}$ ratios, and $\delta^{13} \mathrm{C}$ values to constrain calcite dissolution in shallow groundwater from several catchments in south- 
east Australia. Taken in isolation, the $\delta^{13} \mathrm{C}$ values of DIC and ${ }^{87} \mathrm{Sr} /{ }^{86} \mathrm{Sr}$ ratios in the groundwater imply that there has been significant calcite dissolution. However, the covariance of ${ }^{3} \mathrm{H}$ concentrations and a ${ }^{14} \mathrm{C}$ together with the calculated initial ${ }^{14} \mathrm{C}$ activities imply that most of the groundwater cannot have dissolved more than $20 \%$ of ${ }^{14} \mathrm{C}$-free calcite under closed-system conditions. Rather, calcite dissolution must have been partially an open-system process. Recognising that open-system calcite dissolution has occurred is important for dating deeper groundwater that is removed from its recharge area in southeast Australia and elsewhere.

\title{
051 - STABLE ISOTOPIC STUDY FOR THE UPPER CRETACEOUS SUCCESSION OF NORTHWESTERN IRAQ: IMPLICATION FOR PALEOENVIRONMENT INTERPRETAION
}

\author{
Mohamed A. Al-Haj ${ }^{1}$ - Ali I. Al-Juboury ${ }^{1}-$ Aboosh H. Al-Hadidy ${ }^{2}$ \\ ${ }^{1}$ Department of Geology, Mosul University, Mosul, Iraq; e-mail: alialjubory@yahoo.com \\ ${ }^{2}$ Northern Oil Company, Kirkuk, Iraq
}

Carbon and oxygen stable isotopic analysis is conducted for the Upper Cretaceous (Cenomanian-Early Campanian) successions from northwestern Iraq. These successions are represented by Gir Bir, Wajna and Mushorah formations. The study reveals that the upper parts of the Gir Bir Formation was deposited under the mixing zone effect depending on the gradual increment in oxygen and carbon isotopes and strontium with depth. Whereas sharp negative values of $\delta^{18} \mathrm{O}$ and $\delta^{13} \mathrm{C}$ and decline in $\mathrm{Sr} / \mathrm{Al}$ and $\mathrm{Ba} / \mathrm{Al}$ ratios in the uppermost surface of the Gir Bir Formation and in the overlying conglomerate bed are indicative of exposure surface conditions and effect of meteoric water. Homogeneity in the values of oxygen and carbon isotopes and other elements in the Mushorah Formation indicates that it was unaffected by diagenesis near the surface. Gradual variation in $\delta^{13} \mathrm{C}$ from positive in the upper part of Gir Bir Formation to low and negative values at the surface of the formation and in the bed of conglomerate reflects a regressive sequence from deeper to shallower areas upwards of lagoonal facies and then to exposure (marine regression and platform exposure) forming unconformity surface. Sharp increase in $\delta^{13} \mathrm{C}$ in Mushorah Formation reflects deep marine (transgressive) conditions covering most of exposed parts of the platform.

\section{2 - GENESIS OF PB AND ZN DEPOSITS FROM NORTHERN IRAQ: CONSTRAINTS FROM STABLE ISOTOPIC AND FLUID INCLUSIONS CHARACTERISTICS}

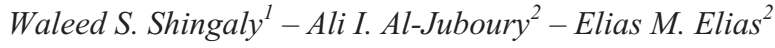 \\ ${ }^{1}$ Department of Geology, Salahaddin University, Erbil, Iraq \\ ${ }^{2}$ Department of Geology, Mosul University, Mosul Iraq; e-mail, alialjubory@yahoo.com
}


Lead-zinc deposits in Kurdistan Region, northern Iraq are occurred mainly as stratabound and open-space fillings ore bodies in the platform carbonates and hosted by dolostone and dolomitic-limestone. The ores at Dure and Lefan sections are hosted by Kurra Chine (Upper Triassic) and Bekhme (Upper Cretaceous) formations respectively. Pyrite, sphalerite and galena are the major sulfides, but the mineral paragenesis and relative proportions of these sulfides vary from deposit to other. They have commonly been deposited through dissolution/replacement process and/or through void infilling. The average $\delta^{34} \mathrm{~S} \%$ values for sulfide minerals of Dure and Lefan are $-0.8 \%$ o and $1.8 \%$, respectively. The source of sulfur in the deposits is most likely seawater sulfate possibly from Paleozoic or Triassic evaporates, and/or connate water. The $\delta^{13} \mathrm{C}$ and $\delta^{18} \mathrm{O}$ values of carbonate host rocks fall in the range of marine carbonates. Homogenization temperatures of primary and secondary fluid inclusions in Dure and Lefan deposits range from $45^{\circ} \mathrm{C}$ to $183^{\circ} \mathrm{C}$ and from $68^{\circ} \mathrm{C}$ to $284^{\circ} \mathrm{C}$, respectively. The salinities are ranging from 13.93 to $>23 \mathrm{wt} \% \mathrm{NaCl}$ equiv. in Dure deposit, and from 3.06 to $14.57 \mathrm{wt} \% \mathrm{NaCl}$ equiv. in Lefan deposit. Petrographic evidence and stable isotope data with fluid inclusions suggest that lead-zinc mineralization was caused by deeply circulating high temperature mineralizing fluids (brines) within the source basin or by tectonic processes, which possibly leached metals from either the diagenesis of host rocks and/or the dewatering of deeper buried siliciclastic beds. The studied carbonate-hosted lead-zinc deposits share many similarities with Mississippi Valley Type (MVT) deposit.

\section{3 - PB AND SR ISOTOPES AS TRACERS TO INVESTIGATE THE POTENTIAL SOURCES OF LEAD IN SOIL AND GROUNDWATER: A CASE STUDY OF HUN RIVER ALLUVIAL FAN}

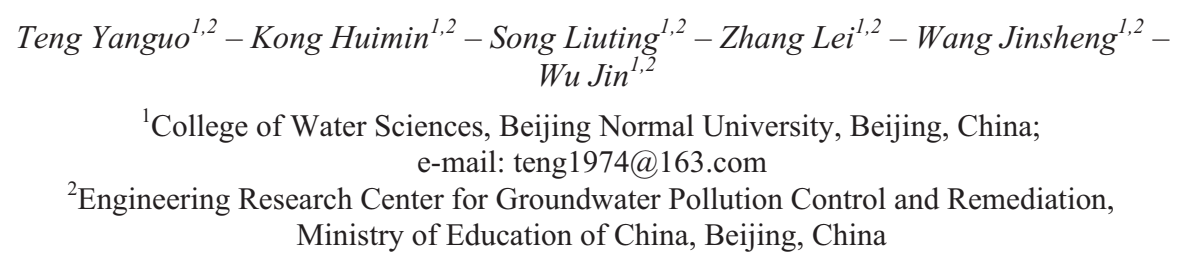

Geogenic and anthropogenic lead sources have different isotopic ratios, thus lead isotopes have been introduced as "fingerprints" in tracing the contamination sources in soil [1,2], groundwaterand [3-5] other environmental compartments. Strontium isotopes are often applied to study the water-rock interactions [6-8] and groundwater pollution monitoring [9] since there is no measurable fractionation of strontium isotopes during mineral precipitation and weathering. Therefore, lead isotopes and strontium isotopes were good combined multiple geochemical tracers to differentiate lead pollutions in groundwater. In this study, soil, surface water, groundwater and river sedi- 
ment samples were investigated for lead and strontium contents and their isotopic ratios to better understand the potential sources of lead in soil and groundwater of Hun River alluvial fan, Liaoning, China.

Chemical speciation plays an influential role in solubility, potential bioavailability, toxicity and abilities of translocation of heavy metals in soils [10]. Pb of anthropogenic source was of high solubility and abilities of translocation, and it was relatively stable after deposition in soils [11]. Therefore, lead speciation and the isotopic ratios of acids extraction fraction and residual fraction in soils and river sediments were also measured to get detailed information of the anthropogenic pollutions in this study.

Most lead in soil is of geogenic origin in the studied area, while the surface soils were affected by sewage irrigation, combustion leaded fuel oil and coal significantly, and this effect decreases gradually with the increase of depth. Although all vehicles use unleaded gasoline and fuel additives instead of leaded petrol since 1998, lead pollution in surface soils resulted from leaded gasoline is still existed. It reflects history accumulation effect of lead released by automobile exhaust emissions in surface soil.

In accordance with the interactions of water-rock and weathering sources by strontium isotopic composition and high correlation between lead and strontium concentration in groundwater, most of the lead in groundwater is from dissolution of carbonate rock aquifer. In the front area of Hun River alluvial fan, horizontal and vertical runoff conditions of groundwater flow became gradually worse. Besides, the discharge of organic acids from industrial wastewater accelerated the iron and lead dissolution into the groundwater from bedrocks. Therefore, the regional shallow groundwater water quality is poor.

There is close hydraulic connection between surface water and shallow groundwater which is vulnerable to pollution in study area, therefore groundwater was slightly affected by human activities. In some sites of shallow groundwater in the studied area, the lead concentrations were several times higher than the groundwater quality standard $(0.01 \mathrm{mg} / \mathrm{L})$. Combined with the analysis of $\mathrm{NO}_{3}{ }^{-}$and other ionic concentrations, it was polluted by the discharge of industrial sewage, recharge by polluted surface water and the leaching of exposed domestic waste while the influences of vehicle exhausts and coal combustion can be ignored.

\section{References}

1. Bove, M.A., Ayuso, R.A., De Vivo, B., Lima, A. and Albanese, S., Geochemical and isotopic study of soils and waters from an Italian contaminated site: Agro Aversano (Campania). J. Geochem. Explor., 109(1-3), pp. 38-50, 2011.

2. Ettler, V., Mihaljević, M. and Komárek, M., ICP-MS measurements of lead isotopic ratios in soils heavily contaminated by lead smelting: tracing the sources of pollution. Anal. Bioanal. Chem., 378(2), pp. 311-317, 2004.

3. Landmeyer, J.E., Bradley, P.M. and Bullen, T.D., Stable lead isotopes reveal a natural source of high lead concentrations to gasoline-contaminated groundwater. Environ. Geol., 45(1), pp. $12-22,2003$ 
4. Toner, R.T., Frost, C.F. and Chamberlain, K.C., Isotopic identification of natural vs. anthropogenic sources of $\mathrm{Pb}$ in Laramie basin groundwaters, Wyoming, USA. Environ. Geol., 43(5), pp. 580-591, 2003.

5. Grezzi, G., Ayuso, R.A., De Vivo, B., Lima, A. and Albanese, S., Lead isotopes in soils and groundwaters as tracers of the impact of human activities on the surface environment: The Domizio-Flegreo Littoral (Italy) case study. J. Geochem. Explor., 109(1-3), pp. 51-58, 2011.

6. Négrel, P. and Roy, S., Investigating the sources of the labile fraction in sediments from silicate-drained rocks using trace elements, and strontium and lead isotopes. The Science of the Total Environment, 298(1-3), pp. 163-181, 2002.

7. De Caritat, P., Kirste, D., Carr, G. and McCulloch, M., Groundwater in the Broken Hill region, Australia: Recognising interaction with bedrock and mineralisation using $\mathrm{S}, \mathrm{Sr}$ and $\mathrm{Pb}$ isotopes. Appl. Geochem., 20(4), pp. 767-787, 2005.

8. Relvas, J., Tassinari, C., Munhá, J. and Barriga, F., Multiple sources for ore-forming fluids in the Neves Corvo VHMS Deposit of the Iberian Pyrite Belt (Portugal): Strontium, neodymium and lead isotope evidence. Miner. Deposita, 36(5), pp. 416-427, 2005.

9. Siegel, D.I., Bickford, M.E. and Orrell, S.E., The use of strontium and lead isotopes to identify sources of water beneath the Fresh Kills landfill, Staten Island, New York, USA. Appl. Geochem., 15(4), pp. 493-500, 2000.

10. Peakall, D. and Burger, J., Methodologies for assessing exposure to metals: Speciation, bioavailability of metals, and ecological host factors. Ecotox Environ. Safe, 56(1), pp. 110-121, 2003.

11. Wong, S.C., Li, X.D., Zhang, G., Qi, S.H. and Min, Y.S., Heavy metals in agricultural soils of the Pearl River Delta, South China. Environ. Pollut., 119(1), pp. 33-44, 2002.

\title{
054 - STABLE CARBON ISOTOPE RATIOS OF CRUDE OIL EXPOSED TO ENVIRONMENTAL DEGRADATIONS
}

\author{
Eunsic Kim ${ }^{1}$ - Moonkoo Kim ${ }^{1}$ - Jun Geon An $^{1}$ - Beom Kim ${ }^{1}$ - Sung Yong $\mathrm{Ha}^{1}$ - \\ Un Hyuk Yim ${ }^{1}$ - Jee-Hyun Jung ${ }^{1}$ - Won Joon Shim ${ }^{1}$ - Gi Beum Kim ${ }^{2}$ \\ ${ }^{1}$ Oil and POPs Research Group, Korea Institute of Ocean Science and Technology, \\ Geoje 656-834, Republic of Korea; e-mail: mkim@kiost.ac \\ ${ }^{2}$ Department of Marine Environmental Engineering, Institute of Marine Industry, \\ Gyeongsang National University, Tongyeong 650-160, Republic of Korea
}

Crude oil is a complex mixture of thousands of different organic compounds formed from a variety of organic materials that are chemically converted under differing geological conditions over long periods of time. Oils from different sources have distinct chemical compositions, which can be used to identify the source of oil pollution. The chemical compositions of spilled oils, however, can be altered in the environment by a number of physicochemical and biological factors, making source characterization by GC or GC/MS ambiguous. Source identification of spilled oil requires more discriminative parameters that are relatively resistant to weathering processes. The stable isotope compositions of individual compounds in weathered oil are known to remain relatively less affected than molecular compositions and therefore can be effectively used as a correlation parameter. However, under extensive degradation, isotopic composition of crude oil can also be affected and thus it is important to understand isotopic 
changes during environmental weathering for clearer source identification. In this study, a crude oil was exposed to natural environmental weathering during a simulated oil spill using an in-situ experimental mesocosm. The crude oil was also exposed to various artificial weathering processes in controlled lab experiments including evaporation, dissolution, adsorption, photooxidation and microbial degradation. The weathered oils were analyzed by GC/IRMS for stable isotope ratios and GC/MS or GC/FID for molecular compositions. Changes in molecular and isotopic compositions under various artificial weathering processes were monitored and compared with the result from the mesocosm study. The preliminary results showed that the individual compounds in the weathered oil showed varying degree of isotopic change depending on the molecular weight and the relative composition in the crude oil. Interestingly, while evaporation process explains the major mass loss of oil after a spill, isotopic variation of crude oil during the simulated oil spill cannot be explained fully by evaporation process. The isotopic compositions of weathered oil are the results of a combination of multiple weathering processes. The result will give insights when identifying the source of oil residues that have undergone severe compositional change.

\title{
055 - ESTIMATING GLACIER AND SNOWMELT CONTRIBUTIONS TO STREAM FLOW IN A CENTRAL ANDES CATCHMENT IN CHILE USING NATURAL TRACERS
}

\author{
Maximiliano Rodriguez ${ }^{1}$ - Nils Ohlanders ${ }^{2}$ - James McPhee ${ }^{3}$ \\ ${ }^{1}$ Advanced Mining Technology Center, University of Chile, Tupper avenue 2007, \\ Santiago, Chile; e-mail: xam.rodriguez@gmail.com \\ ${ }^{2}$ Department of Civil Engineering, University of Chile, Santiago, Chile \\ ${ }^{3}$ Department of Civil Engineering and Advanced Mining Technology Center, \\ University of Chile, Santiago, Chile
}

Fresh water resources in the semi-arid region of Central Chile are highly limited and derived mainly from snow and glacial melt. However, the contributions of each of these two sources are poorly known. This results partly from little and unreliable information on precipitation spatial variability in the high Andes and therefore the water equivalent of high elevation snowpacks. On the other hand, discharge appears to be less correlated with snowmelt in glacierized basins, compared to those with little or no influence of glaciers.

In this study we aim at discriminating between glacier and seasonal snowpack melt contributions to streamflow in high elevation semi-arid Andean watersheds. Ohlanders et al. (2013) documented the contribution of different sources to the river flow using only isotopic data measured in different sections of the river, in the snowpack and rainfall. Now we improve this study incorporating chemical data recorded during the same period. 
The study area is located in the Central Chilean Andes, comprises $256 \mathrm{~km}^{2}$ of alpine, largely unvegetated terrain with an altitude range of 2200-5900 m a.s.1.

We obtained and analysed water samples, recorded discharge and meteorological data to analyse the contributing sources to streamflow during a water-year running from April 2011 to April 2012. We used $\mathrm{Cl}^{-}, \mathrm{SO}_{4}{ }^{2-}, \mathrm{Ca}^{2+} \mathrm{Na}^{+}, \mathrm{Mg}^{2+}, \mathrm{K}^{+}, \mathrm{Si}, \delta^{18} \mathrm{O}$ and $\delta^{2} \mathrm{H}$ as natural tracers which are useful to distinguish snow-, glacier melt and soil water.

Historical data from the Chilean water agency was compared against new data in order to evaluate river chemistry evolution and find differences in the behaviour of two types of data record: seasonally data on 17 years and daily one year data set.

Precipitation records from meteorological stations near the basin indicate the period 2011-2012 was a dry hydrologic year which was expressed in the basin as high conductivity values during winter, reflecting the presence of soil water as the principal source on this period.

In order to evaluate the number of sources necessary to explain river chemistry two approaches were considered, a residual analysis (Hooper, 2003) and the "rule of 1" (Joreskog et al., 1976).

We performed hydrograph separations (HS) into many sources using temporal tracers properties. Three methods were developed:

i) Isotopic model: Enrichment on $\delta^{2} \mathrm{H}$ and depletion on $\delta^{18} \mathrm{O}$ is observed when fractionation between water and soil minerals is produced. Since autumn samples follow this behavior whereas spring samples behave in an opposite fashion a new HS model was created.

ii) End member mixing analysis (EMMA): HS was performed using a deterministic approach. PCA was applied to reduce the dimensionality of a problem originally including nine tracers.

iii) Simple bayesian model: A probabilistic approach was implemented in order to determinate a posterior distribution of each source contribution. We considered an informative prior distribution using Ragettli and Pellicciotti (2012) and Liu et al. (2004) result.

Models predict at least $30 \%$ of discharge originating directly from glacier melt with little or no contact with the subsurface (quickflow) and $20 \%$ from snowmelt in one year (Fig. 1). The remaining 50\% is representative of soil water that is composed by both aforementioned sources. In spring and summer, glacier contribution increased, reaching a contribution near of $50 \%$ of seasonal streamflow, whereas only $10 \%$ can be associated directly with snowmelt (Fig. 2).

Our results improve the understanding of hydrologic cycle and give more information to decision makers to evaluate water resources policy. By characterizing the different water storage components in these sparsely monitored watersheds, our conclusion contribute to the process of applying climate change scenarios to predictions of future freshwater availability. 


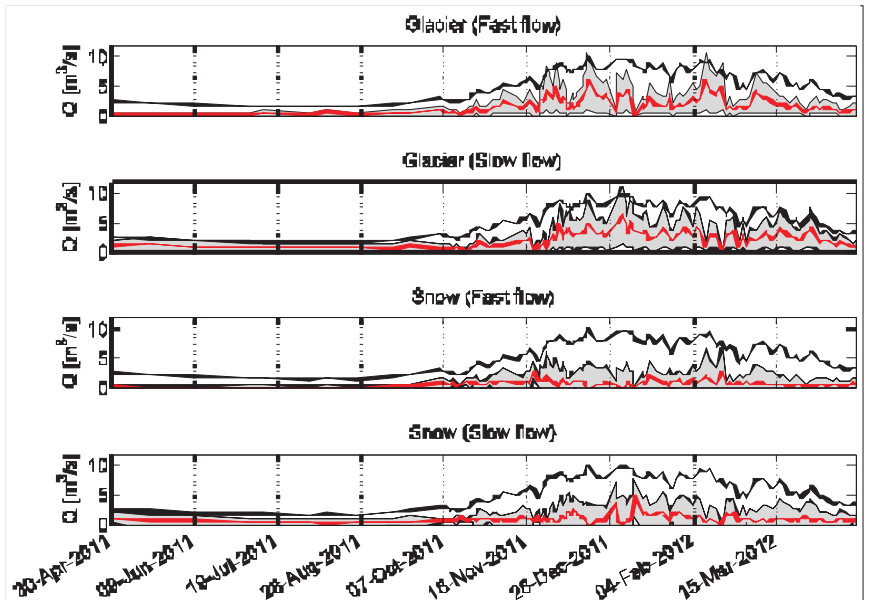

Figure 1. Annual hydrograph separation using isotopic model in water-year 2011-2012. Grey range depicts $95 \%$ confidence interval where red line is the discharge of source.

The upper black line shows the total discharge on each plot

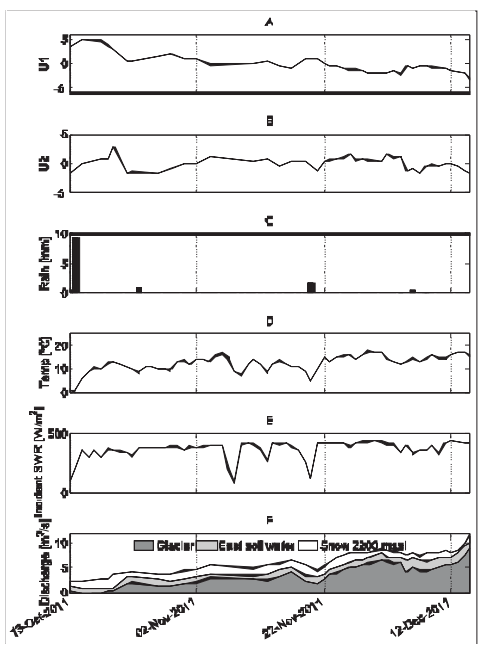

Figure 2. Hydrograph Separation using EMMA on spring. A) and B) shows Juncal data projected on eigenvector U1 and U2, respectively. C), D) and E) show rain, temperature and incident solar short wave radiation on Hornitos. F) depicts hydrograph separation on Juncal en Juncal

\section{References}

1. N. Ohlanders, M. Rodriguez and J. McPhee, Stable water isotope variation in a Central Andean watershed dominated by glacier and snowmelt. Hydrol. Earth Syst. Sci., 17, pp. 1-16, 2013.

2. R. Hooper, Diagnostic tools for mixing models of stream water chemistry. Water Resources Research, 39(3), p. 1055, doi: 10.1029/2002WR001528, 2003.

3. K.G. Joreskog, J.E. Klovan and R.A. Reyment, Geological Factor Analysis: Methods in Geomathematics, Vol. 1, Elsevier, New York. 
4. S. Ragettli and F. Pellicciotti, Calibration of a physically based, spatially distributed hydrological model in a glacierized basin: On the use of knowledge from glaciometeorological processes to constrain model parameters. Water Resources Research, Vol. 48, W03509, doi: 10.1029/2011WR010559, 2012.

5. F. Liu, M.W. Williams and N. Caine, Source waters and flow paths in an alpine catchment, Colorado Front Range, United States. Water Resources Research, Vol. 40, W09401, doi: 10.1029/2004WR003076, 2004.

\title{
056 - RELATIONSHIPS BETWEEN STABLE C AND O ISOTOPE SIGNATURES OF CHAROPHYTE CARBONATES AND LAKE WATERS
}

\author{
Mariusz Pełechaty ${ }^{1}$ - Karina Apolinarska ${ }^{2}$ - Joanna Krupska ${ }^{1}$ - Eugeniusz Pronin ${ }^{1}-$ \\ Andrzej Pukacz ${ }^{3}$ - Patrycja Boszke ${ }^{1}$ \\ ${ }^{1}$ Department of Hydrobiology, Faculty of Biology, Adam Mickiewicz University in Poznań, \\ Umultowska 89, PL-61-614, Poznań, Poland; e-mail: marpelhydro@poczta.onet.pl \\ ${ }^{2}$ Institute of Geology, Faculty of Geographical and Geological Sciences, \\ Adam Mickiewicz University in Poznań, Maków Polnych 16, PL-61-606 Poznań, Poland \\ ${ }^{3}$ Collegium Polonicum, Adam Mickiewicz University in Poznań - Europa Universität \\ Viadrina Frankfurt (Oder), Kościuszki 1, PL-69-100 Słubice, Poland
}

Photosynthetic activity of charophytes (macroscopic green algae, Characeae family) leads to precipitation of $\mathrm{CaCO}_{3}$ onto the surface of their thalli in amounts exceeding $70 \%$ of the dry weight ( $\mathrm{Pe}^{3}$ echaty et al. 2013 and references therein). These autochthonous carbonates may substantially contribute to the deposition of lacustrine sediments, where charophytes may be preserved as remains of thalli encrustations and calcified female gametangia called gyrogonites. The oldest charophyte fossils are Upper Silurian in age thus these macroalgae are a potential archive of palaeonvironmental conditions, which can be expressed in stable $\mathrm{C}$ and $\mathrm{O}$ isotope composition of gyrogonites and calcite encrustations. However, in order to carry out correct, reliable palaeolimnological reconstructions using stable isotope record of the charophyte carbonates it is essential to know the relation between $\delta^{13} \mathrm{C}$ and $\delta^{18} \mathrm{O}$ of recent encrustations and gyrogonites and $\delta^{13} \mathrm{C}$ of DIC (dissolved inorganic carbon) and $\delta^{18} \mathrm{O}$ of ambient water, respectively. This issue was undertaken in investigation of five charophyte species (large and small species) in four morphologically varied lakes of western Poland (study project NN305 337534, financed by the Polish Ministry of Science and Higher Education). The study project aimed at (i) analysis of $\mathrm{C}$ and $\mathrm{O}$ isotope composition of charophyte thalli and oospores as compared to water above charophytes and (ii) year-to-year, species-to-species and lake-to-lake comparison of stable $\mathrm{C}$ and $\mathrm{O}$ isotope composition in charophyte carbonates and oospores to water collected from above the studied charophytes (based on the examples of large species Chara rudis and Chara tomentosa). The dynamics of the stable isotope composition of charophyte 
encrustations over the growth season as well as the encrustation - environment interdependencies were recognised and allowed to answer the question if and under what conditions carbonates precipitate in an isotopic equilibrium with ambient waters.

Samples of charophytes and water from above the plants were collected at permanent study sites monthly since the beginning of charophyte growing season up to the time when first signs of decomposition were noted. This part of study was carried out in 2008 and 2009 and concerned the top whorls and internodia of charophytes stems as they are considered to be the most effective parts of thalli in terms of photosynthesis. Additionally, in the summer season 2012, the whole thalli of a large species (Chara tomentosa) and a small one (Chara globularis) were collected in five lakes each species and the isotope composition of their thalli was compared to the isotope ratios of waters above charophytes.

Results of the first part of our investigations revealed that charophyte carbonates were isotopically heavier than $\delta^{13} \mathrm{C}$ of DIC and lighter than $\delta^{18} \mathrm{O}$ of water, being in agreement with the suggestions by Coletta et al. (2001) and Andrews et al. (2004). In our opinion ${ }^{13} \mathrm{C}$ enrichment is a consequence of ${ }^{12} \mathrm{C}$ utilization by charophytes for photosynthesis and ${ }^{18} \mathrm{O}$ depletion results from rapid calcification. Despite the differences observed, the results obtained indicate the presence of correlation between $\delta^{13} \mathrm{C}$ and $\delta^{18} \mathrm{O}$ of charophyte carbonates and $\delta^{13} \mathrm{C}$ DIC and $\delta^{18} \mathrm{O}$ of water, respectively, making them a potential tool for palaeoreconstructions. Clear isotopic disequilibrium was observed in a small shallow lake, where drainage is primarily through evaporation and large bottom areas are overgrown by charophyte meadows (Pełechaty et al., 2010).

In the second step of the study, $\delta^{13} \mathrm{C}$ and $\delta^{18} \mathrm{O}$ of charophyte carbonates and waters confirmed the above tendencies of differences in case of the large species and in all lakes this species was studied. The small species turned out to be ${ }^{12} \mathrm{C}$-enriched as compared to waters. For $\delta^{18} \mathrm{O}$ the tendency of differences between charophyte carbonates and water found in the previous stage of the study was confirmed.

\section{References}

1. J. Andrews, P. Coletta, A. Pentecost, R. Riding, S. Dennis, P.F. Dennis and B. Spiro, Equilibrium and disequilibrium stable isotope effects in modern charophyte calcites: Implications for palaeoenvironmental studies. Palaeogeogr. Palaeocl., 204, pp. 101-114, 2004.

2. P. Coletta, A. Pentecost and B. Spiro, Stable isotopes in charophyte incrustations: Relationships with climate and water chemistry. Palaeogeogr. Palaeocl., 173, pp. 9-19, 2001.

3. M. Pełechaty, K. Apolinarska, A. Pukacz, J. Krupska, M. Siepak, P. Boszke and M. Sinkowski, Stable isotope composition of Chara rudis incrustation in Lake Jasne, Poland. Hydrobiol., 656, pp. 29-42, 2010.

4. M. Pełechaty, A. Pukacz, K. Apolinarska, A. Pełechata and M. Siepak, The significance of Chara vegetation in the precipitation of lacustrine calcium carbonate. Sedimentology, doi: 10.1111/sed.12020, 2013. 


\title{
057 - REACTION MECHANISMS OF CONCRETE ATTACK REVEALED BY STABLE ISOTOPES
}

\author{
Florian Mittermayr ${ }^{1,2}$ - Albrecht Leis $^{3}$ - Martin Dietzel ${ }^{2}$ \\ ${ }^{1}$ Institute of Technology and Testing of Building Materials, Graz University of Technology, \\ Inffeldgasse 24, 8010 Graz, Austria; e-mail: f.mittermayr@tugraz.at \\ ${ }^{2}$ Institute of Applied Geosciences, Graz University of Technology, Graz, Austria \\ ${ }^{3}$ RESOURCES - Institute for Water, Energy and Sustainability, Joanneum Research, \\ Graz, Austria
}

Despite the fact that the destructive nature of sulfate attack on concrete is well known, reaction paths and mechanisms responsible for the deterioration of concrete are still hotly debated and obviously not completely resolved $[1,2]$. The aim of the present study is to contribute to a deeper understanding by introducing methods that are novel and promising for investigating concrete damage. The methodology comprises advanced mineralogical and hydro-geochemical methods as well as stable isotope signals.

Investigations were carried out at various field case studies in Austria, where the locally occurring ground water was classified as slightly aggressive by DIN EN 206-1. Even though intense concrete damage caused by sulfate attack was found. Severely damaged mushy concrete consisted mainly of thaumasite, secondary calcite, gypsum and aggregate relicts. Expressed interstitial solutions from such material were extremely enriched in $\mathrm{SO}_{4}\left(>30000 \mathrm{mg} \mathrm{L}^{-1}\right)$ [3]. The distribution of stable hydrogen and oxygen isotopes was feasible of verifying and quantifying the effect of evaporation, but also distinct degrees of relative humidity during evaporation. Evaporation was found to be responsible for the enrichment in $\mathrm{SO}_{4}$ and other dissolved, potential harmful ions such as $\mathrm{Cl}$. Furthermore an enormous and linear correlated accumulation of incompatible dissolved ions (e.g. K, Rb and $\mathrm{Li}$ ) clearly indicated that numerous wetting and drying cycles had occurred. In particular such a highly dynamic system can cause severe destructive effects on concrete.

In this study we used a multi proxy approach including stable isotopes, elemental, mineralogical and micro-structural results that yielded an advanced understanding of the complexity of reaction mechanisms involving chemical attack on concrete. Detailed knowledge on the individual reactions - responsible for concrete damage in field structures - are highly required to find individual counter measures for already affected buildings and to develop tailored concrete recipes, applications and constructive measures for future projects.

\section{References}

1. Neville, A., The confused world of sulfate attack on concrete. Cement and Concrete Research, 34(8), pp. 1275-1296, 2004.

2. Santhanam, M., M.D. Cohen, and J. Olek, Sulfate attack research - whither now? Cement and Concrete Research, 31(6), pp. 845-851, 2001.

3. Mittermayr, F. et al., Evaporation - a key mechanism for the thaumasite form of sulfate attack. Cement and Concrete Research, 49(0), pp. 55-64, 2013. 


\title{
058 - ISOTOPE COMPOSITION AND HOST PHASES OF LEAD IN AIRBORNE PARTICULATE MATTER FROM BUDAPEST, HUNGARY
}

\author{
Péter Sipos ${ }^{1}$ - Tibor Németh ${ }^{1}-$ Viktória Kovács Kis ${ }^{2}$ \\ ${ }^{1}$ Institute for Geological and Geochemical Research, Research Centre for Astronomy and \\ Earth Sciences, Hungarian Academy of Sciences, Budaörsi út 45, \\ H-1112 Budapest, Hungary; e-mail: sipos.peter@csfk.mta.hu \\ ${ }^{2}$ Institute of Technical Physics and Materials Science, Research Centre for Natural Sciences, \\ Hungarian Academy of Sciences, Konkoly-Thege Miklós út 29-33, \\ H-1121 Budapest, Hungary
}

Lead is a frequent potentially toxic pollutant of the urban environment. Its complete risk assessment in the airborne particulate matter requires data both on its speciation and potential sources. In this paper we present results on detailed mineralogical (XRD and TEM) and geochemical (selective chemical extractions and lead isotope ratio analyses) study of total suspended particulate (TSP) matter samples from Budapest, Hungary to fulfil this requirements.

The lead showed significant enrichment in the studied TSP samples as compared to its geochemical background value. It could be associated to several host phases. The potentially mobile fraction of lead, which could be also harmful to human, can be as high as $16 \%$ of the total lead. This is represented by $\mathrm{Pb}$ sorbed on the surface of clay minerals and in from of carbonates (and sulphates). Contrarily, between 20 and $30 \%$ of total lead of TSP materials is hosted by magnetite, a highly resistant mineral. However, its fast oxidation during combustion processes to hematite and/or weathering in the acidifying urban environment to ferrihydrite may result the enhanced mobilization of lead.

Lead isotope composition of the TSP samples suggests the mixing of several sources for this metal with slight variation among the sampling sites. Despite the phasing out of leaded gasoline, its contribution to the $\mathrm{Pb}$ content of the TSP was observed. Our data also supported that the presence of lead of gasoline origin decreases in the airborne TSP in the last decade in Budapest. Another important source for lead is found to be the coal combustion due to domestic and industrial heating. Lead isotope ratio data suggest additional source(s) for this metal at least in certain localities, but further investigations are necessary to specify them.

Acknowledgement: This project was financially supported by the Hungarian Scientific Research Fund (OTKA K76317). 


\title{
059 - GEOLOGICAL AND GEOCHEMICAL STEPS IN EVALUATING COMPOSITIONAL AND ISOTOPE DATA TO IDENTIFY THE ORIGIN OF COMBUSTIBLE GASES IN GROUNDWATER
}

\author{
Kinga M. Révész ${ }^{1}-$ Kevin J. Breen ${ }^{2}-$ Alfred J. Baldassare $^{3}-$ Robert C. Burruss $^{4}-$ \\ Anthony W. Gorody ${ }^{5}$ \\ ${ }^{1}$ U.S. Geological Survey, Mail Stop 431, National Center, Reston, VA, USA, 20192; \\ e-mail: krevesz@usgs.gov \\ ${ }^{2}$ U.S. Geological Survey, 215 Limekiln Road, New Cumberland, PA, USA, 17070; \\ e-mail: kjbreen@usgs.gov \\ ${ }^{3}$ ECHELON Applied Geoscience Consulting, e-mail: fbaldassare@echelonagc.com \\ ${ }^{4}$ U.S. Geological Survey, Mail Stop 956, National Center, Reston, VA, USA, 20192; \\ e-mail: burruss@usgs.gov \\ ${ }^{5}$ Universal Geoscience Consulting, Inc.; e-mail: agorody@gmail.com
}

The US has compensated for the decline of conventional natural gas production by accelerating wide spread production from unconventional gas fields. Innovative research is required to understand gas migration to water wells and evaluate the risks to groundwater resources. Our case study illustrates how to evaluate compositional and stable isotope data of both methane and ethane to identify the origin of natural gas dissolved in water supply wells. The investigation, located near Tioga Junction, Tioga County, north-central Pennsylvania, USA, was conducted by the U.S. Geological Survey in cooperation with the Pennsylvania Department of Environmental Protection (PADEP).

First, we identified and analyzed plausible natural gas sources that could potentially contaminate water wells at Tioga Junction to include the following: (1) deep native gas in the Oriskany Sandstone (thermogenic), (2) shallow native gas in Devonian shale bedrock (thermogenic), (3) microbial gas from organic debris (drift gas) in unconsolidated sediments and (4) non-native gas from a gas-storage field (thermogenic). Although gases from the Oriskany Sandstone and the gas-storage field were similar in chemical composition, where methane $\left(\mathrm{CH}_{4}\right)$ and ethane $\left(\mathrm{C}_{2} \mathrm{H}_{6}\right)$ are predominant, the gases had different stable carbon and hydrogen isotopic compositions.

Second, we investigated the hydrologic and geologic setting where contaminated water wells were located. Groundwater for rural-domestic supply and other uses near Tioga Junction is derived from two aquifer systems in and adjacent to the Tioga River valley. An unconsolidated aquifer of outwash sand and gravel of Quaternary age underlies the main river valley and extends into the valleys of tributaries. Outwash-aquifer wells are seldom deeper than $30 \mathrm{~m}$. The river-valley sediments and uplands adjacent to the valley are underlain by a fractured-bedrock aquifer in sandstones and shales of Devonian age, primarily the Lock Haven Formation. Most bedrock-aquifer wells produce water from the Lock Haven Formation at depths of $76 \mathrm{~m}$ or less in upland and valley settings. Water wells with high dissolved methane concentrations occurred in clusters along the flank of an anticline and near a gas-storage field along the anticline axis. 
Third, 35 out of 91 sampled water wells had measurable dissolved natural gas concentrations which we extracted and analyzed.

Results showed that the $\delta^{13} \mathrm{C}$ and $\delta^{2} \mathrm{H}$ values of methane in water samples from 14 wells reflected a microbial origin, while the composition of the other 21 wells was thermogenic (Fig. 1). The $\mathrm{C}$ and $\mathrm{H}$ stable isotope ratios of methane and ethane in thermogenic gases from water wells either matched or were intermediate between samples of non-native storage-field gas from injection wells and gas samples from storage-field observation wells indicating, that the thermogenic gas in water wells is coming from the Tioga Gas-Storage Field.

\title{
Reference
}

Révész, K.M., Breen, K.J., Baldassare, A.J. \& Burruss, R.C., Applied Geochemistry, 17(1), pp. 361-375, 2012.

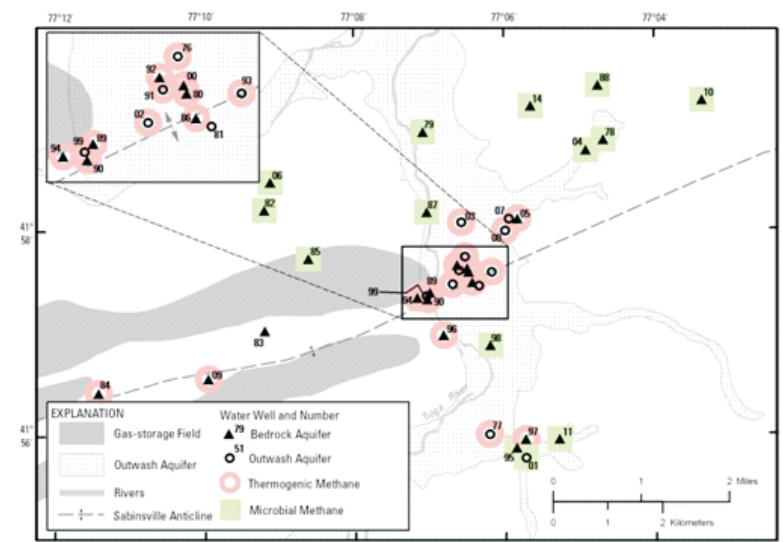

Figure 1. Distribution of groundwater wells with methane of microbial or thermogenic origins from bedrock and outwash-aquifer wells in the study area, June-August 2005 based on isotopic compositions of methane and ethane (Figure from Révész et al., 2012)

\section{0 - SEDIMENTOLOGICAL AND GEOCHEMICAL CHARACTERISTICS OF TWO RECENT TRAVERTINE FORMATION IN SW OF KONYA (CENTRAL TURKEY)}

\author{
Hükmü Orhan ${ }^{1}-$ Sándor Kele ${ }^{2}-$ Seda Karaisaoğlu ${ }^{1}$
}

${ }^{1}$ Department of Geology, Selcuk University, Faculty of Engineering, Turkey; e-mails: horhan@selcuk.edu.tr, seda@selcuk.edu.tr

${ }^{2}$ Institute for Geological and Geochemical Research, Research Centre for Astronomy and Earth Sciences, Hungarian Academy of Sciences, Budaörsi út 45, H-1112 Budapest, Hungary; e-mail: keles@geochem.hu 
Factors governing the travertine formation at two active sites in Kavak region (Konya, Central Turkey) were evaluated by sedimentological, mineralogical and geochemical analyses. Besides, stable isotope data were used to describe isotope fractionation processes during travertine deposition.

In the Kavak region, there are four Quaternary travertine mounds which are roughly aligned in a row and considered to be related to the Seydişehir fault zone extending NW-SE. They lie disconformably upon the Seydişehir formation comprising Upper Cambrian-Lower Ordovician interbedded metasandstone-shale and phyllite. In the South and West of the Kavak region, the mountainous area comprises mainly carbonate rocks ranging from Cambrian to Paleocene.

Recently travertine deposition is taking place around the output of an artificial artesian well $\left(230 \mathrm{~m}\right.$ deep, $\left.\mathrm{T}=39^{\circ} \mathrm{C}\right)$ and a spring $\left(\mathrm{T}=19^{\circ} \mathrm{C}\right)$ located $2 \mathrm{~km}$ further. At the well site, snow-white travertine crust covers the walls of an artificial pool and the bedrock in the surrounding area. A few meters further from the vent oncolites with varying size are common.

Travertine is forming along a smooth-sloping surface where the water flows as a sheet and deposition takes place also in the microterrace-pools having length between 5-40 cm and height ranging from 0,1 to $1 \mathrm{~cm}$.

The travertines around the artesian well are composed of almost pure calcite (based on XRD analysis) with a $\delta^{13} \mathrm{C}$ value of $+7.7 \%$ (VPDB) and $\delta^{18} \mathrm{O}$ value of $-8.7 \%$ (VPDB). Travertines around the spring are also composed of pure calcite with a $\delta^{13} \mathrm{C}$ value of $+5.4-4.9 \%$ (VPDB) and $\delta^{18} \mathrm{O}$ values of $-11.5 \%$ (VPDB). $\delta^{18} \mathrm{O}$ values of spring waters vary between -10.1 and $-9.8 \%$ (VSMOW). Comparing the measured and calculated $1000 \ln \alpha$ values we observed a positive shift from the equilibrium curve of Friedman and O'Neil [1]. Our study confirms the results of Kele et al. [2] and emphasizes the importance of empirical observations on the calcite-water system.

\title{
References
}

1. Friedman, I. and O’Neil, J.R., Data of Geochemistry 6th, Geol. Surv. Prof. Paper 440-KK, 61 pp., 1977.

2. Kele, S. et al., Sedimentary Geology, 238, pp. 191-212, 2011.

\section{1 - WHY TREE RING $\delta^{15}$ N RATIOS CAN PROVIDE A RETROSPECTIVE LOOK AT ANTHROPOGENIC NITROGEN ACCUMULATIONS}

\author{
Martine M. Savard - Christian Bégin - Joëlle Marion - Anna Smirnoff \\ Geological Survey of Canada, Natural Resources Canada, Québec (QC), Canada; \\ e-mail:msavard@nrcan.gc.ca
}


In North America, the direct measurement of N-bearing air pollutants rarely goes beyond the last 25 years in rural regions where stationary sources are active or in urban areas typified by diffuse industrial pollution. To palliate for the lack of long-term measurements of air quality and of depositional monitoring, tree-ring $\delta^{15} \mathrm{~N}$ values have started to be used in the early 2000s. Short-term tree-ring $\delta^{15} \mathrm{~N}$ variations have been interpreted to reflect climatic conditions [1], but most studies have interpreted the $\delta^{15} \mathrm{~N}$ trends in terms of contributions from various $\mathrm{N}$ sources [2], based on the premise that many atmospheric emissions have $\delta^{15} \mathrm{~N}$ values distinct from the natural $\mathrm{N}$ background $(-10.0$ to $-5 \%)$. However, the trends of exposed trees during the pollution periods generally show significant decreases even when industrial sources produce NOx with $\delta^{15} \mathrm{~N}$ values significantly higher than the soil background. Why?

In order to closely look at the relationship between emission types or rates, and ring $\delta^{15} \mathrm{~N}$ responses in exposed trees, we investigated white spruce specimens (Picea glauca) growing in two distinct diffuse pollution contexts separated by $470 \mathrm{~km}$ in northeastern Alberta: the Lower Athabasca oil sands district (north of Fort McMurray), and the coal fired power plant (CFPP) area west of Edmonton. The NOx emissions started in 1967 and 1956, respectively, but the direct air quality monitoring has only been initiated in 1997 and 1985, in the same order. The signal of nitrate and ammonium PM emissions near the main oil extraction operations has been reported to be $\sim+2$ and $+11 \%$, respectively [3], whereas the one for NOx emitted by CFPP is generally reported to vary between +8 and $+26 \%$ [ [4].

Tree-ring subsamples covering the 1880-2010 period were analyzed using a combustion-EA-CF-IRMS for their $\delta^{15} \mathrm{~N}$ values (precision $=0.3 \%$ ). Statistical analyses of the $\delta^{15} \mathrm{~N}$ values and climatic parameters for the pre-operation calibration periods (1910-1961 and 1900-1951) allowed to develop transfer functions for the two sites, and predict the natural $\delta^{15} \mathrm{~N}$ responses to climatic conditions for the operation periods. This approach [5] permits to set objective criteria for interpreting anthropogenic impacts on the local $\mathrm{N}$ cycle. The measured series depart negatively from the modeled natural trends, by an average of $-1.5 \%$ during the oil sands 1967-2009 period of operations, and by $-1.0 \%$ during the 1956-2010 CFPP operations. Interestingly, the negative trends of the measured data in the two regions can be nicely reproduced by multiple-regression models combining local climatic parameters with acidifying emissions.

We interpret the negative anomalies depicted here as anthropogenic perturbations of the nitrogen cycle in the two $\mathrm{N}$-emission contexts. These anomalies agree with several negative trends documented in previous studies. However, they cannot be interpreted in terms of direct modifications of the overall soil $\delta^{15} \mathrm{~N}$ values, because such an effect would increase the overall soil ratios. Our hypothesis is that anthropogenic $\mathrm{N}$ favours micorhizal fungi activities associated to the root system of the two studied stands, which release light $\mathrm{N}$ for the host trees growing under non-saturated conditions. The overall increase of regional soil isotopic signal due to the positive $\delta^{15} \mathrm{~N}$ val- 
ues of the emissions will only be detectable if soil $\mathrm{N}$ saturation is attained and fungi activities do not dominate the local $\mathrm{N}$ dynamics anymore.

The perspective given by the tree-ring $\delta^{15} \mathrm{~N}$ series reflects similar changes in two contrasted $\mathrm{N}$ emission regions, and provides a retrospective recognition of changes in soil biogeochemistry. Most importantly, the hypothesis of micorhizal control on the tree-ring $\delta^{15} \mathrm{~N}$ trends has significant implications on the main interpretative frame for this type of results. If confirmed by further biogeochemical research, this model might open the possibility of semi-quantitative reconstruction of depositional $\mathrm{N}$ rates.

\title{
References
}

1. M.M. Savard, C. Bégin, A. Smirnoff, J. Marion and E. Rioux-Paquette. Tree-ring nitrogen isotopes reflect climatic effects and anthropogenic $\mathrm{NO}_{\mathrm{x}}$ emissions. Env. Sci. \& Tech., 43, pp. 604-609, 2009.

2. M.M. Savard. Tree-ring stable isotopes and historical perspectives on pollution - an overview. Env. Poll., 158, pp. 2007-2013, 2010.

3. B.C. Proemse and B. Mayer. Tracing industrial nitrogen and sulfur emissions in the Athabasca oil sands region using stable isotopes, in Development in Environmental Science, vol. 11, Elsevier Ltd., Amsterdam, pp. 243-266, 2012.

4. J.D. Felix, E.M. Elliott and S. Shaw. Nitrogen isotopic composition of coal-fired power plant NOx: Influence of emission controls and implications for global emission inventories. Env. Sci. \& Tech., 46, pp. 3528-3535, 2012.

5. A. Doucet, M.M. Savard, C.B. Bégin, J. Marion, A. Smirnoff and T.B.M.J. Ouarda. Combining tree-ring metal concentrations and lead, carbon and oxygen isotopes to reconstruct peri-urban atmospheric pollution. Tellus B, 64, 2012.

\section{2 - DETERMINING THE SOURCE OF FLUIDS ACTIVE DURING BRITTLE-DUCTILE DEFORMATION IN THE MEXICAN FOLD AND THRUST BELT BY COMPARING $\delta^{2} H$ FROM THE LOCAL METEORIC WATER AND INCLUSION FLUIDS IN SYNTECTONIC VEINS}

\author{
César F. Aguilar-Ramírez ${ }^{1}$ - Elisa Fitz-Díaz ${ }^{2}$ - Edith Cienfuegos-Alvarado ${ }^{3}-$ \\ Antoni Camprubi ${ }^{3}-$ Pedro Morales-Puente ${ }^{3}$ \\ ${ }^{1}$ Facultad de Ingeniería, Universidad Nacional Autónoma de México, México; \\ e-mail: aguilar.ce.fe@gmail.com \\ ${ }^{2}$ Department of Geological Sciences, University of Michigan, USA \\ ${ }^{3}$ Instituto de Geología, Universidad Nacional Autónoma de México, México
}

The Mexican Fold and Thrust Belt (MFTB) lies on the eastern edge of the Late Cretaceous-Paleocene Cordilleran Orogen and its evolution can be envisioned through the orogenic wedge model. Its slope averages probably reached $3^{\circ}$ during deformation, and after deformation erosion decreased down to $1-1.5^{\circ}$. The deformed stratigraphic sequence consists mainly of carbonate rocks, and includes two marine platforms 
(named El Doctor and Valles-San Luis Potosí) and two basins (Zimapán and Tampico-Misantla). Pore-fluid pressure played an important role during deformation by reducing tectonic stress, facilitating extensional fracturing, and by enabling mineral dissolution and solution transfer on the grain scale. The determination of $\delta^{2} \mathrm{H}$ and $\delta^{18} \mathrm{O}$ composition of present-day meteoric water helps to evaluate the contribution of meteoric water to pore-fluid active during the buildup of the MFTB. We thus determined the meteoric water line by means of the analysis of 23 samples of rain, cave and river water across the MFTB, taken both before and after the rain season at heights between 0 and 3000 masl. Geographic $\left(22^{\circ} \mathrm{N}\right)$ and climatic constraints were based on average annual atmospheric temperature and on the frequency of northward running Gulf marine streams from the Lesser Antilles, the resulting regional equation for isotopic correlation of meteoric water is $\delta^{2} \mathrm{H}=\delta^{18} \mathrm{O} * 8+11$, was calculated. This equation shows a more negative value compared to the actual global meteoric line. Provided that no significant latitudinal changes occurred in the region since the Late CretaceousPaleocene, the obtained regional meteoric water isotopic line can be used to reasonably estimate the involvement of meteoric water in water-rock interaction processes during deformation by comparing with existing data from fluid inclusion analyses. The $\delta^{2} \mathrm{H}$ composition for inclusion fluids was obtained in 5 syntectonic vein samples after decrepitation at $300^{\circ}$ and $400^{\circ} \mathrm{C}$. Such decrepitation steps ideally correspond to the release of inclusion fluids from mostly pseudosecondary or primary inclusions, respectively. Their respective $\delta^{2} \mathrm{H}$ values range from -22.5 to $-58.4 \%$, and from -0.6 to $-57 \%$ (Zimapán and Tampico-Misantla basins). The corresponding local $\delta^{2} \mathrm{H}$ values from the meteoric water line range are $-25.35 \%$ and $-60 \%$. $\delta^{2} \mathrm{H}$ values from inclusion fluids in syn-tectonic veins from the Zimapán basin (shortened by deformation at $\sim 70 \%$ ) reflect a significantly higher influence of meteoric fluids during deformation than in similar veins from the Tampico-Misantla basin (shortened only $40 \%$ ), which recorded fluid sources that entirely correspond to marine or slightly evolved marine water reservoirs during early stages of deformation.

\section{References}

Campani, M., Mulch, A., .Kempf, O., Schlunegger, F. and Mancktelow, N. 2012. Miocene paleotopography of the Central Alps. Earth and Planetary Science Letters, 337-338, pp. 174-185.

Eguiluz de Antuñano, Samuel, Aranda García, Mario and Marrett, Randall, 2000. Tectónica de la Sierra Madre Oriental, México. Boletín de la Sociedad Geológica Mexicana V. LIII, pp. 1-26.

Fitz-Díaz, Elisa and Hudleston, Tolson, G. 2011. Comparison of tectonic styles in the Mexican and Canadian Rocky mountain fold-thrust belt. In: Poblet, J., Lisle, R. (eds), Kinematics and Tectonics Styles of Fold-Thrust Belt Geological Society, London, Special Publications 2011, 349, pp. 149-167.

Fitz-Diaz, Elisa, Hudleston, Peter, Siebenaller, Luc, Kirschner, David, Camprubí, Antoni, Tolson, Gustavo and Puig, Teresa Pi, 2011. Insights into fluid flow and water-rock interaction during deformation of carbonate sequences in the Mexican fold-thrust belt. Journal of Structural Geology, 33, pp. 1237-1253. 
Poulsen J., Christopher and Jeffery M. Louise 2011. Climate change imprinting on stable isotopic compositions of high-elevation meteoric water cloaks past surface elevations of major orogens. Geological Society of America, Geology, 39(6), doi:10.1130/G32052.1 pp. 595-598.

Roedder, E. 1984, Fluid inclusions: Mineralogical Society of America, Reviews in Mineralogy, 12, $644 \mathrm{pp}$.

Rowley, B., David and Garzione N. Carmala, 2007. Stable Isotope-Based Paleoaltimetry. Annu. Rev. Earth Planet. Sci. ,35, pp. 463-508.

Sharp, Zachary, 2007. Principles of Stable Isotope Geochemistry, Pearson Prentice Hall, p. 344.

Steven, Stanley M. 1992. Earth System History, Second Edition. Ed. Chronicle Books, San Francisco, pp. 417-443.

Mook, Willem G. 2002. Isótopos Ambientales en el Ciclo Hidrológico Principios y Aplicaciones, Instituto Geológico y Minero de España, Serie: Guías y manuales No. 1, pp. 13-89, 177-223.

\section{3 - SULFUR AND LEAD ISOTOPES STUDIES OF SULFIDES MINERALS FROM THE JEBEL MECELLAF-BA (ZN-PB) DEPOSIT, NE TUNISIA: CONSTRAINTS ON ORE GENESIS}

Nejib Jemmali ${ }^{1}$ - Fouad Souissi ${ }^{1}$ - Emmanuel John Carranza ${ }^{2}$ - Jean Jacques Orgeval ${ }^{3}$

${ }^{1}$ Université de Tunis El Manar, Faculté des Sciences, Département de Géologie, Tunis, Tunisia, Laboratoire des Matériaux Utiles, Institut National de Recherche et d'Analyse Physico-chimiques, 2026 Technopole de Sidi Thabet, Tunisia; e-mail: nejib.jemmali@yahoo.fr

${ }^{2}$ Economic Geology Research Unit, School of Earth and Environmental Sciences, James Cook University, Townsville, Queensland, Australia

${ }^{3}$ Bureau de Recherches Géologiques et Minières, Département Exploration, BP 36009, 45060 - Orléans Cedex 2, France

Large F-(Ba-Pb-Zn) deposits are located within the Fluorite District of Zaghouan (Fig. 1). The mineralization of Jebel Mecella occurs as stratabound or stratiform bodies, either within or immediately above the Jurassic reef limestones of KimmeridgianTithonian-Berriasian age (Ressas Formation), along unconformity surfaces highlighted by shoals, condensed layers, stratigraphic gaps, karstification and pedogenesis, that separate Ressas Formation from overlying units (Souissi et al., 2013). The mineral association consist of fluorite, barite, sphalerite and galena. Values of $\delta^{34} \mathrm{~S}$ of barite $(14.8-15.4 \%)$ are consistent with the reduction of sulfates from Triassic evaporites compared to the Triassic gypsum of Jebel Ressas $\left(16.8<\delta^{34} \mathrm{~S}<17.9 \%\right.$ ). Values of $\delta^{34} \mathrm{~S}$ of sphalerite and galena, ranging from -5.9 to $-2.2 \%$, suggest involvement of bacterially-mediated sulfate reduction in the mineralization. Sulfur may have been derived by dissolution of pre-existing early sulfide minerals hosted in organic-matter-rich layers. $\mathrm{Pb}$ isotope data are homogeneous and more radiogenic than those of Nappe and Domes zone (Jemmali et al., 2011, 2013a, b), with ${ }^{206} \mathrm{~Pb} /{ }^{204} \mathrm{~Pb},{ }^{207} \mathrm{~Pb} /{ }^{204} \mathrm{~Pb}$ and ${ }^{208} \mathrm{~Pb} /{ }^{204} \mathrm{~Pb}$ ratios of $18.891-18.902,15.687-15.699$ and $38.850-38.880$, respectively, which suggest a single source reservoir of $\mathrm{Pb}$ at depth in the upper crust. The Late Paleozoic basement seems to be the plausible source for base metals concentrated 
in the deposit. The genesis of the Jebel Mecella ore deposit is likely associated with the reactivation of the Zaghouan Fault during the Late Miocene period.

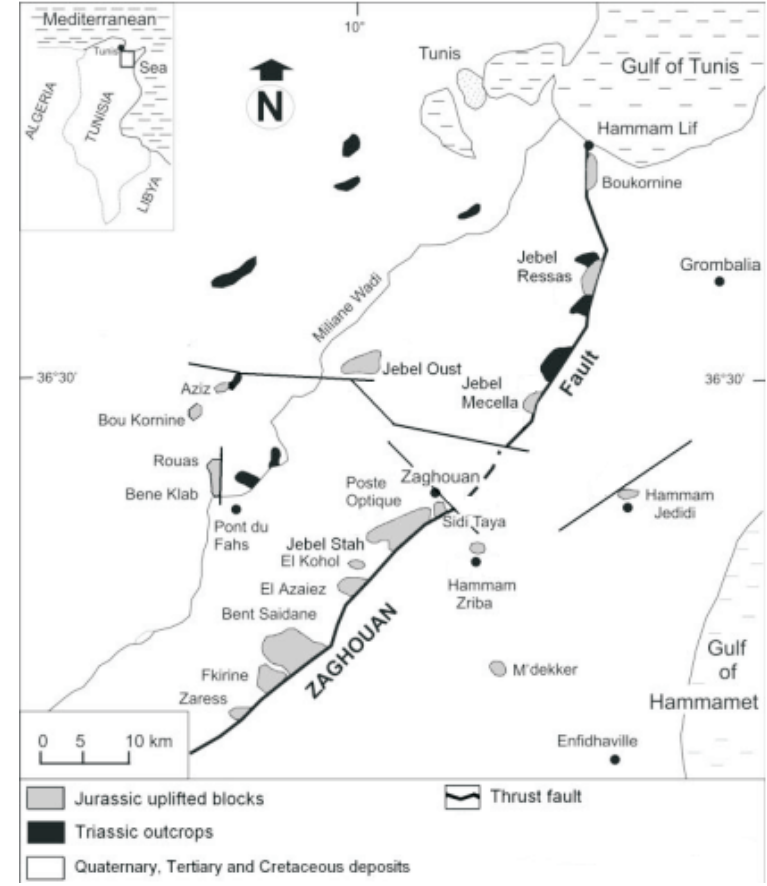

Figure 1. Map showing Jurassic uplifted blocks and Triassic outcrops, along with $\mathrm{F}-(\mathrm{Ba}, \mathrm{Pb}, \mathrm{Zn})$ deposits, in North-eastern Tunisia

\section{References}

1. N. Jemmali, F. Souissi, T. Vennemann and E. J. M. Carranza. Genesis of the Jurassic carbonate-hosted $\mathrm{Pb}-\mathrm{Zn}$ deposits of Jebel Ressas (North-Eastern Tunisia): evidence from mineralogy, petrography and trace metal contents and isotope $(\mathrm{O}, \mathrm{C}, \mathrm{S}, \mathrm{Pb})$ geochemistry. Resource Geology, special publication, 61, 4, pp. 367-383. 2011.

2. N. Jemmali., F. Souissi., E.J.C. Carranza and M. Bouabdellah. Lead and sulfur isotope constraints on the genesis of the polymetallic mineralization at Oued Maden, Jebel Hallouf and Fedj Hassene carbonate-hosted $\mathrm{Pb}-\mathrm{Zn}$ (As-Cu-Hg-Sb) deposits, Northern Tunisia. doi:10.1016/j.gexplo. 2013.03.004. 2013a.

3. N. Jemmali, F. Souissi, E.J.M. Carranza and T. Vennemann. Sulfur and lead isotopes of Guarn Halfaya and Bou Grine deposits (Domes zone, Northern Tunisia): implications for sources of metals and timing of mineralization. doi:10.1016/j.oregeorev.2012.04.005. 2013b.

4. F. Souissi, N. Jemmali, R. Souissi and J.L. Dandurand. REE and isotope ( $\mathrm{Sr}, \mathrm{S}, \mathrm{Pb}$ ) geochemistry to constrain the genesis and timing of the F-(Ba-Pb-Zn) ore of the Zaghouan District (NE Tunisia). doi: 10.1016/j.oregeorev.2013.04.0012013. 2013. 


\title{
064 - CSIA ON $\mathrm{CO}_{2}$ AND ALKANES IN THE GAS PHASE OF LOW PERMEABILITY SEDIMENTARY ROCKS
}

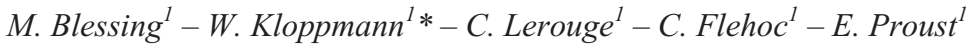 \\ ${ }^{1}$ BRGM, Laboratory Division, Orléans, France; \\ *e-mail: w.kloppmann@brgm.fr
}

Since the 1970ies, isotope fingerprinting on $\mathrm{CO}_{2}$ and gaseous alkanes proved to be a powerful tool in hydrocarbon exploitation [1]. In particular, isotope fingerprinting allows distinguishing between methane of biogenic or thermogenic origin [2]. Recently, alkanes confined in low permeability rocks (shales) have drawn economical attention as non-conventional energy resource. The same rocks are equally of interest as targets for $\mathrm{CO}_{2}$ sequestration (as caprocks), and for solid waste disposal (as host rocks), since they form natural barriers for fluid and gas migration. Characterisation of carbon, oxygen and hydrogen isotopes on $\mathrm{CO}_{2}$ and alkanes can reveal information on the origin and mobility of gases in the pore space of argillaceous sedimentary rock series thus providing additional constraints on their aptitude to act as barriers for the confinement of fluids and gases.

Earlier work in the frame of research on radioactive waste disposal had allowed the prototyping of degassing cells for gas characterisation of shale rock drilling cores $[3,4,5]$. Here we present a method making use of steel degassing cells specifically designed for large core samples and of CF-IRMS to determine $\mathrm{C}, \mathrm{H}$ and $\mathrm{O}$ isotope ratios on the extracted gases [7]. After placing the core sample in the cell, atmospheric contamination is eliminated by several flushing cycles with an inert gas. The cell is then sealed to allow degassing over several months until the gas composition is stabilised. This process is monitored for gas pressure, temperature and relative humidity; regular measurements of bulk chemical gas composition are performed using gas chromatography. Once stabilised, the gas is recovered from the cell and transferred into He-conditioned vials.

Carbon and oxygen of $\mathrm{CO}_{2}$ are measured by Gasbench-IRMS on a Thermo Finnigan Delta plus XP continuous flow mass spectrometer. $\delta^{13} \mathrm{C}$ and $\delta^{2} \mathrm{H}$ of alkanes are determined after manual injection by GC-IRMS combining a Thermo Electron Trace GC Ultra and a Delta plus XP GC-IRMS. Standard deviations are less than $0.5 \%$ for $\delta^{13} \mathrm{C}$, and $5 \%$ for $\delta^{2} \mathrm{H}$, respectively. Required concentrations for determinations of the different alkanes vary between 300 and $900 \mathrm{ppmv}$. The influence of sample volume and time lapse before analysis was investigated. For concentrations $\leq 500$ ppmv ( 1 to $10 \mathrm{ml}$ injection volume) a $\mathrm{N}_{2}$-cooled PTV system including a Carbosieve liner was tested for different trapping-and desorption temperatures.

The method was tested on a synthetic gas mixture and on natural samples obtained from cores from different depths (780 to $974 \mathrm{~m}$ ) in the Opalinus Clay (Middle Jurassic) of the Mont Terri underground rock laboratory (Jura, Switzerland). 


\title{
References
}

1. Fuex, The use of stable carbon isotopes in hydrocarbon exploration. J.Geochem. Expl., 7, pp. 155-188, 1976.

2. Schoell, The hydrogen and carbon isotopic composition of methane from natural gases of various origins. Géochim. Cosmochim. Acta, 44, pp. 649-661, 1979.

3. Lassin, A., Gaucher, E., Crouzet, C., Measurements of partial pressure of $\mathrm{CO}_{2}$ and alcanes in core samples of Opalinus Clay from Benken, Switzerland. BRGM Report RC-50537-FR, 2000.

4. Girard, J.P., Fléhoc, C. and Gaucher, E., Stable isotope composition of CO2 outgassed from cores of argillites: a simple method to constrain $\delta^{18} \mathrm{O}$ of porewater and $\delta^{13} \mathrm{C}$ of dissolved carbon in mudrocks. Appl. Geochem., 20, pp. 713-725, 2005.

5. Prinzhofer, A., Girard, J.P., Buschaert, S., Huiban and Y., Noirez, S., Chemical and isotopic characterization of hydrocarbon gas traces in porewater of very low permeability rocks: The example of the Callovo-Oxfordian argillites of the eastern part of the Paris Basin. Chem. Geol., 260, pp. 269-270, 2009.

6. Blessing, M., Bellenfant, G., Widory, D. and Guyonnet, D., Compound-specific isotope analysis of methane and $\mathrm{CO} 2$ landfill emissions. 8. International Symposium on Applied Isotope Geochemistry, La Malbaie, Québec, Canada, 30.08.-04.09.2009.

7. Gaucher, E. C., Lassin, A., Lerouge, C., Fléhoc, C., Marty, N. C., Henry, B., Tournassat, C., Altmann, S., Vinsot, A., Buschaert, S., Matray, J.M., Leupin, O.X. and De Craen, M., $\mathrm{CO}_{2}$ partial pressure in clayrocks: A general model. Water-Rock Interaction XIII - Water-Rock Interaction WRI-13, Mexico, 2010.

\section{5 - PLANKTONIC FORAMINIFERAL DYNAMICS IN THE EASTERN ARABIAN SEA AS A PROXY OF THE SOUTH-WEST MONSOONAL ACTIVITY IN INDIAN SUB CONTINENT DURING THE LAST MILLENNIUM}

\author{
Ashish Sarkar ${ }^{1}-$ Neil Ogle ${ }^{2}$ \\ ${ }^{1}$ School of Petroleum Technology, Pandit Deendayal Petroleum University, \\ Gandhinagar 382 007, Gujarat, India; e-mail: ashish29s@yahoo.co.in \\ ${ }^{2}$ Environmental Engineering Research Centre, School of Planning, \\ Architecture and Civil Engineering, The Queen's University of Belfast, Belfast, BT9 5AG, \\ Northern Ireland; e-mail: n.ogle@qub.ac.uk
}

The Indian subcontinent, the second largest populous country on earth largely depends on agriculture, which in turn is dependent on precipitation in terms of rainfall. India witnesses a very regular reversing monsoonal rainfall mainly during June to September every year, popularly and technically known as the south-west monsoon. The instrumental record of south-west monsoon induced precipitation shows annual variability in wide limits, and also exhibits decadal to multi-decadal trends and centennial scale cyclicity.

The present work is intended to look at variability in monsoonal intensity in the sub continent. In order to understand the system, the planktonic foraminiferal population dynamics and stable isotopic data through time have been studied in a short sediment core retrieved from a continental slope region in the eastern Arabian Sea. The 
AMS ${ }^{14} \mathrm{C}$ dates from a very nearby sediment core hints at the age of the base of the studied core at $\sim 1 \mathrm{ka}$.

Cole and Fairbanks (1990) and Sarkar et al. (2000) have earlier demonstrated that sea water $\delta^{18} \mathrm{O}$ gets is influenced by the precipitation induced fresh water flux, which is eventually picked up by the carbonate secreting organisms. As the dataset is a short one, time series analyses could not be attempted. However, variations in $\delta^{18} \mathrm{O}$ measured on surface/near surface, and intermediate depth dwelling planktonic foraminiferal select species; abundances of different species of planktonic foraminifera; and diversity of planktonic foraminiferal population through time visually depicts cyclicity. It is also discernible from the data that though there exists an overall enhancement in southwest monsoonal intensity in the region. A weakening southwest monsoonal strength for the last $\sim 200$ years to $\sim 40$ years before present is evident from the time series. $\delta^{13} \mathrm{C}$ measured on the select species of planktonic foraminifera helps in understanding sea surface productivity in the region.

\title{
References
}

1. Cole, J.E. and Fairbanks, R.G., The Southern Oscillation recorded in the stable isotopes of coral from Tarawa Atoll. Paleoceanography, pp. 669-683, 1990.

2. Sarkar, Ashish, Ramesh, R., Somayajulu, B.L.K., Agnihotri, R., Jull, A.J.T. and Burr, G.S. High resolution paleomonsoon record from the Eastern Arabian Sea. Earth and Planetary Science Letters, 173(3-4), pp. 209-218, 2000.

\section{6 - AMINO ACIDS IN DEEP-SEA CORAL: WHAT COMPOUND SPECIFIC ISOTOPES REVEAL ABOUT THE BIOGEOCHEMISTRY OF A WESTERN BOUNDARY CURRENT IN A CHANGING CLIMATE}

\author{
Kelly M. Strzepek ${ }^{1}$-Andrew T. Revill ${ }^{2}-$ Ron E. Thresher ${ }^{2}-$ Colin Smith $^{3}-$ \\ Stewart J. Fallon ${ }^{1}$ \\ ${ }^{1}$ Research School of Earth Sciences, Australian National University, Acton, Canberra, \\ ACT 0200, Australia; e-mail: kelly.strzepek@anu.edu.au \\ ${ }^{2}$ CSIRO Marine and Atmospheric Research, Hobart, TAS 7000, Australia \\ ${ }^{3}$ Department of Archaeology, Environment and Community Planning, La Trobe University, \\ Melbourne, Australia
}

The East Australian Current (EAC) is a complex and energetic western boundary system in the south-western Pacific off eastern Australia (Fig. 1). Over the past 50 years the EAC has strengthened, caused by the overall spin-up of the South Pacific Gyre. While increasing sea surface temperatures are well constrained along the East Australian coastline, the flow on effects occurring in open ocean marine ecosystems are more difficult to document. In this study, the nitrogen isotope composition of individual amino acids in the deep-sea Bamboo Coral Lepidisis spp. (Isididae) are used to reconstruct a century of nutrient distribution and food web dynamics from two sites on the Lord Howe Rise (Fig. 1). 


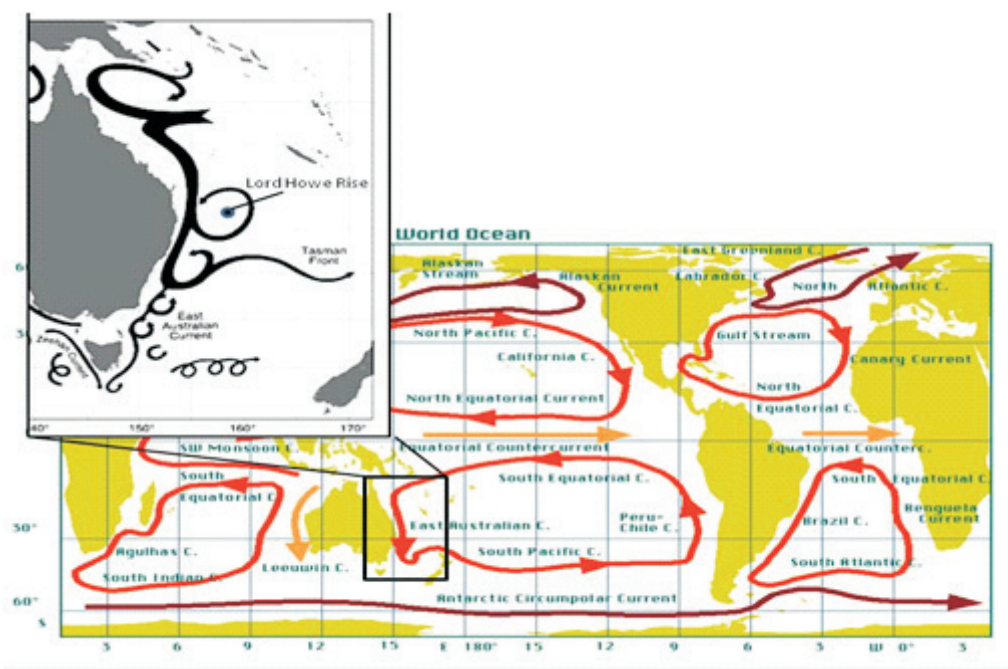

Figure 1. East Australian Current (EAC) and sample location

There is enormous potential for deep-sea corals to act as archives of surface and deep-water processes, due to their longevity, distribution and feeding strategies. Bamboo Corals continuously integrate surface-derived particulates into discrete protein bands within their skeleton; analogous to sedimentary organic matter records down core. However, the interpretation of isotopic signatures from bulk samples extracted from these skeletons can be confounded due to the a priori information needed to differentiate between trophic enrichment and the original isotopic composition at the base of the food web. By comparing amino acids that remain relatively unchanged from the 'source', to those that fractionate significantly with 'trophic' transfer, an internally consistent record of regional food web dynamics emerges (McClelland and Montoya, 2002; Popp et al., 2007). In addition, investigating the spread of 'trophic' amino acids provides insight in to the reprocessing, or reworking, of the particulate food source through the water column (McCarthy et al., 2007).

The compound specific isotope approach clearly shows the multi-decadal oscillations previously reported in the EAC (Ridgway and Hill, 2009) but also provides strong evidence that in the last 50 years strengthening of the EAC has induced broader biogeochemical changes. The isotopic composition of source material appears to have become more depleted while overall food chain length has increased. We discuss these results in the context of the physical mechanisms that dictate the regional distribution of phytoplankton and nitrogen-fixing organisms.

Acknowledgements: The authors would like to acknowledge the Australian Research Council's Post Graduate Award for funding K.M Strzepek, and CSIRO's "Wealth from Oceans" Flagship. We would also like to thank Tara Anderson and Geosciences Australia for the coral samples, Hilary Stuart-Williams for providing the EA-IRMS data, Rhys 
Leeming and Danny Holdsworth for technical support and Stephen Eggins and Michael Ellwood for helpful discussion.

\title{
References
}

McCarthy, M.D., Benner, R., Lee, C. and Fogel, M.L. (2007). Amino acid nitrogen isotopic fractionation patterns as indicators of heterotrophy in plankton, particulate, and dissolved organic matter. Geochimica et Cosmochimica Acta, 71, pp. 4727-4744.

McClelland, J.W. and Montoya, J.P. (2002). Trophic relationships and the nitrogen isotopic composition of amino acids in plankton. Ecology, 83, pp. 2173-2180.

Popp, B.N., Graham, B.S., Olson, R.J., Hannides, C.C.S., Lott, M., Lopez-Ibarra, G. and Galvan Magana, F. (2007). Insight into the trophic level of yellowfin tuna, Thunnus albacares, from compound-specific nitrogen isotope analysis of proteinaceous amino acids. Terrestrial Ecology, 1, pp. 173-190.

Ridgway, K. and Hill, K. (2009). The East Australian Current. In A Marine Climate Change Impacts and Adaptation Report Card for Australia 2009 (Eds. E.S. Poloczanska, A.J. Hobday and A.J. Richardson), NCCARF Publication 05/09, ISBN 978-1-921609-03-9.

\section{7 - TRACE METAL CONTAMINATION AND PB ISOTOPIC COMPOSITION IN ASIAN DUST AND NON-ASIAN DUST DURING SPRING 2008, KOREA}

\author{
Pyeong-Koo Lee ${ }^{1}$ - Seung-Jun Youm ${ }^{1}-$ Ho Young $J^{2}$ \\ ${ }^{1 *}$ Korea Institute of Geoscience and Mineral Resources, 30 Kajung-dong, Yusung-gu, \\ Taejon, 305-350, Korea \\ ${ }^{2}$ Department of Earth and Environmental Sciences, Korea University, Anam-dong, \\ Seongbuk-gu, Seoul 136-713, Korea \\ * Corresponding author; e-mail: pklee@kigam.re.kr, Tel: +82-42-868-3371, \\ Fax: +82-42-862-5056
}

The concentration levels of Asian dust (AD) and non-Asian dust (NAD) samples and the associated trace metals were investigated during the springtime period for the year 2008 in Daejeon city in Korea $\left(36^{\circ} 20^{\prime} \mathrm{N}\right.$ and $\left.127^{\circ} 22^{\prime} \mathrm{E}\right)$. Based on a comparison of the trace metal concentrations of $\mathrm{AD}$ and uncontaminated Chinese desert soils, the elements were classified into two main groups according to their sources: natural $(\mathrm{Cr}, \mathrm{Co}$ and $\mathrm{Ni}$ ) and anthropogenic ( $\mathrm{S}, \mathrm{Zr}, \mathrm{Zn}, \mathrm{Pb}, \mathrm{Mo}, \mathrm{Cu}, \mathrm{As}$ and $\mathrm{Cd})$. The geo-accumulation index $\left(I_{\text {geo }}\right)$ analyses and enrichment factor $(\mathrm{EF})$ values indicated that all of the $\mathrm{AD}$ and NAD fractions were classified as extremely polluted with $\mathrm{S}$, Mo and $\mathrm{Cd}$ and strongly to extremely polluted with $\mathrm{Pb}, \mathrm{Zn}, \mathrm{Zr}$, As and $\mathrm{Cu}$, indicating the rather important contribution of non-crustal/anthropogenic contamination sources from the developed and heavily industrialized Chinese cities. However, the $\mathrm{Cr}$, $\mathrm{Co}$ and Ni contamination contributions are not significant.

The mean ${ }^{206} \mathrm{~Pb} /{ }^{207} \mathrm{~Pb}$ ratios for the airborne particles in certain developed and heavily industrialized cities of China are identical and/or fairly close to those of $\mathrm{AD}$ and NAD, possibly indicating a significant contribution of the Chinese airborne parti- 
cles from heavily industrialized cities, with minor influence of detrital $\mathrm{Pb}$ from the Alashan desert soil samples. In addition, our results show that an increase in the atmospheric heavy-metal pollution of AD and NAD shifted the Pb-isotopic values towards lower ${ }^{206} \mathrm{~Pb} /{ }^{207} \mathrm{~Pb}$ ratios due to the remarkable increase in Chinese industrial $\mathrm{Pb}$ sources.

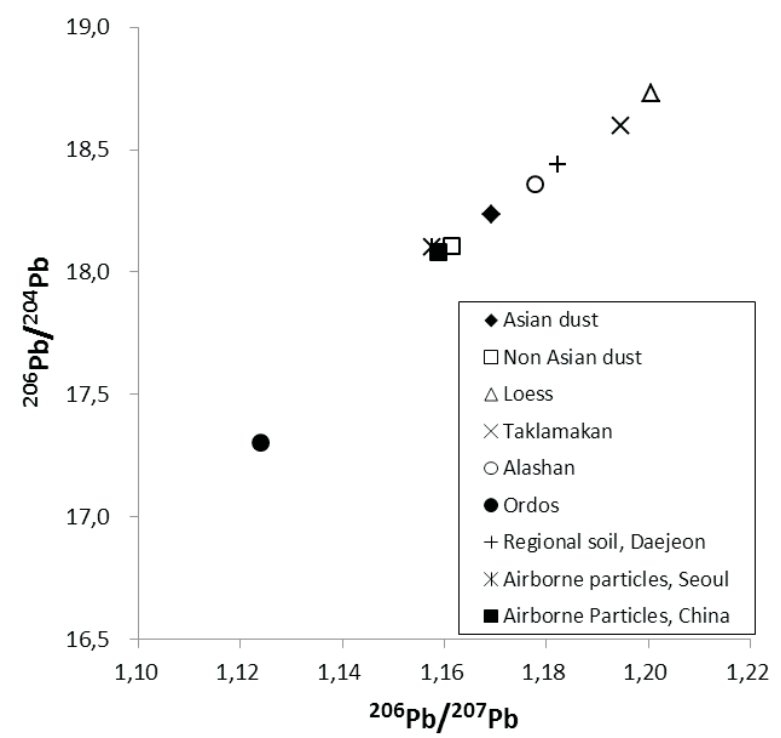

Figure 1. Mean ${ }^{206} \mathrm{~Pb} /{ }^{207} \mathrm{~Pb}$ vs ${ }^{206} \mathrm{~Pb} /{ }^{204} \mathrm{~Pb}$ isotopic compositions of Asian dust, non-Asian dust and Chinese desert soils. For comparison, Pb isotopic compositions of roadside sediments from Seoul, Korea and airborne particles from several heavily industrial cities, China are shown (Mukai et al., 1993; Bollhöfer and Rosman, 2001; Mukai et al., 2001; Zhu et al., 2001; Lee et al., 2005)

Therefore, this study on heavy-metal contamination and $\mathrm{Pb}$ isotope signatures in $\mathrm{AD}$ and NAD provides valuable information on the environmental impact of urbanization and industrialization in China on the atmospheric environmental quality of Korea. This study also suggests that AD and NAD may threaten the health of Korean residents due to high deposition rates of AD containing significantly elevated levels of toxic elements. Therefore, action should be taken to control the atmospheric emission of industrial pollutants derived from developed cities and heavily industrialized Chinese cities.

\section{References}

Bollhöfer, A.L. and Rosman, K.J.R. 2001. Isotopic source signatures for atmospheric lead: The Northern Hemisphere. Geochim. Cosmochim. Acta, 65, pp. 1727-1740.

Lee, P.K., Yu, Y.H., Yun, S.T. and Mayer, B. 2005. Metal contamination and solid phase partitioning of metals in urban roadside sediments. Chemosphere, 60, pp. 672-689. 
Mukai, H., Furuta, N., Fujii, T., Ambe, Y., Sakamoto, K. and Hashimoto, Y. 1993. Characterization of sources of lead in the urban air of Asia using ratios of stable lead isotopes. Environ. Sci. Technol., 27, pp. 1347-1358.

Mukai, H., Tanaka, A., Fujii, T., Zeng, Y., Hong, Y., Tang, J., Guo, S., Xue, H., Sun, Z., Zhou, J., Xue, D., Zhao, J, Zhai, G., Gu, J., Zhai, P., 2001. Regional characteristics of sulfur and lead isotope ratios in the atmosphere at several Chinese urban sites. Environ. Sci. Technol., 35, pp. 1064-1071.

Zhu, B.Q., Chen, Y.W., Peng, J.H., 2001. Lead isotope geochemistry of urban environment in the Pearl River Delta. Appl. Geochem., 16, pp. 409-417.

\title{
068 - VALIDATION OF SEAWATER INTRUSION PROCESS BY HYDROGEOCHEMICAL, ISOTOPIC AND NUMERICAL SIMULATION APPROACHES
}

\author{
Henda Jelassi $^{1}$ - Tsutomu Yamanaka ${ }^{2}$ - Tadashi Tanaka ${ }^{3}$ - Mourad Bedir ${ }^{4}$ \\ ${ }^{1}$ Water Researches and Technologies Center CERTE. Borj Cedria Science and Technology \\ Park, Soliman, Tunisia; e-mail: henda-jelassi@hotmail.com \\ ${ }^{2}$ Terrestrial Environmental Research Center, Tsukuba, Japan \\ ${ }^{3}$ Department of International Affairs, Tsukuba, Japan \\ ${ }^{4}$ CERTE Borj Cedria Science and Technology Park, Soliman, Tunisia
}

In the management of groundwater resources, the quantitative and qualitative problems often cannot be separated from each other. Coastal aquifers in Odawara region, central Japan, present problems of groundwater quality degradation that might be related to groundwater use and succeeding disturbance in groundwater flow systems. Despite its importance,there is insufficient information about hydrogeochemical processes that govern the chemical composition of the groundwater and its relation to groundwater flow systems and human activities.

The principal objectives of the present study are twofold: one is to clarify the hydrogeochemical processes regulating the water quality of the groundwater in coastal aquifers in Odawara region, and another is to reveal the mechanisms and controlling factors of seawater intrusion, which is the most important process in the region, with special focusing on three-dimensional groundwater flow process and its relation to human activities of the groundwater withdrawals. A hydrogeochemical and isotopic approaches were applied for the first objective, and then a numerical simulation was applied for the second objective, considering results from the hydrogeochemical and isotopic approaches.

Chemical and isotopic analyses for totally 112 groundwater samples from both unconfined and confined aquifers were performed, and the water quality data together with hydrometric data were used for hydrogeochemical interpretations by means of conventional graphical methods and the source-rock deduction approach. As the results, it was concluded that important processes regulating groundwater quality in the study area are (1) silicate weathering, (2) natural softening through ion exchange, (3) 
contamination from anthropogenic sources, and (4) seawater intrusion and succeeding reverse-softening. The factors affecting these processes are the topography, geology and land use in the study area. The first process is dominant for both unconfined and confined aquifers in the most areas, the second is dominant in the unconfined aquifer only at boundary zones between different geologic units, the third is dominant in the unconfined aquifer in unrban and agricultural areas, and the fourth is dominant in confined aquifers in areas close to the coast, within a distance of $1 \mathrm{Km}$. It was also deduced that the groundwater salinization at coastal confined wells is caused through saltwater up-coning rather than by horizontal shift of the seawater-freshwater interface.

To validate the groundwater salinization process proposed above, numerical simulations with 48 experimental cases were conducted using a three- dimensionnal groundwater-flow model that involves solute transport and density driven flows. Using appropriate combination of hydraulic parameters and boundary conditions, simulated results showed good agreement with observed results and successfully confirmed the saltwater up-coning as a cause of the observed salinization. Under the fixed conditions of hydraulic conductivity in aquifers, the important factors regulating the seawater intrusion were concluded to be (i) horizontal hydraulic gradient toward the coast, (ii) vertical profile of upstream hydraulic head, and (iii) groundwater pumping rate. The first factor regulates the horizontal movement of the seawater-freshwater interface. The second factor affects the shape of the interface and the occurrence of of saltwater up-coning. The third factor controls saltwater up-coning, while its effect on the horizontal movement of the seawater-freshwater interface is not remarkable.

Keywords: groundwater, Odawara region, hydrogeochemical processes, isotopes, numerical simulation, seawater intrusion, coastal aquifer

\title{
069 - STABLE CARBON ISOTOPE MEASUREMENTS OF ALKYLNAPHTHALENES IN SEDIMENTS: SOURCE IMPLICATIONS
}

\author{
Yongge Sun ${ }^{1}-$ Aizhu Jiang ${ }^{2}$ \\ ${ }^{1}$ Department of Earth Science, Zhejiang University, Hangzhou 310027, Zhejiang, P R China; \\ e-mail:ygsun@zju.edu.cn \\ ${ }^{2}$ SKLOG, Guangzhou Institute of Geochemistry, Chinese Academy of Sciences, \\ Guangzhou 510640, P R China
}

Alkylnaphthalenes are common constituents of petroleum and sedimentary organic matter. Although the isomeric distributions of various Alkylnaphthalenes were used as an indicator of the thermal maturity of sedimentary organic matter in the field of petroleum geochemistry over the last three decades, the origins of these structurally simple alkylnaphthalenes in sediments are still poorly understood to date. In this study, The 11 Tertiary lacustrine sediments were collected from the Huanghua depression, Bohai 
Bay basin, North China, and the alkylnaphthalenes in sediments were separated using two-step column chromatography with Alumina as a station phase for further compound-specific stable carbon isotopic measurements (Jiang et al., 2013).

Compound-specific stable carbon isotope analyses showed that most of alkylnaphthalenes in one given source rock have similar ${ }^{13} \mathrm{C}$ values same as that of total organic matter and significant discrepancies from that of $n$-alkanes, isoprenoids, and terpenoids, possibly an indicative of geosynthetic process for those compounds as the ${ }^{13} \mathrm{C}$ values of alkylnaphthalenes can be homogenized during bio-chemical and early diagenetic stage. Interestingly, carbon isotopic compositions of ethylnaphthalene, 1,2-dimethylnaphthalene, and 1,2,5-trimethylnaphthalene show large ${ }^{13} \mathrm{C}$ or ${ }^{12} \mathrm{C}$ enrichments compared to other homologues, suggesting distinct source pools rather than geosynthetic process for these compounds. The results suggest that the occurrence of alkylnaphthalenes in sedimentary organic matter may be mainly controlled by the geosynthetic process at the bio-chemical and early diagenetic stage, in some cases, with contributions from the diagenetic aromatization of natural product precursors for some specific alkylnaphthalenes.

\title{
References
}

1. A. Jiang, P. Zou, Y. Sun and L. Xie Rapid column chromatography separation of alkylnaphthalenes from aromatic components in sedimentary organic matter for compound-specific stable isotope analysis. Organic Geochemistry, in press.

\section{0 - CALIBRATION OF THE 'CLUMPED ISOTOPE' THERMOMETER ON THERMAL SPRING TRAVERTINES IN THE 22-95 ${ }^{\circ} \mathrm{C}$ TEMPERATURE RANGE}

\author{
Sándor Kele ${ }^{1}$-Stefano M. Bernasconi ${ }^{2}-$ Kluge Tobias $^{3}$ - John M. Cédric ${ }^{3}-$ \\ Isabel M. Millan ${ }^{2}-$ Nele M. Meckler ${ }^{2}-$ Martin Ziegler $^{2}-$ Sebastian F.M. Breitenbach $^{2}-$ \\ Enrico Capezzuoli ${ }^{4}$-Mehmet Özkul ${ }^{5}$ - Ali Gökgöz $z^{5}$-József Deák ${ }^{6}$ \\ ${ }^{1}$ Institute for Geological and Geochemical Research, RCAES-HAS, Budapest, Hungary; \\ e-mail: keles@geochem.hu \\ ${ }^{2}$ Dept. of Earth Science, ETH Zurich, Switzerland \\ ${ }^{3}$ Imperial College, London, Earth Sci. and Eng., London, UK \\ ${ }^{4}$ Dept. of Phys., Earth and Env. Sci., Univ. of Siena, Italy \\ ${ }^{5}$ Pamukkale University, Denizli, Turkey \\ ${ }^{6}$ Gwis Ltd, Dunakeszi, Hungary
}

Valuable paleoclimate records for continental areas are provided by non-marine carbonates, including travertines, freshwater tufas and speleothems. Their formation temperatures can be estimated using both the conventional carbonate-water paleothermometry [1,2] and the newly developed clumped isotope method [3, 4]. The latter requires no assumptions about the oxygen isotope composition of water from 
which the carbonate precipitated. However, there is still a large uncertainty in the published clumped-isotope based temperature calibrations.

In this work recent travertines forming from natural springs and wells between 22 and $95^{\circ} \mathrm{C}$ from Hungary, Turkey and Italy were studied for stable- and 'clumped' isotopes. For clumped-isotope analyses both the newly developed technique of Schmid and Bernasconi [5] and the procedures of Huntington et al. [6] and Dennis et al. [7] were used. Samples were measured with a Thermo Fisher Scientific Kiel IV carbonate device connected to a Thermo Fisher Scientific MAT 253 dual inlet mass spectrometer at ETH Zurich and on a Thermo Fisher MAT 253 dual-inlet gas-source isotope ratio mass spectrometer in the Qatar Stable Isotope Lab of Imperial College London.

Clumped isotope data show an excellent correlation with temperature, indicating precipitation under equilibrium conditions close to the spring orifice. $\Delta_{47}$ values decreased with increasing distance from the springs, which may be related to kinetic isotope fractionation due to $\mathrm{CO}_{2}$ degassing in the different depositional sub-environments (e.g. channel, terrace-pool, cascade).

All vent travertine samples show a strong $\Delta_{47}$-temperature relationship $\left(\mathrm{r}^{2}>\right.$ $0.9)$ defining an empirical equation with a slightly lower slope (i.e. lower temperature sensitivity) than that of Ghosh et al. [3]. This empirical calibration significantly extends the calibration range of the clumped isotope thermometer to temperatures of $95^{\circ} \mathrm{C}$ and can be used to derive the oxygen isotope composition of travertine-depositing waters from ancient deposits to reconstruct glacial-interglacial variations in meteoric water compositions and the paleohydrological regimes of the study areas.

\title{
References
}

1. McCrea, J. M. Journal Chem. Physics, 18, pp. 849-857, 1950.

2. Kim, S-T., O’Nei,1 J.R. Geochim. Cosmochim. Acta, 61, pp. 3461-3475, 1997.

3. Ghosh, P. et al. Geochim. Cosmochim. Acta 70, pp. 1439-1456, 2006.

4. Eiler, J. M. Earth Planet. Sci. Lett. 262, pp. 309-327, 2007.

5. Schmid, T.W., Bernasconi, S. M. Rapid Commun. Mass Spec., 24, pp. 1955-1963, 2010.

6. Huntington, K. W. et al. J. Mass. Spectrom. 44, pp. 1318-1329, 2009.

7. Dennis, K. J. et al. Geochim. Cosmochim. Acta 75, pp. 7117-7131, 2011.

\section{1 - EXPERIMENTAL SCALES AS A FACTOR FOR COPPER ISOTOPE FRACTIONATION IN PLANTS}

\author{
Nathalie Pérez Rodríguez ${ }^{1}$ - Aurora Neagoe ${ }^{2}$ - Björn Öhlander ${ }^{1}$ \\ ${ }^{1}$ Department of Civil, Environmental and Natural Resources Engineering, \\ Luleå University of Technology, Luleå, Sweden \\ ${ }^{2}$ Research Centre for Ecological Services (CESEC), University of Bucharest, \\ Bucharest, Romania \\ * e-mail: nathalie.perez@1tu.se
}




\section{Background}

Within the studies of the geochemical cycle of metals, an important process is the plant metabolism that involves metals such as $\mathrm{Fe}$ and $\mathrm{Cu}$. Through biogeochemical activity, $\mathrm{Fe}$ and $\mathrm{Cu}$ are remobilised from soils in a series of redox transformations in the rhizosphere and inside the plant.

$\mathrm{Fe}$ and $\mathrm{Cu}$ isotope fractionation can occur during redox transformations, as a product of biotic [1] and non-biotic processes [2]. Among the biotic processes, the uptake and translocation by higher plants can produce an isotope shift for $\mathrm{Cu}$ similar to abiotic processes such as mineral precipitation [3] and metal sorption into minerals [4].

The study of the fate of heavy metals in former mine dumps is especially relevant. The process of Acid Mine Drainage (AMD) takes place preferably in tailings (the milled sulphide material from ores, often left exposed to weather) which is an essential during the decommission and remediation of mine sites. Due to successive oxidation of sulphide-bearing minerals such as pyrite, AMD leads to a low $\mathrm{pH}$ and high concentration of metals such as $\mathrm{Fe}$ and $\mathrm{Cu}$ in groundwater and stream waters. One of the remediation techniques relies on avoiding the oxidation of sulphide minerals within the tailings. Phytoremediation is a well-known treatment for contaminated soils, in which a well-balanced interaction between soil, bacteria and plants can lead to successful outcomes [5].The extraction of heavy metals by plants in polluted sites is the main aim of phytoremediation. Furthermore, a vegetation cover can act as a barrier that hinders the circulation of dissolved oxygen to the unoxidized layers of tailings, thereby avoiding AMD. Most of these techniques have been experimented with at different scales, but how can the dimensions of the test sites and its intrinsic parameters actually affect the isotopic ratio in a system? How accurate are our determinations regarding indoor and outdoor variables?

\section{Study Site}

The Valea Mică tailings pond is the product of the removal of material from the primary flotation of poly-metallic minerals $(\mathrm{Cu}, \mathrm{Pb}$, and $\mathrm{Zn})$ originated from the ZlatnaStănija deposits (Romania). A large heterogeneity is found along the tailings surface regarding metal distribution and $\mathrm{pH}$ among other parameters.

\section{Methods}

In this study a lysimeter experiment was carried out. The upper part was filled with a mixture of tailings substrate from the Valea Mică pond and 30\% compost, and seeded with Agrostis capillaris. Secondly, field samples were taken from the Valea Mică tailings pond where pioneer plants (Agrostis c.) were growing at its border. For all experiments and sample points soils, as well as underground and aboveground plant material were collected. The soil and plant samples were analyzed for their $\mathrm{Cu}$ isotope concentration using a multi-collector inductively coupled plasma-mass spectrometer 
(MC-ICP-MS) in medium resolution mode. Analytical procedure is specified in detail in [2].

\section{Results and analysis}

Results show that in the lysimeter and field samples the overall trend indicates an enrichment of the lighter $\mathrm{Cu}$ isotope from the soil to the plant material (Fig. 1). Small variations in the different scale setups can be observed. The main difference arises in the isotopic shift from soil to roots in both site samples. A higher amount of organic material in the substrate -as in the lysimeter experiment- can cause formation of $\mathrm{Cu}$ complexes with humic substances which get enriched in the heavier $\mathrm{Cu}$ isotope [6]. Due to this fractionation process the available $\mathrm{Cu}$ pool in the substrate is enriched in the lighter $\mathrm{Cu}$ isotope which is then taken up by the plant.

In the field samples, the presence of organic material in the substrate is less than in the lysimeters, as it was observed during the sampling session. However, once the uptake process occurred, the translocation in the plants leads to a similar isotope signature. The latter can be interpreted that regardless which substrate is used, the translocation processes will not significantly affect the isotopic distribution of $\mathrm{Cu}$. The main isotopic shift follows in the rhizosphere system and during later uptake. Microbial activity can also contribute, but could not be proven in this study.

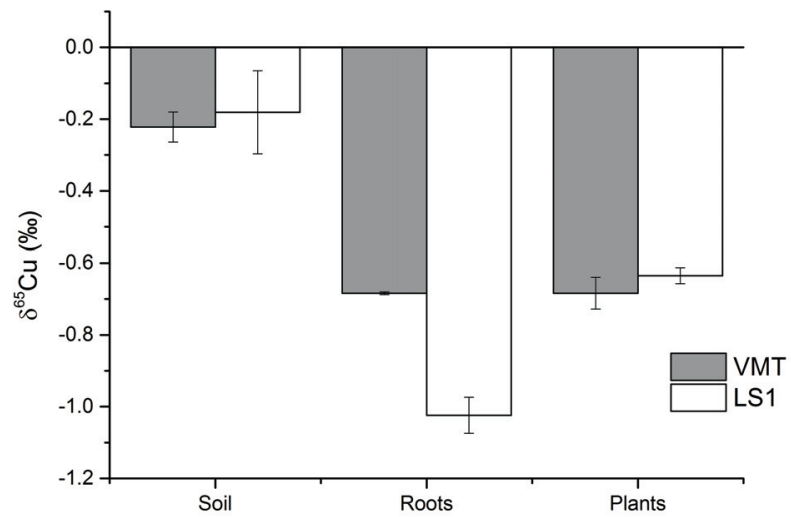

Figure 1. Isotopic variations between soil, roots and aboveground material (plant) in the lysimeter experiment (LS1) and the Vale Mică tailings pond (VMT). Error bars represent $2 \sigma$

\section{Conclusions}

When we express the scale of the experiment, we also talk about the different variables that affect the metal uptake in such systems. Metal-organic complexation can lead to an appreciable $\mathrm{Cu}$ isotopic shift during plant uptake. Also, atmospheric variables and the competence for nutrients available in the substrate are factors to be considered when extrapolating results from small to medium and big scales. 


\title{
References
}

1. Navarrete, J.U., Borrok, D.M., Viveros, M. and Ellzey, J.T. Copper isotope fractionation during surface adsorption and intracellular incorporation by bacteria. Geochim. Cosmochim. Ac., 75, pp. 784-799, 2011.

2. Pérez Rodríguez, N., Engström, E., Rodushkin, I., Nason, P., Alakangas, L. and Öhlander, B. Copper and iron isotope fractionation in mine tailings at the Laver and Kristineberg mines, northern Sweden. App. Geochem., 32, pp. 204-215, 2013.

3. Ehrlich, S., Butler, I., Halicz, L., Rickard, D., Oldroyd, A. and Matthews, A. Experimental study of the copper isotope fractionation between aqueous $\mathrm{Cu}$ (II) and covellite, $\mathrm{CuS}$. Chem. Geol., 209, pp. 259-269, 2004.

4. Pokrovsky, O.S., Viers, J., Emnova, E.E., Kompantseva, E.I. and Freydier, R. Copper isotope fractionation during its interaction with soil and aquatic microorganisms and metal oxy(hydr) oxides: Possible structural control. Geochim. Cosmochim. Ac., 72, pp. 1742-1757, 2008.

5. Glick, B.R. Using soil bacteria to facilitate phytoremediation. Biotech. Adv., 28, pp. 364-374, 2010.

6. Bigalke, M., Weyer, S. and Wilcke, W. Copper isotope fractionation during complexation with insolubilized humic acid. Environ. Sci. Technol., 44, pp. 5496-5502, 2010.

\section{2 - Pb-Zn-Cd-Hg MULTI ISOTOPIC CHARACTERIZATION OF THE LOIRE RIVER BASIN, FRANCE}

\author{
R. Millot ${ }^{1}-$ A.M. Desaulty ${ }^{1}-$ D. Widory ${ }^{2}-C$. Guerrot $^{1}-C$. Innocent ${ }^{1}-$ \\ J. Gattacceca ${ }^{1}-$ X. Bourrain ${ }^{3}-$ G. Bartov ${ }^{4}-$ T.M. Johnson ${ }^{4}$ \\ ${ }^{1}$ BRGM, Laboratory Division, Orléans, France; e-mail: r.millot@brgm.fr \\ ${ }^{2}$ UQAM/GEOTOP, Earth and Atmosphere Sciences Dept., Montréal, Canada \\ ${ }^{3}$ Agence de l'Eau Loire Bretagne, Orléans, France \\ ${ }^{4}$ University of Illinois, Department of Geology, Urbana, IL, USA
}

Introduction: The impact of human activities such as industries, agriculture and domestic inputs, becomes more and more significant on the chemical composition (major ions and pollutants including metals) of the dissolved load of rivers in addition with natural inputs. Furthermore, this influence can also be evidenced in the suspended solid matter known to play a major role in the transport of heavy metals through river systems. Human factors act as an additional key process. Therefore the mass-balance for the budget of catchments and river basins includes anthropogenic disturbances.

Here we are reporting concentration and isotope data for heavy metals zinc $(\mathrm{Zn})$, cadmium $(\mathrm{Cd})$, lead $(\mathrm{Pb})$ and mercury $(\mathrm{Hg})$ in river waters and suspended sediments from the Loire River Basin. In addition, we also report concentration and isotope data for these metals for the different anthropogenic sources within the Loire Basin, as well as data for biota samples such as mussels and oysters from the Bay of Biscay and North Brittany, these organisms are known to be natural accumulators of metal pollutants.

Results: The Loire River in Central France is approximately $1010 \mathrm{~km}$ long and drains an area of $117,800 \mathrm{~km}^{2}$. Upstream, the Loire River flows south to north from the 
Massif Central down to the city of Orléans, $650 \mathrm{~km}$ from its source. The Loire River is one of the main European riverine inputs to the Atlantic Ocean. Over time, its basin has been exposed to numerous sources of anthropogenic metal pollutions, such as metal mining, food industry, agriculture and domestic inputs. The Loire River basin is thus an excellent study site to develop new isotope systematics for tracking anthropogenic sources of metal pollutions.

We have chosen to analyse the isotope composition of $\mathrm{Cd}, \mathrm{Zn}, \mathrm{Hg}$ and $\mathrm{Pb}$. These heavy metals have been selected for their toxicity, even at low levels, to humans. The main goal of this study is to characterize 1) the sources and behaviour of these heavy metals in the aquatic environment, and 2) their spatial distribution using a multi-isotope approach. Sources responsible for the release of $\mathrm{Pb}-\mathrm{Zn}-\mathrm{Cd}-\mathrm{Hg}$ in the Loire basin were sampled and analysed for their concentrations and corresponding isotope compositions. We also analysed river waters, suspended solids samples and biota samples (mussels, oysters).

All trace elements were analysed in the BRGM laboratories using a Q-ICPMS. $\mathrm{Pb}-\mathrm{Zn}-\mathrm{Cd}$ isotope compositions were measured using a Neptune MC-ICPMS at the BRGM. Hg isotope compositions were measured at the University of Illinois using a $\mathrm{Nu}$ Plasma MC-ICPMS. To analyse $\mathrm{Zn}$ and $\mathrm{Cd}$, we carried out a two-steps analytical development: 1) a chromatographic separation, followed by 2) analysis on the MC-ICPMS.

Each of these isotope systematics on their own reveals important information about their geogenic or anthropogenic origin but, considered together, provide a more integrated understanding of the budgets of these pollutants within the Loire River Basin.

Acknowledgments: We would like to thank the IFREMER (French Oceanographic Institute) for providing biota samples and we also cordially thank AMP (Analyses Mesures Pollution) for their help during the sample collection of suspended sediments.

\section{3 - MONITORING OXIDATION OF BTEX BY PERSULFATE IN GROUNDWATER USING STABLE ISOTOPES}

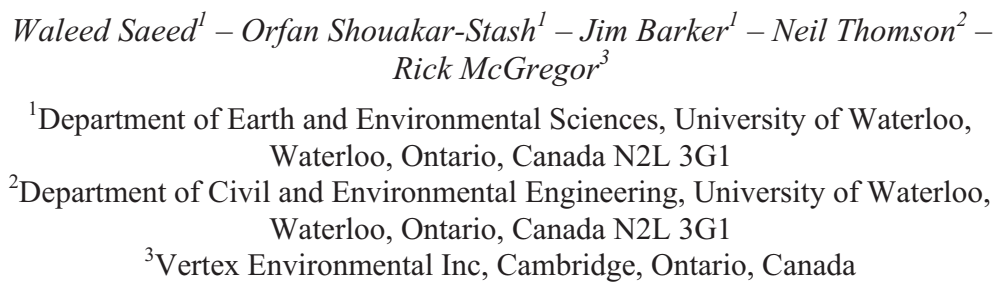

A bench top batch experiments were carried out to investigate the usefulness of compound-specific carbon and hydrogen stable isotope analyses in assessing the effective- 
ness of persulfate (PS) as an oxidation agent to remediate petroleum hydrocarbons in saline environments at elevated groundwater temperatures.

The conducted chemical oxidation experiments of Benzene, Toluene, Ethylbenzene, $\rho$-Xylenes and o-Xylenes by non-activated PS at $30^{\circ} \mathrm{C}$, showed significant carbon isotope fractionations with isotope enrichment factors of $-2.0 \%,-1.6 \%$, $-1.6 \%,-0.6 \%$ and $-1.4 \%$, respectively. Similar results were observed with the alkaline-activated PS experiment and the following carbon enrichment factors were determined of Benzene, Toluene, Ethylbenzene, $\rho$-Xylenes and o-Xylenes $-2.0 \%,-1.2 \%$, $-1.1 \%,-0.4 \%$ and $-1.3 \%$, respectively.

In contrast, chemical oxidation by PS was associated with insignificant hydrogen isotope fractionations. The following isotopic enrichment factors: $-10.9 \%$, $-6.6 \%,-2.5 \%,-5.6 \%$ and $-9.4 \%$ were determined for Benzene, Toluene, Ethylbenzene, $\rho$-Xylenes and o-Xylenes, respectively. Similar results were observed during the alkaline-activated PS experiment and the following hydrogen enrichment factors were determined for Benzene, Toluene, Ethylbenzene, $\rho$-Xylenes and o-Xylenes: $-10.6 \%,-6.4 \%,-2.1 \%,-7.4 \%$ and $-7.1 \%$, respectively.

Two-dimensional isotope fractionations were calculated and $\wedge$ values were determined. The obtained $\wedge$ values from the non-activated PS experiment are 5.5, 4.1, 1.6, 9.3, and 6.7 for Benzene, Toluene, Ethylbenzene, $\rho$-Xylene and o-Xylene, respectively. Nearly identical results were observed from the alkaline-activated PS experiment where the $\wedge$ values are found to be 5.3, 5.3, 1.9, 18.5, and 5.5 for Benzene, Toluene, Ethylbenzene, $\rho$-Xylenes and o-Xylenes, respectively. The data obtained from these experiments demonstrated the potential of utilizing two-dimensional isotope analyses approach in differentiating transformation pathways of petroleum hydrocarbons such as chemical oxidation and biodegradation.

\section{4 - HYDROGEOCHEMICAL AND ISOTOPIC ASSESSMENT OF SEAWATER INTRUSION INTO ALLUVIAL AQUIFERS IN THE WESTERN ALGIERS COASTAL AREA (TIPASA, ALGERIA)}

\footnotetext{
A.S. Moulla ${ }^{1}-$ A. Guendouz ${ }^{2}-$ M. Belaidi ${ }^{3}-H$. Maamar $^{3}-$ S. Ouarezki ${ }^{1}$

${ }^{1}$ Dating \& Isotope Tracing Dept., Algiers Nuclear Research Centre, P.O Box 399, Alger-RP, Algiers, 16000, Algeria; e-mail: asmoulla@gmail.com

${ }^{2}$ Blida University, Engineering and Science Faculty, BP-270, Soumaa, Blida, Algeria

${ }^{3}$ National Agency for Water Resources, ANRH-DRC, Soumaa, Blida, Algeria
}

Western Algiers coastal region that extends up to the city of Tipasa is known for both tourists and agricultural vocations. It is composed of three alluvial valleys, namely Wadi El-Hachem, Wadi Mazafran and Wadi Nador. These three small catchments being exorheic, the alluvial aquifers that they host are thus very likely to be subjected to a saline hazard through seawater encroachment. Besides industrial and agricultural de- 
velopments, unrestrained demographic growth has induced important needs for freshwater. Unfavourable climatic conditions causing long period droughts have predictably led to a contamination of coastal groundwaters along the Mediterranean by ingressive seawater. Intensive pumping practices in use for the sake of securing water allocation for both populations and agriculture have drastically affected the groundwater reserves through overexploitation of the resource creating a consequent drawdown in the water table. During the dry season, the mobile fresh/sea water interface moves forward farther inland contaminating wells and boreholes. Two out of the three valleys that are present in the investigated sector were targeted by the present study. Two approaches making use of both hydrochemical and isotopic tools were applied to assess the extent of seawater intrusion. For Wadi Nador, the $\mathrm{Br}$ vs. Cl plot showed that the points align in a parallel way to seawater dilution line confirming thus a marine origin for those elements. $\mathrm{Na} / \mathrm{Cl}$ ratio vs. $\mathrm{Cl}$ plot brings to the fore two poles of points: one composed of shallow unaffected groundwater and a second one composed of deeper boreholes and wells for which seawater is present to different extents. This is further confirmed by isotopes which exhibited a wide range of values mirroring the affected and the unaffected areas as well as those points submitted to intermingling between different end-members.

\title{
075 - PALAEOCLIMATIC IMPLICATIONS AND STABLE ISOTOPIC COMPOSITION OF QUATERNARY KOCABAŞ TRAVERTINE OUTCROPS, DENIZLI, SW TURKEY
}

\author{
Ezher Toker ${ }^{l}-$ M. Sezgül Kayserý-Özer ${ }^{2}-$ Mehmet Özkul $^{l}-$ Sandor Kele $^{3}$ \\ ${ }^{1}$ Pamukkale University, Geology Engineering Department, 20017, Kinikli/Denizli, Turkey; \\ e-mail: egulbas@pau.edu.tr \\ ${ }^{2}$ Dokuz Eylül University, Geology Engineering Department, Buca/İzmir,Turkey \\ ${ }^{3}$ Institute for Geological and Geochemical Research, Research Centre for Astronomy and \\ Earth Sciences, Hungarian Academy of Sciences, Budaörsi u. 45, H-1112 Budapest, Hungary
}

In this study, it has been investigated of the palaeoclimatic conditions using stable carbon and oxygen isotopes of Late Pleistocene travertine deposits precipitated in a depressional depositional system. Study area is located between Kocabaş and Gürlek villages approximately $35 \mathrm{~km}$ northeast of Denizli (SW-Turkey) which is most popular travertine occurrences in the world such as Pamukkale (Cotton castle). The main goal of this study, to reconstruct the palaeoenvironmental and palaeoclimatic evolutions using radiometric dating, stable isotopes and pollen evidences of the Late Quaternary travertines. For this aim, it has been collected systematically rock samples for $\mathrm{U} / \mathrm{Th}$ dating, stable isotopic analysis and claystone, mudstone samples for palynological analysis from travertine outcrops. Furthermore, depositional system, sedimentary facies and lithotypes have been described and identified according to de- 
tailed observations from field work. Kocabaş travertines have been precipitated in depression depositional system such as lake or pool and this system consists of flat pool, marsh-pool and shrub flat facies. In addition, Kocabaş travertines which are studied have been classified into seven lithotypes and one erosional horizon, based on depositional features such as colour, bedding, lamination, and fossil content. These are namely: laminated, coated bubble, reed, paper-thin raft, intraclasts, micritic travertine with gastropods, extra formational pebbles and paleosol layer. Besides, 13 travertine samples have been analyzed U/Th dating and absolute ages shows that travertine occurrence has commenced to precipitate from $181.267 \mathrm{kyr}$ (MIS 6) to $85.512 \mathrm{kyr}$ (MIS 4) and these ages indicate that travertine outcrop deposited during a series of climatic changes including glacial and interglacial intervals. Moreover, the stable isotope analyses were performed on 60 travertine samples and $\delta^{13} \mathrm{C}$ and $\delta^{18} \mathrm{O}$ values change between $1.1 \%$ to $2.6 \%$ and $-6.4 \%$ to $-10.4 \%$, respectively. According to isotopic results, $\delta^{18} \mathrm{O}$ values show significant fluctuations reflected warm and cold periods among MIS 6 (glacial), MIS 5 (interglacial) and MIS 4 (glacial). The $\delta^{13} \mathrm{C}$ values indicate that the waters of the depositional environment were mainly thermal in origin what were occasionally mixed with meteoric water. 76 samples collected from paleosols for palynological analysis and 150 individual palynomorphs were counted. It can be clearly said that abundance of the NAP percentage and xerophytic plant (e.g. Poaceae, Asteraceae, Oleaceae and Quercus evergreen type) indicates drought, on the other hand presence of Isoetes indicates summer dryness and wet winters. MIS 6 is represented by C4-plants (grassland species and straws), while MIS 5 is represented by C3-plants (e.g. Pinaceae, Quercus, Abies). Stratigraphical and sedimentological data have shown that Kocabaş travertine development was mostly controlled by fault-related movements such as other travertine outcrops in western Turkey. Based on the good correlation among stratigraphical, sedimentological, isotopic and palynological data, provides a detailed reconstruction of travertine evolution, which can

serve as a base for further palaeoclimatic and palaeoenvironmental studies in SW-Turkey and can be used for international comparison as well.

Keywords: Kocabaş travertines, travertine lithotypes, stable isotopes, pollen analysis, dating, palaeoclimate, Late Pleistocene, SW Turkey

\section{6 - LATE HOLOCENE PRODUCTIVITY IN THE SOUTHEAST BRAZILIAN CONTINENTAL SHELF}

Bruna B. Dias - Leandro Galliza - Cátia F. Barbosa-Ana Luiza S. Albuquerque

Departamento de Geoquímica, Universidade Federal Fluminense,

Outeiro de São João Batista, s/n, Niterói, RJ. Brazil; e-mail: diasbb@hotmail.com 


\section{Introduction}

The Holocene was marked by an instable climate suggesting $1.5 \mathrm{kyr}$ cyclicity. Millennial-scale oscillations are observed as consequence of cool and ice-bearing water from Iceland into North Atlantic [1]. According to some models [2, 3], a freshening increase turn the South Atlantic warm and changed South America and Africa precipitation. South Atlantic heating shifts the Intertropical Convergence Zone (ITCZ) southward, intensifying the precipitation and NE winds. Thus, high latitudes changes modify significantly the tropics climate as observed in Holocene grain size variation at the Brazilian shelf [4]. Millennial-scale oscillations in oceanographic processes as bottom currents and productivity, have not yet been explained and this motivates the development of this research.

Cabo Frio shelf actually is a distinct environment due to different oceanographic, geomorphologic and climatic features. A high primary productivity also differs from the oligotrophic coast due to the coastal upwelling. Cold and nutritive water from upwelled South Atlantic Central Water (SACW) increase the productivity and under the occurrence of NE winds moves surface waters cross-shelf, besides other factors that are important to upwelling occurrence. Cabo Frio is also marked by an abrupt coastline change NE-SW to E-W, a narrow shelf width and is a site where the Brazil Current (BC) is rotated cyclonic near the shelf break and originates meanders [5] and vortices. These NE winds associated with the ITCZ southward displacement generate meanders and increase the coastal upwelling productivity. The $\mathrm{BC}$ is pushed down and the offshore bottom waters upwelled may be mixed in SACW and Tropical Water (TW) increasing the productivity.

This work aim to apply $\delta^{18} \mathrm{O}$ and $\delta^{13} \mathrm{C}$ isotopes associated with the biometry of benthic foraminifera to define bottom water masses and paleoproductivity oscillations along the Late Holocene in order to understand the variability of this oceanographic process in southeast Brazilian coast.

\section{Materials and Methods}

In Cabo Frio continental shelf, southeast Brazil, the predominant current is the $\mathrm{BC}$, which transport TW with temperature between $18-27^{\circ} \mathrm{C}$ and $36-37.3$ salinity [6]. This current flows to the south until it meets the Malvinas Current in Brazil-Malvinas Confluence region, where $\mathrm{SACW}$ is produced with $6-18^{\circ} \mathrm{C}$ temperature and $34,5-36,0$ salinity $[5,7,8]$. By density difference the SACW flows northward inversely to BC. The SACW in Cabo Frio occupy bottom waters and under strong NE winds conditions (summer) SACW can be pushed up by Ekman effect.

Under $128 \mathrm{~m}$ of water column dominated by these oceanographic features $386 \mathrm{~cm}$ of sediment was recovered in the core CF10-01B at $23^{\circ} 24^{\prime} 67^{\prime \prime}-41^{\circ} 30^{\prime} 38^{\prime \prime}$ (Fig. 1). A chronological model was created through the radiocarbon dating of 20 samples of organic matter. The first $100 \mathrm{~cm}$ of the bottom was analyzed every $2 \mathrm{~cm}$ to determine the isotopic and paleoecological composition of benthic foraminifera. The test 
size of 30 specimens of Globocassidulina subglobosa and Uvigerina peregrina (indicators of TW and SACW, respectively) was determinate in each sample to infer fluctuations in the paleoproductivity. At least 15 specimens larger than $150 \mu \mathrm{m}$ was cleaned on ultrason in methanol and analyzed in Optima IRMS at Stable Isotope Laboratory, University of California to determine $\delta^{18} \mathrm{O}$ composition of Cibicides sp. and $\delta^{13} \mathrm{C}$ composition of $U$. peregrina.

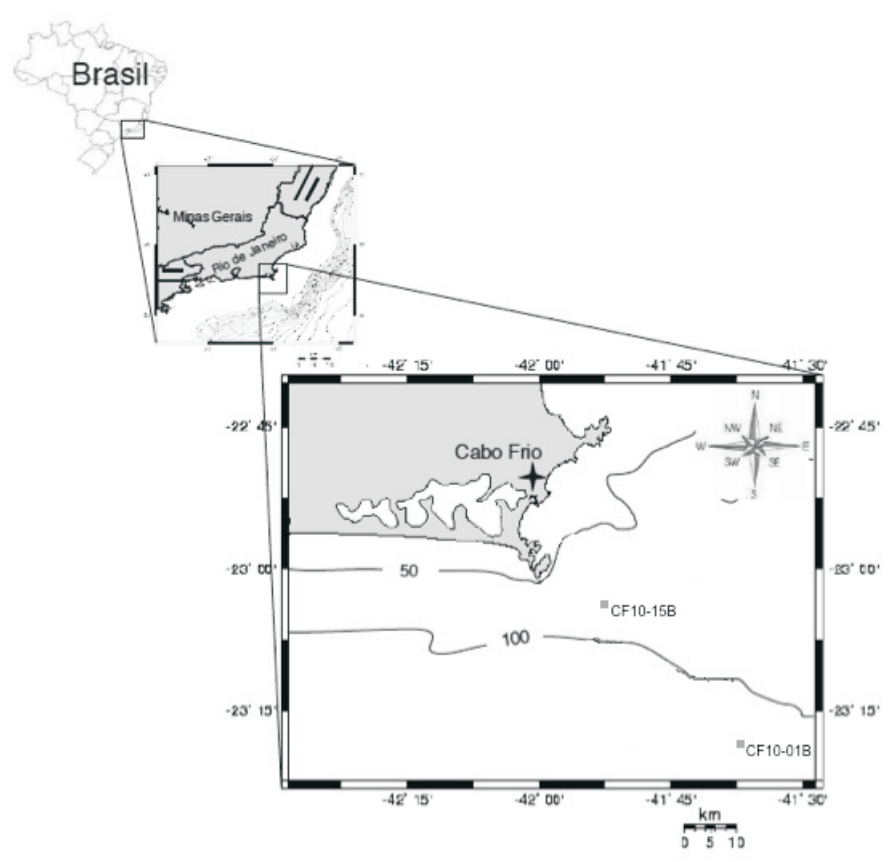

Figure 1. Cabo Frio region and offshore location of CF10-01B core

\section{Results and Discussion}

The $\delta^{13} \mathrm{C}$ results showed two distinct phases in the late Holocene: Phase 1 with low ratio (values ranging among 0.0 to $0.2 \%$ ) until $2.8 \mathrm{kyr}$ and Phase 2 with an increase of $\delta^{13} \mathrm{C}(-0.11$ to 0.37$)$ between $2.8-0.8 \mathrm{kyr}$ (Fig. 2). These results indicate a constant productivity increase since the last $2.8 \mathrm{kyr}$ as a result of upwelling intensification. Paleobiological biometry analysis is in accordance with $\delta^{13} \mathrm{C}$ showing major sizes of G. subglobosa and U. peregrina during this upwelling intensification in Cabo Frio (Fig. 3). The increase in accumulation of organic matter induces the reproduction and size of benthic species, reaffirming an intensification of upwelling process toward the recent in the last $2.8 \mathrm{kyr}$.

The variability showed by $\delta^{18} \mathrm{O}$ indicates a SACW constantly present in bottom waters but with an influence of surface waters during some periods. $\delta^{18} \mathrm{O}$ variation 


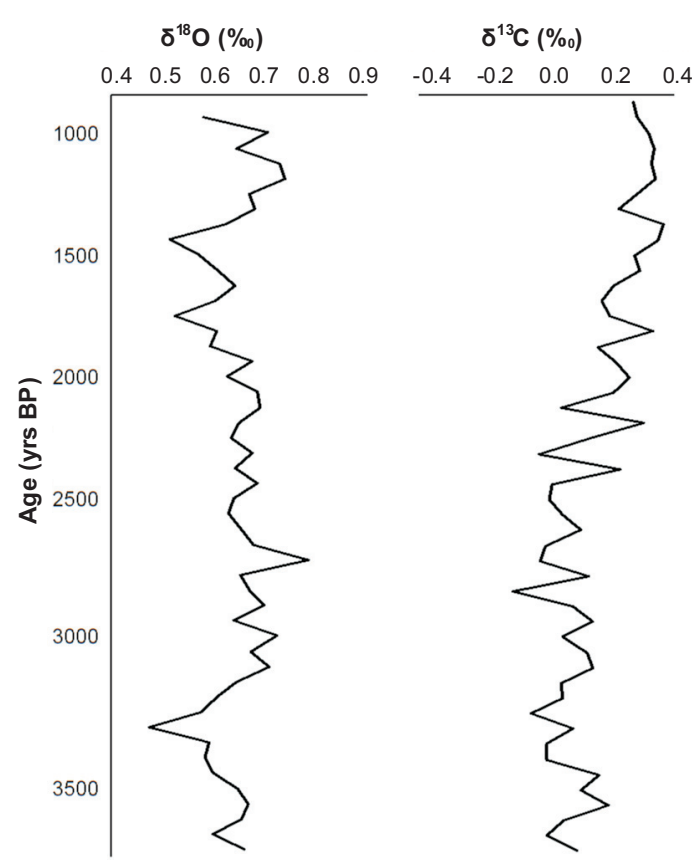

Figure 2. Late Holocene variations of $\delta^{13} \mathrm{C}$ and $\delta^{18} \mathrm{O}$ of Uvigerina peregrina and Cibicides sp., respectively

showed a raging between 0.5 and 0.8 (Fig. 2) and four periods was determined: two with low positive values (1.5-1.9 kyr and 3.2-3.7 kyr) and another two with high positive values (1.0-1.4 kyr and 2.0-3.2 kyr). These results represent different bottom condition in the shelf. More negative values may be related to SACW intensification by Ekman process (values between 0.47-0.60). High positive values may be related to a mix of SACW and TW in the bottom (values between 0.60 and 0.78 ). This interpretation is based on recent $\delta^{18} \mathrm{O}_{\mathrm{w}}$ of SACW and TW in Cabo Frio, where SACW presents lower values than TW $(0.41 \pm 0.23$ and $0.95 \pm 0.05$, respectively) probably as a result of biological activity and air-sea exchange in the upper mass [6]

The test size of G. subglobosa was negatively correlated to $\delta^{18} \mathrm{O}$ as expect. This species is a TW indicator and the smallest sizes were found in TW+SACW conditions as a response of productivity pulses generated by vortices that can push down surface waters [9] increasing the productivity generated by Ekman process. This productivity process occurs under strong winds conditions as a response of South Atlantic gyre intensification and ITCZ displacement in a millennial time scale oscillation during the late Holocene. This variability was currently identified based on grain size records along the Mid- to Late Holocene in southeastern Brazil [4]. Now it is corroborated based on waters dynamics and productivity of Cabo Frio shelf in the late Holocene. 


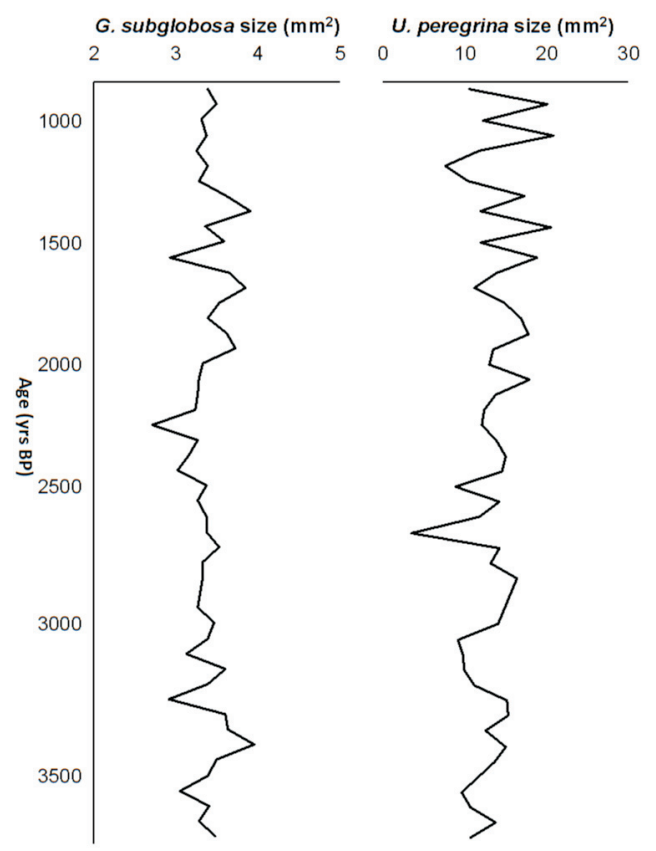

Figure 3. Test size variation of G. subglobosa (TW indicator) and U. peregrina (SACW indicator) during the Late Holocene at Cabo Frio continental shelf

The approach integrating $\delta^{13} \mathrm{C}$ and $\delta^{18} \mathrm{O}$ isotopes and biometry showed an intensification of upwelling process in the last $2.8 \mathrm{kyr}$ in Cabo Frio shelf and a millennial-scale variability along the late Holocene. Future studies will determine the occurrence of millennial-scale oscillation along Mid- and Early Holocene in the region.

\section{References}

1. G. Bond, W. Showers, M. Cheseby, R. Lotti, P. Almasi, P. de Menocal, P. Priore, H. Cullen, I. Hajdas and G. Bonari, A pervasive millennial-scale cycle in North Atlantic Holocene and glacial climates. Science, 278, pp. 1257-1266, 1997.

2. M. Vellinga and R.A. Wood, Global climatic impacts of a collapse of the Atlantic Thermohaline Circulation. Climatic Change, 54, pp. 251-267, 2002.

3. K.A. Dahl, A.J. Broccoli and R.J. Stouffer, Assessing the role of North Atlantic freshwater forcing in millennial scale climate variability: a tropical Atlantic perspective. Clim. Dynam., 24, pp. 325-346, 2005.

4. R. Gyllencreutz, M.M. Mahiques, D.V.P. Alves and I.K.C. Wainer, Mid- to late-Holocene paleoceanographic changes on the southeaster Brazilian shelf based on grain size records. Holocene, 20, pp. 863-875, 2010.

5. I.C.A. Silveira, A.C.K. Schmidt, E.J.D. Campos, S.S. Godoi and Y. Ikeda, A Corrente do Brasil ao largo da costa leste brasileira. Rev. Bras. Oceanog., 48, pp. 171-183, 2000.

6. C. Pierre, C. Vergnaud-Grazzini and J.C. Faugeres, Oxygen and carbon stable isotopes traces of the water masses in the Central Brail Basin. Deep-Sea Res., 38, pp. 597-606, 1991. 
7. A.L. Gordon, South Atlantic thermocline ventilation. Deep-Sea Res., 28A, pp. 1239-1264, 1981.

8. L. Memery, M. Arhan, X.A. Alvarez-Salgado, M.J. Messias, H. Mercier, C.G. Castro and A.F. Rios, The water masses along the western boundary of the south and equatorial Atlantic. Prog. Oceanogr., 47, pp. 69-98, 2000.

9. L. Calado, A. Gangopadhyay and I.C.A. Silveira, A parametric model for the Brazil Current meanders and eddies off Southeastern Brazil. Geophys. Res. Lett., 33, p. 12602, 2006.

\title{
078 - NITRATE AND SULFATE ISOTOPES IN THE GROUNDWATER OF THE SANDY HALTERN FORMATION (GERMANY) TO INVESTIGATE NITRATE REDUCTION PROCESSES
}

\author{
Frank Wisotzky ${ }^{l}$ - Martin Leson ${ }^{2}-$ Andre Banning $^{l}$ \\ ${ }^{1}$ Hydrogeology Department, Ruhr-University Bochum, 44801 Bochum, Germany; \\ e-mails: frank.wisotzky@rub.de; andre.banning@rub.de \\ ${ }^{2}$ FEhS - Institut für Baustoff-Forschung e.V., 47229 Duisburg-Rheinhausen, Germany; \\ e-mail:m.leson@fehs.de
}

\section{Introduction}

With a thickness of up to $300 \mathrm{~m}$, the sandy aquifer of the Haltern Formation is one of the most important drinking water resources in north-west Germany (NRW). Six water works extract around 53 Mio. $\mathrm{m}^{3}$ a year of groundwater and deliver drinking water to around 4 Mio. costumers. Five of these catchment areas were investigated in this study. Due to the intensive agricultural land use a strong nitrate input into the shallow groundwater occurs and leads to significantly increasing nitrate concentrations in the shallow groundwater. There, the nitrate concentrations are often between 50 and $200 \mathrm{mg} / \mathrm{l}$ and thus above the legal limit for drinking water $(50 \mathrm{mg} / \mathrm{l})$. The filter screens of the abstraction wells are situated in the deeper part of the Cretaceous aquifer ( $25 \mathrm{~m}-$ $140 \mathrm{~m}$ below ground level). The deep groundwater of the wells displays lower nitrate concentrations of up to a maximum of $30 \mathrm{mg} / \mathrm{l}$. Due to groundwater recharge and groundwater abstraction a transport of the shallow groundwater to the deeper part of the aquifer occurs. To give a prediction of the development of the nitrate concentration in the wells (deep groundwater), it is necessary to know if the nitrate moves conservatively or is retarded while flowing from shallow to deep groundwater. The aim of this study was to investigate possible nitrate reduction processes and to make a prognosis concerning the development of the deep groundwater in the future.

\section{Methods}

Groundwater chemistry data from the last 20 years were displayed and analysed from five catchment areas. Rock samples from 4 deep drillings (in four different catchment areas) were analysed for parameters indicative for nitrate reduction processes. For the lithotrophic nitrate reduction, a reaction with the pyritic sulfur content releases sulphate and $\mathrm{N}_{2}$ as reaction products. The organotrophic nitrate reduction uses the organic 
carbon content of the aquifer as reducing agent. As reduction products, $\mathrm{N}_{2}$ and $\mathrm{CO}_{2}$ species are released into the groundwater. Three of the drilling holes were used to install multi-level-observation wells with at least 8 mini screens. The depth specific distribution of the groundwater chemistry was analysed in the installed multi-level-observation wells [1]. Additionally these water samples were used to analyse the nitrate and sulphate isotope signatures of the groundwater. We used $\delta^{15} \mathrm{~N}_{\mathrm{NO} 3}-$ and $\delta^{18} \mathrm{O}_{\mathrm{NO} 3}$ - to investigate the source of nitrate and the nitrate reduction processes in the aquifer. Additionally, the $\delta^{34} \mathrm{~S}_{\mathrm{SO} 4}$ and $\delta^{18} \mathrm{O}_{\mathrm{SO} 4}$ isotope signatures were measured to determine if lithotropic nitrate reduction happens, leading to sulphate release into the groundwater and thereby changing the isotope values of $\delta^{34} \mathrm{~S}_{\mathrm{SO} 4}$ and $\delta^{18} \mathrm{O}_{\mathrm{SO} 4}$.

\section{Results}

In all three multi-level-observation wells a decrease of the nitrate concentrations with increasing depth was analysed (Fig. 1). This decrease can result from a nitrate reduction in the deep groundwater of the aquifer, as one possibility. Another possibility is the increase of the groundwater age with depth. This can also lead to a mixture of shallow, young and nitrate rich groundwater with old nitrate free groundwater and probably produces the same distribution pattern (Fig. 1).
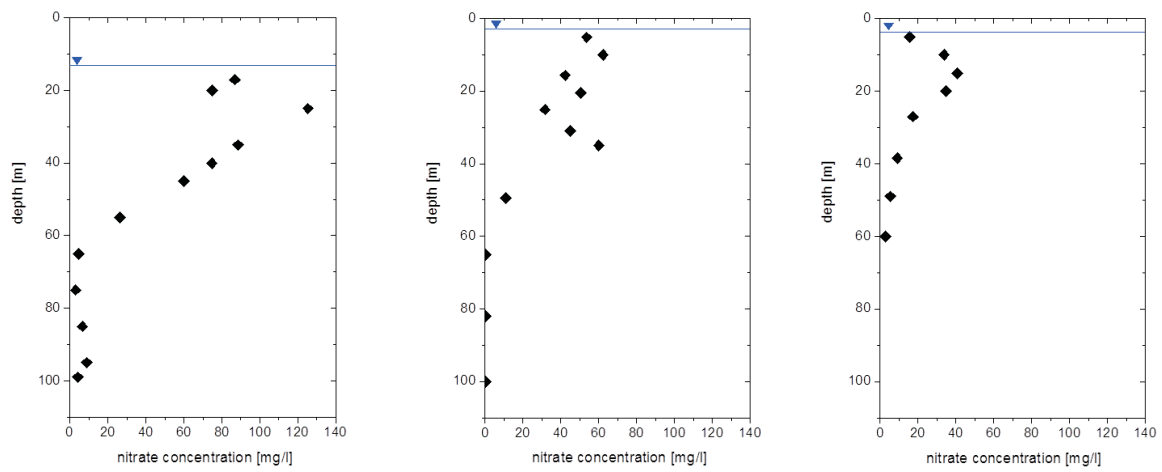

Figure 1. Depth specific distribution of nitrate in the groundwater of different multi-levelobservation wells (left: catchment 1; middle: catchment 2; right: catchment 3)

However, in the catchment area 1 no measurable pyritic-sulphur and no organic carbon content were analysed in nearly all the rock samples [1]. The measured isotope signature of the nitrate is displayed in Fig. 2 (left). In the isotope values no sustained trend is observed in the $\mathrm{d}^{15} \mathrm{~N}_{\mathrm{NO} 3}-$ and $\delta^{18} \mathrm{O}_{\mathrm{NO} 3}$ data. This indicates that no intensive nitrate reduction is responsible for the observed distribution pattern. Nitrate reduction should lead to increasing $\delta^{15} \mathrm{~N}_{\mathrm{NO} 3}$ - and $\delta^{18} \mathrm{O}_{\mathrm{NO} 3}$ isotope values with increasing depth, which is not observed (Fig. 2, left). The isotope values of nitrate in catchment area 1 are typical for nitrate from ammonia fertilizer, mineralization from the soil or nitrate 

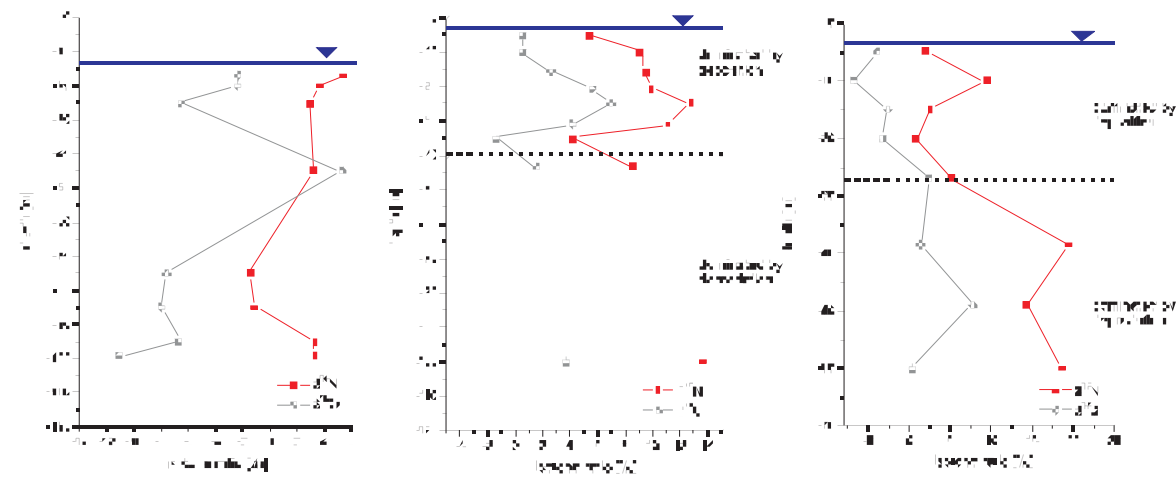

Figure 2. Depth specific distribution of $\delta^{15} \mathrm{~N}_{\mathrm{NO}^{-}}$and $\delta^{18} \mathrm{O}_{\mathrm{NO} 3}$-isotope values in the groundwater of different multi-level-observation wells (left: catchment 1; middle: catchment 2; right: catchment 3 )
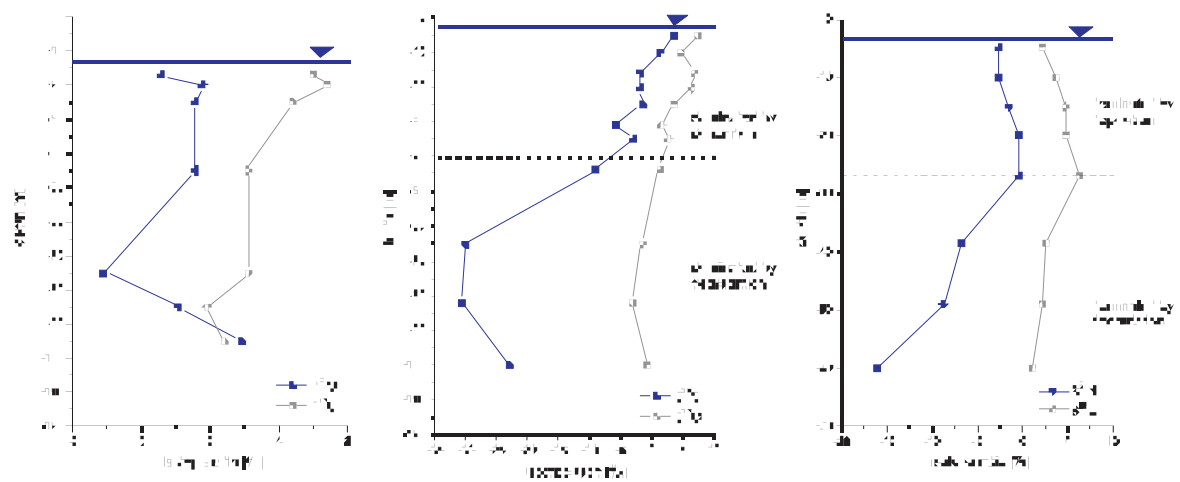

Figure 3. Depth specific distribution of $\delta^{34} \mathrm{~S}_{\mathrm{SO} 4}$ and $\delta^{18} \mathrm{O}_{\mathrm{SO} 4}$-isotope values in the groundwater of different multi-level-observation wells (left: catchment 1; middle: catchment 2; right: catchment 3)

from organic manure [2]. Summing up all data, the decrease of the nitrate concentration with depth is probably the result of an admixture of older deep groundwater with low nitrate concentrations in catchment 1 and not the result of nitrate reduction in the aquifer. In this catchment area 1 the nitrate is more or less transported conservatively and therefore not retarded by nitrate reduction.

In catchment area 3 a similar decrease of the nitrate concentration with increasing depth is observed (Fig. 1, right). However, with increasing depth, a sustained trend to heavier $\delta^{15} \mathrm{~N}_{\mathrm{NO}_{3}-}$ and $\delta^{18} \mathrm{O}_{\mathrm{NO} 3}$ isotope ratios is measured (Fig. 2, right). In the shallow groundwater up to $20 \mathrm{~m}$ below ground surface approximately comparable $\delta^{15} \mathrm{~N}_{\mathrm{NO}^{-}}$and $\delta^{18} \mathrm{O}_{\mathrm{NO} 3}$ isotope values were analyzed in the groundwater of this multi-level-observation well. In the deeper groundwater rising $\delta^{15} \mathrm{~N}_{\mathrm{NO}^{-}}$and $\delta^{18} \mathrm{O}_{\mathrm{NO} 3}-$ isotope values were found. This correlates with measurable and rising contents of pyritic sulfur and organic carbon below $20 \mathrm{~m}$ [1]. Together, this is interpreted as an evi- 
dence for nitrate reduction in the deeper part of catchment area 3 (Fig. 2, right) which causes decreasing nitrate concentrations in deep groundwater (Fig. 1, right). Therefore, a longer time for nitrate transport to the screen depth is expected in this catchment area 3 , because of nitrate retardation.

In catchment 2 also decreasing nitrate concentrations below $40 \mathrm{~m}$ are observed (Fig. 1, middle). In the shallow groundwater of catchment area 2 approximately equal $\delta^{15} \mathrm{~N}_{\mathrm{NO} 3}-$ and $\delta^{18} \mathrm{O}_{\mathrm{NO} 3}$ isotope values are found. Below $40 \mathrm{~m}$ the low nitrate concentrations did not enable nitrate isotope measurements with one exception $(100 \mathrm{~m}$ below ground surface).

Pyritic sulfur content measurements displayed differing values. However, in some depths pyritic sulfur was detected [1] and indicates the possibility of nitrate reduction at least in some depths of the aquifer in catchment area 2. Additionally, the $\delta^{34} \mathrm{~S}_{\mathrm{SO} 4}$ and $\delta^{18} \mathrm{O}_{\mathrm{SO} 4}$ isotope signatures were measured in the groundwater of the three catchment areas (Fig. 3). In catchment area 1 relatively homogeneous $\delta^{34} \mathrm{~S}_{\mathrm{SO} 4}$ - und $\delta^{18} \mathrm{O}_{\text {SO4 }}$ isotope values with increasing depth were analyzed (fig. 3, left). This is interpreted as missing lithotropic nitrate reduction, and no release of light ${ }^{32} \mathrm{~S}_{\mathrm{SO}^{-}}$and ${ }^{16} \mathrm{O}_{\mathrm{SO} 4}$-isotopes into the groundwater occurs in this catchment.

In contrast, a clear decrease of the $\delta^{34} \mathrm{~S}_{\mathrm{SO} 4^{-}}$and $\delta^{18} \mathrm{O}_{\mathrm{SO} 4}$-isotope values in the catchment areas 2 (below $40 \mathrm{~m}$ ) and 3 (below $27 \mathrm{~m}$ ) was found (Fig. 3 middle and right). This indicates that lithotropic nitrate reduction occurs in both catchments and release of light ${ }^{32} \mathrm{~S}_{\mathrm{SO} 4}{ }^{-}$and ${ }^{16} \mathrm{O}_{\mathrm{SO} 4}$ isotopes into the deep groundwater causes falling $\delta^{34} \mathrm{~S}_{\mathrm{SO} 4}$ and $\delta^{18} \mathrm{O}_{\mathrm{SO} 4}$ isotope values. These findings are supported by the observation of changing redox conditions at variable aquifer depth associated with sharp boundaries of rock composition and iron mineralogy (Fe-sulphidic in the lower part and Fe-hydroxidic in the upper part) in other areas of the Haltern Formation aquifer system [3].

In summary, the presented isotope data $\left(\delta^{15} \mathrm{~N}_{\mathrm{NO} 3}, \delta^{18} \mathrm{O}_{\mathrm{NO} 3}, \delta^{34} \mathrm{~S}_{\mathrm{SO} 4}\right.$ and $\left.\delta^{18} \mathrm{O}_{\mathrm{SO} 4}\right)$ together with conventional groundwater analyses and the measurement of reducing agents (pyritic sulfur, organic carbon) are necessary to characterize nitrate reduction processes in aquifers.

Acknowledgements. We thank Dr. Stephan Weise and Dr. Kai Knöller from Helmholtz centre for environmental research UFZ (Halle, Germany) for the isotope measurements. This study was financed by five water supplying companies from the "Arbeitsgemeinschaft der Wasserwerke Halterner Sande" (www.awhs.de).

\section{References}

1. Leson, M. and Wisotzky, F.: Hydrogeochemische Untersuchungen von Nitrateinträgen in das Grundwasser und möglichen Denitrifikationsprozessen. Grundwasser, Heft 17-2012, pp. 137-145, 2012.

2. Kendall, C. and McDonnell, J.J: Isotope tracers in catchment hydrology. Elsevier, 839 pp., 2000.

3. Banning, A., Rüde, T.R. and Dölling, B.: Crossing redox boundaries - Aquifer redox history and effects on iron mineralogy and arsenic availability. J. Hazardous Materials, 10 pp, 2012. 


\title{
080 - STABLE ISOTOPE GEOCHEMISTRY AND SM-ND, U-PB DATING OF SULPHIDES FROM LAYERED INTRUSIONS IN THE NORTHERN PART OF BALTIC SHIELD
}

\author{
M. Huber ${ }^{1}$ - S. Hałas $^{2}$ - P.A. Serov ${ }^{3}$ - N.A. Ekimova ${ }^{3}$ - T.B. Bayanova ${ }^{3}$ \\ ${ }^{1}$ Maria Curie-Skłodowska University, Electron and Optical Microscopy Laboratory, \\ Department of Geology and Lithosphere Protection, 2 cd Kraśnicka St., \\ 20-718 Lublin, Poland; e-mail: miloh@interia.pl \\ ${ }^{2}$ Maria Curie-Skłodowska University, Mass Spectrometry Laboratory, Institute of Physics, \\ Lublin, 1 M. Curie-Skłodowska Sq., 20-031 Lublin, Poland \\ ${ }^{3}$ GI KSC RAN, Apatity, Russia,e-mail: serov@geoksc.apatity.ru
}

We report new data on the $\delta^{34} \mathrm{~S}$ of sulfides from samples of layered intrusion rocks from the northern part of Baltic Shield. The selected ore minerals were analyzed with optical and electron microscopy (Hitachi SU6600 with EDS attachment) in the Electron and Optical Microscopy Laboratory, Maria Curie-Skłodowska University (total number of analysis was 488), whereas the $\delta^{34} \mathrm{~S}$ of sulfides was determined in the Mass Spectrometry Laboratory, Maria Curie-Skłodowska University. These samples were dated by the Sm-Nd method. This method has been described by Kong et al. (2000). The Sm-Nd dates were compared with respective dates of zircon and baddeleyite obtained by U-Pb method with the mass spectrometer in Kola Science Center, Russian Academy of Science in Apatity (Russia). In al the collected samples the folowing minerals were present: pyrite, chalcopyrite and pentlandite (Huber et al., 2008, Bayanova et al., 2010). These sulfide samples were subjected earlier to the REE analysis (Nerovich et al., 2009; Ekhimova et al., 2011; Elizarova, Bayanova, 2012).

The Sm-Nd analysis was made for the main ore-bearing rocks of the layered Fedorovo-Pansky intrusion, Monchetundra massif and Pilguyarvi (Pechenga) deposit. These results was compared with U-Pb ages of zircon and badeleyite show good agreement. The possibility of using sulfide minerals for Sm-Nd isotope-geochronological dating method from mafic-ultramafic intrusions was considered by Serov \& Mitrofanov (2005) and Serov et al. (2007, 2009).

The result of geochronometric analysis of the chalkopyrite-pentlandite ore from gabbroides of lower horizon of Fiodoro-Pansky Tundra massif shows the age of $2467 \pm 39 \mathrm{Ma}(\mathrm{Sm}, \mathrm{Nd}$, from sulfide) and $2470 \pm 9 \mathrm{Ma}$ (U-Pb from zircon). The anortosite with Pd-Pt elements occurrence from upper horizon has age of $2447 \pm 12$ $\mathrm{Ma}(\mathrm{Sm}-\mathrm{Nd})$ and $2442 \pm 74 \mathrm{Ma}(\mathrm{U}-\mathrm{Pb})$. The oldest rocks, with $\varepsilon \mathrm{Nd}(\mathrm{T})=1.04 \pm 0.5 \mathrm{pa}-$ rameter, were formed by the mantle character plutonism, which well corresponds with published $\delta^{34} \mathrm{~S}$ data (Huber et al., 2009). The most late age of crystallization is most likely associated with postmagmatic processes, where the measured $\delta^{34} \mathrm{~S}$ values pointed to non primitive magmas (Huber, Halas 2008).

The gabbronorites from the Pentlanditovaya Ushchelie deposits in the lowermost part of Monchegorsk pluton received $2489 \pm 49 \mathrm{Ma}(\mathrm{Sm}-\mathrm{Nd})$ and $2501 \pm 5.6 \mathrm{Ma}$ 
$(\mathrm{U}-\mathrm{Pb})$, respectively. The difference in these ages may be explained as result of contamination of supracrustal material or secondary magma injection with another isotope characteristics. Pyrite from Monchegorsk pluton has $\delta^{34} \mathrm{~S}$ value of $1.72 \%$.

The samples from Pilguyarvi of Pechenga massif received $1950 \pm 58 \mathrm{Ma}(\mathrm{Sm}$, $\mathrm{Nd}$ ), which is compatible with U-Pb age for these massive (Hanski et al., 1990, Bayanova, 2004). However $\delta^{34} \mathrm{~S}$ values of sulfides from this massif are ranging from 0.23 to $3.60 \%$. A contamination effect of the primordial magma with supracrustal rocks seems to be the most likely interpretation of these data

\section{References}

1. Bayanova, T.В., Возраст реперных геологических комплексов Кольского региона и длительноцть процессов магматизма. С.-Пб.: Наука 174, 2004.

2. Bayanova, T.B., Nerovich, L.I. and Mitrofanov, F.P, Мончетундровский базитовый массив Кольского региона: новые геологические и изотопно-возрастные данные. Doklady Akademii Nauk, 431, 2, pp. 216-222, 2010.

3. Elizarova, I.R. and Bayanova, T.B., Mass-spectrometric REE analysis in sulphide minerals. J. Biol. Earth Sci. 2(1): E45-E49, 2012.

4. Ekhimova, N.A., Serov, P.A. and Вayanova, Т.В., Распределение РЗЭ в сульфидных минералах и Sm-Nd датирование рудогенеза расслоенных базитовых интрузий. Doklady Akademii Nauk, 436, 1,2011

5. Hanski, E., Huhma, H., Smolkin, V.F. and Vaasjoki, M., The age of the ferropicritic volcanics and comagmatic Ni-bearing intrusions at Pechenga, Kola Peninsula, USSR Bull. Geol. Soc. Finl. 62, pp. 123-133, 1990.

6. Huber, M., Halas, S. and Piestrzyński, A., Petrology of gabroides and isotope signature of sulfide mineralization from Fedorov-Pansky layered mafic intrusion, Kola Peninsula, Russia; Geochronometria 33, pp. 19-22, 2009.

7. Nerovich, L.I., Bayanova, T.B. and Savchenko, E.E., Новые данные по геологии, петрографии, изотопной геохимии и ЭПГ минерализации Мончетундровского массива, Viestnik MGTU, 12, 3, pp. 461-477, 2009.

8. Serov, P.A. and Ekhimova N.A., Бозможности Sm-Nd датирования рудных процессов с использованием сульфидов. Viestnik MGTU, 12(3), pp. 456-460, 2009.

9. Serov, P.A. and Mitrofanov, F.P., Платиноносный расслоенный Федоровско-Панский интрузив (Кольский полуостров): новые $\mathrm{Sm}-\mathrm{Nd}$ изохроны и изотопно-геохимические данные. Doklady Akademii Nauk, 403(5), pp. 1-4, 2005.

10. Serov, P.A., Nitkina E.A. and Mitrofanov F.P., Сопостав.ление данных по датированию изотопными $\mathrm{U}-\mathrm{Pb}$ и $\mathrm{Sm}-\mathrm{Nd}$ методами пород ранней безрудной фазы и рудовмешаюших пород платинометалльного Федорово-Панского расслоенного массива. Doklady Akademii Nauk, 415(5), pp. 1-3, 2007. 


\title{
081 - STUDY OF D34S AND CHEMICAL COMPOSITION OF SULFIDES FROM ALKALINE INTRUSION IN SE PART OF KHIBINA MASSIF (KOLA PENNISULA, N RUSSIA)
}

\author{
M. Huber ${ }^{l}-$ S. Hatas $^{2}-$ L. Lata ${ }^{l}$ \\ ${ }^{1}$ Maria Curie-Skłodowska University, Electron and Optical Microscopy Laboratory, \\ Department of Geology and Lithosphere Protection, 2 cd Kraśnicka St., \\ 20-718 Lublin, Poland; e-mail: miloh@interia.pl \\ ${ }^{2}$ Maria Curie-Skłodowska University, Mass Spectrometry Laboratory, Institute of Physics, \\ Lublin, 1 M. Curie-Skłodowska Sq., 20-031 Lublin, Poland
}

In this study we report new data on the $\delta^{34} \mathrm{~S}$ of sulfides from SE part of Khibina Massif from the northern part of Baltic Shield. The selected ore minerals were analyzed with optical and electron microscopy (Hitachi SU6600 with EDS attachment) in the Electron and Optical Microscopy Laboratory, Maria Curie-Skłodowska University (total number of analyses was 2488 and 607, respectively), whereas the $\delta^{34} \mathrm{~S}$ of sulfides from syenites of central part of the massif was determined in the Mass Spectrometry Laboratory, Maria Curie-Skłodowska University. These sulfides were analyzed by ICP MS in Department of Soil Science in order to figure out typical metallic concentrations.

We have analyzed 10 sulfide samples from the outcrop in Centralnyj Rudnik located near Juksporr Mountain. This intrusion has age of late Devonian (350 $\mathrm{mln}$ years) and it was formed as a result of a hot plume action (Arzamatsev 1994, 2008; Kogarko et al. 1995; Mitrofanov 2000; Pozhylienko 2002). In this outcrop predominantly occur massve aegirine syenites, apatite-nefeline urtites containing apatite-nefeline ores, trachites and other vein rocks. These rocks contain plagioclase crystals with dark aegirine accompanying eudialyte, Fe-oxides, titanite, and apatite and nepheline (Kukharenko et al. 1965; Borucky 1989; Huber 2013). Ore minerals which are occur in the rocks: ilmenite, magnetite and sulfide (pyrite).

In these rocks occur carbonatite veins with carbonate-francolite mineralization (Huber et al. 2007). Microscopic analysis with EDS demonstrate the presence of $\mathrm{V}_{2} \mathrm{O}_{5}$ and $\mathrm{TiO}_{2}$ in magnetite, and $\mathrm{Cu}, \mathrm{Ni}$ in pyrite. These results are show in Table 1.

Table 1. Results of elemental SEM-EDS analysis of typical ore minerals, concentrations are expressed in \%

\begin{tabular}{|c|c|c|c|c|c|c|c|c|}
\hline mineral & sample & $\mathrm{O}$ & $\mathrm{Si}$ & $\mathrm{S}$ & $\mathrm{Ca}$ & $\mathrm{Ti}$ & $\mathrm{Fe}$ & $\mathrm{Cu}$ \\
\hline chalcopyrite & $18 \mathrm{CH}$ & & & 30.56 & & & 26.23 & 43.22 \\
\hline ilmenite & $28 \mathrm{CH}$ & 18.57 & & & & 9.10 & 45.00 & \\
\hline ilmenite & $18 \mathrm{CH}$ & 26.46 & & & & 28.53 & 45.01 & \\
\hline magnetite & $06 \mathrm{CH}$ & 27.52 & & & & & 72.48 & \\
\hline magnetite & $06 \mathrm{CH}$ & 27.57 & & & & 2.89 & 69.53 & \\
\hline piritet & $16 \mathrm{CH}$ & & & 16.09 & & & 58.13 & \\
\hline rutile & $06 \mathrm{CH}$ & 44.46 & & & & 40.58 & & \\
\hline rutile & $06 \mathrm{CH}$ & 44.15 & & & & 40.15 & & \\
\hline tytanite & $06 \mathrm{CH}$ & 37.83 & 15.78 & & 23.16 & 23.23 & & \\
\hline tytanite & $06 \mathrm{CH}$ & 37.91 & 18.71 & & 18.99 & 24.39 & & \\
\hline
\end{tabular}


The analyzed sulfides from Khibina Massif contain $\mathrm{Zn}$ in major concentrations, whereas $\mathrm{Au}$ and $\mathrm{Ni}$ in minor concentrations (Table 2). They contain relatively small amounts of $\mathrm{As}, \mathrm{Cd}$ and $\mathrm{Ag}$. The concentrations listed in Table 2 point onto mixing of two types of sulfide assotiations: (1) more basic rocks, (2) secondary hydrothermal stage.

Table 2. The ICP analysis of sulfide minerals, concentrations are expressed in ppm

\begin{tabular}{lccrrrrr}
\hline Sample & $\mathrm{Au}$ & $\mathrm{As}$ & $\mathrm{Co}$ & $\mathrm{Ni}$ & $\mathrm{Cd}$ & $\mathrm{Zn}$ & $\mathrm{Ag}$ \\
\hline $01 \mathrm{Ch}$ & 48.94 & 3.31 & 51.53 & 12.14 & 0.78 & 298.2 & - \\
04Ch & 71.29 & 4.85 & 3.08 & 2.14 & 0.65 & 141.4 & - \\
10CH & 33.01 & 2.23 & 36.86 & 9.40 & 1.34 & 73.6 & 5.71 \\
\hline
\end{tabular}

The sulfide minerals were also subjected to isotope analysis. The results of isotope analysis are shown in Table 3 . The analyzed sulfide minerals most likely belong to 2 generations.

Table 3. Sulfur isotope composition of sulfide minerals

\begin{tabular}{lc}
\hline Sample & $\delta^{34} \mathrm{~S}_{\mathrm{VCDT}}[\%]$ \\
\hline \multirow{2}{*}{$0 \mathrm{CH}$} & 2.06 \\
\hline $01 \mathrm{CH}$ & $\sim 1.9$ \\
\hline $04 \mathrm{CH}$ & 0.69 \\
\hline
\end{tabular}

In summary we may state that the investigated sulfide samples from Centralnyj Rudnik outcrop belong to 2 generations. The first one is related to more basic magma of deep origin, which is seen in $\delta^{34} \mathrm{~S}$ values close to zero and $\mathrm{Ni}$ and Co admixtures, whilst the second one is result of late magma crystallization accompanied with hydrothermal processes, which is seen in distinctly positive $\delta^{34} \mathrm{~S}$ values and $\mathrm{Zn}$ and $\mathrm{Au}$ admixtures.

\section{References}

1. Arzamastsev, A.A., Unique Paleozoic Intrusions of the Kola Peninsula. Apatity: Kola Scientific Centre,79, 1994.

2. Arzamastsev, A., Yakovenchuk, V., Pakhomovsky, Y. and Ivanyuk, G., The Khibina and Lovozero alkaline massifs: Geology and unique mineralization. 33 IGC excursion materials, 2008.

3. Kogarko, L.N., Kononova, V.A., Orlova, M.P. and Woolley, A.R., Alkaline Rocks and Carbonatites of the World. Part 2: Former USSR. London: Chapman \& Hall, p. 226, 1995.

4. Borucky, B.E., Basic minerals of alkaline complexes. Publ. Nauka, 214 pp. 1989. [In Russian]

5. Huber, M., Preliminary characterization of the mineral veins occurring in the Malaya Belaya Valley in the Khibiny. J. Biol. Earth Sci., 3(1), pp. E1-E11, 2013.

6. Huber, M., Hałas, S. and Sikorska, M., Evolution of prehnite-albite-calcite veins in metamorphic rocks from the Lapland Granulite Belt (Kandalaksha region of Kola Peninsula). Geologija, 57, pp. $1-7,2007$. 
7. Kramm, U., Kogarko, L.N., Kononova, V.A. and Vartiainen, H., The Kola alkaline province of the CIS and Finland: Precise Rb-Sr ages define 380-360 Ma age range for all magmatism. Lithos 30, pp. 33-34, 1993.

8. Kukharenko, A.A., Orlova, M.P., Bulakh, A.G., Bagdasarov, E.A., Rimskaya-Korsakova, O.M., Nefedov, E.I. et al., The Caledonian Complex of Ultrabasic Alkaline Rocks and Carbonatites of the Kola Peninsula and North Karelia [In Russian]. Moscow: Nedra, 772 pp., 1965.

9. Mitrofanov, A.F., Geological characteristics of Kola Peninsula. Russian Academy of Science, Apatity, 166 pp., 2000.

10. Pozhylienko, W.I. et al., Geology of the ore zones in Murmansk region. Apatity, 360 pp., 2002. [in Russian],

\title{
085 - TRACKING PHOTOCHEMICAL TRANSFORMATION OF CHLOROANILINES IN AQUATIC ENVIRONMENTS BY COMPOUND-SPECIFIC ISOTOPE ANALYSIS
}

\author{
Marco Ratti ${ }^{1,2}$ - Silvio Canonica ${ }^{1}$ - Kristopher McNeill ${ }^{2}$ - Thomas B. Hofstetter ${ }^{1,2}$ \\ ${ }^{1}$ Department of Environmental Chemistry, Swiss Federal Institute of Aquatic Science and \\ Technology, EAWAG, Dübendorf, Switzerland; e-mail: marco.ratti@eawag.ch \\ ${ }^{2}$ Institute of Biogeochemistry and Pollutant Dynamics, ETH, Zürich, Switzerland
}

Substituted anilines are frequently found as soil and water pollutants because of their use as industrial chemicals, biocides, and pharmaceuticals. In the environment, substituted anilines can undergo different degradation reactions that are initiated by enzymatic dioxygenation, $\mathrm{N}$-atom oxidation, by excited triplet states of natural organic matter as well as by direct photolysis. Because these reactions are very difficult to track from reactant and product concentration analysis, it has been suggested the use of compound-specific isotope analysis to identify transformation pathways from changes of $\mathrm{C}$ and $\mathrm{N}$ isotope signatures of the pollutant molecule. While some information the isotope effects associated with microbial and abiotic oxidation already exists (Skarpeli-Liati et al., Pati et al.), none is available for photochemical transformation of substituted anilines. The goal of this study was therefore to explore the apparent ${ }^{13} \mathrm{C}$ and ${ }^{15} \mathrm{~N}$-kinetik isotope effects $\left({ }^{13} \mathrm{C}\right.$ - and ${ }^{15} \mathrm{~N}$-AKIE) associated with the direct photolysis of ortho-, meta-, and para-Cl-substituted anilines. Chlorinated anilines were selected because they represent both water contaminants as well as reactive substructures of various biocides and pharmaceuticals. It has been shown in the past, that photolysis of chloroanilines leads to aromatic dechlorination but it is currently unclear if $\mathrm{C}$ and $\mathrm{N}$ isotope fractionation can reveal indicative trends for this reaction in environmental samples.

In our experimental setup, chloroanilines were dissolved in buffered aqueous solutions (pH 2.0 to 9.0) and irradiated with monochromatic light at $254 \mathrm{~nm}$. Direct photolysis experiments were conducted in a merry-go-round photoreactor equipped with a low pressure mercury lamp and a quartz cooling jacket. Concentrations and $\mathrm{C}$ and $\mathrm{N}$ isotope ratios were analyzed by HPLC/UV-Vis, and GC/IRMS, respectively. In 
selected samples we performed a qualitative product analysis by high-resolution LC/MS.

The ${ }^{13} \mathrm{C}$ - and ${ }^{15} \mathrm{~N}$-AKIE-trends pertinent to the direct photochemical transformation of chloroanilines varied substantially in the pH-range 2.0 to 9.0 and depended on the position of the $\mathrm{Cl}$-substituent. 4-Cl-aniline photolysis showed normal ${ }^{13} \mathrm{C}$ - and ${ }^{15} \mathrm{~N}$-AKIEs between $1.008-1.018$ and $1.001-1.008$, respectively, that were strongly $\mathrm{pH}$-dependent. For both elements, AKIE-values were largest at $\mathrm{pH}$ 3.0. The much smaller ${ }^{13} \mathrm{C}$-AKIEs for 3-Cl-aniline photolysis increased from inverse $(0.997$ at $\mathrm{pH}$ 2.0 ) to normal (1.002 at $\mathrm{pH} 7.0)$. The ${ }^{15} \mathrm{~N}$-AKIEs showed the same trend and were almost identical in magnitude. Finally, ${ }^{13} \mathrm{C}$-AKIEs for 2-Cl-aniline were always inverse (0.990 at $\mathrm{pH} 4.0$ and 0.992 at $\mathrm{pH} 7.0$ ) while ${ }^{15} \mathrm{~N}$-AKIEs were normal (1.003 at $\mathrm{pH} 4.0$ and 7.0). Even though photochemical chloroaniline transformation always involves dechlorination, different reaction pathways have been proposed. The substantial variation of isotope effects found here agrees with this premise. The more detailed evaluation of each reaction mechanism reveals that in addition to $\mathrm{Cl}^{-}$-elimination, photophysical effects (e.g. photoionization) and proton-exchange reactions of singlet and triplet excited states of Cl-anilines could play an important role for the observable isotope fractionation. While further study is needed to elucidate the origin of chloroaniline photolysis isotope effects, a comparison of our results for $\mathrm{pH} 7.0$ illustrates that photolysis leads to isotope fractionation patterns that are very different from those of enzymatic and abiotic oxidation. Our work therefore illustrates the potential of CSIA to track different transformation pathways of substituted anilines in the environment.

\title{
References
}

1. Skarpeli-Liati, M., Jiskra, M., Turgeon, A., Garr, A.N., Arnold, W.A., Cramer, C.J., Schwarzenbach, R.P. and Hofstetter, T.B., Environ. Sci. Technol., 45, pp. 5596-5604, 2011.

2. Skarpeli-Liati, M., Pati, S.G., Bolotin, J., Eustis, S.N. and Hofstetter, T.B., Environ. Sci. Technol., 46, pp. 7189-7198, 2012.

3. Pati, S.G., Shin, K., Skarpeli-Liati, M., Bolotin, J., Eustis, S.N., Spain, J.C. and Hofstetter, T.B., Environ. Sci. Technol., 46, pp. 11844-11853, 2012.

\section{6 - THE FATE OF NITROGEN IN A LAKE OCCUPIED BY PHRAGMITES AUSTRALIS: A STABLE ISOTOPE TRACER STUDY}

\author{
Sara Chlot-Anders Widerlund
}

Division of Geosciences and Environmental Engineering, Luleå University of Technology, SE-97187 Luleå, Sweden; sara.chlot@1tu.se

\section{Introduction and scope}

The discharge of nutrient-rich mine water may lead to eutrophication, with increased growth, changed species composition of both phytoplankton and macrophytes and oxygen deficiency of the receiving streams and lakes [1]. For the purpose of natural nutri- 
ent removal in lakes through macrophyte uptake, common reed (Phragmites australis) (Cav.) Steud.) is considered to be an efficient species [2].

The presented study was performed in Lake Bruträsket, northern Sweden, which receives nitrogen $(\mathrm{N})$ rich mine effluents from the Boliden sulphide ore concentration plant. Common reed is the dominating macrophyte species in the lake, covering $\sim 20 \%$ of the lake area.

The main objectives with the presented study were to a) investigate the role of lake water versus the sediment pore-waters as a nutrient source and b) investigate whether $\mathrm{NH}_{4}^{+}$or $\mathrm{NO}_{3}^{-}$is the preferred $\mathrm{N}$ species for common reed grown at this specific site. To accomplish this we employed a nitrogen stable tracer $\left({ }^{15} \mathrm{~N}\right)$ and traced the ${ }^{15} \mathrm{~N}$ in the various plant parts.

\section{Methodology}

A labelling experiment was performed in the littoral zone of Lake Bruträsket, from $28^{\text {th }}$ of June until $20^{\text {th }}$ of July $2011[3] .{ }^{15} \mathrm{~N}$ labelled $\mathrm{NO}_{3}{ }^{-} / \mathrm{NH}_{4}{ }^{+}$was applied/ injected to the lake water or sediment (named NOX or NAM treatment). Sampling was performed at day $0,6,13,16$ and 22 after tracer application/injection. Macrophytes were collected and separated into root stem and leaves, which were analysed for total $\mathrm{N}(\mathrm{TN})$, organic $\mathrm{C}(\mathrm{OC})$ and $\mathrm{C}-\mathrm{N}$ isotopic composition using a PDZ Europa ANCA-GSL elemental analyser coupled to a PDZ Europa 20-20 isotope ratio mass spectrometer.

Based on initial and enriched $\delta^{15} \mathrm{~N}$ (in atom- $\%$ ) values in the various plant parts, specific uptake rates $\left(\mathrm{V}_{\mathrm{f}} / \mathrm{h}\right)$ of $\mathrm{NO}_{3}{ }^{-}$and $\mathrm{NH}_{4}{ }^{+}$by common reed were calculated based on the equations originally proposed by Dugdale and Wilkerson [4]. Using the same information, the fate of added tracer $(\% \mathrm{Ndft})$ was estimated using an equation adapted from Barraclough [5]. Finally, nitrogen use efficiency (NUE) of each plant fraction was estimated using an equation adapted from Ehaliotis et al. [6].

\section{Results}

$\delta^{15} \mathrm{~N}$ in the various plant parts increased during the course of the experiment indicating that the tracer was taken up by the plant. Plant parts from the NAM-treatment had significantly higher $\delta^{15} \mathrm{~N}$ values than plant parts from the NOX-treatment $(\mathrm{P}<0.05)$. For both treatments, roots were significantly more enriched in $\delta^{15} \mathrm{~N}$ than stem and leaf. Average specific uptake rate $\left(\mathrm{V}_{\mathrm{f}} / \mathrm{h}\right)$ of tracer from the chamber shown as the total rate for the various plants parts was significantly higher $(\mathrm{P}>0.05)$ in the NAM-treatment compared to the NOX-treatment (Fig. 1).

Calculations on Ndft also showed significantly higher values for the NAMtreatment compared to the NOX-treatment and higher values for the roots compared to stem and leaves. The same trend was found for estimation of NUE.

The tracer study has added new information regarding the importance of macrophytes for nitrogen removal in mine water impacted lakes. 


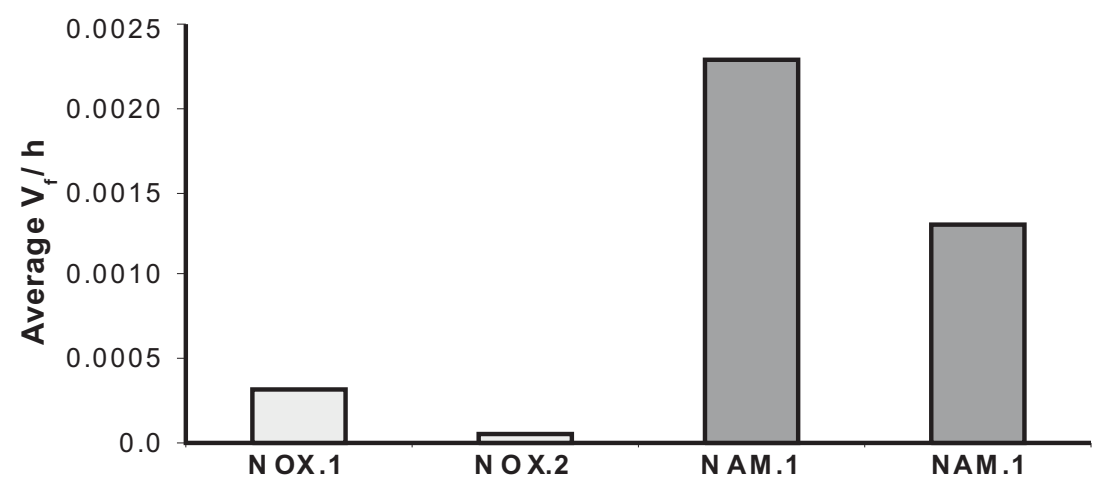

Figure 1. Average specific uptake rates $\left(\mathrm{V}_{\mathrm{f}} / \mathrm{h}\right)$ calculated for the two treatments (NOX and NAM). $\mathrm{Vf} / \mathrm{h}$ for each treatment is the summarized value of root, stem and leaf

\title{
References
}

1. D.W. Koren, W.D. Gould and P. Bedard, Biological removal of ammonia and nitrate from simulated mine and mill effluents. Hydrometallurgy, 56, pp. 27-144, 2000.

2. S. Sollie, H. Coops and J.T.A. Verhoeven, Natural and constructed littoral zones as nutrient traps in eutrophicated shallow lakes. Hydrobiologia, 605, pp. 19-233, 2008.

3. S. Chlot, A. Widerlund and B. Öhlander, Studying nitrogen cycling and uptake in macrophytes using ${ }^{15} \mathrm{~N}$ tracer tehoniques. AIG-9, p. 48, 2011.

4. R.C. Dugdale and F.P. Wilkerson, The use of ${ }^{15} \mathrm{~N}$ to measure nitrogen uptake in eutrophic oceans; experimental considerations. Limnol. Oceanogr., 31, pp. 673-689, 1986.

5. D. Barraclough, ${ }^{15} \mathrm{~N}$ isotope dilution techniques to study soil nitrogen transformations and plant uptake. Fert. Res., 42, pp. 185-192, 1995.

6. C. Ehaliotis, G. Cadish and K.E. Killer, Substrate amendments can alter dynamics and N availability from maize residues to subsequent crops. Soil Bio. Biochem., 30, pp. 1281-1292, 1998.

\section{7 - CAVE AIR DYNAMIC AND WATER INFILTRATION CONTROLLING THE CARBON ISOTOPE EXCHANGE PROCESS AT KARST SUBSURFACE}

\author{
M. Alvarez-Gallego ${ }^{1}-$ E. Garcia-Anton ${ }^{1}-$ L.M. Robredo ${ }^{2}-$ L. Sanchez $^{2}-$ \\ A. Garralon ${ }^{2}-$ S. Cuezva ${ }^{3}$ - A. Fernandez-Cortes ${ }^{1}-$ S. Sanchez-Moral ${ }^{1}$
}

${ }^{1}$ Department of Geology, MNCN-CSIC, E-28006 Madrid, Spain; e-mails:

mag@mncn.csic.es; elena.garcia@mncn.csic.es; acortes@mncn.csic.es; ssmilk@mncn.csic.es

${ }^{2}$ Department of Environment, CIEMAT, E-28040 Madrid, Spain; e-mails:

1.robredo@ciemat.es; lorenzo.sanchez@ciemat.es; antonio.garralon@ciemat.es

${ }^{3}$ Department of Earth Sciences and Environment, University of Alicante, E-03080 Alicante, Spain; e-mail: scuezva@ua.es

Understanding the role of subterranean karst processes on the terrestrial carbon balance and climate interpretation from cave proxy records require of an assessment of the connection between surface weather and cave environment, including factors con- 
trolling the carbonate deposition, gas exchange, cave ventilation and other hydrogeochemical features related to water infiltration. In this regards, the transfer of the isotopic signals and the trace element abundances in speleothems depends of the gas-aqueous-solid equilibrium conditions in the cave environment (Fairchild and Treble, 2009; Frisia et al., 2011).

A comprehensive study of $\delta^{13} \mathrm{C}_{\mathrm{CO} 2}$ (air) and $\delta^{13} \mathrm{C}_{\mathrm{DIC}}$ (karst water) was carried out over an annual cycle in an atmosphere-soil-cave system (Castañar cave, west-central Spain), by using wavelength scanned cavity ring-down spectroscopy. Carbon isotope ratio of air samples was monthly analyzed in this system. Simultaneous microclimatic parameters of cave air were logged together with external meteorological conditions. Dissolved inorganic carbonate DIC, $\delta^{13} \mathrm{C}_{\mathrm{DIC}}$, alkalinity, anions and cations of seepage water were monthly monitored in a set of three interrelated active speleothems, comprising a dripping stalactite that feeds an upper gour and this, in turn, to a lower lake. In addition, water temperature, electrical conductivity and level of the lower lake were hourly monitoring by low maintenance loggers.

Spatiotemporal changes in the isotopic composition of the cave air and water were identified in relation to soil and atmosphere. Two opposing patterns of cave atmosphere are distinguished: 1) $\mathrm{CO}_{2}$-reservoir during the wetter months: cave air reaches up to $4500 \mathrm{ppm}$ with a light $\delta^{13} \mathrm{C}_{\mathrm{CO} 2}(-24.6 \%)$ due to soil contribution ( $>5500$ ppm, $25.0 \%$ ), and 2) $\mathrm{CO}_{2}$-source during summer: cave air is above $2800 \mathrm{ppm}$ in the drier and warmer months with a heavier $\delta^{13} \mathrm{C}_{\mathrm{CO} 2}(\sim 23.7 \%)$ due to the ventilation of the cave and the mix with the air from the external atmosphere ( $440 \mathrm{ppm}, \sim 10.8 \%)$ and soil ( $\sim 1400 \mathrm{ppm}, \sim 19.5 \%)$. Seasonal alternation of these patterns is controlled by blockage of airways such as thin fractures and connected pores by water, following an increase in hydrological infiltration and water saturation of soil (Fernandez-Cortes et al., 2011).

The average $\delta^{13} \mathrm{C}_{\mathrm{DIC}}$ of cave water (-13.6\% ) corresponds to the fractionation signature (coef. close to $+9 \%$ ) of soil- $\mathrm{CO}_{2}$ dissolution $\left(\delta^{13} \mathrm{C}_{\mathrm{CO} 2 \text { soil }}-22.4 \%\right.$ ) and formation of $\mathrm{HCO}_{3}{ }^{-}$, and its heavier values match with seepage water exposed to a high interaction with the host rock $\left(\delta^{13} \mathrm{C} \sim 0\right.$ to $+3 \%$ dolomite, Herrero et al., 2011). In addition, $\delta^{13} \mathrm{C}_{\mathrm{DIC}}$ values are congruent with the precipitation of primary calcium-carbonated phases in isotopic equilibrium $\left({ }^{13} \mathrm{C}-9.6 \%\right.$ for calcite and $-8.7 \%$ for aragonite speleothems, Martin-Garcia et al., 2009). Nevertheless, the annual cycle of the aqueous phase isotopic signatures displays a variation $\left(\delta^{13} \mathrm{C}_{\mathrm{DIC}}\right.$ ranges from -14 to $-12 \%$ o coeval to fluctuations observed in the cave air, which demonstrates the seasonal influence of the gaseous exchange between cave and exterior atmosphere on the isotopic signature of water. Thus, the driest and warmest weather conditions at mid-summer enhance the cave ventilation and, consequently, it forces both the influx of outer ${ }^{13} \mathrm{C}$-enriched air and the degassing of $\mathrm{CO}_{2}$ from water that causes kinetic isotope fractionation, i.e ${ }^{13} \mathrm{C}$-enrichment of the dripping and stagnant cave waters. 
The $\delta^{13} \mathrm{C}_{\mathrm{DIC}}$ of water sampled in the interrelated suite of speleothems (stalactite ${ }^{\circledR}$ gour ${ }^{\circledR}$ lake) displayed a co-evolution throughout year, except for two distinctive periods controlled by infiltration: 1) water disconnection of the active dripping stalactite and gour with the lake under the lowest infiltration rate of summer, which implied a higher gas exchange between the water surface of lake and the cave atmosphere (with an $\mathrm{CO}_{2}$ and ${ }^{13} \mathrm{C}$-depleted air); and 2) the intense rainfalls (60 $\mathrm{mm}$ in just 3 days) provoked the hydraulic pressure increase causing the release, like a piston flow system, of the existing reserve of water held in the microfissures and pores of the karst matrix (water level of lake rapidly rose $+0.75 \mathrm{~m}$ and E.C $+110 \mu \mathrm{S} / \mathrm{cm}$ ). After this sharp event of water recharge, the lake remained storing a high proportion of this dislodged water with a heavier $\delta^{13} \mathrm{C}_{\mathrm{DIC}}$ due to its high interaction with host rock during the infiltration route. By contrast the other speleothems that feed the lake started to incorporate the water storage with a lighter $\delta^{13} \mathrm{C}_{\mathrm{DIC}}$ related to recent rainfall.

Contribution to project CGL2010-17108.

\title{
References
}

1. I.J. Fairchild and P.C. Treble, Trace elements in speleothems as recorders of environmental change. Quaternary Sci. Rev., 28(5-6), pp. 449-468, 2009.

2. S. Frisia, I.J. Fairchild, J. Fohlmeister, R. Miorandi, C. Spötl and A. Borsato, Carbon mass-balance modelling and carbon isotope exchange processes in dynamic caves. Geochim. Cosmochim. Ac., 75, pp. 380-400, 2011.

3. A. Fernandez-Cortes, S. Sanchez-Moral, S. Cuezva, D. Benavente and R. Abella, Characterization of trace gases fluctuations on a low energy cave (Castañar de Ibor, Spain) using techniques of entropy of curves. Int. J. Climatol., 31, pp. 127-143, 2011.

4. M.J. Herrero, A. Martin-Perez, A.M. Alonso-Zarza, I. Gil-Peña, A. Melendez and R. Martin-Garcia, Petrography and geochemistry of the magnesites and dolostones of the Ediacaran Ibor Group (635 to $542 \mathrm{Ma}$ ), Western Spain: Evidences of their hydrothermal origin. Sediment. Geol., 240, pp. 71-84, 2011.

5. R. Martin-Garcia, A.M. Alonso-Zarza and A. Martin-Perez, Loss of primary texture and geochemical signatures in speleothems due to diagenesis: evidences from Castanar Cave, Spain. Sediment. Geol., 221, pp. 141-149, 2009.

\section{$088-\delta^{13} \mathrm{CO}_{2}$ (AIR) AS A PROXY OF $\mathrm{CO}_{2}$ (gas) FLUX IN A SHALLOW UNDERGROUND ENVIRONMENT}

\author{
E. Garcia-Anton ${ }^{1}-$ S. Cuezva ${ }^{2}-$ A. Fernandez-Cortes ${ }^{1}-$ M. Alvarez-Gallego ${ }^{1}-$ \\ S. Sanchez-Moral ${ }^{1}$ \\ ${ }^{1}$ Department of Geology, MNCN-CSIC, E-28006 Madrid, Spain; \\ e-mails: elena.garcia@mncn.csic.es; acortes@mncn.csic.es; mag@mncn.csic.es; \\ ssmilk@mncn.csic.es \\ ${ }^{2}$ Department of Earth Sciences and Environment, University of Alicante, \\ E-03080 Alicante, Spain; e-mail: scuezva@ua.es
}


Underground environments are capable to store high concentrations of $\mathrm{CO}_{2}$ gas. Previous monitoring of underground environments located in the shallow vadose zone has shown certain common seasonal and even daily-depending cyclic behaviour (Fernandez-Cortes et al., 2011). Lately, diverse studies are pointing out that omit the interchange of $\mathrm{CO}_{2}$ between subsurface and open atmosphere could induce to a relevant error in quantify the relative contribution of these sources to the annual atmospheric carbon balance (Serrano-Ortiz et al., 2010). In that sense, caves are interesting emplacements to study processes affecting $\mathrm{CO}_{2}$ concentration in the shallow vadose zone. Observed cycles show the alternation of the cave role as reservoir or source of stored carbon dioxide to the exterior atmosphere.

The present work shows the results of a daily survey developed in September 2012 in Altamira cave where seasonal variations inside the cave have been well characterized previously (Cuezva et al., 2011; Garcia-Anton et al., 2012). Altamira cave shows an outgassing stage during summer season and a gas recharge phase during wet and rainy periods. Summer $\mathrm{CO}_{2}$ concentration are relatively steady, maintaining values close to $500 \mathrm{ppm}$ while during winter levels can exceed $5000 \mathrm{ppm}$. And not only seasonal but also daily $\mathrm{CO}_{2}$ cyclic variations have been observed. During monitoring $\mathrm{CO}_{2}$ air concentration has been measured parallel to isotope relationship $\delta^{13} \mathrm{CO}_{2}$ in a continuous mode ( 1 measure per 2 second) with a very high precision $(0.2 \mathrm{ppm}$ and $0.3 \%$, respectively) in order to observe variation with time of relationship between both parameters. $\delta^{13} \mathrm{CO}_{2}$ is used here as a marker of $\mathrm{CO}_{2}$ origin to identify the processes and mechanisms affecting carbon dioxide concentration in cave air. Analysis technology employed (Picarro G2101-i) uses cavity ring down spectrometry to reach the accuracy required. During surveillance temperature and relative humidity inside the cave remained constant in $13.97^{\circ} \mathrm{C}$ and $100 \%$. Daily cycle obtained shows an increase of $\mathrm{CO}_{2}$ since the beginning of measuring (16:00 of September $\left.25^{\text {th }}\right)$ to next midday (12:30 of September $\left.26^{\text {th }}\right)$ of $421 \mathrm{ppm}$ joined to a decrease of $3.5 \%$ in the isotopic relationship (Fig. 1). Concentration reaches its maximum of $\mathrm{CO}_{2}$ in $1475 \mathrm{ppm}$ with an isotopic signal of $-24.2 \%$. Afterwards concentration decreases up to $1322.4 \mathrm{ppm}$ with an isotopic relationship of $-22 \%$ at 18:30 of September $26^{\text {th }}$. The first stage $\left(\mathrm{CO}_{2}\right.$ recharge) is pointing to an input of isotopically light $\mathrm{CO}_{2}$, while the second stage (degassing) indicates an input of heavier air. Measures registered during recharge stage have been treated using the Keeling plot method (Keeling 1957), that approximates the isotopic signal of the source contribution in the resulting air mix. Value obtained is $-31.2 \%$ pointing directly to the soil produced $\mathrm{CO}_{2}$ (with a characteristic signal of $-27 \%$ for C3 plants, Amundson et al., 1998) as the source but affected by a fractionation process due to a diffusive influx mechanism (with ${ }^{12} \mathrm{D} /{ }^{13} \mathrm{D}$ ratio quantified in 1.0044, Cerling et al., 1991), depressing the incoming isotopic signal respect to the original.

For degassing period, a simplified mass balance model can be used to approach a quantification of the air movement, assuming that exterior air (with heavier $\delta^{13} \mathrm{C}$ ) in- 
comes to underground atmosphere by advective airflow mechanism modifying cave air conditions. Exterior $\mathrm{CO}_{2}$ concentration has been calculated as the average of 13 samples collected during the campaign: $434.7 \mathrm{ppm}$ with an isotopic relationship of $-11.3 \%$. At the end of the advective process period (12:30 to 18:30 of September $26^{\text {th }}$ ) a $14.6 \%$ of the air contained inside the cave has been renewed. The renewal rate results in $2.4 \%$ per hour. Concentration and isotopic relationship of the outlet air corresponds to the concentration inside the cave at the beginning of the ventilation. Output $\mathrm{CO}_{2}$ flux calculated resulting in $0.53 \mu \mathrm{mol} / \mathrm{m}^{2} \cdot \mathrm{s}$ with an isotopic signal of $-24 \%$.

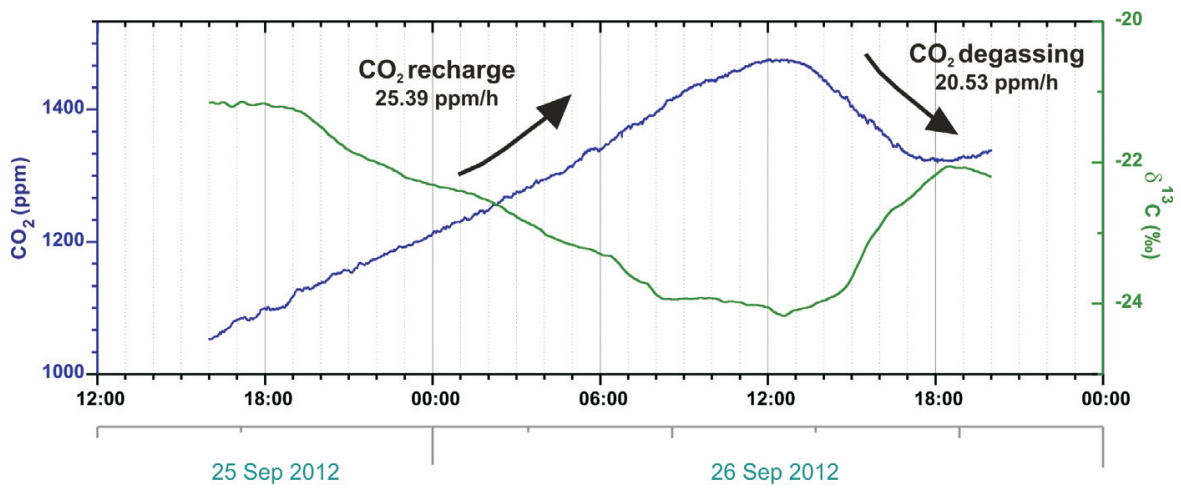

Figure 1. Daily cycle of $\mathrm{CO}_{2}$ concentration and $\delta^{13} \mathrm{CO}_{2}$ registered inside Altamira cave during September 2012

Developed survey and interpretation of collected data have allowed us distinguish processes and mechanisms affecting underground atmosphere during a daily cycle and approach a quantification of the efflux of $\mathrm{CO}_{2}$ established. Observations in short time scale could be key to better understand the role of the underground systems as sink or source of $\mathrm{CO}_{2}$ at longer time scale (year or multiyear). Quantified flux points out those shallow underground systems could have a non negligible influence in annual atmospheric balances of $\mathrm{CO}_{2}$ and even in the troposphere $\delta^{13} \mathrm{CO}_{2}$ net composition.

Contribution to project CGL2010-17108.

\section{References}

1. R. Amundson, L. Stern, T. Baisden and Y. Wang, The isotopic composition of soil and soil-respired $\mathrm{CO}_{2}$. Geoderma, 82(1-3), pp. 83-114, 1998.

2. S. Cuezva, A. Fernandez-Cortes, D. Benavente, P. Serrano-Ortiz, A.S. Kowalski and S. Sanchez-Moral, Short-term $\mathrm{CO}_{2}(\mathrm{~g})$ exchange between a shallow karstic cavity and the external atmosphere during summer: Role of the surface soil layer. Atmos. Environ. 45(7), pp. 1418-1427, 2011.

3. T.E. Cerling, D.K. Solomon, J. Quade and J.R. Bowman, On the isotopic composition of carbon in soil carbon-dioxide. Geochim. Cosmochim. Ac. 55(11), pp. 3403-3405, 1991. 
4. A. Fernandez-Cortes, S. Sanchez-Moral, S. Cuezva, D. Benavente and R. Abella, Characterization of trace gases fluctuations on a low energy cave (Castañar de Ibor, Spain) using techniques of entropy of curves. Int. J. Climatol. 31, pp. 127-143, 2011.

5. E. Garcia-Anton, S. Cuezva et al. Multiparametric surveillance of conservation measures at subterranean rock-art sites: Case of Altamira cave. Geophysical Research Abstracts, 14, EGU2012-831, 2012.

6. C.D. Keeling, The concentration and isotopic abundances of atmospheric carbon dioxide in rural areas. Geochim. Cosmochim. Ac., 13(4), pp. 322-334, 1958.

\title{
$089-\delta^{97 / 95}$ MO VARIATION IN MOLYBDENITES: A LINK WITH MINERALIZING PROCESSES?
}

\author{
Noemie Breillat ${ }^{1,2}$ - Catherine Guerrot ${ }^{1}$ - Philippe Negrel ${ }^{1}$ - Eric Marcoux ${ }^{2}$ \\ ${ }^{1}$ BRGM, ISTO, UMR 7327, BP 36009, 45060 Orléans, France; \\ e-mail: n.breillat@brgm.fr \\ ${ }^{2}$ Université d'Orléans, ISTO, UMR 7327, 45071 Orléans, France
}

Molybdenum (Mo) isotopic compositions are usually studied to reconstruct (paleo-) redox conditions in ocean (e.g., Siebert et al., 2003). Some studies also focus on isotopic compositions of Mo in molybdenite in order to decipher a possible genetic link between isotopic variations and mineralizing processes. This is also the aim of our work based on a wide molybdenite databank. We propose here a comparison of $\delta^{97 / 95} \mathrm{Mo}$ of 101 molybdenite samples from different localities, different types of occurrences and different ages. This databank of 101 molybdenites, presently analyzed, represents various types of mineralization as samples from 5 skarns, 7 porphyry deposits, 9 pegmatites, 5 granites, 2 greisens, 7 perigranitic veins and 9 alpine-type fissure veins have been studied. Molybdenite sample ages vary from $5 \mathrm{Ma}$ to $2.7 \mathrm{Ga}$.

The Mo isotopic composition has been determined on molybdenites using a MC-ICP-MS Neptune after aqua regia dissolution and adjustment to $[\mathrm{Mo}]=1 \mu \mathrm{g} \cdot \mathrm{g}^{-1}$. Mass bias was corrected by using $\mathrm{Zr}$ as dopant and standard-sample-standard bracketing. The $\delta{ }^{97 / 95}$ Mo ratios have been normalized to NIST 3134. The external reproducibility is $0.07 \% 0(2 \sigma)$.

The overall range of the $\delta^{97 / 95}$ Mo ratio in the 101 molybdenite samples varies from -0.58 to $0.89 \%$. The $\delta^{97 / 95}$ Mo ratio is higher for the molybdenites formed in alpine-type fissure veins, greisens and perigranitic veins than for the molybdenites issued from granites, pegmatites, porphyry deposits and skarns.

The crystallization temperature can explain this difference as alpine-type fissure veins, greisens and perigranitic veins crystallize at lower temperatures than the other types of deposits. For some occurrences, the $\delta^{97 / 95}$ Mo has been performed on several molybdenite samples and variability at occurrence scale has been observed. For example, in Azegour skarn (Morocco), the $\delta^{97 / 95}$ Mo varies from -0.40 to $0.32 \%$ $(\mathrm{n}=29)$ and in "Ravin de la Ruine" alpine-type fissure veins (France) from -0.08 to $0.77 \%$ o $(\mathrm{n}=3)$. As noted by Hannah et al. (2007), no correlations appear between 
$\delta^{97 / 95} \mathrm{Mo}$ and age of the deposits. Further Re-Os dating, $\mathrm{Pb}$ and $\mathrm{S}$ isotopic compositions in particular deposits (e.g. Azegour skarn) will help to decipher the origins of these variations.

\title{
References
}

1. C. Siebert, T.F. Nägler, F. von Blanckenburg and J.D. Kramers, Molybdenum isotope records as a potential new proxy for paleoceanography. Earth and Planetary Science Letters, 211, pp. 159-171, 2003.

2. J.L. Hannah, H.J. Stein, M.E. Wieser, J.R. de Laeter and M.D. Varner, Molybdenum isotope variations in molybdenite: Vapor transport and Rayleigh fractionation of Mo. Geology, 35(8), pp. 703-706, 2007.

\section{0 - NOBLE GASES AS NATURAL TRACERS OF CARBON SEQUESTRATION IN INJECTION FIELDS}

Domokos Gyore ${ }^{1}$ - Finlay M. Stuart ${ }^{1}$ - Susan Waldron $^{2}$ - Stuart Gilfillan ${ }^{3}$

\author{
${ }^{1}$ Isotope Geoscience Unit, Scottish Universities Environmental Research Centre (SUERC), \\ University of Glasgow, East Kilbride, G75 0QF, Scotland, UK; \\ e-mail: d.gyore.1@research.gla.ac.uk \\ ${ }^{2}$ School of Geographical and Earth Sciences, University of Glasgow, \\ Glasgow, G12 8QQ, Scotland, UK \\ ${ }^{3}$ School of Geosciences, University of Edinburgh, Edinburgh, EH9 3JW, Scotland, UK
}

The storage of $\mathrm{CO}_{2}$ in deep geological formations is an option for significantly reducing anthropogenic $\mathrm{CO}_{2}$ emissions. It is vital to be able to track the fate of injected $\mathrm{CO}_{2}$ within the targeted disposal site. Isotopic measurements have proved viable for investigating gas origin, gas-fluid-rock interaction and the duration of storage in natural gas deposits [1]. Depleted hydrocarbon fields, where gas is injected to enhance hydrocarbon extraction, are natural analogues for $\mathrm{CO}_{2}$ sequestration sites. This study assesses the feasibility of using injected $\mathrm{CO}_{2}$ to understand of the mechanism of storage in the Cranfield (MS, USA) enhanced oil recovery field. Major gas concentrations $\left(\mathrm{CO}_{2}\right.$, $\left.\mathrm{CH}_{4}\right)$, stable isotopes $\left(\delta^{13} \mathrm{C}, \delta^{18} \mathrm{O}\right)$ and noble gas isotopes ( $\left.\mathrm{He}, \mathrm{Ne}, \mathrm{Ar}\right)$ have been analysed in injection and production wells over a three year period: December 2009: immediately after injection started, April-May 2010; March 2012. The injected $\mathrm{CO}_{2}$ is piped from the Jackson Dome natural $\mathrm{CO}_{2}$ deposit (MS, USA) and distributed to a large number of injectors. It is distinct from the reservoir gas in ${ }^{3} \mathrm{He} /{ }^{4} \mathrm{He}\left(5.02 \mathrm{R}_{\mathrm{A}} \mathrm{vs}\right.$ $\left.4.76 \mathrm{R}_{\mathrm{A}}\right)$ and ${ }^{3} \mathrm{He} / \mathrm{CO}_{2}\left(\sim 2 \times 10^{10}\right)$ measured in the Cranfield site just before injection. $\mathrm{CO}_{2}$ recycled from the produced gas is mixed with the Jackson Dome gas and re-injected. Over the observation period the amount of the recycling gas has changed from 9 to $32 \%$ to the total injected gas [2]. Changes in the injected gas with time have been quantified. $\delta^{13} \mathrm{C}$ has changed from -2.6 to $-3.6 \%$ and ${ }^{3} \mathrm{He} /{ }^{4} \mathrm{He}$ decreased to $\sim 4.0 \mathrm{R}_{\mathrm{A}}$ by 2012. This means that the injected gas is mixing with the naturally occurring crustal-derived reservoir gas with time and is changing the ${ }^{3} \mathrm{He} /{ }^{4} \mathrm{He}$ and $\delta^{13} \mathrm{C}$ of the ini- 
tial gas. The proportion of $\mathrm{CO}_{2}$ in the injected gas has also decreased to $88 \%$ due to mixing and/or sequestration processes. Data from a network of production wells will allow us to determine the mechanism of sequestration such as dissolution in formation water and precipitation as carbonate minerals and to the extent that each process is responsible for any $\mathrm{CO}_{2}$ loss. This will inform us on the fate of the gas injected and whether the original fingerprint is preserved. In addition we can assess how well a unique geochemical tracer for carbon-dioxide can be used in an engineered storage site.

\title{
References
}

1. Gilfillan, S.M.V., Haszeldine, R.S., Poreda, R. and Hovorka, S., Natural and artificial noble gases as tracers of injected $\mathrm{CO}_{2}$ migration within a deep reservoir, 21st Goldschmidt Geochemistry Conference, Prague, August 2011. Geochimica et Cosmochimica Acta Supplement.

2. Hovorka, S.D. et al., Monitoring a large-volume injection at Cranfield, Mississippi Project Design and recommendations. Int. J. Greenhouse Gas Control (2013) http://dx.doi.org/10.1016/ j.ijggc.2013.03.021

\section{1 - USING LEAD ISOTOPES TO CHARACTERISE THEIR SOURCE, LABILITY AND SOLUBILITY IN ALLUVIAL SOILS OF THE TRENT CATCHMENT, UK}

\author{
Andrew Tye - Maria Izquierdo - Simon Chenery \\ British Geological Survey, Keyworth, Nottingham, NG12 5GG UK; \\ e-mail: atye@bgs.ac.uk
}

\section{Introduction}

Fluvial environments are a major pathway for the dispersal of trace metal pollutants. A regional geochemical survey of the UK (G-BASE) revealed that alluvial soils of the Trent Catchment were enriched with $\mathrm{Zn}, \mathrm{Cd}$ and $\mathrm{Pb}$ (Johnson et al., 2007). Sources of $\mathrm{Pb}$ contamination are likely to include petrol $\mathrm{Pb}$, the $\mathrm{Pb}$ mines in the Peak district, industry and energy production. We investigated the source, lability and solubility of $\mathrm{Pb}$ using a range of isotope techniques in topsoils $(0-15 \mathrm{~cm}$ depth, $\mathrm{n}=27)$ and subsoils (35-50 $\mathrm{cm}$ depth, $\mathrm{n}=19)$ taken within $10 \mathrm{~m}$ of the river bed (Izquierdo et al., 2012) throughout the course of the catchment of the River Trent. We measured Pb isotope ratios $\left({ }^{206} \mathrm{~Pb} /{ }^{207} \mathrm{~Pb}\right.$ vs $\left.{ }^{208} \mathrm{~Pb} /{ }^{207} \mathrm{~Pb}\right)$ in the whole soil, the labile $\mathrm{Pb}$ pool and in soil pore waters to enable us to examine the variation and proportion of $\mathrm{Pb}$ from different sources in each of these pools.

\section{Materials and Methods}

Full details of materials and methods can be found in Izquierdo et al. (2012). The concentrations of major and trace elements in pore waters and soil digests and $\mathrm{Pb}$ ratios were determined using an Agilent 7500 quadrupole ICP-MS along with $\mathrm{Pb}$. Lead iso- 
tope dilution, using ${ }^{204} \mathrm{~Pb}$ as the spike, was used to assess $\mathrm{Pb}$ lability (E-values) using equation 1 after Atkinson et al. (2011).

$E$-value $=\left(\frac{M_{P b}}{W}\right)\left(\frac{C_{\text {spike }} V_{\text {spike }}}{M_{\text {Pbspike }}}\right)\left(\frac{{ }^{204} I A_{\text {spike }}-{ }^{208} I A_{\text {spike }} R_{S S}}{{ }^{208} I A_{\text {soil }} R_{S S}-{ }^{204} I A_{\text {soil }}}\right)$

where $\mathrm{M}_{\mathrm{Pb}}$ is the average atomic mass of $\mathrm{Pb}, \mathrm{C}$ is the gravimetric $\mathrm{Pb}$ concentration $(\mathrm{mg} / \mathrm{L}), \mathrm{V}$ is the volume of added spike $(\mathrm{L}), \mathrm{W}$ is the weight of soil $(\mathrm{kg}), \mathrm{IA}$ denotes isotopic abundance of a particular isotope in the spike or soil and $\mathrm{R}_{\mathrm{SS}}$ is the ${ }^{204} \mathrm{~Pb} /{ }^{208} \mathrm{~Pb}$ ratio for the spiked soil supernatant. We also examined the sources of $\mathrm{Pb}$ in the pore water and the labile pool using the following equation (eqn 2) after Atkinson et al. (2011).

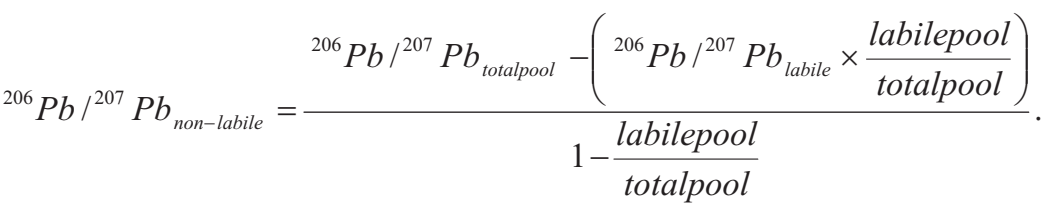

\section{Results and Discussion}

Total $\mathrm{Pb}$ concentrations in the top and subsoils ranged between 43 and $1282 \mathrm{mg} \mathrm{kg}^{-1}$. The labile pools of $\mathrm{Pb}$ in the soil were found to be in the range $10-315 \mathrm{mg} \mathrm{kg}^{-1}$ and despite the relatively narrow $\mathrm{pH}$ range $(5.5-8.0)$ they were found to decrease with increasing soil $\mathrm{pH}$. Pb lability (\% of total) was generally similar in both the top and sub soils reflecting the similar nature of soil properties that control $\mathrm{Pb}$ solubility $(\mathrm{Fe} / \mathrm{Mn}$ oxides, organic matter) and the way alluvial soils build up through time. Centrifuged pore waters from the samples had concentrations of $0.17-6.47 \mu \mathrm{g} \mathrm{L}^{-1}$. Source apportionment analysis showed that $\mathrm{Pb}$ isotopic signatures in the total, labile and soil pore water pools fitted along the mixing line between local ore/local coal and petrol derived (tetra-ethyl) $\mathrm{Pb}$ sources, known as 'BHT' $\mathrm{Pb}$ (Fig. 1).

As expected the local ore and/or local coal signature is dominant in the labile pools of most soils, whilst traffic-related $\mathrm{Pb}$ appears to substantially contribute to the elevated $\mathrm{Pb}$ concentrations in some samples, particularly those close to major road systems or sewage outlets. The occurrence of 'BHT' $\mathrm{Pb}$ in subsoils indicates considerable post-depositional vertical migration. The isotopic compositions of the labile pool and the pore water also suggests that ' $\mathrm{BHT}$ ' $\mathrm{Pb}$ is enriched in the labile and pore water pools compared to their respective total soil pool, suggesting that petrol $\mathrm{Pb}$ is still being deposited to these soils and/or it has undergone a poor fixation since the withdrawal of leaded petrol. Theoretically, the $\mathrm{Pb}$ isotope ratios in the pore waters should be similar to those of the labile pool as it is the labile pool of metal, as measured using the E-value, that should buffer the soil pore water pool of $\mathrm{Pb}$. Whilst a reasonable correlation was found between the labile pool and pore waters (Fig. 2), further statistical 


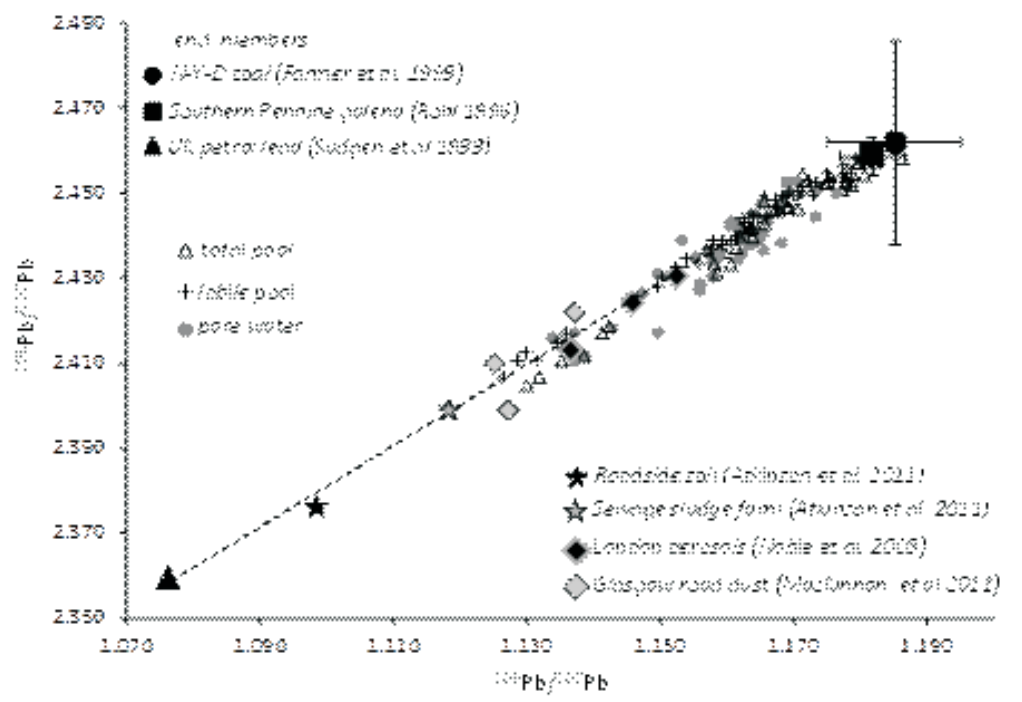

Figure 1. ${ }^{206} \mathrm{~Pb} /{ }^{207} \mathrm{~Pb}$ vs ${ }^{208} \mathrm{~Pb} /{ }^{207} \mathrm{~Pb}$ ratio plot for the total, labile and pore water pools. Also shown for comparative purposes: potential sources, mixing line between the possible end-members, ratios for UK aerosols and contaminated soils

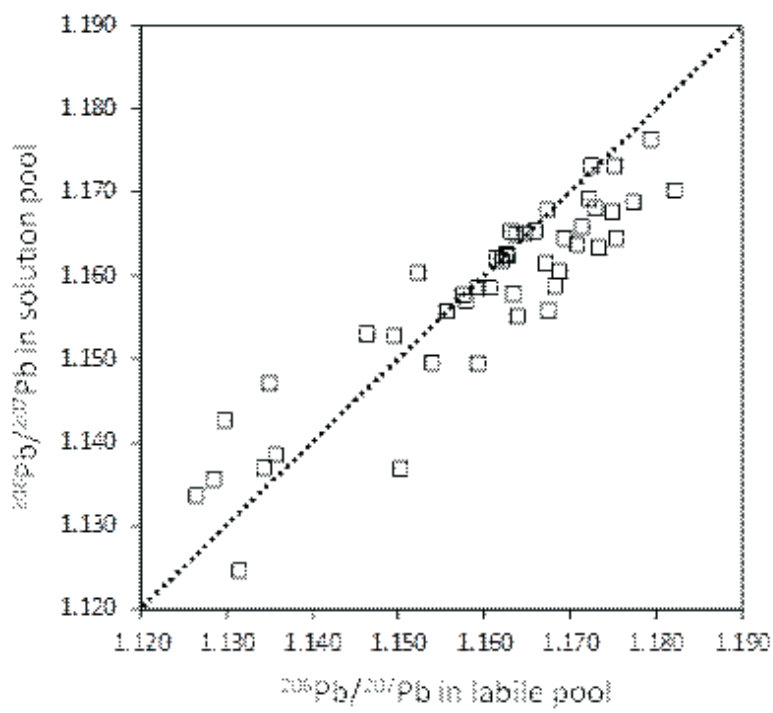

Figure 2. Relationship between ${ }^{206} \mathrm{~Pb} /{ }^{207} \mathrm{~Pb}$ ratios in the labile and pore water pools in soils from the Trent Catchment 
analysis showed that there was still a statistical difference $(\mathrm{P}<0.001)$ between the two pools. The most likely explanation is that non-labile $\mathrm{Pb}$ is attached to sub-micron colloids $(\mathrm{FeOx})$ in the pore waters.

\title{
Conclusions
}

Alluvial soils sampled within $10 \mathrm{~m}$ of the banks of the rivers Dove and Trent floodplain show significant spatial differences in $\mathrm{Pb}$ concentration and isotopic composition with strong anthropogenic influences linked to past $\mathrm{Pb}$ mining and smelting activity, coal mining/combustion, sewage works, canal dredging and the deposition of traffic-related atmospheric $\mathrm{Pb}$. Comparison of the $\mathrm{Pb}$ ratios in the labile and pore water pools suggest (i) that they are enriched in petrol $\mathrm{Pb}$ compared to the total soil, (ii) that petrol $\mathrm{Pb}$ is sorbed to sub-micron colloids (in particular $\mathrm{FeO}$ ) and this provides a potential transport pathway.

\section{References}

1. N.R. Atkinson, E.H. Bailey, A.M. Tye, N. Breward and S.D. Young, Fractionation of lead in soil by isotopic dilution and sequential extraction. Environ. Chem., 8, pp. 493-500, 2011.

2. J.G. Farmer, L.J. Eades and M.C. Graham, The lead content and isotopic composition of British coals and their implications for past and present releases of lead to the UK environment. Environ Geochem Health, 21, pp. 257-272,1999.

3. C.C. Johnson, N. Breward, E.L. Ander and L. Ault, G-BASE: Baseline geochemical mapping of Great Britain and Northern Ireland. Geochemistry: Exploration, Environment, Analysis, 5, pp. 347-357, 2005.

4. M. Izquierdo, A.M .Tye and S.R. Chenery, Sources, lability and solubility of $\mathrm{Pb}$ in alluvial soils of the River Trent catchment, U.K. Sci. Tot. Environ., 433, pp. 110-122, 2012.

5. S.R. Noble, M.S.A. Horstwood, P. Davy, V. Pashley, B. Spiro and S. Smith, Evolving Pb isotope signatures of London airborne particulate matter (PM10) - constraints from on-filter and solution-mode MC-ICP-MS. J. Environ. Monit., 10, pp. 830-836, 2008.

6. C. Sugden, J. Farmer, A. MacKenzie, Isotopic ratios of lead in contemporary environmental material from Scotland. Environ. Geochem. Health, 15, pp. 59-65, 1993.

\section{4 - MIDDLE PLIOCENE MICROPALEONTOLOGICAL AND STABLE ISOTOPE RECORDS FROM CYPRUS ISLAND (EASTERN MEDITERRANEAN)}

\author{
Efthymios Tsiolakis ${ }^{1}$ - Assimina Antonarakou ${ }^{2}$ - Hara Drinia ${ }^{2}$ - George Kontakiotis ${ }^{2}-$ \\ Mario Sprovieri ${ }^{3}$ - Stella Tsaila-Monopolis ${ }^{4}$ - George Ferentinos ${ }^{4}-$ \\ George Theodorou ${ }^{2}$ - Andreas M. Zissimos ${ }^{1}$ \\ ${ }^{1}$ Cyprus Geological Survey Department, Lefkonos, 1, 1415, Nicosia, Cyprus; \\ e-mail: etsiolakis@gsd.moa.gov.cy \\ ${ }^{2}$ Faculty of Geology \& Geoenvironment, National \& Kapodistrian University of Athens, \\ Panepistimiopolis Zografou 15784 Athens, Greece \\ ${ }^{3}$ Istituto per 1' Ambiente Marino Costiero (IAMC) e CNR, Via del Faro 3, Torretta Granitola \\ (Fraz. Campobello di Mazara, Tp) 91021, Italy \\ ${ }^{4}$ Faculty of Geology, University of Patras, Patras, Greece
}


The section Essovouyes-Exovouyes in Cyprus Island provides a continuous record of Pliocene to early Pleistocene marine deposits in the eastern Mediterranean. It is located on the south margin of Messaoria basin, central Cyprus. The section is about 100 $\mathrm{m}$ thick and its middle part consists of well-preserved cyclic marine sediments including laminated brownish marly layers alternating with grey homogeneous marls.

Micropaleontological and stable isotope analyses highlight Pliocene climate variability of the eastern part of Mediterranean. Our analyses are centered in the interval 3.9-3.0 Ma. Seven astronomically dated planktonic foraminiferal bioevents were recognized and constrained the age model of the studied interval through linear interpolation: (1) LCO of Globorotalia margaritae, (2) LO of Globorotalia margaritae, (3) FO of Globorotalia crassaformis, (4) disappearance of Globorotalia puncticulata, (5) reappearance of G. crassaformis, (6) reappearance of G. puncticulata and (7) LO of Sphaeroidinellopsis.

Long term trends in oxygen isotopes are correlated with SST record derived from the planktonic foraminiferal assemblages and mostly reflect changes in global climatic conditions, with a more local or regional signal superimposed on this record.

Planktonic foraminifera and oxygen isotope record indicate three distinct warm periods interrupted by two cooling intervals. Significant higher values in $\delta^{18} \mathrm{O}$ due to decreases surface water temperature occurred at 3.62 and around 3.54-3.36 Ma and reveal that the glacial cycles are also influenced the eastern Mediterranean.

High amplitude shifts in oxygen isotope record are correlated with TOC and carbon isotopic data as well as micropaleontological data and revealed the presence of numerous cycles including organic-rich laminated brownish sapropelitic layers alternating with homogeneous marls, suggesting a climate characterised by a period of warm/temperate and humid conditions and a highly stratified water column that occurred at times of precession minima.

\section{5 - BIOGEOCHEMICAL AND ISOTOPICAL FRACTIONATION MODELS: A TOOL FOR CONTROL ENHANCED IN-SITUBIODENITRIFICATION}

\footnotetext{
Paula Rodríguez-Escales ${ }^{1,2,3}$ - Boris M. van Breukelen ${ }^{4}$-Georgina Vidal-Gavilan ${ }^{1,2}$ Albert Soler ${ }^{2}-$ Albert Folch $^{3,5}$

${ }^{1}$ d D'ENGINY biorem S.L., C. Madrazo 68, 08006 Barcelona, Spain; e-mail: prescales@gmail.com , Tel.: (0034) 934186129

${ }^{2}$ Grup de Mineralogia Aplicada i Medi Ambient, Departament de Cristallografia, Mineralogia i Dipòsits Minerals, Universitat de Barcelona, Martí Franquès s/n, 08028, Barcelona, Spain

${ }^{3}$ Unitat de Geodinàmica Externa i Hidrogeologia. Departament de Geologia, Universitat Autònoma de Barcelona, 08193 Bellaterra, Spain ${ }^{4}$ Department of Earth Sciences, Faculty of Earth and Life Sciences, VU University Amsterdam, De Boelelaan 1085, NL-1081 HV Amsterdam, The Netherlands ${ }^{5}$ GHS, Dept. of Geotechnical Engineering and Geo-Sciences, Universitat Politècnica de Catalunya-BarcelonaTech, Jordi Girona 1-3, Modul D-2, 08034 Barcelona, Spain
} 
Enhanced in-situ biodenitrification is a feasible technology to recovery groundwater polluted by nitrates and achieves drinking water standards. Under optimum conditions, autochthonous bacteria degrade nitrate through different nitrate-reducing reactions to harmless nitrogen gas. In field applications of biodenitrification, isotopic fractionation monitoring allows to know the exact degree and the real scope of this technology. Using the Rayleigh equation the change in the isotope ratio of the nitrate molecule $\left(\delta^{15} \mathrm{~N}-\mathrm{NO}_{3}{ }^{-}, \delta^{18} \mathrm{O}-\mathrm{NO}_{3}{ }^{-}\right)$is related to the fraction of molecules remaining as a result of biodenitrification. However, Rayleigh application at field scale is sometimes limited for the existence of other processes in groundwater such as dispersion or adsorption and geological media heterogeneities that interferes in concentration values. Then, include isotope fractionation processes in reactive transport models is a useful tool to interpret and predict data from in-situ biodenitrification.

To assess the viability of an in situ biodenitrification performance in complex media, lab and pilot-scale tests were carried out in a fractured aquifer. Biogeochemical and isotope models have been built up for both batch and pilot-scale experiments. We have carried out an integral model of biodenitrification at batch scale using ethanol and glucose as external carbon sources. The used code was Phreeqc-2. We have considered microbiological processes: exogenous and endogenous respiration, water-rock interaction processes: precipitation and dissolution of calcite and isotopic fractionation using $\delta^{15} \mathrm{~N}-\mathrm{NO}_{3}{ }^{-}, \delta^{18} \mathrm{O}-\mathrm{NO}_{3}{ }^{-}$and $\delta^{13} \mathrm{C}$-DIC.

Modeling results allow evaluating the interaction between biodenitrification, calcite equilibrium and isotopic fractionation processes. We demonstrate that the source of organic carbon plays an important role in the calcite equilibrium (dissolution or precipitation). To model the $\delta^{13} \mathrm{C}$-DIC we have considered the complete flow of carbon isotopes in all processes involved (biodenitrification and interaction with carbonate minerals). At pilot-scale, a simplified fractured groundwater flow at 1D was successfully incorporated into the numerical model. Results indicate that the modeled biogeochemical processes behave according to experimental data.

Acknowledgments: This work was financed by d D'ENGINY biorem, the Catalan Water Agency (\#CT06001637), the Spanish Government (through the CICYT projects CGL2008-06373-C03-01, CGL2011-29975-C04-01 and TRACE PET2008-0034) and projects 2009SGR00103, 2009SGR1199, TEM-2009 from the Catalan Government.

\section{6 - RADIOCESIUM AND RADIOSTRONTIUM IN ALLUVIAL SOIL AND RIVERSIDE PLANTS RHIZOSPHERE (NEAR IMPACT ZONE OF KRASNOYARSK MCC)}

Marya Kropacheva - Michail Melgunov - Irina Makarova

Sobolev Institute of Geology and Mineralogy of SB RAS, 3 Koptyuga Ave., Novosibirsk 630090, Russia; e-mail: marya@igm.nsc.ru 
Studies of geochemistry of technogenic radionuclides in major components of biogeocenose of Yenisei flood plain have been carried since seventies of 20th century. It has been found that the most significant pollution occurs in close vicinity to Krasnoyarsk Mining-Chemical Complex, in so called near impact zone (approximately $25 \mathrm{~km}$ downstream of the reactor cooling water discharge point). In this zone all components of the flood plain biogeocenose are exposed to pollution (Bolsunovsky et al., 1999, 2002, 2005; Linnik et al., 2004, 2005, 2006; Bondareva and Bolsunovsky, 2008; Nosov, 1997; Nosov and Martiynova, 1996; Nosov et al., 1993; Sukhorukov et al., 2004).

The area for selecting sampling sites includes the right bank of the Yenisei river in the near zone of influence of the MCC and the islands located within the zone (Fig. 1). In the area the contaminated disposal waters don't distance themselves from the right bank down to the inflow of the Kan river into the Yenisei river. In Balchugovskaya channel (M-4) sampling site was chosen on the right bank, in the zone that is flooded only in high floods.

Granulometric contents of soil and rhizosphere were estimated only in M-1 and M-4 sites, in which conditions for formation of alluvial soil differed the most. Samples were exposed to granulometric fractionation with standard method (Kovrigo et al., 2000). Fractions of $0.16-0.25 \mathrm{~mm}$ and $>0.25 \mathrm{~mm}$ sizes were separated by scattering through standard sieves. Fraction of $>0.25 \mathrm{~mm}$ size mostly consisted of mineral particles and noticeable part of small remains of undecomposed organic matter. Fraction of $0.001-0.01 \mathrm{~mm}$ and $0.01-0.16 \mathrm{~mm}$ sizes were separated by levigation. Fraction of 0.001-0.00022 mm size consisted of muddy colloid and silt (Kovrigo et al., 2000) and was separated by filtration (filter MFAC-OC-1, Vladipor). Levigation filtrate $(<0.00022 \mathrm{~mm})$ containing water-soluble forms was evaporated to volume of $100 \mathrm{ml}$. Each studied sample contained large remains of organic matter, which were separated in different fraction of $>0.25 \mathrm{~mm}$ size "organics" (Table 1).

Table 1. Granulometric fractions, mass $\%$

\begin{tabular}{lcccc}
\hline & \multicolumn{2}{c}{ Atamanovskaya spit (M-1) } & \multicolumn{2}{c}{ Balchugovskaya channel (M-4) } \\
\hline & Soil & Rhizosphere & Soil & Rhizosphere \\
\hline$<0.00022 \mathrm{~mm}$ & 3.1 & 1.2 & 1.7 & 0.7 \\
$0.00022-0.001 \mathrm{~mm}$ & 0.7 & 0.03 & 0.04 & 0.04 \\
$0.001-0.01 \mathrm{~mm}$ & 7.6 & 0.6 & 1.1 & 0.4 \\
$0.01-0.16 \mathrm{~mm}$ & 37 & 28 & 42 & 20 \\
$0.16-0.25 \mathrm{~mm}$ & 38 & 58 & 46 & 70 \\
$>0.25 \mathrm{~mm}$ & 13 & 11 & 0.9 & 7.9 \\
$>0.25 \mathrm{~mm}$ "organics" & 0.58 & 1.08 & & 1.14 \\
\hline
\end{tabular}

Specific activities of ${ }^{137} \mathrm{C}$ were determined by the method of gamma-spectrometric analysis with the usage of well-type HPGe semiconductor detector with an EGPC 192-P21/SHF 00-30A-CLF-FA (EURISYS MEASURES, France) low-back- 


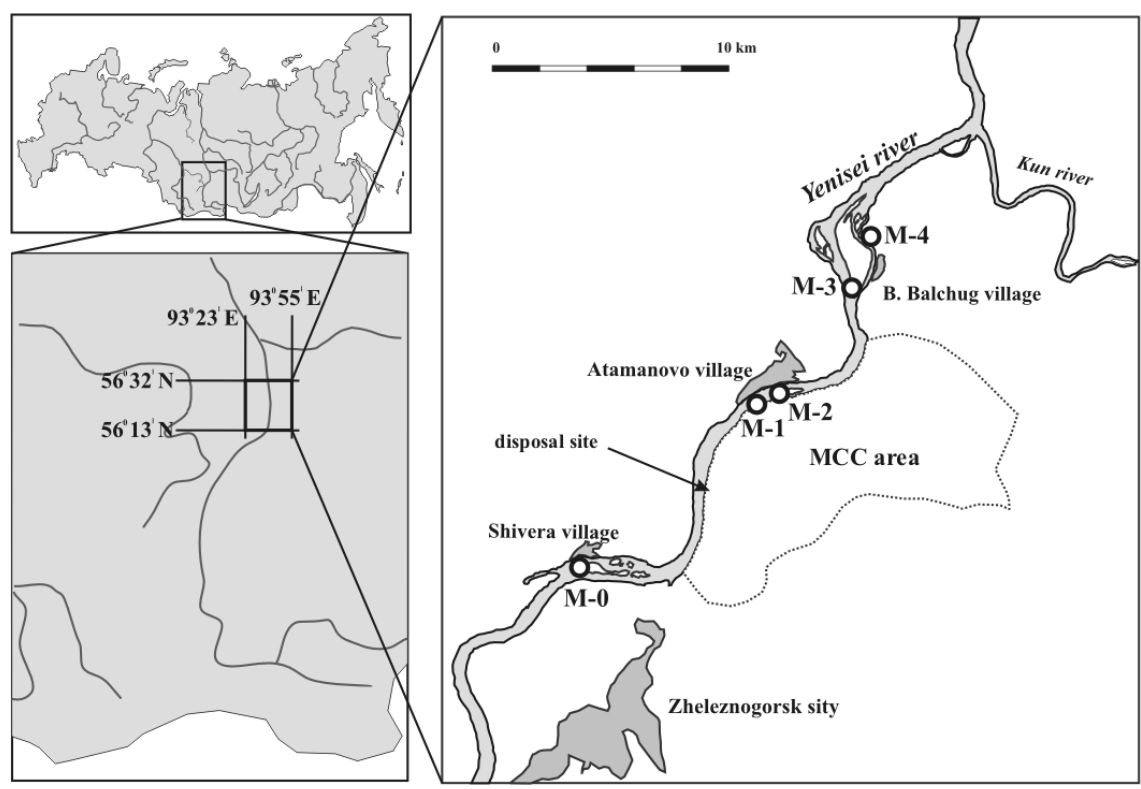

Figure 1

ground cryostat and a coaxial Ge(Li) DGDK-100B (Dubna) semiconductor detector. Determination of ${ }^{90} \mathrm{Sr}$ was performed by beta-spectrometry analysis with radiochemical samples preparation.

On the background site, the specific activities of the radionuclides were less than the world fallout levels. On the sample sites situated in the heads of the islands (M-1, M-2, M-3), specific activities of the radionuclides in soil and rhizosphere were close to each other but nonuniform, that comply with previous data by other researchers (Vakulovsky et al., 1995, 2005; Nosov, 1997; Kuznetsov et al., 1999; Sukhorukov et al., 2000, 2004) (Fig. 2). Upon removing from source of pollution, tendency of decrease of the specific activities of ${ }^{137} \mathrm{Cs}$ in soil and rhizosphere was demonstrated. The increase of specific activities of radiocesium content at the Balchugovskaya channel was due to differences in hydrologic behavior between heads of the mentioned islands and the channel, especially during floods. The heads of the islands have been exposed to active backwashing over whole period of annual floods regardless of their altitude elevation. The Balchugovskaya channel presents a stagnant marshy bay, in which continuous flow has been setting in only during high floods and seldom has been prolonged. Even with such regime, favorable conditions for accumulation of radionuclides that move with silt have been created here (Linnik et al., 2004, 2005).

The radiocesium contents in the bulk soil and the rhizosphere were virtually the same. However, significant difference between the specific activities of the bulk soil and the rhizosphere in the Balchugovskaya channel (M-4) has been observed. In this 

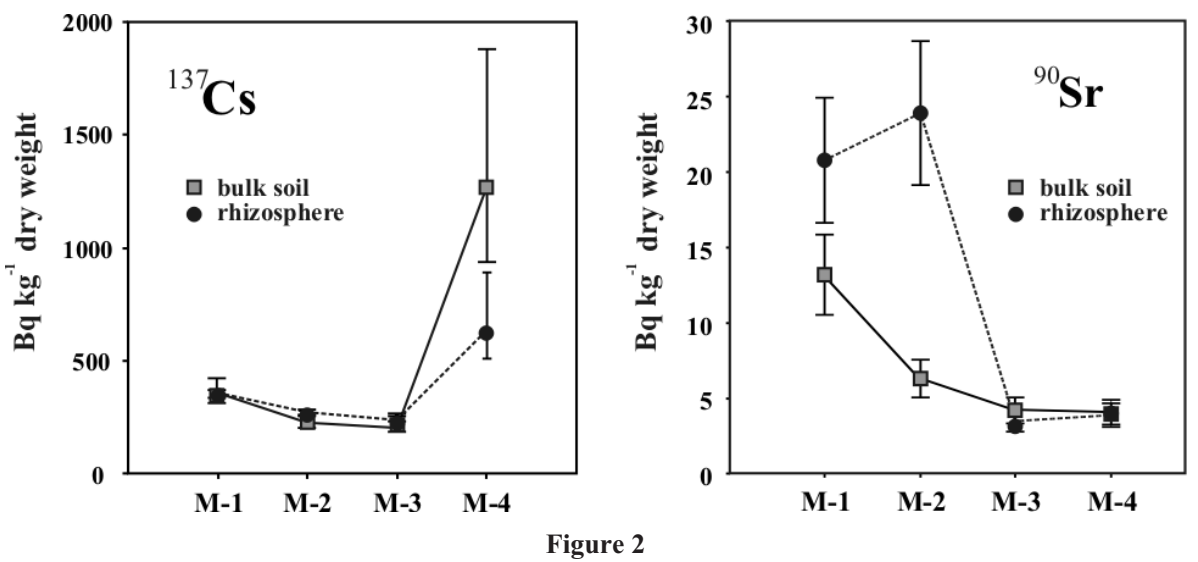

sample site, the radiocesium specific activity in the rhizosphere has been significantly below upon the average than in the bulk soil. It is known that radiocesium has affinity to organic matter (Moiseev and Ramzaev, 1975; Rigol et al., 2002), and is related to activity of microbiota (Kabata-Pendias and Pendias, 1989). Regardless of noticeable presence of organic matter in the rhizosphere of the Balchugovskaya channel (M-4) ( $\sim 5 \%$ comparing with bulk soil), accumulation of ${ }^{137} \mathrm{Cs}$ has not taken place.

The specific activities of ${ }^{90} \mathrm{Sr}$ are by an order of magnitude lower than specific activities of ${ }^{137} \mathrm{Cs}$. The spatial division pattern of radiostrontium is exactly the opposite of distribution of ${ }^{137} \mathrm{Cs}$. Maximum of specific activity of ${ }^{90} \mathrm{Sr}$ has been observed in rhizosphere at Atamanovskaya spit (M-1) and on the Atamanovsky island (M-2). Values of specific activities decrease lower than background values on the island Berezovy and in the Balchugovskaya channel.

Total content of radiostrontium in soil is lower than in rhizosphere. It has been established that ${ }^{90} \mathrm{Sr}$ is very mobile in light-textured soils, easily absorbed by plants, and has great affinity to organic matter (Kabata-Pendias and Pendias, 1989, 2001). Thus, such distribution of ${ }^{90} \mathrm{Sr}$ on bulk soil and rhizosphere may be caused by plant extraction of water-soluble forms of radiostrontium from rhizosphere, where are more such forms than in bulk soil.

Isotopes distribution in the granulometric fractions of bulk soil and rhizosphere at Atamanovskaya spit (M-1) and in the Balchugovskaya channel (M-4) have similar characteristics. An average value weighted by fractions correlates well with the specific activities of gross samples.

Alteration of radiocesium content with fraction size increasing is nonuniform but in general shows tendency to increase with fraction size decreasing, and that comply with previous data by other researchers (Korobova et al., 2007; Kruglov et al., 1995; Moiseev and Ramzaev, 1975). The finest fractions (0.001-0.00022 $\mathrm{mm}$ and $0.01-0.001 \mathrm{~mm}$ ) are enriched by rediocesium the most in bulk soil and rhizosphere (Fig. 3). It is known from the literature (Popov, 2006) that these fractions contain up to 

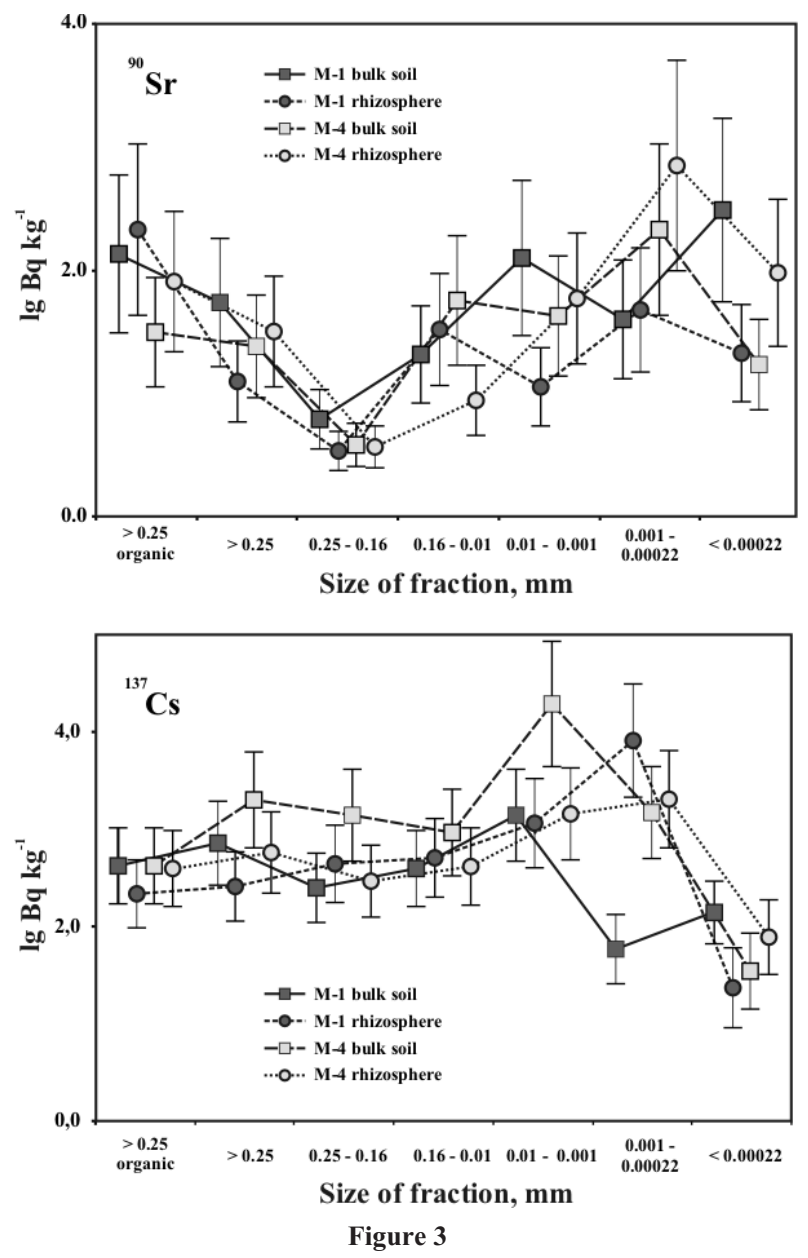

$94 \%$ of the fractional amount of ${ }^{137} \mathrm{Cs}$ in alluvial soils, which is due to the presence of clay minerals in it. Decreasing of radiocesium content is taken place in fractions of $0.01-0.16 \mathrm{~mm}$ and $0.16-0.25 \mathrm{~mm}$ sizes. Content level of ${ }^{137} \mathrm{Cs}$ increases in the coarse fractions. In general, radiocesium distributions in the granulometric fractions of soil and rhizosphere in the sample sites are very similar.

Fraction of $0.00022-0.001 \mathrm{~mm}$ size must be considered irrespectively. Its material consists of muddy colloids and silt that are able to migrate easily with flow. Percentage of radiocesium in this fraction is higher in 5-8 times in the rhizosphere than in soil, and correlates with weight percent of the fraction. Fraction of $>0.05 \mathrm{~mm}$ size "organics", which includes small roots and plant remains, is of special interest. Its weight percent is the smallest (0.6-1.1 mass.\%), but in the same time its special activities can be equal to those of most massive fractions of $0.01-0.016 \mathrm{~mm}$ and $0.16-0.25$ 
$\mathrm{mm}$ sizes, which agrees with affinity of ${ }^{137} \mathrm{Cs}$ to organic matter (Moiseev and Ramzaev, 1975; Pavlotskaya, 1974).

The lowest specific activities of radiostrontium has been observed in the most massive fraction of $0.16-0.25 \mathrm{~mm}$ size. Fraction of $0.001-0.01 \mathrm{~mm}$ size is enriched by readiostrontium. Enrichment correlates with increasing fraction size. For the fraction of $>0.25 \mathrm{~mm}$ size increasing of special activities of radiostrontium in 3-9 times comparing to fraction of $0.16-0.25 \mathrm{~mm}$ size has been observed. Fraction of $>0.25 \mathrm{~mm}$ size "organics" are enriched by radiostrontium the most. Special activities of fraction of $<0.00022 \mathrm{~mm}$ size differ significantly for soil and rhizosphere. For the Balchugovskaya channel (M-4), removal of the isotope in soluble form may amount to $8 \%$ of its content in the sample.

Thus, the fine $(0.001-0.01 \mathrm{~mm})$ and the coarse $(>0.25 \mathrm{~mm},>0.25 \mathrm{~mm}$ "organics") granulometric fractions both are enriched with isotopes. The enrichment of the fine fractions is determined by not only the increase of adsorption surface with decreasing the size of the fraction (He and Walling, 1996; Kruglov et al., 1995; Linnik et al., 2004; Popov, 2006), but also by the increase of percentage of clay minerals in these fractions (Korobova et al., 2007; Moiseev and Ramzaev, 1975). In the fine fraction of $0.001-0.01 \mathrm{~mm}$ size $30-50 \%$ of sample bulk falls on clay minerals. Quartz and feldspars (plagioclase and potassium feldspar) predominate in mineral composition of the samples. A considerable part consists of pelitic minerals such as $\mathrm{Mg}$-Fe-chlorites and illite. Most probably, the enrichment of the coarse fractions is determined by high percent of organic matter in these fractions, hence, by sorbing isotopes by humus. (Beneš et al., 2003; Kruglov et al., 1995). Moreover, fixation of isotopes in the coarse fractions is possible due to incomplete dispergation of small water-stable aggregates that are forming in the process of natural dewatering of alluvial soils after floods (Korobova et al., 2007).

Acknowledgments: The work was partly supported by RFBR Grants 12-05-31083 and 12-05-31087.

\section{References}

1. A.Ya. Bolsunovsky, V.P. Aturova et al., Radioactive pollution of inhabited localities of Krasnoyaksk region in KMCC area. Radiochem., 41, pp. 563-568, 1999.

2. A. Bolsunovsky, T. Zotina and L. Bondareva, Accumulation and release of $241 \mathrm{Am}$ by a macrophyte of the Yenisei River (Elodea canadensis) .J. Env. Radioact. 82, pp. 33-46, 2005.

3. V.G. Linnik, V.V. Surkov et al., Lithomorphological specifics of radionuclides distribution in flood-plain landscapes of Enisey River. Russian Geol. and Geophys., 45, pp. 1220-1234, 2004.

4. V.G. Linnik, V.V. Surkov and V.N. Potapov, Recent accumulation dynamics in the Yenisei flood plain on the basis of landscape-hydrologic, lithologic and radio-dating analysis (Cheremukhov Island as an example). Geomorphology, 3, pp .42-51, 2005.

5. V.G. Linnik, J.E. Brown et al., Patterns and inventories of radioactive contamination of island sites of the Yenisey River, Russia. J. Env. Radioact., 87, pp. 188-208, 2006.

6. L.G. Bondareva and A.Ya. Bolsunovskii, Speciation of artificial radionuclides ${ }^{60} \mathrm{Co},{ }^{137} \mathrm{Cs},{ }^{152} \mathrm{Eu}$, and ${ }^{241} \mathrm{Am}$ in bottom sediments of the Yenisei river. Radiochem., 50, pp. 475-480, 2008. 
7. A.V. Nosov, Research of radioactive substances migration mechanism in Yenisei river floodplain. Russian Meteorol. and Hydrol., 12, pp. 84-91, 1997.

8. A.V. Nosov and A.M. Martynova, Analysis of the radiation environment on the Enisei River after decommissioning of dtraight-through reactors at the Krasnoyarsk Mining-Chemical Complex. Atomic Energy, 81, pp. 226-232, 1996.

9. A.V. Nosov, M. V. Ashanin et al., Radioactive contamination of the R. Enisey due to discharges from Krasnoyarsk Mining and Chemical Corporation. Atomic Energy, 74, pp. 144-150, 1993.

10. F.V. Sukhorukov, A.G. Degermendzhy et al., Distribution and Migration of Radionuclides in the Yenisei Plain. Geo. Novosibirsk, 2004.

11. V.P. Kovrigo, I.S. Kaurichev and L.M. Burlakova, Soil Science with Geology Basics. Kolos, Moscow, 2000.

12. S.M. Vakulovsky, I.I. Kryshev et al., Radioactive contamination of the Yenisei River. J. of Env. Radioact., 29, pp. 225-236, 1995.

13. S.M. Vakulovsky, E.G. Tertyshnik et al., Man-made radionuclides in the Yenisey River. Proc. of Int. Conf. Radioactivity After Nuclear Explosions and Accidents, 2, pp. 294-299, 2005.

14. Yu.V. Kuznetsov, V.K. Legin et al., The study of behavior of ${ }^{239,240} \mathrm{Pu}$ and ${ }^{137} \mathrm{Cs}$ within the system of Yenisei River - Kara Sea. Radiochem., 41, pp. 181-186, 1999.

15. F.V. Sukhorukov, M.S. Melgunov and S.I. Kovalev, The main traits of distribution of technogenous radionuclides in alluvial soils and bottom sediments of the Yenisei River. Contemporary Prob. of Ecol., 1, pp. 39-50, 2000.

16. A.A. Moiseev and P.V. Ramzaev, Caesium-137 in Biosphere. Atomizdat, Moscow, 1975.

17. A. Rigol, M. Vidal and G. Rauret, An overview of the effect of organic matter on soil-radiocaesium interaction: implications in root uptake. J. of Env. Radioact., 58, pp. 191-221, 2002.

18. A. Kabata-Pendias and H. Pendias, Trace elements in soils and plants. Mir, Moscow, 1989.

19. A. Kabata-Pendias and H. Pendias, Trace elements in soils and plants. CRC Press LLC, Boca Raton, FL, USA, 2001.

20. E.M. Korobova, N.P. Chizhikova and V.G. Linnik, Distribution of 137 Cs in the particle-size fractions and in the profiles of alluvial soils on floodplains of the Iput and its tributary Buldynka Rivers (Bryansk oblast). Eurasian Soil Sc., 40, pp. 367-379, 2007.

21. S.V. Kruglov, N.A. Vasilieva et al., Distribution of Chernobyl fallouts radionuclides on granulometric fractions of sod-podzol soils. Eurasian Soil Sc., 5, pp. 551-557, 1995.

22. V.E. Popov, Effect of ${ }^{137} \mathrm{Cs}$ accumulation by organomineral coarse particles in sandy soils contaminated during the Chernobyl NPP accident. Eurasian Soil Sc., 39, pp. 344-351, 2006.

23. F.I. Pavlotskaya, Migration of Global Fallout Radioactive Products in Soils. Atomizdat, Moscow, 1974.

24. Q. He and D.E. Walling, Interpreting particle size effects in the adsorption of ${ }^{137} \mathrm{Cs}$ and unsupported ${ }^{210} \mathrm{~Pb}$ by mineral soils and sediments. J. Env. Radioact., 30, pp. 117-137, 1996.

25. P. Beneš, K. Štamberg et al., Kinetics of radioeuropium sorption on Gorleben sand from aqueous solutions and ground water. J. Radioanal. Nucl. Chem., 256, pp. 465-472, 2003. 


\title{
097 - 7500 YEARS OF CLIMATE FROM PINE TREE-RING $\delta^{13} \mathrm{C}$ AND GROWTH RATES FROM NORTHERN FINLAND
}

\author{
Laura Arppe $^{1 *}$-Samuli Helama ${ }^{2}-$ Kari Mielikäinen $^{3}$ - Markku Oinonen ${ }^{4}$ - \\ Mauri Timonen ${ }^{5}$ \\ ${ }^{1}$ Finnish Museum of Natural History, Laboratory of Chronology, P.O. Box 64, \\ FI-00014 University of Helsinki, Finland; e-mail: laura.arppe@helsinki.fi \\ ${ }^{2}$ Finnish Forest Research Institute, P.O. Box 16, FI-9630 Rovaniemi , Finland; \\ e-mail:samuli.helama@metla.fi \\ ${ }^{3}$ Finnish Forest Research Institute, P.O. Box 18, FI-01301 Vantaa, Finland; \\ e-mail: kari-mielikainen@metla.fi \\ ${ }^{4}$ Finnish Museum of Natural History, Laboratory of Chronology, P.O. Box 64, \\ FI-00014 University of Helsinki, Finland; e-mail: markku.j.oinonen@helsinki.fi \\ ${ }^{5}$ Finnish Forest Research Institute, P.O. Box 16, FI-9630 Rovaniemi, Finland; \\ e-mail: mauri.timonen@metla.fi
}

This contribution presents a recently launched 4-year research project, "CARATE", aiming to produce new climatic and plant physiological records at high temporal resolution by the synthesis of annually/decadally resolved pine tree-ring archives of growth-rates and cellulose $\delta^{13} \mathrm{C}$ values from high-latitude continental Europe. By combining isotope and growth rate information, we aim to reconstruct regional highand low-frequency climate variability over the past 7500 years with increased reliability. The project relies on a supra-long pinewood chronology from Finnish Lapland covering the mid and late Holocene times continuously since $5634 \mathrm{BCE}$ until the present-day (Eronen et al., 2002; Helama et al. 2008).

The strength of the common climatic signal both within- and between-sites, and associations to tree-physiological and forest-descriptive parameters was studied on a set of 70 living pine trees (Pinus sylvestris), growing in proximity of the subfossil pinewood collection sites (Fig. 1). $\alpha$-cellulose was extracted from decadal samples

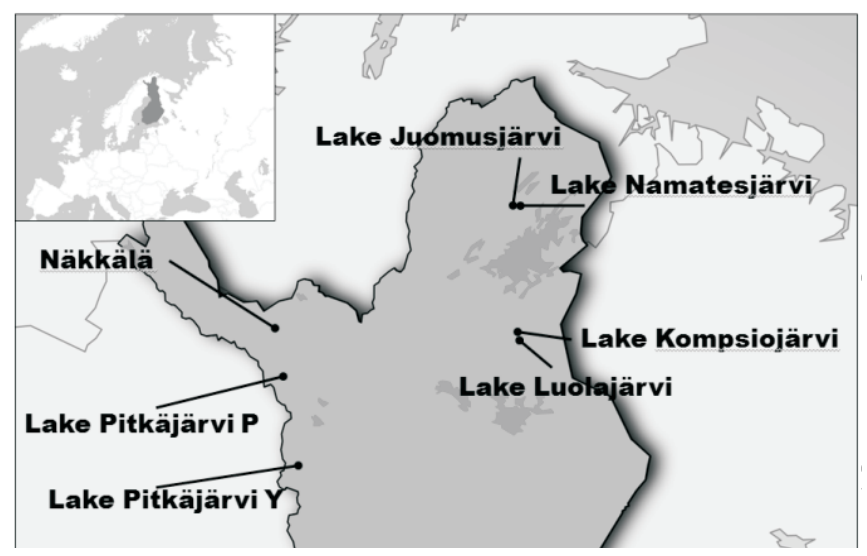

Figure 1. Subfossil pinewood collection lake sites in Northern Finland 
corresponding to the time period 1970-2010 including both early- and latewood. The $\delta^{13} \mathrm{C}$ time series show a consistent response to regional environmental forcing over the entire study area, with no discernable differences between western and eastern Lapland. Within a single site, a typical (e.g. Leavitt, 2010) between-tree variability of $1-3 \%$ in $\delta^{13} \mathrm{C}$ values is observed. Mean $\delta^{13} \mathrm{C}$ time series between sites are highly correlated (grand mean 0.87 ), and mean within-site correlations between individual tree $\delta^{13} \mathrm{C}$ chronologies ( $\mathrm{n}=8-10$ per site) range from 0.45 to 0.8 . A significant negative correlation with latitude, most likely reflecting differences in growing season temperature and photosynthetically active radiation, is observed. $\delta^{13} \mathrm{C}$ values do not show systematic responses to tree- or forest-descriptive variables, such as biological age, relative growth rate, diameter, height, canopy $\%$ and stand density.

A volcanic eruption at around $535 \mathrm{AD}$ produced a dust veil in Europe, causing extreme cooling, crop failures (Larsen et al. 2008) and a clear signal in tree growth rates around the northern hemisphere. The period was be sampled and analysed at annual resolution, and the resulting $\delta^{13} \mathrm{C}$ chronologies show a distinct negative anomaly at $535-536 \mathrm{AD}$.

The ultimate goal is the construction of 7500-year-long climate chronology. Dendroclimatic data will be calibrated to regional instrumental observations for $\mathrm{AD}$ 1808-2010 with response and transfer functions. Based on the amalgamation of the isotope and growth rate data, the reconstruction is expected to surpass previous regional climate records in reliability.

\title{
References
}

S. Helama et al., Norwegian Journal of Geography, 62, pp. 271-277, 2008.

M. Eronen et al., The Holocene, 12, pp. 673-680, 2002.

S.W. Leavitt, Science of the Total Environment, 408, pp. 5244-5253, 2010.

\section{8 - WATER LEVEL CHANGES IN LAKE ANSTAZEWO AND LAKE SKULSKIE (CENTRAL POLAND) DURING THE LAST 20 YEARS AND ITS STABLE C ISOTOPE RECORD: IMPLICATIONS FOR PALEOLIMNOLOGY}

\author{
Michat Woszczyk $k^{1}$ - Nathalie Grassineau ${ }^{2}$ - Wojciech Tylmann ${ }^{3}$ - Monika Lutyńska ${ }^{4}$ \\ Grzegorz Kowalewski ${ }^{5}$ \\ ${ }^{1}$ Department of Quaternary Geology \& Paleogeography, Adam Mickiewicz University, \\ Dziȩgielowa 27, 61-680 Poznań, Poland; e-mail: woszczyk@amu.edu.pl \\ ${ }^{2}$ Department of Earth Sciences, Royal Holloway University of London, London, UK \\ ${ }^{3}$ Department of Geomorphology \& Quaternary Geology, University of Gdansk, \\ Gdansk, Poland \\ ${ }^{4}$ Department of Quaternary Geology \& Paleogeography, Adam Mickiewicz University, \\ Poznań, Poland \\ ${ }^{5}$ Department of Biogeography \& Paleoecology, Adam Mickiewicz University, \\ Poznań, Poland
}


Reconstruction of temporal changes in lake water levels is one of the greatest challenges of paleolimnology. There are many tools to estimate past lake levels and the ratio of stable $\mathrm{C}$ isotopes in lacustrine carbonates and/or organic matter is one of the most promising paleohydrological indicators. However, the interpretation of $\delta^{13} \mathrm{C}$ signatures is often ambiguous and requires calibration of $\delta^{13} \mathrm{C}$ data with the instrumental records of lake water levels.

In our study we aimed to show and discuss $\delta^{13} \mathrm{C}_{\mathrm{TOC}}$ record of water level changes in Lake Anastazewo and Lake Skulskie (SE part of the Gniezno Lakeland, central Poland) within the last 20 years. During that time both lakes displayed considerable lowering in the water level which was explained by brown coal open-cast mining and temporal changes in the precipitation pattern in the vicinity of these lakes.

Despite the fact that the lakes differ significantly with respect to the surface area and the water depth the amplitudes of lake water level drop is similar (ca. 0.5-2.0 $\mathrm{m})$. Consequently, we are able to compare geochemical imprints of the same process in a small and shallow as well as large and deep water body.

We analyzed vertical/temporal changes in the stable $\mathrm{C}$ isotope composition of bulk organic matter $\left(\delta^{13} \mathrm{C}_{\mathrm{TOC}}\right)$, and bulk geochemical composition (TOC/N, TOC, $\mathrm{SiO}_{2 \text { ter }}, \mathrm{SiO}_{2 \text { biog }}$, carbonates) in the sediment cores from Lake Anastazewo and Lake Skulskie. Geochemical data were supplemented with the analysis of subfossil diatoms and plant macroremains. The age model was established on the basis of the ${ }^{210} \mathrm{~Pb}$ dating. Lake water levels were measured since mid-1960s.

Preliminary results are shown in Fig. 1 and Fig. 2.

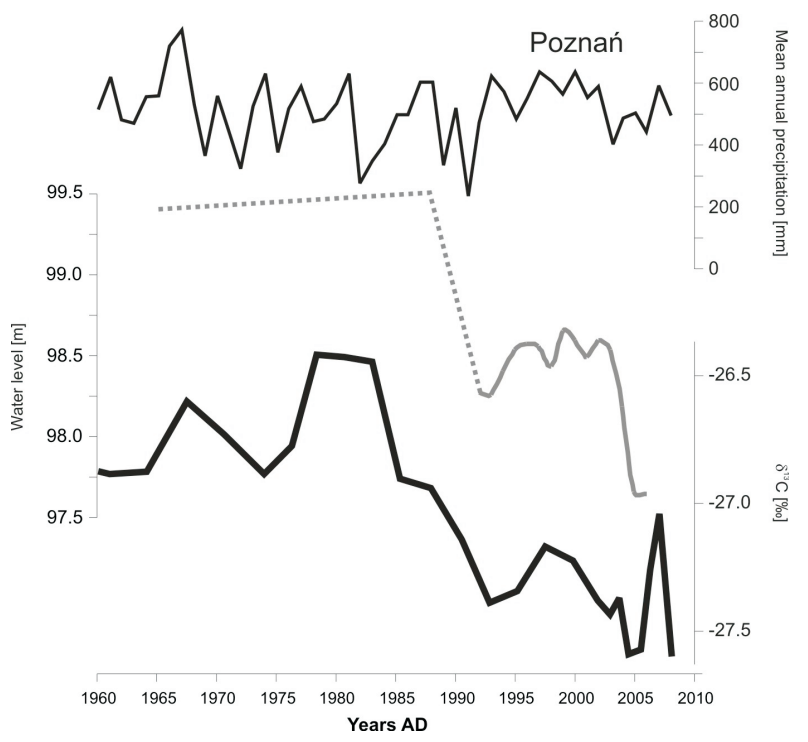

Figure 1. Precipitation, lake level changes and $\delta^{13} \mathrm{C}_{\mathrm{TOC}}$ record in Lake Anastazewo 


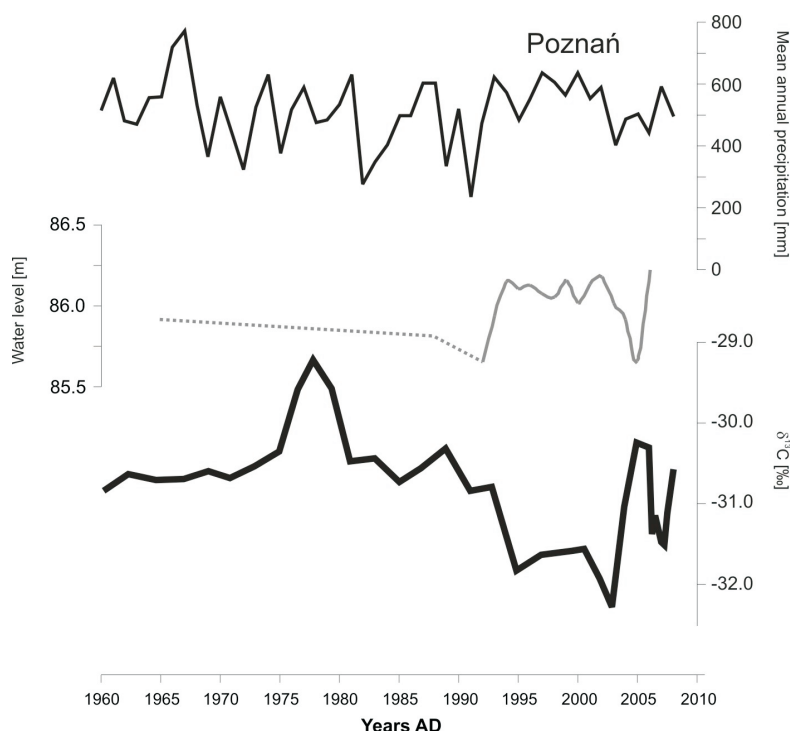

Figure 2. Precipitation, lake level changes and $\delta^{13} \mathrm{C}_{\mathrm{TOC}}$ record in Lake Skulskie

In both cores stable $\mathrm{C}$ isotopes clearly reflect the fluctuations of lake water level, however in a shallow lake, Lake Anastazewo, $\delta^{13} \mathrm{C}_{\mathrm{TOC}}$ varies parallel to the lake water level, and in a deeper lake, Lake Skulskie, the relationship between $\delta^{13} \mathrm{C}_{\mathrm{TOC}}$ and lake level is the reverse, i.e. the higher lake water level, the lower $\delta^{13} \mathrm{C}_{\mathrm{TOC}}$.

The obtained relationships can be explained by the changes in the source of $\mathrm{C}$ used by phytoplankton to produce organic matter in the studied lakes. In Lake Anastazewo enrichment in ${ }^{12} \mathrm{C}$ occurs owing to increased contribution of $\mathrm{C}$ derived from decomposing organic matter. This isotopically lighter $\mathrm{C}$ is released to the water when organic-rich deposits in the nearshore section of the lake bottom are exposed to the atmosphere during lowstand levels of the lake.

On the other hand, lowered $\delta^{13} \mathrm{C}_{\mathrm{TOC}}$ in Lake Skulskie during higher water level can be explained by the input of ${ }^{12} \mathrm{C}$ from the catchment' soils. As the increase in the lake water level is coincident with enhanced atmospheric precipitation it seems likely that lighter $\mathrm{C}$ is delivered to the lake by percolating meteoric waters. This mechanism results in the enrichment of lake water DIC in ${ }^{12} \mathrm{C}$ and consequently in a shift towards more negative values of $\delta^{13} \mathrm{C}$ in autochthonous organic matter. 


\title{
099 - ORIGIN OF FRENCH $14^{\mathrm{TH}}$ TO $16^{\mathrm{TH}}$ CENTURY ALABASTER ARTWORK FROM ILE-DE-FRANCE ASSESSED THROUGH MULTI-ISOTOPE ARCHAEOMETRY (S, O, SR)
}

\author{
W. Kloppmann ${ }^{1}$ - L. Leroux ${ }^{2}-$ Pierre-Yves Le Pogam ${ }^{3}-$ E. Saint-Omer ${ }^{4}-$ \\ G. Bresc-Bautier ${ }^{3}-$ C. Guerrot1 -A.M. Gallas ${ }^{1}-$ A.T. Montech ${ }^{1}-$ E. Proust $^{1}-$ \\ Ph. Bromblet ${ }^{5}$ \\ ${ }^{1}$ BRGM, Laboratory Division, Orléans, France; e-mail: w.kloppmann@brgm.fr \\ ${ }^{2}$ Laboratoire de Recherche des Monuments Historiques, Champs, France \\ ${ }^{3}$ Musée du Louvre, Département des Sculptures, Paris, France \\ ${ }^{4}$ Université de Versailles-St-Quentin-en-Yvelines, France \\ ${ }^{5}$ CICRP, Marseille, France
}

The trade roads of Medieval and Renaissance gypsum and anhydrite alabaster $\left(\mathrm{CaSO}_{4} \cdot 2 \mathrm{H}_{2} \mathrm{O}\right.$ and $\left.\mathrm{CaSO}_{4}\right)$ have so far been investigated mainly by art historians based on iconographic or stylistic comparisons. Unlikely to marble artwork, only few studies have so far addressed the mineralogical, geochemical and isotopic fingerprints of raw alabaster compared to those of alabaster sculptures [1-3].

A pilot study of isotope fingerprinting on French alabaster sculptures [4] has shown that sulphur and oxygen isotopes of gypsum can be used in combination with ${ }^{87} \mathrm{Sr} /{ }^{86} \mathrm{Sr}$ ratios to trace alabaster artwork back to the historical quarries from which the raw material was extracted. Samples of medieval and renaissance sculpture fragments of different provenance (Burgundy, Lorraine, Languedoc, Pyrenees) could be successfully and unambiguously linked to the ancient gypsum quarries from France (Jura, Alps, Provence, Burgundy, Lorraine), Spain (Aragon and Catalonia), England (Nottingham). Indeed the isotopic signatures of the different historical exploitations show high intra-group homogeneity and strong inter-group contrasts, main condition for forensic work on artwork provenance. Furthermore, the chosen analytical techniques (continuous flow IRMS, TIMS) permits the use of microsamples in the low $\mathrm{mg}$ range ensuring that damage to sculptures is minimal.

The Louvre Museum currently undertakes an art-historical study on the provenance of its alabaster artwork of the Ile de France region and more generally of the North of France from the $14^{\text {th }}$ to the $16^{\text {th }}$ century and has included isotope characterization as a means to better constrain the hypotheses on alabaster trade during this period. The Louvre samples are completed by related alabaster artwork provided by the Cleveland Museum of Art and from the towns of Calais and Cluny. The data base of French historical raw alabaster is further extended, notably for the Burgundy region. Here we present first results on $\mathrm{S}, \mathrm{O}$ and $\mathrm{Sr}$ isotope fingerprints of the Ile-de-France statuary and its relations with French, Spanish and English alabaster exploitations.

\section{References}

1. Gale, N.H., Einfalt, H.C., Hubberten, H.W. and Jones, R.E., The sources of Mycenaean gypsum. Journal of Archaeological Science, 15(1), pp. 57-72, 1988. 
2. Ligeza, M., Panczyk, E., Rowinska, L., Walis, L. and Barbara, N., A contribution of INAA to the determination of the provenance of the fourteenth century sculpture. NUKLEONIKA 46, pp. 71-74, 2001.

3. Costagliola, P., Benvenuti, M., Corsini, F., Maineri, C. and Mascaro, I., Pb-isotope signatures of Italian alabasters: Possible application to provenance studies of works of art. Eur. J. Mineral., 13, pp. 421-428, 2001.

4. Kloppmann, W., Leroux, L., Bromblet, P., Guerrot, C., Proust, E., Cooper, A.H., Worley, N., Smeds, S.A., Bengtsson, H., Tracing Medieval and Renaissance alabaster artwork back to quarries: A multi-isotope (Sr, S, O) approach. Archaeometry, in press, doi: 10.1111/arcm.12008, 2013.

\title{
100 - DO STABLE ISOTOPE ANALYSIS ALLOWS TO IDENTIFY THE ORIGIN OF CARBON IN FOOD WEB OF DAM RESERVOIR ECOSYSTEM?
}

\author{
Elżbieta Wilk-Woźniak ${ }^{1}$-Antoni Amirowicz ${ }^{1}$ - Agnieszka Pociecha ${ }^{1}-$ \\ Michat Gąsiorowski ${ }^{2}$ \\ ${ }^{1}$ Karol Starmach Department of Freshwater Biology, Institute of Nature Conservation, \\ Polish Academy of Sciences, al. A. Mickiewicza 33, 31-120 Kraków, Poland; \\ e-mail: wilk@iop.krakow.pl \\ ${ }^{2}$ Institute of Geological Sciences, Polish Academy of Sciences, Twarda 51/55, \\ 00-818 Warsaw, Poland
}

Dam reservoirs are usually loaded by external input of dissolved nutrients, which elevates level of primary production, and results in increased trophy. However, in the same time, reservoirs receive considerable load of particulate allochthonous organic matter, which is directly introduced into food chains of consumers. In the classic models of lacustrine food webs the most of chains started from autochthonous primary producers. However, the results of recent studies [1,2] evidence the importance of external sources of organic matter, even to large water bodies. The reservoir ecosystem receives inputs of allochthonous nutrients and organic matter during the periods of relative large inflows. Therefore, it may be supposed that the flushing rate should be regarded an important controlling factor of the carbon flux in reservoir food web.

The aim of our study was to determine the main carbon source in the food web of reservoir ecosystem. According to a recent knowledge, the organic matter of various origin is isotopically distinct [3], and in aquatic ecosystems the gradients in $\delta^{13} \mathrm{C}$ (the ratio of carbon isotopes ${ }^{13} \mathrm{C}$ to ${ }^{12} \mathrm{C}$, expressed as permille deviation from the standard) are related to different food chains [4] and reveal the contributions of different food sources to the food web [5].

The study was carried out in the Dobczyce Reservoir (S Poland; $49^{\circ} 52^{\prime} \mathrm{N}$, $20^{\circ} 03^{\prime} \mathrm{E}$, altitude $270 \mathrm{~m}$; the Raba river), a medium-sized dimictic water body $(9.58$ $\mathrm{km}^{2}$, length about $10 \mathrm{~km}$, mean depth $11 \mathrm{~m}$ ) which receives inflow from the montane/submontane catchment of $763 \mathrm{~km}^{2}$. The average annual flushing amounts to 
$2.94 \mathrm{y}^{-1}$ (the respective residence time is $0.34 \mathrm{y}$ ) which figure corresponds to diel flushing rate of $0.80610^{-2} \mathrm{~d}^{-1}$ (i.e. to about $0.8 \%$ of average reservoir volume per $24 \mathrm{~h}$ ). Samples of plankton (containing also an amount of suspended detritus) were collected at inflow of the main tributary and at the dam from April till October 2011 at monthly intervals. Plankton was sampled from $50 \mathrm{~L}$ of water with $10-\mu \mathrm{m}$ mesh net, centrifuged, dried in $60^{\circ} \mathrm{C}$ for $48 \mathrm{~h}$ and homogenized [6]. Isotopic composition of carbon was estimated using MAT-253 spectrometer in continuous flow mode coupled with an elementary analyzer FlashEA 1112 HT. The results were calculated as $\delta^{13} \mathrm{C}$ basing on calibration curves constructed using international standards USGS 40, USGS 41 and IAEA 600, where the measurements were made with every sample set. Data on the water balance of the Dobczyce Reservoir are provided by the regional authority of water management (RZGW, Kraków).

The obtained values of $\delta^{13} \mathrm{C}$ median and the interquartile range in plankton which were equal to $-27.9 \%$, and -28.7 to $-26.9 \%$, respectively. These values are close to signature of terrestrial vegetation, i.e. to about -29 to $-27 \%$. The dependences between the $\delta^{13} \mathrm{C}$ values and flushing were analyzed for six periods preceding the sampling date, which ranged from 5 to 30 days. The $\delta^{13} \mathrm{C}$ values of plankton became more correlated with flushing rate with increasing length of the considered period, and the organic matter of plankton become enriched in ${ }^{13} \mathrm{C}$ relative to ${ }^{12} \mathrm{C}$ with increasing flushing of the reservoir. Probably the plankton receives external input of organic matter indirectly, i.e. through decomposition processes, what effects in delayed reaction. As the whole range of recorded $\delta^{13} \mathrm{C}$ values was narrow and similar to terrestrial vegetation, it seems probable that photosynthesis in the reservoir phytoplankton may be fuelled almost exclusively by carbon recycled from allochthonous organic matter, while in situ fixing of atmospheric $\mathrm{CO}_{2}$ is relatively unimportant. In conclusion we supposed that the ecosystem of the Dobczyce Reservoir is heterotrophic, at least in pelagic portion of the food web. This may be the general feature of other similar medium-sized and moderately eutrophicated dam reservoirs.

\section{References}

1. J.J. Cole, S.R. Carpenter, J. Kitchell, M.L. Pace, C.T. Solomon and B. Weidel, Strong evidence for terrestrial support of zooplankton in small lakes based on stable isotopes of carbon, nitrogen, and hydrogen. Proc. Natl. Acad. Sci. USA, 108(5), pp. 1975-1980, 2011.

2. S.E. Jones, C.T. Solomon and B.C. Weidel, Subsidy or subtraction: how do terrestrial inputs influence consumer production in lakes? Freshwater Reviews, 5, pp. 37-49, 2012.

3. K.A. Hobson, Tracing origins and migration of wildlife using stable isotopes: A review. Oecologia, 120(3), pp. 314-326, 1999.

4. R.L. France, Relationships between DOC concentration and epilithon stable isotopes in boreal lakes. Freshwater Biology, 41, pp. 101-105, 1999.

5. J. Grey, The use of stable isotope analyses in freshwater ecology: Current awareness. Polish Journal of Ecology, 54(4), pp. 563-584, 2006.

6. T. Yioshioka, E. Wada and H. Hayashi, A stable isotope study on seasonal food web dynamics in a eutrophic lake. Ecology, 75, pp. 835-846, 1994. 


\title{
101 - GEOGRAPHICAL VARIATION IN FEEDING ECOLOGY OF TRACHURUS TRACHURUS IN THE WESTERN BASIN AND IN THE CENTRAL MEDITERRANEAN SEA USING STABLE ISOTOPE ANALYSIS
}

\author{
Paola Rumolo ${ }^{1,2}$ - Gualtiero Basilone ${ }^{1}$ - Marco Barra ${ }^{2}$ - Emanuela Fanelli ${ }^{3}$ - \\ Monica Calabró ${ }^{4}$ - Simona Genovese ${ }^{4}$ - Serena Gherardi ${ }^{2}$ - Biagio De Luca $^{4}$ - \\ Angelo Bonanno ${ }^{4}$ \\ ${ }^{1}$ IAMC-CNR UOS di Mazara del Vallo, Via Luigi Vaccara, 61 - 91026, \\ Mazara del Vallo (TP), Italy \\ ${ }^{2}$ IAMC-CNR Sede di Napoli, Calata Porta di Massa - 80100, Naples, Italy \\ ${ }^{3}$ ENEA, Marine Environment Research Centre - Santa Teresa Pozzuolo di Lerici -19100, \\ La Spezia, Italy \\ ${ }^{4}$ IAMC-CNR UOS di Capo Granitola, Via del Mare, 3 Torretta Granitola - 91021, \\ Campobello di Mazara, Italy
}

Carbon and nitrogen stable isotope ratios of Trachurus trachurus were examined and compared among various sectors of the western basin and the central Mediterranean sea. Significant differences in $\delta^{15} \mathrm{~N}$ values were found between samples collected in the Strait of Sicily (central Mediterranean sea) and in the Tyrrhenian sea (western Mediterranean basin), whilst not significant differences were estimated in $\delta^{13} \mathrm{C}$ values for both areas. Differences both in fish body lengths and in the geographical sampling locations were considered.

Although the highest $\delta^{15} \mathrm{~N}$ values (12.2\%o) and high mean body length (160.7 $\mathrm{mm}$ ) were found in the Tyrrhenian sea samples, the correlation between body length and the two isotope ratios were stronger in the Strait of Sicily $\left(\mathrm{R}^{2}=0.5\right.$ for both $\delta^{15} \mathrm{~N}$ and $\left.\delta^{13} \mathrm{C}\right)$ than in the Tyrrhenian sea $\left(\mathrm{R}^{2}=0.3\right.$ and 0.2 for $\delta^{15} \mathrm{~N}$ and $\delta^{13} \mathrm{C}$, respectively).

A further analysis of samples belonging to different sub-areas of the Tyrrhenian sea highlighted that Trachurus trachurus likely adopted different feeding ecology. In particular, in some areas the estimated linear relationships between $\delta^{15} \mathrm{~N}$ and $\delta^{13} \mathrm{C}$ values suggest similar isotopic baselines; in other areas Trachurus trachurus specimens seem to feed in ecosystems with different isotopic baseline or on the same food sources apart from specimens' length.

\section{2 - ISOTOPIC COMPOSITION $\left(\delta^{13} \mathrm{C}\right.$ AND $\left.\delta^{15} \mathrm{~N}\right)$ OF SUSPENDED PARTICULATE ORGANIC MATTER IN CENTRAL MEDITERRANEAN SEA ALONG A TRANSECT FROM SICILY (ITALY) TO MISURATA (LIBYA) AND IN THE GULF OF SYRTE (LIBYA)}

\author{
Paola Rumolo $^{1,2}$ - Angelo Bonanno ${ }^{3}$ - Salem Zgozi ${ }^{4}$ - Marco Barra ${ }^{2}-$ \\ Simona Genovese ${ }^{3}$ - Del Core Marianna ${ }^{3}$ - Serena Gherardi2 - Biagio De Luca ${ }^{3}$ - \\ Gualtiero Basilone ${ }^{1}$
}




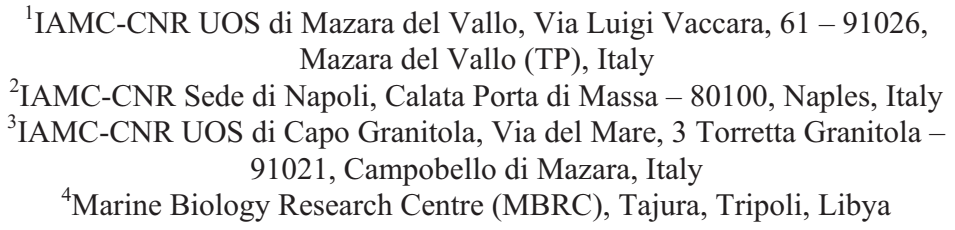

Carbon and nitrogen stable isotope ratios of Particulate Organic Matter (POM) were examined along a transect from Sicily (Italy) to Misurata (Libya) and in Gulf of Syrte (Libya). Data have been collected during two oceanographic surveys performed in summer period (July 2008 and July 2010) in the Libyan waters in the framework of the FAO MedSudMed regional Project. This is the first dataset available in this southern area of the Central Mediterranean Sea (CMED) and permitted to characterize the POM. Vertical profiles of some oceanographic variables and macro-nutrients have been contemporarily acquired.

Along the transect, mean $\delta^{15} \mathrm{~N}$ and $\delta^{13} \mathrm{C}$ values in the first $200 \mathrm{~m}$ were more enriched in summer 2010 than in 2008. Mean $\delta^{15} \mathrm{~N}$ and $\delta^{13} \mathrm{C}$ values in deep water $(>200 \mathrm{~m})$, collected only for the 2010 and in two stations, were $8.2 \%$ \pm 1.4 and $-23.9 \%$ o \pm 0.8 .

In the Gulf of Syrte, POM collected during the 2008 cruise showed a wider range than in transect with $\delta^{15} \mathrm{~N}$ values from -4.3 to $9.6 \%$ and $\delta^{13} \mathrm{C}$ from -28.1 and $-21.8 \%$.

The high variability of $\delta^{15} \mathrm{~N}_{\text {POM }}$ seems to be due to the distribution patterns of macro nutrients in the study areas, while $\delta^{13} \mathrm{C}_{\mathrm{POM}}$ variability is mainly linked to oceanographic variables.

\title{
103 - CALCIUM AND STRONTIUM ISOTOPIC CHARACTERIZATION OF SURFACE WATERS IN A SMALL BASALTIC WATERSHED (MASSIF CENTRAL, FRANCE)
}

\author{
Philippe Négrel - Catherine Guerrot - Romain Millot- \\ Emmanuelle Petelet-Giraud \\ BRGM, Laboratory Division, Orléans, France; e-mail: p.negrel@brgm.fr
}

Introduction: The chemical weathering of rocks is one of the essential processes in the geochemical cycling of elements because during this process at the earth's surface, rocks and primary minerals are transformed into solutes and secondary minerals, which form soils and sediments. In most countries, human activities also impact the cycle of dissolved species in catchments. We present here a series of calcium isotopes in surface waters draining a basaltic catchment in the Massif Central (France). These data will be interpreted by coupling measurements of $\delta^{44} \mathrm{Ca}$ isotope ratio in waters, 
rocks, sediments and soils, together with $\mathrm{Sr}$ isotopes on the same media. Coupling $\mathrm{Ca}$ and $\mathrm{Sr}$ isotopes may permit an examination of the relationships of these isotope systematics as $\mathrm{Ca}$ and $\mathrm{Sr}$, and $\mathrm{K}$ and $\mathrm{Rb}$ may behave similarly during weathering of such silicate rocks.

Materials and Methods: Main bedrocks in the volcanic zone (11 to $2.5 \mathrm{Ma}$ ) are basanites $\left(\mathrm{SiO}_{2}: 41-45 \%, \mathrm{Na}_{2} \mathrm{O}+\mathrm{K}_{2} \mathrm{O}<5 \%\right)$ and a ground mass of clinopyroxene and plagioclase. Surrounding rocks are feldspatic basalts $\left(\mathrm{SiO}_{2}: 46-49 \%, \mathrm{Na} 2 \mathrm{O}+\right.$ $\mathrm{K} 2 \mathrm{O}<5 \%$ ). The main phase in these basalts is plagioclase with hyperstene and olivine. The Sr isotopes were analysed using a Finnigan MAT 262 after chemical separation and ${ }^{44 / 40} \mathrm{Ca}$ isotopic ratios were measured by double spike method on the same TIMS and normalized to seawater.

$\mathrm{Sr}$ and $\mathrm{Ca}$ isotopes in river waters: $\mathrm{The}^{87} \mathrm{Sr}{ }^{86} \mathrm{Sr}$ ratios of the riverwater increase from the headwaters to the outlet and the $\mathrm{Sr}$ isotope ratios and $\mathrm{Cl}$ content exhibits a good relationship. These relationships imply the existence of a first component with low $\mathrm{Cl}$ content and low ${ }^{87} \mathrm{Sr} /{ }^{86} \mathrm{Sr}$ ratios and a component with high $\mathrm{Cl}$ content and high ${ }^{87} \mathrm{Sr} /{ }^{86} \mathrm{Sr}$ ratios. These two components have been related to rock weathering and to addition of fertilizers from land. Once the correction for atmospheric contribution for any element $\mathrm{Z}$ in the river water being done $\left(\mathrm{Cl}_{\text {river }} \times \mathrm{Z} / \mathrm{Cl}_{\text {rainwater }}\right)$, the anthropogenic correction was done in the same way considering that all the residual $\mathrm{Cl}$ after the atmospheric correction derives from anthropogenic input, the ultimate correction leads to all the samples having zero $\mathrm{Cl}$ content. Applying the dual correction to all river water shows a good relationship between the ${ }^{87} \mathrm{Sr} /{ }^{86} \mathrm{Sr}$ and $1 / \mathrm{Sr}$ values in the water resulting from weathering $\left({ }^{87} \mathrm{Sr}{ }^{86} \mathrm{Sr}_{\mathrm{WRI}}\right)$ and the bedrock $\left(\mathrm{R}^{2}=0.70\right)$, reflecting different degrees of weathering.

The $\delta^{44} \mathrm{Ca}$ of the riverwater is ranging between -1.18 to $-0.95 \%$, close to that of basanite bedrock $\left(\delta^{44} \mathrm{Ca}=-0.94 \pm 0.05 \%, \mathrm{n}=7\right)$, without any relationship with the $\mathrm{Cl}$ content or the distance to the headwaters. The dual correction applied to Ca highlighted that between 24 and $81 \%$ of $\mathrm{Ca}$ in the river water can be related to anthropogenic inputs and conversely, between 13 and $69 \%$ of $\mathrm{Ca}$ can be related to weathering. But such inputs seems to have no influence on the Ca isotopic signature of the river water since its $\delta^{44} \mathrm{CaCa}$ remains close to that of bedrocks. Coupling $\delta^{44} \mathrm{Ca}$ and ${ }^{87} \mathrm{Sr} /{ }^{86} \mathrm{SrWRI}$ in the surface water draining the volcanic area confirm the influence of weathering on the $\mathrm{Sr}$ isotopes and not on the $\mathrm{Ca}$ isotopes. 


\title{
104 - USING MULTI-ISOTOPIC APPROACH TO ASSESS THE EFFICACY OF INDUCED DENITRIFICATION IN AN ARTIFICIAL RECHARGE PILOT POND IN SANT VICENÇ DELS HORTS, CATALONIA
}

\author{
Alba Grau-Martínez ${ }^{1}$ - Albert Folch ${ }^{2}-$ Clara Torrentó $^{1}-$ Raúl Carrey $^{1}-$ \\ Cristina Valhondo ${ }^{3}$ - Neus Otero ${ }^{1}$ - Albert Soler ${ }^{l}$ \\ ${ }^{1}$ Grup de Mineralogia Aplicada i Medi Ambient, Universitat de Barcelona, \\ C/ Martí i Franquès, s/n - 08028 Barcelona, Spain; e-mail: albagrau@ub.edu \\ ${ }^{2}$ Hydrogeology Group, Department of Geotechnical Engineering and Geo-Science Universitat \\ Politècnica de Catalunya-BarcelonaTech, C/Jordi Girona 1-3, Mòdul D-2, \\ 08034 Barcelona, Spain \\ ${ }^{3}$ Hydrogeology Group, Department of Geosciences, Institute of Environmental Assessment \\ and Water Research (IDAEA-CSIC), C/Jordi Girona 18-26, 08034 Barcelona, Spain
}

In the aquifers of the Llobregat River (Catalonia, NE Spain) overexploitation has led to decrease of groundwater level and seawater intrusion, with the consequent deterioration of the groundwater quality. In order to increase water availability and enhance water quality, different artificial aquifer recharge systems have been implemented along the main aquifer.

In the middle part of the aquifer, in Sant Vicenç dels Horts, there is an artificial recharge system consisting of a decantation and an infiltration ponds, which are recharged by water coming from the Llobregat River and/or from treated wastewater. Both ponds were installed in 2007, in the framework of the ENSAT Life+ project. At the bottom of the infiltration pond, a vegetal compost layer was installed to create favourable conditions for contaminant biodegradation. Previous laboratory results showed that this layer might enhance degradation of some emerging organic micropollutants by inducing anaerobic redox conditions (Barbieri et al., 2012). Furthermore, an ethanol-induced denitrification experiment was planned to assess whether ethanol can be used in the future to enhance denitrification processes in this area.

The aim of this study is to track the source of nitrate and to evaluate the capability of the organic layer and the ethanol injection to induce denitrification. To these ends, a multi-isotopic approach $\left(\delta^{15} \mathrm{~N}\right.$ and $\delta^{18} \mathrm{O}$ of dissolved nitrate, $\delta^{34} \mathrm{~S}$ and $\delta^{18} \mathrm{O}$ of dissolved sulphate, $\delta^{13} \mathrm{C}$ of dissolved inorganic carbon, and $\delta^{2} \mathrm{H}$ and $\delta^{18} \mathrm{O}$ of water) was coupled with hydrogeochemical data.

Isotopic composition of groundwater before injecting ethanol $\left(\delta^{15} \mathrm{~N}_{\mathrm{NO} 3}\right.$ and $\delta^{18} \mathrm{O}_{\mathrm{NO} 3}$ values ranging from +15 to $+23 \%$ and from +10 to $+16 \%$, respectively) showed that heterotrophic denitrification induced by the compost layer was taking place during the artificial recharge of the ponds. An approximation to the extent of nitrate attenuation was calculated, showing a range between 95 and $99 \%$ or between 35 and $45 \%$, by using $\varepsilon \mathrm{N}$ values of $-4 \%$ and $-22 \%$, respectively (Aravena and Robertson, 1998; Pauwels et al., 2000). Further laboratory work will be required to obtain 
more realistic nitrogen and oxygen fractionation in order to more precisely estimate the extent of denitrification.

With regards to the second biodenitrification strategy planned, the daily ethanol injections, they were performed during 5 consecutive days in the injection well, located close to the infiltration pond and upstream of the observation well. 11 days after the first ethanol injection no changes in the nitrate isotopic signature were detected in the control well, indicating that the ethanol injections did not significantly enhance denitrification. Longer-term experiments and/or an increase in the ethanol quantity are proposed in order to enhance denitrification.

These results allowed confirming that the compost layer was inducing denitrification in the recharge ponds area whereas the ethanol injection was not effective. Then, this study confirms the usefulness of a combined chemical and isotopic approach to evaluate and characterize water quality improvement occurring during artificial aquifer recharge.

Acknowledgment: This study was supported by the projects CGL2011-29975-C04-01 from the Spanish Government, 2009SGR-00103 from the Catalan Government and ENPI/2011/280-008 from the European Commission.

\title{
References
}

1. Aravena, R. and Robertson, W.D., Use of multiple isotope tracers to evaluate denitrification in ground water: Study of nitrate from a large-flux septic system plume. Ground Water, 36(6), pp. 975-982, 1998.

2. Barbieri, M., Carrera, J., Ayora. C., Sanchez-Vila. X., Licha.T., Nödler, K., Osorio, V., Pérez, S., Köck-Schulmeyer, M., López de Alda, M. and Barceló, D., Formation of diclofenac and sulfamethoxazole reversible transformation products in aquifer material under denitrifying conditions: Batch experiments. Sci. Total Environ., 426, pp. 256-263S, 2012.

3. Pauwels, H., J.C., Kloppmann, W., Denitrification and mixing in a schist aquifer: Influence on water chemistry and isotopes. Chemical Geology, 168(3-4): pp. 307-324, 2000.

\section{5 - TRACING THE ORIGIN OF SULPHUR IN DARZILA KARST CAVE, NE IRAQ}

\author{
Anna Seither ${ }^{1,3}$ - Karin Heiland ${ }^{2,3}$-Sascha Kummer ${ }^{3}$ \\ ${ }^{1}$ Norges Geologiske Undersøkelse, 7040 Trondheim, Norway; \\ e-mail: anna.seither@ngu.no \\ ${ }^{2}$ Ingenieurbüro für Grundwasser GmbH, 04229 Leipzig, Germany \\ ${ }^{3}$ TU Bergakademie Freiberg, 09596 Freiberg, Germany
}

\section{Introduction}

Darzila cave, located in the Sangaw district in Northern Iraq, develops by the dissolution of limestone by sulphuric acid through oxidation of $\mathrm{H}_{2} \mathrm{~S}$. Previous workers such as Khanaqa and Al-Manmi (2011) were uncertain about the origin of hydrogen sulphide 
in the cave waters. They suggested gypsum from the Lower Fars Formation as main sulphur source and mentioned a potential influence of nearby petroleum fields. The main deliverable of this study was to resolve these speculations and to trace back the origin of cave waters by hydrogen, oxygen and sulphur isotopic analyses.

\title{
Methodology
}

Sulphur extracts from the possible endmembers crude oil and gypsum were subject to isotopic analyses $\left(\delta^{34} \mathrm{~S}, \delta^{18} \mathrm{O}\right)$. The water of three prominent floor feeders inside the cave was analyzed for its content of major ions, trace elements, total organic carbon, as well as for the stable isotopic composition of water $\left(\delta \mathrm{D}, \delta^{18} \mathrm{O}\right)$, dissolved sulphide $\left(\delta^{34} \mathrm{~S}\right)$ and sulphate $\left(\delta^{34} \mathrm{~S}, \delta^{18} \mathrm{O}\right)$.

\section{Results}

Investigations of water samples pointed towards a potential influence of hydrocarbon-bearing layers at two sites. Indices were significantly elevated $\mathrm{SO}_{4}{ }^{2-} / \mathrm{Ca}^{2+}$ ratios, an increased content of total dissolved solids $(10-31 \mathrm{~g} / \mathrm{L})$ and dissolved organic carbon (14-20 mg/L), and relative enrichments of trace elements such as $\mathrm{Cr}, \mathrm{Be}, \mathrm{Ga}, \mathrm{Ni}$, $\mathrm{Co}, \mathrm{Mn}$, and $\mathrm{V}$. The isotopic investigations confirmed the influence of $\mathrm{H}_{2} \mathrm{~S}$ affluxes from hydrocarbons $\left(\delta^{34} \mathrm{~S} \approx 9 \% \mathrm{VCDT}\right)$ at these sites. Evidence was given by depleted $\delta^{34} \mathrm{~S}$ and $\delta^{18} \mathrm{O}$ values in sulphate, small differences between the sulphur isotopic signature of sulphate and sulphide, as well as elevated $\delta \mathrm{D}$ values in ambient water.

The third floor feeder had an entirely different isotopic signature, showing distinct signs of bacterial sulphate reduction and therefore pointing towards primary gypsum from the Lower Fars Formation $\left(\delta^{34} \mathrm{~S} \approx+22 \%\right.$ VCDT $)$ as sulphur source. Main indications were a $\delta^{34} \mathrm{~S}$ value of sulphate above that of gypsum and strongly depleted sulphide. However, it appears that sulphate reduction was superimposed by several secondary transformation processes.

\section{References}

1. P. Khanaqa and D. Al-Manmi, Hydrogeochemistry and geomicrobiology of Darzila spring in Sangaw, Sulaimaniyah, NE Iraq. Iraqi Bulletin of Geology and Mining, 7, pp. 63-79, 2011.

\section{6 - A MILLENNIAL CLIMATIC RECONSTRUCTION FOR NORTH-EASTERN CANADA USING OXYGEN ISOTOPES IN SUBFOSSIL TREES}

\author{
Maud Naulier ${ }^{1}$ - Martine Savard ${ }^{2}-$ Christian Bégin $^{2}$ \\ ${ }^{1}$ Institut national de la recherche scientifique, 490 rue de la Couronne , QC, G1K9A9, \\ Canada; e-mail: maud.naulier@ete.inrs.ca \\ ${ }^{2}$ Geological Survey of Canada, Natural Resources Canada, 490 rue de la Couronne, \\ QC, G1K9A9, Canada
}


Knowledge of past variations in regional climate registered in natural archives contributes to a better understanding of current global climate change. For that purpose, trees represent one of the best archives because stable isotopes in their rings can record climatic conditions prevailing during their yearly growth. At this stage, isotopic series of riparian black spruce trees have never been used to reconstruct the past climate of North-Eastern Canada, and there is no study that utilises oxygen isotopic series for millennial climatic reconstruction. Importantly, there is no isotopic millennial dendrochronological series existing for the North American boreal forest, but there is a need for such a long-term perspective. Consequently, the objectives of this study were to: (i) evaluate the climatic significance of $\delta^{13} \mathrm{C}$ and $\delta^{18} \mathrm{O}$ series, and select the best ratio for climatic reconstruction; (ii) decide on the best sub-fossil ring sampling method that could minimize the number of sub-samples to be analyzed while producing an annual resolution with a good replication for the millennial isotope series, and produce a millennial climatic reconstruction for the north-eastern Canada.

From one boreal lake, we collected four riparian living trees and selected 230 well-preserved subfossil stems from the lake floor. We have analyzed the $\delta^{18} \mathrm{O}$ and $\delta^{13} \mathrm{C}$ ring series of the living trees and compared them for the 1860 to 2010 period. We have also assessed the isotopic responses for the instrumental period (1949-2010) to normalized climatic conditions from three meteorological stations near the studied lake. For the investigation of sub-fossil trees, we have pre-selected every sub-fossil stems according to their excellent degree of preservation [1], ring width $(>2 \mathrm{~mm})$ and age, then we have chosen to adapt the cohort [2] and the join-point correction [3] methods to obtain an annual resolution with a replication of 5 . The prepared $\alpha$-cellulose was analyzed using peripherals on-line with gas-source isotope ratio mass spectrometers (IRMS): a pyrolysis elemental analyzer-CF-IRMS, giving an external precision of $0.2 \%$ for $\delta^{18} \mathrm{O}$ values, and a combustion elemental analyzer-CF-IRMS for $\delta^{13} \mathrm{C}$ values, with a precision of $0.1 \%$.

The $\delta^{18} \mathrm{O}$ values of the living trees show stable trends, whereas, the $\delta^{13} \mathrm{C}$ series show positive slopes from 1910 to 1980 , which are not due to climatic conditions. Moreover, the $\delta^{18} \mathrm{O}$ ratios present the strongest correlations with climatic conditions $(\mathrm{R}=-0.40$ for June-July precipitation; $\mathrm{R}=-0.42$ for the June-August climatic index, which includes precipitation and maximal temperature), indicating that the $\delta^{18} \mathrm{O}$ values represent the best indicator for climatic reconstruction in the studied context. To produce millennial series, we have established 13 cohorts, between 55 and 111 years in length, and 12 join points with a number of trees varying between 10 and 25 . The intersections between two successive cohorts are surprisingly matching, and it seems that, except in two cases, correcting with join-point averages would introduce non-natural isotopic departures from the rest of the measured curve. The cohorts of the modern period (over 80 years) show isotopic results matching the series of the living trees, indicating that lakeshore living trees and subfossil stems from boreal lakes have coherent isotopic records, and may turn out to be useful for paleo-climatic studies. 
We are currently reconstructing the climatic conditions for the last millennium using bootstrap to develop isotopic response functions, and multiple linear regressions, for transfer functions to calculate the past climatic parameters [4]. We will compare the results of this reconstruction with other independent climatic series produced for the circum-Atlantic regions. Our purpose is to find out if the North-Eastern Canadian climate presents contrasted climatic periods that are similar to other series over the last millennium. Overall we hope to bring new data and perspectives on the circum-Atlantic climatic system.

\title{
References
}

1. M.M. Savard, C. Bégin, J. Marion, D. Arseneault and Y. Bégin, Evaluating the integrity of C and O isotopes in sub-fossil wood from boreal lakes. Palaeogeography, Palaeoclimatology, Palaeoecology , 21-31, pp. 348-349, 2012.

2. T. Boettger and M. Friedrich, A new serial pooling method of shifted tree ring blocks to construct millennia long tree ring isotope chronologies with annual resolution. Isot. Environ. Health Stud., 68-80, 45 pp., 2009.

3. M. Gagen, D. Mccarroll, R. Jalkanen, N.J. Loader, I. Robertson and G.H.F. Young, A rapid method for the production of robust millennial length stable isotope tree ring series for climate reconstruction. Global and Planetary Change, 96-103, pp. 82-83, 2012.

4. J. Guiot, Bootstrapped response function. Tree-ring Bulletin, 51, pp. 39-42, 1991.

\section{7 - STABLE ISOTOPIC COMPOSITION OF METHANE IN GROUNDWATER AND SURFACE WATER IN CARROLL COUNTY, OHIO, USA, ALONG A TIME SERIES OF HYDRAULIC FRACTURING}

\author{
Amy Townsend-Small \\ Department of Geology, University of Cincinnati, Cincinnati, OH USA; \\ e-mail: amy.townsend-small@uc.edu
}

Hydraulic fracturing for natural gas and fossil fuel resources has been correlated with increased methane concentrations in groundwater wells, corresponding with a stable isotopic signature of methane indicative of a fossil fuel rather than biological source [1]. However, there is little published information about methane concentration and isotopic composition in groundwater wells prior to hydraulic fracturing. The current study investigated methane concentration and isotopic composition $\left(\delta^{13} \mathrm{C}\right.$ and $\left.\delta \mathrm{D}\right)$ in surface and groundwater wells in Carroll County, Ohio, USA along a time series of hydraulic fracturing. This region, overlying the Utica Shale, is slated for development of hundreds of hydrofracking wells over the next several years, and also has a long history of conventional oil and gas extraction as well as coal mining. We are establishing a network of sampling sites along a gradient of fracking development from permitted sites to producing wells. Preliminary data show that methane concentrations in groundwater are generally higher than in surface streams. Some groundwater wells 
had methane concentrations near the flammability range, but some of these had isotopic composition indicative of a microbial, not fossil fuel source [2]. Future work will include adding more sites as well as some sites overlying a proposed underground coal mine also being considered for the area.

\title{
References
}

1. S.G. Osborn, A. Vengosh, N.R. Warner and R.B. Jackson, Methane contamination of drinking water accompanying gas-well drilling and hydraulic fracturing. Proc. Nat. Acad. Sci. doi:10.1073/pnas.110682108, 2011.

2. A. Townsend-Small, S.C. Tyler, D.E. Pataki, X. Xu and L.E. Christensen, Isotopic measurements of atmospheric methane in Los Angeles, California, USA: Influence of fugitive fossil fuel emissions. J. Geophys. Res., 117: D07308, 2012.

\section{8 - NITROGEN DYNAMICS IN A COASTAL AQUIFER IMPACTED BY INDUSTRIAL AND URBAN WASTES}

\author{
Ramon Aravena ${ }^{1}$ - Chiara Sbarbati ${ }^{2}-$ Marco Pettita $^{2}$ - Nicolò Colombani ${ }^{3}-$ \\ Micol Mastrocicco ${ }^{3}-$ Josh Neufeld ${ }^{4}$ \\ ${ }^{1}$ Department of Earth and Environmental Sciences, University of Waterloo, \\ Waterloo, Ontario, Canada; email: roaraven@uwaterloo.ca \\ ${ }^{2}$ University of La Sapienza, Rome, Italy \\ ${ }^{3}$ University of Ferrara, Ferrara, Italy \\ ${ }^{4}$ University of Waterloo, Waterloo, Canada
}

Geological, hydrogeological and geochemical investigations were conducted in a polluted site in Italy, with the aim of improving and validating a conceptual model of groundwater flow and contaminant transport and of providing an evaluation of contaminant evolution with time under a permanent remediation perspective. The site is a coastal aquifer impacted by organic (petroleum hydrocarbons and chlorinated solvents) and inorganic contaminants (nitrogen) and a hydraulic barrier and a P\&T system is operating to control the contaminant plumes. As part of the study, a geochemical investigation was carried out to evaluate the processes controlling contaminant transport in the aquifer. Geochemical tracers including inorganic and organic chemistry, oxygen and deuterium in water, carbon- 13 and chlorine- 37 in chlorinated compounds, nitrogen-15 and oxygen-18 in nitrate and nitrogen-15 in ammonium were used in the study. Samples for microbiological analysis were also collected to evaluate the role of anammox on the attenuation of nitrogen in the aquifer. Only data collected to evaluate sources and processes that affect nitrogen in the aquifer will be presented at this conference. The main sources of nitrogen are: in the western area, leakages of the sewage network system, an old fertilizer plant and a treatment plant for the contaminated groundwater; in the central area, sewage treatment plants and an old industrial plant used to produce acrylonitrile; and in the eastern area, a landfill where industrial wastes were deposited. The groundwater is under anaerobic and highly reducing conditions. 
Ammonium and nitrate co-exist in the groundwater and nitrite is also present in some part of the aquifer. A wide range in ammonium concentration that varies between 2 and $3000 \mathrm{mg} / \mathrm{L}$ has been observed at the study site. The higher ammonium concentrations were observed in the plume associated with the groundwater treatment plant which is characterized by $\delta^{15} \mathrm{~N}$ values near $0 \%$. The more enriched $\delta^{15} \mathrm{~N}$ values (10 to $15 \%$ ) associated to an ammonium concentration around $300 \mathrm{mg} / \mathrm{L}$ were observed in the plume related to the fertilizer plant. The ammonium associated to leakage of the sewage network system and to the sewage treatment and the acrylonitrile plants with concentration ranging between 150 and $400 \mathrm{mg} / \mathrm{L}$ are characterized by $\delta^{15} \mathrm{~N}$ values between 0 and $-1 \%$. Two general patterns have been observed between isotope and concentration data for ammonium. One pattern shows a decrease in concentration associated with a decrease in $\delta^{15} \mathrm{~N}$ values that could be associated to the effect of sorption. The other pattern shows a trend of decreasing ammonium concentration associated with a trend toward more enriched ${ }^{15} \mathrm{~N}$ values. This pattern is also accompanied by a trend toward more enriched $\delta^{15} \mathrm{~N}$ values and lower concentration for nitrate. These types of patterns for ammonium and nitrate have been associated to the role of anammox [1], however the role of denitrification in the attenuation of nitrate cannot also be discarded. The typical enrichment trend for $\delta^{18} \mathrm{O}$ and $\delta^{15} \mathrm{~N}$ values associated to denitrification has indeed been observed at the study area however this trend could be also associated to anammox when ammonium and nitrate co-exist in groundwater. On-going microbiological analyses [2] will provide a more definitive answer for evaluating the role of anammox at the study site. Summarizing, the combined use of chemical and isotopic tracers allowed us to evaluate the role of the different nitrogen sources on the distribution of nitrogen in the groundwater and the processes that control the behaviour of nitrogen in the aquifer in a complex contaminated site impacted by industrial and urban wastes.

\section{References}

1. Clark, I.D., Timlin, R., Bourbonnais, A., Jones, K., Lafleur, D. and Wickens, K.,Origin and fate of industrial ammonium in anoxic ground water- $15 \mathrm{~N}$ evidence for anaerobic oxidation (anammox). Ground Water Monitoring and Remediation, 28(3), pp. 73-82, 2008.

2. Moore, T.A., Xi., Y., Lazenby, B., Lynch, M.D., Schiff, S., Robertson, W.D., Timlin, R., Lanza, S., Ryan, M.C., Aravena, R., Fortin, D., Clark, I.D. and Neufeld, J.D., Prevalence of Anaerobic Ammonium-Oxidizing Bacteria in Contaminated Groundwater. Environmental Science \& Technology, 45, pp. 7217-7225. 


\title{
109 - EXPERIMENTAL STUDY ON STABLE ISOTOPE FRACTIONATION OF EVAPORATING WATER OF DIFFERENT INTIAL ISOTOPIC COMPOSITION AT $26^{\circ} \mathrm{C}$
}

\author{
Pooja Devi ${ }^{1,2}$ - A.K. Jain ${ }^{1}$ - M.S. Rao ${ }^{2}$ \\ ${ }^{1}$ Department of Physics, Indian Institute of Technology Roorkee, Roorkee - 247667, India; \\ e-mail: pujaiitr09@gmail.com \\ ${ }^{2}$ National Institute of Hydrology, Roorkee - 247667, India
}

The studies of evaporative isotopic fractionation in controlled conditions are of particular importance for understanding the evaporation fractionation that occurs in natural conditions. This encourages the detailed investigation of the process of isotope enrichment in surface waters by controlled evaporation pan experiments in the laboratory. In this paper, in order to study the stable isotopic fractionation mechanism of water and examine the influence of different initial isotopic compositions of water at $26^{\circ} \mathrm{C}$ temperature, evaporation pan experiment was carried out. The results showed that the isotopic compositions of residual water were more enriched over the time and the initial isotopic composition of evaporating water had a little effect on water evaporation fractionation. The average isotopic fractionation factors at $26^{\circ} \mathrm{C}$ were found to be $0.985198 \pm 0.0052$ and $0.930723 \pm 0.0215$ for $\mathrm{H}_{2}{ }^{16} \mathrm{O} / \mathrm{H}_{2}{ }^{18} \mathrm{O}$ and $\mathrm{H}_{2} \mathrm{O} / \mathrm{HDO}$, respectively. The results also showed that the average enrichment degree of deutrium (D) was 4.318 times that of the oxgyen isotope $\left({ }^{18} \mathrm{O}\right)$. The data generated in this work would be helpful for better understanding and use of stable isotope techniques in isotope hydrology.

\section{References}

1. H. Hu, W. Bao, T. Wang and S. Qu, Experimental study on stable isotopic fractionation of evaporating water under varying temperature. Water Science and Engineering, 2(2), pp. 11-18, 2009.

2. X. P. Zhang, L. D. Tian and J. M. Liu, Fractionation mechanism of stable isotope in evaporating water body. Journal of Geographical Science, 15(3), pp. 375-384, 2005.

\section{0 - ISOTOPIC GROUNDWATER MONITORING FOR ASSESSING POTENTIAL IMPACT FROM UNCONVENTIONAL GAS PRODUCTION IN ALBERTA, CANADA}

\author{
Bernhard Mayer - Michael Nightingale - Jenifer Ing \\ Department of Geoscience, University of Calgary, 2500 University Drive NW, \\ Calgary, Alberta, Canada; e-mail: bmayer@ucalgary.ca
}

With the rapid expansion of natural gas exploitation from unconventional reservoirs including coalbed methane and shale gas plays, there is significant public concern about potential future contamination of shallow potable groundwater with stray gases, formation waters or chemicals used during hydraulic fracturing. In order to enable a 
scientifically sound assessment of potential future deterioration of freshwater resources in shallow aquifers, it is essential to first establish and understand the current baseline of groundwater quality including its dissolved or free gases.

Since 2006, we have conducted monitoring programs determining the chemical and isotopic compositions of water, its dissolved constituents, and of gases obtained from shallow groundwater and formation fluids collected from coalbed methane and shale gas plays in Western Canada. We found that total dissolved solids, $\delta^{18} \mathrm{O}$ of water, and chloride concentrations are excellent indicators for monitoring for potential impact of formation waters on shallow groundwater [1]. Stray gas intrusion from deeper formations into shallow aquifers can be effectively monitored by determining the $\delta^{13} \mathrm{C}$ values of methane and ethane in dissolved or free gas. Provided that baseline data for shallow groundwater have been determined, and that chemical and isotopic data for mudlog gases and production gases are available, it may be possible to identify the formation from which gas leakage occurs [2]. This presentation will detail the approach used in Alberta (Canada) for monitoring for potential negative impacts on shallow groundwater from stray gases or formation waters mobilized during unconventional gas production and summarize the chemical and isotopic results obtained so far.

\title{
References
}

1. K. Cheung et al., Major ion and isotope geochemistry of fluids and gases from coalbed methane and shallow groundwater wells in Alberta, Canada. Applied Geochemistry, 25, pp. 1307-1329, 2010.

2. B. Tilley and K. Muehlenbachs, Fingerprinting of gas contaminating groundwater and soil in a petroliferous region, Alberta, Canada. Proceedings, International Network of Environmental Forensics, Cambridge, UK, July 25-27, 2011, 10 pp.

\section{1 - EXPERIMENTAL FLUID-ROCK STUDIES OF NATURAL GAS-BEARING BLACK SHALES AND APPLICATION TO PALEOENVIRONMENT, FORMATION FLUIDS, AND ENVIRONMENTAL IMPACTS OF HYDRAULIC FRACTURING}

\author{
Brian W. Stewart ${ }^{1}$-Rosemary C. Capo ${ }^{1}$-Elizabeth C. Chapman ${ }^{1,2}-$ Thai T. Phan ${ }^{1}-$ \\ James B. Gardiner ${ }^{1}$ - Jason Johnson ${ }^{3}$ - Joseph Graney ${ }^{3}$ - Shikha Sharma ${ }^{4}$ \\ Jaime Toro ${ }^{4}$ \\ ${ }^{1}$ Department of Geology and Planetary Science, University of Pittsburgh, \\ Pittsburgh, PA 15260, USA; e-mail: bstewart@pitt.edu \\ ${ }^{2}$ Echelon Applied Geoscience Consulting, 1229 Twelve Oaks Ct., \\ Murrysville, PA 15668, USA \\ ${ }^{3}$ Department of Geological Sciences, Binghamton University, Binghamton, NY 13902, USA \\ ${ }^{4}$ Department of Geology and Geography, West Virginia University, \\ Morgantown, WV 26506, USA
}


Organic-rich shales which are both the source and reservoir for extensive natural gas deposits, such as those of the Marcellus Formation in the eastern USA, are increasingly exploited using the combined technologies of directional drilling and hydraulic fracturing. Intensive research is focused on the sedimentary source for these productive shales, their depositional environment, and fluid flow processes that took place during and after diagenesis and catagenesis. In addition, the natural gas extraction technologies result in the required disposal of significant amounts of black shale drill cuttings and of highly saline produced water, which has also become an area of scientific and public interest. To address these issues, we report results from a multi-isotope and geochemical investigation of the Marcellus shale through sequential extraction of core and cutting material.

Marcellus shale material from two widely separated sites was subject to different sets of leachates designed to extract some or all of the following components: water soluble salts, exchangeable cations, carbonate minerals, oxidizables (organic matter and sulfides), and silicate/oxide residues. Some of the initial findings include (1) The major element chemistry of the water leachates differs significantly from produced water1, and most (>90\%) of the Ba extracted is in the exchangeable fraction. (2) ${ }^{87} \mathrm{Sr} /{ }^{86} \mathrm{Sr}$ ratios of the water-soluble and exchangeable fractions fall within the range of values for Marcellus produced waters1, while the carbonate ratios approach those of Middle Devonian shales; silicate residues yield significantly higher (by $>0.02$ ) ratios. (3) The ${ }^{238} U{ }^{235} U$ of carbonate cement in the black shale tends to be higher (by 0.2 to $0.6 \%$ ) than coexisting silicate and organic matter, and in most cases all are higher than limestone from adjacent units by 0.3 to $1.3 \%$. (4) ${ }^{143} \mathrm{Nd} /{ }^{144} \mathrm{Nd}$ ratios and model ages suggest that post-depositional disturbance to the organic and clastic portion of the shale lithologies has been minimal. Taken together, these data indicate that the Marcellus shale has preserved isotopically distinct reservoirs that reflect their petrogenesis from deposition of the shale to diagenesis, as well as possible later tectonically-driven fluid flow, and long-term interaction with formation waters. This complex history is also reflected in the geochemistry and isotopic composition of produced waters from Marcellus natural gas wells.

\section{Reference}

1. E.C. Chapman, R.C. Capo, B.W. Stewart, C.S. Kirby, R.W. Hammack, K.T. Schroeder and H.M. Edenborn, Geochemical and strontium isotope characterization of produced waters from Marcellus shale natural gas extraction. Env. Sci. Technol., 46, pp. 3545-3553, 2012. 


\title{
112 - APPLICATION OF THE SR ISOTOPIC COMPOSITION OF PRODUCED WATERS FROM DEVONIAN GAS WELLS IN THE APPALACHIAN BASIN, USA, AS A TRACER OF SUBSURFACE REACTIONS
}

\author{
Rosemary C. Capo ${ }^{1}$ - Brian W. Stewart ${ }^{1}$ - Elisabeth Rowan ${ }^{2}-$ Courtney Kolesar $^{1}-$ \\ Andy Wall $^{3}$ - Elizabeth Chapman ${ }^{1,4}$ - Richard W. Hammack ${ }^{3}$ - Karl T. Schroeder ${ }^{3}$ \\ ${ }^{1}$ National Energy Technology Laboratory-Regional University Alliance and Department of \\ Geology \& Planetary Science, University of Pittsburgh, Pittsburgh, PA 15260, USA; \\ e-mail: rcapo@pitt.edu \\ ${ }^{2}$ United States Geological Survey, 12201 Sunrise Valley Dr., Reston, VA 20192, USA \\ ${ }^{3}$ National Energy Technology Laboratory, 626 Cochrans Mill Rd., \\ Pittsburgh, PA 15236, USA \\ ${ }^{4}$ Echelon Applied Geoscience Consulting, 1229 Twelve Oaks Ct., \\ Murrysville, PA 15668, USA
}

The $\mathrm{Sr}$ isotope composition of water can be a sensitive natural tracer of groundwater interactions with the ability to distinguish between inputs from deep and shallow contamination sources, and between interactions with mineralogically similar but stratigraphically distinct units. This is of particular relevance to regions such as the Appalachian Basin, USA where development of the Marcellus Shale, one of the world's largest natural gas plays, has increased rapidly with the application of horizontal drilling and hydrofracturing techniques. Thousands of active and abandoned oil and gas wells in the region are potential conduits for the movement of waters impacted by coal, oil and gas production. Recent events have highlighted the need for sensitive methods to distinguish between multiple contaminant sources and to better understand water-brine-rock interactions in areas with complex hydrogeology affected by over a century of legacy mining and drilling.

Strontium isotopic ratios of produced waters collected from Marcellus shale gas wells over a geographic range of $\sim 375 \mathrm{~km}$ from six counties across southwestern to northeastern Pennsylvania define a relatively narrow set of values $(0.7095-0.7121)$. This isotopic range lies above that of Middle Devonian seawater, and our results to date indicate that this is distinct from most western Pennsylvania acid mine drainage and Upper Devonian Venango, Bradford and Burkett oil and gas units [1]. These data suggest that the $\mathrm{Sr}$ isotope ratios can be an extremely sensitive tracer with strong potential as a tool that can be used for verification of safe water disposal, and to identify and quantify mixing and determine the source of TDS in surface and ground waters potentially affected by AMD, produced waters or fly ash impoundments. For example, strontium isotope analysis of artesian discharges from a series of abandoned gas wells in western Pennsylvania indicates the of high TDS waters result from the interaction of AMD with siderite-cemented aquifers and that upward migration of Devonian oil and gas brines associated with the wells did not contribute significantly to the discharge geochemistry [2]. 
Because Marcellus Formation produced waters can have $\mathrm{Sr}$ concentrations that are an order of magnitude greater than those of the Upper Devonian waters in this region, Sr isotopic composition of the latter $\left({ }^{87} \mathrm{Sr} /{ }^{86} \mathrm{Sr}\right.$ ranges from 0.7199 to 0.7209$)$ are sensitive to small $(>1-2 \%)$ intrusions of the former [3]. Preliminary comparison of water samples from Upper Devonian gas wells and local spring water before and after hydraulic fracturing of Marcellus Shale wells in the same area suggest no communication of Marcellus-derived fluids into local groundwater or the Upper Devonian wells ( $>3000 \mathrm{ft}$ above the Marcellus and $\sim 2000 \mathrm{ft}$ below freshwater aquifers).

Strontium concentrations and isotope compositions of flowback and produced water are controlled primarily by mixing with formation waters, which contain very high levels of $\mathrm{Sr}$ (up to $5000 \mathrm{ppm}$ ), but other chemical species vary depending on the content of the fracturing fluid, shale, and formation water. Based on two unconventional gas wells, Chapman et al. [1] reported that as the returned waters shifted from mixed injection fluids and formation waters to predominantly formation waters, the $\mathrm{Sr}$ isotope composition reached a constant value within 2-10 days of water return, while the $\mathrm{Sr}$ concentration rose more slowly and appeared to hit a steady state value within 30 days. To investigate longer-term changes in chemistry and isotope composition, $\mathrm{Sr}$ isotope and geochemical data were obtained from flowback and produced water from four horizontally drilled wells in the Marcellus Formation in southwestern Pennsylvania. Samples were collected from the first day of flowback after hydraulic fracturing (Day 0), and then at intervals spanning over 10-15 months. Results indicate that steady state is achieved more slowly than previously thought, perhaps on a time scale of months rather than days. As production continues the returned waters primarily reflect the formation water end-member, allowing better understanding of shale water chemistry and evolution

\section{References}

1. E.C. Chapman, R.C. Capo, B.W. Stewart, C.S. Kirby, R.W. Hammack, K.T. Schroeder and H.M. Edenborn, Geochemical and strontium isotope characterization of produced waters from Marcellus shale natural gas extraction. Env. Sci. Technol., 46, pp. 3545-3553, 2012.

2. E.C. Chapman, R.C. Capo, B.W. Stewart, R.S. Hedin, T.J. Weaver and H.M. Edenborn, Strontium isotope quantification of siderite, brine, and acid mine drainage contributions to abandoned gas well discharges in the Appalachian Plateau. Appl. Geochem., 31, pp. 109-118, 2013.

3. C.A. Kolesar, R.C. Capo, A.J. Wall, B.W. Stewart, K.T. Schroeder, R.W. Hammack, Using strontium isotopes to test stratigraphic isolation of injected and formation waters during hydraulic fracturing. AAPG Ann. Meeting, 2013. 


\title{
113 - STABLE ISOTOPES FOR NITROGEN CYCLING IN STREAMS AND RIVERS: REVISITING THE PARADIGMS
}

\author{
Sherry L. Schiff ${ }^{1}$ - John Spoelstra ${ }^{1,2}$ - David M. Snider ${ }^{3}$ - Jason J. Venkiteswaran ${ }^{1}-$ \\ Madeline S. Rosamond ${ }^{1}-$ Richard J. Elgood $^{l}-$ T. Fraser Cummings ${ }^{1}-$ \\ Eduardo Cejudo ${ }^{1}-$ Laura A. Sauder ${ }^{4}-$ Puntipar Sonthiphand ${ }^{4}-$ Josh D. Neufeld ${ }^{4}$ \\ John M. Quinn ${ }^{5}$ - Mohamed N. Mohamed ${ }^{6}-$ Ramon O. Aravena $^{1}$ - William D. Taylor ${ }^{4}$ \\ Michael C. English ${ }^{7}$ \\ ${ }^{1}$ Department of Earth \& Environmental Sciences, University of Waterloo, \\ Waterloo, ON Canada N2L 3G1; e-mail: sschiff@uwaterloo.ca \\ ${ }^{2}$ National Water Research Institute, Environment Canada, Burlington, ON Canada L7R 4A6 \\ ${ }^{3}$ University of Guelph, Guelph, ON Canada N1G 2W1 \\ ${ }^{4}$ Department of Biology, University of Waterloo, Waterloo, ON Canada N2L 3G1 \\ ${ }^{5}$ National Institute of Water and Atmospheric Research, PO Box 11115, \\ Hamilton, New Zealand \\ ${ }^{6}$ Ontario Ministry of Environment, Toronto, ON Canada M9P 3V6 \\ ${ }^{7}$ WiIfrid Laurier University, Waterloo, ON Canada N2L 3C5
}

Stable isotopes of nitrate $\left(\delta^{15} \mathrm{~N}, \delta^{18} \mathrm{O}\right)$ have been used with great success in groundwaters to probe the extent of denitrification [1] and to examine sources of nitrate $\left(\mathrm{NO}_{3}{ }^{-}\right)$contamination in aquifers [2]. This approach was then extended to watersheds to examine the importance of atmospheric versus microbial sources ${ }^{2}$ of $\mathrm{NO}_{3}{ }^{-}$ and in atmospheric sciences to examine the origins of atmospheric $\mathrm{NO}_{3}{ }^{-}$and $\mathrm{N}$ reaction chemistry [2]. Advances in analytical methods facilitated the use of stable isotopes in marine $\mathrm{N}$ cycling [3]. The approach has also been broadened to the watershed scale to identify sources of $\mathrm{NO}_{3}^{-}$to lakes, large rivers, estuaries, the Great Lakes and coastal marine environments. Heightened concern about worldwide fertilization with $\mathrm{N}$ in combination with advent of new molecular approaches for microbial ecology has spawned significant advances in our knowledge of $\mathrm{N}$ cycling [4, 5], including new organisms and $\mathrm{N}$-cycling pathways (e.g., anaerobic ammonium oxidation, archaeal nitrification). Concurrently, isotopic analysis of $\mathrm{NO}_{3}{ }^{-}$has become widely available on a routine basis while techniques for isotopic analysis of other $\mathrm{N}$ species $\left(\mathrm{NH}_{4}^{+}, \mathrm{N}_{2} \mathrm{O}\right.$, $\mathrm{NO}_{2}^{-}$, DON) have become more robust. New emphasis on enzyme based approaches to understanding isotopic fractionations in both marine environments and terrestrial soils $[3,6]$ has lead to new insights on $\mathrm{N}$ cycling, especially on the importance of $\mathrm{NO}_{2}^{-}$. Now is an excellent time to re-examine paradigms associated with isotopic fractionation in N-cycling processes and the widely used "Kendall" plot [2] for N sources. We use data from soils, small streams $\left(1^{\text {st }}-4^{\text {th }}\right.$ order $)$ and large rivers in New Zealand and Canada that are either pristine or impacted by agriculture and/or wastewater treatment plants and the stable isotopic analysis of $\mathrm{NO}_{3}{ }^{-}, \mathrm{NH}_{4}{ }^{+}, \mathrm{N}_{2} \mathrm{O}$ and $\mathrm{NO}_{2}{ }^{-}$to strengthen the scientific foundations for the use of stable isotopes for $\mathrm{N}$ cycling 


\title{
References
}

1. A. Mariotti, A. Landreau and B. Simon, ${ }^{15} \mathrm{~N}$ isotope biogeochemistry and natural denitrification process in groundwater: Application to the chalk aquifer of northern France. Geochim. Cosmochim Acta, 52, pp. 1869-1878, 1988.

2. C. Kendall and J. J. McDonnell (eds), Isotope Tracers in Catchment Hydrology? Elsevier Science B.V., Amsterdam, 1998.

3. C. Buchwald and K.L. Casciotti, Isotopic ratios of nitrite as tracers of the sources and age of oceanic nitrite. Nature Geoscience, 6, pp. 308-313, 2013.

4. J.J. Elser. A World Awash with Nitrogen. Science, 334, p. 1504, 2011.

5. B. Thamdrup, New pathways and processes in the global nitrogen cycle, Annu. Rev. Ecol. Syst., 43, pp. 407-428, 2012.

6. D.M. Snider, J.J. Venkiteswaran, S.L. Schiff and J. Spoelstra, Deciphering the oxygen isotope composition of nitrous oxide produced by nitrification. Global Change Biol., 18, pp. 356-370, 2012.

\section{4 - THE BEHAVIOUR OF STABLE ISOTOPES OF CHLORINATED SOLVENTS DURING DIFFUSION AND SORPTION PROCESSES IN LOW-PERMEABILE ZONES}

\author{
Fatemeh Vakili ${ }^{1}$ - Orfan Shouakar-Stash ${ }^{2}-$ Shaun Frape $^{3}$ \\ ${ }^{1}$ Department of Earth and Environmental Sciences, University of Waterloo, \\ 200 University Ave. W., Waterloo, ON, Canada; e-mail: fvakili@uwaterloo.ca \\ ${ }^{2}$ Department of Earth and Environmental Sciences, University of Waterloo, \\ 200 University Ave. W., Waterloo, ON, Canada; e-mail: orfan@uwaterloo.ca \\ ${ }^{3}$ Department of Earth and Environmental Sciences, University of Waterloo, \\ 200 University Ave. W., Waterloo, ON, Canada; e-mail: shaun@uwaterloo.ca
}

Chlorinated solvents are prevalent and persistent groundwater contaminants that are mostly arising from industrial contamination. Once chlorinated contaminants make it to the subsurface, they might undergo several different processes such as physical (sorption, diffusion, volatilization), chemical (abiotic degradation), and biological (biodegradation) processes. Understanding the sources and/or fate of these contaminants is essential to set up proper remediation strategies. In the last decade compound-specific isotope analysis (CSIA) has emerged as one of the most useful techniques to fingerprint the organic contaminants sources and also to understand the transformation mechanisms of these contaminants in the subsurface. CSIA has been increasingly used as an indicator for chemical and biological degradation of the chlorinated solvents to address the contaminant source. However, most of the studies on CSIA (mainly ${ }^{13} \mathrm{C}$ ) assume that the stable isotope fractionations associated with physical processes such as diffusion and sorption are negligible. Slater et al. (2000) examined the stable carbon isotopic fractionations during the equilibrium sorption of dissolved VOC (over a range of $10-90 \%$ sorption) and concluded that no significant isotope fractionation occurs during sorption. The fractionation of carbon isotopes during equilibrium sorption of chlorinated solvents onto carbonaceous minerals were also 
studied by Schüth et al. (2003) and study confirmed that sorption does not affect the carbon isotopic ratios of the examined organic contaminants. LaBolle et al. (2008) investigated the effect of diffusion on carbon isotope fractionation of MTBE using a simulated stratified aquifer-aquitard system and reported isotopic depletion in the aquitard units. To our knowledge, the effect of sorption and diffusion on chlorine and hydrogen stable isotopes of chlorinated solvents has not been studied to date. This study was carried out by conducting several laboratory batch experiments in order to investigate the isotopic behaviours $\left({ }^{13} \mathrm{C},{ }^{37} \mathrm{Cl}\right.$, and $\left.{ }^{2} \mathrm{H}\right)$ that are associated with sorption and diffusion of trichloroethylene (TCE) and cis-dichloroethylene (cis-DCE) in a low-permeable medium. The media used for the experiment included silt, shale, and dolostone. Overall, the obtained results showed that sorption caused enrichment of both chlorine and carbon isotope values over time while hydrogen isotopes became depleted. The results also showed a similar trend for hydrogen isotopes during the back-diffusion process (diffusion of chlorinated solvents from contaminated low-permeable material into the water). In this study, measurable fractionations were observed for both carbon and chlorine isotopes however, the fractionations were not very significant compared to those associated with chemical and biological transformation processes. On the other hand, the observed hydrogen isotope fractionations associated with the physical processes were quite significant.

\title{
References
}

1. E.M. LaBolle, G.E. Fogg, J.B. Eweis, J. Gravner and D.G. Leaist, Isotopic fractionation by diffusion in groundwater. Water Resources Research, 44, W07405, 2008.

2. C. Schuth, H. Taubald, N. Bolano and K. Maciejczyk, Carbon and hydrogen isotope effects during sorption of organic contaminants on carbonaceous materials. Journal of Contaminant Hydrology, 64, pp. 269-281, 2003.

3. G.F. Slater, J.M.E. Ahad, B.S. Lollar, R. Allen-King and B. Sleep, Carbon isotope effects resulting from equilibrium sorption of dissolved VOCs. Analytical Chemistry, 72, pp. 5669-5672, 2000 .

\section{5 - THE IMPERATIVE OF ISOTOPE GEOCHEMISTRY AND MACRO FOSSIL ANALYSIS IN UNDERSTANDING THE PALEOCLIMATOLOGY AND ENVIRONMENTAL CHANGES IN THE NIGER DELTA OF NIGERIA}

\author{
Ezekwe I. Clinton - S.B Arokoyu \\ Department of Geography and Environmental Management, University of Port Harcourt, \\ Port Harcourt, Nigeria
}

The Niger delta (Tertiary to Recent) is one of the biggest wetlands in the world (70,000 $\mathrm{km} 2$ ) and maintains the third-largest drainage basin in Africa. This incredibly well-endowed ecosystem contains one of the highest concentrations of biodiversity on the 
planet, in addition, it supports abundant flora and fauna, arable terrain that can sustain a wide variety of crops, lumber or agricultural trees, and more species of freshwater fish than any ecosystem in West Africa [1]. Regrettably, it is also an oil-rich region, and has been the centre of international controversy over unabated gas flaring of over 50 decades and devastating oil pollution and ecocide. The region is currently experiencing unprecedented changes in weather patterns and increasing devastating floods, ecological changes and loss of biodiversity attributed to negative environmental activity.

The only solution to controversies that has arisen from these activities and trends is paleoenvironmental investigations. Paleoenvironmental records are derived from a wide variety of natural archives, such as: lake and ocean sediments, tree rings, wind-blown deposits, coral, and ice cores, as well as historical documents. Chemical, isotopic, and ecological analyses of these records have demonstrated that the natural climate system has varied locally and globally over a far greater range than can be inferred from relatively short-term instrumental records. In most locations, instrumental records might provide 100 years of climate data, whereas an ice core might provide an annual climate record of 10,000 to 30,000 years. Understanding the natural environmental changes of our planet on long timescales (years to millennia) provides the context for understanding today's climate dynamics and for elucidating the impacts of natural versus anthropogenic influences [2].

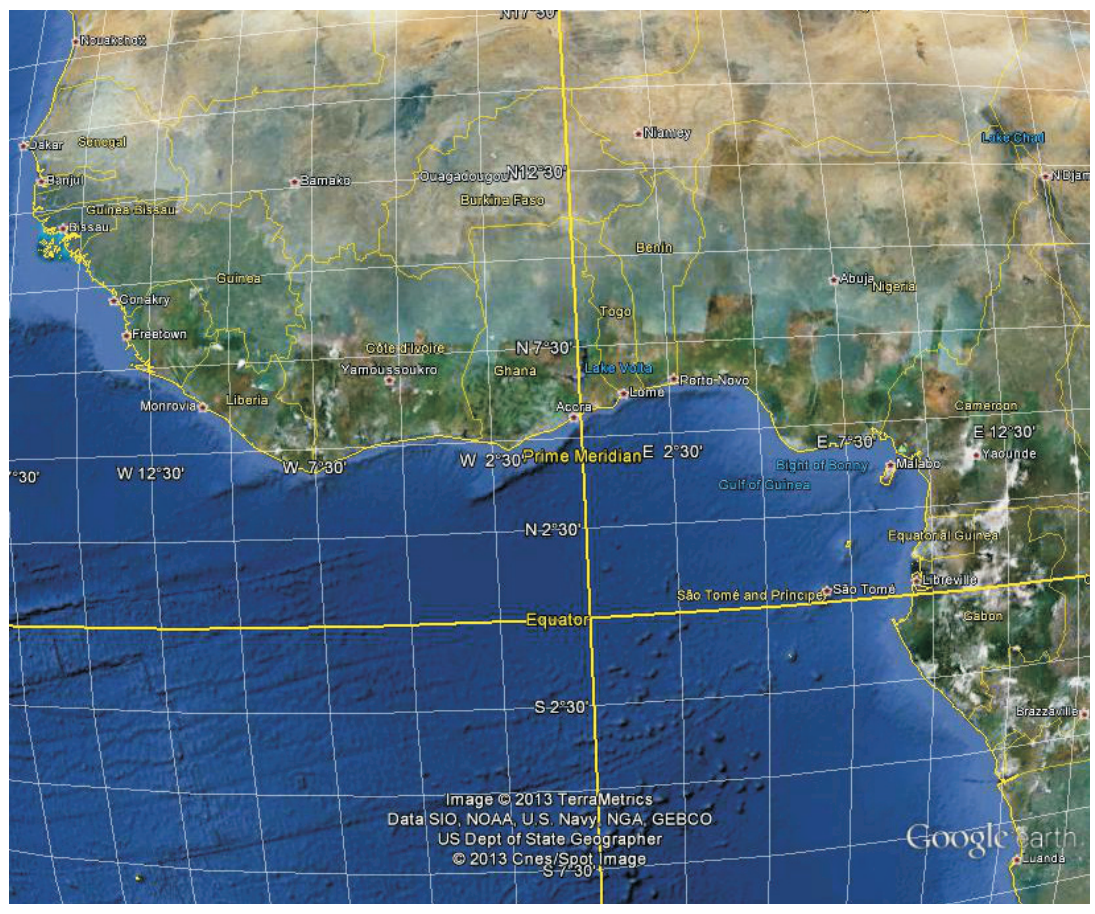


The Niger Delta region still has patches of precinct forests and also lakes unaffected by the devastation of oil pollution. Sediments from these lakes and evidence from biota especially tree rings could be used as veritable sources for a quantitative understanding of the past environment of the Niger delta and to define the impacts of human activities in this important wetland of the world and implications for future climate and environment. Reconstructing the historical climate record of the Niger Delta hence, will offer an enhanced understanding of the mechanisms controlling the region's climate system and, together with insight that may be obtained from numerical modeling exercises; it could be easy to predict how the climate of the region might respond to current and future stressors [2].

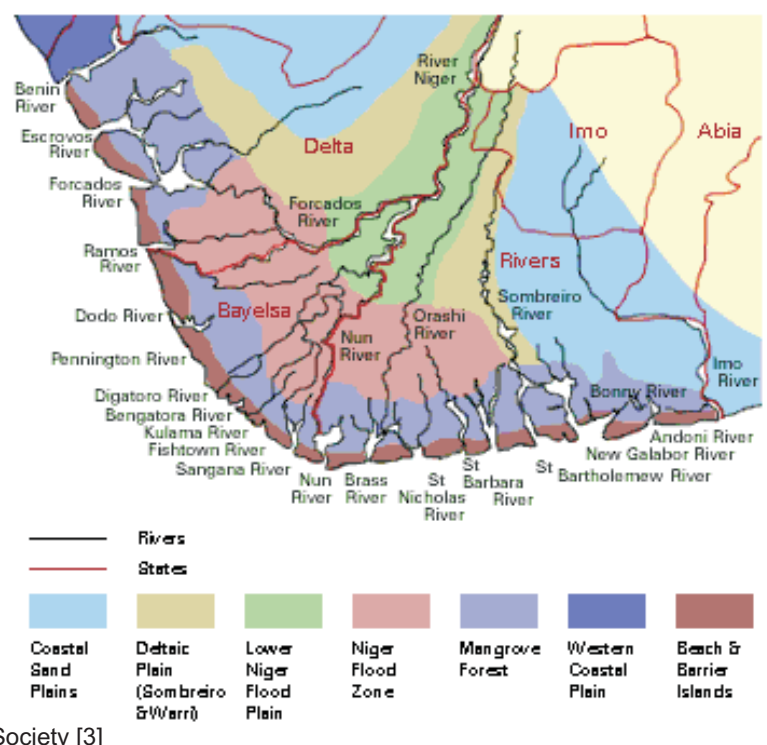

Isotope geochemistry will be invaluable also in more environmentally friendly oil and gas exploration and exploitation; addressing organic contaminants in groundwater; and assessing current impacts. Geochemical fingerprinting will boost the differentiation between natural and anthropogenic pollution [4].

The major force militating against quality scientific research in Africa is not lack of manpower but paucity of technology and funding. It is therefore imperative to establish a regional centre for paleoenvironmental studies and isotopic geochemistry and a paleoecology laboratory in the West African subregion to not only cater for environmental investigations in the subregion but also make future climatic projections in an environment where paleoenvironmental investigations are still very primary.

The Centre for Disaster Risk Management and Development in the University of Port Harcourt in Nigeria is currently interested in detailed investigations of wetland 
and lake-sediment cores in West Africa. This will involve investigations into climate change and the long-term effects of human activity on terrestrial and lake ecosystems, flood frequency analysis and the long-term dynamics of the rainforest of the Niger Delta using sediment cores and macro fossils. It also has long term plans of creating a regional centre for Paleoenvironmental Change studies in the West African SubRegion.

Collaborations in obtaining new and used equipment for sediment coring, and sediment/plant macrofossil analysis and with individual researchers, institutions and training for staff and students may be the way out for peace in an otherwise troubled subregion.

\section{References}

1. Wikipedia, 2013. Environmental Issues in the Niger Delta. http://en.wikipedia.org/wiki/Environmental issues in the Niger_Delta:

2. US Climate Change Science Program / US Global Change Research Program (accessed 21st march, 2013) Paleoenvironment \& Paleoclimate. USGCRP Program Element through Fiscal Year 2001. http://www.usgcrp.gov/usgcrp/ProgramElements/paleo.htm

3. Urhobo Historical Society, 2012. Niger Delta: Rivers, States, Vegetation. Http://Www.Waado. org/Nigerdelta/Maps/Nigerdelta_Rivers.Html

4. http://www.aig10.com/? $\mathrm{mod}=$ content $\& \mathrm{cla}=$ content $\&$ fun $=$ access $\& \mathrm{id}=97 \& \mathrm{mid}=47 \&$ temp $=$ full

\section{6 - MULTIPLE EVIDENCES OF CHLORINATED METHANES NATURAL ATTENUATION IN A COMPLEX POLLUTED AQUIFER}

Mònica Rosell ${ }^{1}$ - Clara Torrentó ${ }^{1}$ - Diana Rodríguez-Fernández ${ }^{1}$ - Carme Audí-Miró ${ }^{1}$ Massimo Marchesi ${ }^{1,2}$ - Jordi Palau ${ }^{1,3}$ - Miriam Guivernau ${ }^{4}$ - Marc Viñas ${ }^{4}-$ Neus Otero ${ }^{1}$ - Albert Soler ${ }^{1}$

${ }^{1}$ Grup de Mineralogia Aplicada i Medi Ambient, Facultat de Geologia, Universitat de Barcelona, C/ Martí i Franquès s/n, 08028 Barcelona, Spain; e-mails: diana.rodriguez@ub.edu; monica.rosell@ub.edu; clara.torrento@ub.edu; carmeaudi@ub.edu; albertsolergil@ub.edu

${ }^{2}$ Department of Earth \& Environmental Sciences, 200 University Ave. W,

N2L 3G1 Waterloo, Ontario, Canada; e-mail: m2marchesi@uwaterloo.ca

${ }^{3}$ Centre d'hydrogéologie et de géothermie, Université de Neuchâtel, Rue Emile-Argand 11, Neuchâtel 2000, Switzerland; e-mail: jordi.palau@unine.ch

${ }^{4}$ GIRO Joint Research Unit IRTA-UPC, IRTA, Torre Marimon,

Caldes de Montbui E-08140 Spain; e-mails: marc.vinas@irta.cat; miriam.guivernau@irta.cat

The activity of a former chemical plant (1978-1985) in Òdena (Barcelona, Spain) resulted in the contamination of a fractured bedrock aquifer with a complex mixture of chlorinated organic compounds (chlorinated ethenes, ethanes, methanes and chlorobenzenes), together with traces of BTEX and pesticides. Among them, chloroform (CF) and carbon tetrachloride (CT) remain at very high concentrations (above $1 \mathrm{mg} / \mathrm{L}$ ) in some monitoring wells related to former contamination sources (underground 
wastewater tank and a disposal lagoon) which were removed in 2006. The fact that low levels of these chlorinated methanes can severely inhibit the reductive dechlorination of the other major group of pollutants at the site, the chlorinated ethenes, by dehalorespiring bacteria such as Dehalococcoides-like bacteria (Maymó-Gatell et al., 2001) makes of vital importance the characterization and stimulation of in situ natural attenuation processes affecting the removal of $\mathrm{CT}$ and $\mathrm{CF}$.

Although, up to now, CT seems not to serve as a metabolic electron acceptor for any known species, dechlorination of $\mathrm{CT}$ has been observed in a range of anaerobic microbial cultures (methanogenic, denitrifying, sulphate and iron reducing and fermentative) as well as linked to naturally occurring reductants (e.g. metal sulphides) in low-redox environments. In contrast, $\mathrm{CF}$ biodegradation to dichloromethane (DCM) by chlororespiration has been observed by Dehalobacter-containing mixed cultures (Grostern et al. 2010) associated to the activity of the reductive dehalogenase encoded by the CfrA genes (Tang et al., 2013) and followed by chlorofermentation (Lee et al., 2012).

In our field site, the installation and monitoring (campaigns 2010 and 2013) of a ten multilevel wells network permitted to detect significant shifts in carbon isotopic compositions of CT and CF in depth and along the contamination plume, coupled with concentration data of pollutants and detection of metabolites or by-products (such as high amounts of carbon disulphide, CS2) linked to specific degradation pathways and under particular geochemical conditions. In addition, a thorough microbial community analysis by $16 \mathrm{SrDNA}$-based DGGE profiling and 454-pyrosequencing in some of the monitoring wells revealed the presence of dehalorespiring bacteria (Desulfitobacterium and Dehalobacter genus) but the absence of Dehalococcoides-like bacteria neither its related reductive dehalogenases ( $v c r A, b v c A$, tce $A$ genes).

In order to confirm field observations and to evaluate the impact of different biostimulation strategies on the indigenous microbial community composition, microcosm experiments were set up in batch using a homogeneous slurry (groundwater and sediments from the bottom of the most contaminated well) as inoculum. Three treatments were tested - (1) lactate, (2) methanol and (3) acetate-, together with two types of controls - (4) live control and (5) autoclaved control -, all of them with and without vitamin B12 as bacterial corrinoid model compound or redox-active molecule. The microcosms were incubated statically, in the dark at room temperature and monitored regularly for concentration and carbon isotopic composition (when possible) of the main pollutants.

All live-cultures showed significant decrease of $\mathrm{CT}$ along the incubation, but the addition of vitamin $\mathrm{B}_{12}$ accelerated considerably the biodegradation of $\mathrm{CT}$ and $\mathrm{CF}$ with consequent accumulation of high amounts of $\mathrm{CS}_{2}$ as observed by Koenig et al. (2012) and no apparent accumulation of other chlorinated intermediates (DCM). Pure $\mathrm{CT}$ abiotic reactions with present minerals were discarded in killed controls. The consumption of the added electron donors did not show any apparent biostimulating effect 
on the degradation of the target chlorinated methanes neither ethenes with respect the natural potential of the indigenous microbial community.

Two replicates of each treatment were sacrificed after 197 days of incubation. Initial and final measurements of relevant geochemical parameters as well as microbial community composition and detection of several reductive dehalogenases were carried out.

The conclusions of this study would serve to elucidate relevant in situ natural attenuation processes, potential of biostimulation strategies and possibly to evaluate the convenience of isotopic measurements and the sensitivity of some commonly used biomarkers for monitoring the efficiency of target organochlorides biodegradation at the field site.

Acknowledgments: The present research is supported by Agència de Residus de Catalunya, a Marie Curie Career Integration Grant in the framework of IMOTEC-BOX project (PCIG9-GA-2011-293808) within the $7^{\text {th }}$ Framework Programme and the ATTENUATION project (CGL2011-29975-C04-01) from the Spanish Government.

\title{
References
}

Grostern, A., Duhamel, M., Dworatzek, S. and Edwards, E., 2010. Chloroform respiration to dichloromethane by a Dehalobacter population. Environ. Microbiol., 12, pp. 1053-1060.

Koenig, J.C., Lee, M.J., Manefield, M., 2012. Successful microcosm demonstration of a strategy for biodegradation of a mixture of carbon tetrachloride and perchloroethene harnessing sulfate reducing and dehalorespiring bacteria. Journal of Hazardous Materials, 219-220, pp. 169-175.

Lee, M.; Low, A.; Zemb, O.; Koenig, J.; Michaelsen, A.; Manefield, M., 2012. Complete chloroform dechlorination by organochlorine respiration and fermentation. Environ. Microbiol., 14 (4), pp. 883-894.

Maymó-Gatell, X., Nijenhuis, I., Zinder, S.H., 2001. Reductive dechlorination of cis-1,2-dichlorethene and vinyl chloride by Dehalococcoides ethenogenes. Environ. Sci. Technol., 35 (3), $516-$ 521 .

Tang S., Edwards E.A., 2013 Identification of Dehalobacter reductive dehalogenases that catalyze dechlorination of chloroform, 1,1,1-trichloroethane and 1,1-dichloroethane. Phil. Trans. R. Soc. B, 368, 20120318.

\section{7 - SR-ND-PB ISOTOPES IN MIOCENE PORPHYRY COPPER DEPOSITS FROM PRECORDILLERA OF MENDOZA, ARGENTINA}

\author{
Silvia Irene Carrasquero ${ }^{1}$ - Nora A. Rubinstein ${ }^{2}$ - Denis Fontignie ${ }^{3}-$ \\ Massimo Chiaradia ${ }^{3}$
}

${ }^{1}$ Facultad de Ciencias Naturales y Museo (Universidad Nacional de La Plata)-INREMI, 64 y 120, La Plata (1900), Argentina; e-mail: silviacarrasquero@yahoo.com.ar

${ }^{2}$ IGEBa (CONICET) Dto. de Cs. Geológicas - FCEyN, Ciudad Universitaria, pabellón 2, CABA

${ }^{3}$ Department of Mineralogy, University of Geneva, Switzerland 
The Paramillos de Uspallata mining district is located in the southern part of the Precordillera of Mendoza Province $\left(69^{\circ} 05^{\prime}-69^{\circ} 07^{\prime} \mathrm{W}\right.$; $\left.32^{\circ} 24^{\prime}-32^{\circ} 31^{\prime} \mathrm{S}\right)$, in the Cenozoic flat-slab segment $\left(27-33^{\circ} \mathrm{S}\right)$ of Chile and Argentina [1]. The district includes the porphyry copper deposits Paramillos Norte, Paramillos Centro and Paramillos Sur [2]. These ore deposits are genetically linked to the Miocene volcanism with an adakite-like signature [3].

$\mathrm{Sr}, \mathrm{Nd}$ and $\mathrm{Pb}$ isotope (corrected to $16.9 \mathrm{Ma}$ ) analyses were carried out on the subvolcanic intrusive rocks spatially and genetically associated with these three porphyry deposits. Sr-Nd isotopes ratios of these rocks display a wide range of $\left({ }^{87} \mathrm{Sr} /{ }^{86} \mathrm{Sr}\right) \mathrm{i}$ $(0.703700-0.705592)$ and $\left({ }^{143} \mathrm{Nd} /{ }^{144} \mathrm{Nd}\right) \mathrm{i}(0.512514-0.512846)$ ratios. They plot in the Mantle Array towards to the EMI field (Fig. 1a) suggesting a crust component. The $\mathrm{Pb}$ isotopes ratios suggest that all the samples can be assembled in a single group, with ranges in $\mathrm{Pb}$ isotope ratios of $18.4732-18.7841\left({ }^{206} \mathrm{~Pb} /{ }^{204} \mathrm{~Pb}\right), 15.5797-15.6309$ $\left({ }^{207} \mathrm{~Pb} /{ }^{204} \mathrm{~Pb}\right)$ and $38.2557-38.5662\left({ }^{208} \mathrm{~Pb} /{ }^{204} \mathrm{~Pb}\right)$. In the thorogenic diagram (Fig. $1 \mathrm{~b}$ ) the samples show a linear array towards the upper crust field and plot within the mature arcs area in full agreement with $\mathrm{Sr}-\mathrm{Nd}$ isotopes results and confirming the involvement of the upper crust in their genesis. The isotopic composition of the Miocene volcanism from the Paramillos de Uspallata mining district support the presence of a thickened crust during the intrusion of the mineralized porphyries.

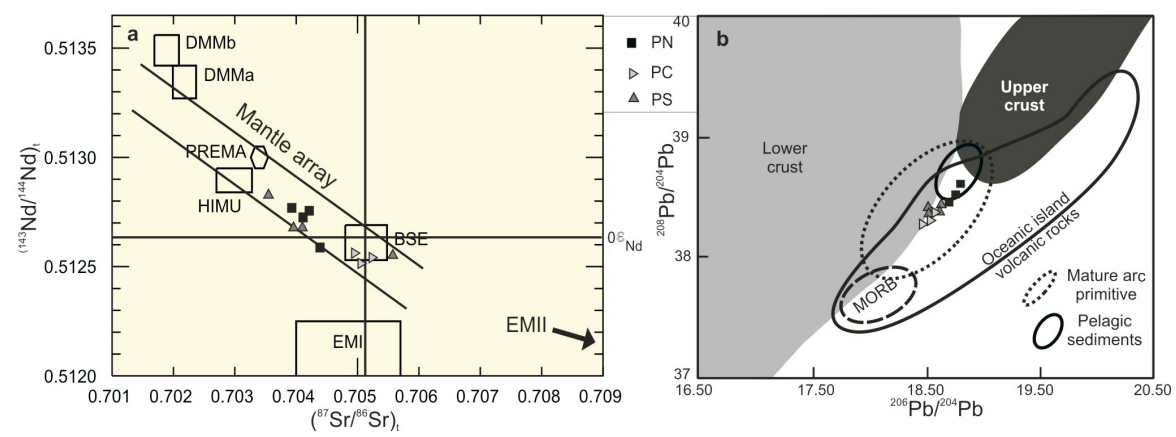

Figure 1. a) $\left({ }^{87} \mathrm{Sr} /{ }^{86} \mathrm{Sr}\right) \mathrm{t}$ vs $\left({ }^{143} \mathrm{Nd} /{ }^{144} \mathrm{Nd}\right) \mathrm{t}$ isotope correlation diagram, showing the main reservoirs [4]: DM (depleted mantle); PREMA (PREvalent Mantle); HIMU (mantle with high U/Pb);EMI and EMII (Enriched mantle type I and II); BSE (Bulk Silicate Earth). b) ${ }^{208} \mathrm{~Pb} /{ }^{204} \mathrm{~Pb}$ vs ${ }^{206} \mathrm{~Pb} /{ }^{204} \mathrm{~Pb}$ correlation diagram define the fields for mantle, upper crust, lower crust and orogene [5]. The samples plot in mature arc primitive to sediments field and upper crust

\section{References}

1. M. Barazangi and B.L. Isacks, Spatial distribution of earthquakes and subduction of the Nazca plate beneath South America. Geology, 4, pp. 686-692, 1976.

2. H. Navarro, Area de reserva $\mathrm{N}^{\circ} 3$. Zona Paramillos Norte, provincia de Mendoza. 4 Jornadas Geológicas Argentinas, 3, pp. 105-125, Mendoza, 1972. 
3. S.I. Carrasquero, N.A. Rubinstein and D. Fontignie, Adakite-like signature in volcanic rocks associated with the Oro del Sur $\mathrm{Au}-(\mathrm{Cu})$ epithermal deposit, Southern Precordillera, Argentina. N. Jb. Geol. Paläont. Abh., 261, pp. 309-320, 2011.

4. A. Zindler and S.R. Hart, Chemical geodynamics. Ann. Rev. Earth Planet. Sci., 14, pp. 493-571, 1986.

5. R.E. Zarmant and B.R. Doe, Plumbotectonics: the model. Tectonophysics, 75, pp, 135-162, 1982.

\title{
118 - USING STABLE ISOTOPES AND CONSERVATIVE TRACERS TO IDENTIFY FLOWBACK WATER COMPONENTS IN PETROLEUM WELLS FROM THE WESTERN CANADA SEDIMENTARY BASIN
}

\author{
Serguey Arkadakskiy ${ }^{1}-$ Ben Rostron $^{2}$ \\ ${ }^{1}$ Isobrine Solutions Inc., 4-341, 10230 Jasper Ave., Edmonton, AB T5J 4P6, Canada; \\ e-mail: serguey@isobrine.com \\ ${ }^{2}$ EAS Department, University of Alberta, CCIS 3-065 , Edmonton, AB, Canada; \\ e-mail: ben.rostron@ualberta.ca
}

The Western Canadian Sedimentary Basin (WCSB) contains a staggering volume of hydrocarbons with shale reservoirs estimated to hold ca. $30 \times 10^{12} \mathrm{~m}^{3}$ natural gas [1] and the Bakken Formation in the Canada and USA alone estimated to contain between 300 and 500 billion bbl of light crude oil [2]. A significant fraction of that, however, may only be produced by enhanced recovery technologies, such as horizontal drilling and multistage hydraulic fracturing. The implementation of those technologies has increased dramatically the volume of gaseous and liquid hydrocarbon production in the basin and the fraction of natural gas, condensate and light crude oil produced from petroleum wells subjected to hydraulic fracturing in Western Canada is now gradually replacing conventional sources. Hydraulic fracturing requires large quantities of water mixed with various organic compounds. Concerns have been raised not only about the volume of the water used but also about the safe disposal and/or recycling of the aqueous flow back fluids, which are often mixed with variable quantities of formation water/brine and salts and/or may carry naturally occurring radioactive materials.

Petroleum wells drilled in water unsaturated $\left(S_{w i}\right)$ reservoirs exhibit a gradual decrease of flowback volumes, which may completely disappear in time (e.g., in parts of the Horn River shale and the Montney shale reservoirs). Low to very low flowback volumes at some wells in those areas suggest that reservoir lithologies are absorbing hydraulic fracturing fluid. Wells in other parts of those reservoirs, however, co-produce variable amounts of aqueous fluids with volumes that may increase during the lifetime of the well. Aqueous flowback fluids consist of three principal components. These are: a) fluids used in the process of hydraulic fracturing; b) formation water/brines, and in the case of gas wells; c) water of condensation. Flowback fluids may also contain lesser quantities of drilling and/or other completion fluids. Casing prob- 
lems, fracture propagation into nearby water saturated formations or the intersection of natural tectonic conduits may also lead to invasion of external water in the production zones of the wells. Therefore, the source(s) and proportion of different components in the co-produced aqueous fluids need to be determined not only to optimize hydrocarbon production and to improve well economics but also to reduce potential environmental impact related to excessive water co-production.

Standard water identification methods are based on the analysis of dissolved inorganic species ( $\mathrm{Na}, \mathrm{Ca}, \mathrm{Mg} \mathrm{SO}_{4}, \mathrm{HCO}_{3}$ ), which are for the most part non-conservative and/or may be added to the fracturing fluid mixture. Hence, these may fail to unambiguously identify flowback water contents. In contrast, analyses of thousands of aqueous samples from WCSB petroleum wells subjected to hydraulic fracturing in the last ten years demonstrate that the stable isotope compositions of water $\left(\delta^{18} \mathrm{O}\right.$ and $\left.\delta^{2} \mathrm{H}\right)$ and the concentrations and ratios of dissolved halogen elements $\mathrm{Cl}, \mathrm{Br}$ and I are capable of successfully identifying the origin and proportions of the different flowback components. Hydraulic fracturing fluids consist predominantly of local surface waters. The large differences between the $\delta^{18} \mathrm{O}$ and $\delta^{2} \mathrm{H}$ values of local surface waters those of formation water and brines form hydrocarbon bearing shale in W Canada and $\mathrm{N}$ USA, which reach tens of permil for $\mathrm{O}$ and about hundred permil for $\mathrm{H}$, render $\delta^{18} \mathrm{O}$ and $\delta^{2} \mathrm{H}$ particularly well suited for water fingerprinting. The concentrations and ratios of the halogen elements $\mathrm{Cl}, \mathrm{Br}$ and/or I are also powerful tracers of the origin of dissolved salts in formation-waters and brines [3]. Halogens are seldom used in fracturing fluid preparations, hence, they provide a sensitive and reliable fingerprint of the presence and origin of formation-waters/brines in the flowback fluids.

In this presentation we will review individual cases of flowback water production from a variety of environments from the WCSB including mature shale gas plays in NW Alberta and NE BC, the Colorado Shale and the Bakken formation. We will also discuss the benefits of accurate identification of different flowback components for production optimization and water co-production mitigation.

\section{References}

1. National Energy Board (Canada), Understanding Canadian Shale Gas - Energy Brief (modified October 10, 2012), http://www.neb.gc.ca/clf-nsi/rnrgynfmtn/nrgyrprt/ntrlgs/prmrndrstndngshlgs 2009/prmrndrstndngshlgs2009nrgbrf-eng.html (accessed April 29, 2013).

2. J. Flannery and J. Kraus, American Association of Petroleum Geologists Search and Discovery Article No. 10105, 2006.

3. A.B. Carpenter, Oklahoma Geol. Surv. Circ., 79, pp. 60-77, 1978. 


\title{
119 - THE ISOTOPIC DISTRIBUTION OF $\delta^{37}$ CL AND $\delta^{81}$ BR IN HIGHLY EVAPORATED ALKALINE LAKES OF THE SAND HILLS, NEBRASKA, USA
}

\author{
Shaun Frape ${ }^{1}-$ Randy Stotler ${ }^{2}-$ F. Edwin Harvey ${ }^{3}$ - David C. Gosselin ${ }^{4}$ \\ ${ }^{1}$ Department of Earth and Environmental Sciences, University of Waterloo, \\ Waterloo, Ontario, Canada; e-mail: shaun@uwaterloo.ca \\ ${ }^{2}$ Department of Geology, University of Kansas, Lawrence, Kansas, USA \\ ${ }^{3}$ Water Resources Division U.S. National Park Services, Fort Collins, Colorado, USA \\ ${ }^{4}$ School of Natural Resources, University of Nebraska, Lincoln, Nebraska, USA
}

Highly saline alkaline lakes occur in arid and semi-arid environments throughout the world. Many such environments like the African Rift, Altiplano of Chile/Argentina and Siberia are extreme climates and are often tectonically active. Lakes have high $\mathrm{pH}$, high $\mathrm{HCO}_{3} / \mathrm{CO}_{3}$ and are usually sodic $(\mathrm{Na}) /$ potash $(\mathrm{K})$ rich. Carbonate and sulphate mineral species dominate the salt precipitates adjacent to these lakes.

The Sand Hills region of western Nebraska, U.S.A. is an area of extensive large sand dunes, kilometers in scale, the largest dune field in North America. The area formed from extensive aeolian reworking of continental glacial deposits most recently during two major periods from 7500 to 5000 and 3500 to 1500 years before present (Swinehart, 1989). A large number of inter-dunal lakes, many of which are alkaline, developed across the area as early as 13,000 years before present (Swinehart, 1989; Zlotnik, 2012). The area has very little surface drainage, and the lakes are recharged from dilute groundwater $(\sim 0.2 \mathrm{~g} / \mathrm{L})$, sourced in most cases from the local adjacent hydrogeological environment (Gosselin, 1997; Winter, 1986). Winter (1986) implied that deeper local flow systems might contribute a higher initial mineralization to some lakes due to longer flow paths and greater water/rock interaction. However, strontium isotopic values from a large number of lakes are relatively unradiogenic $(\sim 0.701)$ and very uniform (Gosselin et al., 1997). Evidence for fresh groundwater recharge as the major solute source can be seen in the many springs and fresh water vegetation islands that form and flow year round in the middle of extensive salt flats in all highly mineralized lakes.

Many lakes are highly evaporated with salinities between 0.3 to $>300 \mathrm{~g} / \mathrm{L}$ TDS. The most saline lakes are Na-K- $-\mathrm{CO}_{3}-\left(\mathrm{SO}_{4}\right)-(\mathrm{Cl})$ and Na-K- $-\mathrm{SO}_{4}-\mathrm{CO}_{3}-(\mathrm{Cl})$ in composition. Potassium concentrations can exceed $86 \mathrm{~g} / \mathrm{L}$; thus the area was once a major mining centre for potash mineralization. Carbonate concentrations are the highest recorded in North America. Major mineral species that occur in thick salt crusts surrounding these lakes are thenardite $\left(\mathrm{Na}_{2} \mathrm{SO}_{4}\right)$ and thermonatrite $\left(\mathrm{Na}_{2} \mathrm{CO}_{3} \cdot \mathrm{H}_{2} \mathrm{O}\right)$. Consequently, many lake waters have variable $\mathrm{CO}_{3}{ }^{-} \mathrm{Cl} \mathrm{SO}_{4}$ contents as precipitated mineral form during dry periods and dissolve incongruently during wet years.

Initially, a historical data set and samples archived from 1992-93, gathered across the northwestern lakes by Gosselin et al. (1994) were used for analysis. Many of 
the more saline lakes were sampled again the late summer of 2012 by the authors. For a number of the most saline lakes the $\delta^{37} \mathrm{Cl}$ and $\delta^{81} \mathrm{Br}$ values were the most enriched by the late summer of 1992, which was a severe drought year. Much wetter conditions in the winter of 1993 generally saw declining isotopic values. However, simple evaporative recycling of $\mathrm{Br}-\mathrm{Cl}$ from fluid to salt to fluid cannot fully explain the range of values. The range of $\delta^{81} \mathrm{Br}$ observed in the lakes in our study area at any one time is $\sim 3 \%$. This range is greater than that reported for crystalline rocks $(\sim 2 \%)$ (Stotler et al., 2010), greater than most groundwater samples from the salt dominated Siberian Platform $(\sim 1.5 \%)$ (Shouakar-Stash et al., 2007$)$ and the Great Australian Basin $(\sim 0.5 \%)$ (Gwynne et al., 2013). The range of values in a single lake with time is twice that of samples results reported from the crystalline shields of Canada, Finland and Sweden.

The origin of the large isotopic range of values and variability is the focus of an ongoing study. An easy explanation of the values could lie in isotopic fractionation during precipitation and dissolution of evaporite salts. However, most of the salt mineralization found around these lakes does not incorporate large amounts of halides (Cl-Br). Many lakes emit large volumes of $\mathrm{H}_{2} \mathrm{~S}$ gas and contain extensive bacterial mats. A field observation in 2012 was that lakes with the strongest rotten egg smell have the lowest $\mathrm{SO}_{4}$ concentrations and the largest changes in $\delta^{81} \mathrm{Br}$ isotopic composition. Studies such as Wood and Sanford (2007) on the Abu Dhabi salt flats, UAE, observed $\mathrm{Br}$ losses that were estimated at 5 to $30 \mathrm{~g} / \mathrm{km}^{2} /$ day. Volatilization of bromine/bromide to $\mathrm{HBr}, \mathrm{HOBr}$ and $\mathrm{CH}_{3} \mathrm{Br}$ in marine aerosols has been well documented (Wofsy et al., 1975; Sturges and Harrison, 1986). More recently Kochler and Wassenaar (2009) showed fractionation of $\delta^{37} \mathrm{Cl}$ isotopes during volatilization and aerosol transport of $\mathrm{HCl}$ compounds. The role of halide isotopes in understanding volatile and microbial processes in these environments is clearly of interest for future research.

\section{References}

1. D.C. Gosselin, S. Sibray and J. Ayers, Geochemistry of closed-basin, K rich alkaline lakes, western Sand Hills, Nebraska, USA. Geochim. Cosmochim Acta, 58, pp. 1403-1418, 1994.

2. D.C. Gosselin, Major-ion chemistry of compositionally diverse lakes, Western Nebraska, USA: Implications for paleoclimatic interpretations. J. Paleolimn., 17, pp. 33-49, 1997.

3. D.C. Gosselin, P.E. Nabelek, Z.E. Peterman and S. Sibray, A reconnaissance study of oxygen, hydrogen and strontium isotopes in geochemically diverse lakes, Western Nebraska, USA. J. Paleolimn., 17, pp. 51-65, 1997.

4. G. Kohler and L.I. Wassenaar, The stable isotopic compositions $\left({ }^{37} \mathrm{Cl} /{ }^{35} \mathrm{Cl}\right)$ of dissolved chloride in rainwater. Applied Geochem., 25, pp. 91-96, 2010.

5. F. Risacher, G. Fritz and H. Alonso, Non-conservative behavior of bromide in surface waters and brines of Central Andes: A release into the atmosphere. Geochim. Cosmochim Acta, 70, pp. 2143-2152, 2006

6. O. Shouakar-Stash, S. Alexeev, S. Frape, L. Alexeeva and R. Drimmie, Geochemistry and stable isotopics signatures, including chlorine and bromine isotopes, of the deep groudwaters of the $\mathrm{Si}$ berian Platform, Russia. Appl. Geochem., 22, pp. 589-605, 2007. 
7. R.L. Stotler, S.K. Frape and O. Shouakar-Stash, An isotopic survey of $\delta^{81} \mathrm{Br}$ and $\delta^{37} \mathrm{Cl}$ of dissolved halides in the Canadian and Fennoscandian Shields. Chem. Geol., 274, pp. 38-55, 2010.

8. J.B. Swinehart, Wind-blown deposits. In: A. Bleed and C. Flowerday (eds), An Atlas of the Sand Hills, Res. Atlas 5, Conservation and Survey Division, U. of Nebraska, 1989.

9. T.C. Winter. Effect of ground-water recharge on configuration of the water table beneath sand dunes and on seepage lakes in the Sand hills of Nebraska, USA. J. Hydrol., 86, pp. 221-237, 1986.

10. W.W. Wood and W.F. Sandford, Atmospheric bromine flux from the coastal Abu Dhabi, sabkhat: A groundwater mass balance investigation. Geophys. Res. Lett., 34, L14405, 2007.

11. S.C. Wofsy, M.B. McElroy and Y.L. Yung, The chemistry of atmospheric bromine. Geophys. Res. Lett., 2, pp. 215-218, 1975.

12. V.A. Zlotnik, J.B. Ong, J.D. Lenters, J. Schmieder and S.C. Fritz, Quantification of salt dust pathways from a groundwater-fed lake: Implications for solute budgets and dust emission rates. Journal of Geophysical Research, 117, F02014, 2012.

\title{
120 - ZIRCON FISSION TRACK DATING: EVIDENCE FOR MINERALIZING AGES OF THE WULONGGOU GOLD DEPOSITS, EASTERN KUNLUN MOUNTAINS, QINGHAI-TIBET PLATEAU
}

\author{
Wanming Yuan* - Yuehao Liu - Lei Zhang - Chuanbao Zhu \\ Institute of Earth Science, China University of Geosciences, Beijing 100083, China
}

It is a puzzle to determine metallogenetic ages in the world. The zircon fission track dating is used to determine the metallogenetic epochs for Wulonggou gold ore deposits in this paper. A total of six zircon FT ages are obtained and can be divided into 235-216 Ma and 197-181 Ma, as well as $162 \mathrm{Ma}$ and $124 \mathrm{Ma}$. In particular, the age group of 197-181 Ma is first achieved in the Wulonggou area. It is shown that the FT ages consist with other isotopic data and reflect different regional thermotectonic events.

These dating results reflect a fact that there were multiple metallogenetic epochs in the Wulonggou area, in which the epochs of 235-216 Ma and 197-181 Ma are dominant. The multiple metallogenetic times indicated by FT age groups are coincident with the ore deposit characteristics of multiple mineralizations. It is overlapping of multi-stages of metallogenetic processes that intensified the mineralizing intensity and so resulted in Wulonggou supper large gold ore deposit area.

The significance of the zircon FT ages of 235-216 Ma and 197-181 Ma, as well as $162 \mathrm{Ma}$ and $124 \mathrm{Ma}$, represent the collision and post-collision orogeny linked to the accretion of the Qiangtang block, the collision between the Qiangtang block and the Kumlun block, and the ductile deformation along the Xidatan fault repectively.

Acknowledgements: This work was supported by China Geological Survey Bureau (Base 2011-03-04-06) and the Nature Science Foundation of China (Nos. 41172088 and 40872141). 


\title{
121 - USE OF STABLE ISOTOPES FOR DETERMINING BACKGROUND LEVELS ACCORDING TO GROUNDWATER DIRECTIVE. STUDY OF SULFATE LEVELS IN SOUTHERN SPAIN
}

\author{
Begoña Urresti ${ }^{1}$ - Iñaki Vadillo ${ }^{1}$ - Albert Soler $^{2}$ \\ ${ }^{1}$ Group of Hydrogeology, Faculty of Science, University of Málaga, 29071 Málaga, Spain; \\ e-mail: b.urresti@uma.es, Telephone: +34 952134213 \\ ${ }^{2}$ Group of Applied Mineralogy and Environment, Faculty of Geology, \\ University of Barcelona, Spain
}

Determine Natural Background Levels (NBL) are a key element in characterization of groundwater bodies, according to Water Framework Directive 2000/60/EC and, more specifically, Groundwater Directive 2006/118/EC. The NBL are the result of numerous factors, such as water-rock interactions, chemical and biological processes in the unsaturated zone, the residence time of water in the aquifer, recharge by rain and relations with other aquifers. In many cases, these levels present very high values for some parameters and types of groundwater, which is significant for their correct determination as a prior step to establishing thresholds, assessing the status of water bodies and subsequently identifying contaminant patterns.

The Upper Guadalhorce river basin (located in southern Spain) presents widely varying hydrogeological and hydrochemical conditions associated with lithology. Specifically, the evaporite Triassic substrate of aquifers confers to groundwater from upper basin a very high sulfate concentration a natural form, which may range above $500 \mathrm{mg} / \mathrm{l}$. In addition to natural factors, determination of NBL is further hampered by longstanding anthropogenic influence in some of the groundwater bodies in the basin. The most important sources of contamination are urbanized areas, rainfed and irrigated agriculture, grassland (livestock) and golf courses, but the largest surface area is affected by agriculture.

For development of this agriculture is common the use of many fertilizers that contain large quantities sulfate. Therefore, it is difficult to differentiate which sulfate concentrations are natural (from Triassic substrate) and which are due to the use of fertilizers.

Because chemical analyses only provide the concentration of sulfate in water but not its source, four isotopic sampling campaigns $\left({ }^{34} \mathrm{~S}-\mathrm{SO} 4\right)$ were carried out on 2004, 2006, 2009 and 2012 on groundwater bodies in the Upper Guadalhorce river ba$\sin$ in order to trace the origin of sulfate. The objective of the present study is to quantify the percentage of natural (Evaporites) and anthropogenic (Fertilizers) sulfate and match a concentration associated with this percentage that allow to know the NBL on the upper basin. 


\title{
122 - STABLE ISOTOPE STUDY OF MARINE BIOGENIC APATITE: A CASE STUDY FROM THE LATE CRETACEOUS-EARLY EOCENE PHOSPHATE SERIES OF MOROCCO
}

\author{
László Kocsis $^{1}$ - Emmanuel Gheerbrant ${ }^{2}$ - Mustapha Mouflih ${ }^{3}$ - Henri Cappetta ${ }^{4}$ - \\ Johan Yans ${ }^{5}$ - Mbarek Amaghzaz \\ ${ }^{1}$ Institute of Earth Sciences, University of Lausanne, Switzerland; \\ e-mail: laszlo.kocsis@unil.ch \\ ${ }^{2}$ CNRS and Muséum National d'Histoire Naturelle, Département Histoire de la Terre, \\ UMR 7207 - CR2P, Paris, France \\ ${ }^{3}$ Faculté des Sciences Ben M'Sik, Casablanca, Morocco \\ ${ }^{4}$ CNRS, Institut des Sciences de l'Evolution, Université de Montpellier II, France \\ ${ }^{5}$ Université de Namur, Department of Geology, NAGRIDD, Belgium \\ ${ }^{6}$ Groupe Office Chérifien des Phosphates, Centre Minier de Khouribga, Morocco
}

Here we present phosphate oxygen $\left(\delta^{18} \mathrm{O}_{\mathrm{PO} 4}\right)$ and carbon isotope $\left(\delta^{13} \mathrm{C}\right)$ compositions of structural carbonate from biogenic apatite fossils across the Moroccan phosphate series in the Ouled Abdoun and Ganntour basins. The aim of the study is to test if global climate variations can be traced in these shallow marine settings and whether the isotope signals can be used to refine local stratigraphy. Three fossil archives shark tooth enameloid and dentin, and coprolites - were investigated. The vertebrate remains show particularly good structural, mineralogical and chemical preservations. The three archives yielded different $\delta^{13} \mathrm{C}$ results where coprolites have the most negative values, followed by dentine, while enameloid retain mostly positive carbon isotope composition. The data are in good agreement with modern analogues for the shark teeth supporting further the good preservation of these fossils. Conversely, the relatively low $\delta^{13} \mathrm{C}$ values and high carbonate content of the coprolites indicate early burial condition with intensive organic matter recycling.

The $\delta^{18} \mathrm{O}_{\mathrm{PO} 4}$ values of the shark teeth relate to different shark's habitat. In case of certain groups (e.g., Anomotodon) the high isotopic compositions concur with cold and deep water dwelling. However the $\delta^{18} \mathrm{O}_{\mathrm{PO} 4}$ compositions of most investigated species indicates warm conditions. Despite the habitat related variation among the teeth, the mean $\delta^{18} \mathrm{O}_{\mathrm{PO} 4}$ values for the studied beds show important temporal variations. Combining these data with the corresponding average $\delta^{13} \mathrm{C}$ values, the sequential isotope changes allow comparison with the global isotope record.

The youngest phosphate beds in the Ouled Abdoun basin correlates with the Early Eocene Climatic Optimum and the related variations in the global carbon cycle. Down-section the isotope data imply local sedimentary gap at the Paleocene-Eocene boundary, where the Paleocene-Eocene Thermal Maximum event and partly the latest Thanetian are most likely absent. The top of the Paleocene series is dated to late Selandian-early Thanetian. At the base, the isotope signals correlates well with the Early Late Paleocene Event (ELPE). The recognition of ELPE implies that the earliest 
known placental mammals from Africa [1, 2] discovered from the layer just below this isotope signal (Eritherium Bone Bed) can be dated to a minimum age of late Selandian.

The relation of the isotope data from the older layers to the global record is less certain and further research need to be performed on these beds. Nevertheless, the older Paleocene units in the Ouled Abdoun Basin (Bed IIb), which is Danian based on the selachian fauna [3-5], may associate with the latest Danian-early Selandian isotope record, while the condensed Cretaceous beds are most probably latest Maastrichtian. The much well developed Cretaceous sequence in the Ganntour Basin seems to cover most part of the Maastrichtian ( $67-70.5 \mathrm{Ma})$.

\title{
References
}

1. Gheerbrant, E., Sudre, J., Iarochene, M. and Moumni, A., First ascertained African "condylarth" mammals (primitive ungulates: cf. Bulbulodentata \& cf. Phenacodonta) from the Earliest Ypresian of the Ouled Abdoun Basin, Morocco. J. Vert. Pal., 21, pp. 107-118, 2001.

2. Gheerbrant, E., Paleocene emergence of elephant relatives and the rapid radiation of African ungulates. Proc. Nat. Acad. Sci., 106, pp. 10717-10721, 2009.

3. Cappetta, H., Extinctions et renouvellements fauniques chez les sélaciens post-jurassiques. Mém. Soc. Géol. France, 150, pp. 113-131, 1987.

4. Noubhani, A. and Cappetta, H., Les Orectolobiformes, Carcharhiniformes et Myliobatiformes (Elasmobranchii, Neoselachii) des bassins à phosphate du Maroc (Maastrichtien-Lutétien basal). Systématique, biostratigraphie, évolution et dynamique des faunes. Palaeo Ichthyologica, 8, pp. 1-327, 1997.

5. Cappetta, H., Chondrichthyes (Mesozoic and Cenozoic Elasmobranchii: teeth). In: Handbook of Paleoichthyology, Chondrichthyes, 3E (Mesozoic and Cenozoic Elasmobranchii: teeth), pp. 1-512, H.-P. Schultze (ed.), München, Verlag F. Pfeil, 2012.

\section{3 - THE CONTROVERSY OF CONTINENTAL CLIMATE SHIFT AT THE EOCENE-OLIGOCENE BOUNDARY: NEW INSIGHTS FROM STABLE ISOTOPE COMPOSITION OF MAMMAL TEETH IN EUROPE'S MID-LATITUDE}

\author{
László Kocsis ${ }^{1}$ - Péter Ozsvárt ${ }^{2}$ - Damien Becker ${ }^{3}$ - Reinhard Ziegler ${ }^{4}$ - Vlad Codrea ${ }^{5}$ \\ ${ }^{1}$ Institute of Earth Sciences, University of Lausanne, Switzerland; \\ e-mail: laszlo.kocsis@unil.ch \\ ${ }^{2}$ Research Group for Paleontology, MTA-MTM-ELTE, Budapest, Hungary \\ ${ }^{3}$ Section d'archéologie et paléontologie, Office de la culture, Porrentruy, Switzerland \\ ${ }^{4}$ Staatlichen Museum für Naturkunde Stuttgart, Germany \\ ${ }^{5}$ Department of Geology, Babeș-Bolyai University, Cluj-Napoca, Romania
}

\section{Introduction}

The major shift between greenhouse and icehouse climate modes placed at the Eocene-Oligocene transition (EOT), when rapid step-wise positive anomalies occurred in the marine oxygen isotope record [1-3]. This relates to the combined effects of decreasing temperature and increasing ice-volume in the polar regions [2, 4]. The 
terrestrial responses to the EOT climate shift show strong spatial heterogeneity and the reported palaeoclimate records are often contradictory (i.e., cooling vs. stable climate) and the causes and effects are still widely debated [5-8].

To comprehend better the E-O continental climate, here we investigated stable isotope compositions of tooth enamel of large-sized ground dwelling herbivore mammals from several different fossil vertebrate localities with ages between 40 and 27 million years across Europe's mid-latitudes (N 40-50).

\section{Background}

The oxygen isotope composition of mammal teeth is the function of the physiological fractionation between body fluid and animal tissues during metabolic activity, and of the fluxes and isotopic compositions of the oxygen-containing substances entering and leaving the animal's body [9]. For large herbivore mammals the body fluid is dominated by the consumed water (i.e., drinking water, food source), hence the isotopic composition of their teeth largely depends on the isotopic composition of local meteoric water $\left(\delta^{18} \mathrm{O}_{\mathrm{MW}}\right.$, i.e., precipitation) [10-13] and partly on relative humidity (RH) $[12,14]$.

Based on empirical and theoretical studies on large herbivores, the $\delta^{18} \mathrm{O}_{\mathrm{PO} 4}$ show positive correlation to $\delta^{18} \mathrm{O}_{\mathrm{MW}}[10,12-13]$. Consecutively, the $\delta^{18} \mathrm{O}_{\mathrm{MW}}$ is governed by isotopic values of the moisture source and alteration during transport (i.e., altitude, latitude, Rayleigh distillation effects, amount of precipitation, etc.), but it also shows significant correlation with mean annual temperature (MAT) [15]. Conversely, RH show a negative correlation to $\delta^{18} \mathrm{O}_{\mathrm{PO} 4}$ where about $0.1-0.2 \%$ increase in $\delta^{18} \mathrm{O}_{\mathrm{PO} 4}$ match $1 \%$ decrease in $\mathrm{RH}[12,14]$. Proxy to palaeo-RH is rare, which potentially complicate palaeoclimate research. However, $\delta^{13} \mathrm{C}$ values in herbivores teeth reflect the diet of the animals [13], and thus can be linked to the palaeoflora. The $\delta^{13} \mathrm{C}$ value of plants, in turn, can be linked to water stress as it increases with decreased humidity [16]. Consequently, herbivores browse under warm arid climate (i.e., low RH) would have higher $\delta^{13} \mathrm{C}$ values fixed in their teeth, than those that live in more humid environment.

\section{Results}

Our data demonstrates a general decrease in average $\delta^{18} \mathrm{O}_{\mathrm{PO} 4}$ and $\delta^{13} \mathrm{C}$ values during the studied period. However, strong spatial heterogeneity is apparent. Southern localities close to the sea (Paratethys) have high and steady isotope values indicating warm and dry climate. Such condition observed till the middle Rupelian ( 32 Ma). Other sites mainly those that are north of the Alpine thrust, yielded lower isotopic compositions with about $1-2 \%$. These data can be linked to higher RH together with increased precipitation and more fractionated moisture source. Further on, variation in the isotope values in the north reveals about $3^{\circ} \mathrm{C}$ degrees cooling in MAT at the EOT, which was followed by a short term warming $\left(\sim 5^{\circ} \mathrm{C}\right)$. 
Between 32 and 27 Ma major decreases in the $\delta^{18} \mathrm{O}_{\mathrm{PO} 4}$ values are observed $(\sim 3-4 \%)$, while the $\delta^{13} \mathrm{C}$ values are rather steady. At this time the global climate was quite stable [2], hence the observed negative shift in the isotopic composition of the drinking water can be linked to changes in palaeoelevation in the Alps. Based on modern relationship between altitude and isotopic composition of precipitation in the Alps, the relative elevation changes could have been as high as 2000 meters, which is comparable with other studies $[17,18]$.

\section{References}

1. Miller, K.G., Wright, J.D. and Fairbanks, R.G, Unlocking the icehouse: Oligocene-Miocene oxygen isotopes, eustasy, and margin erosion. J. Geophys. Res., 96, pp. 6829-6849, 1991.

2. Zachos, J.C., Pagani, M., Sloan, L., Thomas, E. and Billups, K., 2001. Trends, rhythms, and aberrations in global climate $65 \mathrm{Ma}$ to present. Science, 292, pp. 686-693.

3. Katz, M.E., Miller, K.G., Wright, J.D., Wade, B.S., Browning, J.V., Cramer, B.S. and Rosenthal, Y., Stepwise transition from the Eocene greenhouse to the Oligocene icehouse. Nature Geoscience, 1, pp. 329-333, 2008.

4. Lear, C.H., Bailey, T.R., Pearson, P.N., Coxall, H.K. and Rosenthal, Y., Cooling and ice growth across the Eocene-Oligocene transition. Geology, 36, pp. 251-254, 2008.

5. Kohn, M.J., Josef, J.A., Madden, R., Kay, R., Vucetich, G. and Carlini, A.A., Climate stability across the Eocene-Oligocene transition, southern Argentina. Geology, 32, pp. 621-624, 2004.

6. Grimes, S.T., Hooker, J.J., Collinson, M.E. and Mattey, D.P., Summer temperatures of late Eocene to early Oligocene freshwaters. Geology, 33, pp. 189-192, 2005.

7. Zanazzi, A. Kohn, M.J., MacFadden, B.J. and Terry Jr, D.O., Large temperature drop across the Eocene-Oligocene transition in central North America. Nature, 445, pp. 639-642, 2007.

8. Sheldon, D.N., Mitchell, L.R., Collinson, E.M. and Hooker, J.J., Eocene-Oligocene transition paleoclimatic and paleoenvironmental record from the Isle of Wight (UK). Geol. Soc. Am. Spec. Paper, 452, pp. 249-259, 2009.

9. Longinelli, A., Oxygen isotopes in mammal bone phosphate-a new tool for paleohydrological and paleoclimatological research. Geochim. Cosmochim. Acta, 48, pp. 385-390, 1984.

10. Luz, B., Kolodny, Y. and Horowitz, M., Fractionation of oxygen isotopes between mammalian bone-phosphate and environmental drinking water. Geochim. Cosmochim. Acta, 48, pp. 1689-1693, 1984.

11. Bryant, J.D. and Froelich, P.N., A model of oxygen isotope fractionation in body water of large mammals. Geochim. Cosmochim. Acta, 59, pp. 4523-4537, 1995.

12. Kohn, M.J., Predicting animal $\delta^{18} \mathrm{O}$ : Accounting for diet and physiological adaptation. Geochim. Cosmochim. Acta, 60, pp. 4811-4829, 1996.

13. Kohn, M.J. and Cerling, T.E., Stable isotopes of biological apatite. Mineralogical Society of America Reviews in Mineralogy, 48, pp. 455-488, 2002.

14. Luz, B., Cormie, A.B. and Schwarcz, H.P., Oxygen isotope variations in phosphate of deer bones. Geochim. Cosmochim. Acta, 54, pp. 1723-1728, 1990.

15. Dansgaard, W., Stable isotopes in precipitation. Tellus, 16, pp. 436-468, 1964.

16. Farquhar, G.D., O'Leary, M.H. and Berry, J.A., On the relationship between carbon isotope discrimination and the intercellular carbon dioxide concentration in leaves. Aust. J. Plant Physiol., 9, pp. 121-137, 1982.

17. Jourdan, S., Bernet, M., Tricart, P., Hardwick, E., Paquette, J.-L., Guillot, S., Dumont, T. and Schwartz, S., Short-lived, fast erosional exhumation of the internal western Alps during the late 
early Oligocene: Constraints from geothermochronology of pro- and retro-side foreland basin sediments. Lithosphere, 5, pp. 211-225, 2013.

18. Glodny, J., Ring, U., Kühn, A., Gleissner, P. and Franz, G., Crystallization and very rapid exhumation of the youngest Alpine eclogites (Tauern Window, Eastern Alps) from Rb/Sr mineral assemblage analysis. Contrib. Mineral. Petrol., 149, pp. 699-712, 2005.

\title{
124 - FE ISOTOPIC RATIOS IN SELECTED GROUNDWATER SAMPLES FROM THE RAVENNA AND FRIULI COASTAL PLAINS, NE ITALY AND SIGNIFICANCE FOR THE ENVIRONMENT
}

\author{
Francesca Castorina ${ }^{1,2}$ - Umberto Masi ${ }^{2}$ \\ ${ }^{1}$ Dipartimento di Scienze della Terra, Università "La Sapienza", P. le A. Moro, \\ 00185 Rome, Italy; e-mail: francesca.castorina@uniroma1.it \\ ${ }^{2}$ Istituto di Geologia Ambientale e Geoingegneria del CNR, Sezione di Roma "La Sapienza", \\ Rome, Italy
}

High Fe concentrations (from 1.34 to $12.72 \mathrm{mg} / \mathrm{L}$ ) were measured by Pezzetta et al. (2011) in groundwater samples from the Lower Friulan Plain near the north Adriatic seacoast. The research has unveiled a positive correlation between Fe concentrations and groundwater salinization $(0.9-19679 \mathrm{mg} / \mathrm{L} \mathrm{Cl})$ and a particularly wide range of $\delta^{56} \mathrm{Fe}$ (from -5.3 to $+2.15 \%$ relative to IRMM-14 international standard, Castorina et al., 2013), compared with literature data. Furthermore, a positive correlation between $\delta^{56} \mathrm{Fe}$ and $\mathrm{Fe}$ concentrations has been found.

The present study has investigated the relationship of $\mathrm{Fe}$ isotopic ratios to $\mathrm{Fe}$ and chloride concentrations in groundwater samples from the Ravenna Plain near the north Adriatic seacoast aimed at comparing the results with those obtained from the Friulan Plain area. Therefore, the following characteristics have been recognized: a) Ravenna groundwater displays a smaller isotopic range ( $\delta^{56} \mathrm{Fe}$ from -2.6 to $0 \%$ ) than Friulan groundwater, b) unlike the positive correlation in Friulan groundwater, no correlation exists between $\delta^{56} \mathrm{Fe}$ and $\mathrm{Fe}$ concentrations $(<0.02-3.13 \mathrm{mg} / \mathrm{L})$ in Ravenna groundwater, c) there is a positive correlation between $\delta^{56} \mathrm{Fe}$ and $\mathrm{pH}$ in Ravenna groundwater while there are negative or nil correlations in Friulian groundwater, and d) there is a negative correlation between $\delta^{56} \mathrm{Fe}$ and chloride concentrations $(55-16,800 \mathrm{mg} / \mathrm{L})$ in Ravenna groundwater, while there are positive or nil correlations in Friulian groundwater. These different characteristics of groundwater from the two coastal Plains likely reflect different processes taking place in the two sites despite the broadly similar environments. The particularly isotopic lighter $\mathrm{Fe}$ compositions of most of groundwater samples from the Friulan Plain have been explained by isotopic fractionation during repeated cycling of Fe precipitation. This multi-staged process apparently does not significantly operate in the Ravenna Plain, where groundwater generally contains much lower Fe concentrations, suggesting that redox conditions are 
comparatively less exasperated. The low Fe concentrations may also explain the lack of any correlation with $\delta^{56} \mathrm{Fe}$ as well as the positive correlation between $\delta^{56} \mathrm{Fe}$ and $\mathrm{pH}$ in groundwater from the Ravenna Plain. Lastly, the negative correlation between $\delta^{56} \mathrm{Fe}$ and $\mathrm{Cl}$ in Ravenna groundwater indicates that with increasing salinization, there is likely precipitation of ${ }^{56} \mathrm{Fe}$-rich ferrihydrite, thus leaving groundwater ${ }^{56} \mathrm{Fe}$-poor. In contrast, in lower-salinity waters, probably biologically-mediated reduction of $\mathrm{Fe}(\mathrm{III})$ to $\mathrm{Fe}$ (II) in the ${ }^{56} \mathrm{Fe}$-rich ferrihydrite present in sediments, can release ${ }^{56} \mathrm{Fe}$-rich $\mathrm{Fe}$ (II) to groundwater, that thus acquires the ${ }^{56} \mathrm{Fe}$-rich signature.

Lastly, as the Friulan Plain was significantly disseminated of $\mathrm{Fe}$ wastes from smelter plants in the past, the more positive $\delta^{56} \mathrm{Fe}$ values measured in those groundwater samples were explained by waste leaching (Castorina et al., 2013). As Fe industrial pollution does not occur in the Ravenna Plain, where however, isotopic values nearing those positive of the Friulan Plain, have also been measured, this may render the above explanation not fully plausible, suggesting that the more positive $\delta^{56} \mathrm{Fe}$ measured in the Friulan Plain can be due mainly to more extreme natural causes.

\title{
References
}

1. E. Pezzetta, A. Lutman, I. Martinuzzi, C. Viola, G. Bernardis and V. Fuccaro, Iron concentrations in selected groundwater samples from the lower Friulian Plain, northeast Italy: Importance of salinity. Environ. Earth Sci., 62, pp. 377-391, 2011.

2. F. Castorina, R. Petrinic, A. Galic, F.F. Slejko, U. Aviani, E. Pezzetta and G. Cavazzini, The fate of iron in waters from a coastal environment impacted by metallurgical industry in northern Italy: Hydrochemistry and Fe-isotopes. Applied Geochemistry, 2013 (in press).

\section{5 - CHLORINE, HYDROGEN AND CARBON MULTI ISOTOPIC APPROACH TO ASSESS NATURAL ATTENUATION AND ZVI-PRB INDUCED DEGRADATION IN A DNAPLS CONTAMINATED SITE}

\author{
Carme Audi-Miró $^{1}$ - Stefan Cretnik ${ }^{3}$ - Clara Torrentó ${ }^{1}$ - Mònica Rosell ${ }^{1}$ - \\ Jordi Palau ${ }^{1,2}$ - Orfan Shouakar-Stash ${ }^{4}-$ Martin Elsner $^{3}-$ Neus Otero $^{1}-$ Albert Soler $^{1}$ \\ ${ }^{1}$ Grup de Mineralogia Aplicada i Medi Ambient, Facultat de Geologia, \\ Universitat de Barcelona, C/ Martí i Franques s/n, 08028 Barcelona, Spain; \\ e-mail: carmeaudi@ub.edu \\ ${ }^{2}$ Université de Neuchâtel. CHYN - Centre d'hydrogeologie, Rue Emile-Argand 11, \\ $\mathrm{CH}-2000$, Neuchâtel, Switzerland \\ ${ }^{3}$ Institute of Groundwater Ecology, Helmholtz Zentrum München-National Research Center \\ for Environmental Health, Ingolstädter Landstrasse 1, D-85764 Neuherberg, Germany \\ ${ }^{4}$ Department of Earth and Environmental Sciences, University of Waterloo, \\ 200 University Ave. West, Waterloo, Ontario, Canada N2L 3G1
}

The study site is polluted with dense non aqueous phase liquids (DNAPLs), mainly tetrachloroethene (PCE), trichloroethene (TCE) and the degradation product 1,2-cis-dichloroethene (cis-DCE). Contamination was produced due to a poor man- 
agement of the waste generated by an automotive industry, which were discharged into a seepage pit. As a result, soil contamination was produced in the seepage pit area and a plume of dissolved chlorinated ethenes contaminated a shallow alluvial aquifer along a creek situated at the S-SW of the factory, located in Granollers, $40 \mathrm{~km} \mathrm{NW}$ from Barcelona.

As a remediation strategy, a dual action had been carried out: 1) the removal of the contamination source consisting of a selective excavation of the seepage pit area and an offsite management of the contaminated soil, and 2) the construction of a Permeable Reactive Barrier (PRB) of Zero-Valent Iron (ZVI) as a passive treatment to restore the groundwater quality by inducing dechlorination of the DNAPLs.

Compound specific isotopic analysis (CSIA) of chlorine, hydrogen and carbon of the chlorinated ethenes has been proposed for monitoring the efficiency of the ZVI-PRB in degrading the target pollutants and for evaluating natural biodegradation processes. When chlorinated compounds are degraded, isotope fractionation occurs producing a shift in the heavy/light isotope ratio $\left({ }^{13} \mathrm{C} /{ }^{12} \mathrm{C},{ }^{37} \mathrm{Cl} /{ }^{35} \mathrm{Cl},{ }^{2} \mathrm{H} /{ }^{1} \mathrm{H}\right)$ in the residual compound, something that is not significant when non transformation processes such as dilution, dispersion and sorption occurs. Using the Rayleigh equation, the isotopic composition of a specific element in the residual compound can be related to the amount of compound degraded. Therefore, isotope fractionation analysis might permit the evaluation of the extent of degradation due to a specific degradation process.

The aim of this study is to use this multi isotopic tool a) to monitor the pollution attenuation of the site contaminated by DNAPLs; b) to evaluate the efficiency of the installed ZVI reactive barrier; c) to discriminate the abiotic ZVI-PRB degradation from the naturally occurring biodegradation by means of dual isotope $(\mathrm{C}$ and $\mathrm{Cl})$ approach (Audí-Miró et al., 2013); and d) to determine the origin of the cis-DCE found in the site by utilizing compound specific hydrogen isotopes.

At the study area there are a total of eleven monitoring wells located along the creek (Pz1 to Pz-11) and three monitoring wells at the source area (OMW5, MW17 and MW10). In March 2012, we installed 5 multilevel monitoring wells around the ZVI-PRB, two immediately upstream of the barrier and three immediately downstream of the PRB. The multilevel piezometers were installed in order to allow discrete water sampling every half meter, down to $14 \mathrm{~m}$ deep.

Four groundwater sampling campaigns have been conducted since April 2011 (April 2011, June 2012, October 2012 and March 2013). Concentrations and carbon isotopic values have been determined for all samples whereas chlorine isotopic values of PCE and cis-DCE as well as hydrogen isotopic values of cis-DCE have been determined for samples collected in the October 2012 campaign. To our knowledge this is the first time that the hydrogen isotopic composition of chlorinated ethenes has been analysed from field site groundwater samples following the introduction of the hydrogen compound-specific isotope analyses by Shouakar-Stash and Drimmie (2013). 
The results revealed that biodegradation of TCE and cis-DCE is occurring upstream of the ZVI-PRB according to the observed enrichment of both $\delta^{13} \mathrm{C}$ and $\delta^{37} \mathrm{Cl}$ values $\left(\delta^{13} \mathrm{C}_{\mathrm{TCE}}:-12.2 \%\right.$ o, $\delta^{13} \mathrm{C}_{\text {cis-DCE: }}:-15.5 \%$ and $\delta^{13} \mathrm{Cl}_{\text {cis-DCE }}:+5.2 \%$ in comparison with those measured at the source area $\left(\delta^{13} \mathrm{C}_{\mathrm{TCE}}:-20.0 \%, \delta^{13} \mathrm{C}_{\text {cis-DCE }}:-19.9 \%\right.$ and $\delta^{13} \mathrm{Cl}_{\text {cis-DCE: }}$ : $+3.8 \%$ ) .

In addition the results showed that carbon isotopic composition may be used for discriminating bypass processes around the barrier, having found evidence of a more effective degradation at the central part of the barrier.

Regarding chlorine isotope results, dual carbon-chlorine isotope plot of cis-DCE have discriminated two different slopes between upstream of the barrier, where biodegradation has been evidenced from the different campaigns, and downstream of the barrier, similar to what was observed in Audí-Miró et al. (2013) experiments with cis-DCE in contact with zero valent iron where a slope almost four times lower was observed in comparison to the one obtained in Abe et al. (2009) biodegradation experiments.

Hydrogen isotopic results of cis-DCE have revealed slight more negative values of those points where cis-DCE might be coming from a TCE produced by PCE rather than by the TCE original compound. These last results suggest that hydrogen isotope analysis of chlorinated ethenes may be a new expedient way to give evidence of the origin of cis-DCE in order to recognise whether it is coming from a TCE source or from a PCE source through degradation processes of these two compounds.

Acknowledgements: This study was funded by the Spanish Government CICYT projects CGL2008-06373-C03-01/03-BTE and CGL2011-29975-C04-01 and by the Catalan Government project 2009 SGR 103.

\section{References}

Audí-Miró, C., Cretnik, S., Otero, N., Palau, J., Shouakar-Stash, O., Soler, A. and Elsner, M. 2013. Cl and $\mathrm{C}$ isotope analysis to assess the effectiveness of chlorinated ethene degradation by zero-valent iron: Evidence from dual element and product isotope values. Appl. Geochem., 32, pp. 175-183. DOI: $10.1016 /$ j.apgeochem.2012.08.025

Shouakar-Stash, O. and Drimmie, R.J. 2013. Online methodology for determining compound-specific hydrogen stable isotope ratios of trichloroethene and 1,2-cis-dichloroethene by continuous-flow isotope ratio mass spectrometry. Rapid Commun. Mass Spectrom., 27, pp. 1-10. DOI: $10.1002 / \mathrm{rcm} .6578$. 


\title{
126 - EVALUATION OF THE EFFECTS OF A CHECK DAM AT CHENNAI (INDIA) ON AQUIFER RECHARGE
}

\author{
S. Parimala Renganayaki ${ }^{1}$ - Michael Schneider ${ }^{2}$ - L. Elango \\ ${ }^{1}$ Department of Geology, Anna University, Chennai 600025, India; \\ e-mail: elango@annauniv.edu \\ ${ }^{2}$ Institute of Geological Sciences, Freie Universität Berlin, Germany
}

In India the construction of check dams is one important option of Managed Aquifer Recharge (MAR). Check dams are constructed across non perennial rivers in order to store the excess runoff during monsoon seasons. The objective of this study is to assess the benefit acquired through the construction of the check dam at Paleshwaram across Arani River, located northwest of Chennai, Tamil Nadu, India. Groundwater levels and water levels in the check dam were measured periodically from July 2010 to March 2013. Groundwater and surface water were sampled and analyzed during the field survey for stable isotopes deuterium $\left(\delta^{2} \mathrm{H}\right)$ and oxygen-18 $\left(\delta^{18} \mathrm{O}\right)$. Groundwater levels and water levels in the check dam were compared to identify the wells that are influenced by water stored in the check dam. The groundwater levels in the wells influenced by the check dam show similar temporal variation as that of water level in the check dam. Stable isotope data show that water in the check dam is enriched with heavy stable isotopes due to evaporation processes. Groundwater samples of the wells located closer to the check dam have isotopic signatures similar to that of the water in the check dam indicating that the aquifer is recharged by surface water. Whereas, groundwater samples from the wells located farther away from the check dam are showing more depleted isotopic signatures indicating that the influence of the check dam is decreasing with distance and groundwater recharge is dominated by infiltration of rain water. The water level measurements and environmental isotopes indicate that an area of about $3 \mathrm{~km}^{2}$ surrounding the check dam gets maximum benefit from this MAR structure by rise in the groundwater table.

Keywords: Arani River, non perennial river, recharge structure, water level, stable isotopes 


\title{
127 - INDUCED ATTENUATION BY GLUCOSE IN NITRATE CONTAMINATED GROUNDWATER: FLOW-THROUGH EXPERIMENT
}

\author{
Raúl Carrey $^{1}$ - Neus Otero ${ }^{1}-$ Georgina Vidal $^{1}-$ Albert Soler $^{1}-$ Carlos Ayora $^{2}-$ \\ Juan José Gómez-Alday ${ }^{3}$ \\ ${ }^{1}$ Grup de Mineralogia Aplicada i Medi Ambient. Facultat de Geologia, \\ Universitat de Barcelona, C/ Martí i Franquès s/n, 08028, Barcelona, Spain; \\ e-mail: raulcarrey@ub.edu, notero@ub.edu, albertsoler@ub.edu, georginavidal@biorem.cat \\ ${ }^{2}$ Instituto de Diagnostico Ambiental y Estudios del Agua, IDAEA- CSIC, C/Jordi Girona, \\ 18, 08028 Barcelona, España; e-mail: cayora1@gmail.com \\ ${ }^{3}$ Remote Sensing and GIS Group, Institute for Regional Development (IRD), \\ University of Castilla-La Mancha (UCLM) Campus Universitario de Albacete \\ 02071 Albacete, España; e-mail: JuanJose.Gomez@uclm.es
}

\section{Introduction}

Nitrate $\left(\mathrm{NO}_{3}{ }^{-}\right)$is one of the most common groundwater pollutants. $\mathrm{NO}_{3}{ }^{-}$can cause health problems in both humans and domestic animals, and contributes to the eutrophication of surface water bodies. Frequent sources of $\mathrm{NO}_{3}{ }^{-}$pollution are linked to extensive application of synthetic and organic fertilizers, inappropriate placement of animal waste and spills from septic system effluents. The $\mathrm{NO}_{3}{ }^{-}$concentration threshold established by Directive 98/83/CE for human water supply is $50 \mathrm{mg} / \mathrm{L}$. Denitrification is an effective process that reduces $\mathrm{NO}_{3}{ }^{-}$to nitrogen gas $\left(\mathrm{N}_{2}\right)$ under anaerobic conditions. However, in natural systems, denitrification is mainly restricted by the availability of electron donors (Knowles et al., 1982).

Many areas of Spain are affected by nitrate contamination. Examples of exposed areas to $\mathrm{NO}_{3}{ }^{-}$pollution are endorheic basins located in arid and semiarid regions. An excellent example of an endorheic system affected by $\mathrm{NO}_{3}{ }^{-}$pollution is the Pétrola basin where despite that natural heterotrophic denitrification is taking place; it is limited, with average $\mathrm{NO}_{3}{ }^{-}$attenuation value around 20\% (Carrey et al., 2013). In this context, one of the most frequent treatments to remove $\mathrm{NO}_{3}{ }^{-}$where attenuation is not present or is limited is the enhancement of biological denitrification in the aquifer. The main goal of this work was to evaluate the viability of periodical injections of glucose to promote denitrification preventing the generation of adverse effects/undesirable compounds. The study was performed at laboratory scale by means of a flowthrough experiment. A secondary goal of this study was to obtain the isotopic fractionation factor $(\varepsilon)$ of $\mathrm{N}$ and $\mathrm{O}$ of the induced denitrification reaction.

\section{Methodology}

The experiment consisted on a glass cylindrical column (40 cm high, $9 \mathrm{~cm}$ inner diameter) filled with a homogeneous mix of sediment from Pétrola basin and clean silica 
(siliceous) sand. During the experiment, 3 different time periods with variable $\mathrm{C} / \mathrm{N}$ ratio were tested. Initially (Stage I, day 0 to 39), C/N molar ratio used was about 1.6. After day 39 to day 87 (Stage II), addition of glucose was changed to reach the stoichiometric ratio of 1.25. Finally, from day 87 to day 124 (Stage III), C/N molar ratio was changed to 1.12 .

\section{Results and Discussion}

Once glucose was added to the system, $\mathrm{NO}_{3}{ }^{-}$reduction increased rapidly. The $\mathrm{NO}_{3}{ }^{-}$ concentration in the outflow varied from below the detection limit to $55 \mathrm{mg} / \mathrm{L}$. During first stage $\mathrm{NO}_{3}{ }^{-}$concentration showed a cyclical behaviour with several increase-decrease tendencies up to day 18. After that day up to day 39, most of the samples showed $\mathrm{NO}_{3}{ }^{-}$concentrations below the detection limit. During stages II and III, detected $\mathrm{NO}_{3}{ }^{-}$concentration ranged from below detection limit to $1.2 \mathrm{mg} / \mathrm{L}$. The induced denitrification was constant even with $\mathrm{C} / \mathrm{N}$ ratio under stoichiometric value due to the use of a secondary carbon source such as dissolved organic carbon in the input water and/or lysed and dead cells.

Associated with the $\mathrm{NO}_{3}{ }^{-}$reduction, $\mathrm{NO}_{2}{ }^{-}$was accumulated in the outflow during the first stage. $\mathrm{NO}_{2}{ }^{-}$concentration in the outflow samples ranged from below the detection limit up to $29.4 \mathrm{mg} / \mathrm{L}$. After day 27 most of the samples had $\mathrm{NO}_{2}{ }^{-}$concentration below detection limit. $\mathrm{NO}_{2}{ }^{-}$accumulation was related with $\mathrm{pH}$ variations in the outflow water. Samples with detected $\mathrm{NO}_{2}{ }^{-}$had a $\mathrm{pH}$ range from 8.5 to 8.8 whereas samples without $\mathrm{NO}_{2}^{-}$had a $\mathrm{pH}$ ranged from 8.0 to 8.4.

The $\mathrm{SO}_{4}{ }^{2-}$ concentration at the outflow ranged from 302 to $348 \mathrm{mg} / \mathrm{L}$ and the isotopic composition of sulphate showed a narrow range of $\delta^{34} \mathrm{~S}$ between $-17.1 \%$ and $-17.2 \%$, whereas $\delta^{18} \mathrm{O}$ varied from +5.2 to $+5.8 \%$ suggesting that no sulphate reduction was produced during induced denitrification.

During $\mathrm{NO}_{3}{ }^{-}$reduction, the isotopic composition increased from $+9.5 \%$ o to $+39.5 \%$ for $\delta^{15} \mathrm{~N}-\mathrm{NO}_{3}{ }^{-}$, and from $+3.3 \%$ to $+39.9 \%$ for $\delta^{18} \mathrm{O}-\mathrm{NO}_{3}{ }^{-}$. The $\delta^{15} \mathrm{~N}$ showed a linear relationship with $\delta^{18} \mathrm{O}$, with a slope of $0.92\left(\mathrm{R}^{2}=0.88\right)$, a common value for denitrification reaction (Böttcher et al., 1990). A plot of $\delta^{15} \mathrm{~N}$ or $\delta^{18} \mathrm{O}$ versus $\mathrm{Ln}\left[\mathrm{NO}_{3}{ }^{-}\right]$should show a linear correlation where the slope of the regression line is the isotopic fractionation. The studied samples showed an acceptable correlation of these parameters $\left(\mathrm{r}^{2}=0.9\right.$ for $\varepsilon \mathrm{N}$ and $\mathrm{r}^{2}=0.8$ for $\left.\varepsilon \mathrm{O}\right)$. $\varepsilon$ values attained were $-8.8 \%$ for $\delta^{15} \mathrm{~N}$ and $-8.0 \%$ for $\delta_{18} \mathrm{O}$.

Periodical injections of an organic carbon source are a suitable method to remove $\mathrm{NO}^{-}$from groundwater in long-term treatments. This strategy tested at laboratory-scale achieved complete and constant $\mathrm{NO}^{-}$removal after 13 days with $\mathrm{C} / \mathrm{N}$ ratio close to stoichiometric value or lower. Furthermore, the $\mathrm{C} / \mathrm{N}$ ratios studied were adequate to prevent generation of $\mathrm{H}_{2} \mathrm{~S}$ from $\mathrm{SO}_{4}{ }^{2-}$ reduction reactions in the water. Data obtained in this study support a further investigation in this way with, for instance, a field-scale/pilot-test assay. 
Acknowledgements: This work has been financed PEIC11-0135-8842 from Castilla La Mancha Government, the projects CICYT-CGL2011-29975-C04-01 from the Spanish Government, and the project 2009SGR 103 from the Catalan Government.

\title{
References
}

1. J. Böttcher, O. Strebel, S. Voerkelius and H.-L. Schmidt, Using isotope fractionation of nitrate-nitrogen and nitrate-oxygen for evaluation of microbial denitrification in sandy aquifer. J. Hydrol., 114, pp. 413-424, 1990.

2. R. Carrey, N. Otero, A. Soler, C. Ayora and J.J. Gómez-Alday. The role of Lower Cretaceous sediments in groundwater nitrate attenuation in central Spain: Column experiments. Appl. Geochem., 32, pp. 142-152, 2013.

3. R. Knowles. Denitrification. Microbiol. Rev., 42, pp. 43-70, 1982.

\section{8 - PAST CLIMATE CHANGES REVEALED BY FOSSIL CHIRONOMID CHITIN $\delta^{18}$ O: CALIBRATION WITH OSTRACOD CALCITE $\delta^{18}$ O IN ANNECY LAKE SEDIMENTS (FRENCH ALPS)}

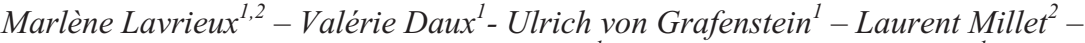 \\ Monique Pierr ${ }^{e} 1$ - Michel Stievenard ${ }^{1}$ - Valérie Masson-Delmotte ${ }^{l}$ \\ ${ }^{1}$ Laboratoire des Sciences du Climat et de 1'Environnement (LSCE), CEA - Orme des \\ Merisiers, F-91191 Gif-sur-Yvette, France; e-mail: marlene.lavrieux@1sce.ipsl.fr \\ ${ }^{2}$ Chrono-Environnement, La Bouloie, UFR Sciences et Techniques, 16 route de Gray, \\ F-25030 Besançon Cedex, France
}

While information about central Greenland past temperatures is provided by ice cores, the reconstruction of past coastal temperatures remains a key challenge. In these areas lakes are numerous, and their sediments are pertinent archives for high resolution paleoclimatic and paleoenvironmental records (e.g. [1,2]). In suitable lakes, the water $\delta^{18} \mathrm{O}$ is controlled by the $\delta^{18} \mathrm{O}$ of precipitation, which at high latitudes is itself strongly correlated with fluctuations in the mean annual temperature (MAT). Past lake water $\delta^{18} \mathrm{O}$ of mid-latitude lakes is commonly reconstructed using ostracod calcite $\delta^{18} \mathrm{O}$ (e.g. [3]), but the acidity of most Arctic lakes water precludes calcite preservation. Chitineous organisms such as chironomid (i.e. non-biting midges) larvae head capsules are well preserved in lake sediments over long time scales, and have a worldwide distribution. The potential of their $\delta \mathrm{D}$ and $\delta^{18} \mathrm{O}$ to reconstruct past lake water has recently been explored (e.g. $[4,5,6])$, but the signal calibration remains to be established [7].

In this context, this study focuses on the relevance of chironomid chitin $\delta^{18} \mathrm{O}$ as a proxy for lake water $\delta^{18} \mathrm{O}$. The first step consisted in comparing chironomid chitin $\delta^{18} \mathrm{O}$ to ostracod calcite $\delta^{18} \mathrm{O}$ in the well-studied context, of the Annecy Lake (French Alps), where former studies have already described the chironomid distribution in the surface sediments [8] and the past variations of the $\delta^{18} \mathrm{O}$ of lake water, reconstructed from ostracod calcite $\delta^{18} \mathrm{O}[9]$. This presentation shows the first results obtained on chironomids from Late Glacial and Early Holocene sediments. Their implications for 
the applicability of the method to evaluate past lake water temperature and the associated constraints for coastal subarctic contexts is discussed.

\section{References}

1. W.J. D'Andrea, Y. Huang, S.C. Fritz and N.J. Anderson, Abrupt Holocene climate change as an important factor for human migration in West Greenland. P. Natl. Acad. Sci., 108, pp. 9765-9769, 2011.

2. C. Massa, B.B. Perren, E. Gauthier, V. Bichet, C. Petit and H. Richard, A multiproxy evaluation of Holocene environmental change from Lake Igaliku, South Greenland. J. Paleolimnol., 48, pp. $241-258,2012$.

3. U. von Grafenstein, Oxygen-isotope studies of ostracods from deep lakes, The Ostracoda: Applications in Quaternary Research. Geophys. Monogr., 131, pp. 249-266, 2002.

4. Y. Wang, D.R. Francis, D.M. O'Brien and M.J. Wooller, A protocol for preparing subfossil chironomid head capsules (Diptera: Chironomidae) for stable isotope analysis in paleoclimate reconstruction and considerations of contamination sources. J. Paleolimnol., 40, pp. 771-781, 2008.

5. Y.V. Wang, D.M. O'Brien, J. Jenson, D. Francis and M.J. Wooller, The influence of diet and water on the stable oxygen and hydrogen isotope composition of Chironomidae (Diptera) with paleoecological implications. Oecologia, 160, pp. 225-233, 2009.

6. F. Verbruggen, Stable oxygen isotopes in fossil chironomids. Development of a new proxy for past climate change. PhD Thesis, Utrecht University (Netherlands), 2010.

7. O. Heiri, J. Schilder and M. van Hardenbroek, Stable isotopic analysis of fossil chironomids as an approach to environmental reconstruction: State of development and future challenges. Fauna, No. 31, pp. 7-18, 2012.

8. V. Frossard, L. Millet, V. Verneaux, J.P. Jenny, F. Arnaud, J. Poulenard, M. Magny and M.E. Perga, Chironomid assemblage reconstructions at multiple depths describe the oxygen-driven changes in a deep French lake during the last 150 years. J. Paleolimnol., accepted.

9. P.A. Danis, U. von Grafenstein and V. Masson-Delmotte, Sensitivity of deep lake temperature to past and future climatic changes: A modeling study for Lac d'Annecy, France, and Ammersee, Germany. J. Geophys. Res., 108, p. 4609, 2003.

\section{9 - STABLE ISOTOPE COMPOSITION OF BULK AND SECONDARY CARBONATES FROM QUATERNARY LOESS-PALEOSOL SEQUENCES IN HUNGARY AND IRAN}

Manfred Frechen ${ }^{1}$ - Gabriella Barta ${ }^{2}$ - Erzsébet Horváth ${ }^{2}$ - Martin Kehl ${ }^{3}$ Farhad Khormali ${ }^{4}$ - Paul Koeniger ${ }^{5}-$ Eva Lehndorff $^{6}$

${ }^{1}$ Leibniz Institute for Applied Geophysics (LIAG), Geochronology and Isotope Hydrology, Stilleweg 2, D-30655 Hannover, Germany

${ }^{2}$ Department of Physical Geography, Eötvös Loránd University, Pázmány Péter sétány 1/c, H-1117 Budapest, Hungary

${ }^{3}$ Institute of Geography, University of Cologne, Albertus Magnus Platz, 50923 Cologne, Germany

${ }^{4}$ Dept. of Soil Sciences, Faculty of Agriculture, Gorgan University of Agricultural Sciences and Natural Resources, Gorgan, 49138-15739, Iran

${ }^{5}$ Federal Institute for Geosciences and Natural Resources (BGR), Stilleweg 2, D-30655 Hannover, Germany

${ }^{6}$ Institute of Crop Science and Resource Conservation (INRES) - Soil Sciences, Bonn University, Nussallee 13, 53115 Bonn, Germany 
Stable carbon and oxygen isotope composition of pedogenic carbonates were studied from the Quaternary loess-paleosol sequences of Süttő in Hungary and Now Deh in Iran to investigate pedogenetic processes in a paleoenvironmental context and to distinguish morphological (?) subtypes. Bulk carbonate samples taken at $2 \mathrm{~cm}$ vertical resolution, and microscale secondary (authigenic) carbonates (calcified root cells, carbonate coatings, hypocoatings, and earthworm biospheroids) and concretions at $10 \mathrm{~cm}$ resolution were analysed to interpret stable isotope variations. At Süttő in northern Hungary, the isotope compositions of secondary carbonates clearly distinguished between the organically related and inorganic (direct) precipitation of the different subtypes (Königer et al. in press). In general, secondary carbonates showed more depleted values than bulk samples. Results indicate that loess and paleosol secondary carbonates reveal pedogenetic information (of which kind?) during the different climatic phases. Carbon and oxygen isotope analyses are valuable to classify secondary carbonates and to serve as proxies for the interpretation of paleoenvironmental conditions, e.g. moisture conditions, leaching, the role of organic matter or vegetation. Secondary carbonates are more reliable than bulk samples because of their connection to the host strata is known. At Now Deh in Northern Iran similar loess/paleosol sequences were sampled and studied to compare with those results determined for Süttő. Results from Süttő and Now Deh will be presented at the conference.

\title{
Reference
}

Königer, P., Barta, G., Thiel, C., Bajnóczi, B., Novothny, Á., Horváth, E., Techmer, A., Frechen, M., Stable isotope composition of bulk and secondary carbonates from the Quaternary loess-paleosoil sequence in Süttő, Hungary. Quaternary International, http://dx.doi.org/10.1016/j.quaint. 2012.06.038 (in press)

\section{0 - MULTI-ISOTOPIC (CR, PB, LI, ND) CHARACTERISATION OF CR-BEARING ROCKS AND ALTERATION PRODUCTS FROM DIFFERENT GEOLOGICAL ENVIRONMENTS}

\author{
Julie C. Gattacceca - Philippe Négrel - Romain Millot - Wolfram Kloppmann- \\ Thierry Augé - Laurent Bailly \\ BRGM, BP 36009, 45060 Orléans, France; e-mail: j.gattacceca@brgm.fr
}

Chromium exists in two oxidation states $(\mathrm{Cr}(\mathrm{III}) / \mathrm{Cr}(\mathrm{VI}))$ and present four stable isotopes $\left({ }^{50} \mathrm{Cr},{ }^{52} \mathrm{Cr},{ }^{53} \mathrm{Cr},{ }^{54} \mathrm{Cr}\right)$. Cr isotopic variations have been correlated in surface processes with change in redox conditions, and used as a redox proxy in different geochemical reservoirs (Ellis et al., 2002; Frei et al., 2009). In this context, Schoenberg et al. (2008) emphasized the primary importance of background knowledge of $\mathrm{Cr}$ isotope composition of rocks reservoirs, as a starting point of the global chromium cycle. So far, only few studies have reported $\mathrm{Cr}$ isotope signature of rock reservoirs, with Schoenberg et al. reporting a uniform ${ }^{53} \mathrm{Cr} /{ }^{52} \mathrm{Cr}$ isotope ratio in mantle derived rocks 
and chromite ores from layered intrusions. However, $\mathrm{Cr}$ isotope fractionation has been identified in secondary products formed during metamorphic processes and/or hydrothermal activity (Schoenberg et al., 2008; Farkas et al. 2011).

Here, we are reporting $\mathrm{Cr}$ isotope compositions, along with chemical concentrations of major and trace elements of a new set of $\mathrm{Cr}$-bearing rocks. A representative set of structural chromite and altered chromite of different textures have been selected from two characteristic geological environments:

(1) Baula complex, Orissa, India: ultramafic complex with high-grade chromite deposits, intruded by the Bangur Gabbro forming a breccia zone with hydrothermalism alteration. Two samples have been collected in two different chromitite layers (massive chromite and occluded silicate texture), and three others collected in the Gabbro (nodule of massive chromite and two types of ferrian chromite)

(2) Badondo Mount, Republic of the Congo: Banded Iron Formation, one of the few that has been identified worldwide with the presence of chromites. Three samples have been selected in the quartz and magnetite layers, and present various concentrations of chromite crystals.

Because of the refractory nature of chrome-rich spinels, total digestion has often been an obstacle to this kind of study. We based our analytical development for $\mathrm{Cr}$ isotopes determinations on recent advances in digestion methods: an aliquot of $100 \mathrm{mg}$ was submitted to a wet acid digestion $\left(\mathrm{HNO}_{3}: \mathrm{HCl} 3: 1\right)$ using pressurized vessels at $240^{\circ} \mathrm{C}$ for a few hours (Paliulionyte et al., 2006). To ensure the complete digestion and verify potential nugget effect, the concentration results were validated by using the more established procedure of sintering $\left(\mathrm{Na}_{2} \mathrm{O}_{2}, 450^{\circ} \mathrm{C}\right)$ on every samples as well as a set of chromitite standards and certified reference materials often used in the literature. Major and trace elements analysis were performed in BRGM Labs using ICP-AES and ICP-MS. Cr, lead $(\mathrm{Pb})$, lithium $(\mathrm{Li})$ and neodymium $(\mathrm{Nd})$ isotopes were analysed by MC-ICP-MS (Neptune) and TIMS in BRGM.

Preliminary results show that chromites and transformed chromites (alteration products) present differences in their chemical concentrations. Specifically, for the Cr-rich samples from Baula complex $\left(25-50 \mathrm{wt} \% \mathrm{Cr}_{2} \mathrm{O}_{3}\right), \mathrm{Pb}$ varies between 6 and 50 ppm, $\mathrm{Li}$ and $\mathrm{Nd}$ are enriched in the ferrian chromite, with an average of 25 and $3 \mathrm{ppm}$, respectively. The analytical protocol for the dissolution being validated, corresponding isotope compositions will be analysed $(\mathrm{Cr}, \mathrm{Li}, \mathrm{Pb}$ and $\mathrm{Nd})$, as potential isotopic tools to better constrain the alteration processes involved. We will also discuss how this multi-isotopic characterisation of this various range of Cr-bearing rocks can help better constraining chromite origin, crystallization and alteration processes.

\section{References}

1. A.S. Ellis et al., Chromium isotopes and the fate of hexavalent chromium in the environment. Science, 295, pp. 2060-2062, 2002. 
2. R. Frei et al., Fluctuations in precambrian atmospheric oxygenation recorded by chromium isotope. Nature, 461, pp. 250-253, 2009.

3. R. Schoenberg et al., The stable Cr isotope inventory of solid Earth reservoirs determined by double spike MC-ICP-MS. Chem. Geol., 249, pp. 294-306, 2008.

4. J. Farkas et al., Chromium isotope variations $\left(\delta^{53} \mathrm{Cr}\right)$ in globally distributed chromite- and chromate-bearing minerals and rocks. AGU Fall Meeting Abstracts, 1, p. 03, 2011.

5. Paliulionyte et al., High Pressure Asher Digestion and an Isotope Dilution-ICP-MS Method for the Determination of Platinum-Group Element Concentrations in Chromitite Reference Materials CHR-Bkg, GAN Pt-1 and HHH. Geostandard Newslett., 30(2), pp. 87-96, 2006.

\title{
131 - LONG-TERM MONITORING OF THE EVOLUTION OF THE CHLORINATED VOCS POLLUTION IN A FRACTURED BEDROCK AQUIFER USING CSIA
}

\author{
Diana Rodríguez-Fernández ${ }^{1}$ - Mònica Rosell ${ }^{1}$ - Clara Torrentó $^{1}$ - Carme Audí-Miró ${ }^{1}-$ \\ Massimo Marchesi ${ }^{1,2}-$ Jordi Palau $^{1,3}-$ Neus Otero $^{1}-$ Albert Soler $^{1}$ \\ ${ }^{1}$ Grup de Mineralogia Aplicada i Medi Ambient. Facultat de Geologia, \\ Universitat de Barcelona, C/ Martí i Franques s/n, 08028 Barcelona, Spain; \\ e-mails: diana.rodriguez@ub.edu; monica.rosell@ub.edu; clara.torrento@ub.edu; \\ carmeaudi@ub.edu; albertsolergil@ub.edu \\ ${ }^{2}$ Department of Earth \& Environmental Sciences, 200 University Ave. W, \\ N2L 3G1 Waterloo, Ontario, Canada; e-mail: m2marchesi@uwaterloo.ca \\ ${ }^{3}$ Centre d'hydrogéologie et de géothermie, Université de Neuchâtel, Rue Emile-Argand 11, \\ Neuchâtel 2000, Switzerland; e-mail: jordi.palau@unine.ch
}

An unconfined fractured bedrock aquifer with low permeability and polluted with a complex mixture of chlorinated organic compounds is located in a former industrial area next to Barcelona (NE Spain). The pollution derives from the manufacture of phytosanitary products and chemical compounds of a textile industry between 1978 and 1985. The main contaminants are a variety of chlorinated VOCs (chlorinated ethenes, ethanes, methanes and chlorobenzenes) with traces of BTEX and pesticides. An underground wastewater tank and a disposal lagoon were identified as the main contaminant sources and were removed in 2006 as an early measure for contamination mitigation. A long-term monitoring was performed from 2006 to 2013 distributed in seven field campaigns in order to assess the effectiveness of the sources removal as well as to shed light on natural attenuation processes.

Ten multilevel wells were installed by the Catalan Waste Agency $(A R C)$ as a groundwater monitoring network which has allowed the characterisation of the contamination plumes and their evolution for years. Carbon compound-specific stable isotope analysis (CSIA) coupled with concentration data have been used to prove the existence of biodegradation processes affecting some of the organic pollutants. Moreover, a comprehensive mapping of the different geochemical conditions including: physicochemical parameters (temperature, eh, $\mathrm{pH}$, conductivity, $\mathrm{DO}$, water level) combined with chemical (DIC, DOC, TOC, anions, cations) and isotopic data $\left(\delta^{2} \mathrm{H}\right.$ 
and $\delta^{18} \mathrm{O}$ of water, $\delta^{15} \mathrm{~N}$ and $\delta^{18} \mathrm{O}$ of dissolved nitrate and $\delta^{34} \mathrm{~S}$ and $\delta^{18} \mathrm{O}$ of dissolved sulphate) have permitted an exhaustive characterization of the zones of the aquifer where some specific metabolic pathways could be possible.

Integrated results show that biodegradation processes affecting chlorinated methanes (CT and CF) as well as chlorinated ethenes (PCE and TCE) are taking place in restricted zones of the aquifer as evidenced by the presence of metabolites and the thorough study of the physicochemical parameters and isotopic data.

Long-term monitoring of isotopic data in combination with characterization of contaminant distribution and redox conditions has proved the positive effect linked to the removal of the sources and the contribution of natural attenuation processes happening in such a complex polluted site.

Acknowledgments: The present research is supported by Agència de Residus de Catalunya, a Marie Curie Career Integration Grant in the framework of IMOTEC-BOX project (PCIG9-GA-2011-293808) within the 7th Framework Programme and the ATTENUATION project (CGL2011-29975-C04-01) from the Spanish Government.

\title{
132 - USING ISOTOPES $\left(\delta^{18} \mathrm{O}_{\mathrm{NO} 3}, \delta^{15} \mathrm{~N}_{\mathrm{NO} 3}, \delta^{18} \mathrm{O}, \delta \mathrm{D}\right)$ TO RECOGNIZE GROUNDWATER QUALITY ALTERATIONS DUE TO PUMPING IN LARGE SCALE AQUIFERS
}

\author{
Albert Folch ${ }^{1}$ - Roger Puig ${ }^{2}$ - Anna Menció ${ }^{3}$ - Albert Soler ${ }^{2}$ - Josep Mas-Pla ${ }^{3,4}$ \\ ${ }^{1}$ Grup d'Hidrologia Subterrània, Departament d'Enginyeria del Terreny, Cartográfica i \\ Geofísica, Universitat Politècnica de Catalunya, Barcelona Tech, Barcelona 08034, Spain \\ ${ }^{2}$ Grup de Mineralogia Aplicada i Medi Ambient, Departament de Cristalolografia, \\ Mineralogia i Dipòsits Minerals, Facultat de Geologia, Universitat de Barcelona, \\ Barcelona 08028, Spain \\ ${ }^{3}$ Grup de Geologia Aplicada i Ambiental (GAiA), Centre de Geologia i Cartografia \\ Ambiental (Geocamb), Universitat de Girona, Girona 17071, Spain \\ ${ }^{4}$ Catalan Institute for Water Research, 17003 Girona, Spain
}

\section{Introduction}

Groundwater has become an important issue worldwide as it is a primary resource for supplying human demand and is related with several ecosystems. However, the increase of groundwater pumping has modified the natural water budget that defines the available water resources [1]. Intense exploitation modifies the natural flow paths of the aquifers with effects on water quantity. This alteration brings also groundwater quality problems due to inducted recharge and/or mixing between different types of water/flow systems.

In large scale, regional hydrogeological systems, groundwater behaviour is even more complex due to the heterogeneities of the geological setting and the potential contributions from distinct recharge areas, which affect both quantity and quality. 
Mixing between groundwater local flow systems, mainly affected by pollution, and regional flow systems characterized by water rock interaction and different physicochemical parameters ( $\mathrm{pH}, \mathrm{Eh}$, etc.), can significantly affect water quality.

With the objective of understand the effect of pumping in groundwater quality in large scale hydrogeological systems, the range-and-basin area of the Selva graben (NE Spain) has been studied as an example of the effects of groundwater development on regional flow fields [2].

\section{Geological and hydrogeological setting}

The Selva basin $\left(565 \mathrm{~km}^{2}\right)$, located near Girona in NE Spain, is a tectonic area surrounded by different mountain ranges with altitudes between 550 and $1202 \mathrm{~m}$ asl. Two main watersheds are found within these ranges: Santa Coloma River Basin (SCRB) and Onyar River Basin (ORB) (Fig. 1). The main fault direction in the area is NW-SE, with other significant faults, oriented NE-SW and N-S.

Three main hydrogeological units can be determined: (1) the upper aquifer formed by alluvial materials associated with the main rivers, surface Neogene sedimentary layers, and weathered igneous rocks outcropping in the basin; (2) an alterna-

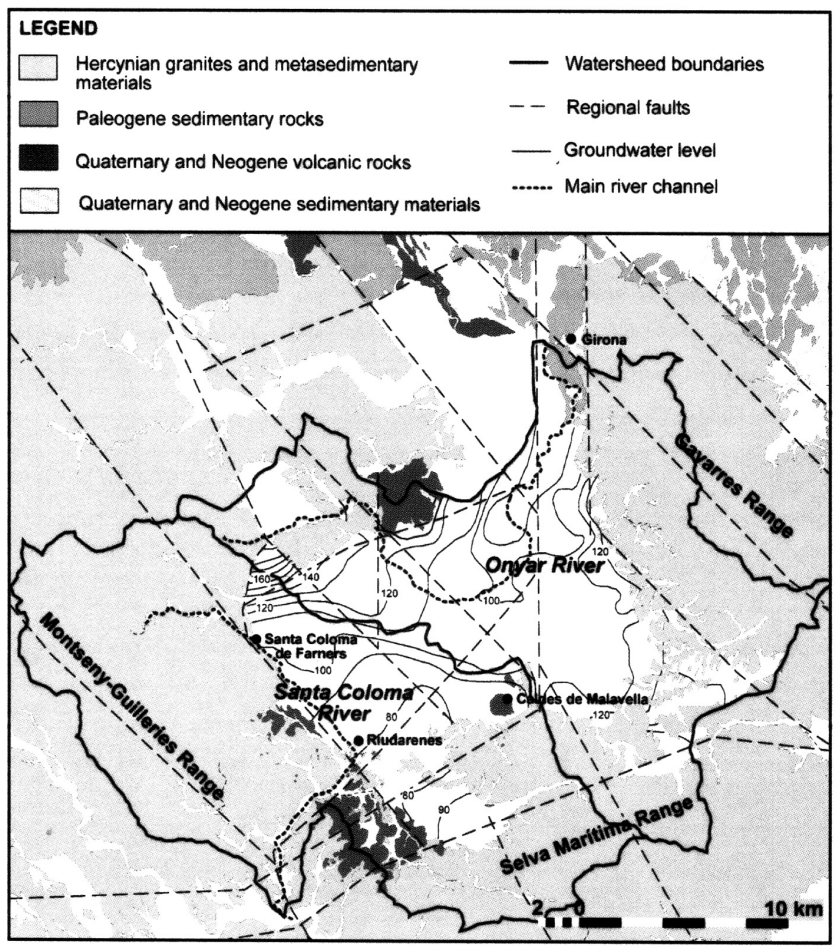

Figure 1. Geological and hydrogeological setting of la Selva basin 
tion of silts, arkosic sands, gravels and conglomerates with low clay content of Neogene sediment, resulting in an intermediate multilayer aquifer with thicknesses from 20 to $300 \mathrm{~m}$, and (3) a deep aquifer, constituted by an igneous rock basement affected by local and regional faults and by a weathering cap in its upper zones.

\section{Methodology}

Different field surveys were carried out between 2000 and 2006 in the sedimentary infill of the basin and in its surrounding ranges. Groundwater heads were measured in different seasons during this period. Environmental isotopes $\left(\delta^{18} \mathrm{O}, \delta \mathrm{D}\right)$ were sampled in three different seasons in 2003: May, September, December (around 20 samples per campaign), and in May 2006 (60 samples). In this last campaign, main ions composition in all wells as well as $\delta^{18} \mathrm{O}_{\mathrm{NO} 3}$ and $\delta^{15} \mathrm{~N}_{\mathrm{NO} 3}$ in 37 wells were also analyzed. More details about sampling and analytical methods for hydrochemical and isotopic data are referred in [3] and [4].

\section{Results and Discussion}

Hydrochemistry and groundwater levels of several years [3] indicate that water withdrawal, mainly from the basin sediments, modifies the local and regional flow paths depending on recharge periods and seasonal exploitation regimes. Changes in groundwater head and the occurrence of sodium and chloride enriched facies indicate a vertical upward flow from the granitic basement. They also indicate that faults act as recharge elements controlling the efficiency of wells and, overall, the recharge flows [5].

According to isotopic composition of rainfall $\left(\delta^{18} \mathrm{O}, \delta \mathrm{D}\right)$, two meteoric water lines are defined based on local data. The first one, based on data from IAEA/WMO station "Gerona Aeropuerto" located at the central part of the basin, represents groundwater infiltrated at the basin surface; i.e. local flow systems. The second, according to rainfall isotopic data presented by [6] and [7] for the nearby ranges, represents groundwater recharged at the surrounding ranges at higher altitude, i.e. regional flow systems.

Seasonal isotopic data (May, September and December of 2003 and May 2006) of groundwater samples shift between local and regional flow systems. During the May surveys, following the wet season that lasts from October to May, most wells show isotopic values shifted to local recharge at the basin surface. Such isotopic composition is attributed to local recharge pulses during the wet season. This recharge is therefore the most important resource that is captured by pumping wells after the end of the wet season. In September, intensive water withdrawal has exhausted such local resources, and the isotopic content reveals the dominant influence of groundwater flow from regional systems on the captured water. That is to say, the lateral and vertical upward recharge from the surrounding ranges and the basement provides water to the sedimentary aquifers of the basin, fulfilling major water needs. In the December 2003 survey, isotopic data show a transitional distribution between the end of the dry 
season (mainly summer) and the beginning of the recharge period in October and November [3].

Dissolved nitrate isotopic composition $\left(\delta^{18} \mathrm{O}_{\mathrm{NO} 3}, \delta^{15} \mathrm{~N}_{\mathrm{NO} 3}\right)$ of the May 2006 survey indicates that the main sources of nitrogen in the Selva basin are pig manure and synthetic fertilizers, without disregarding sewage point-pollution [4]. Samples related with regional flow system show: 1) isotopic values in agreement with a denitrification trend, and 2) low nitrate content $(<0.5 \mathrm{mg} / \mathrm{l})$ that not allowed isotopic analysis. These samples also presented the lowest values of dissolved $\mathrm{O}_{2}\left(0^{-1} \mathrm{mg} \mathrm{L}^{-1}\right)$, Eh $(<300 \mathrm{mV})$, and $\mathrm{SO}_{4}$, and the highest values of iron and manganese. Hence, those samples linked to the regional flow system appeared to be affected by natural attenuation processes of nitrate [4]. Despite shallow wells indicated no denitrification, deep wells located in Neogene sediments also show a denitrification trend and, in some cases, they presented fluoride content around $0.5 \mathrm{mg} \mathrm{L}^{-1}$, associated to higher water-rock interaction within the granite basement [3].

Then, at the end of the wet season, deep wells may show a high nitrate content even above the standard drinking levels, due to the groundwater recharge originated at the basin surface affected by agricultural and livestock activities. Oppositely, during the dry season, when local, shallow resources are exhausted due to pumping, nitrate content tends to reduce and fluoride concentration to increase (in some wells above drinking levels $>1 \mathrm{mg} / \mathrm{l}$ ) due to upward regional flow systems from the basement. Mixing between both flow systems produce a simultaneous occurrence of nitrate and fluoride in some wells. Furthermore, mixing of local resources with regional systems contributes to diminish nitrate concentration by means of denitrification, induced by the redox reducing conditions of these regional flows. These natural attenuation processes were observed during the May 2006 campaign, corresponding to the wet season when the maximum influence of local flow systems occur. Then, it is expected that denitrification rates will increase during the summer months, when local recharge is minimum and the influence of reduced regional flow systems will prevail because of groundwater withdrawal.

\section{Conclusions}

In range-and-basin areas, where groundwater pumping in the basin induces recharge from regional large-scale flow systems, mixing of different groundwater sources modifies groundwater quality seasonally. In the studied case, groundwater withdrawal within the basin sedimentary aquifers increased an upward recharge from the igneous basement during the dry season, generating a rise of fluoride concentration and reducing nitrate content in deep basin wells. Water quality of induced upward vertical recharge from the basement is only due to high water-rock interaction, free of human pressures, and its contribution to the basin recharge generally improves water quality in the sedimentary aquifer. Furthermore, the reduced conditions prevailing in the re- 
gional flow systems enhance denitrification that reduces the nitrate content in deep sedimentary aquifer layers.

Acknowledgments: This study has been financed by the Spanish Government CGL2011-29975-C04-01 and CGL2011-29975-C04-04 projects.

\title{
References
}

1. J.F. Devlin and M. Sophocleos, The persistence of the water budget myth and its relationship to sustainability. Hydrogeo. J., 13, pp. 549-554, 2005.

2. A. Menció, A. Folch and J. Mas-Pla, Analyzing hydrological sustainability through water balance, Environ. Manage., 45, pp. 1175-1488, 2010.

3. A. Folch, A. Menció, R. Puig, A. Soler and J. Mas-Pla, Grondwater development effects on different scale hydrogeological systems using head, hydrochemical and isotopic data and implications for water resources management: The Selva basin (NE Spain). J. Hydrol., 403, pp. 83-102, 2011.

4. R. Puig, A. Folch, A. Menció, A. Soler and J. Mas-Pla, Multi-isotopic study $\left({ }^{15} \mathrm{~N},{ }^{34} \mathrm{~S},{ }^{18} \mathrm{O},{ }^{13} \mathrm{C}\right)$ to identify nitrate and sulfate evolution under the effect of local and regional groundwater mixing in a large-scale flow system. Appl. Geochem., 32, pp. 129-140, 2013.

5. A. Folch and J. Mas-Pla, Hydrogeological interactions between fault zones and alluvial aquifers in regional flow systems. Hydrol. Process., 22, pp. 3476-3487, 2008.

6. M. Neal, A. Warrington, A. Avila, J. Piñol and F. Roda, Stable hydrogen and oxygen isotope studies of rainfall and stream waters for two contrasting holm oak areas of Catalonia, northeastern Spain. J. Hydro., 140, pp. 163-178, 1992.

7. J. Mas-Pla, E. Font, O. Astui, A. Menció and A. Pérez-Paricio, Tracing stream leakage towards an alluvial aquifer in a mountain basin using environmental isotopes. Ap. Geochem., 32, pp. 85-94, 2013.

\section{3 - APPLICATION OF ENVIRONMENTAL ISOTOPES $\left(\delta^{18} \mathrm{O}, \delta \mathrm{D}\right)$ AS TRACERS TO DETERMINE STREAM WATER ORIGIN}

\author{
Anna Menció ${ }^{1}$ - Marta Galán ${ }^{1}$ - Albert Folch ${ }^{2}$ - Josep Mas-Pla ${ }^{1,3}$
}

${ }^{1}$ Grup de Geologia Aplicada i Ambiental (GAiA), Centre de Geologia i Cartografia Ambiental (Geocamb), Universitat de Girona, Girona 17071, Spain; e-mail: anna.mencio@udg.edu

${ }^{2}$ Grup d'Hidrologia Subterrània, Departament d'Enginyeria del Terreny, Catogràfica i

Geofísica, Universitat Politècnica de Catalunya-Barcelona Tech, Barcelona 08034, Spain

${ }^{3}$ Catalan Institute for Water Research (ICRA), 17003 Girona, Spain

\section{Introduction}

Stream flow is not only a climatic response, since it also depends on the interaction between geological, hydrological, ecological and other factors [1, 2, 3 and 4]. Human pressures on the entire hydrological cycle have a profound influence on stream hydrology and its ecology [5], specially, on the hydrogeological characteristics of alluvial aquifers and their exploitation regime.

According to the European Water Framework Directive (WFD; Directive 2000/60/EC), European countries are under obligation to insure both, water supplies 
for human needs and protect riparian areas from environmental deterioration. To meet these requirements, distinct management practices must to be based on a good knowledge of the hydrogeological processes, and their dynamics.

The Onyar River is located in NE Spain, about $100 \mathrm{~km} \mathrm{NE}$ of Barcelona (Fig. 1). Its watershed is located in a tectonic graben, the Selva Basin, which is closely surrounded by the Gaverres, Selva Maritima, Guilleries and Transversal ranges. The Onyar River is a Mediterranean stream that presents a mean flow of $1.82 \mathrm{~m}^{3} / \mathrm{s}(57.4$ $\mathrm{Hm}^{3} /$ year), and a minimum monthly mean flow of $0.46 \mathrm{~m}^{3} / \mathrm{s}$ in summer. The alluvial deposits of the Onyar River are composed of fine sand layers with a high content of silt and clay, especially near the surface, as a result of igneous rock weathering, and with layers of coarse sand and gravel in some specific areas. They have a maximum thickness of $15 \mathrm{~m} \mathrm{[6]}$ and [7].

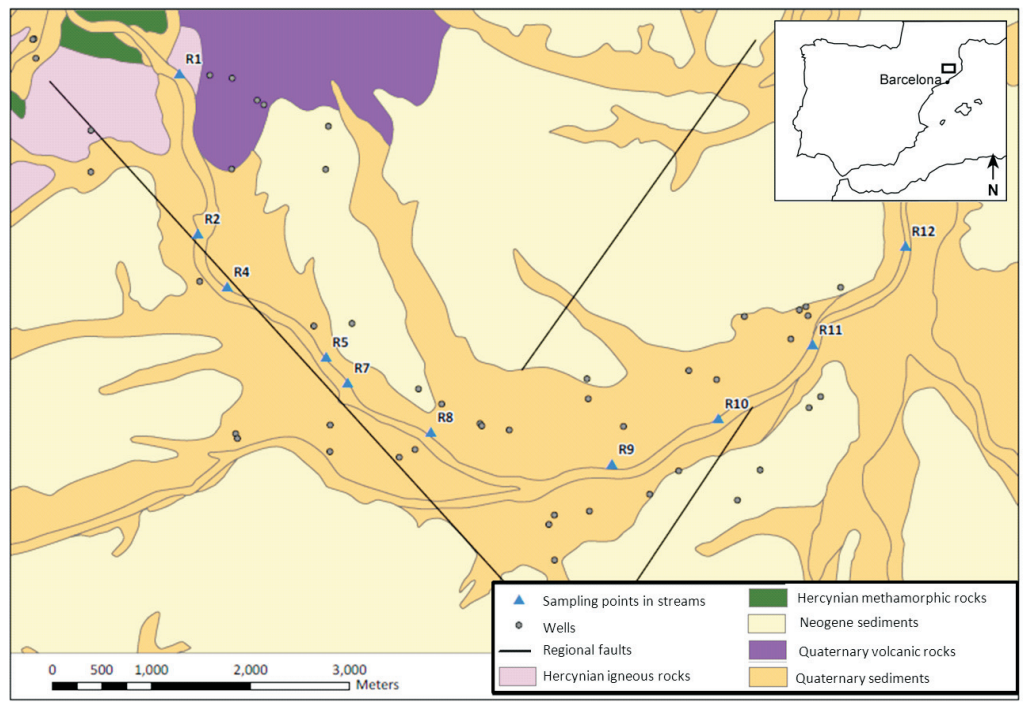

Figure 1. Geographical and geological setting of the Onyar River

The Onyar River is affected by groundwater withdrawal from its alluvial aquifer. This withdrawal is mainly caused by agricultural uses, with intense extraction rates during the irrigation season (from May to the end of September). Furthermore, inputs of wastewater (part of them treated) in the middle course of this stream are another pressure on the quality of this stream.

In order to analyse the stream-aquifer relationship and how is affected by groundwater withdrawal and wastewater discharges, the middle reach of the Onyar River has been studied as an example of overexploited stream-connected alluvial aquifer, using isotopic data, together with stream discharge and potentiometric groundwater levels. 


\section{Methodology}

Four filed surveys were conducted in November 2010, February 2011, May 2011 and July 2011. Stream discharge, and water table depth in 50 wells and in 4 piezometers drilled in the river bed, was measured. Furthermore, surface water, groundwater and wastewater were sampled to analyse their environmental isotope content $\left(\delta^{18} \mathrm{O}\right.$ and $\delta \mathrm{D})$.

Discharge was recorded by measuring stream flow velocity using a current meter at intervals of 0.30 to $0.50 \mathrm{~m}$ along a cross-section of the stream. Measurement points were located in variable intervals to track discharge changes along the Onyar River. Water samples were also taken in these points for isotope analysis. In addition, at R5, R8, R9, R10 and R11 locations piezometers were drilled in the river bed up to $1 \mathrm{~m}$ depth (Fig. 1).

Isotopic characterization $\left(\delta^{18} \mathrm{O}\right.$ and $\left.\delta \mathrm{D}\right)$ of the water samples were obtained by pyrolysis and $\mathrm{CO} 2$ equilibrium, respectively, and using EA-HT-Thermo Flash 1112 and Thermo Gas Bench coupled in continuous flow to two isotope ratio mass spectrometers (IRMS) Thermo Delta V (SIdI, Universidad Autónoma de Madrid). Notation is expressed in terms of the\% deviation of the isotope ratio of the sample relative to that of the V-SMOW standard. Reproducibility of the samples calculated from standards systematically interspersed in the analytical batches is $\pm 0.06 \%$ for $\delta^{18} \mathrm{O}$, and $\pm 0.7 \%$ for $\delta \mathrm{D}$.

\section{Results and Discussion}

Discharge evolution along the studied stream and, the relative position of head level measurements in the different river-bed piezometers (compared to the stream water level), are represented in Figure 2. This comparison of the stream and the piezometers head levels allows determining vertical fluxes between the stream and the aquifer. According to these results:

- The first campaign was conducted after the summer period. It was the first month in which the stream discharge was maintained through the whole studied reach. Potentiometric data was in accordance to the runoff evolution. In the piezometers located before any discharge increase, head level values were higher than the stream water level; and lower head level values were detected before any runoff decrease.

- The second campaign, in February 2011, was carried out fifteen days after a rainfall event $\left(40 \mathrm{l} / \mathrm{m}^{2}\right)$. Stream discharge progressively increased along the studied reach, with the exception of the third point. However, this gaining stream scenario is not detected in the piezometers, since all of them presented head values lower that the stream water level.

- The May 2011 campaign was conducted at the end of the spring rainfalls, in the recession curve of the stream hydrograph (according to the ACA database, 

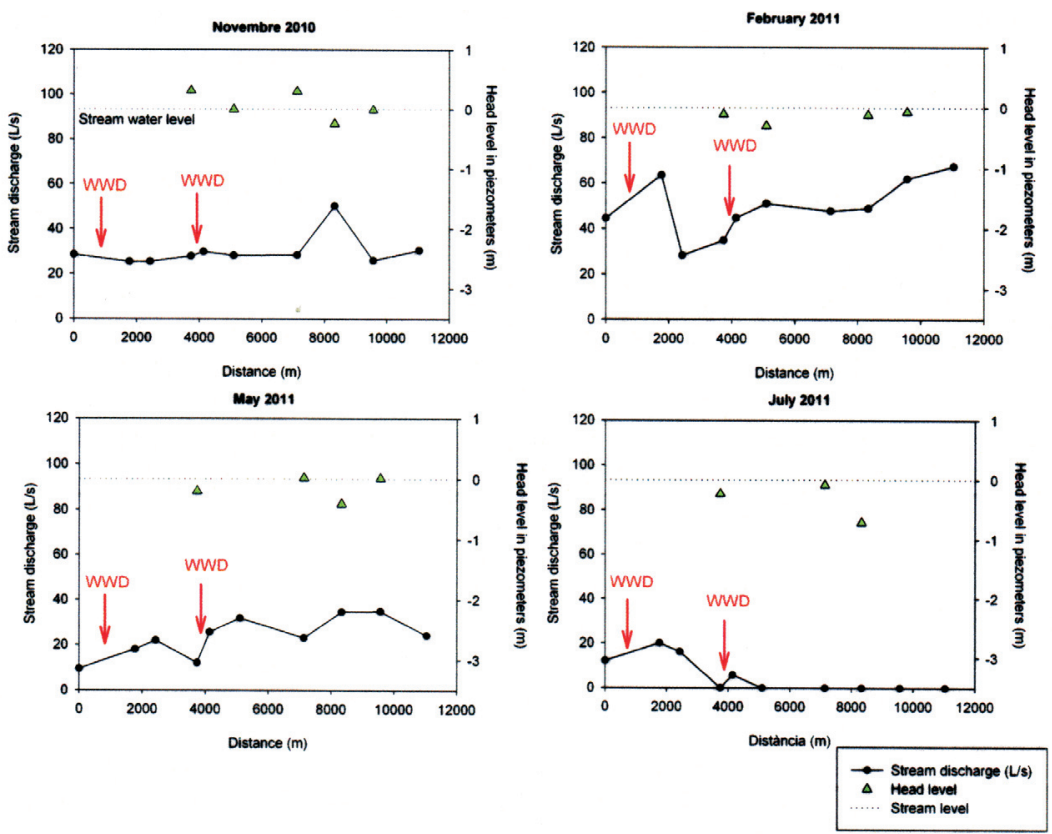

Figure 2. Stream discharge and head level measured in the river-bed piezometers Legend: WWD, waste water discharge

www.gencat.net/aca). In this campaign, head levels were again in accordance to stream discharge.

- In the last field campaign, conducted in the driest period (July 2011), the whole stream discharge, as well as the distinct waste water discharges, was infiltrated in the aquifer induced by groundwater withdrawal. This was a clear loosing stream scenario, where all the piezometers presented lower head level values than the stream bed.

Using potentiometric and discharge data we could clearly distinguish a gaining stream situation (May 2011), a losing stream situation (July 2011), and a campaign with little influence of the aquifer (November 2010). However, in February 2011, all the piezometers shown a losing stream situation when the stream discharge was increasing.

In Figure 3 isotopic composition of surface water, ground water and waste water are presented for the distinct campaigns. In [8] was defined the altitudinal gradient for the Montseny-Guilleries-Montnegre area, where the isotopic content for the highest altitudes of the basin (200-300 m) was around -35 for $\delta \mathrm{D}$. In addition, in [9] a mean isotopic composition for the rainfall in this basin was stated in $-35.5 \%$ of $\delta \mathrm{D}$. 

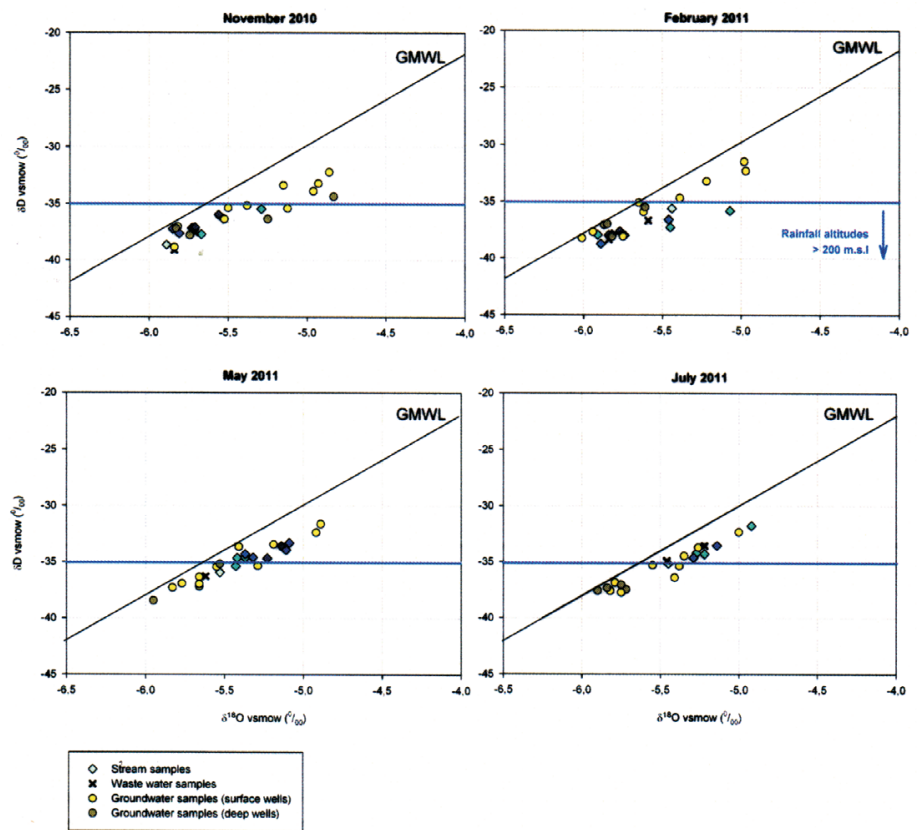

Figure 3. Surface water, groundwater and waste water isotopic content for each sampling campaign Legend: Rainfall altitude limit based on Menció et al. (2012); GMWL: Global meteoric water line

Consequently, lighter values of $\delta \mathrm{D}$ represent rainfall out of the basin, at the headwaters area. Therefore, stream water with lighter values should be mainly composed by surface water coming from the headwaters, while heavier isotopic contents should be representative of local recharge in the basin and ground water influence in the stream.

In the November 2010 campaign, stream water mainly presented $\delta \mathrm{D}$ contents between -38.6 to $35.5 \%$, confirming its surface origin. In contrast, in the May and July 2011 campaigns, $\delta \mathrm{D}$ presented heavier values, close to the groundwater composition of the surface wells in the area, and showing thus, the groundwater contribution to the surface water. Finally, in February 2011, the surface water isotopic composition is closer to the headwaters composition, although the gaining stream situation shown by the runoff increase in the whole stream reach studied. This situation could be explained through the bank storage effect. Two weeks before, an important rainfall event occurred so runoff recharged the banks next to the stream. During the sampling campaign, this surface water was laterally returning back to the stream due to distinct head levels between the banks and the stream. However, lower head levels detected in the piezometers suggest that a downward flux is also occurring at the same time, infiltrating again part of the bank stored water to the aquifer, through the river bed. 


\title{
Conclusions
}

Although discharge and potentiometric data are useful to determine the distinct situations between the stream and the alluvial aquifer in the Onyar River, isotopic composition allow us to better interpret these results, showing a bank storage effect in the February campaign. This kind of processes can be a key factor maintaining a higher stream runoff, and thus, preserving the surface water quality for longer.

Acknowledgment: This study has been financed by the Spanish Government CGL2011-29975-C04-04 project.

\section{References}

1. M. Brunke and T. Gonser, The ecological significance of exchange processes between rivers and groundwater. Freshwater Biol., 37, pp. 1-33, 1997.

2. N.L. Poff, J.D. Allan, M.B. Bain, J.R. Karr, K.L. Prestegaard, B.D. Richter, R.E. Spearks and J.C. Stromberg, The naturalflowregime. A paradigm for river conservation and restoration. BioScience, 47(11), pp. 769-784, 1997.

3. D.A. Sear, P.D. Armitage and F.H. Dawson, Groundwater dominated rivers. Hydrol. Process., 13, pp. 255-276, 1999.

4. D. Gasca and D. Ross, The use of wetland water balances to link hydrogeological processes to ecological effects. Hydrogeo. J., 17, pp. 115-133, 2009.

5. H.P. Hancock, Human impacts in the stream-groundwater exchange zone. Environ. Manage., 29, pp. 763-781, 2002.

6. A. Menció and J. Mas-Pla, Assessment by multivariate analysis of groundwater - surface water interactions in urbanized Mediterranean streams. J. Hydrol., 352, pp. 355-366, 2008.

7. A. Menció and J. Mas-Pla, Influence of groundwater exploitation on the ecological status of streams in a Mediterranean system (Selva Basin, NE Spain). Ecol. Indic., 10, pp. 915-926, 2010.

8. J.M. Carmona, K. Bitzer, E. López and M. Bouazza, Isotopic composition and origin of geothermal waters at Caldetes (Maresme-Barcelona). J. Geochem. Explor., 69-70, pp. 441-447, 2000.

9. A. Folch, A. Menció, R. Puig, A. Soler and J. Mas-Pla, Groundwater development effects on different scale hydrogeological systems using head, hydrochemical and isotòpic data and implications for water resources management: The Selva basin (NE Spain). J. Hydrol., 403, pp. 83-102, 2011.

\section{4 - STABLE CARBON ISOTOPE SIGNATURES OF ANCIENT MAIZE AGRICULTURE AT EL KINEL, GUATEMALA}

\author{
Chris Balzotti-Richard E. Terry
}

Department of Plant and Wildlife Sciences, Brigham Young University, Provo, UT 84602, USA; e-mail: richard_terry@byu.edu

\section{Archaeometry, Biogeochemistry and ecological applications}

Stable $\mathrm{C}$ isotope studies of the soil organic matter (SOM) have delineated areas with histories of vegetation change from $\mathrm{C}_{3}$ forest to $\mathrm{C}_{4}$ maize (Zea mays $\mathrm{L}$.) agriculture and back to the contemporary $\mathrm{C}_{3}$ forest. The objectives were to: (1) determine if land around $\mathrm{El} \mathrm{Kinel,} \mathrm{Guatemala} \mathrm{possessed} \mathrm{a} \mathrm{vegetative} \mathrm{history} \mathrm{of} \mathrm{shifts} \mathrm{from} \mathrm{C}_{3}$ forest to 
$\mathrm{C}_{4}$ maize agriculture in the past, (2) determine if 10 years of contemporary maize production is sufficient time to deposit an isotopic signature of $\mathrm{C}_{4}$ plants in the root zone (top $40 \mathrm{~cm}$ ), and (3) to examine the extractable phosphorus concentrations and $\delta^{13} \mathrm{C}$ in soils of important archaeological features that included a midden, a burial, and two ancient reservoirs (aguadas). Carbon isotopic evidence was found in soil pedons to confirm that long-term agriculture was practiced by ancient Maya farmers at El Kinel. The man-made aguadas did not show isotopic shifts greater than $3.5 \%$ in any part of the profile, indicating they were used for other purposes not associated with maize growth or storage. The lack of a shift in $\delta^{13} \mathrm{C}$ greater than $3.5 \%$ in the top $40 \mathrm{~cm}$ of the contemporary maize field suggested that continual maize cultivation of more than ten years is required to create an isotopic signature for maize agriculture

\section{5 - ASSESING GROUNDWATER CONTAMINATION BY AN INDUSTRIAL MEGA-SITE THROUGH A MULTI-ISOTOPE $\left(\mathrm{S}, \mathrm{O}_{\mathrm{SO} 4}, \mathrm{~N}, \mathrm{O}_{\mathrm{NO} 3}, \mathrm{~B}, \mathrm{H}, \mathrm{O}_{\mathrm{H} 2 \mathrm{O}}\right)$ APPROACH H. Pauwels ${ }^{1}-$ W. Kloppmann ${ }^{1}-$ V. Wypych ${ }^{2}$ \\ ${ }^{1}$ BRGM, Laboratory Division, Orléans, France; e-mail: w.kloppmann@brgm.fr ${ }^{2}$ BRGM, DRP/DPSM/NORD, Billy-Montigny, France}

Industrial mega-sites* are characterised by the multiplicity and the generally complex succession of industrial activities. Consequently, the history of contamination, not always well documented, induces a succession or superposition of contaminant sources and contamination pathways. Assessment of the contamination of the different reservoirs (soil, surface water, groundwater, biota) at a given moment and the related risks for their present and future use as well as the conception of remediation strategies requires indications on both the origin and the timeline of contamination processes in order to foresee their release and propagation in the receptor milieus. Isotope fingerprinting and groundwater dating increase our ability of disentangling the chronology of multiple contaminations; the large choice of isotopic tools offers the possibility of selecting specific direct or indirect tracers of most inorganic or organic contaminants.

Here we present results from an industrial area in Northern France, a former coal mining area, where the first coking plant was installed in 1897. Over the following century, a large diversity of coal-based chemical industries developed on this site, including the treatment of coke oven gas, ammonia and PVC production. Coking activities ceased in 1986, the present day production concerns ammonia water, fertilisers and PVC. Over time, several decantation basins were constructed and two settling

* The FP5 project WELCOME (http://publicwiki.deltares.nl/display/imsw/Megasites) defines megasite as "large area with multiple contaminant sources related to (former) industrial activities, with a considerable impact on the environment, through groundwater, surface water and/or air migration". 
zones representing potential contamination pathways for groundwater in the Upper Cretaceous chalk aquifer, partly overlain by Tertiary to Pleistocene sediments and modern alluvial deposits. Main contaminants are cyanides, arsenic, nitrate, ammonium and sulphate, found mainly in groundwater but also, to a lesser extent, in surface waters downstream of the site

To complete a comprehensive chemical monitoring programme, a multi-isotope and groundwater dating study was conducted combining $\delta^{15} \mathrm{~N}$ and $\delta^{18} \mathrm{O}$ of nitrate, $\delta^{34} \mathrm{~S}$ and $\delta^{18} \mathrm{O}$ of sulphate, stable isotopes of the water molecule and $11 \mathrm{~B}$ of dissolved boron with $\mathrm{CFCs}$ and $\mathrm{SF}_{6}$ as indicators of groundwater residence times.

For part of the contaminated groundwaters, mean CFC-derived residence times exceed 30 years so that the contamination can be qualified as historical. A rough anticorrelation of $\mathrm{SF}_{6}$ with total cyanide and arsenic points to the same conclusion. Arsenic concentrations are not clearly correlated with any major compound or isotope tracer. Nitrate contents are related to ammonium and fertiliser production [1] and are partly limited by denitrification processes induced by the release of organic compounds by the industrial processes. $\delta^{34} \mathrm{~S}$ values of sulphate around $0 \%$ vs. CDT are compatible with hydrolysis and oxidation of sulphur produced by coal combustion [2],

$\delta^{18} \mathrm{O}$ of sulphate indicates variable contribution of atmospheric oxygen and water depending on the reaction mechanism (hydrolysis-oxidation, or oxidation-hydrolysis, [3]). Boron concentrations and isotope signatures of most groundwaters in the vicinity of the industrial site and immediately downstream do not significantly differ from upstream baseline values. Boron appears rather as a tracer of groundwater-surface water mixing processes than as co-tracer of the industrial contaminations. Stable isotopes of the water molecule show clear signs of evaporation for the highly contaminated groundwater below the site and directly downstream which indicate a strong impact of decantation basins as vector of contamination.

\section{References}

1. Kendall, C., Tracing nitrogen sources and cycling in catchments, In: C. Kendall and J.J. McDonnell (eds), Isotope Tracers in Catchment Hydrology. Elsevier, Amsterdam, pp. 519-576, 1998.

2. Kloppmann, W., Bromblet, P., Vallet, J.M., Verges-Belmin, V., Rolland, O., Guerrot, C. and Gosselin, C., Building materials as intrinsic sources of sulphate: A hidden face of salt weathering of historical monuments investigated through multi-isotope tracing (B, O, S). Sci. Total Environ., 409, pp. 1658-1669, 2011.

3. Holt, B. D., Kumar ,R. and Cunningham, P.T., Oxygen-18 study of the aqueous-phase oxidation of sulfur dioxide. Atmospheric Environment, (1967) 15, pp. 557-566, 1981. 


\title{
136 - STABLE ISOTOPIC STUDY FOR THE UPPER CRETACEOUS SUCCESSION OF NORTHWESTERN IRAQ: IMPLICATION FOR PALEOENVIRONMENT INTERPRETAION
}

\author{
Mohamed A. Al-Haj ${ }^{1}$ - Ali I. Al-Juboury ${ }^{1}$ - Aboosh H. Al-Hadidy ${ }^{2}$ \\ ${ }^{1}$ Department of Geology, Mosul University, Mosul, Iraq; \\ e-mail: alialjubory@yahoo.com \\ ${ }^{2}$ Northern Oil Company, Kirkuk, Iraq
}

Carbon and oxygen stable isotopic analysis is conducted for the Upper Cretaceous (Cenomanian-Early Campanian) successions from northwestern Iraq. These successions are represented by Gir Bir, Wajna and Mushorah formations. The study reveals that the upper parts of the Gir Bir Formation was deposited under the mixing zone effect depending on the gradual increment in oxygen and carbon isotopes and strontium with depth. Whereas sharp negative values of $\delta^{18} \mathrm{O}$ and $\delta^{13} \mathrm{C}$ and decline in $\mathrm{Sr} / \mathrm{Al}$ and $\mathrm{Ba} / \mathrm{Al}$ ratios in the uppermost surface of the Gir Bir Formation and in the overlying conglomerate bed are indicative of exposure surface conditions and effect of meteoric water. Homogeneity in the values of oxygen and carbon isotopes and other elements in the Mushorah Formation indicates that it was unaffected by diagenesis near the surface. Gradual variation in $\delta^{13} \mathrm{C}$ from positive in the upper part of Gir Bir Formation to low and negative values at the surface of the formation and in the bed of conglomerate reflects a regressive sequence from deeper to shallower areas upwards of lagoonal facies and then to exposure (marine regression and platform exposure) forming unconformity surface. Sharp increase in $\delta^{13} \mathrm{C}$ in Mushorah Formation reflects deep marine (transgressive) conditions covering most of exposed parts of the platform.

\section{8 - TERRESTRIAL BIOME DISTRIBUTION CHANGE IN THE LATE NEOGENE}

\author{
Donghyun Kim ${ }^{1}$ - Yong Il Lee ${ }^{1}$ - Kiseong Hyeong ${ }^{2}$ - Chan Min Yoo ${ }^{2}$ \\ ${ }^{1}$ School of Earth and Environmental Sciences, Seoul National University, \\ Seoul 151-747, Korea; e-mail: senipah88@naver.com \\ ${ }^{2}$ Deep-sea Resources Research Center, Korea Ocean Research Development Institute, \\ Ansan P.O. Box 29, Seoul 425-600, South Korea
}

Evolution and expansion of $\mathrm{C}_{4}$ plants has been an important topic of Cenozoic terrestrial ecological change, yet there is no quantitative information on the contribution of $\mathrm{C}_{4}$ plants to the vegetation after their Miocene expansion at global scale. Pre-industrial black carbon (BC) in deep-sea sediment preserves isotopic characteristics of original plant, with long-time records relatively free from other disturbance. Also, the proportion of $\mathrm{BC}$ can also provide the scale of fire occurred in the continents upwind, giving important resolution about current debate on the role of fire in the $\mathrm{C}_{4}$ expansion event. 
We present the proportion and stable carbon isotope records of BC of a sediment core from the northeastern equatorial Pacific, covering the past 15.5 million years. Stable carbon isotope record of $\mathrm{BC}$ suggests not only the existence the Late Miocene $\mathrm{C}_{4}$ expansion, but also the $\mathrm{C}_{4}$ maximum period during Pliocene to Early Pleistocene, and the collapse of $\mathrm{C}_{4}$ dominance at the Late Pleistocene. Coincidence of $\mathrm{BC}$ content and carbon isotope record during the $\mathrm{C}_{4}$ maximum period, and records showing the expansion of $\mathrm{C}_{4}$ plants after large disturbance of fire proves the role of fire as a cleaning agent of $\mathrm{C}_{3}$-dominated forest. On the other hand, records showing discordance between the scale of fire and proportion of $\mathrm{C}_{4}$ plants also exist. This study suggests that both fire and environmental advantage for $\mathrm{C}_{4}$ plants are necessary for expansion and dominance of $\mathrm{C}_{4}$ plants: fires allow grasses to invade forests, while other environmental conditions favorable to $\mathrm{C}_{4}$ plants allowed $\mathrm{C}_{4}$ grasses to invade $\mathrm{C}_{3}$ grasslands. Thus, global $\mathrm{C}_{4}$ plant expansion at the Late Miocene can be understood as the combined results of low atmospheric $\mathrm{CO}_{2}$ levels threshold value for a considerable time and fire activity which globally increased grassland extent. Also, the global collapse of $\mathrm{C}_{4}$ dominance in the Late Pleistocene seems to be caused by global cold temperatures at that period, which caused environmental conditions unfavorable for $\mathrm{C}_{4}$ vegetation.

\title{
139 - ISOTOPES IN THE ASSESSMENT OF GROUNDWATER TURNOVER IN TWO COASTAL AQUIFERS
}

\author{
Gunnar Jacks $^{1}$ - Xhume Kumanova ${ }^{2}$ - Sonila Marku ${ }^{2}$ - Unnikrishnan Warrier ${ }^{3}$ \\ ${ }^{1}$ Department of Land and Water Resources Eng., KTH, SE-100 44 Stockholm, Sweden; \\ e-mail: gunnjack@kth.se \\ ${ }^{2}$ Albanian Geological Survey, Tirana, Albania \\ ${ }^{3}$ CWRDM, Kozhicode, Kerala, India
}

Coastal aquifers are at risk globally due to heavy extraction rates and a changing climate that is likely to be manifested as a rising sea level (Ericson et al., 2006). Two coastal aquifers have been studied to assess the risk for saline intrusion and the groundwater turnover in general. In both cases isotopes, radioactive and stable have been found to be useful for deciphering the groundwater turnover.

The Kerala Coastal aquifers consist of three aquifers from Pleistocene to Miocene age. The total depth of the sediments is about $300 \mathrm{~m}$. The pumping from the aquifers has lowered the groundwater level below sea level. The lowermost aquifers are brackish and the aim of the investigation was to assess the risk for sea water intrusion. There was a geographical distribution of water types from $\mathrm{Ca}-\mathrm{HCO}_{3}$ in the south via $\mathrm{Na}-\mathrm{HCO}_{3}$ to a brackish saline further north.

The Mati plain in northern Albania is underlain by three partly communicating aquifers of Pleistocene age with a total thickness of $250 \mathrm{~m}$ close to the coastline. The groundwater is brackish close to the coastline but artesian indicating that sea water intrusion is not imminent. 
The groundwater was dated by ${ }^{14} \mathrm{C}$ in both aquifers. The ages in the Kerala coastal aquifer ranged from $22 \mathrm{ky}$ to $35 \mathrm{ky}$ indicating a very slow turnover. The presence of $\mathrm{Na}-\mathrm{HCO}_{3}$ types of water indicate flushing with fresh water rather than sea water intrusion (Mercado 1985). Looking into data from sediments in the Arabian sea indicated that the groundwater was largely recharged during a period with low sea water level before $20 \mathrm{ky}$ ago. This period was followed by an arid period. $\delta^{18} \mathrm{O}$ data for fresh to brackish groundwater did not show a mixing line from fresh water to sea water ratio. At a certain chloride level the $\delta^{18} \mathrm{O}$ did not change with chlorinity hinting about that the salinity had entered the water through diffusion from saline pore water in intercalated clay layers. A clay sample taken during drilling confirmed this conclusion. Possibly the sea water-fresh water front is still situated offshore.

In the Albanian aquifer there was in parallel to what was found in Kerala no mixing towards sea water of the $\delta^{18} \mathrm{O}$ ratio. Thus even here the brackishness of the groundwater is likely to be due to diffusion from intercalated clay layers. This was further supported by $\delta^{34} \mathrm{~S}$ analyses. The sulphate in brackish groundwater had a $\delta^{34} \mathrm{~S}$ in excess of $21 \%$ indicating sulphate reduction which may occur in the clays while groundwater in the aquifers shows no sign of anaerobia. The brackish groundwater was dated by ${ }^{14} \mathrm{C}$ to have ages up to 7000 years presumably recharged during the Flandrian transgression. A major well field supplying 220,000 people could be shown to be fed from the river Mati by analysis of $\delta^{34} \mathrm{~S}$ which was around $4 \%$ due to the presence of sulphide rich mining wastes upstream.

Summing up is can be concluded the use of isotopes largely facilitated the assessment of the groundwater recharge and turnover in these two aquifers.

\section{References}

1. J. P. Ericson, C.J. Vörösmarty, S.L. Dingman, L.G. Ward and M. Meybeck, Effective sea level rise and deltas. Global Planetary Change, 50, pp. 63-82, 2006.

2. A. Mercado, The use of hydrogeochemical patterns in carbonate sand aqnd sandstone to identify intrusion and flushing of saline water. Ground Water, 23, pp. 635-645, 1985.

\section{0 - RECOVERIES BY THREE CROPS OF N APPLIED} AS ${ }^{15}$ N GOAT MANURE OR ${ }^{15}$ N GLIRICIDIA BIOMASS

\footnotetext{
Everardo V. S. B. Sampaio ${ }^{1}$ - Dário C. Primo ${ }^{2}-$ Rômulo S. C. Menezes ${ }^{3}-$

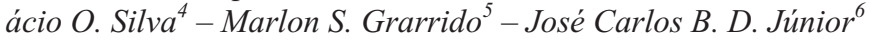

${ }^{1}$ Department of Nuclear Energy, Universidade Federal de Pernambuco, Av. Prof. Luís Freire, 1000, 50740-540, Recife, PE, Brazil; e-mail: esampaio@ufpe.br

${ }^{2}$ Universidade Federal de Pernambuco, Recife, Brazil

${ }^{3}$ Universidade Federal de Pernambuco, Recife, Brazil

${ }^{4}$ Universidade Federal de Sergipe, Aracaju, Brazil

${ }^{5}$ Universidade do Vale do São Francisco, Petrolina, Brazil

${ }^{6}$ Universidade Federal Rural de Pernambuco, Recife, Brazil
} 
Recoveries of nitrogen following fertilization with ${ }^{15} \mathrm{~N}$-labeled goat manure and ${ }^{15} \mathrm{~N}$-gliricidia biomass were evaluated in a greenhouse experiment with three successive planting cycles of three crops: cotton, corn, and cowpea. Nitrogen is frequently the most limiting crop nutrient and its dynamics in the soil - plant system is rather complex. The best way to monitor this dynamics is to use material labeled with ${ }^{15} \mathrm{~N}$ [1]. Much has been written about the application of labeled mineral fertilizers to several crops and under many different environmental conditions. Far less has been published about the application of labeled organic material, usually green manure crops or manure $[2,3]$ and no paper was found with application of labeled goat manure or gliricidia biomass.

Each $1 \mathrm{~kg}$ soil pot received $8 \mathrm{~g}$ (equivalent to $20 \mathrm{Mg} \mathrm{ha}^{-1}$ ) of either manure $\left(12.3 \mathrm{mg} \mathrm{g}^{-1}\right.$ of $\left.\mathrm{N}\right)$ or gliricidia $\left(37.8 \mathrm{mg} \mathrm{g}^{-1}\right.$ of $\left.\mathrm{N}\right)$. Plants were harvested 50 days after germination and real $\left({ }^{15} \mathrm{~N}\right)$ and apparent recoveries of the applied $\mathrm{N}$ were determined. The real recovery was calculated dividing the amounts of $\mathrm{N}$ derived from the source by the amount of $\mathrm{N}$ applied to the soil as gliricidia or manure. The apparent $\mathrm{N}$ recovery was calculated subtracting the amounts of $\mathrm{N}$ in the control from the amounts of $\mathrm{N}$ in the fertilized treatments (gliricídia or manure) and dividing by the by the amount of $\mathrm{N}$ applied to the soil as gliricidia or manure [4]. The proportions and amounts of $\mathrm{N}$ derived from symbiotic fixation of atmosphere $\mathrm{N}$ in the cowpea plants were calculated considering the cotton plants as reference non-fixing plants. The ratio of $\mathrm{N}$ derived from the soil and $\mathrm{N}$ derived from the fertilizer was calculated for the cotton plants and this ratio was used to calculate the proportion of $\mathrm{N}$ derived from the soil in the cowpea plants, based on the proportion derived from the fertilizer. The proportion derived from fixation in the cowpea was estimated subtracting from $100 \%$ the proportion derived from the source and the proportion derived from the soil.

In general, biomass and $\mathrm{N}$ amounts in the cotton and corn crops, in all three cycles, were higher with gliricidia application than with manure and both higher than the control treatment. There was no treatment effect in the cowpea. Gliricidia has a faster decomposition rate than manure $[5,6]$ and its biomass had a higher $\mathrm{N}$ concentration. The proportion and amount of symbiotic fixation $\mathrm{N}$ in the cowpea increased from the first to the their cycle, reaching more than $90 \%$ in this last one. Estimates of fixation by cowpea usually vary from 40 to $90 \%$ of the plant $\mathrm{N}$.

In the first cycle, the largest recoveries of ${ }^{15} \mathrm{~N}$ were obtained with gliricidia, for all three crops, but in the second and third cycles recoveries were greater with manure, so that the real recoveries of gliricidia and manure $\mathrm{N}$ at the end of the three cycles were were similar (cotton, 35 and 37\%; corn, 27 and 26\%; and cowpea, 41 and $38 \%$ of the applied N). Nitrogen recoveries of cattle manure applied for three years in a corn crop were of the same order, 35 to $49 \%$ [3] but those obtained by Thomsen [4] were of lower proportions ( 13 a $22 \%$ ). 
Estimates of apparent recoveries were different from the real ones and therefore inadequate for cotton and cowpea. The residual effect of manure to subsequent cropping cycles should be considered by farmers in their fertilization strategies.

\section{References}

1. G.J.C. Gava, P.C.O. Trivelin, M.W. Oliveira et al., Balanço do nitrogênio da uréia $\left({ }^{15} \mathrm{~N}\right)$ no sistema solo-planta na implantação da semeadura direta na cultura do milho. Bragantia, 65, pp. 477-486, 2006.

2. W.E. Jokela, Nitrogen fertilizer and dairy manure effects on corn yield and soil nitrate. Soil Sci. Soc. Am. J., 56, pp. 148-154, 1992.

3. I.K. Thomsen, Recovery of nitrogen from composted and anaerobically stored manure labelled with ${ }^{15} \mathrm{~N}$ Europ. J. Agron., 15, pp. 31-41, 2001.

4. N.K. Fageria, Otimização da eficiência nutricional na produção das culturas. Ver. Eng. Agríc. Ambi., 2, pp. 6-16, 1998.

5. P.L. Mafongoya, P. Barak and J.D. Reed, Carbon, nitrogen and phosphorus mineralization of tree leaves and manure. Biol. Fertil. Soils, 30, pp. 298-305, 2000.

6. S. Mundus, R.S.C. Menezes, A. Neergaard et al., Maize growth and soil nitrogen availability after fertilization with cattle manure and/or gliricidia in semi-arid NE Brazil. Nutr. Cycl. Agroecosyst., 82, pp. 61-73, 2008.

\section{1 - DOWNSTREAM SECTION CHANGES OF FRESHWATER TUFA DEPOSITING STREAMS, MECSEK MTS, HUNGARY}

$$
\begin{gathered}
\text { Gabriella Koltai }^{1,3}-\text { László Palcsu }^{1}-\text { Sándor Kele }^{2}-\text { Istvan Futó }^{1}-\text { Enikö Heim }^{1}- \\
\text { Ilona Bárány-Kevei }
\end{gathered}
$$

${ }^{1}$ Hertelendi Laboratory of Environmental Studies, Institute for Nuclear Research, Hungarian Academy of Sciences, P.O.Box 51, H-4001 Debrecen, Hungary; e-mail: koltaig@atomki.hu ${ }^{2}$ Institute for Geological and Geochemical Research, Research Centre for Astronomy and Earth Sciences, Hungarian Academy of Sciences, Budaörsi út 45, H-1112 Budapest, Hungary ${ }^{3}$ Department of Climatology and Landscape Ecology, University of Szeged, P.O Box 653, H-6701 Szeged, Hungary

Many freshwater tufas contain millimetre-scale laminae that are attributed to the seasonal differences in physicochemical parameters of water and biological activity. The analysis of the various factors controlling modern tufa deposition can greatly contribute to their palaeoclimatological significance in terms of studying seasonal changes [1-3].

In Mecsek Mts, Hungary three freshwater tufa depositing streams (Csurgó Spring, Anyák Spring and Pásztor Spring) have been monitored since May 2012 in order to investigate the present-day sedimentary dynamics of carbonate deposition. The downcurrent changes of the basic hydrochemical parameters and the stable isotope composition of water were measured on a regular basis.

Similarly to other studies [3], our results show clear seasonal and downstream changes in the physicochemical parameters of water. Alkalinity and water temperature 
was higher from late spring to autumn and lower from winter early spring, while water temperature reflected the variations in air temperature. Downstream the water temperature increased in summer and decreased in winter. Contrary to $\mathrm{pH}$ values, electric conductivity and alkalinity gradually declined downstream.

Water samples for stable isotope measurements were collected at two places: at the spring site and at the last measurement point. The studied springs were characterized by similar changes in their stable isotopic composition over the studied period. The highest values were measured at Anyák Spring and the lowest at Pásztor Spring that can be contributed to the elevation differences of their catchment areas. $\delta^{18} \mathrm{O}$ and $\delta \mathrm{D}$ values changed from -10.5 to $-9.3 \%$, -71.2 to $-67.9 \%$ at Anyák and between -76.5 to $-69.2 \%$, -10.8 to $-10.1 \%$ (VSMOW) at Pásztor springs, respectively. Csurgó Spring was characterized by isotope ratios similar to Pásztor Spring. Differences between the $\delta^{18} \mathrm{O}$ of water collected at the spring and the last measurement site usually remained within the range of measurement uncertainty (below $0.8 \%$ ). The highest downstream difference $(5.9 \%$ ) in $\delta \mathrm{D}$ was measured at Csurgó Spring in October 2012.

Carbonate samples were collected for stable isotope analyses along the streams in June 2012. $\delta^{13} \mathrm{C}$ of bulk tufa samples varied between -11.2 and $-9.2 \%$, -11.8 and $-11.7 \%$, -11.7 and $-10.7 \%$ (VPDB) in case of Anyák, Csurgó and Pásztor springs respectively, first showing slight depletion and then slight enrichment in ${ }^{13} \mathrm{C}$. Except for Anyák Spring, $\delta^{18} \mathrm{O}$ showed less variation and changed from -9.4 to $-8.4 \%,-9.3$ to $-9.2 \%$ and -9.3 to $-9.2 \%$ (VPDB).

In order to estimate the growth rate of tufa, nails and glass substrates were placed at the measurement points along the stream and the deposited tufas have been collected in every second month and analysed separately since August 2012. Our study presents the seasonal hydrochemical and sedimentary data obtained from Anyák, Csurgó and Pásztor springs.

\section{References}

1. M. Vazquez-Urbez, C. Arenas, C. Sancho, C. Osacar, L. Auque and G. Pardo, Factors controlling present-day tufa dynamics in the Monasterio de Piedra Natural Park (Iberian Range, Spain): depositional environmental settings, sedimentation rates and hydrochemistry. Int. J. Earth Sci., 99, pp. 1027-1049, 2010.

2. J.E. Andrews and A.T. Brasier, Seasonal records of climatic change in annually laminated tufas. JQS, 20(5), pp. 411-421.

3. A. Kano, J. Matsuoka, T. Kojo and H. Fujii, Origin of annual laminations in tufa deposits, southwest Japan. Palaeogeography, Palaeoclimatology, Palaeoecology, 191, pp. 243-262, 2003. 


\title{
142 - WATER AND GAS INCLUSIONS IN TERRESTRIAL AND AQUATIC CARBONATE AND APATITE RECORDS AS NEW PALAEOCLIMATE PROXIES
}

\author{
László Palcsu ${ }^{I}$ - László Papp ${ }^{l}$ - Zoltán Major ${ }^{1}$ - Gabriella Koltai ${ }^{1}$ - István Futó ${ }^{1}-$ \\ Anikó Horváth ${ }^{1}$ - István Tóth ${ }^{2}$ \\ ${ }^{1}$ Hertelendi Laboratory of Environmental Studies, Institute for Nuclear Research, \\ Hungarian Academy of Sciences, Bem tér 18/c, Debrecen, 4026-Hungary; \\ e-mail: palcsu.laszlo@atomki.mta.hu \\ ${ }^{2}$ Isotoptech Ltd. Piac 53, II/9, Debrecen, 4025-Hungary; e-mail: isotoptech@t-online.hu
}

Besides the carbon and oxygen isotope signatures in the carbonate layers, oxygen and hydrogen stable isotope compositions of fluid inclusion waters in speleothems have been shown to be powerful tools as palaeoclimate indicators. Recently, noble gas concentrations in water inclusions might provide temperature information from past carbonate deposits $[1,2]$. This presentation presents our new results of noble gas measurements of $0.1-2.0 \mu \mathrm{l}$ of water extracted from fluid inclusions of numerous solid geological archives, such as speleothems, coral skeletons, stromatolites, oncolites, secondary carbonates from loess paleosols, and mollusc shells. As our preparation method allows us to collect the water into glass tubes, stable isotope analyses for oxygen and hydrogen are also performed using the TC/EA device of the stable isotope ratio mass spectrometer. Additionally, our first results of the quadrupole mass spectrometric $\mathrm{CO}_{2}$ mixing ratio measurements from gas inclusions of stalagmites will be also presented.

\section{References}

1. T. Kluge, T. Marx, D. Scholz, S. Niggemann, A. Mangini and W. Aeschbach-Hertig, A new tool for palaeoclimate reconstruction: Noble gas temperatures from fluid inclusions in speleothems. Earth and Planetary Science Letters, 296, pp. 408-415, 2008.

2. Y. Scheidegger, M.S. Brennwald, D. Fleitmann, P. Jeannin, R. Wieler and R. Kipfer, Determination of Holocene cave temperatures from $\mathrm{Kr}$ and $\mathrm{Xe}$ concentrations in stalagmite fluid inclusions. Chemical Geology, 288, pp. 61-66, 2011.

\section{3 - DIFFERENT FRACTIONATION OF OXYGEN ISOTOPES IN TWO LOW-TEMPERATURE TRAVERTINE-DEPOSITING SYSTEMS WITH DIFFERING HYDRODYNAMIC CONDITIONS}

$$
\text { Yan Hao }{ }^{1,2} \text { - Liu Zaihua }{ }^{l} \text {-Sun Hailong }{ }^{l}
$$

${ }^{1}$ State Key Laboratory of Environmental Geochemistry, Institute of Geochemistry, Chinese Academy of Sciences, Guiyang 550002, China; e-mail: casillas163@163.com

${ }^{2}$ Université de Strasbourg et CNRS, Laboratoire d'Hydrologie et de Géochimie de Strasbourg, Ecole et Observatoire des Sciences de la Terre, 1, rue Blessig, 67084 Strasbourg Cedex, France 
Travertine/tufa, due to its unique advantages in providing high-resolution (up to seasonal, monthly or even daily) paleoclimate information, has been regarded as an important source of terrestrial paleoclimatic data. However, there may be isotopic disequilibrium fractionation between deposits and parent solutions, which makes the reconstruction less robust.

In order to understand the behaviour of oxygen isotopic fractionation and obtain more reliable paleoclimatic data from surficial travertine deposits, the hydrochemistry, carbonate precipitation rates, and the temporal and spatial variations in $\delta^{18} \mathrm{O}$ values of the modern travertine in two low-temperature travertine-depositing systems (canal and pool) with differing hydrodynamic conditions at Baishuitai, Yunnan, SW China, were investigated during the warm rainy season. It was found that the oxygen isotopic composition of travertine in the two systems showed distinct controlling mechanisms mainly due to different carbonate precipitation rates. For the canal system with fast flow, large deviations between the calculated and measured temperatures indicated that travertine precipitated out of isotopic equilibrium. This was due to rapid carbonate precipitation with intense $\mathrm{CO}_{2}$ degassing. $\delta^{18} \mathrm{O}_{\text {travertine values }}$ and water temperature increased downstream $\left(\sim 1 \%\right.$ and $4^{\circ} \mathrm{C}$, respectively) while $\delta^{18} \mathrm{O}_{\text {water }}$ values remained relatively stable. It was shown that variation in $\delta^{18} \mathrm{O}$ values of travertine in the canal system were synchronized with that in $\delta^{18} \mathrm{O}$ values of dissolved carbonates $\left(\mathrm{HCO}_{3}^{-}\right)$which also increased along the canal, controlled by Rayleigh-distillation effects. In contrast, in the pools system with slow flow, oxygen isotopic equilibrium between dissolved carbonates $\left(\mathrm{HCO}_{3}{ }^{-}\right)$and $\mathrm{H}_{2} \mathrm{O}$ was achieved and the $\delta^{18} \mathrm{O}$ travertine values did not display spatial variations. Calculated water temperatures using the equilibrium fractionation factors of Coplen (2007) were identical to the measured ones, which indicates that travertine in such pools system is suitable for the reconstruction of paleo-precipitating temperatures.

Finally, by comparing these two systems we have obtained a simple criterion to determine the suitability of travertine to estimate temperatures - the $\delta^{18} \mathrm{O}$ value of $\mathrm{BaCO}_{3}$ precipitated from water samples is compared with the theoretical $\delta^{18} \mathrm{O}$ value of

dissolved carbonate calculated using water temperature and $\delta^{18} \mathrm{O}_{\text {water }}$, to check if the oxygen isotopes of the dissolved carbonate are in equilibrium with the water.

\section{References}

1. Coplen, T.B., Calibration of the calcite-water oxygen-isotope geothermometer at Devils Hole, Nevada, a natural laboratory. Geochim. Cosmochim. Acta, 71, pp. 3948-3957, 2007. 


\title{
144 - A MEDIEVAL WARM PERIOD $\delta^{13}$ C RECORD FROM THE GAURA CU MUSCA CAVE, SW ROMANIA
}

\author{
Bogdan P. Onac ${ }^{1,2}$ - Ferenc Forray ${ }^{1}$ - Alexandra Giurgiu ${ }^{1}$ - Jonathan G. Wynn ${ }^{2}$ \\ ${ }^{1}$ Department of Geology, Babe?-Bolyai University, Kogãlniceanu 1, \\ 400084 Cluj Napoca, Romania; e-mail: ferenc.forray@ubbcluj.ro \\ ${ }^{2}$ Department of Geology, University of South Florida, 4202 E. Fowler Ave., SCA 528, \\ Tampa FL 33620 USA
}

Stable isotopes investigations of cave guano deposits are limited (Wurster et al., 2007). However, previous such researches have demonstrated that carbon, nitrogen, and hydrogen stable isotope records derived from bat guano are useful to interpret vegetation and climate change (Mizutani et al., 1992; Bird et al., 2007; Wurster et al., 2008).

The advantages of using cave bat guano deposits as environmental/climate proxy are four fold: 1) many caves of Romania host important guano accumulations, 2) the ability to generate an accurate age-depth model based on ${ }^{14} \mathrm{C}$ dating (some guano deposits are as old as 8,500 years; Carbonnel et al., 1999), 3) the presence of significant amounts of pollen grains and charcoal, and 4) the possibility of recovering a variety of stable isotope signatures by analyzing bulk guano and/or insect chitin samples. Therefore, this archive offers a unique opportunity to examine at high resolution past environmental and climate changes using a multi-proxy approach (isotope ratios in guano, pollen, major/trace elements, and phosphate minerals).

Gaura cu Muscã (GM; meaning the Cave with Flies) opens in the left bank of the Danube Gorge downstream the village of Coronini and has a total length of $254 \mathrm{~m}$ (Negrea and Negrea, 1969). A short fossil gallery (Bats Passage) that bypasses the main water passage of the cave hosts a thick clay deposit in which centimetre-thick guano layers or lenses and fragments of charcoal are interbedded. The guano deposits are related to the presence of Myotis myotis and Rhinolophus ferrumequinum bat colonies (Negrea and Negrea, 1979). Samples of guano and charcoal for radiocarbon dating and $\delta^{13} \mathrm{C}$ analyses were collected from a $25-\mathrm{cm}$ deep profile opened in the clay deposit accumulated on the floor of the Bats Passage. For this study we only used the samples collected to a depth of $17 \mathrm{~cm}$, because the remaining $8 \mathrm{~cm}$ of the profile are entirely made up of ochre clays with limited fragments of charcoal and no guano.

Dating control for the GM profile is based on three radiocarbon AMS ages (Poznan Radiocarbon Laboratory, Poland) from bulk guano (2) and charcoal (2); the lowermost sample gave $(-16.5 \mathrm{~cm})$ an age of $989 \mathrm{cal} \mathrm{yr} \mathrm{AD}$, whereas the other two samples recovered from depths of 6.9 and $0.5 \mathrm{~cm}$, respectively, not only are in stratigraphic order, but also cover the rest of the Medieval Warm Period (1171 and $1277 \mathrm{cal}$ yr AD).

Stable isotope ratios of carbon $\left(\delta^{13} \mathrm{C}\right)$ were measured in twenty-three samples of bulk guano and ten pieces of charcoal using a Picarro G2121-i CM-CRDS system at the Stable Isotope Laboratory in the Department of Geology, Babes-Bolyai University 
in Cluj-Napoca, Romania. The $\delta^{13} \mathrm{C}$ values range from -27.1 to $-25.2 \%$ in bulk guano and from -27.4 to $-24.5 \%$ in charcoal. Precisions on internal standards were better than $\pm 0.06 \%$. Overall, the trend of guano and charcoal $\delta^{13} \mathrm{C}$ values parallel each other, bearing similarity to the PU-2 stalagmite (Ursilor Cave) $\delta^{13} \mathrm{C}$ record of NW Romanian climate variability for the same time period. The dry/wet periods identified as more positive/negative $\delta^{13} \mathrm{C}$ values in the PU-2 (Onac et al., in prep.) nicely match the shifts observed for both bulk guano and charcoal $\delta^{13} \mathrm{C}$. Furthermore, the guano-inferred wet and dry intervals from the GM Cave also mirror changes in the color (from yellowish during the dry period to dark brown when wet conditions prevailed) and amount of clay accumulated. This suggests bats were present in the cave during both periods, but apparently, the production of guano was higher at the beginning of the MWP. Around the year 1171, the $\delta^{13} \mathrm{C}$ values in the GM Cave guano document a short-lived (few years) wet period also seen in the PU-2 stalagmite and other location throughout Europe (Marusek, 2011). Towards the upper part of the profile, corresponding to the demise of MWP, the guano layers are thinner and vanishing completely at the onset of the Little Ice Age.

In summary, the guano $\delta^{13} \mathrm{C}$ values from the short clay/guano sediment profile in the GM Cave made possible to preliminary characterize the MWP hydroclimate. The beginning of the period was rather wet for more than a century, and then became progressively drier. After a distinct but brief wet season around AD 1171, drier conditions prevailed for almost half a century before climate deteriorated at the onset of the Little Ice Age.

Acknowledgement: Financial support from the Romanian National Authority for Scientific Research (grant PCE-2011-3-0588 to BPO) is gratefully appreciated.

\section{References}

1. M.I. Bird, E.M. Boobyer, C. Bryant, H.A. Lewis, V. Paz and W.E. Stephens, A long record of environmental change from bat guano deposits in Makangit Cave, Palawan, Philippines. Earth and Environmental Science Transactions of the Royal Society of Edinburgh, 98, pp. 59-69, 2007.

2. J.R. Carbonnel, P. Olive, V.G. Decu and D. Klein, Datation d'un dépôt de guano holocène dans la Carpates méridionales (Roumanie). Implications tectoniques. C.R. Acad.Sci. Paris, 328, pp. 367-370, 1999.

3. J.A. Marusek, A chronological listing of early weather events. SPPI Reprint Series, p. 580, 2011 http://scienceandpublicpolicy.org/reprint/.

4. H. Mizutani, D.A. McFarlane and Y. Kabaya, Carbon and nitrogen isotopic signatures of bat guanos as a record of past environments. Mass Spectroscopy, 40, pp. 67-82, 1992.

5. A. Negrea and St. Negrea, The caves of Danube Gorge and their terrestrial fauna. In: T. Orghidan and S. Negrea (eds), Speologia, Bucuresti: Editura Academiei RSR, pp. 30-75, 1979 [in Romanian].

6. St. Negrea and A. Negrea, The caves from the Danube Gorge. Trav. Inst. Spéol. Emil Racovită, 8, pp. 25-50, 1969 [in Romanian].

7. C.M. Wurster, D.A. McFarlane and M.I. Bird, Spatial and temporal expression of vegetation and atmospheric variability from stable carbon and nitrogen isotope analysis of bat guano in the southern United States. Geochimica et Cosmochima Acta, 71, pp. 3302-3310, 2007. 
8. C.M. Wurster, W.P. Patterson, D.A. McFarlane, L.I. Wassenaar, K.A. Hobson, N.B. Athfield and M.I. Bird, Stable carbon and hydrogen isotopes from bat guano in the Grand Canyon, USA, reveal Younger Dryas and 8.2 ka events. Geology, 36, pp. 683-686, 2008.

\title{
145 - FOLIAR $\delta^{15}$ N AND USE OF THE NATURAL ABUNDANCE METHOD FOR IDENTIFYING FIXING LEGUMES ALONG A PRECIPITATION GRADIENT IN NORTHEAST BRAZIL
}

\author{
Ana Dolores Santiago de Freitas ${ }^{1}$ - Everardo Valadares de Sá Barretto Sampaio ${ }^{2}$ - \\ Andresa P.S. Ramos ${ }^{3}$ - Maria Regina V. Barbosa ${ }^{4}$ - Rosângela P. Lyra ${ }^{5}-$ \\ Elcida Lima Araújo ${ }^{6}$ \\ ${ }^{1}$ Department of Agronomy, Universidade Federal Rural de Pernambuco, Av. Dom Manoel de \\ Medeiros, s/n, 52171-900, Recife, PE, Brazil; e-mail: ana.freitas@depa.ufrpe.br \\ ${ }^{2}$ Universidade Federal de Pernambuco, Recife, Brazil \\ ${ }^{3}$ EMBRAPA, Cruz das Almas, Brazil \\ ${ }^{4}$ Universidade Federal da Paraíba, João Pessoa, Brazil \\ ${ }^{5}$ IMA, Maceió, Brazil \\ ${ }^{6}$ Universidade Federal Rural de Pernambuco, Recife, Brazil
}

The biogeochemical cycle of nitrogen in land ecosystems involves several isotopic fractionation processes whose balance determines the $\delta^{15} \mathrm{~N}$ signals of their soil and plant components [1]. Inputs, mainly from biological fixation, have $\delta^{15} \mathrm{~N}$ signal close to $0 \%$. Losses, from volatilization and leaching, have negative $\delta^{15} \mathrm{~N}$ signals leaving the soil with positive signals $[1,2,3]$. Thus, a promising application of the signals is the possibility to relate the signals of the plants with the $\mathrm{N}$ availability of the soil [4].

The $\delta^{15} \mathrm{~N}$ signal also allows identifying plants with symbiotic $\mathrm{N}_{2}$ fixation if the soil signal is distinctly different from zero, which occurs in same places [7] but not in others [8]. In spite of these potential applications, the interpretation of patterns is still subject to controversies. Several exceptions to the general trends have been reported [6] and the relation between plant $\delta^{15} \mathrm{~N}$ and climate is not completely clear [4]. The isotopic signals of most of the tropical forests are unknown and there are few systematic surveys of signals along climate and soil gradients within the same region. In this article we describe the ${ }^{15} \mathrm{~N}$ signals of plants along a rainfall gradient in Northeast Brazil and evaluated the possibility to estimate biological $\mathrm{N}_{2}$ fixation from the signals of fixing and non-fixing plants.

Fourteen areas with native vegetation without any major disturbance were selected following roughly three parallel east - west transects, along the states of Paraíba (PB), Pernambuco (PE) e Alagoas (AL), in the Northeastern region of Brazil. The areas cover a large span of rainfall (from 400 to more than $2000 \mathrm{~mm} \mathrm{y}^{-1}$ ) and water availability, conditioned by different rainfall distribution and evapotranspiration rates along the year. This variation translates into six vegetation types: 1) coastal perennial rainforest, in João Pessoa (PB), Recife (PE) and Rio Largo (AL) municipalities; 
2) coastal semidecidual forest in Aliança (PE) and São Vicente (PE) municipalities; 3) subhumid deciduous forest (agreste caatinga), in Caruaru (PE) and Remígio (PB); 4) semiarid deciduous forest (sertão caatinga), in Santa Teresinha (PB), Serra Talhada (PE) and Pão de Açúcar (AL) municipalities; 5) semideciduos mountain forest in Areia (PB), Caruaru (PE) and Mata Grande (AL); and 6) savanna - caatinga transition in Araripina (PE).

In each site, five to six circular plots of about $20 \mathrm{~m}$ radius each and at least $50 \mathrm{~m}$ apart were marked in native mature vegetation patches. In each plot, one plant of the species previously selected was sampled. The species included all the legumes in the plot and also those with the most abundant and largest plants, based on previous phytosiological studies. One composite sample of 10 to 20 fully expanded healthy leaves was collected from each plant. Part of the data for the subhumid deciduous forest, in Caruaru (PE) and Remígio (PB), and for the semiarid deciduous forest, in Santa Teresinha (PB) and Serra Talhada (PE) was already published by Freitas et al. [5, 7]. The plants were classified as nodulating legumes, non-nodulating legumes and non-legumes. The non-nodulating legumes and the non-legumes were considered as reference species, to calculate $\mathrm{N}_{2}$ fixation of the nodulating legumes. All legume species without complete botanical identification or for which the nodulating potential was unknown was considered as a potentially nodulating species.

Soil samples were collected from the top $20 \mathrm{~cm}$ layer of each plot, air-dried, sieved and cleaned of any plant debris. Subsamples were ground to finer powder. The plant samples were dried and also ground to fine powder. Plant and soil samples were analyzed for their ${ }^{15} \mathrm{~N}$ natural abundance, expressed in $\delta$ units in relation to international standard (atmospheric $\mathrm{N}_{2}$ ). The data was submitted to analysis of variance and the averages compared using the Tukey test at the $5 \%$ probability level. Comparisons of $\delta^{15} \mathrm{~N}$ signals of different areas were made using the values of the reference plants to avoid the interference of atmospheric $\mathrm{N}_{2}$ fixation of the nodulating legume species. Comparisons of $\delta^{15} \mathrm{~N}$ signals of nodulating and reference plants were made within each area.

The leaves of the non-fixing species had a broad range of $\delta^{15} \mathrm{~N}$ values. The highest values occurred in the savanna - caatinga transition (12.7\%o) and in the subhumid deciduous forests (Agreste caatinga, 10.2\% e 9.4\%o), both with annual rainfall around $800 \mathrm{~mm}$ (Table 1). In some of the more humid ecosystems the $\delta^{15} \mathrm{~N}$ values were only slightly above zero (1.5 to $1.9 \%$ ), as in the semideciduos mountain forests and in the coastal perennial rainforests of João Pessoa and Rio Largo. However, in other humid ecosystems the values were higher, as in the coastal semidecidual forest of Aliança $(5.10 \%)$, with a value not significantly different from that of the semiarid deciduous forest (Sertão caatinga) of Serra Talhada (6.34\%o). The values of the non-fixing species had another characteristic feature: they had a higher variability (standard deviations) in areas with lower $\delta^{15} \mathrm{~N}$ values. This may be due to different strategies of $\mathrm{N}$ absorption in these more humid areas. 
A significant $(\mathrm{p}=0.01)$ negative correlation between the plant $\delta^{15} \mathrm{~N}$ values and the mean annual rainfall of the areas was found, in spite of the sampling of different vegetation and soil types. The linear fit accounted for half of the observed variation $\left(R^{2}=0.502\right)$, close to that found by Swap et al. (6) along a rainfall gradient in southern Africa. The tendency of a decrease of the plant signals towards zero as the annual rainfall increases has been demonstrated in several studies. This would occur because in more humid places the $\delta^{15} \mathrm{~N}$ results mainly from the interaction of the internal $\mathrm{N}$ cycling between dead and alive organic compartments, with little $\mathrm{N}$ losses. This almost close cycle is broken in dry places, where proportionally more $\mathrm{N}$ flows between the organic and inorganic compartments, this last one being more subjected to losses, leading to the ${ }^{15} \mathrm{~N}$ enrichment of soil and vegetation components $[2,5,6]$.

To identify symbiotic fixing plants using the natural abundance methodology it is necessary that non-fixing reference plants, obtaining their $\mathrm{N}$ exclusively from the soil, have $\delta^{15} \mathrm{~N}$ values significantly higher than those of the fixing plants, which obtain

Table 1. Leaf $\delta^{15} \mathrm{~N}(\%)$ from non fixing and target tree species growing in different ecosystems in Northeast Brazil

\begin{tabular}{|c|c|c|c|c|c|c|}
\hline \multirow{2}{*}{$\frac{\text { Ecosystem/ }}{\text { Municipality }}$} & \multirow{2}{*}{$\frac{\text { Annual }}{\begin{array}{c}\text { precipitation } \\
(\mathrm{mm})\end{array}}$} & \multicolumn{2}{|c|}{ Reference species } & \multicolumn{3}{|c|}{ Target species } \\
\hline & & $\mathrm{n}^{1}$ & $\begin{array}{c}\text { Average } \delta^{15} \mathrm{~N} \\
(\% 0)\end{array}$ & $\mathrm{n}$ & $\underset{(\%)}{\operatorname{Minimum}} \delta^{15} \mathrm{~N}$ & $\underset{(\%)}{\operatorname{Maximum}} \delta^{15} \mathrm{~N}$ \\
\hline \multicolumn{7}{|c|}{ COASTAL PERENNIAL RAINFOREST } \\
\hline Rio Largo & 1932 & 25 & $1.91 \pm 1.38 \mathrm{GH}$ & 7 & $0.17 \pm 0.68 \mathrm{~ns} 2$ & $0.69 \pm 1.89 \mathrm{~ns}$ \\
\hline Dois Irmãos & 1774 & 62 & $3.46 \pm 2.30 \mathrm{FG}$ & 20 & $2.37 \pm 0.76 \mathrm{~ns}$ & $8.75 \pm 3.55 \mathrm{~ns}$ \\
\hline João Pessoa & 1852 & 17 & $1.53 \pm 1.66 \mathrm{H}$ & 11 & $2.38 \pm 1.23 \mathrm{~ns}$ & $4.13 \pm 0.28 \mathrm{~ns}$ \\
\hline \multicolumn{7}{|c|}{ COASTAL SEMIDECIDUAL FOREST } \\
\hline Aliança & 1131 & 14 & $5.10 \pm 0.98 \mathrm{DE}$ & 8 & $3.53 \pm 2.72 *$ & $6.72 \pm 2.46 *$ \\
\hline São Vicente & 1006 & 35 & $2.71 \pm 1.86 \mathrm{GH}$ & 9 & $3.62 \pm 0.70 \mathrm{~ns}$ & $4.49 \pm 0.46^{*}$ \\
\hline \multicolumn{7}{|c|}{ SEMIDECIDUOS MOUNTAIN FOREST } \\
\hline Mata Grande & 1073 & 12 & $3.76 \pm 1.16 \mathrm{EFG}$ & 22 & $2.12 \pm 1.24 \mathrm{~ns}$ & $5.18 \pm 1.06 \mathrm{~ns}$ \\
\hline Brejo dos Cavalos & 1200 & 24 & $1.57 \pm 1.31 \mathrm{H}$ & 36 & $0.67 \pm 0.69 \mathrm{~ns}$ & $4.80 \pm 2.99 *$ \\
\hline Areia & 1430 & 24 & $4.39 \pm 1.53 \mathrm{EF}$ & 15 & $2.68 \pm 1.96 *$ & $8.22 \pm 2.23 *$ \\
\hline \multicolumn{7}{|c|}{ SUBHUMID DECIDUOUS FOREST (AGRESTE CAATINGA) } \\
\hline Remígio & 700 & 57 & $10.17 \pm 1.15 \mathrm{~B}$ & 33 & $3.47 \pm 1.02 *$ & $10.30 \pm 2.20 \mathrm{~ns}$ \\
\hline Caruaru & 565 & 14 & $9.43 \pm 1.49 \mathrm{~B}$ & 25 & $1.04 \pm 0.74 *$ & $10.39 \pm 1.06 \mathrm{~ns}$ \\
\hline \multicolumn{7}{|c|}{ SEMIARID DECIDUOUS FOREST (SERTÃO CAATINGA) } \\
\hline Pão de Açúcar & 573 & 16 & $8.61 \pm 2.00 \mathrm{BC}$ & 5 & $7.23 \pm 2.45 \mathrm{~ns}$ & - \\
\hline Serra Talhada & 716 & 32 & $6.34 \pm 1.40 \mathrm{D}$ & 24 & $2.05 \pm 0.64 *$ & $5.27 \pm 1.62 \mathrm{~ns}$ \\
\hline Santa Teresinha & 693 & 15 & $6.95 \pm 1.27 \mathrm{CD}$ & 14 & $4.22 \pm 1.68 *$ & $6.72 \pm 0.78 \mathrm{~ns}$ \\
\hline \multicolumn{7}{|c|}{ SAVANNA - CAATINGA TRANSITION } \\
\hline Araripina & 728 & 31 & $12.69 \pm 1.49 \mathrm{~A}$ & 49 & $11.31 \pm 1.53 \mathrm{~ns}$ & $14.10 \pm 0.46 \mathrm{~ns}$ \\
\hline
\end{tabular}

${ }^{1}$ Number of sampled plants.

${ }^{2}$ Averages of reference species followed by the same letter in the column are not significantly different by the Tukey test at 0.05 level. Averages of target species marked with * are significantly different and those marked with ns are not significantly different from values of the reference species in the same area. 
part of their $\mathrm{N}$ from the atmosphere and the difference should be larger than $2 \%(3,9)$. Both conditions were only found in the plants of the drier areas.

\title{
References
}

1. D. Robinson, $\delta^{15} \mathrm{~N}$ as an integrator of the nitrogen cycle. TRENDS in Ecol. Evol., 16, pp. 153-162, 2001.

2. L.L. Handley, A.T. Austin, D. Robinson et al., The ${ }^{15} \mathrm{~N}$ natural abundance $\left(\delta^{15} \mathrm{~N}\right)$ of ecosystem samples reflects measures of water availability. Aust. J. Plant Physiol., 26, pp. 185-199, 1999.

3. P. Högberg, ${ }^{15} \mathrm{~N}$ natural abundance in soil-plant systems. New Phytol., 137, pp. 179-203, 1997.

4. J.M. Craine, A.J. Elmore, M.P.M. Aidar et al., Global patterns of foliar nitrogen isotopes and their relationships with climate, mycorrhizal fungi, foliar nutrient concentrations, and nitrogen availability. New Phytol., 183, pp. 980-992, 2009.

5. A.D.S. Freitas, E.V.S.B. Sampaio, R.S.C. Menezes et al., ${ }^{15} \mathrm{~N}$ natural abundance of non-fixing woody species in the Brazilian dry forest (caatinga). Isotopes Environ. Health Stud., 46, pp. 210-218, 2010.

6. R.J. Swap, J.N. Aranibar, P.R. Dowty, et al., Natural abundance of ${ }^{13} \mathrm{C}$ and ${ }^{15} \mathrm{~N}$ in C3 and C4 vegetation of southern Africa: Patterns and implications. Global Change Biol., 10, pp. 350-358, 2004.

7. A.D.S. Freitas, E.V.S.B. Sampaio, A.R. Fernandes et al., Biological nitrogen fixation in legume trees of the Brazilian caatinga. J. Arid Environ., 74, pp. 344-349, 2010.

8. J.C. Roggy, M.F. Prevost, J. Garbaye et al., Nitrogen cycling in the tropical rain forest of French Guiana: Comparison of two sites with contrasting soil types using $\delta^{15} \mathrm{~N}$. J Trop. Ecol., 15, pp. $1-22,1999$.

9. G. Shearer, D.H. Kohl, $\mathrm{N}_{2}$-fixation in field settings: Estimations based on natural ${ }^{15} \mathrm{~N}$ abundance. Australian Journal of Plant Physiology, 13, pp. 699-756, 1986.

10. J.N. Aranibar, L. Otter, S.A. Macko et al. Nitrogen cycling in the soil-plant system along a precipitation gradient in the Kalahari sands. Global Change Biol., 10, pp. 359-373, 2004.

\section{6 - LATITUDINAL VARIATION IN STABLE CARBON ISOTOPE COMPOSITION OF VEGETATION AT HIGH-LATITUDES}

\author{
Mun Gi Kim ${ }^{1}$ - Yong Il Lee ${ }^{1}$ - Hyun Soo $\mathrm{Lim}^{2}$ - Ho Il Yoon ${ }^{3}$ \\ ${ }^{1}$ School of Earth and Environmental Sciences, Seoul National University, Seoul 151-742, \\ Korea; e-mail: lancearth@snu.ac.kr \\ ${ }^{2}$ Department of Geological Sciences, Pusan National University, Busan 609-735, Korea \\ ${ }^{3}$ Korea Polar Research Institute, KIOST, Incheon 406-840, Korea
}

At high latitude regions, environmental conditions for vegetation are quite different from those of lower to middle latitude regions. While most terrestrial ecosystems tend to rely on direct precipitation for water supply, snow and glacier melting during growing seasons is another important water source in Arctic and Antarctic ecosystem. Together with the restricted evaporation due to low temperature, the melt water keeps ground from getting dehydrated. Stable carbon isotope composition of vegetation, which is widely known as an index of water-use efficiency of plants, is expected to reflect this characteristic of polar environment. By collecting published carbon isotope data from literature, we investigated the relationship between mean annual precipita- 
tion (MAP) and $\delta^{13} \mathrm{C}$ of vegetation in Arctic and Antarctic areas. Data were exclusively taken from study locations higher than $60^{\circ}$ latitude, and three major groups of polar vegetation, $\mathrm{C}_{3}$ plants, mosses, and lichens, were assessed separately. The results showed no significant correlation, neither positive nor negative, between MAP and $\delta^{13} \mathrm{C}$ for all three vegetation groups. This result is in contrast with the general perception that stable carbon isotope ratio of plant is largely dependent on MAP, and supports that precipitation does not necessarily determine water-status of vegetation in polar regions. Instead, a significant negative correlation was observed between latitude and $\delta^{13} \mathrm{C}$. We attribute this trend to the decrease in photosynthetic rate with increasing latitude, affected by varying sunlight conditions. The latitudinal change in height of the sun and duration of daytime sharpens near poles, therefore results in stronger variation of $\delta^{13} \mathrm{C}$. It further explains why such a latitudinal change of $\delta^{13} \mathrm{C}$ was not much pronounced in previous global-scale analyses. To reconstruct past climate and ecology from organic $\delta{ }^{13} \mathrm{C}$ record, there have been several attempts to define influence of various environmental factors on vegetation at a natural field condition. Our finding of distinct plant ecology in polar regions, suggests that care must be taken in assuming same global $\delta^{13} \mathrm{C}$ pattern for different environments on Earth.

\title{
148 - VARIABILITY OF TREE RING ISOTOPIC SIGNAL: A CASE STUDY IN FONTAINEBLEAU FOREST, FRANCE
}

\author{
Valérie Daux ${ }^{1}$ - Alice Michelot ${ }^{2}$ - Claire Damesin ${ }^{2}$ - Inga Labuhn ${ }^{1}-$ \\ Michel Stievenard ${ }^{l}-$ Monique Pierre $^{l}$ \\ ${ }^{1}$ LSCE/IPSL, laboratoire CEA/CNRS/UVSQ, L'Orme des Merisiers, France; \\ e-mail: valerie.daux@1sce.ipsl.fr \\ ${ }^{2}$ Laboratoire d'Ecologie Systématique, Université Paris Sud, Orsay, France
}

It has been shown that carbon and oxygen isotopic compositions of tree-rings $\left(\delta^{13} \mathrm{C}_{\mathrm{TR}}\right.$ and $\delta^{18} \mathrm{O}_{\mathrm{TR}}$ ) can be interpreted in terms of paleoclimatic and paleoenvironmental conditions during the tree growth. In past climate reconstruction studies, the methodology most often consists in 1) establishing the best relationships between $\delta^{13} \mathrm{C}_{\mathrm{TR}}$ and $\delta^{18} \mathrm{O}_{\mathrm{TR}}$ and the climate parameters over the instrumental time (calibrated model) and 2), back-calculating the climate parameters in pre-instrumental times by applying the calibrated model to long isotopic series. The isotopic series are built using stacked chronologies of woods from cohorts of living trees, beams and sub-fossils woods. This approach does not provide us with the confidence that the transfer functions are robust through time, across taxa and across geographical location. Here, we have investigated the last two aspects by analysing $\delta^{13} \mathrm{C}_{\mathrm{TR}}$ and $\delta^{18} \mathrm{O}_{\mathrm{TR}}$ in pines, oaks and beeches of the Fontainebleau forest (France, site dominated by the Atlantic Ocean influence). We have conducted an analysis of inter-trees, inter-species and inter-stands variability. We have also compared the isotopic signals recorded by the Fontainebleau trees to those from other French sites under Atlantic ocean/Mediterranean influence. 
We have shown that the inter-trees variability was about $\mathrm{SD}=0.7$ and $0.6 \%$ for $\delta^{13} \mathrm{C}_{\mathrm{TR}}$ and $\delta^{18} \mathrm{O}_{\mathrm{TR}}$ respectively, that the isotopic signatures of trees from stands of different available soil water capacities did not exhibit significant differences, that the isotopic chronologies of the three species depicted similar variations (thought different mean values) and that the $\delta^{18} \mathrm{O}_{\mathrm{TR}}$ signal was consistent over a wide area under Atlantic ocean influence (Fig. 1).
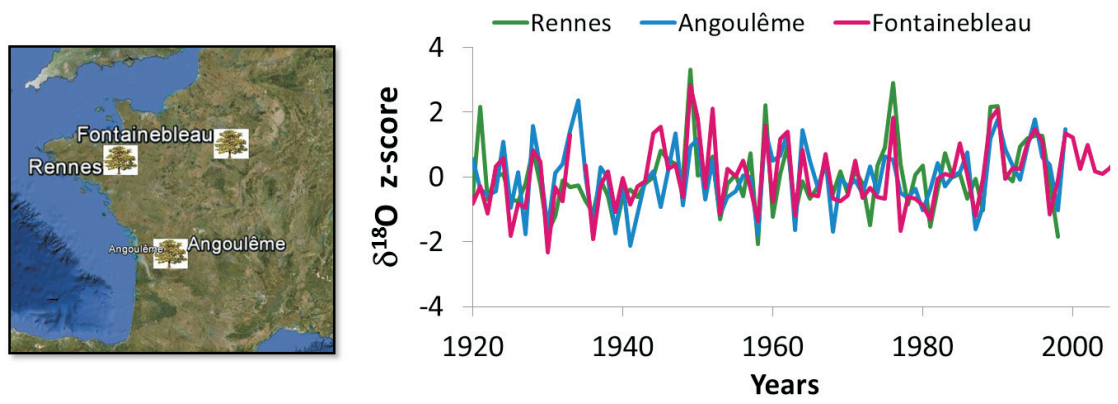

Figure 1. 18OTR standard score calculated from oak trees from Rennes, Angoulême and Fontainebleau

\title{
149 - TREE RING STABLE ISOTOPES RELATED TO CLIMATIC VARIATIONS IN MIDDLE-ATLAS (MOROCCO)
}

\author{
Mahmoud Ed Dabdouby ${ }^{1}$ - Michel Stiévenard ${ }^{2}$ - Valérie Daux ${ }^{2}-$ Hamid Marah $^{1}$ \\ Monique Pierre ${ }^{2}$ - Jean-Louis Edouard ${ }^{3}-$ Abdelhakim Sabir $^{4}$ \\ ${ }^{1}$ CNESTEN, Water and Climate Unit, Rabat, Morocco \\ ${ }^{2}$ LSCE/IPSL, laboratoire CEA/CNRS/UVSQ, L'Orme des Merisiers, France; \\ e-mail: michel.stievenard@1sce.ipsl.fr \\ ${ }^{3}$ Maison Méditerranéenne des Sciences de l'Homme, Aix-en-Provence, France \\ ${ }^{4}$ Université Mohamed V, Rabat, Morocco
}

Carbon and oxygen isotopic compositions $\left(\delta^{13} \mathrm{C}\right.$ and $\left.\delta^{18} \mathrm{O}\right)$ of annual tree rings of Cedrus Atlantica from Middle-Atlas Mountains (Morocco) have been analysed over the last centuries.

Chronologies correspond to living trees from two sites (Zad path and Azrou forest) separated by only a few dozen kilometres but immersed in very different climatic environments, Zad being dryer than Azrou. Correlations to recorded meteorological parameters and to calculated climatic indices are examined to highlight the possible trends and extremes in temperature and dryness over the last decades. The best correlations are obtained between $\delta^{13} \mathrm{C}$ and the growing season mean temperature and potential evapotranspiration. To our knowledge, the four centuries isotopic series from Zad path are the first for Morocco, which is mostly influenced by the North Atlantic variations. 


\title{
150 - METHOD DEVELOPMENT FOR THE DETERMINATION OF $\delta^{18}$ O VALUES IN ARSENIC OXYANIONS IN NATURAL WATERS
}

\author{
Xiaohui Tang ${ }^{1}-$ Zsolt Berner $^{1}-$ Stefan Norra ${ }^{1}$ - Torsten W. Vennemann ${ }^{2}$ \\ ${ }^{1}$ Institute of Mineralogy and Geochemistry, Karlsruhe Institute of Technology, \\ Adenauerring 20b, Building 50.40,76131 Karlsruhe, Germany; e-mail: xiaohui.tang@kit.edu \\ ${ }^{2}$ Institute of Earth Sciences, University of Lausanne, Quartier UNIL-Mouline, \\ Bâtiment Géopolis 4634, 1015 Lausanne, Switzerland
}

\section{Introduction}

As a well-known toxic element in the environment, arsenic causes severe water quality problems in many areas of the world. Despite considerable efforts in understanding its mobilization in natural water, the mechanism of the regional occurrence of high arsenic concentration in groundwater is still unclear [1].

Arsenic has only one naturally occurring isotope $\left({ }^{75} \mathrm{As}\right)[2]$, but arsenic occurs mostly in the form of oxyanions in natural waters. The investigation of the isotopic composition of oxygen in As-oxyanions may offer some new insights into arsenic mobilization in groundwater [3]. The focus of the study is to develop an efficient method: first, for quantitative separation of the various dissolved oxyanionic species, like $\mathrm{PO}_{4}{ }^{3-}, \mathrm{HCO}_{3}{ }^{-}, \mathrm{SO}_{4}{ }^{2-}$, whereras the presence of $\mathrm{NO}_{3-}$ anions is not critical but concentration of $\mathrm{Cl}^{-}$ions must be reduced; second, for quantitative precipitation of arsenate/arsenite; and third, measurement of $\delta^{18} \mathrm{O}$ values in arsenic oxyanions.

\section{Separation of arsenic oxyanions from water}

Eight adsorbents were applied to carry out the experiments for separation of $\mathrm{AsO}_{4}{ }^{3-}$ and $\mathrm{AsO}_{3}{ }^{3-}$ from natural water. First of all, $\mathrm{HCO}_{3-}$ is easily removed by adjusting $\mathrm{pH}$ below 4.3 [4]. Arsenate and $\mathrm{PO}_{4}{ }^{3-}$ were quantitatively separated from $\mathrm{AsO}_{3}{ }^{3-}, \mathrm{SO}_{4}{ }^{2-}$ and $\mathrm{Cl}^{-}$by an alumino-silicate based sorbent. The separation of $\mathrm{AsO}_{4}{ }^{3-}$ and $\mathrm{PO}_{4}{ }^{3-}$ is a challenging task due to their similar chemical behavior, which was successfully done by using the resin Amberlite IRA-400 with $\mathrm{OH}$ form [5]. $\mathrm{AsO}_{4}{ }^{3-}$ or $\mathrm{AsO}_{3}{ }^{3-}$ was quantitatively separated from $\mathrm{SO}_{4}{ }^{2-}$ and $\mathrm{Cl}^{-}$by using basic yttrium carbonate or nanoparticlate iron oxide. During the tests, it was established that nanoparticulate iron oxide is much more effective than basic yttrium carbonate because of its adsorption properties.

\section{Precipitation of arsenate and arsenite}

Considering the low solubility of Ag-arsenate and Ag-arsenite [6], the most appropriate way to extract arsenic oxyanions from aqueous solutions is their precipitation with $\mathrm{AgNO}_{3}$. After precipitating with $\mathrm{AgNO}_{3}$ by using ammonia to rapidly adjust the $\mathrm{pH}$ to 7.5, the recovery of the extracted arsenate and arsenite as $\mathrm{Ag}_{3} \mathrm{AsO}_{4}$ and $\mathrm{Ag}_{3} \mathrm{AsO}_{3}$ were $96.5 \pm 5.6 \%(\mathrm{n}=10)$ and $94.2 \pm 1.3 \%(\mathrm{n}=5)$, respectively. 


\section{Measurement of $\delta^{18} \mathrm{O}$ values}

Because As and $\mathrm{P}$ belong to the same group of elements in the periodic table and hence can be expected to behave in a similar way, the well-established analytical method for measurements of $\delta^{18} \mathrm{O}$ values in phosphate $[7,8]$ was adapted to measurements of $\delta^{18} \mathrm{O}$ in arsenate and arsenite, that is using high temperature reduction with graphite and continuous flow mass spectrometry (TC-EA-Py-CF-IRMS). The calibration was made using the international standards of IAEA N3 $\left(\mathrm{KNO}_{3}\right), \mathrm{Ag}_{3} \mathrm{PO}_{4}$ from NBS $120 \mathrm{c}$ (in-house standard, [7]), NBS $127\left(\mathrm{BaSO}_{4}\right)$. The preliminary results show that the comparable mean $\delta^{18} \mathrm{O}$ value of $\mathrm{Ag}_{3} \mathrm{AsO}_{4}$, which was prepared from $\mathrm{Na}_{2} \mathrm{HAsO}_{4} \cdot 7 \mathrm{H}_{2} \mathrm{O}$, was $0.32 \pm 0.23 \%$ o $(\mathrm{n}=33)$, whereas the $\delta^{18} \mathrm{O}$ value in $\mathrm{Ag}_{3} \mathrm{AsO}_{3}$ material, which was prepared from $\mathrm{NaAsO}_{2}$, was $-7.86 \%$ $\pm 0.34 \%$ o $(n=12)$.

\section{References}

1. P. Bhattacharya, A.H. Welch, K.G. Stollenwerk, M.J. McLaughlin, J. Bundschuh and G. Panaullah, Arsenic in the environment: Biology and Chemistry. Sci. Total Environ., 379, pp. 109-120, 2007.

2. G. Audi, O. Bersillon, J. Blachot and A.H. Wapstra, The NUBASE Evaluation of Nuclear and Decay Properties. Nuclear Physics A (Atomic Mass Data Center), 729, pp. 3-128, 2003.

3. Z. Berner, X.H. Tang and S. Norra, Oxygen isotopy of arsenate/arsenite: A novel approach to constrain the source of As in groundwater. Goldschmidt 2010, A84.

4. R.M. Garrels and C.L. Christ, Solution, Minerals, and Equilibria. Harper and Row, New York, 1965.

5. X.H. Tang, Z.A. Berner, P. Khelashvilli and S. Norra, Preparative separation of arsenate from phosphate by IRA-400 $(\mathrm{OH})$ for oxygen isotopic work. Talanta, 105, pp. 46-51, 2013.

6. A.I. Vogel, A textbook of quantitative inorganic analysis including elementary instrumental analysis. Woolwich Polytechnic, England. 3rd ed., John Wiley and Sons, Inc., New York, 1961.

7. T.W. Vennemann, H.C. Fricke, R.E. Blake, J.R. O’Neil and A. Colman, Oxygen isotope analysis of phosphates: A comparison of techniques for analysis of $\mathrm{Ag}_{3} \mathrm{PO}_{4}$. Chemi. Geol., 185(3-4), pp. 321-336, 2002.

8. Ch. Lécuyer, F. Fourel, F. Martineau, R. Amiot, A. Bernard, V. Daux, G. Escarguel and J. Morrison, High-precision determination of $18 \mathrm{O} / 16 \mathrm{O}$ ratios of silver phosphate by EA-pyrolysis-IRMS continuous flow technique. J. Mass Spectrom., 42, pp. 36-41, 2007.

\section{1 - GAS ION SOURCE BASED MICRO SAMPLE C-14 AMS ANALYSES AT HEKAL AND ITS APPLICATIONS IN ISOTOPE GEOCHEMISTRY}

\footnotetext{
Mihály Molnár ${ }^{1}$ - László Rinyu ${ }^{1}$ - István Major ${ }^{1}-$ Mihály Veres $^{2}-$ A.J.Timothy Jull ${ }^{1,3}$ Martin Seiler ${ }^{4}$-Lukas Wacker ${ }^{4}$

${ }^{1}$ Institute of Nuclear Research of the Hungarian Academy of Sciences (Atomki), 4026

Debrecen, Bem tér 18/c, Hungary; e-mail: molnar.mihaly@atomki.mta.hu

${ }^{2}$ Isotoptech Zrt, Debrecen, Hungary

${ }^{3}$ NSF Arizona AMS Laboratory, University of Arizona, Tucson, AZ, USA

${ }^{4}$ Laboratory of Ion Beam Physics, ETHZ, Zürich, Switzerland
} 
Since 2012 a more developed and modern technology took over from the old C-14 measuring methods based on isotope separation by accelerator mass spectrometry (AMS) in the Hertelendi Laboratory of Environmental Studies (HEKAL) (Debrecen, Hungary). A multipurpose gas-handling system was developed for the gas ion source of MICADAS type AMS at ETH Zürich and was designed for the measurement of small environmental origin samples ( $<50 \mu \mathrm{g}$ carbon) with moderate precision requirements [1.]. The ultimate aim is an automated device for high sample throughput.

In the versatile gas handling system, a stepping motor driven syringe presses a mixture of helium and sample $\mathrm{CO}_{2}$ into the gas ion source, allowing continuous and stable measurements of different kinds of samples [2]. $\mathrm{CO}_{2}$ can be provided in three different ways to the versatile gas interface. As a primary method, $\mathrm{CO}_{2}$ is delivered in glass or quartz ampoules. Secondly, C-14 standard (Ox-I) and blank gas (fossil borehole $\mathrm{CO}_{2}$ ) in helium can be provided to the syringe by directly connecting gas bottles to the gas interface at the stage of the cracker. Thirdly, solid samples can be combusted in an elemental analyzer or a thermo-optical OC/EC aerosol analyzer where the produced $\mathrm{CO}_{2}$ is transferred to the syringe via a zeolite trap for gas concentration. If $\mathrm{CO}_{2}$ is released from carbonates with phosphoric acid in septum-sealed vials it can be loaded also onto the same trap used for the elemental analyzer.

This unique instrumentation gives us the possibility to analyze as small samples $(5-50 \mu \mathrm{g} \mathrm{C})$ like as compound specific radiocarbon from airborne aerosol, soil, ice-core, groundwater or biomedical samples. This technique can also detect the in-situ produced C-14 in the extracted tracer level carbon content of rock surfaces or meteorites.

In this study we would present the performance of the gas ion source based C-14 AMS technique at HEKAL, including blank level, overall precision and sample throughput. Newly developed special sample preparation techniques will also be presented and evaluated using some real sample examples.

\section{References}

1. Wacker, L., Fahrni, S.M., Hajdas, I., Molnar, M., Synal, H.-A., Szidat, S. and Zhang, Y.L., A versatile gas interface for routine radiocarbon analysis with a gas ion source. Nuclear Instruments and Methods in Physics Research B, 294, pp. 315-319, 2013.

2. Molnár, M., Rinyu, L., Janovics, R., Major, I. and Veres, M., Az új debreceni C-14 AMS Laboratórium bemutatása (Introduction of the new AMS C-14 Laboratory in Debrecen). Arceometriai Mühely 9(3), pp. 147-160, 2012 [in Hungarian with English abstract]. 


\title{
152 - A NOVEL CARBON AND HYDROGEN ISOTOPE METHOD FOR QUANTIFYING PAST METHANE RECYCLING BY SPHAGNUM-METHANOTROPH SYMBIOSIS
}

\author{
Jonathan E. Nichols ${ }^{1}-$ Peter Isles ${ }^{2}-$ Dorothy Peteet $^{1,3}$ \\ ${ }^{1}$ Lamont-Doherty Earth Observatory, 61 Route 9W, Palisades, NY 10964, USA; \\ e-mail: jnichols@1deo.columbia.edu \\ ${ }^{2}$ Rubenstein School of Environment and Natural Resources, University of Vermont, \\ Burlington, VT, USA \\ ${ }^{3}$ NASA Goddard Institute for Space Studies, New York, NY, USA
}

Northern wetlands, dominated by Sphagnum, are an important part of the Earth's methane cycle. To constrain one part of the peatland methane cycle, we present a novel method for quantifying carbon assimilated by Sphagnum from its methanotrophic symbionts using stable isotope ratios of leaf wax biomarkers. We also apply this method to several circum-Arctic peatlands to compare methane cycle changes in peatlands with the global record of atmospheric methane. Carbon isotope ratios of Sphagnum leaf waxes are confounded by two competing influences, water content and the carbon isotope ratio of source carbon [1]. We disentangled these two effects using a combined hydrogen and carbon isotope approach. We constrained Sphagnum water content using the contrast between the hydrogen isotope ratios of Sphagnum and vascular plant biomarkers [2]. We then used the resulting estimate of Sphagnum water content to calculate the carbon isotope ratio of Sphagnum's carbon pool. Using a mass balance equation we then calculate the percent contribution of recycled methane to the Sphagnum carbon pool, "PRM". We quantified the PRM in peat monoliths from three different microhabitats in a North American peatland where modern studies of peatlands have shown that water table depth and vegetation have strong influences on the peatland methane cycle on instrumental timescales [3]. With this new method, we now have the ability to constrain the relationships among hydrology, vegetation, and methanotrophy in Sphagnum peatlands over Holocene timescales. We find that over millennial timescales, at a suite of locations from the Arctic and Subarctic, relationships among hydrology, vegetation, and methane cycling are consistent with modern observations. We are also able to better place northern peatlands into the context of atmospheric concentrations of methane through the Holocene.

\section{References}

1. T. Williams and L. Flanagan, Effect of Changes in Water Content on Photosynthesis, Transpiration and Discrimination against ${ }^{13} \mathrm{CO}_{2}$ and $\mathrm{C}^{18} \mathrm{O}^{16} \mathrm{O}$ in Pleurozium and Sphagnum. Oecologia, 108(1), pp. 38-46, 1996.

2. J.E. Nichols, R.K. Booth, S.T. Jackson, E.G. Pendall and Y. Huang, Differential hydrogen isotopic ratios of Sphagnum and vascular plant biomarkers in ombrotrophic peatlands as a quantitative proxy for precipitation-evaporation balance. Geochimica et Cosmochimica Acta, 74(4), pp. 1407-1416, 2010. 
3. T.R. Moore, A. De Young, J.L. Bubier, E.R. Humphreys, P.M. Lafleur and N.T. Roulet, A Multi-year Record of Methane Flux at the Mer Bleue Bog, Southern Canada. Ecosystems, 14(4), pp. 646-657, 2011.

\title{
153 - RADIOCARBON INVESTIGATION OF AIR PARTICULATE MATTER COLLECTED DURING SMOG ALERT PERIODS IN HUNGARY
}

\author{
István Major ${ }^{1}$ - Sándor Bán ${ }^{2}$ - Csaba Balogh ${ }^{2}$ - Mihály Molnár ${ }^{3}$ \\ ${ }^{1}$ University of Debrecen, Debrecen, Hungary, Bem tér 18/c, H-4026 Debrecen, Hungary; \\ e-mail: imajor@atomki.hu \\ ${ }^{2}$ National Inspectorate For Environment, Nature and Water, Debrecen, Hungary \\ ${ }^{3}$ MTA Institute of Nuclear Research, Debrecen, Hungary
}

The radiocarbon content of ambient air particulate matter (PM) collected in three different locations of Hungary (city of Debrecen, city of Nyíregyháza and at a background site near Nyírlugos) through routine state government PM10 sampling was C-14 analysed by accelerator mass spectrometry (AMS). Using the C-14 method it was possible to determine the contribution of fossil and biogenic carbon aerosol to the "smog alert" air pollution observed on certain days of 2012 in Hungary. The AMS measurements were carried out at Atomki, where a unique sample preparation line and modified combustion protocol was installed for determination of carbon fraction of PM collected on prebaked quartz fibre filters. The reliability of the system was determined by background, standard samples and repeated parallel sample analyses. According to our tests, the preparation way of aerosol samples and the method elaborated for their ${ }^{14} \mathrm{C}$ measurements has a good reproducibility. Measurements of the carbon content (0.1-1.0 mg C/sample) of aerosol samples were performed by a high sensitivity accelerator mass spectrometer (EnviroMICADAS) developed by ETHZ (Zürich, Switzerland) [1].

The aims of this set of measurements are the quantitative determination of the fossil/biomass carbon ratio of atmospheric particulate matter that may be very useful to discover the possible sources and also to help in the distinction of portion of biomass burning and transport emission. Our results may significantly contribute to the analysis of the reasons of the weeks long crucial aerosol air pollution (smog alert) observed for instance in Nyíregyháza, Hungary in 2012.

\section{Reference}

1. Molnár, M., Rinyu, L., Janovics, R., Major, I. and Veres, M., Az új debreceni C-14 AMS Laboratórium bemutatása (Introduction of the new AMS C-14 Laboratory in Debrecen). Arceometriai Mühely, 9(3), pp. 147-160, 2012 [in Hungarian with English abstract]. 


\title{
154 - INVESTIGATING RECHARGE AND DISCHARGE OF YOUNG GROUNDWATER BASED ON MULTI-TRACERS APPROACH: A CASE STUDY OF SEBOU BASIN - MOROCCO
}

\author{
Hamid Marah ${ }^{1}$ - Fatima Raibi ${ }^{1}-$ Fouad Taous $^{1}$ - Redouan Saadi ${ }^{1}$ \\ ${ }^{1}$ Water and Climate Unit - CNESTEN, BP 1382 Rabat Morocco; \\ e-mail:marah@cnesten.org.ma
}

Tritium-helium and stables isotopes has been used to date young ground water (1-50 years old) and to determine the relations between surface water and groundwater of the Sebou basin. The comparison between the results of $\mathrm{T} / \mathrm{He}$ investigations and classical hydrological methods shows a good agreement. The exponential correlation between depth and $\mathrm{T} / 3 \mathrm{He}$ age and/or the age and flow path showed the potential of using $\mathrm{T} / \mathrm{He}$ for the estimation of the recharge rate and GW velocity, those results will help to develop an improved version of the hydrologic flow model, which can be used for management purposes. The $\mathrm{T} / \mathrm{He}$ approach is very applicable to determine groundwater flow path and recharge rate and he has advantages in that they do not require special field instrumentation and can be used to provide estimates of groundwater age, transit time and/or horizontal and vertical groundwater velocity that are difficult to be derived with other methods.

\section{5 - THE GEOCHEMISTRY AND ISOTOPEIC COMPOSITION OF THE AYUB-PEIGHAMBAR HOT SPRING, BOJNURD, NE OF IRAN}

\author{
Hossein Mohammadzadeh - Ali Keivan Zeraatkar \\ Groundwater Research Center (GRC), Faculty of Science, Ferdowsi University of Mashhad, \\ P.O. Box: 91775-1436, Iran; \\ e-mails: mohammadzadeh@um.ac.ir; mohammadzadeh@alumni.uottawa.ca
}

Ayub-Peighambar hot spring is located about $95 \mathrm{~km}$ northeast of Bojnurd city, NE of Iran The field observation, field measurements of T, $\mathrm{pH}, \mathrm{Eh}, \mathrm{EC}\left(38.4^{\circ} \mathrm{C}, 7.5,418 \mathrm{mv}\right.$, and $935 \mu \mathrm{mohs} / \mathrm{cm}$, respectively), and the measured laboratory geochemical data, indicates that the type of water is calcium-sulphate. Base on saturation index of gypsum $($ SIgypsum $=-0.25<0)$ and calcite (SIcalcite $=0.75>0$ ), the calcium-sulphate composition of water is due to existence of karstic aquifer in core of Asiazow anticline and also the dissolution of halite and sulphate minerals such as gypsum available in shale and marl formations. This can be confirmed by $\mathrm{H} 2 \mathrm{~S}$ out gassing from spring and high concentration of $\mathrm{SO}^{-}{ }^{-}$and dissolved inorganic carbon (DIC) in springs water (248 and $91 \mathrm{mg} / \mathrm{l}$, respectively) and the fairly enriched ${ }^{13} \mathrm{C}$ value of DIC in springs water $(-1.3 \%$ VPDB $)$. The high temperature of water in Ayub-Peighambar hot spring is probably is due to geothermal gradient and also chemical reactions that happen at the flow path in Ayub fault zone. The aim of this paper is investigation on the origin and 
the source of thermal energy of Ayub-Peighambar hot spring using geochemistry and isotopic composition approach.

\title{
References
}

1. C.A.J. Appelo and D. Postma, Geochemistry, groundwater and pollution. A.A.Balkema, Rotterdam, 1999.

2. D.R. Faulkner, C.A.L. Jackson, R.J. Lunn, R.W. Schlische, Z.K. Shipton, C.A.J. Wibberley and M.O. Withjack, A review of recent developments concerning the structure, mechanics and fluid flow properties of fault zones. J. Structural Geo. doi: 10.1016/ j.jsg.2010.06.009, 2010.

\section{6 - USE OF RADIOACTIVE FALLOUT CESIUM-137 AND GEOCHEMICAL ELEMENTS TO TRACE SEDIMENT SOURCE IN A SUB-CATCHMENT SCALE}

\author{
Hossein Asadi ${ }^{1}$ - Elham Alidoost ${ }^{2}$ \\ ${ }^{1}$ Department of Soil Science, University of Guilan, Rasht-Tehran Highway- km 5, \\ Rasht 41889-58643, Iran; e-mail: asadi@guilan.ac.ir \\ ${ }^{2}$ Department of Soil Science, College of Agriculture, Isfahan University of Technology, \\ Isfahan 84156-83111, Iran; e-mail: e.alidoust@ag.iut.ac.ir
}

Soil erosion and sediment-related environmental problems pose a serious threat to land management sustainability and water resources utilization in many countries. Traditional methods used to study soil erosion are time consuming and the results obtained for an experimental plot are usually incomparable with one another (Poreba, 2006). The use of radionuclides to measure soil erosion overcomes some of the limitations of the traditional methods. The fallout radionuclide cesium-137 ((137)Cs) has been successfully used in soil erosion studies worldwide (Li et al., 2009). Caesium137 measurements can be used as a basis for studying both the spatial variability of soil loss and its magnitude. This method can be used also for identifying sediment sources (Walling and Quine, 1991; Wallbrink et al., 1999). The fallout radionuclides (FRNs) (137) $\mathrm{Cs},(210) \mathrm{Pb}(\mathrm{ex})$ and (7)Be are increasingly used as a means of obtaining quantitative information on soil erosion and sediment redistribution rates within agricultural landscapes (Mabit et al., 2008). They have been also used for assessing the effectiveness of soil conservation measures for sustainable watershed management and crop production (Dercon et al., 2012).

The determination of relative contributions of potential sediment sources is an important step in the development of management strategies to combat soil erosion. In this case also, because of many problems associated with traditional procedures for identifying sediment sources, fingerprinting techniques, based on geochemical, radionuclides and organic properties of sediment and source materials, are increasingly being used as valuable and effective approach to assemble such information (Collins and Walling, 2002). 
This investigation has tested the use of a quantitative composite fingerprinting technique to identify the main sources of the suspended sediment load in the Nav subbasin $\left(4.5 \mathrm{~km}^{2}\right)$, located in the west of Giulan province, north of Iran. The properties used were geochemical elements ( $\mathrm{Co}, \mathrm{Cu}, \mathrm{Fe}, \mathrm{Mn}, \mathrm{Mg}, \mathrm{Ni}, \mathrm{Pb}$ and $\mathrm{Zn}$ ), fallout radionuclide cesium-137, organic carbon, nitrogen and phosphorous. Based on field survey, the study area was grouped to four types of sediment sources including forest, gully wall, pasture and degraded pasture. A multivariate mixing model was used to determine contributions of those sources to sediment yield. The suitable composite fingerprints (elements) obtained using discriminant were $\mathrm{Pb}, \mathrm{Mn}$ (extracted by sodium pyrophosphate), $137 \mathrm{Cs}, \mathrm{Fe}, \mathrm{Ni}$ and N. Mean contributions from the four sediment sources of gully wall, destroyed pasdure, pasture and forest were estimated as $92 \%$, $6.5 \%, 1 \%$ and $0.5 \%$, respectively. Low mean relative errors of the estimates (less than $1 \%$ ) showed high precision and accuracy of the model. Also it is argued that fingerprinting estimates for sediment sources are consistent with field observations.

\section{References}

A.L Collins and D.E. Walling, Selecting fingerprint propertis for discriminating potential suspended sediment sources in river basins. J. Hydrol., 261, pp. 218-244, 2002.

G. Dercon, L. Mabit, G. Hancock, M.L. Nguyen, P. Dornhofer, O.O. Bacchi, M. Benmansour, C. Bernard, W. Froehlich, V.N. Golosov, S. Haciyakupoglu, P.S. Hai, A. Klik, Y. Li, D.A. Lobb, Y. Onda, N. Popa, M. Rafiq, J.C. Ritchie, P. Schuller, A. Shakhashiro, P. Wallbrink, D.E. Walling, F. Zapata and X. Zhang, Fallout radionuclide-based techniques for assessing the impact of soil conservation measures on erosion control and soil quality: an overview of the main lessons learnt under an FAO/IAEA Coordinated Research Project. J. Environ. Radioact., 107, pp. 78-85, 2012.

S. Li, D.A. Lobb, K.H. Tiessen and B.G. McConkey, Selecting and applying cesium-137 conversion models to estimate soil erosion rates in cultivated fields. J. Environ. Qual., 39(1), pp. 204-219, 2009.

L. Mabit, M. Benmansour and D.E. Walling, Comparative advantages and limitations of the fallout radionuclides (137) Cs, (210) $\mathrm{Pb}(\mathrm{ex})$ and (7)Be for assessing soil erosion and sedimentation. J. Environ. Radioact., 99(12), pp. 1799-1807, 2008.

J. Nishizawa and K. Suto, Semiconductor Raman laser. J. Appl. Phys., 51, pp. 2429-2431, 1980.

G.J. Poreba, Caesium-137 as a soil erosion tracer: A review. Geochronometria, 25, pp. 37-46, 2006.

S.M. Sze, Physics of Semiconductor Devices. John Willey and Sons, New York, 1981.

P.J. Wallbrink, A.S. Murray and J.M. Olley, Relating suspended sediment to its orginal soil depth using fallout radionuclides. Soil Sci. Soc. Am. J., 63, pp. 369-378, 1999.

D.E. Walling and T.A. Quine, Use of 137Cs measurements to investigate soil erosion on arable fields in the UK: Potentials applications and limitations. J. Soil Sci., 42, pp. 147-165, 1991. 


\title{
157 - ORGANIC AND INORGANIC ISOTOPIC VARIATION IN MODERN SOILS AND PALEOSOLS IN NORTHERN IRAN
}

\author{
Farhad Khormali ${ }^{1}$-Martin Kehl ${ }^{2}-$ Ali Shahriari $^{l}$-Eva Lehndorff ${ }^{3}$ - Manfred Frechen ${ }^{4}$ \\ ${ }^{1}$ Dept. of Soil Sciences, Faculty of Water and Soil Engineering, Gorgan University \\ of Agricultural Sciences and Natural Resources, Gorgan, 49138-15739, Iran \\ ${ }^{2}$ Institute of Geography, University of Cologne, Albertus Magnus Platz, \\ 50923 Cologne, Germany \\ ${ }^{3}$ Institute of Crop Science and Resource Conservation (INRES) - Soil Sciences, \\ Bonn University, Nussallee 13, 53115 Bonn, Germany \\ ${ }^{4}$ Leibniz Institute for Applied Geophysics (LIAG), Geochronology and Isotope Hydrology, \\ Stilleweg 2, D-30655 Hannover, Germany
}

The northern footslopes of the Alborz Mountains and an extensive hilly area in eastern Golestan Province are covered by thick (up to $70 \mathrm{~m}$ ) loess deposits, intercalated by different types of interstadial and interglacials paleosols. $\mathrm{C}$ stable isotope ratios of soils and sediments are valuable tools to study the relationship between aboveground vegetation and climate conditions. In this regard, both organic and inorganic $\mathrm{C}$ isotopic compositions have been studied in three selected regions presenting an ecological gradient with modern precipitation ranging from $250 \mathrm{~mm}$ to $700 \mathrm{~mm}$. Morphology, physicochemical properties and micromorphology of the soils and paleosols were also studied. Modern soil properties show a strong correlation with precipitation along the pronounced climate gradient in the area (Khormali and Kehl, 2011). This gives a climosequence of modern soils that is partly mirrored by climatophytomorphic paleosols of the last interglacial period indicating a similar climatic gradient from semiarid to subhumid conditions during the past. This hypothesis was also supported by the isotopic studies of C. Isotopic signals in the modern soils correlate well with the present aboveground vegetation showing stronger depletion in ${ }^{13} \mathrm{C}$ and dominance of $\mathrm{C}_{3}$ vegetation in the more humid regions and less depletion in ${ }^{13} \mathrm{C}$ related to $\mathrm{C}_{4}$ vegetation in the semiarid counterpart. Isotopic signatures of interglacial paleosols showed similar isotope signals as the modern soils. In contrast, heavier isotopic compositions in the interstadial palaeosols indicate dominance of $\mathrm{C}_{4}$ vegetation during the respective soil forming periods. More investigations are needed to further decipher the paleoclimate implications of soil stable isotope signatures.

\section{Reference}

Khormali, F., Kehl, M., Micromorphology and development of loess-derived surface and buried soils along a precipitation gradient in Northern Iran. Quaternary International, 234, pp. 109-123, 2011). 


\title{
159 - RADIOCARBON MEASUREMENT FROM DISSOLVED INORGANIC AND ORGANIC COMPONENTS OF GROUNDWATER
}

\author{
Róbert Janovics ${ }^{1}$ - Anita Molnár ${ }^{2}$ - Alexander G. Leonard ${ }^{3}$ - Mihály Molnár ${ }^{1}$ \\ ${ }^{1}$ Institute for Nuclear Research of the Hungarian Academy of Sciences, Bem tér 18/c, \\ Debrecen, Hungary; e-mail: robert.janovics@mta.atomki.hu \\ ${ }^{2}$ University of Debrecen, Egyetem tér 1, Debrecen, Hungary \\ ${ }^{3}$ University of Arizona, Tucson, AZ, USA
}

In most cases radiocarbon (C-14) content of groundwater is referred to the activity of dissolved inorganic carbon (DIC) exclusively which is in the water in the form of mainly $\mathrm{HCO}_{3-}$ and $\mathrm{CO}_{3}{ }^{2-}$ as $\mathrm{C}-14$ analyses of the other dissolved carbon forms is rather difficult. On the other hand it is obvious that dissolved carbon can be found in organic form besides the inorganic form as well. In the surrounding of the Püspökszilágy Radioactive Waste Treatment and Disposal Facility (RWTDF) groundwater monitoring well network is operating, from which radiocarbon measurement occurs systematically from the DIC fraction of the water. On the basis of results of previous measurements it is suspicious that in the monitoring wells besides the inorganic fraction small amount of organic fraction with elevated ${ }^{14} \mathrm{C}$ activity can be found. For this reason we adapted and improved a method [1] for measuring directly ${ }^{14} \mathrm{C}$ from dissolved non-purgeable organic carbon (NPOC) from water samples. The main point of the method is that water samples are acidified with $\mathrm{H}_{3} \mathrm{PO}_{4}$ so that the dissolved inorganic carbon can be released as $\mathrm{CO}_{2}$. After the acidification the water is evaporated away in a $35^{\circ} \mathrm{C}$ water bath with the help of a membran pump. With this step the inorganic carbon and water content of the water sample are eliminated. Phosphoric acid and NPOC fraction of the water sample remain in the bulb. Thereafter chromosulfuric acid is given to the sample which oxidizes NPOC to $\mathrm{CO}_{2}$. The produced $\mathrm{CO}_{2}$ gas is cleaned and graphitized to form a solid graphite target suitable for AMS C-14 measurement. The elaborated method is validated with international ${ }^{14} \mathrm{C}$ reference materials (IAEA-C6 and IAEA-C9). During the experiments the DIC, total carbon (TC) and NPOC ${ }^{14} \mathrm{C}$ activity of the same water sample were measured and compared to each other. Direct measurement of dissolved organic NPOC fraction of groundwater monitoring wells seems to be a very sensitive and effective tool to detect C-14 release of nuclear waste storage facilities.

\section{Reference}

1. G.S. Burr, J.M. Thomas, D. Reines, D. Jeffrey, C. Courtney, A.J.T. Jull and T. Lange, Sample preparation of dissolved organic carbon in groundwater for AMS ${ }^{14} \mathrm{C}$ analysis. 43(2A), 2001. 


\title{
160 - USING WATER ISOTOPES TO DETERMINE THE WATER STATUS OF LAS TABLAS DE DAIMIEL NATIONAL PARK (CENTRAL SPAIN).
}

\author{
Silvino Castaño ${ }^{1}$ - Almudena de la Losa ${ }^{1}$ - María Fe Díaz-Teijeiro ${ }^{2}$ - \\ Javier Rodríguez Arévalo ${ }^{2}$ - Héctor Aguilera ${ }^{3}$ - Pedro Martínez-Santos ${ }^{3}$ \\ ${ }^{1}$ Geological Survey of Spain (IGME), Ríos Rosas 23 28003-Madrid, Spain; \\ e-mail: s.castano@igme.es \\ ${ }^{2}$ Centro de Estudios y Experimentación de Obras Públicas (CEDEX), Madrid, Spain \\ ${ }^{3}$ Universidad Complutense de Madrid (UCM), Madrid, Spain
}

Las Tablas de Daimiel National Park (TDPN) is an emblematic wetland in Spain. It is located in an area of steppe, in the Centre of the Iberian Peninsula, with a continental, dry climate. It is used by birds during their migration between Africa and Europe or between northern and southern Europe. The area was declared a National Park in 1973 and today has all the national and international protection figures.

The wetland was fed with seasonal and brackish superficial waters, mainly from the North, and by groundwater, constant and sweet, from the East and South. However, the intensive exploitation of the aquifer feeding the wetland originated this to dry for the first time in 1987. To allow the existence of a sheet of water, various actions have been such as the construction of dams and diversions of water from the Tagus River basin. The first dam built is known as Puente Navarro, who is currently out of the wetland and its lowest point. Nevertheless, and despite these measures, Las Tablas have behaved as a big recharge pond by the disconnection of surface waters and the main aquifer.

Since the first drying of TDNP, strong floods have taken place. These have managed to fill the wetland. The first occurred in 1997, and the last from 2010 to 2013. Between those two dates, there has been a decrease in the volume of exploitation of the aquifer, which, along with the intense recharged by rain, by infiltration from rivers and adjacent aquifers, has allowed a significant rise in groundwater levels. In the autumn of 2012 appeared groundwater in some points near TDNP. In addition, in (very dry) 2012 and 2013 (very wet) winters, groundwater appeared near the ancient points of upwelling, but not flow was observed. All these facts have led to great excitement among different stakeholders, because it is considered to be proof that the aquifer is close to recovery and therefore exploitation restrictive measures could be deleted.

However, at least until December 2012, this recovery was not evident in the Park, based on geological and piezometric data [1]. It is therefore important to know the relationship between surface water and groundwater in the National Park, especially if the wetland is gaining or losing water.

The situation of loss of water to the underlying levels is known since the $1980 \mathrm{~s}$ and even has been quantified on a global basis for the wetland $[2,3]$. Also, general models of behavior relating surface water and groundwater have been established 
based on the flooding area, the piezometric evolution, the variation of electrical conductivity (EC), and the hydrochemical and isotopic compositions around the TDNP in specific dates [4].

In some of these studies $[4,5]$, it is in evidence that the final area of the TDNP, where is the Puente Navarro dam is located, is one of the best places to check qualitatively the loss or gain of water from the wetland (Fig. 1). The dam was built in the
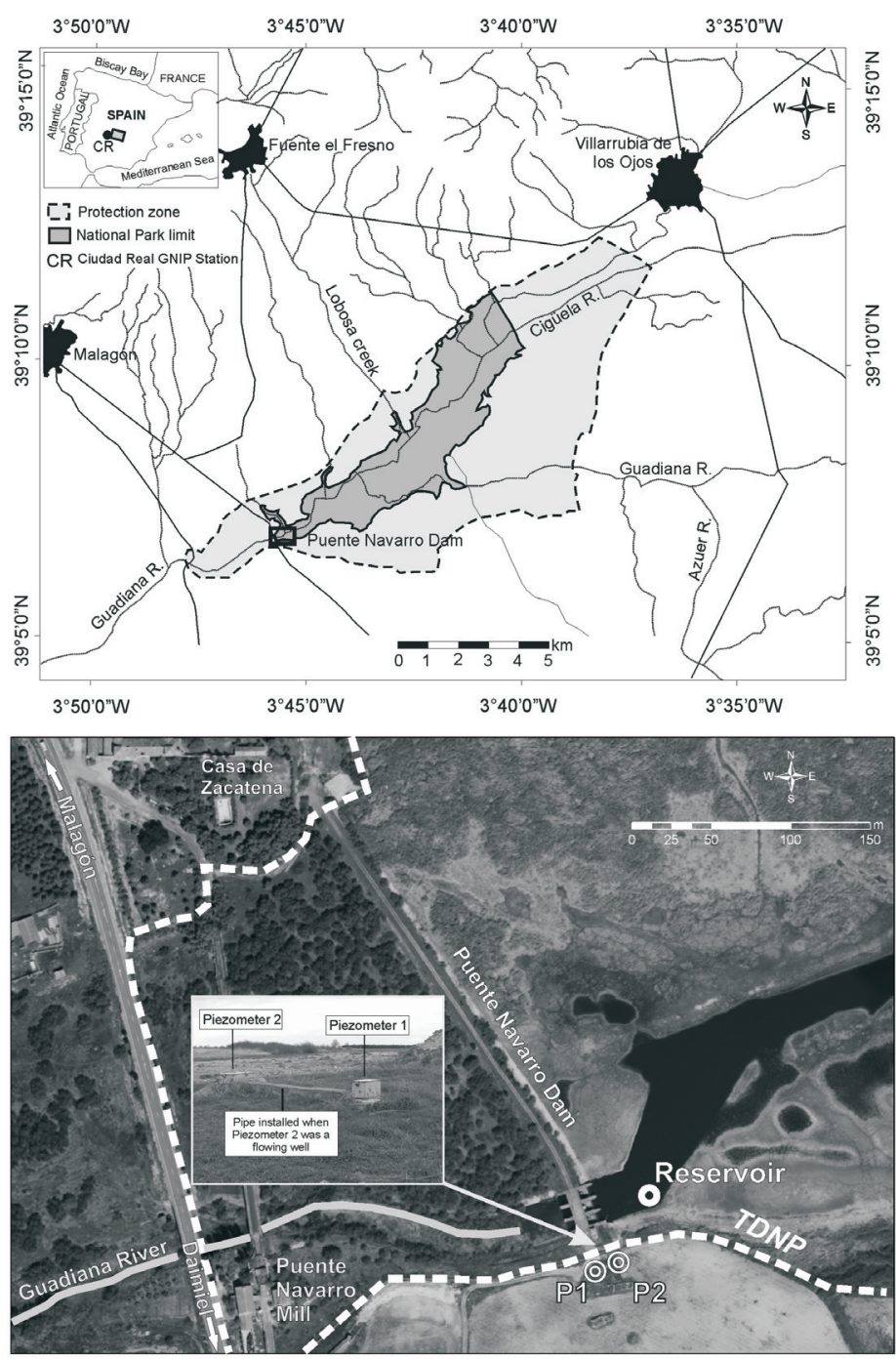

Figure 1. Situation of TDNP, and the sampling points in the surroundings of the Puente Navarro Dam (P1: Piezometer 1, P2: Piezometer 2) 
1980s to maintain a large ponding surface, but its reservoir has dried in different stages. Next to the dam, there are two piezometers with different accessible depths: up to $11 \mathrm{~m}$ (piezometer 1) and up to $84 \mathrm{~m}$ (piezometer 2). The latter must have been flowing when built, since it has a device to drain water (Fig. 1). The shortest is considered representative of waters linked to aquitards, while the longest would be representative of the regional (with local variability) aquifer [4].

The geology of the site is known by means of reconnaissance surveys for the construction of the dam, one of which reached $77 \mathrm{~m}$ deep and was located in the vicinity of the piezometers. The lithologic log (Fig. 2) shows, in the Tertiary materials, a detrital sequence at the base, then evaporite and finally carbonated one, although is very heterogeneous, as the National Park is situated in the edge of a sedimentary basin. At the time of this survey, the groundwater level was measured over $4 \mathrm{~m}$ depth [6], so that the deep levels were no longer flowing.
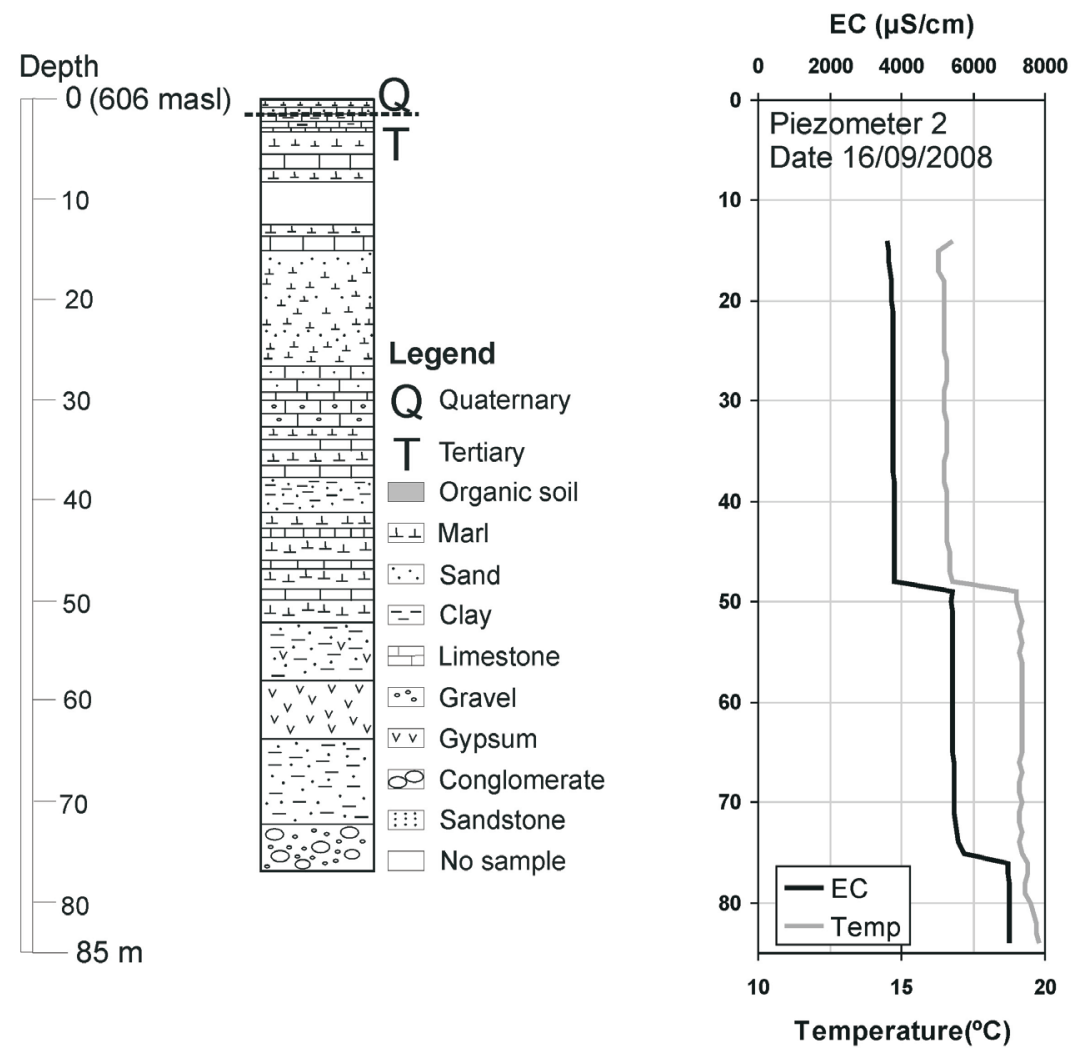

Figure 2. The nearest lithological log to sampling points in Puente Navarro, and electrical conductivity and temperature profiles of in the Piezometer 2, in September 2008 
On the other hand, in both piezometers several EC and temperature profiles were performed in 2008 and 2009, being all of them similar. They show (Fig. 2) three clearly differentiated sections of EC and temperature, which could correspond to main lithologies. However, the depths are not the same found in the survey previously mentioned, which would agree with great lithological variability at small-scale. The average temperature gradient in the water column is $4.3^{\circ} \mathrm{C} / 100 \mathrm{~m}$, but the values in each section are very homogeneous, as of the EC. This could be related with the distribution of screens in depth (unknown) and vertical movement of groundwater through limited sections of the well, which would not be in equilibrium with the rock matrix [7]. In any case, both piezometers have only been sampled in the upper part of the water column, and have shown significant differences in many chemical parameters, as well as a relationship between the water of the shorter piezometer and that of the reservoir [4].

Some of those results could be conditioned by the geological structure, lithology, or works of maintenance of the reservoir. Therefore, it is contemplated to monitor the water isotopes, deuterium, oxygen-18 and tritium, in order to check the relationship between groundwater and surface water in the reservoir, and the variation that they can have. The strong evaporation that the water in the reservoir can record, as it has been proven in previous studies [8], would show a track on stable isotopes that could be found in the groundwater if there is a recharge from the reservoir. In addition, TDNP has received transferred water from another basin, with high content of tritium (more than 285 UT in 2009) for years, by what this isotope could be used as a tracer of water behavior in the system.

The study of the behavior of water isotopes was made by comparing different isotopes each other and with the EC as representative of the chemical quality of water, and also by analyzing the temporal evolution of the isotopes with some variables reflects environmental water conditions (Fig. 3). This could help determine if the wetland lost water or if the groundwater discharge on it. Stable isotope data are available from 2006 until 2012 in the reservoir (since 2008 in the piezometers). Data of tritium have since 2008 in all sampling points

The ratios of water stable isotope, ${ }^{2} \mathrm{H} /{ }^{1} \mathrm{H}$ and ${ }^{18} \mathrm{O} /{ }^{16} \mathrm{O}$, are expressed by convention as parts per thousand deviation relative to the standard VSMOW (Vienna Standard Mean Ocean Water). The widely used delta notation, $\delta^{2} \mathrm{H}$ or $\delta^{18} \mathrm{O}(\%)$, is defined as $\left(R_{\text {sample }} / R_{\text {standard }}-1\right) \times 1,000$, where $R_{\text {sample }}$ and $R_{\text {standard }}$ stand for the isotope ratios ${ }^{2} \mathrm{H} /{ }^{1} \mathrm{H}$ or ${ }^{18} \mathrm{O} /{ }^{16} \mathrm{O}$ of the sample and the standard, respectively. Stable isotopes were measured with a double entry isotope ratio mass spectrometer (IRMS) with analytical uncertainties of $\pm 0.2 \%$ for $\delta^{18} \mathrm{O}$ and $\pm 1.5 \%$ or for $\delta^{2} \mathrm{H}$. The tritium radioisotope activity in water samples was determined by electrolytic enrichment and liquid scintillation counting. Tritium concentrations are expressed in tritium units (TU), where one TU corresponds to one tritium atom per 1018 hydrogen atoms, with a detection limit of 0.4 TU. All the isotopic analyses were performed at the laboratory of Isotopic Applications of the Centro de Estudios y Experimentación de Obras Públicas (CEDEX). 


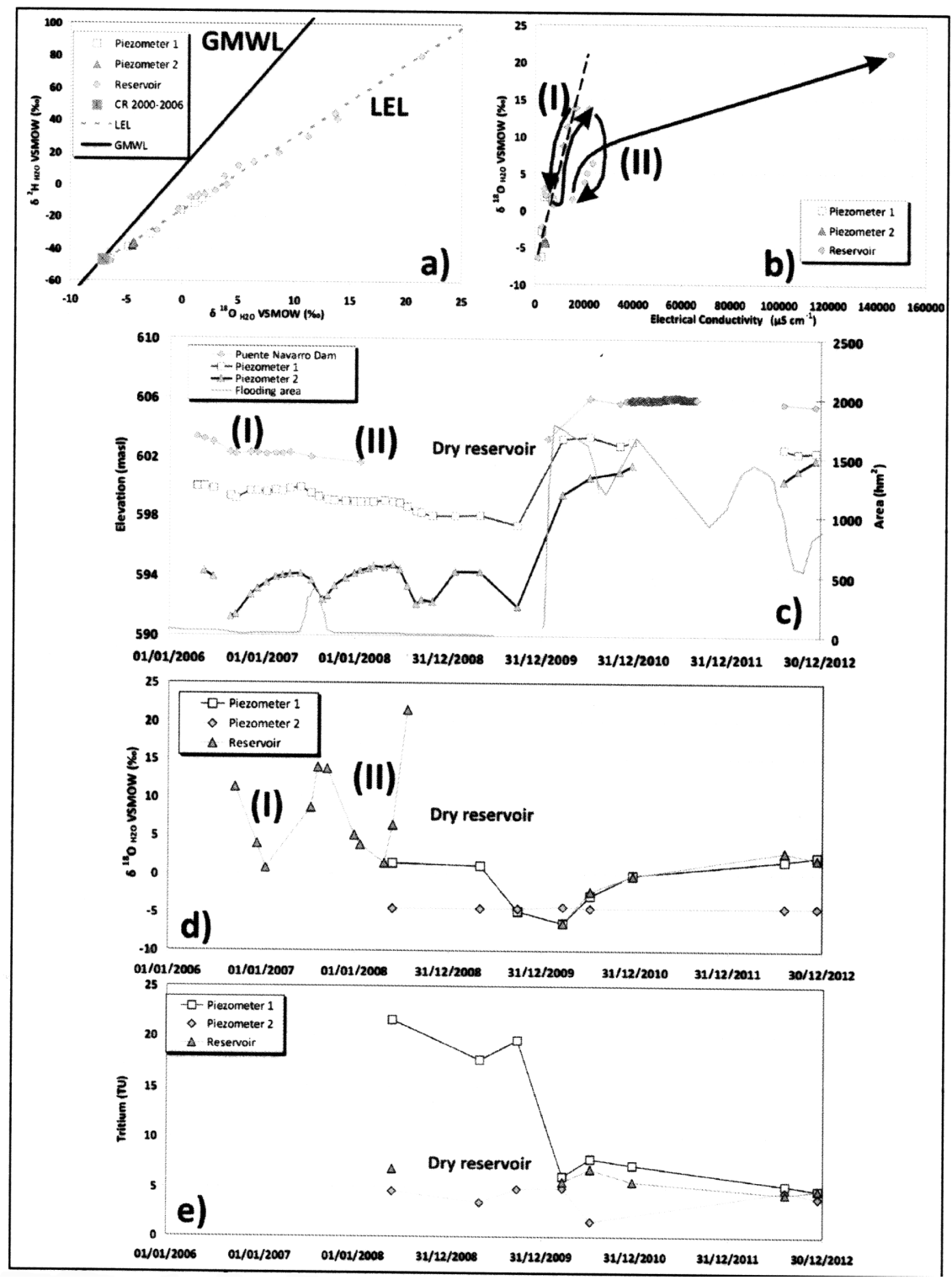

Figure 3. a) $\delta^{18} \mathrm{O}$ against $\delta^{2} \mathrm{H}$ for the sampling monitoring system in Puente Navarro. GMWL: Global Meteoric Water Line [8]. LEL: Local evaporation line [9]. CR 2000-2006: Mean weighted stables isotopes values in Ciudad Real REVIP/GNIP Station [10]; b) EC against $\delta^{18}$ O. Dashed line:

$\mathrm{CE}-\delta^{18} \mathrm{O}$ fit for samples used in LEL calculation [9]. (I) and (II): See text; c) Comparison of the total floding area of the National Park and water elevation in Puente Navarro Dam and in the piezometers 1 and 2. Note: The reference for the piezometric measures is estimated; d) Evolution of $\delta^{18} \mathrm{O}$ in the sampling monitoring system; e) Evolution of tritium in the sampling monitoring system 
The period with isotope data are divided into two stages. Until 2009, there was a dry period in which the scarce water inputs do not reach the end of the wetland area. In January 2010 there is an extraordinary flood that fills the whole TDNP, which remained in 2011 and 2012 in the Puente Navarro reservoir.

The behavior of the stable isotopes of water from the reservoir shows these stages. In the first stage, in which a continuous decrease in the water level occurs (Fig. 3c) to dry, the $\delta^{18} \mathrm{O}-\delta^{2} \mathrm{H}$ ratio varies widely along the local evaporation line, LEL (Fig. 3a), while in the second, corresponding to a wet period, the trend is to increase heavy isotopes by slow evaporation from a point on the line meteoric world, GMWL [9], which is similar to the isotopic ratio of the precipitation in Ciudad Real weather station [10]. In the period with full reservoir (Fig. 3c, d), the increase of heavy isotopes in the groundwater, similar to that produced in the reservoir, would indicate a recharge from this one.

In the dry stage, can distinguish two different types of behavior in the water, drawn as (I) and (II) in Figure 3b, taking as a reference the fit between the EC and the $\delta^{18} \mathrm{O}$ during dry stage in a ditch located in the northern area of the wetland [10]. In step (I), the samples move in the vicinity of the dashed line taken as a reference, with a contribution of light and low CE water in autumn and winter, and an intense evaporation in summer. In step (II) water contributions are more limited and they have poor quality, probably coming from groundwater that has been scarcely renewed. $\delta^{18} \mathrm{O}$ values in the cold months coincide with the highest values in the piezometer 1, which is linked to the level of the reservoir (Fig. 3c). The final stage of drying of the reservoir produces extremely evaporated water with high concentration of salts in residual pools (Fig. 3b).

As the piezometers, behaviors of the stable isotopes are completely different from each other (Fig. 3a, b, d). So while the shorter piezometer presents a similarity in values and evolution with reservoir water, especially after filling in 2010, the longer one presents practically constant values. Furthermore, the evolution of water levels also has different trends (Fig. 3c). In piezometer 2, levels show an upward trend, although there are declines in pumping season. In the other piezometer, levels continue the evolution of reservoir water levels, with a clear downward trend in the period 2006-2009. Also, the footprint of the evaporation is different (Fig. 3a), since samples collected in the piezometer 1 present considerable variations of evaporation of water recharge, probably by being linked to the wetland surface water, while those of the piezometer 2 are located practically in the same point of the line of evaporation, as would correspond to an integrated groundwater recharge with different degrees of evaporation for a long time.

Stable isotopes data show that a connection between the reservoir and high aquifer levels occurs, being the reservoir looser when filling, and the opposite when drying. The deeper piezometer does not seem to be connected with the other sampling points. Nor does it seem that a significant mixture of water between the highest and the 
deepest permeable levels, although cannot be it known whether there is indeed flow through the longer piezometer because samples were taken only at the top of it.

On the other hand, and as indicated above, during the drying stages TDNP receives transferred surface water with high tritium content. High values of this radioisotope in the piezometro1 have been measured (Fig. 3e), with more than 20 UT during that stage, while the average tritium in the precipitation of the nearest REVIP/GNIP station is 4.3 UT [10]. After the extraordinary flood in January 2010, the values are reduced, being around 5 UT.

However, values of reservoir water are not, but the only sample during drying stage was taken in a residual pool. The rest of samples of the reservoir have the same trend as the shorter piezometer.

Piezometer 2 shows significant variations in the tritium content. Most of the values are similar to the average content in precipitation, but a value of less than 2 UT is reached after the greatest increase piezometric (Fig. 3c), which could indicate upward flow from deeper levels with little water renew. However, this could be a temporary situation, since the rest of available values for the wet season are very similar to those of piezometer 1 and reservoir water.

Thus, the analysis of water stable isotopes in the end zone of TDNP, from surface and groundwater samples, shows a mutual influence between the higher permeable levels and the water of reservoir, while the deeper piezometer shows a much reduced interaction with them. In addition, data from 2012 show that the water of reservoir have an evaporation process which is reflected in the waters of the shorter piezometer. It seems that surface water is recharging the aquifer in the end sector of the wetland, at least until December 2012.

Tritium values, however, do not show a clear interpretation. According to the available values, could have influence of surface water in all aquifers and even vertical flow through the piezometers. Therefore, it seems necessary to continue controlling these three sampling points and, especially, to make isotopic profiles in the piezometers.

Acknowledgements: This research has been financed by the MINECO project CGL2011-30302-C02. It has also benefited from the Collaborative Agreement for the Joint Laboratory IGME-CEDEX of Isotopic Hydrology. Special thanks must be given to the IGME staff and to Las Tablas de Daimiel National Park Direction for the provided data and all the facilities and support for access and sampling.

\section{References}

1. S. Castaño, R. Mediavilla, J.I. Santisteban, A. de la Losa and P. Martínez-Santos, Aportación al conocimiento del comportamiento hidrogeológico del límite Terciario-Cuaternario en el entorno del Parque Nacional de Las Tablas de Daimiel. Geogaceta, In press.

2. S. Castaño, P. Martínez-Santos and P.E. Martínez-Alfaro, Evaluating infiltration losses in a Mediterranean wetland: Las Tablas de Daimiel National Park, Spain. Hydrol. Process., 22, pp. 5048-5053, 2008. 
3. V. Navarro, B. García and L. Asensio, Characterization of the infiltration rate in Las Tablas de Daimiel National Park, Central Spain. Hydrol. Process., 26, pp. 367-378, 2012.

4. H. Aguilera, S. Castaño, L. Moreno, M.E. Jiménez-Hernández and A. de la Losa, Model of hydrological behaviour of the anthropized semiarid wetland of Las Tablas de Daimiel National Park (Spain) based on surface water-groundwater interactions. Hydrogeology Journal, 21, pp. 623-641, 2013.

5. M. García-Rodríguez, Hidrogeología de Las Tablas de Daimiel y de los Ojos del Guadiana: bases hidrogeológicas para una clasificación funcional de humedales ribereños. Ph.D. Thesis, Universidad Complutense de Madrid, Madrid, 1996.

6. Servicio Geológico de Obras Púbicas y Urbanismo. Informe 09/82. Sobre las características del terreno en Puente Navarro Parque Nacional de Las Tablas de Daimiel (Ciudad Real). MOPU, Madrid, 1982.

7. J.A. Corcho-Alvarado, F. Barbecot and R. Purtschert, Ambient vertical flow in long-screen wells: A case study in the Fontainebleau Sands Aquifer (France). Hydrogeology Journal, 17(2), pp. 425-431, 2008.

8. S. Castaño, M.F. Díaz-Teijeiro, J. Rodríguez-Arévalo, L. Moreno, H. Aguilera, A. de la Losa and M.E. Jiménez-Hernández, Characterization of evaporation in Las Tablas de Daimiel National Park using stable isotopes of water. In: 9th International Symposium on Applied Isotope Geochemistry (AIG-9). Book of Abstracts. CIMNE, Tarragona, 2011.

9. H. Craig, Isotopic Variations in Meteoric Waters. Science, New Series, 133, No. 3465, pp. 1702-1703, 1961.

10. M.F. Díaz-Teijeiro, J. Rodríguez-Arévalo and S. Castaño, La Red Española de Vigilancia de Isótopos en la Precipitación (REVIP): distribución isotópica espacial y aportación al conocimiento del ciclo hidrológico. Ingeniería Civil, 155, pp. 87-97, 2009.

\title{
161 - TRACING RESIDUAL GAS SATURATION AND GEOCHEMICAL REACTIONS AT THE CO2CRC OTWAY SITE STAGE 2B
}

\author{
Dirk Kirste $^{1,2}-$ Ralf Haese $^{1,3}-$ Chris Boreham $^{1,4}$ \\ ${ }^{1}$ Cooperative Research Centre for Greenhouse Gas Technologies, GPO Box 463, \\ Canberra, Australia \\ ${ }^{2}$ Dept. of Earth Sciences, Simon Fraser University, Burnaby, BC, Canada; dkirste@sfu.ca \\ ${ }^{3}$ Peter Cook Centre for CCS Research, School of Earth Sciences, \\ University of Melbourne, Victoria, Australia \\ ${ }^{4}$ Geoscience Australia, GPO Box 378, Canberra, Australia
}

The CO2CRC Otway site Stage 2 field test was a residual CO2 saturation and dissolution experiment carried out on the Paaratte Formation at a depth of 1436-1443 m. The test took place between June and September of 2011 and involved a series of procedures designed to help determine the residual gas saturation in situ. The initial process consisted of extraction of 680 tonnes of formation water followed by injection of 150 tonnes of $\mathrm{CO}_{2}$ and to drive the $\mathrm{CO}_{2}$ to residual saturation, 454 tonnes of $\mathrm{CO}_{2}$ saturated formation water was re-injected. The methods applied to determine residual gas saturation included: pressure response; neutron logging in the well bore; thermal testing using a fibre optic distributed temperature sensor; noble gas tracer partitioning; reactive ester tracer partitioning; and dissolution testing. During the test formation water 
samples were collected at various times using a downhole U-tube sampling assembly. The waters were analysed for chemical composition, dissolved gas content and stable isotopic composition of $\mathrm{H}$ and $\mathrm{O}$.

The isotopic composition of the formation water evolved from the initial production to the last samples collected during the dissolution test. The main processes indicated by the isotopic variation included: mixing with drill fluids; mixing with isotopically enriched injection fluids; depletion of the ${ }^{18} \mathrm{O}$ content of the water from isotopic fractionation with $\mathrm{CO}_{2}$; mixing with isotopically enriched injection fluids; and gradual decrease in the $\delta^{18} \mathrm{O}$ and $\delta^{2} \mathrm{H}$ to background levels. The chemical composition follows a similar trajectory dominated by mixing but there is also clear indication of mineral reactions, in particular carbonate and some silicate dissolution had occurred in the relatively short time frame of the test. The use of chemical and isotopic composition to resolve the deep subsurface processes enhances the ability to understand and interpret data collected for the residual saturation test.

\title{
162 - ORIGIN OF DISSOLVED CARBON IN GROUNWATERS FROM CARBONATED AQUIFERS IN LISBON - CASCAIS REGION (PORTUGAL) USING $\delta^{13} \mathrm{C}$
}

\author{
M. Rosário Carvalho ${ }^{1}$ - Frederico Ferreira ${ }^{2}$ - Catarina R. Silva ${ }^{1}-$ Carlos Almeida $^{3}$ \\ ${ }^{1}$ Universidade de Lisboa, Faculdade de Ciências, Departamento de Geologia, CeGUL, \\ Ed. C6, Campo Grande, 1749-016 Lisboa, Portugal; e-mail: mdrcarvalho@fc.ul.pt \\ ${ }^{2}$ Instituto Hidrográfico, Rua das Trinas,49, 1249-093 Lisboa, Portugal \\ ${ }^{3}$ Universidade de Lisboa, Faculdade de Ciências, Deparatmento de Geologia, CREMINER, \\ Ed. C6, Campo Grande, 1749-016 Lisboa, Portugal
}

In the region between Lisbon and Cascais (Portugal) there are small aquifers developed in carbonated formations, dated from Upper Jurassic and Cretaceous, and exploited for regional supply and irrigation. Previous studies $[1,2,3]$ show that, although situated in a similar climate and geology context, groundwaters have significant differences in chemical composition. These differences can be attributed to variations in the mineral composition of the hosted formations, changes in recharge conditions, including soil type and thickness, the $\mathrm{CO}_{2}$ partial pressure and water depth circulation. The modelling of reactive process [1], pointed out the role of processes such as: $\mathrm{CO}_{2}$ enrichment of the hosted rocks (lignites), the dissolution of gypsum, followed by calcite and/or dolomite precipitation and ionic exchange.

To better understand the processes that promote the carbonates dissolution in open system conditions, chemical and isotopic analysis of $\delta^{13} \mathrm{C}$ were performed in groundwaters.

The chemical characteristics of the groundwaters are typical of carbonated aquifers, mostly of $\mathrm{Ca}-\mathrm{HCO}_{3}$ type, however it is found waters of $\mathrm{Na}-\mathrm{HCO}_{3}$ and 
$\mathrm{Ca}-\mathrm{SO}_{4}$ types. The waters temperature varying between 16.8 and $26^{\circ} \mathrm{C}$, but most are below $21^{\circ} \mathrm{C}$ (close to the average air temperature of $17^{\circ} \mathrm{C}$ ), and $\mathrm{pH}$ ranging from 6.8 to 7.74. The waters show medium to very high mineralization, with electrical conductivity between 692 and $3317 \mathrm{mS} / \mathrm{cm}$, varying inversely with the water $\mathrm{pH}$. The thermal waters are those with higher values. The major anions are: HCO3 from 130 to 420 $\mathrm{mg} / \mathrm{L}, \mathrm{Cl}$ between 49 and $802 \mathrm{mg} / \mathrm{L}, \mathrm{SO}_{4}{ }^{2-}$ from $50 \mathrm{mg} / \mathrm{L}$ to $322 \mathrm{mg} / \mathrm{L}$. The cations are predominantly $\mathrm{Ca}$, between 54 and $202 \mathrm{mg} / \mathrm{L}$, followed by Na, between 37 and 420 $\mathrm{mg} / \mathrm{L}$, and $\mathrm{Mg}$ from $16 \mathrm{mg} / \mathrm{L}$ to $62 \mathrm{mg} / \mathrm{L}$.

The $\delta^{13} \mathrm{C}$ determinations give values in the range from $-9.55 \%$ to $-0.72 \%$, indicating a complex origin for the $\mathrm{C}$ in these waters. The low mineralized waters have close to $0 \%{ }_{0}^{13} \mathrm{C}$ and it is observed a slight inverse relation between $\delta^{13} \mathrm{C}$ and TDIC content (but thermal waters, 10, 11 and 12; Fig. 1).

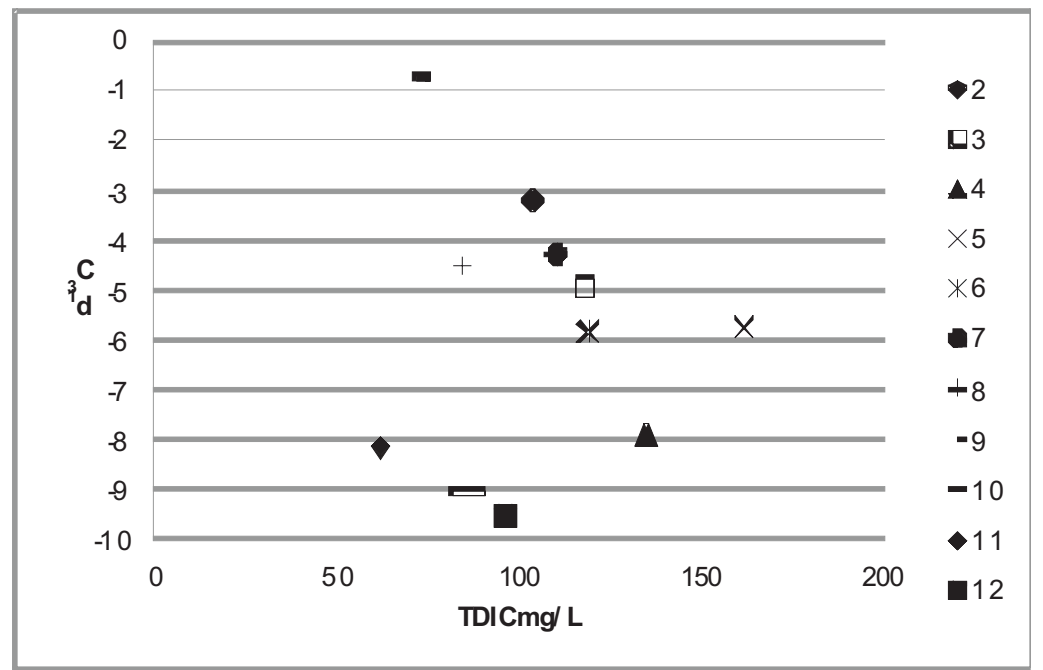

Figure 1. Relation between the TDIC content and $\delta^{13} \mathrm{C}$ in groundwaters from carbonated aquifers in the Lisboa-Cascais region

All waters have strong halite undersaturation, indicating that in case of evaporite rocks dissolution, the water-rock reaction is small. Apart a Ca-SO $\mathrm{S}_{4}$ water, which is close to termochemical equilibrium with gypsum, all waters are undersaturated in this phase; high $\mathrm{SO}_{4}$ content waters show oversaturation to calcite and aragonite, sometimes dolomite. This may result from sequential dissolution, leaching by mixing or due to the gypsum dissolution (increasing of ionic strength). However none of these processes can explain the depletion of $\delta^{13} \mathrm{C}$ with the TDIC increasing.

The isotopic composition of $\delta^{13} \mathrm{C}$ can be related with the dissolution of fossil organic matter present in the formations, favoring carbonate dissolution in $\mathrm{CO}_{2}(\mathrm{~g})$ open system. 


\title{
References
}

1. C.C. Almeida, M.R. Carvalho and S. Almeida, Modelação de processos hidrogeoquímicos ocorrentes nos aquíferos carbonatados da Península de Lisboa. Livro de Resumos do $3^{\circ}$ Congresso Brasileiro de Geoquímica, $1^{\circ}$ Congresso de Geoquímica dos Países de Língua Portuguesa, $1^{\circ}$ Volume, São Paulo, Brasil, pp. 312-313, 1991.

2. C.C. Almeida, M.R. Carvalho and S. Almeida, Modelação de processos hidrogeoquímicos ocorrentes nos aquíferos carbonatados da região de Lisboa-Cascais-Sintra. Actas do V Simpósio de Hidrogeologia, 23-27 Mar., Alicante, Hidrogeologia y Recursos Hidráulicos, XVII, pp. 289-303, 1992.

3. M.R. Jesus, Contaminação em Aquíferos Carbonatados na Região de Lisboa-Sintra - Cascais. MSc thesis, Departamento de Geologia, Faculdade de Ciências, Universidade de Lisboa, Lisboa, 137 pp., 1995.

\section{4 - TREE-RING $\delta^{13}$ C AS A PROXY OF GROSS PRIMARY PRODUCTIVITY IN A NORTH AMERICAN FOREST}

\author{
Soumaya Belmecheri ${ }^{1,2}-$ R. Stockton Maxwell ${ }^{3}-$ Alan. H. Taylor $^{4}-$ Kenneth J. Davis $^{1}-$ \\ Katherine. H. Freeman ${ }^{5}$ - William J. Munger ${ }^{6}$ \\ ${ }^{1}$ Department of Meteorology, Pennsylvania State University, \\ University Park, PA, 16802, USA \\ ${ }^{2}$ Earth and Environmental Institute, Pennsylvania State University, \\ University Park, PA, 16802, USA \\ ${ }^{3}$ Department of Geospatial Sciences, Radford University, Radford, VA, 24142, USA \\ ${ }^{4}$ Department of Geography, Pennsylvania State University, University Park, PA, 16802, USA \\ ${ }^{5}$ Department of Geosciences, Pennsylvania State University, \\ University Park, PA, 16802, USA \\ ${ }^{6}$ School of Engineering and Applied Sciences and Department of Earth and \\ Planetary Sciences, Harvard University, Cambridge, MA 02138, USA
}

We investigate relationships between tree-ring $\delta^{13} \mathrm{C} \&$ growth and flux tower estimates of gross primary productivity (GPP) at Harvard Forest from 1992 to 2010. Annual variations of dervied photosynthetic isotope descrimination $\left({ }^{13} \Delta \sim c_{i} / c_{a}\right)$ and leaf intercellular $\mathrm{CO}_{2}$ concentration $\left(c_{i}\right)$ showed significant increasing trends for two co-dominant species ( $69 \%$ of basal area). Photosynthetic discrimination is strongely correlated to GPP during the growing season and is primarily controlled by pecipitation and soil moisture indicating that site condition maintained high stomatal conductance. These patterns are attributed to upward trends in annual and summer water availability observed at Harvard Forest and at regional scale. Higher stomatal conductance is coincident with enhancement in growth and above ground woody biomass thus providing evidence for an increase in photosynthetic rate and $\mathrm{C}$ gain. 


\title{
165 - ISOTOPE-GEOCHEMICAL FEATURES OF THE REGIME RELATED TO FORMATION OF GOLD MINERALIZATION IN HIGH-CARBONACEOUS ROCKS OF THE SOUTH FAR EAST TYPE
}

\author{
Vladimir P. Molchanov-Evgeny I. Medvedev \\ Far East Geological Institute, the Far Eastern Branch of Russian Academy of Sciences, \\ 159, Prospekt 100-letiya, Vladivostok, Russia; e-mail: Vpmol@mail.ru
}

There are many geological objects within Russian Far East which uniqueness has become evident long after their discovery. Deposits of the Tamgino-Turgenevskiy complex located in the northern part of the Khanka accretionary system are such glowing example. The deposits were surveyed in the 1940s and ranked as the USSR's largest sources of crystalline graphite. And only recent studies (Khanchuk et.al., 2004) have revealed that they accumulated a considerable gold and PGMs reserve as well. Ore mineralization coincides in space with the zone of regional graphitization that extends for $100 \mathrm{~km}$ in submeridional direction and is $3-4 \mathrm{~km}$ wide. Major deposits here are Tamanginskoye (central part), Turgenevskoe, and Innokentyevskoe (northern flank). Their geologic structure is comprised of such rocks as interstratified biotite-feldspar-graphite, garnet-biotite-feldspar-graphite, and biotite-muscovite-feldspar shales with lenses of marmorized limestone, skarnoids, and intrusions of biotite and leucocratic granite gneiss. There are observed also small stocks of young granites containing rare-earth elements, quartz veins and thread veinlets. Industrial 3-22 g/t content of gold is distinctive characteristic of endogenous graphite ores, skarns and quartz veins. Origination and conditions of their formation are the most live issues. For solving these problems, isotope-geochemical composition of calcites from the host limestone and different types of ores: skarns, quartz veins and quartz hydrothermolites has been studied.

On the diagram (Fig. 1) with figurative points showing isotopic compositions of carbonaceous minerals, there are two distinct evolutionary trends; one is demonstration that light isotopes were added to the limestones owing to postmagmatic activity.

$\delta^{18} \mathrm{O}$ and $\delta^{18} \mathrm{C}$ values of limestones vary in ranges of $19.5-20.5 \%$ and 2.3-4.1\%o, respectively, that corresponds with sediments of metamorphogenic origin (Faure, 1989). Skarns display lower values of $\delta^{18} \mathrm{O}$ and $\delta^{18} \mathrm{C}$ : $13.2-18.3 \%$ and $1.2-4.0 \%$, and carbonaceous minerals from quartz veins even lower: $11.7-17.1 \%$ and $10.2-6.0 \%$, respectively. Another trend demonstrates that oxygen and carbon isotope compositions decrease off-center of the field (the Tamginskoe deposit) towards the southern flank (the Turgenevskoe deposit). This could be due to the ingress of isotopically light meteoric water when solutions moved from center to periphery.

The study of veined quartz adds more to the data on isotopic composition of carbonaceous mineralization (Fig. 2). Clear zoning in distribution of $\delta^{18} \mathrm{O}$ values exhibiting maximum in the central part of the studied field of ore mineralization (the Tamanginskoe deposit) and minimum at its southern flank (the Innokentyevskoe 

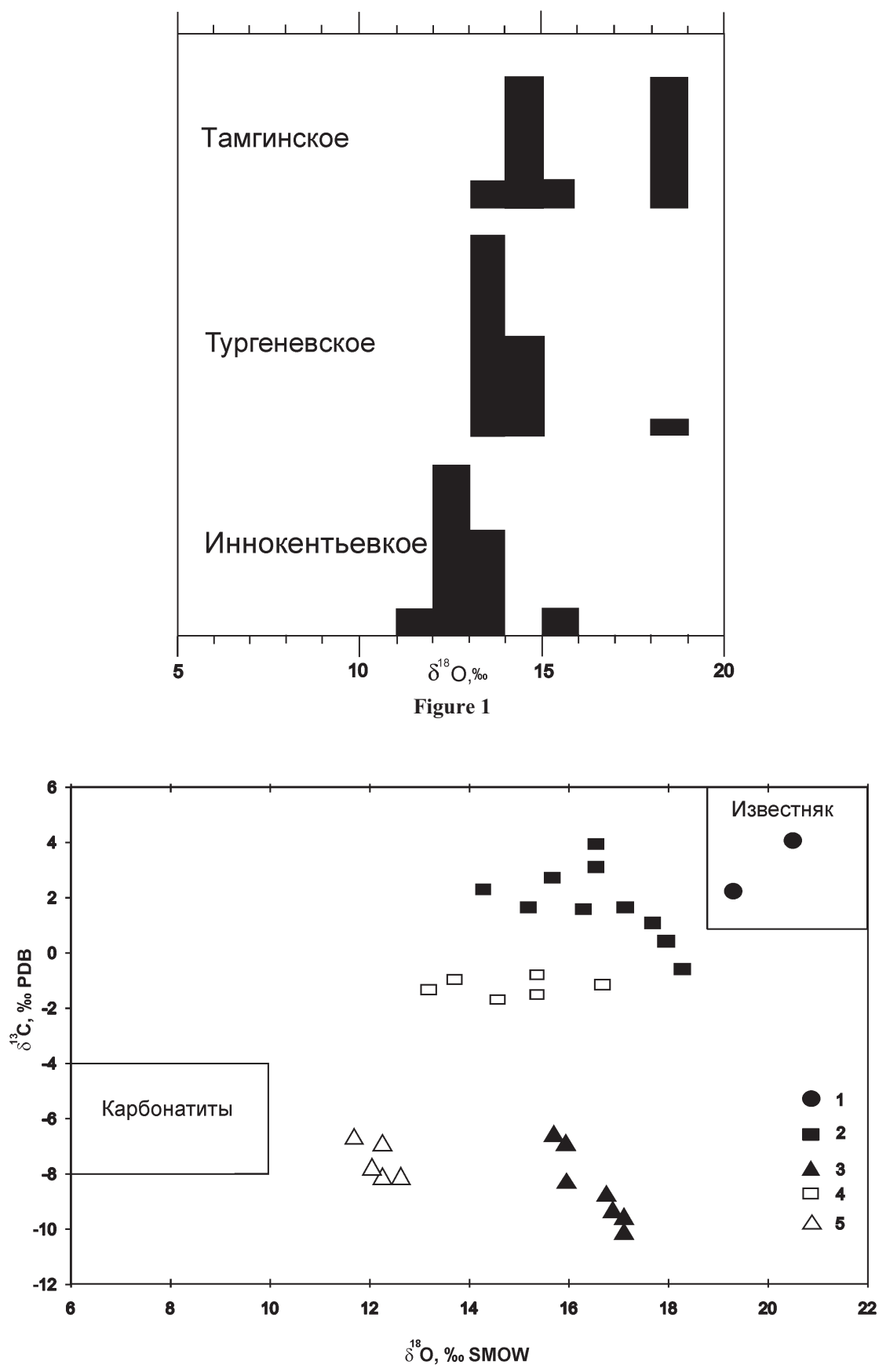

Figure 2 
deposit) suggests an upward current of deep fluids that occurred in the center and was diluted with meteoric water at the flank.

Deposits of the Tamgino-Turgenevsky complex seem to have three stage of formation. At the first stage, limestones were intruded by granite gneisses with the increasing of temperature that forwarded release of water. The water, on interacting with host rocks, metamorphosed into mineral-forming fluid. The second stage was associated with the supply of graphite-rich deep fluids and later intrusion of granitic rocks containing rare-earth elements. At this stage skarns were formed. The third stage underwent influence of the postmagmatic fluids that promoted formation of the quartz veins.

Acknowledgement: This work was financially supported by grants RFFI nos 11-05-00848 and 12-05-31235.

\title{
References
}

1. Khanchuk, A.I., Plusnina, L.P. and Molchanov, V.P., The first data on gold-platinoid mineralization in carbonaceous rocks of the Khanka massif and prediction of a large noble metaldeposit in Primorye. Doklady Earth Sciences, 397(4), pp. 524-529, 2004.

2. Taylor, H.P., Frechen, J. and Degens, E.T., Oxygen and carbon studies of carbonatites from the Laacher See District. West Germany and the Alno District, Sweden. Geochim et Cosmochim. Acta, 31, pp. 407-430, 1967.

3. Faure G. Principle of isotope geology. Mir, Moscow, 1989.

\section{6 - EFFECT OF ORGANIC MATTER DECOMPOSITION ON CARBON FORMS IN THERMAL WATERS}

\author{
József Fekete ${ }^{l}$ - István Vetö ${ }^{2}$ - Csanád Sajgó ${ }^{1}$ \\ ${ }^{1}$ Institute for Geological and Geochemical Research, Research Centre for Astronomy and \\ Earth Sciences, Hungarian Academy of Sciences, \\ H-1112 Budapest, Budaörsi út 45, Hungary; e-mail: fekete.jozsef@csfk.mta.hu \\ ${ }^{2}$ consultant geochemist
}

Decomposition of organic matter in thermal waters or neighbouring reservoirs generates aromatic compounds, aliphatic acids, $\mathrm{C} 1-\mathrm{C} 4$ hydrocarbon gases, and enhances carbonate dissolution and feldspar hydrolysis through $\mathrm{CO}_{2}$ generation. In thermal waters the contribution of organic $\mathrm{CO}_{2}$ originating from soil or organic matter oxidation expectedly decreases the $\delta^{13} \mathrm{C}$ content of dissolved $\mathrm{HCO}_{3-}$ because of the more negative $\delta^{13} \mathrm{C}$ values of organic matter compared to carbonates.

Carbon dioxide reduction and acetate fermentation influences the concentration and isotopic composition of methane. However, the difference between the intensity of both $\mathrm{C}$ and $\mathrm{H}$ isotope fractionation during these processes provides a good tool 
to differentiate between them and to assess the preferential procedure of methane generation.

In recent study dissolved organic and inorganic carbon of 21 thermal waters originating from two sub-basins of the Pannonian Basin (Békés Basin and Makó Trough) were investigated to understand the effect of organic matter (OM) decomposition on concentrations and isotopic composition of dissolved carbon forms. Thermal water samples were taken from different depths (middle of the screened interval) and temperatures (outflow) ranging from 585 to $1733.5 \mathrm{~m}$ and from 38 to $96.5^{\circ} \mathrm{C}$, respectively.

We measured $\delta \mathrm{D}$ and $\delta^{18} \mathrm{O}$ of the water, concentrations and $\mathrm{C}$ isotopic compositions of dissolved $\mathrm{HCO}_{3-}, \mathrm{CO}_{2}, \delta^{13} \mathrm{C}$ and $\delta \mathrm{D}$ of $\mathrm{CH}_{4}$ and also concentrations of phenol and alkylbenzene homologues, which reflect the on-going decomposition of original high molecular weight organic matter $(1,2)$. In our study we observed the following phenomena: i) phenol+alkylbenzene $(p+a b)$ concentration shows pronounced positive correlation with $\mathrm{HCO}_{3-}$ concentration in the Makó Trough, and to some extent in the Békés Basin, too; ii) the $\mathrm{HCO}_{3-} \delta^{13} \mathrm{C}$ values of waters characterised by high $(\mathrm{p}+$ ab) concentration are very close to $-6 \%$ in the Makó Trough and in Békés Basin they are less negative than $-4 \%$ or more negative than $-15 \%$; and iii) isotopic compositions of $\mathrm{CH}_{4}$ and $\mathrm{CO}_{2}$ and differences in $\delta \mathrm{D}$ between methane and water suggest that acetate fermentation, $\mathrm{CO}_{2}$ reduction and to a lesser extent maturation of the OM contributed to the gas content of the thermal waters studied.

To elucidate these observations the investigation of the following possible processes are required: mixing of groundwaters characterised by different origin and/or $\mathrm{OM}$ content; contribution of acetate (propionate); isotope exchange; differences in the origin of methane and $\mathrm{CO}_{2}$ between the two subbasins.

\title{
References
}

1. J. Fekete, Characterisation of aromatic compound in thermal waters and experimental modelling of their generation. PhD Thesis. University of Szeged, 2013.

2. J. Fekete, Cs. Sajgó, I. Horváth, Z. Kárpáti, I. Vető and M. Hetényi, Interaction and variation of isotopic age, temperature, organic and inorganic solutes in Hungarian thermal waters. Central European Geology, 52, pp. 269-285, 2009.

\section{7 - DEVELOPMENTS IN HYDROGEN AND OXYGEN ISOTOPE ANALYSES OF INCLUSION-HOSTED WATERS USING LASER SPECTROSCOPY}

\author{
Gy. Czuppon-A. Demény
}

Institute for Geological and Geochemical Research, RCAES, Hungarian Academy of Sciences, Budaörsi út 45, Budapest, Hungary; e-mails: czuppon@geochem.hu; demeny@geochem.hu 
Laser spectroscopy has been used for coupled $\mathrm{H}$ and $\mathrm{O}$ isotope analyses of water samples from fluid inclusions. A vacuum-based liquid water isotope analyser was chosen (Los Gatos Research, LWIA-24d). Inclusion-bearing samples were vacuum-crushed in stainless steel tubes and the released water was cryogenically transferred to the spectroscope's inlet using a vacuum line. When the fluid contained $\mathrm{CO}_{2}$ (e.g. on the base of microthermometric analyses), the water was purified by releasing $\mathrm{CO}_{2}$ at $-80^{\circ} \mathrm{C}$. Memory and amount effects, as well as isotope shifts related to the isotope range measured were determined by introducing standard waters injected into glass capillaries. Amount effects for both $\mathrm{H}$ and $\mathrm{O}$ isotope compositions were quantified by multiple analyses of a calcite vein. On the base of a set of samples (calcite, quartz and fluorite veins, as well as speleothems), whose $\mathrm{H}$ isotope compositions had been measured by IRMS it can be stated that the precision of $\mathrm{H}$ isotope analyses achieves or even exceeds that of the IRMS analyses with a significant reduction in analysis time and cost. The determination of $\mathrm{O}$ isotope compositions raises more problems. It is demonstrated that the $\delta^{18} \mathrm{O}$ values are prone to alteration during the water release depending on extraction temperature and duration. An on-line vacuum line was developed in order to reduce the effects of fractionations related to vacuum distillation. Extraction temperatures between 120 and $350^{\circ} \mathrm{C}$ were tested for the effect of mineral-water isotope exchange at elevated temperatures. The experiments have shown that no simple solution can be established as samples with very different textural characteristics (dense calcite veins to porous speleothems) behaved differently during extraction temperature changes. Although the measured values may not be equal to the real compositions, internal variations can have a meaning, e.g., in paleohydrological studies.

Acknowledgement: The study was supported by the Hungarian Research Fund and the Hungarian State (project No. CK 80661).

\title{
168 - APPLICATION OF STABLE ISOTOPES $\left(\delta^{18} \mathrm{O}, \delta \mathrm{D}\right)$ IN THE STUDY OF MINERAL WATERS FROM THE EASTERN CARPATHIANS (ROMANIA)
}

\author{
Boglárka Mercedesz Kis $^{1}$ - Krisztina Kármán ${ }^{2}$ - Călin Baciu ${ }^{1}$ \\ ${ }^{1}$ Babeș-Bolyai University, Faculty of Environmental Science and Engineering, \\ Fantanele Street nr. 30, 400294 Cluj-Napoca, Romania; \\ e-mails: kisboglarka85@gmail.com; calin.baciu@yahoo.com \\ ${ }^{2}$ Institute for Geological and Geochemical Research, Research Centre for Astronomy and \\ Earth Sciences, Hungarian Academy of Sciences, Budaörsi út 45, \\ H-1112 Budapest, Hungary; e-mail: karman@geochem.hu
}

The application of stable isotopes in the study of hydrothermal systems is a widespread tool for defining the origin of fluids and the geochemical processes affecting its trail. 
The Eastern Carpathians host the most important mineral water resources of Romania. Although the existence of large water resources has recently boosted the development of the mineral water bottling industry in the area, the knowledge on the origin and circulation of the water is still very poor and few studies on stable isotopic composition make the present day state of knowledge (Cuna et al., 2007, Vaselli et al., 2002).

In the present study we provide constraints on the origin, circulation and geochemical features of 103 mineral waters investigated over a $200 \mathrm{~km}, \mathrm{~N}$ to $\mathrm{S}$ oriented transect in the Eastern Carpathians-Transylvanian Basin boundary from a stable isotopic point of view.

The mineral waters are cold, $\mathrm{CO}_{2}$-rich and can be divided according to the major constituents in three major chemical types: $\mathrm{Ca}-\mathrm{Mg}-\mathrm{HCO}_{3}, \mathrm{Na}-\mathrm{K}-\mathrm{HCO}_{3}$ and $\mathrm{Na}-\mathrm{Cl}$.

The isotopic composition of hydrogen and oxygen, ranging between $\delta \mathrm{D}=$ -80.7 to -8.2 (\%o, SMOW) and $\delta^{18} \mathrm{O}=-11.6$ to +9.1 (\%o, SMOW), reveals the meteoric origin of these fluids. In most cases the absence of oxygen's isotopic shift due to water-rock exchange suggests that, although the waters interact with a large variety of host rocks, the water/rock interactions occur at relatively low-temperature, in agreement with the geothermometric estimations, thus possible shifts due to isotopic exchange are hidden by isotopic fractionation and the occurrence of mixing processes; however, in particular cases the shifts towards the heavy isotopes, with positive values for oxygen, suggest strong fractionation processes that have affected the circulating water.

Acknowledgement: The present work was financially supported by the Romanian National Research Council, Project PN-II-ID-PCE-2011-3-0537

\title{
References
}

1. Cuna, S., Baciu, C., Cuna, C., Berdea, P. and Balas, G., Isotopic approach to the mineral water dynamics in the Eastern Carpathians area. Environment and Progress, 9, pp. 149-153, 2007.

2. Vaselli, O., Minissale, A., Tassi, F., Magro, G., Seghedi, I., Ioane, D. and Szakács, A., A geochemical traverse across the Eastern Carpathians (Romania): Constraints on the origin and evolution of the mineral waters and gas discharge. Chemical Geology, 182, pp. 637-654, 2002.

\section{9 - COMPARISON OF DIFFERENT TYPE RIVERBANK FILTRATED SYSTEMS BY LUMPED PARAMETER MODEL}

\author{
Krisztina Kármán ${ }^{1}$ - József Deák ${ }^{2}$ - István Fórizs ${ }^{1}$ - Piotr Maloszewski ${ }^{3}$ \\ ${ }^{1}$ Institute for Geological and Geochemical Research, Research Centre for Astronomy and \\ Earth Sciences, Hungarian Academy of Sciences, Budapest, Hungary; \\ e-mail: karman.krisztina@csfk.mta.hu \\ ${ }^{2}$ GWIS Ltd., Dunakeszi, Hungary \\ ${ }^{3}$ Institute of Groundwater Ecology, Helmholtz Zentrum München, German Research Center \\ for Environmental Health (GmbH), Munich, Germany
}


We used the lumped steady-state Dispersion Model, which has a very wide application range, especially in all types of riverbank filtration systems (Maloszewski et al., 1983; Stichler et al., 1986, 2008; Maloszewski and Zuber, 1996).

One of the study area is the Szentendre Island (Danube River, Hungary, Fig. 1), where the observation site (production well with multiple horizontal collectors) is located very close $(45 \mathrm{~m})$ to the river while the water level in the Danube is variable. Thus the modelling of isotope data was performed by selecting single oxygen isotopic peaks observed during quasi "steady-state" water levels. Two relatively long-term events were selected, where significant differences were observed between the input (Danube River) and the output (collector well) ${ }^{18} \mathrm{O}$-concentrations. The first peak indicates 12-14 d mean travel time, and 60\% Danube water proportion in the well at water level 98-99 $\mathrm{m}$ a.s.1. The second peak indicates 6-8 d mean travel time, and at least $95 \%$ Danube water in the well at water level $102 \mathrm{~m}$ a.s.l.

The other study area is the Szigetköz (Fig. 1), where one pathway was selected. The 8 measured wells are much farther from the Danube $(12-27 \mathrm{~km})$, and were sampled 4-9 times between 1984 and 2012. In this case tritium data were modelled. The results show that the transit time increase along the pathway, the longest was 75 years. The largest groundwater proportion was $50 \%$.

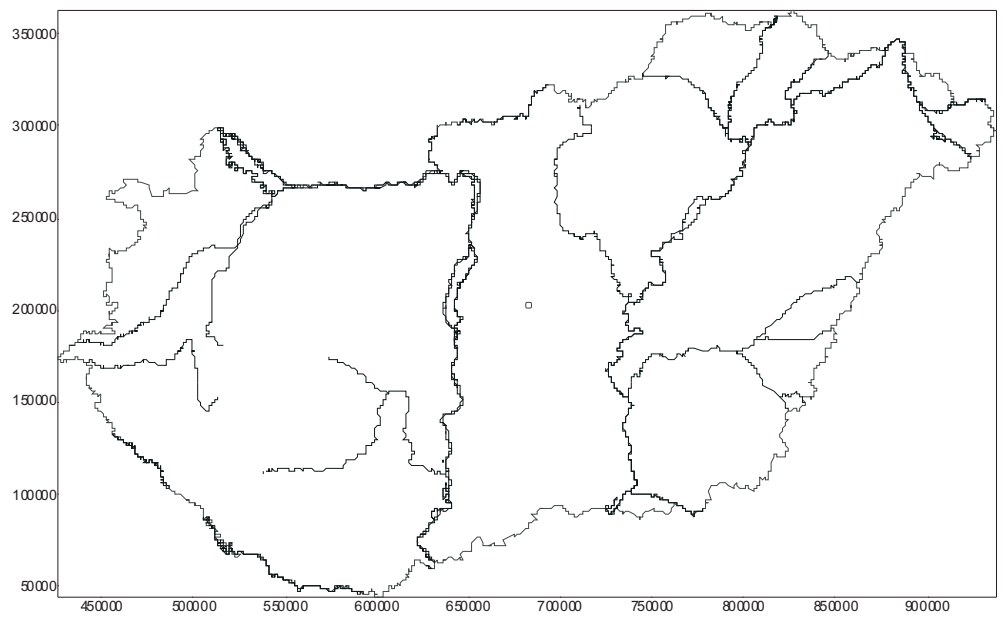

Figure 1. Location of the Szentendre Island and Szigetköz area

Comparing these two sites the usage of the lumped parameter Dispersion Model and the difference between modelling stable and radioactive isotopic data is demonstrated. 


\title{
References
}

1. Maloszewski, P., Rauert, W., Stichler, W. and Herrmann, A. 1983. Application of flow models in an Alpine catchment area using tritium and deuterium data. Journal of Hydrology, 66, pp. 319-330.

2. Maloszewski, P. and Zuber, A. 1996. Lumped parameter models for the interpretation of environmental tracer data. In: Yurtsever, Y. (ed.), Manual on Mathematical Models in Isotope Hydrology, IAEA-TECDOC 910, IAEA, Vienna, pp. 9-58.

3. Stichler, W., Maloszewski, P. and Moser, H. 1986. Modelling of river water infiltration using oxygen-18 data. Journal of Hydrology, 83, pp. 355-365.

4. Stichler, W., Maloszewski, P., Bertleff, B. and Watzel, R. 2008. Use of environmental isotopes to define the capture zone of a drinking water supply situated near a dredge lake. Journal of Hydrology, 362, pp. 220-233.

\section{0 - APPLIED GEOCHEMISTRY OF EARLY EARTH(S) ACROSS TIME AND SPACE}

\author{
Stephen J. Mojzsis ${ }^{1,2}$
}

${ }^{1}$ Department of Geological Sciences, NASA Lunar Science Institute and Center for Lunar

Origin and Evolution (CLOE), University of Colorado, 2200 Colorado Avenue, Boulder, CO 80309-0399, USA; e-mail: mojzsis@colorado.edu

${ }^{2}$ Institute for Geological and Geochemical Research, Hungarian Academy of Sciences, Budaörsi út 45, H-1112 Budapest, Hungary

The geochemical and cosmochemical record of our solar system is the baseline for exploring the question: "when could life appear on a world similar to our own?" Data arising from direct analysis of the oldest terrestrial rocks and minerals from the first 500 Myr of Earth history - termed the Hadean Eon - inform us about the timing for the establishment of a habitable silicate world. Liquid water is the key medium for life. The origin of water, and its interaction with the crust as revealed in the geologic record, guides this exploration.

From the time of primary planetary accretion to the start of the continuous rock record on Earth at ca. 3850 million years ago, the planet experienced a waning bolide flux that partially or entirely wiped out surface rocks, vaporized oceans, and transient serpentinizing atmospheres. Arguably, "Early Earths" across the galaxy may start off as ice planets due to feeble insolation from their young stars, occasionally punctuated by steam atmospheres generated by cataclysmic impacts. Alternatively, early global environments conducive to life spanned from a benign surface zone to deep into crustal rocks and sediments. In some scenarios, early biospheres may benefit from exogenous delivery of essential bio-elements via leftovers of accretion, and the subsequent establishment of large long-lived hydrothermal systems.

If what is now known about the early dynamical regime of the Earth serves as any measure of the potential habitability of worlds across space and time, several key boundary conditions emerge. These are: (i) availability and long-term stability of liq- 
uid water; (ii) presence of energy resources; (iii) accessibility of organic raw materials; (iv) adequate inventory of radioisotopes to drive internal heating; (v) gross compositional parameters such as mantle/core mass ratio, and (vi) $\mathrm{P}-\mathrm{T}$ conditions at or near the surface suitable for sustaining biological activity. Life can emerge in or on a suitable planet with Earth characteristics, within ca. $150 \mathrm{Myr}$ after its formation.

Our understanding of the thermal histories and chemical transformations of the crusts of early Earth, Moon, Mars and asteroids have accumulated to the point where it is now feasible to deduce the habitable potential of the nascent solar system and to place some upward constraints on the timing of life's appearance. The natural lifetime of a biosphere is heavily dependent on the age and composition of the host planet and its proximity to its star.

\title{
171 - HYDROMETEOROLOGY AND STABLE ISOTOPE GEOCHEMISTRY OF PANAMA PRECIPITATION AND RIVERS
}

\author{
Russell S. Harmon ${ }^{1}$ - Zoltán Kern ${ }^{2}$ - István Fórizs ${ }^{2}$ - Christopher Gardner ${ }^{3}-$ \\ Berry Lyons ${ }^{3}-$ Fred L. Ogden ${ }^{4}$ \\ ${ }^{1}$ Department on Marine, Earth, \& Atmospheric Sciences, North Carolina State University, \\ Raleigh, NC 27695 USA; e-mail: rsharmon@ncsu.edu \\ ${ }^{2}$ Institute for Geological and Geochemical Research, Research Centre for Astronomy and \\ Earth Sciences, Hungarian Academy of Sciences, Budaörsi út 45, \\ H-1112 Budapest, Hungary; e-mails: kern@geochem.hu; forizs@geochem.hu \\ ${ }^{3}$ School of Earth Sciences, The Ohio State University, Columbus, OH 43210 USA; \\ emails: christopherbgardner@gmail.com; lyons.142@osu.edu \\ ${ }^{4}$ Department of Civil \& Architectural Engineering, University of Wyoming, \\ Laramie, WY 82071 USA; e-mail: fogden@uwyo.edu
}

The hydrometeorology of Panama is determined largely by the strong influence of the Inter-Tropical Convergence Zone (ITCZ), a global domain of low atmospheric pressure and heavy precipitation. The variable position of the ITCZ determines the season rainfall pattern across southern Central America. The ITCZ is situated over and to the north of Panama from May to December, causing light and variable winds and a strong rainy season that produces about $90 \%$ of annual precipitation. Subsequently, from January through March, the ITCZ crosses the isthmus to a position to the south of Panama causing the predominant influence of northeast trade winds and the dry season, with what little precipitation falls being produced by tropical atmospheric systems that move across Panama from the Caribbean (Windsor, 1990). Precipitation generated in the Caribbean tracks from north to south, so that there is a pronounced N-S precipitation gradient across the Panamanian isthmus. Although year-to-year variations in total precipitation can be significant, the Atlantic coastal region receives an annual average of $>3000 \mathrm{~mm}$ of rainfall as compared to $<2000 \mathrm{~mm}$ for the Pacific coastal region on the leeward side of the continental divide. River hydrographs for storm events tend to rise 


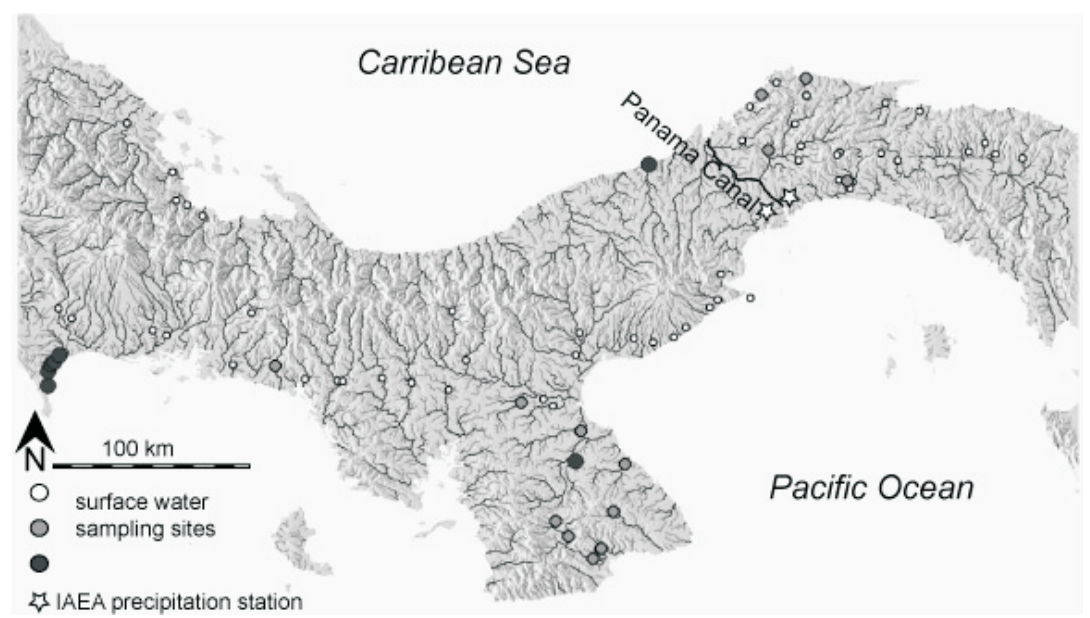

Figure 1. Location map showing the spatial distribution of sampling sites for this study and the location of the IAEA precipitation station in Panama City. TDS values for Panama waters range from $6-1901 \mathrm{mg} / \mathrm{L}($ avg $=136 \pm 138)$; black circles $>400$, grey circles $=100-400$, and open circles $=<100 \mathrm{mg} / \mathrm{L}$ TDS

and decay very rapidly and represent a small portion of the total annual discharge. For example, the annual runoff hydrograph for the Upper Rio Chagres, the primary source of water for operation of the Panama Canal, has several distinctive features. These include: enhanced runoff generation early in the wet season, a threshold doubling of base flow part-way through the wet season, and a general increase in runoff over the course of the wet season.

Hydrochemical and isotope hydrological parameters have been monitored in surface waters (i.e. soil seepage, springs, streams \& rivers) across Panama since 2005 from Lake Bayano in the east to the Costa Rican border in the west, including in the Azuero peninsula, Burica peninsula, and Bocas del Toro areas (Fig. 1).

Relative to the VSMOW standard, respective ranges in $\mathrm{H}$ - and O-isotope composition across Panama for rainfall are $\delta \mathrm{D}=-110.8$ to $-24.2 \%$ and $\delta^{18} \mathrm{O}=-15.3$ to $+3.6 \%$ and for the rainfall-generated rivers of Panama are $\delta \mathrm{D}=-82.0$ to $-3.4 \%$ and $\delta^{18} \mathrm{O}=-12$ to $-1.6 \%$. The $\delta \mathrm{D}-\delta^{8} \mathrm{O}$ relationships for both water types are essentially equivalent, $\delta \mathrm{D}=7.45 \times \delta^{18} \mathrm{O}+5.81\left(\mathrm{R}^{2}=0.97\right)$ for rainfall and $7.12 \times \delta^{8} \mathrm{O}+5.44\left(\mathrm{R}^{2}=\right.$ $0.92)$. Interesting to note that the $\delta^{18} \mathrm{O}$ values of precipitation did not show a pronounced amount effect reported earlier for Panamanian precipitation by (Lachniet and Patterson 2006).

In order to test whether the measured river stable isotopes compositions for Panama do or do not conform to that expected for precipitation in a coastal environment, a simple Rayleigh approach - assuming a progressive distillation and rainout, was employed to estimate the isotopic composition expected for regional precipitation. Caribbean Sea is the dominant source of vapour over Central America (Lachniet 


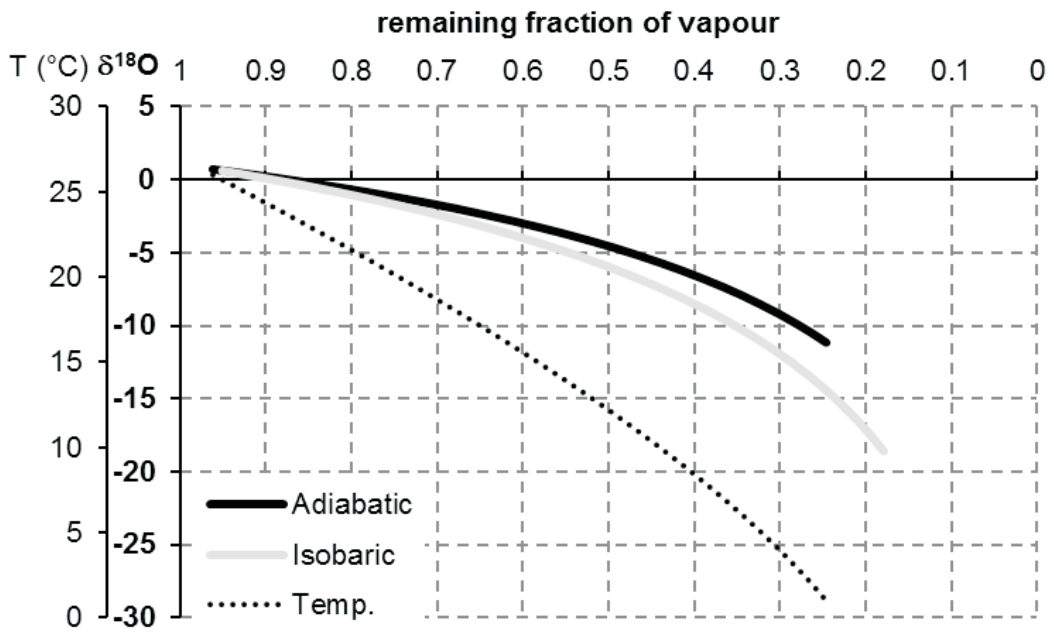

Figure 2. O-isotope composition of precipitation estimated by a Rayleigh distillation-fractionation model, assuming initial conditions of seasurface water temperature $=27^{\circ} \mathrm{C}$, seawater $\delta^{18} \mathrm{O}=+1 \%$, and adiabatic (black) and isobaric (grey) cooling process for the air parcel.

Temperature decrease is also shown (dotted black)

and Patterson 2006), therefore evaporation of Caribbean surface seawater having $\delta^{18} \mathrm{O}$ $=+1 \%$ (LeGrande and Schmidt, 2006) at $27^{\circ} \mathrm{C}$ were selected as initial conditions. Isobaric and adiabatic cooling processes associated with subsequent multi-stage precipitation were modeled. The model results (Fig. 2) showed that a relatively moderate cooling $(\sim 10 \mathrm{oC})$, which is a reasonable assumption for the shallow tropical convective conditions of Panama, can generate $\delta^{18} \mathrm{O}$ values comparable to those measured at the Universidad de Panama IAEA station. These preliminary results suggest that river stable isotopes compositions for Panama can be largely explained by a Rayleigh distillation-fractionation model. The isotopic similarity of rainfall and river waters suggests that runoff is rapid and groundwater residences times are short. There is no isotopic evidence for a hydrothermal component to river waters in Panama, as observed in Costa Rica.

\section{References}

1. D.M. Windsor, Climate and moisture variability in a tropical forest: Long-term records from Barro Colorado Island, Panamá, Smithson. Contrib. Earth Sci., 29, pp. 1-145, 1990.

2. M.S. Lachniet and W.P. Patterson, Use of correlation and multiple stepwise regression to evaluate the climatic controls on the stable isotope values of Panamanian surface waters. J. Hydrol., 324, pp. 115-140, 2006.

3. A.N. LeGrande and G.A. Schmidt, Global gridded data set of the oxygen isotopic composition in seawater. Geophys. Res. Lett., 33, L12604, doi:10.1029/2006GL026011. 2006. 


\title{
172 - DETERMINATION OF AIR MOISTURE SOURCE REGION FOR PRECIPITATION IN HUNGARY
}

\author{
Emese Bottyán ${ }^{1}$ - György Czuppon ${ }^{2}$ - Tamás Weidinger ${ }^{1}$ - László Haszpra ${ }^{3}$ - \\ Krisztina Kármán ${ }^{2}$ \\ ${ }^{1}$ Department of Meteorology, Eötvös Loránd University, \\ H-1117 Budapest, Pázmány P. sétány 1/A, Hungary; e-mail: emese.bottyan@gmail.com \\ ${ }^{2}$ Institute for Geological and Geochemical Institute, Hungarian Academy of Sciences, \\ H-1112 Budapest, Budaörsi út 45, Hungary; e-mail: czuppon@geochem.hu \\ ${ }^{3}$ Hungarian Meteorological Service, H-1675 Budapest, P.O. Box, 39, Hungary, \\ also at Geodetic and Geophysical Institute, Hungarian Academy of Sciences, \\ H-9400 Sopron, Csatkay Endre u. 6-8, Hungary; e-mail: haszpra.1@met.hu
}

Our study presents an investigation about the determination of air moisture source region in Hungary, covering a year period, from April 2012 to April 2013. The examination was carried out by trajectory analysis and examination of hydrogen- and oxygen isotopic composition of precipitation water, involving 7 meteorological stations where precipitation sampling was performed.

The aim of our study was to determine the origin of precipitation, and to evaluate the relation between the isotopic composition of the precipitation and its source region as well as the isotopic effects that influenced the isotopic composition along the trajectories. To reconstruct the path of the air moisture from the source region, we ran the NOAA HYSPLIT trajectory model for every precipitation event, for heights of 500,1500 and $3000 \mathrm{~m}$. We determined the location where water vapour entered into the atmosphere by calculating specific humidity along the trajectories, and evaluating the ratios of the water originated above sea/ocean and continent, and the height at which the moisture was transported from the source to the sampling sites. Furthermore, it was necessary to filter the local precipitation events not related to weather fronts. For this purpose, we used the Daily Report of the Hungarian Meteorological Service, and used the WRF model to evaluate the ratio of convective and total precipitation amount.

Based on the trajectories, we determined five sectors, and examined the statistics of the relevant isotopic data. In addition, we determined the local meteoric water lines for each station. 


\title{
173 - SPATIAL AND TEMPORAL VARIATIONS OF $\delta$ D AND $\delta^{18} O$ VALUES OF CAVE DRIP WATERS: IMPLICATIONS FOR PALEOCLIMATE SIGNAL IN STALAGMITE
}

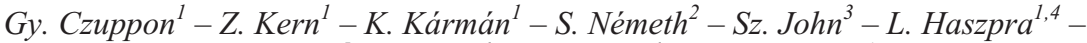 \\ B. Kohán ${ }^{5}-$ K. Kiss ${ }^{6}-$ Z. Siklósy ${ }^{1}-$ Zs. Polacsek ${ }^{4}$ \\ ${ }^{1}$ Institute for Geological and Geochemical Research, Research Centre for Astronomy and \\ Earth Sciences, Hungarian Academy of Sciences, Budapest, Hungary; \\ e-mail: czuppon@geochem.hu \\ ${ }^{2}$ University of Pannonia, Georgikon Faculty, Budapest, Hungary \\ ${ }^{3}$ Balaton Highlands National Park, Csodabogyós Cave Management, Balatonederics, Hungary \\ ${ }^{4}$ Geographical Institute, Hungarian Meteorological Service, \\ H-1675 Budapest, P.O. Box, 39, Hungary \\ ${ }^{5}$ Deparment of Environment and Landscape Geography, ELTE, Pázmány P. sétány 1/C, \\ Budapest, Hungary \\ ${ }^{6}$ Geographical Institute, Research Centre for Astronomy and Earth Sciences, \\ Hungarian Academy of Sciences, Budapest, Hungary
}

\section{Introduction}

Circumspect isotope hydrological monitoring in karstic environment is crucial to support any future climate and/or environmental reconstruction efforts (e.g. Suric et al., 2010; Riechelmann et al., 2011), however it could be essential contribution also to ecohydrological, drinking water supply problems (Ford and Williams, 2007). In order

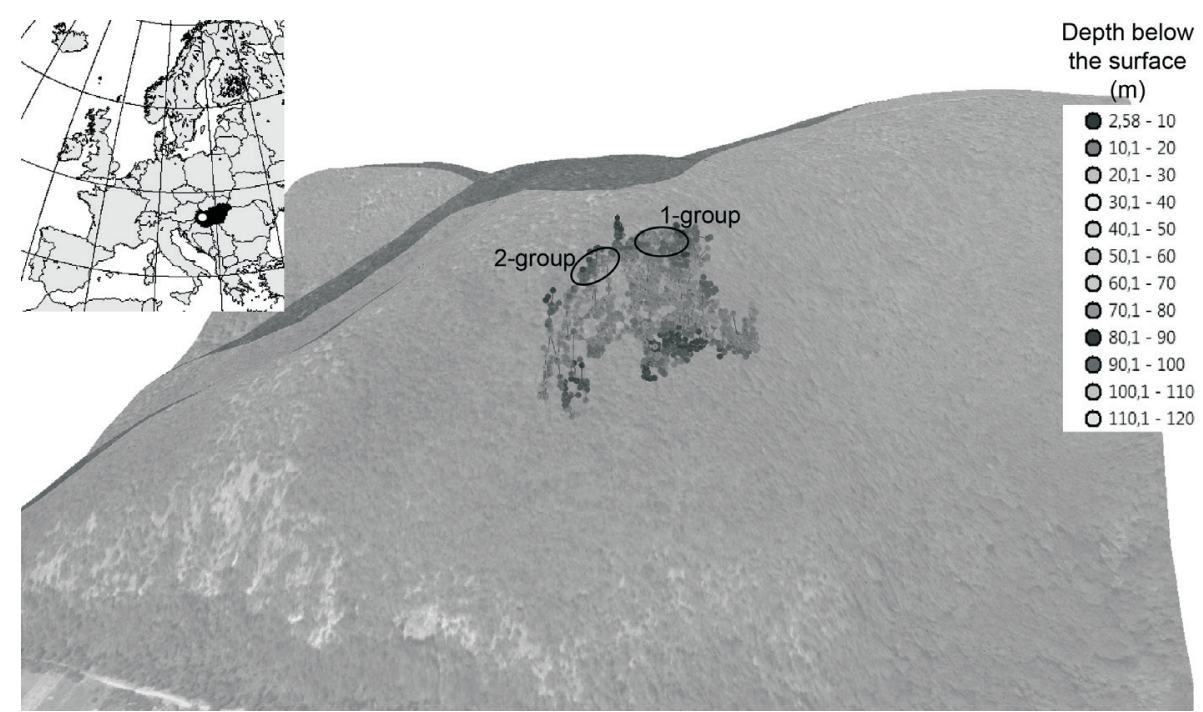

Figure 1. Oblique aerial photograph drapped on a digital elevation model (transparency 50\%) combined with the georeferenced 3D model of Csodabogyós Cave. The two clusters of dripwater monitoring sites are indicated. Inset map shows the location of Hungary (black) within Europe with the study site (white dot) 
to better understand the temporal and spatial variation of stable isotope in karst waters and their implications for interpreting the potential paleohydrological signal preserved in speleothems at the sites we have investigated the stable isotope compositions of precipitation dripping waters within Csodabogyós cave, Keszthely Mt., Western Hungary. Within the cave five dripping sites (1. Oltár, 2. Baldachin, 3. Lián-terem, 4. Bársony-terem, 5. G-járat) in the depths of 15 to $40 \mathrm{~m}$ were monitored from 2011.

\section{Results and Discussion}

Based on the hydrogen and oxygen isotope compositions of dripping water in these five sites two groups can be identified (1-group: $\delta \mathrm{D} \approx-68$ to $64 \%$ and $\delta^{18} \mathrm{O} \approx-10.0$ to $-9.3 \%$; 2 -group: $\delta \mathrm{D} \approx-72$ to $69 \%$ and $\delta^{18} \mathrm{O} \approx-10.6$ to $-9.9 \%$ ) indicating the complexity of the infiltration process within the studied karst-system. Both groups show almost no variation of stable isotope composition during the year (i.e. no seasonal variation) despite $\sim 8-10 \%$ seasonal amplitude for $\delta^{18} \mathrm{O}$ in atmospheric precipitation at the site that was estimated by two independent methods: 1) geospatial model (Kohán and Kern, 2012), using the data from the surrounding stations; 2) based on the $\mathrm{T}-\delta^{18} \mathrm{O}$ scaling in the precipitation obtained in Croatia (Vreca et al., 2006). Furthermore, no obvious relationship was found between the volumes of seepage water at the sites and amount of the precipitation in the area. This suggests a significant karstic reservoir above the dripping sites buffering/filtering the short-term effect of precipitation events. This is in line with the observed lack of seasonal variability of the water isotope signal in drip water. Worth mentioning that water isotopic composition of both groups are lower than the expected amount weighted mean value, therefore the infiltrated water seem to be skewed towards winter season. The tendency toward winter dominance

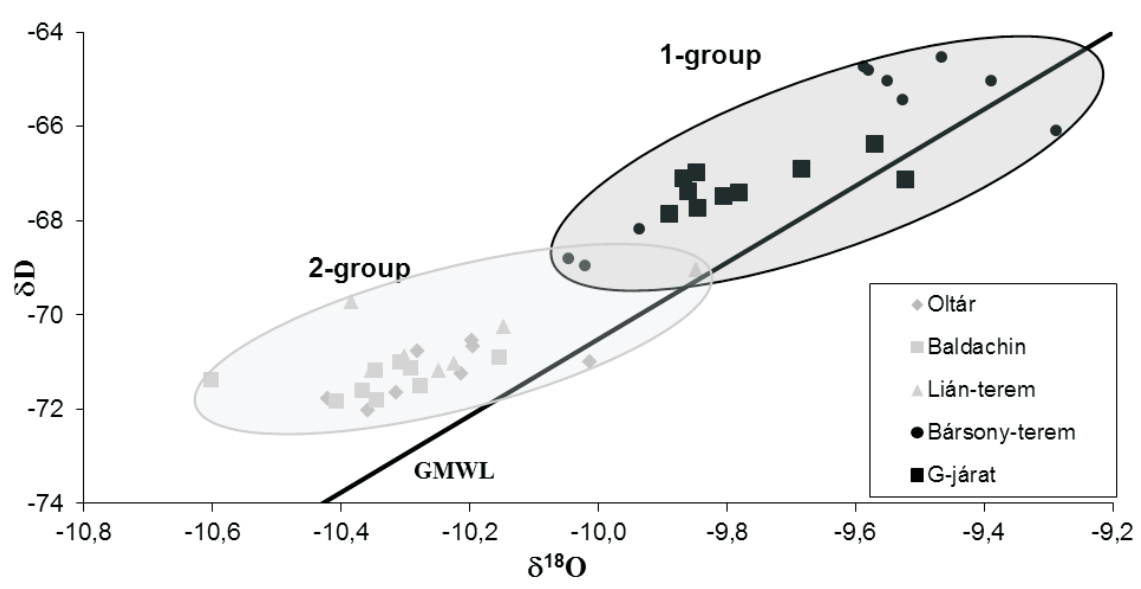

Figure 2. $\delta^{18} \mathrm{O}-\delta \mathrm{D}$ scatter plot of dripwater samples from Csodabogyós Cave shown with Global Meteoric Waterline (Rozanski et al., 1993). Assigned clusters are indicated 
is slightly more pronounced at the 2-group. Deuterium excess $\left(\mathrm{d}=\delta \mathrm{D}-8 \times \delta^{18} \mathrm{O}\right.$ defined by Dansgaard, 1964) for both groups $(\mathrm{d}=10-12 \%)$ are systematically higher than the global value suggesting influence from Mediterranean region which is generally characterized by higher d-excess (e.g. $\mathrm{d}=11-16 \%$ Croatia and Slovenia, Vreca et al., 2006). In addition, stable isotope composition of modern calcite formation also has been determined to evaluate an appropriate site for paleoclimate researches.

Acknowledgements: This study was financially supported by the Hungarian Scientific Research Fund (OTKA NK 101664). We are thankful to Barnabás Korbély (Bakony-Balaton Geopark) for the georeferenced 3D cave-model.

\section{References}

1. Surič, M., Roller-Lutz, Z., Mandič, M. et al. 2010. Modern C, O, and H isotope composition of speleothem and dripwater from Modrič Cave, eastern Adriatic coast (Croatia). International Journal of Speleology, 39, pp. 91-97.

2. Riechelmann, D.F.C., Schröder-Ritzrau, A., Scholz, D., Fohlmeister, J., Spötl, C., Richter, D.K. and Mangini A. 2011. Monitoring Bunker Cave (NW Germany): A prerequisite to interpret geochemical proxy data of speleothems from this site. J. Hydrol., 409, pp. 682-695.

3. Ford, D. and Williams, P. 2007. Karst Hydrogeology and Geomorphology. Chichester, UK, John Wiley.

4. Kohán, B. and Kern Z. 2012. A felszíni csapadék stabil oxigénizotóp összetételének becslése Magyarországon térinformatikai módszerekkel - előzetes eredmények. In: Lóki, J. (ed.): Az elmélet és gyakorlat találkozása a térinformatikában III., Debrecen, Debrecen University Press, pp. 189-196.

5. Dansgaard, W. 1964. Stable isotopes in precipitation. Tellus, 16, pp. 436-468.

6. Vreča, P.; Krajcar Bronić, I., B, Horvatinčić, N., Barešic, J. 2006. Isotopic characteristics of precipitation in Slovenia and Croatia: Comparison of continental and maritime stations. Journal of Hydrology, 330, pp. 457-469.

7. Rozanski, K., Araguás-Araguás, L. and Gonfiantini, R. 1993. Isotopic patterns in modern global precipitation. Climate Change in Continental Isotopic Records, Geophys. Monogr. Ser., vol. 78, edited by P. K. Swart et al., pp. 1-36, doi:10.1029/GM078p0001.

\section{4 - SINGLE-LAYER TH-230 DATING ON A LAMINATED} STALAGMITE AND ITS PALEOCLIMATE IMPLICATIONS

\footnotetext{
Chuan-Chou Shen ${ }^{1}$ - Ke Lin $^{1}-$ Ming Tan ${ }^{2}-$ Wuhui Duan ${ }^{2}-$ R. Lawrence Edwards ${ }^{3}-$ Xiuyang Jiang ${ }^{1,4}$

${ }^{1}$ High-Precision Mass Spectrometry and Environment Change Laboratory (HISPEC), Department of Geosciences, National Taiwan University, Taipei, Taiwan, ROC

${ }^{2}$ Institute of Geology and Geophysics, Chinese Academy of Sciences, Beijing, China

${ }^{3}$ Department of Geology and Geophysics, University of Minnesota, Minneapolis, Minnesota, USA

${ }^{4}$ College of Geography Science, Fujian Normal University, Fuzhou, China
} 
Laminated stalagmites have been used to reconstruct high-resolution paleoclimate for decades. Baker et al. [1] showed that time spans yielded by counting bands agree ages by TIMS Th-230 dating methods with precision of $\pm 62-750$ yrs for a Holocene stalagmite with luminescent laminae. The natural banding could therefore be basically considered to be annual. However, supra-annual and sub-annual layers have been reported. Invisible missing laminae and discontinuous deposition can bias stalagmite-lamina chronology and limit its application. Here we present contemporary single-lamina Th-230 dating techniques by multicollector-inductively coupled plasma mass spectrometry (MC-ICP-MS) [2] at the National Taiwan University with precision of $\pm 1 \mathrm{yr}$ for annual stalagmite layers with an age of 300 years. Comparison of band-counting ages and Th-230 ages shows that the stalagmite laminae did not always form annually. The results suggest that additional absolute methods should be applied to establish robust age models or possible chronological offsets can bias the explanation of stalagmite-lamina inferred paleoclimate and paleoenvironment.

\title{
References
}

1 A. Baker, P.L. Smart, R.L. Edwards and D.A. Richards, Annual growth banding in a cave stalagmite. Nature, 364, pp. 518-520, 1993.

2 C.-C. Shen et al., High-precision and high-resolution carbonate ${ }^{230}$ Th dating by MC-ICP-MS with SEM protocols. Geochim. Cosmochim. Acta, 99, pp. 71-86, 2012.

\section{5 - FORENSIC DIFFERENTIATION OF DIESEL FUELS USING HYDROCARBON ISOTOPE FINGERPRINTS}

\author{
Syahidah A. Muhammad ${ }^{1,2} *$ - Russell D. Frew ${ }^{1,3}-$ Alan R. Hayman $^{1}$ \\ ${ }^{1}$ Department of Chemistry, University of Otago, P.O. Box 56, Dunedin 9054, New Zealand \\ ${ }^{2}$ School of Industrial Technology, Universiti Sains Malaysia, 11800 Minden, \\ Pulau Pinang, Malaysia \\ ${ }^{3}$ FAO/IAEA Division of Nuclear Techniques in Food and Agriculture, Vienna, Austria
}

Compound-specific isotope analysis (CSIA) is fast becoming an important tool to provide chemical evidence in a forensic investigation. Attempts to trace environmental oil spill were successful where isotopic values were particularly distinct. However, difficulties arise when a large dataset is analysed and the isotopic differences between samples are subtle. Thus, this study intends to demonstrate any linkages between diesel fuels in a large number of dataset where subtlety in the isotopic values is accentuated by the near single-point source of origin. Diesel fuels were obtained from various locations in the South Island of New Zealand. Aliquots of these samples were diluted with $n$-pentane and subsequently analysed with gas chromatography-isotope ratio mass spectrometry (GC-IRMS) for carbon and hydrogen isotope values. The data obtained were subjected to principal component analysis (PCA) and hierarchical clustering. A wide range of $\delta^{13} \mathrm{C}$ and $\delta^{2} \mathrm{H}$ values were determined for the ubiquitous alkane com- 
pounds (the greatest value being $-4.5 \%$ and $-40 \%$, respectively). Based on the isotopic character of the alkanes, it is suggested that diesel fuels from different locations were distinguishable and the key components in the differentiation are the $\delta^{2} \mathrm{H}$ values of the shorter chain length alkanes. However, while the stable isotope measurements may provide information to classify a sample at a broad scale much more detailed information is required on the temporal and spatial variability of diesel compositions. Conclusively, the subtle differences of the stable isotope values within the alkanes of different diesel fuels highlighted the power of CSIA as a means of differentiating petroleum products from different origins, even more so when two or more stable isotopes data are combined. This manuscript shows that CSIA when used in tandem with multivariate statistical methods can be a collection of tools for source apportionment of hydrocarbons by demonstrating a straightforward approach thus eliminating lengthy analytical processes.

Keywords: Diesel fuel, alkane, compound-specific isotope analysis (CSIA), principal component analysis (PCA), hierarchical clustering

* Corresponding author; School of Industrial Technology, Universiti Sains Malaysia, 11800 Minden, Pulau Pinang, Malaysia. Tel.: +604 6535987; +604 657 3678. E-mail: syahidah.muhammad@usm.my.

\title{
176 - EFFECTS OF FREEZING AND SOIL DROUGHT ON THE GEOCHEMICAL FRACTIONATION OF AMERICIUM IN FLUVISOL AND CAMBISOL SOILS FROM BULGARIA
}

\author{
Petya Kovacheva* - Desislava Yovkova - Boian Todorov - Rumyana Djingova \\ Faculty of Chemistry and Pharmacy, University of Sofia "St. Kliment Ohridski", \\ 1, J. Bourchier Blvd., Sofia 1164, Bulgaria
}

Extreme changes of the environmental conditions can alter the soil properties and influence the migration ability and bioavailability of the pollutants. Elucidation of the effects of the extreme weather conditions, like sharp temperature change, drought and floods on the fractionation of radionuclides in different soil types is especially important for adequate risk assessment after radioactive contamination. The effects of short-term and prolonged freezing and soil drought on the geochemical fractionation of americium in two soil types (Fluvisol and Cambisol, classified according to the World Reference Base for Soil Resources/FAO) from Bulgaria were studied. The changes of the physicochemical forms of ${ }^{241} \mathrm{Am}$ after storage under different conditions were determined by sequential extraction procedure and gamma-spectrometric measurement. The impact of the sharp temperature decrease and drought on the association of the radionuclide with the various soil phases was considered, regarding the soil characteristics. The results showed that risk of increased mobility and bio- 
availability of americium in the loamy-sand soil with acidic $\mathrm{pH}$ and very low cation exchange capacity (CEC) exists under the examined extreme environmental conditions. The soil with sand-loam texture tended to immobilize americium after freeze and drought storage.

Keywords: americium, geochemical fractionation, soil characteristics, freezing, soil drought

* Corresponding author; Faculty of Chemistry and Pharmacy, University of Sofia "St. Kliment Ohridski”, 1, James Bourchier Blvd., 1164 Sofia, Bulgaria. Tel. +359 2 8161331; fax+3592 9625438. E-mail: PKovacheva@wmail.chem.uni-sofia.bg

\section{6 - THE ROLE OF ISOTOPES IN EVALUATING TRANSBOUNDARY} WATER RESOURCES

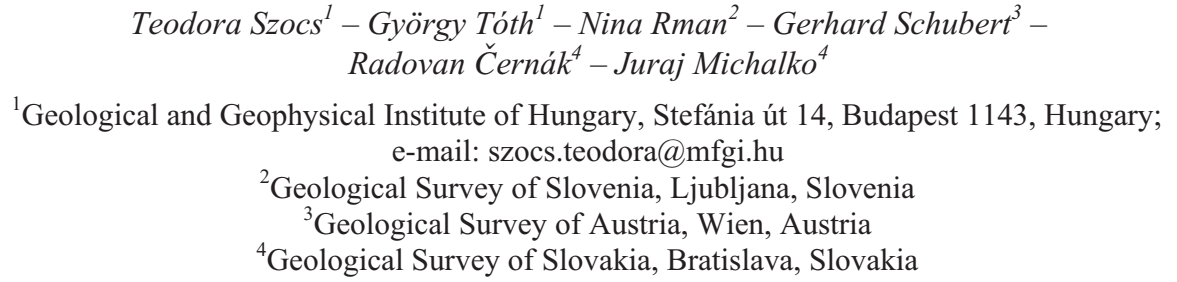

Isotopic analysis of groundwater is increasingly being used as a tool in the modelling of large aquifers and related systems, where it gives additional insight into not only the evolution through time of such water bodies but can demonstrate subsurface links between different aquifers. This has particular significance where regulation of transboundary water resources is an issue.

This study focusses on the Western part of the Pannonian Basin, which is part of the Danube River Basin, and covers 5 pilot areas, namely Bad Radkersbug-Hodoš, Lutzmansburg-Zsira, Vienna Basin, Danube Basin and Komarom-Šturovo in Hungary, Austria, Slovenia and Slovakia.

Archived hydrogeochemical and isotope data, together with analytical data from new groundwater samples were used to characterize the groundwater flow systems, to provide an independent tool for model calibration, and to characterize and subdivide the delineated geothermal reservoirs. Data used also included groundwater use (purpose, volumes extracted, monitoring) and were used to develop a conceptual and numerical hydrogeological model for the entire study area and five pilot areas.

The chemical type of groundwater changes from $\mathrm{Ca}-\mathrm{Mg}-\mathrm{HCO}_{3}$ to $\mathrm{Na}-\mathrm{HCO}_{3}$ and $\mathrm{Na}-\mathrm{Cl}$, passing from the freshly recharged local flow systems to the intermediary and regional flow systems, to aquifers which have no active recharge. Locally sulphate concentrations can also be high due to lithological influence on the groundwater. Oxy- 
gen and deuterium stable isotopes $\left(\delta^{18} \mathrm{O}, \delta \mathrm{D}\right)$ were used to differentiate between cold (Pleistocene) and warm (Holocene or older than Pleistocene) infiltration. Tritium data were used as markers of fresh (last 60 years) infiltration. Based on the available data from all four countries we can conclude that most of the data represent infiltration of precipitation origin. Some of the data indicate signs of evaporation, which in the case of proximity to oil fields implies the possibility of mixing with oil field waters. This is supported by high TOC, hydrocarbon and organic compound values. The positive shift in $\delta^{18} \mathrm{O}$ values can be attributed also to the introduction of pore water squeezed into sandstone from shales during compaction. Two samples, one from the Hungarian Devonian, and one from the Slovak Triassic basement have $\delta^{18} \mathrm{O}$ values of +2.57 and -0.054 , respectively, coming from formation waters with total dissolved content values in the range of $43,000-45,500 \mathrm{mg} / \mathrm{l}$. The most depleted waters in terms of heavy oxygen isotopes were found in the upper 200-300 meters of the Danube Basin, suggesting a much slower groundwater flow rate than in other parts of the Neogene sediment succession. This conclusion is also supported by the very low ${ }^{14} \mathrm{C}$ values. Radiocarbon age calculations of water were carried out both with simple ${ }^{14} \mathrm{C}$ decay and with carbon-13 correction, but based on previous studies [1] the age calculations with carbon-13 correction can not be applied when there is a positive shift in $\delta^{13} \mathrm{C}$ values.

Acknowledgements: Partial funding for this study was provided by the TRANSENERGY project (Transboundary Geothermal Energy Resources of Slovenia, Austria, Hungary and Slovakia) implemented through the Central Europe Programme Priority 3 and by ERDF.

\section{Reference}

1. T. Szocs, N. Rman, M. Süveges, L. Palcsu, Gy. Tóth and A. Lapanje, The application of isotope and chemical analyses in managing transboundary groundwater resources. Applied Geochemistry, 32, pp. 95-107, 2013. 